UNIVERSIDADE DE SĀO PAULO

INSTITUTO DE GEOCIENCIAS

\title{
ANÁLISE CONJUNTA DE DADOS GEOLÓGICOS, GEOFISICOS E DE SENSORIAMENTO REMOTO DO SETOR EXTREMO NORDESTE DA PROVÍNCIA BORBOREMA, NORDESTE DO BRASIL, COM ÊNFASE NAS ZONAS DE CISALHAMENTO DÚCTEIS NEOPROTEROZÓICAS
}

Venerando Eustáquio Amaro

Orientador: Prof. Dr. Gilberto Amaral

TESE DE DOUTORAMENTO

Programa de Pós-Graduação em Recursos Minerais e Hidrogeologia 


$$
\begin{aligned}
& \text { UNIVERSIDADE DE SÃO PAULO } \\
& \text { INSTITUTO DE GEOCIENNCIAS }
\end{aligned}
$$

\title{
ANÁLISE CONJUNTA DE DADOS GEOLÓGICOS, GEOFÍSICOS E DE SENSORIAMENTO REMOTO DO SETOR EXTREMO NORDESTE DA PROVÍNCIA BORBOREMA, NORDESTE DO BRASIL, COM ÊNFASE NAS ZONAS DE CISALHAMENTO DÚCTEIS NEOPROTEROZÓICAS
}

\author{
VENERANDO EUSTÁQUIO AMARO
}

Orientador: Prof. Dr. Gilberto Amaral

TESE DE DOUTORAMENTO

COMISSÃO JULGADORA

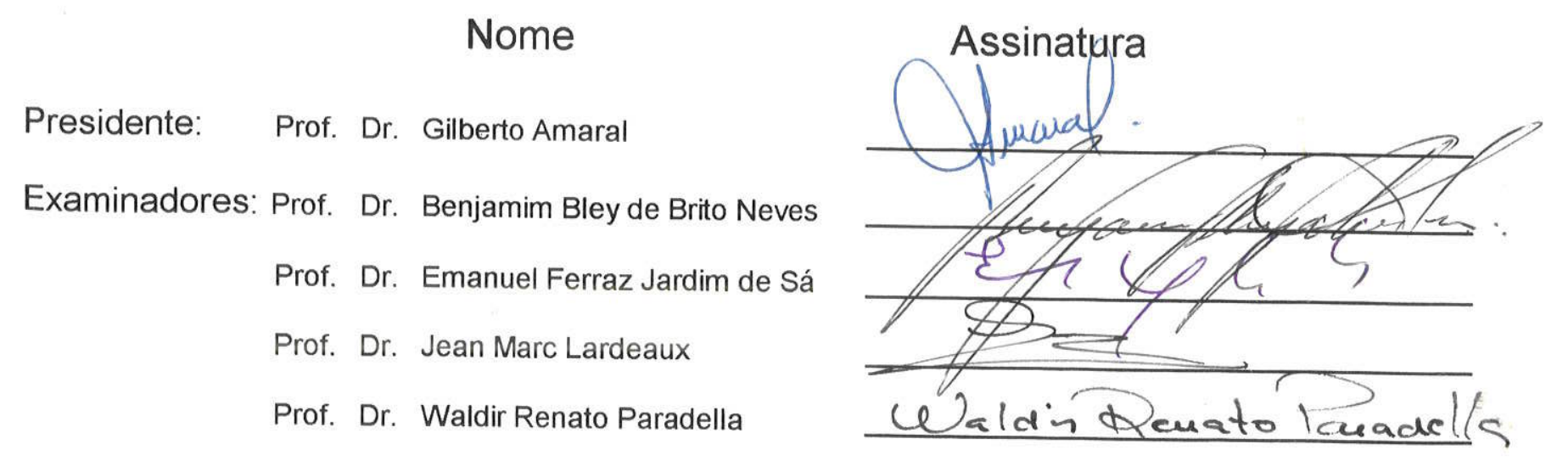


UNIVERSIDADE DE SÃO PAULO

INSTITUTO DE GEOCIÊNCIAS

DEDALUS - Acervo - IGC

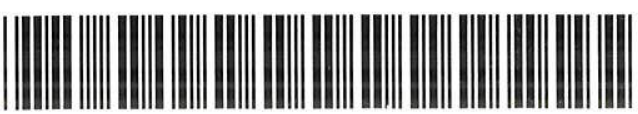

30900004474

ANÁLISE CONJUNTA DE DADOS GEOLÓGICOS, GEOFÍSICOS E DE SENSORIAMENTO REMOTO DO SETOR EXTREMO NORDESTE DA PROVÍNCIA BORBOREMA, NORDESTE DO BRASIL, COM ÊNFASE NAS ZONAS DE CISALHAMENTO DÚCTEIS NEOPROTEROZÓICAS

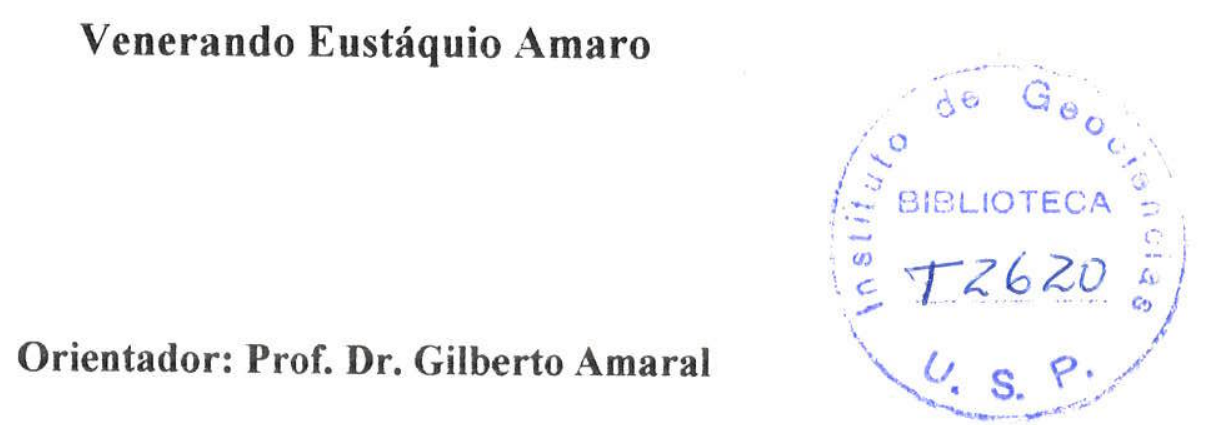

TESE DE DOUTORAMENTO

Programa de Pós-Graduação em Recursos Minerais e Hidrogeologia

SÃO PAULO

1998 
"To see a world in a grain of sand and a heaven in a wild flower hold infinity in the palm of your hand and eternity in an hour"

William Blake

Para minha mãe, pelo amor incondicional e ensinamentos sobre ele. 


\section{AGRADECIMENTOS}

Ao Prof. Dr. Gilberto Amaral pela orientação, apoio, leitura crítica e discussões durante a elaboração deste trabalho. Gilberto, quanto ânimo e disposição!

Ao Prof. Dr. Jean Marc Lardeaux pela difícil tarefa de orientação, inúmeras sugestões e principalmente pelo estimulo e incentivos constantes durante a etapa francesa desta tese. Jean Marc, un grand merci pour l'accueill au laboratoire, pour ton enthousiasme et confiance!

Ao Prof. Dr. Emanuel Ferraz Jardim de Sá pelos anos de ensinamentos e estímulos à pesquisa na Província Borborema, pela convivência e conselhos profícuos. Emanuel, você é um exemplo de dinamismo!

Ao Prof. Dr. Patrick Launeau pela acolhida no Laboratoire de Petrologie Structurale da Universidade de Nantes (França), pela orientação na obtenção e tratamento dos dados de espectrometria de reflectância.

Ao Prof. Dr. José Wilson de Paiva Macedo pelo apoio e confiança na concessão dos dados gravimétricos. Ao Grupo de Geofísica do Departamento de Física Teórica e Experimental/UFRN pela concessão dos dados gravimétricos.

À CAPES/COFECUB que promoveu recursos para as investigações no Brasil e no exterior por meio de bolsas PICD-UFRN e Doutorado Sanduíche. À equipe técnica da CAPES pela presteza e eficiência.

Ao Departamento de Geologia da Universidade Federal do Rio Grande do Norte que me concedeu o afastamento para realização desta tese. Ao Prof. Vanildo Fonseca pela amizade e apoio nesses anos de afastamento. Valeu Vanildo, espero retribuir em breve!

Ao Grupo de Geodinâmica e Geofísica pelo apoio financeiro, suporte técnico e freqüentes discussões. Aos colegas pesquisadores que contribuíram para esta teste.

Aos colegas e professores do Departamento de Geologia Econômica e Geofisica Aplicada do Instituto de Geociências da Universidade de São Paulo pelo apoio técnico na execução deste trabalho.

À CNEN, na pessoa do Dr. Paulo Roberto Cruz, pela autorização na concessão dos dados do Projeto Aerogeofísico Esperança. À PETROBRÁS e à CPRM-Rio de Janeiro pela concessão dos dados aeromagnéticos. 
Ao Prof. Dr. B. B. Brito Neves pelas inúmeras discussões e apoio desde os meus primeiros dias no IG/USP. Prof. Bley, muito obrigado pela revisões e sugestões em cada uma das fases desta tese. Os seus comentários foram sempre marcantes e por isso serão sempre bem vindos!

À Profa. Elizabete Pascholati pelo auxilio com os dados aeromagnéticos, discussões e estímulo. Bete, obrigado pela paciência e apoio logístico durante os dias que duraram as discussões com o Gilberto.

Ao Francisco Hilário pelas discussões e auxílio no tratamento dos dados de sensoriamento remoto. Hilário, Solange e Raul muito obrigado pela acolhida amiga e indispensável durante os longos e frios meses londrinos.

Ao Zorano de Souza pelas discussões e auxílio nos dados sobre metamorfísmo. Zorano, Marieta, Gwen e Bibi muito obrigado pela acolhida e carinho!

À Maria Irian de Mascena Duarte pela amizade e carinho! Obrigado também pela editoração do mapa final e pelo apoio! Irian, muito obrigado por estar sempre presente!

À Rita Conde e Márcia pelo apoio e amizade. Rita, você foi incrível!

Ao Nilson Teixeira pela amizade e apoio.

Aos amigos de (e para, espero...) sempre: Emanuel e Norma, Maria Helena (Chefa) e Zé Wilson, Maria Irian, Maria Helena Hollanda, Luciano Caldas, Eugênio Pacelli, Paulo Accioly, Marco Aurélio, Ricardo Ivan, Mércia Motta, Lúcia Furukawa Couto, Adelir e Sônia, Ana Marques, Gilberto e Bete, Silvia Rolim, Gésia Sant'Anna e Winnie Carvalho. A presença amiga de vocês em minha vida é muito valiosa!!!

À Veronique Gardien pour tes conseils et amitié. Chére Véro, tu m'as beaucoup aidé avec ta façon de croire un monde de respect et fratérnité entre les gens! Merci d'avoir compris et partagé la beauté de la vie!

Je pense aussi a mes amis: Thibault de Garidel, Olivier Ruau, Pierre Faure, François Bassé et Laure Masson, Alex et Christelle, Sophie, Nat Zac, Pochat, Dennis, Laurent, Sylvie et Paschal. Monique Caparros, Danielle Jupille, Anne Marie, Sophie Chazallet, Ronald Bekker et aux amis du Groupe de Spéleo de Aix-en-Provence - UN GRAND MERCI A TOUS! Et a plus! 
À la famille des Nowakowski en Sosnowiec-Bedjin (Pologne): Rafal, Kásia, Andrej, Annia et Maua Kásia. Merci de m'avoir rę̧u avec un tel amour et tendresse au sein de votre famille!

Ao amigo Ronaldo Kirsten pelo apoio, consideração, amizade e estímulos constantes. Sem isso teria sido muito mais dificil e não valeria a pena! Ao Seu Chico, Dona Zilda, Regina e Áurea: muitíssimo obrigado pelo apoio e convivio familiar!!!

Vó Luzia e Vô Venerando, vocês fazem parte de tudo isso! Tia Lucy e Tia Maria, muito obrigado pelas orações!

Esta tese é dedicada a minha mãe Fátima! Foi a forma que encontrei para tentar transmitir a ela, e aos demais membros da familia, a gratidão que sinto pelo privilégio do convivio durante todos esses anos. Sinto muito orgulho de vocês! 


\section{RESUMO}

A presente tese apresenta uma contribuição metodológica à integração de informações geológicas, geofísicas (gravimétricas e aeromagnéticas) e de sensoriamento remoto (Landsat 5-TM e GEMS/Banda X) na melhoria do mapeamento geológico de reconhecimento e semi-detalhe na região semi-árida do Nordeste do Brasil. Os procedimentos favoreceram a composição de um modelo hipotético concernente à evolução geodinâmica da Província Borborema interceptada por um sistema de zonas de cisalhamento dúcteis de escala litosférica em regime transtracional no Neoproterozóico.

O Setor Extremo Nordeste da Província Borborema abrange os terrenos dos Maciços São José do Campestre e Caldas Brandão (MSJC-MCB) afetados por um sistema de zonas de cisalhamento dúcteis transtracionais e extensionais com raizes mantélicas durante a orogênese Brasiliana/Pan-Africana. Os MSJC-MCB compreendem rochas gnáissico-migmatíticas que preservam registros de orogêneses acrescionárias colisionais no Paleoproterozóico, com geração de crosta juvenil e retrabalhamento de protocrosta siálica arqueana, que imprimiram aos terrenos um fabric tangencial penetrativo.

As técnicas de filtragem direcional com filtros Sobel, Prewitt, Kirsch e Laplaciano, aplicadas às imagens Landsat 5-TM, permitiram a detecção e o realce do sistema de lineamentos que demarcam o arranjo geométrico e cinemático das zonas de cisalhamento dúcteis de trends gerais NE e NW e o fabric $\mathrm{D}_{3}$ (foliações e lineações). A configuração dessas estruturas denota uma conformidade mecânica com os sistemas de zonas de cisalhamento em regimes transpressional e transtracional nos setores Norte (Faixa Seridó) e Central (Domínio da Zona Transversal) da Província Borborema, respectivamente.

As medidas de espectrometria de reflectância em amostras de mão de rochas e minerais diagnosticaram os principais minerais constituintes das rochas e revelaram as variações geoquímicas sutis, principalmente nos conteúdos de $\mathrm{Fe}, \mathrm{Ca}, \mathrm{Mg}, \mathrm{Al}$ e $\mathrm{OH}$, entre rochas com aspectos petrológicos similares. A análise comparativa entre as variações no albedo e na forma das curvas espectrais conduziram à adequação de um método estatístico de seleção dos conjuntos de trios e razões de bandas do Landsat 5-TM com melhores desempenhos na distinção entre as unidades litológicas e no realce das feições deformacionais. A interpretação visual desses conjuntos de bandas combinados em 
composições coloridas por técnicas de processamento digital de imagens (RGB, IHS, ACP, Razões de Bandas e HRGB) beneficiaram o realce das unidades litológicas previamente definidas e a deteç̧ão de novas unidades ainda não cartografadas até o presente.

A abordagem das condições de pressão-temperatura (P-T) permitiram o zoneamento metamórfico em relação aos principais elementos da deformação dúctil e granitóides brasilianos. $\mathrm{O}$ ápice do metamorfismo alcançou condições do fácies granulito de baixa-P com extensiva migmatização acompanhando as zonas de cisalhamento dúcteis em regime extensional e transtracional que afetam as faixas metapeliticas e os terrenos gnáissicos do embasamento. Pelo geotermomêtro plagioclásio-anfibólio e geobarômetro do Al no anfibólio, os metapelitos granulíticos migmatizados apresentaram variações de $\mathrm{T} \sim 781$ $811^{\circ} \mathrm{C}$ e $\mathrm{P} \sim 3,8-5,9$ kbar e os granulitos máficos intercalados variações de $\mathrm{T} \sim 799-823^{\circ} \mathrm{C}$ e $\mathrm{P} \sim 3,0-4,5$ kbar. No geotermômetro ortopiroxênio-clinopiroxênio os granulitos máficos indicaram $\mathrm{T} \sim 818-973^{\circ} \mathrm{C}$. No Complexo Campina Grande as variações foram de $\mathrm{T} \sim 713$ $835^{\circ} \mathrm{C}$ e $\mathrm{P} \sim 2,5-5,5$ kbar pelos métodos plagioclásio-anfibólio e $\mathrm{Al}$ no anfibólio. A granitogênese sin- a tarditectônica apresenta idade de $555 \pm 10$ Ma correlata à idade de 575 $\pm 25 \mathrm{Ma}$ das zonas de cisalhamento dúcteis de alta-T. As idades de $403 \pm 38 \mathrm{Ma}$ refletem $\mathrm{o}$ soerguimento e a exumação dos níveis profundos da crosta que promovem $o$ retrabalhamento do fabric de alta-T sob condições retrometamórficas $\left(\mathrm{T}<530^{\circ} \mathrm{C}\right)$.

As filtragens dos dados geofísicos (gravimétricos e aeromagnéticos) nos domínios da freqüência e espaço-temporal caracterizaram os contrastes de densidades e suceptibilidades em diferentes níveis do manto litosférico-crosta continental, em função dos comprimentos de onda. $\mathrm{O}$ ajuste entre as assinaturas geofísicas e as feições geológicas descrevem o enraizamento mantélico das zonas de cisalhamento. As anomalias geofisicas regionais e residuais refletem à estruturação do fabric $\mathrm{D}_{3}$, demonstrado no controle das zonas de cisalhamento dúcteis, na geometria de blocos crustais com características geológicas (geoquímicas e geocronológicas) contrastantes, no alojamento de granitóides subalcalinos/alcalinos sin- a tarditectônicos de origem mantélica, nas condições metamórficas do fácies granulito e na migmatização. Essas feições assinalam a estruturação crustal no MSJC-MCB marcada pela transposição da Moho e soerguimento do manto litosférico, e/ou magmas mantélicos derivados, acompanhando o regime transtracional e extensional das zonas de cisalhamento dúcteis. A evolução geodinâmica proposta para os 
terrenos no Neoproterozóico envolveria: (i) um evento acrescionário em regime transcorrente/transformante ( $c$ a. 850-600 Ma) de fragmentos alóctones (microplacas continentais) e crosta continental juvenil (arcos magmáticos associados), gerada nos estágios precoces ou em eventos prévios (p.ex. o evento $c a$. $950 \pm 50$ Ma no DZT), intermediários aos crátons do Oeste Africano/São Luís, Congo/São Francisco e Leste do Sahara em interação por colisão oblíqua; (ii) o retrabalhamento intracontinental por zonas de transcorrência no estilo extrusão lateral de blocos, em regime colisional do tipo platô Tibetano (ca. $580 \pm 30 \mathrm{Ma}$ ), após a amalgamação das placas e microplacas continentais antigas e juvenis.

A comparação entre as anomalias gravimétricas residuais para a crosta superior, os enxames de lineamentos topográficos, as feições morfotectônicas e os dados de campo sugere a reativação do sistema de zonas de cisalhamento brasilianas, provavelmente em episódios de regime frágil sucessivos, desde o resfriamento e uplift dos terrenos nos estágios finais da orogênese Brasiliana. No Cenozóico, essas estruturas reativadas formariam um dos padrões de falhas que controlam grabens e horsts na Faixa Litorânea do Nordeste. 


\begin{abstract}
The present thesis presents a methodological contribution for the integration of geological, geophysical (gravimetrics and magnetics) and remote sensing (Landsat 5-TM and X-Band airborne SAR) data in the improvement of reconnaissance and detailed geological mapping of the semi-arid Brazilian Northeast region. The results allowed the development of a hypothetical model related to the geodynamical evolution of the Borborema Province affected by a lithospheric-scale ductile shear zone system in transtensional style during the Neoproterozoic.

The extreme northeastern domain of the Borborema Province includes the São José do Campestre and Caldas Brandão Massifs (SJCM-CBM), affected by a system of transtensional and extensional ductile shear zones with roots in the mantle during the Brasiliano/Pan-African orogeny. The SJCM-CBM are formed by gneissic-migmatitic rocks which denote remanents of accretionary collisional Paleoproterozoic orogens, representative of neoformed juvenile crust and reworking of Archean sialic protocrust, resulting in a penetrative tangential fabric to these massifs.
\end{abstract}

Directional filtering (Sobel, Prewitt, Kirsch and Laplacian) applied on Landsat 5-TM images, allowed the detection and enhancement of the lineament system associated with the geometric and kinematic framework of the ductile shear zones with a general $\mathrm{NE}$ and NW trends and $D_{3}$ fabric (foliation and lineation). The organization of these structures is associated with a mechanical conformity with shear zones developed under transtensional and transpressional regimes respectively in the North (Seridó Belt) and Central (Zona Transversal Domain-ZTD) sectors of Borborema Province.

Reflectance spectrometry measurements on mineral and rock samples were diagnostic for the main lithologic components. They allowed the detection of subtle geochemical variation, mainly in the $\mathrm{Fe}, \mathrm{Ca}, \mathrm{Mg}, \mathrm{Al}$ and $\mathrm{OH}$ contents, in rocks petrologically similar. Distinction of lithological units and enhancement of strain features was based in color compositions of bands and ratio triplets, selected from the statistical comparative analysis of the albedo variations and the shape of spectral curves. The visual analysis of color compositions obtained by digital image processing techniques (RGB, IHS, Principal 
Component Analysis, band ratios and HRGB) resulted in improvement of the geological maps for the area and mapping of new units.

Analysis of pressure-temperature (P-T) informations resulted in the definition of metamorphic zoning and its relationship with the main ductile deformational elements and Brasiliano granites. The metamorphism climax reached the low pressure granulite facies and was accompanied by extensive migmatization along transtensional and transpressional shear zones affecting metapelitic belts and basement gneissic terrains. Based on the plagioclaseamphibole geothermometer and amphibole-Al geobarometer, the migmatized granulitic metapelites presented temperature variations in the range $781-811^{\circ} \mathrm{C}$ and pressures between $3.8-5.9 \mathrm{kbar}$. The mafic granulite bands presented variations between $799-823^{\circ} \mathrm{C}$ and $3.0-$ $4.5 \mathrm{kbar}$. Using the orthopyroxene-clinopyroxene geothermometer, the mafic granulites presented a variation in the range $818-973^{\circ} \mathrm{C}$. The plagioclase-amphibole and amphibole-Al methods resulted in a range from $713-835^{\circ} \mathrm{C}$ and $2.5-5.5 \mathrm{kbar}$ for the Campina Grande Complex. The syn- to late-tectonic granitogenesis yielded an age of $555 \pm 10 \mathrm{My}$, correlated with the $575 \pm 25 \mathrm{My}$ age for the high-T ductile shear zones. Uplift and exposure of deeper crustal levels, promoting reworking of the high-T fabric under retrometamorphic conditions $\left(\mathrm{T}<530^{\circ} \mathrm{C}\right)$, presented an age of $403 \pm 38 \mathrm{My}$.

Filtering of magnetic and gravimetric data in the frequency and space-time domains enhanced the mass and susceptibility contrasts among different continental crustlithospheric mantle levels, due to its different wavelenghts. The fit among geophysical signatures and geological features is indicative for mantle rooting of the shear zones. Regional and residual geophysical anomalies reflect the $\mathrm{D}_{3}$ fabric framework. This situation is demonstraded by the ductile shear zones control on the geometry of crustal blocks with contrasting geological characteristics (geochemical and geochronological); in the emplacement of syn- to late-tectonic alkaline and subalkaline granitoids of mantle origin; in the granulite facies metamorphism and migmatization. These features indicate that the crustal structural framework of the SJCM-CBM is marked by Moho transposition and uplift of lithospheric mantle and/or mantle derived magmas following the transpressional and transtensional ductile shear zones. The proposed Neoproterozoic geodynamic evolution involves: (i) an accretionary episode under transcurrent/transform regime (ca. 850-600 My) affecting allochthonous fragments (continental microplates) and juvenile continental crust 
(associated magmatic arcs) formed during early Brasiliano/Pan-African or older (ca. $950 \pm$ 50 My observed in ZTD). This episode occured between the West African/São Luís, Congo/São Francisco and East Sahara cratons, interacting by oblique collision; (ii) intracontinental reworking by transcurrent shear zones, with the style of lateral block extrusion in a collisional regime of the Tibetan Plateau type (ca. $580 \pm 30 \mathrm{My}$ ), after welding of older and juvenile continental plates and microplates.

Comparison among upper crust gravimetric anomalies, the swarm of topographic lineaments, morphotectonic features and field data is suggestive for reactivation of the Brasiliano shear zone system, probably by successive brittle regime episodes since cooling and uplift of late Brasiliano phases. In the Cenozoic these reactivated stuctures are associated with horsts and grabens which control the sedimentation in the Northeast Coastal Region. 


\section{ÍNDICE}

1 - CONSIDERAÇÕES INICIAIS E PROPOSIÇÃO DO PROBLEMA .......................................... 1

1.1 - PrINCIPAIS OBJETIVOS E JUSTIFICATIVA DA INVESTIGAÇÃo PROPOSTA .............................. 1

1.2 - LoCALIZAÇÃo dA ÁrEA E ASPECTOS FisIOGRÁFICOS ..................................................... 4

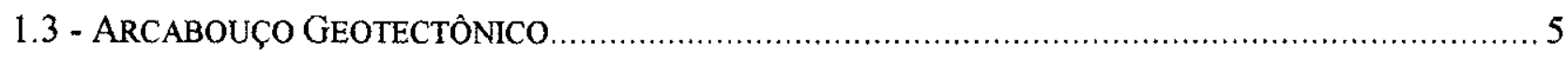

1.3.1 - Contexto Geodinâmico da Província Borborema ........................................................... 5

1.3.2 - Evolução Crustal da Porção Extremo Nordeste da Província Borborema (Maciços

São José do Campestre e Caldas Brandão) .................................................................... 13

2 - BASES CONCEITUAIS E SÍNTESE BIBLIOGRÁFICA .................................................... 18

2.1 - O CONCEIto de lineamentos e a Aplicação do Termo aOs terrenos da

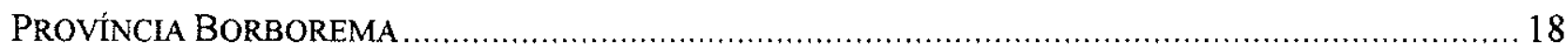

2.2 - O Conceito de Unidade de PaISAGEM No Procedimento de InterpretaÇão

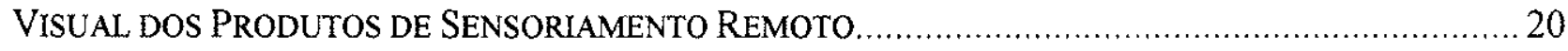

2.3 - NOÇÕES DE ESPECTROMETRIA DE REFLECTÂNCIA ..................................................... 22

2.3.1 - Principais Fenômenos e Feições Diagnósticas nas Assinaturas Espectrais.................. 22

2.3.2 - Processos Atômico-Moleculares de Energia e as Aparências no EEM.......................... 23

2.3.3 - Características Espectrais dos Componentes lônicos Comuns nos Minerias e Rochas entre o Visivel e o Infravermelho de Curto Comprimento de Onda..................................... 25

2.4 - SínTESE SOBRE AS ASSINATURAS GRAVIMÉTRICAS DAS ZONAS DE CISALHAMENTO INTRACONTINENTAIS E A ESTRUTURAÇÃO DA CROSTA CONTINENTAL ........................................29

2.5 - INTEgraÇão de Dados GravimÉtricos e AeromagnÉticos NA CoMPreEnSÃo dA

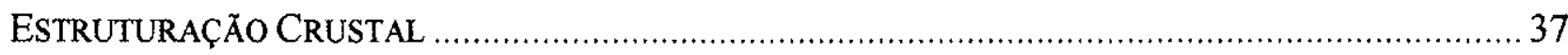

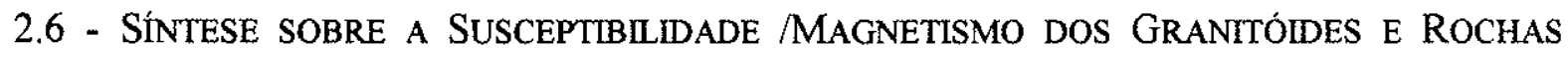

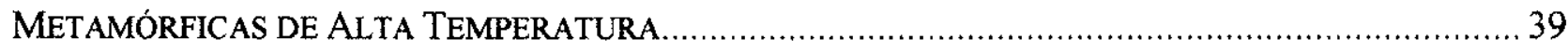

2.7 - Síntese Sobre os Estudos Geofísicos E de SEnsoriamento REMoto APLiCAdos AOS PROBLEMAS TECTÔNICOS DA PROVÍNCIA BorborEMA .................................................... 41

2.7.1 - Trabalhos Prévios de Intepretação Visual de Produtos de Sensoriamento Remoto....... 41

2.7.2 - Mapas de Anomalias Bouguer e Residual do Nordeste do Brasil................................. 43

2.7.3 - Mapas Aeromagnéticos do Nordeste Oriental............................................................... 48

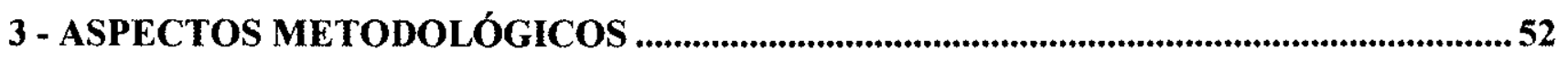

3.1 - Estratégia de tratamentos dos Produtos de Sensoriamento Remoto

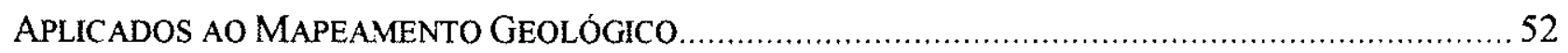

3.1.1 - Realce Digital do Sistema de Lineamentos e as Operações de Convolução................... 55

3.1.2 - A Filtragem Direcional na Deteç̧ão e Realce dos Lineamentos.................................... 57

3.1.3 - Realce Espectral e Composições Coloridas ..................................................................... 63 
3.2 - MÉtodos de Filtragens dos Comprimentos de Onda APlicados aOS Dados de

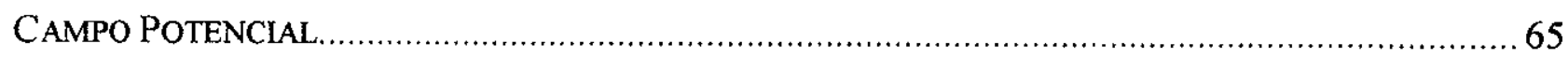

3.2.1 - Levantamento e Tratamento dos Dados Gravimétricos ................................................... 66

3.2 .2 - Levantamento e Tratamento dos Dados Aeromagnéticos ................................................ 73

\section{4 - INTERPRETAÇÃO VISUAL DE PRODUTOS DE SENSORIAMENTO REMOTO} NO MAPEAMENTO TEMÁTICO DO SISTEMA DE LINEAMENTOS. 78

4.1 - CONSIDERAÇÕES INICLAIS .78

4.2 - ANÁlise Visual das lmagens Resultantes das Filtragens Direcionais: O Sistema de LINEAMENTOS doS MACiÇOS SÃo José do CAMPESTRE E CALDAS BRANDÃo......... 78

4.3 - MAPA de Lineamentos da PORÇÃo NORdESTE da PROVÍnCIA Borborema 79

4.4 - ARCABouço Geológico da Região dos MACiços São José do CAMPESTRE E CALDAS BRANDÃO.

4.5 - Mapa Esquemático do Sistema de Zonas de Cisalhamento Dúcteis de AltaTEMPERATURA DA PROVINCIA BORBOREMA

4.6 - GEOMETRIA DOS SistemaS DE LINEAMENTOS E A DIMENSIONALIDADE DAS ZONAS DE CISALHAMENTO DÚCTEIS BRASILIANAS.

5 - ESPECTROMETRIA DE REFLECTÂNCIA APLICADA AO MAPEAMENTO GEOLÓGICO dOS MACIÇOS SÃO JOSÉ DO CAMPESTRE E CALDAS BRANDÃO.... 136

5.1- CONSIDERAÇÕES INICIAIS 136

5.2 - Aspectos Petrográficos e Geoquímicos das Amostras Submetidas à

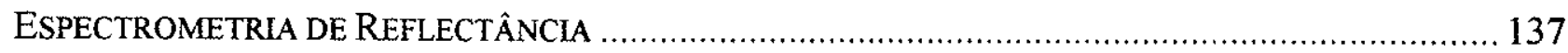

5.3 - RESUlTAdOS E DisCUSSÖES SOBRE AS ASSINATURAS ESPECTRAIS. 150

5.4 - Síntese das PRIncipais feições Espectrais Diagnósticas das amostras ANALISADAS

5.5 - Avaliação EstatístiCa das COMBINAÇŐES DE BANDAS do LANDSAT 5-TM 167

5.6 - PROCESSAMENTO DigITAL DE IMAGENS DO LANDSAT 5-TM 175

5.6.1 - Interpretação Visual das Composições Coloridas em RGB ........................................ 176

5.6.2 - Interpretação Visual das Principais Componentes Combinadas em RGB................... 19.

5.6 .3 - Interpretação Visual das Razões de Bandas Combinadas em RGB .............................. 197

5.6.4 - Interpretação Visual das Composições Coloridas em IHS e HRGB ............................. 201

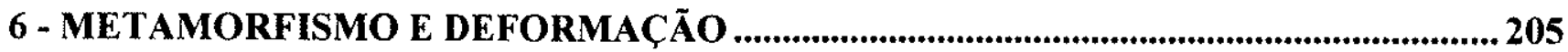

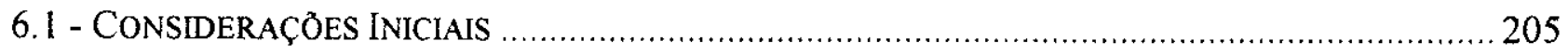

6.2 - Condições Metamórficas dos Eventos PrÉ-Brasilianos ........................................... 207

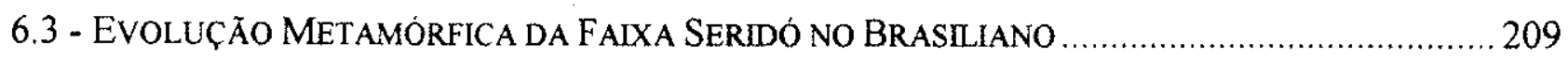

6.4 - DistribuIÇÃo REgIONAL do METAMORFISMo BRASILIANO No MSJC-MCB.................... 212

6.4.1 - Malha Petrogenética e Diagramas AFM.................................................................... 212 
6.4.2 - Reações Metamórficas e a Trajetória PTt do Metamorfismo $M_{3}$................................. 214

6.4.3 - Termobarometria das Condições do Fácies Granulito ................................................ 228

6.4.4 - Aspectos Gerais da Migmatização Associada ao Metamorfismo Brasiliano............... 229

6.4.5 - Modelos Para Geração das Condições do Fácies Granulito........................................ 234

6.5 - Mecanismos Responsáveis Pelo Metamorfismo Granulítico e Migmatização

NO MSJC-MCB.

\section{7 - GEOARQUITETURA CRUSTAL E ASPECTOS DAS ASSINATURAS} GEOFÍSICAS DAS ZONAS DE CISALHAMENTO DÚCTEIS BRASILIANAS..................240

7.1 - INTRODUÇÃO: OS DADOS GEOFÍSICOS E A ANÁLISE QUALITATIVA ….............................240

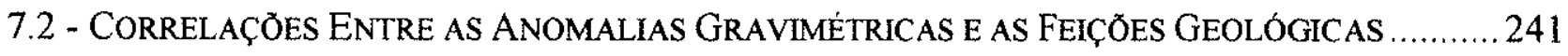

7.3 - MAPA DE LINEAMENTOS DOS GRADIENTES AEROMAGNÉTICOS ....................................... 263

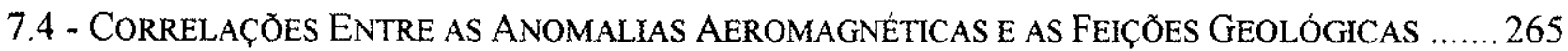

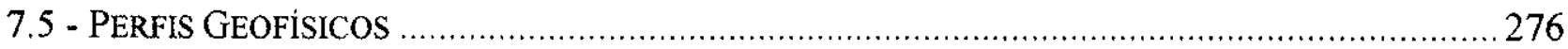

7.5.1 - Localização dos Perfis Selecionados...................................................................... 276

7.5.2 - Perfis Integrados das Anomalias Bouguer e Intensidade Magnética Total .................. 277

7.5.3 - Perfis Integrados das Anomalias Gravimétricas e Aeromagnéticas Resultantes das

Filtragens nos Domínios da Freqüência e Espaço-Temporal .................................................. 283

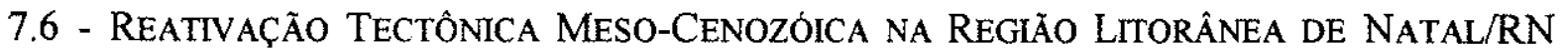

COM BASE NOS DADOS GRAVIMÉTRICOS, IMAGENS LANDSAT 5-TM E GEMS/BANDA X. 300

7.6.1 - Mapa de Lineamentos Frágeis elou Dúcteis-Frágeis e das Anomalias Gravimétricas Para a Crosta Média e Superior .................................................................. 304

7.6.2 - As Feições Gravimétricos, Geométricas e as Estruturas Proterozóicas Reativadas.... 322

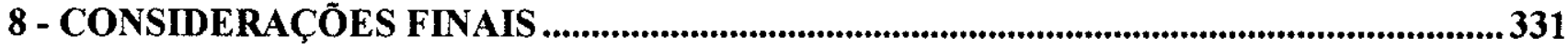

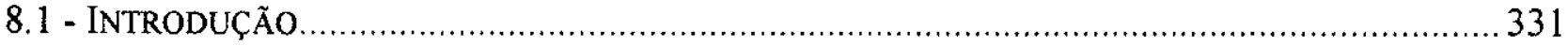

8.2 - SeÇões Esquemáticas e Síntese dos Modelos ANALóGiCos ...................................... 334

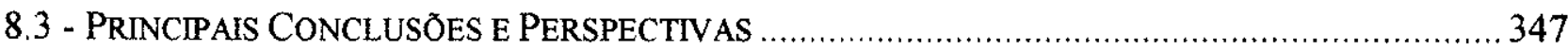

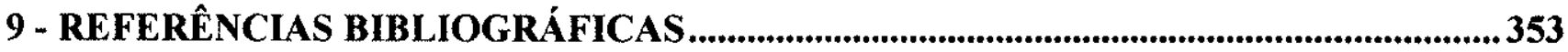




\section{LISTA DE TABELAS}

Tabela 1.1 - Idades arqueanas das unidades litoestratigráficas reconhecidas no Maciço São José do Campestre.

Tabela 1.2 - Idades paleoproterozóicas das unidades litoestratigráficas reconhecidas no Maciço São José do Campestre.

Tabela 1.3 - Dados geocronológicos referentes aos granitóides brasilianos do Maciço São José do Campestre.

Tabela 5.1 - Valores calculados do Fator Índice Ótimo e INDEX para os 20 conjuntos de trios de bandas do Landsat 5-TM

Tabela 5.2 - Valores estatísticos das dispersões nos 20 conjuntos de trios de bandas do Landsat 5 -TM conforme as respostas espectrais das litologias do Setor Extremo Nordeste da Província Borborema

Tabela 5.3 - Razões de bandas do Landsat 5-TM comuns na discriminação composicional de superficies.

Tabela 5.4 - Valores estatísticos das dispersões nos 13 conjuntos de razões de bandas do Landsat 5-TM calculados conforme as espectrais das litologias do Setor Extremo Nordeste da Província Borborema

Tabela A3.1 - Dados estatísticos da cena 214/065 do Landsat 5-TM do Setor Extremo Nordeste da Província Borborema

Tabela A3.2 - Coeficientes de correlação das 6 bandas não-termais do Landsat 5-TM do Setor Extremo Nordeste da Província Borborema

Tabela A3.3 - Matriz de covariância para as 6 bandas não-termais do Landsat 5-TM do Setor Extremo Nordeste da Província Borborema

Tabela A3.4 - Coeficientes de correlação dos auto-vetores referentes às PC's obtidas a partir das 6 bandas não-termais do Landsat 5-TM do Setor Extremo Nordeste da Província Borborema.

Tabela A3.5 - Matriz de covariância entre os auto-vetores e as 6 bandas não-termais do Landsat 5-TM do Setor Extremo Nordeste da Província Borborema

\section{LISTA DE FIGURAS}

Figura 1.1 - Reconstituição pré-deriva mesozóica entre América do Sul, África, Madagascar e parte da Índia.

Figura 1.2 - Mapa de localização da área de estudo mostrando as principais cidades e vias de acesso.

Figura 1.3 - Esboço geológico regional da Província Borborema apresentando as principais unidades tectonoestratigráficas e a localização da área de estudo ...................... 8

Figura 1.4 - Mapa preliminar dos terrenos tectonoestratigráficos da Província Borborema ......... 9

Figura 1.5 - Arcabouço geral dos Maciços São José do Campestre e Caldas Brandão................ 15

Figura 2.1 - Mapa geológico da África Centro-Ocidental comparado ao mapa de anomalias Bouguer.....

Figura 2.2 - Diagramas mostrando um modelo em seção vertical da litosfera baseado nas anomalias gravimétricas Bouguer, residuais e ondas telesísmicas

Figura 2.3 - Mapas de anomalias Bouguer da África e do Brasil combinados 
Figura 2.4a - Imagem das anomalias Bouguer para Madagascar (África) e localização das estações e perfis gravimétricos............................................................................. 36

Figura 2.4b - Mapa de anomalias gravimétricas residuais para o Quênia (África) ..................... 36

Figura 2.5 - Mapa esquemático dos lineamentos da deformação dúctil brasiliana do Setor Central da Província Borborema.

Figura 2.6 - Mapa de anomalias gravimétricas residuais para o Nordeste Setentrional do Brasil e Margem Continental Adjacente.

Figura 2.7 - Mapa de anomalias gravimétricas residuais da Porção Oriental da Faixa Seridó ....

Figura 2.8 - Mapa do contraste de susceptibilidade da América do Sul assumindo uma camada crustal magnetizada de $40 \mathrm{~km}$.

Figura 2.9 - Correlação das anomalias magnéticas para a América do Sul e África numa reconstrução pré-deriva mesozóica ............................................................................. 50

Figura 3.1 - Representação da operação de convolução por filtro de média quadrada $3 \times 3 \ldots \ldots .58$

Figura 3.2 - Diagrama da atenuação dos componentes de comprimentos de onda das anomalias causadas por efeitos combinados das profundidades das fontes e o limite de

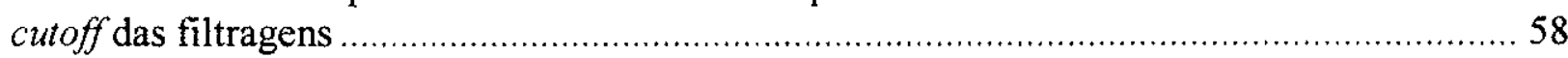

Figura 3.3 - Mapa de localização das estações gravimétricas ............................................ 67

Figura 3.4 - Mapa topográfico digital com pseudo-iluminação de Az $120^{\circ}$ para o Setor Extremo Nordeste da Província Borborema

Figura 3.5 - Modelo topográfico digital combinado às anomalias gravimétricas Ar-Livre ..... 70

Figura 3.6 - Mapa de anomalias Bouguer para o Setor Extremo Nordeste da Província Borborema

Figura 3.7 - Mapa de anomalias de intensidade magnética total-DGRF para o Setor Extremo Nordeste da Província Borborema ................................................................... 74

Figura 4.1 - Arcabouço geológico para o Setor Extremo Nordeste da Província Borborema...... 80

Figura 4.2 - Mapa esquemático dos lineamentos da deformação dúctil brasiliana do Setor Nordeste da Província Borborema

Figura 4.3 - Mapa esquemático da localização, distribuição geométrica e cinemática das principais zonas de cisalhamento brasilianas $e$ os limites dos terrenos tectonoestratigráficos no Setor Nordeste da Província Borborema ................................... 83

Figura 4.4 - Dados geocronológicos do Maciço São José do Campestre .................................. 90

Figura 4.5 - Arcabouço geológico da região entre Taipu e lelmo Marinho (RN) .....................106

Figura 4.6 - Relações mesoscópicas entre as fases de dobramento $F_{3}$ e $F_{2}$ em zonas de deformação tangencial

Figura 4.7 - Mapa geológico simplificado da porção central da faixa de metassedimentos de Barra de Santa Rosa e zona de cisalhamento Remígio-Pocinhos

Figura 4.8 - Relações mesoscópicas das variações na geometria das dobras da fase $\mathrm{F}_{3}$ em perfil a sudeste de Barra de Santa Rosa

Figura 4.9 - Mapa esquemático da localização, distribuição geométrica e cinemática dos sistema de zonas de cisalhamento brasilianas e faixas metassedimentares da Província Borborema

Figura 4.10 - Diagrama da largura $v s$. comprimento (ambos em $\mathrm{km}$ ) para as zonas de cisalhamento brasilianas

Figura 4.11 - Modelo hipotético para a deformação da litosfera continental

Figura 5.1 - Diagrama discriminante QP (Debon \& Lefort 1983).

Figura 5.2 - Diagramas de variação química dos óxidos de elementos maiores vs. $\mathrm{SiO}_{2}$

Figura 5.3 - Diagrama discriminate TAS com linha divisória de Irvine e Baragar (1971)

Figura 5.4 - Diagrama discriminante R1 vs. R2 (De La Roche 1980). 
Figura 5.5 - Curvas espectrais de reflectância para o conjunto de litologias do Setor Extremo Nordeste da Província Borborema

Figura 5.6 - Curvas espectrais de reflectância para a "Categoria A" de litologias do Setor Extremo Nordeste da Província Borborema

Figura 5.7 - Diagrama comparativo entre as assinaturas espectrais médias das rochas da suíte alcalina do plúton de Japi e dos principais componentes minerais félsicos.

Figura 5.8 - Diagrama comparativo entre as assinaturas espectrais médias das rochas da suíte alcalina do plúton de Algodão e dos principais componentes minerais félsicos

Figura 5.9 - Diagrama comparativo entre as assinaturas espectrais médias das rochas do plúton Pocinhos e dos principais componentes minerais máficos e félsicos

Figura 5.10 - Diagrama comparativo entre as assinaturas espectrais médias das rochas gnássico-migmatíticas do embasamento e dos principais componentes minerais máficos e félsicos.

Figura 5.11 - Curvas espectrais de reflectância para a "Categoria B" de litologias do Setor Extremo Nordeste da Província Borborema

Figura 5.12 - Diagrama comparativo entre as assinaturas espectrais médias dos micaxistos da Faixa de Metassedimentos de Barra de Santa Rosa e dos principais componentes minerais: granada, biotita e quartzo

Figura 5.13 - Diagrama comparativo entre as assinaturas espectrais médias das rochas da suíte porfirítica do plúton Jandaíra e dos principais componentes minerais máficos e félsicos.

Figura 5.14 - Diagrama comparativo entre as assinaturas espectrais médias das rochas do Complexo Campina Grande e dos principais componentes minerais máficos e félsicos.

Figura 5.15 - Diagramas comparativos da dispersão nos 20 conjuntos de bandas combinadas 3 x 3 do Landsat 5-TM para as "Categorias A e B".

Figura 5.16 - Diagrama de dispersão 2-D comparativo dos quatro melhores conjuntos de trios de bandas do Landsat 5-TM (1-2-5, 1-3-5, 1-3-7 e 2-3-5)

Figura 5.17 - Imagem da composição colorida das bandas 5-2-1 do Landsat 5-TM combinadas em RGB

Figura 5.18 - Arcabouço geológico da região entre Barra de Santa Rosa e Campina Grande (PB) realizado a partir da integração das interpretações visuais das imagens obtidas nos tratamentos das bandas do Landsat 5-TM

Figura 5.19 - Imagem da composição colorida das bandas 5-3-1 do Landsat 5-TM combinadas em RGB para a porção central da Faixa de Metassedimentos de Barra de Santa Rosa e da zona de cisalhamento de Remígio-Pocinhos.

Figura 5.20 - Arcabouço geológico interpretado visualmente a partir da imagem colorida das bandas 5-3-1 do Landsat 5-TM combinadas em RGB (Figura 5.19).

Figura 5.21 - Imagem da composição colorida das bandas 5-3-1 do Landsat 5-TM combinadas em RGB para a região entre Japi, Monte das Gameleiras e a porção norte da Faixa de Metassedimentos de Barra de Santa Rosa

Figura 5.22 - Arcabouço geológico interpretado visualmente a partir da imagem colorida das bandas 5-3-1 do Landsat 5 - TM combinadas em RGB (Figura 5.21).

Figura 5.23 - Imagem da composição colorida das bandas 7-5-2 do Landsat 5-TM combinadas em RGB

Figura 5.24 - Imagem da composição colorida das bandas 7-5-3 do Landsat 5-TM combinadas em RGB

Figura 5.25 - Imagem da composição colorida das bandas 7-5.2 do Landsat 5-TM combinadas em RGB para a região da Faixa de Metassedimentos de Barra de Santa Rosa, zona de cisalhamento Remígio-Pocinhos e granitóide Pocinhos..... 
Figura 5.26 - Arcabouço geológico interpretado visualmente a partir da imagem colorida das bandas 7-5-2 do Landsat 5-TM combinadas em RGB (Figura 5.25).

Figura 5.27 - Imagem da composição colorida das principais componentes PC1-PC2-PC3 das 6 bandas não-termais do Landsat 5-TM combinadas em RGB

Figura 5.28 - Diagramas comparativos da' dispersão nos 13 conjuntos de razões de bandas do Landsat 5-TM

Figura 5.29 - Imagem da composição colorida das razões de bandas 5/7-5/3-7/4 combinadas em RGB

Figura 5.30 - Imagem da composição colorida das bandas 5-4-3 do Landsat 5-TM combinadas em IHS.

Figura 5.31 - Imagem da composição colorida em HRGB derivada das combinações em IHS dos trios 7-5-2, 5-4-3 e 5-4-2.

Figura 6.1 - Zoneamento metamórfico simplicado referente ao Evento Brasiliano combinado ao mapa geológico esquemático do Setor Extremo Nordeste da Província Borborema.

Figura 6.2 - Diagrama petrogenético P-T calibrado no sistema KFMASH para os metapelitos

Figura 6.3 - Diagramas de projeção AFM de Thompson (1957) representando as assembléias minerais nos metapelitos de pressão baixa a intermediária

Figura 7.1 - Mapa de anomalias gravimétricas obtidas a partir de filtragem no domínio da freqüência com filtro passa-banda que permite a passagem de $80 \mathrm{~km}<\lambda<250 \mathrm{~km}$ e rejeita $\lambda>600 \mathrm{~km}$ e $\lambda<30 \mathrm{~km}$.

Figura 7.2 - Mapa de anomalias gravimétricas obtidas a partir de filtragem no domínio da freqüência com filtro passa-baixa que permite a passagem de $\lambda>250 \mathrm{~km}$ e rejeita $\lambda<$ $10 \mathrm{~km}$

Figura 7.3 - Mapa de anomalias gravimétricas obtidas a partir de filtragem em continuação para cima de $13 \mathrm{~km}$....

Figura 7.4 - Mapa de anomalias gravimétricas obtidas a partir de filtragem em continuação para cima de $1 \mathrm{~km}$

Figura 7.5 - Mapa de anomalias gravimétricas obtidas a partir de filtragem no domínio da freqüência com filtro passa-alta que permite a passagem de $\lambda<50 \mathrm{~km}$ e rejeita $\lambda>$ $250 \mathrm{~km}$

Figura 7.6 - Mapa de anomalias gravimétricas obtidas a partir de filtragem no domínio da frequência com filtro passa-alta que permite a passagem de $\lambda<30 \mathrm{~km}$ e rejeita $\lambda>$ $250 \mathrm{~km}$

Figura 7.7 - Mapa de anomalias gravimétricas obtidas a partir de filtragem no domínio da freqüencia com filtro passa-alta que permite a passagem de $\lambda<30 \mathrm{~km}$ e rejeita $\lambda>50$ $\mathrm{km}$

Figura 7.8 - Mapa de anomalias gravimétricas obtidas a partir de filtragem no domínio da freqüência com filtro passa-alta que permite a passagem de $\lambda<10 \mathrm{~km}$ e rejeita $\lambda>$ $30 \mathrm{~km}$

Figura 7.9 - Mapa de anomalias gravimétricas obtidas a partir da filtragem no domínio espaço-temporal com filtro quadrado de $\lambda=200 \mathrm{~km}$

Figura 7.10 - Mapa de anomalias gravimétricas obtidas a partir da filtragem no domínio espaço-temporal com filtro quadrado de $\lambda=50 \mathrm{~km}$

Figura 7.11 - Mapa de anomalias gravimétricas obtidas a partir da filtragem no domínio espaço-temporal com filtro quadrado de $\lambda=40 \mathrm{~km}$

Figura 7.12 - Mapa de anomalias gravimétricas obtidas a partir da filtragem no domínio espaço-temporal com filtro quadrado de $\lambda=30 \mathrm{~km}$ 
Figura 7.13 - Mapa de anomalias gravimétricas obtidas a partir da filtragem no domínio espaço-temporal com filtro quadrado de $\lambda=20 \mathrm{~km}$.

Figura 7.14 - Mapa de anomalias gravimétricas obtidas a partir da filtragem no domínio espaço-temporal com filtro quadrado de $\lambda=10 \mathrm{~km}$.

Figura 7.15 - Mapa de anomalias gravimétricas obtidas a partir da filtragem no domínio espaço-temporal com filtro quadrado de $\lambda=5 \mathrm{~km}$

Figura 7.16 - Mapa de anomalias gravimétricas obtidas a partir da filtragem no domínio espaço-temporal com filtro quadrado de $\lambda=1 \mathrm{~km}$

Figura 7.17 - Mapa de anomalias gravimétricas obtidas a partir do resíduo da filtragem no domínio espaço-temporal com filtro quadrado de $\lambda=200 \mathrm{~km}$

Figura 7.18 - Mapa de anomalias gravimétricas obtidas a partir do resíduo da filtragem no domínio espaço-temporal com filtro quadrado de $\lambda=50 \mathrm{~km}$

Figura 7.19 - Mapa de anomalias gravimétricas obtidas a partir do resíduo da filtragem no domínio espaço-temporal com filtro quadrado de $\lambda=40 \mathrm{~km}$

Figura 7.20 - Mapa de anomalias gravimétricas obtidas a partir do resíduo da filtragem no domínio espaço-temporal com filtro quadrado de $\lambda=30 \mathrm{~km}$.

Figura 7.21 - Mapa de anomalias gravimétricas obtidas a partir do resíduo da filtragem no domínio espaço-temporal com filtro quadrado de $\lambda=20 \mathrm{~km}$.

Figura 7.22 - Mapa de anomalias gravimétricas obtidas a partir do resíduo da filtragem no domínio espaço-temporal com filtro quadrado de $\lambda=10 \mathrm{~km}$.

Figura 7.23 - Sistema de lineamentos extraídos do mapa de relevo sombreado dos gradientes da intensidade magnética total-DGRF.

Figura 7.24 - Mapa de anomalias aeromagnéticas obtidas a partir de filtragem no domínio da freqüência com filtro passa-banda que permite a passagem de $80 \mathrm{~km}<\lambda<250 \mathrm{~km}$ e rejeita $\lambda>600 \mathrm{~km}$ e $\lambda<30 \mathrm{~km}$.

Figura 7.25 - Mapa de anomalias aeromagnéticas obtidas a partir de filtragem no domínio da freqüência com filtro passa-alta que permite a passagem de $\lambda<50 \mathrm{~km}$ e rejeita $\lambda>$ $250 \mathrm{~km}$

Figura 7.26 - Mapa de anomalias aeromagnéticas obtidas a partir de filtragem no dominio da frequência com filtro passa-alta que permite a passagem de $\lambda<30 \mathrm{~km}$ e rejeita $\lambda>$ $50 \mathrm{~km}$

Figura 7.27 - Mapa de anomalias aeromagnéticas obtidas a partir de filtragem no domínio da freqüência com filtro passa-alta que permite a passagem de $\lambda<10 \mathrm{~km}$ e rejeita $\lambda\rangle$ $30 \mathrm{~km}$

Figura 7.28 - Mapa de anomalias aeromagnéticas obtidas a partir da filtragem no domínio espaço-temporal com filtro quadrado de $\lambda=50 \mathrm{~km}$

Figura 7.29 - Mapa de anomalias aeromagnéticas obtidas a partir da filtragem no domínio espaço-temporal com filtro quadrado de $\lambda=40 \mathrm{~km}$

Figura 7.30 - Mapa de anomalias aeromagnéticas obtidas a partir da filtragem no domínio espaço-temporal com filtro quadrado de $\lambda=30 \mathrm{~km}$

Figura 7.31 - Mapa de anomalias aeromagnéticas obtidas a partir da filtragem no domínio espaço-temporal com filtro quadrado de $\lambda=20 \mathrm{~km}$

Figura 7.32 - Mapa de anomalias aeromagnéticas obtidas a partir da filtragem no domínio espaço-temporal com filtro quadrado de $\lambda=10 \mathrm{~km}$

Figura 7.33 - Mapa de anomalias aeromagnéticas obtidas a partir da filtragem no domínio espaço-temporal com filtro quadrado de $\lambda=5 \mathrm{~km}$

Figura 7.34 - Mapa de anomalias aeromagnéticas obtidas a partir da filtragem no domínio espaço-temporal com filtro quadrado de $\lambda=1 \mathrm{~km}$ 
Figura 7.35 - Mapa de anomalias aeromagnéticas obtidas a partir do resíduo da filtragem no domínio espaço-temporal com filtro quadrado de $\lambda=50 \mathrm{~km}$.....

Figura 7.36 - Mapa do arcabouço geológico com a localização das seções geológicas e anomalias gravimétricas para a Porção Extremo Nordeste da Província Borborema

Figura 7.37 - Mapa do arcabouço geológico com a localização das seções geológicas e anomalias aeromagnéticas para a Porção Extremo Nordeste da Província Borborema

Figura 7.38 - Perfis integrados da anomalia Bouguer, da intensidade magnética totalDGRF e do esboço geológico simplificado para as seçőes BB', CC', DD' e EE'.....

Figura 7.39 - Perfis integrados das anomalias gravimétricas resultantes de filtragem no domínio da freqüência por filtros passa-banda e passa-alta e do esboço geológico simplificado para as seções $\mathrm{AA}^{\prime}, \mathrm{BB}^{\prime}, \mathrm{CC}^{\prime}, \mathrm{DD}^{\prime}$ e $\mathrm{EE} \mathrm{E}^{\prime}$. O filtro passa-banda que permite a passagem de $80 \mathrm{~km}<\lambda<250 \mathrm{~km}$ e rejeita $\lambda>600 \mathrm{~km} \mathrm{e} \lambda<30 \mathrm{~km}$. O filtro passa-alta permite a passagem de $\lambda<30 \mathrm{~km}$ e rejeita $\lambda>50 \mathrm{~km}$

$284-285$

Figura 7.40 - Perfis integrados das anomalias gravimétricas resultantes de filtragem no domínio espaço-temporal por filtros quadrados de $\lambda=200 \mathrm{~km}$ e seu residual, de $\lambda=$ $50 \mathrm{~km}$ e seu residual, de $\lambda=40 \mathrm{~km}$ e seu residual, de $\lambda=30 \mathrm{~km}$ e seu residual, de $\lambda=$ $20 \mathrm{~km}$ e seu residual e de $\lambda=10 \mathrm{~km}$ e seu residual, e do esboço geológico simplificado para a seção AA'

Figura 7.41 - Perfis integrados das anomalias gravimétricas resultantes de filtragem no domínio espaço-temporal por filtros quadrados de $\lambda=200 \mathrm{~km}$ e seu residual, de $\lambda=$ $50 \mathrm{~km}$ e seu residual, de $\lambda=30 \mathrm{~km}$ e seu residual e de $\lambda=10 \mathrm{~km}$ e seu residual, e do esboço geológico simplificado para a seção BB'.

Figura 7.42 - Perfis integrados das anomalias gravimétricas resultantes de filtragem no domínio espaço-temporal por filtros quadrados de $\lambda=200 \mathrm{~km}$ e seu residual, de $\lambda=$ $50 \mathrm{~km}$ e seu residual, de $\lambda=30 \mathrm{~km}$ e seu residual e de $\lambda=10 \mathrm{~km}$ e seu residual, e do esboço geológico simplificado para a seção CC'.....

Figura 7.43 - Perfis integrados das anomalias aeromagnéticas resultantes de filtragem no domínio da frequêencia por filtros passa-banda e passa-alta e do esboço geológico simplificado da seção BB'. O filtro passa-banda que permite a passagem de $80 \mathrm{~km}<\lambda$ $<250 \mathrm{~km}$ e rejeita $\lambda>600 \mathrm{~km}$ e $\lambda<30 \mathrm{~km}$. Os filtros passa-alta permitem a passagem de $\lambda<50 \mathrm{~km}$ e rejeita $\lambda>250 \mathrm{~km} ; \lambda<30 \mathrm{~km}$ e rejeita $\lambda>50 \mathrm{~km} ; \lambda<10 \mathrm{~km}$ e rejeita $\lambda>$ $30 \mathrm{~km}$.

Figura 7.44 - Perfis integrados das anomalias aeromagnéticas resultantes de filtragem no domínio da frequêencia por filtros passa-banda e passa-alta e do esboço geológico simplificado da seção CC'. O filtro passa-banda que permite a passagem de $80 \mathrm{~km}<\lambda$ $<250 \mathrm{~km}$ e rejeita $\lambda>600 \mathrm{~km}$ e $\lambda<30 \mathrm{~km}$. Os filtros passa-alta permitem a passagem de $\lambda<50 \mathrm{~km}$ e rejeita $\lambda>250 \mathrm{~km} ; \lambda<30 \mathrm{~km}$ e rejeita $\lambda>50 \mathrm{~km} ; \lambda<10 \mathrm{~km}$ e rejeita $\lambda>$ $30 \mathrm{~km}$

Figura 7.45 - Perfis integrados das anomalias aeromagnéticas resultantes de filtragem no domínio da freqüência por filtros passa-banda e passa-alta e do esboço geológico simplificado da seção EE'. O filtro passa-banda que permite a passagem de $80 \mathrm{~km}<\lambda<$ $250 \mathrm{~km}$ e rejeita $\lambda>600 \mathrm{~km}$ e $\lambda<30 \mathrm{~km}$. Os filtros passa-alta permitem a passagem de $\lambda<50 \mathrm{~km}$ e rejeita $\lambda>250 \mathrm{~km} ; \lambda<30 \mathrm{~km}$ e rejeita $\lambda>50 \mathrm{~km} ; \lambda<10 \mathrm{~km}$ e rejeita $\lambda>$ $30 \mathrm{~km}$.

Figura 7.46 - Perfis integrados das anomalias aeromagnéticas resultantes da filtragem no domínio espaço-temporal por filtros quadrados de comprimento de onda de $50 \mathrm{~km}$ e seu residual, de $30 \mathrm{~km}, 10 \mathrm{~km}, 5 \mathrm{~km}$ e do esboço geológico para a seção $\mathrm{BB}^{\prime}$ 
Figura 7.47 - Perfis integrados das anomalias aeromagnéticas resultantes da filtragem no domínio espaço-temporal por filtros quadrados de comprimento de onda de $50 \mathrm{~km}$ e seu residual, de $30 \mathrm{~km}, 10 \mathrm{~km}, 5 \mathrm{~km}$ e do esboço geológico para a seção CC'.

Figura 7.48 - Perfis integrados das anomalias aeromagnéticas resultantes da filtragem no domínio espaço-temporal por filtros quadrados de comprimento de onda de $50 \mathrm{~km}$ e seu residual, de $30 \mathrm{~km}, 10 \mathrm{~km}, 5 \mathrm{~km}$ e do esboço geológico para a seção EE'

Figura 7.49 - Arcabouço geológico da região costeira de Natal/RN com indicações das principais falhas inferidas da análise dos mapas gravimétricos residuais

Figura 7.50 - Mapa de anomalias gravimétricas da região costeira de Natal/RN obtidas a partir de filtragem no domínio da freqüência com filtro passa-alta que permite a passagem de $\lambda<30 \mathrm{~km}$ e rejeita $\lambda>250 \mathrm{~km}$

Figura 7.51 - Mapa de anomalias gravimétricas da região costeira de Natal/RN obtidas a partir de filtragem no domínio da freqüência com filtro passa-alta que permite a passagem de $\lambda<30 \mathrm{~km}$ e rejeita $\lambda>50 \mathrm{~km}$.

Figura 7.52 - Mapa de anomalias gravimétricas da região costeira de Natal/RN obtidas a partir do resíduo de filtragem no domínio espaço-temporal com filtro quadrado de $\lambda=$ $20 \mathrm{~km}$

Figura 7.53 - Mapa de anomalias gravimétricas da região costeira de Natal/RN obtidas a partir de filtragem no domínio da freqüência com filtro passa-alta que permite a passagem de $\lambda<10 \mathrm{~km}$ e rejeita $\lambda>30 \mathrm{~km}$

Figura 7.54 - Mapa de anomalias gravimétricas da região costeira de Natal/RN obtidas a partir do resíduo de filtragem no domínio espaço-temporal com filtro quadrado de $\lambda=$ $10 \mathrm{~km}$

Figura 7.55 - Mapa de lineamentos gravimétricos de contorno zero realizado com base na imagem da Figura 7.51

Figura 7.56 - Mapa de lineamentos gravimétricos de contorno zero realizado com base nas imagensdas Figura 7.52 e 7.53

Figura 7.57 - Mapa de lineamentos gravimétricos de contorno zero realizado com base na imagem da Figura 7.54

Figura 7.58 - Mapa esquemático de lineamentos da deformação frágil tardi- a pósbrasiliana do Setor Extremo Nordeste da Província Borborema, para os lineamentos com orientações entre $\mathrm{N} 15^{\circ} \mathrm{E}$ e $\mathrm{N} 80^{\circ} \mathrm{E}$

Figura 7.59 - Mapa esquemático de lineamentos da deformação frágil tardi- a pósbrasiliana do Setor Extremo Nordeste da Província Borborema, para os lineamentos com orientações entre $\mathrm{N} 15^{\circ} \mathrm{W}$ e $\mathrm{N} 70^{\circ} \mathrm{W}$

Figura 7.60 - Mapa esquemático de lineamentos da deformação frágil tardi- a pósbrasiliana do Setor Extremo Nordeste da Província Borborema, para os lineamentos com orientações próximas a NS e entre $\mathrm{N} 85^{\circ} \mathrm{E}$ e EW

Figura 7.61 - Conjunto de rosáceas para os enxames de lineamentos topográficos do Setor Extremo Nordeste da Província Borborema

Figura 7.62 - Conjunto de pétalas com trend geral NE para o Setor Extremo Nordeste da Província Borborema

Figura 7.63 - Conjunto de pétalas com trend geral NW para o Setor Extremo Nordeste da Província Borborema...

Figura 7.64 - Rosáceas dos lineamentos de contorno zero dos mapas gravimétricos residuais comparados à rosácea dos lineamentos referentes às estruturas frágeis

Figura 7.65 - Mapa geológico simplificado da Faixa Litorânea Oriental do Estado do Rio Grande do Norte, entre as cidades de Natal e Baía Formosa 
Figura 7.66 - Seções geológicas transversais aos principais vales da Faixa Litorânea entre Natal e Baía Formosa $(\mathrm{RN})$.

Figura 8.1 - Modelos analógicos para os padrões de deformação da litosfera continental composta por 3 camadas (Ricard \& Froidevaux 1986).

Figura 8.2 - Seção crustal esquemática para a região dos blocos arqueanos do MSJC ao final do Ciclo Brasiliano.

Figura 8.3 - Modelo numérico para o comportamento mecânico da litosfera continental de parte da Província Borborema (Tommasi 1995).

Figura 8.4 - Seção crustal esquemática para o MSJC-MCB ao final do Ciclo Brasiliano ...........342

Figura 8.5 - Esquema da distribuição e canalização dos fluidos pelas zonas de cisalhamentos brasilianas na crosta continental do MSJC-MCB, com base na proposta de Etheridge et al. (1983) e Pili (1997)

\section{LISTA DE FOTOGRAFIAS}

Foto 4.1 - Mosaico de imagens em composição colorida RGB das bandas 2-3-4 do Landsat 5-TM para o setor Centro-Oriental da Província Borborema

Foto 4.2 - Ortognaisses do embasamento com diques básicos anfibolitizados pré- $\mathrm{D}_{2} \ldots \ldots \ldots \ldots \ldots 92$

Foto 4.3a-4.3b - Aspecto geral dos ortognaisses do embasamento paleoproterozóico............... 92 Foto 4.4 - Remobilizados graníticos na foliação composta $S_{2} \pm S_{1} \ldots \ldots \ldots \ldots \ldots \ldots \ldots \ldots \ldots \ldots \ldots \ldots . . \ldots 2$

Foto 4.5 - Aspecto geral do padrão de interferência do tipo de interferência do tipo bumerangue entre dobras $\mathrm{F}_{3}$ e $\mathrm{F}_{2}$.

Foto 4.6a-4.6b - Aspecto geral dos gnaisses do embasamento

烈

Foto 4.7 - Gnaisses tonalíticos do embasamento afetados pelo fabric $\mathrm{D}_{3}$. ............................. 94

Foto 4.8 - Migmatitos bandados do embasamento interceptados por zonas de cisalhamento

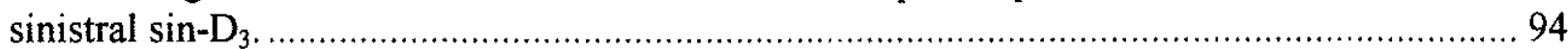

Foto 4.9a-4.9c - Aspecto geral do gnaisse diorítico a granodiorítico do embasamento migmatizado e milonitizado na ZCSE .................................................................... 96

Foto 4.10 - Aspecto em seção vertical do embasamento gnáissico migmatizado na ZCSE ......... 96

Foto 4.11a-4.11b - Aspecto geral do gnaisse granodiorítico do embasamento envolvido

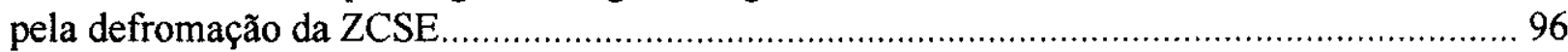

Foto 4.12a-4.12e - Aspectos do granitóide Serrinha de composição dominantemente

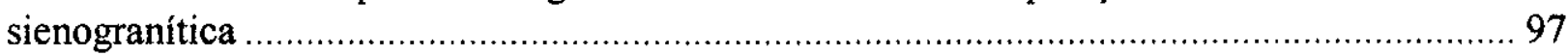

Foto 4.13a-4.13e - Gnaisses tonalíticos do embasamento afetado pelo fabric $\mathrm{D}_{3}$ sob

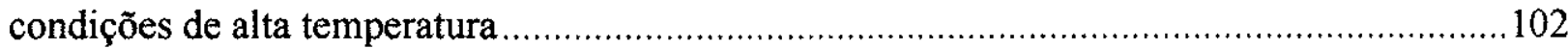

Foto 4.14a-4.14d - Aspecto geral dos xenólitos e enclaves nos granitóides Pitombeira e Taipu.

Foto 4.15 - Veios de quartzo $\sin -\mathrm{D}_{3}$ em micaxistos miloníticos de alta temperatura .................112

Foto 4.16a-4.16b - Aspecto geral dos micaxistos da Faixa de Metassedimentos de Barra de Santa Rosa e da ZCRP .

Foto 4.17 - Porfiroclasto rotacionado dextral de K-feldspato com cauda de recristalização do tipo- $\delta$ em micaxistos migmatizados e ultramilonitizados na ZCRP

Foto 4.18 - Estruturas S-C, C', veios de quartzo e de neossomas com granada boudinados e sigmoidais com cinemática dextral em micaxistos migmatizados e milonitizados.

Foto 4.19 - Veio de leucogranito boudinado sigmoidal dextral em micaxistos migmatizados e milonitizados na ZCRP

Foto 4.20 - Paragnaisses com porfiroclastos de feldspatos e agregados quartzo-feldspáticos com cinemática dextral 
Foto 4.21 - Aspecto geral e de detalhe dos afloramentos do granitóide Pocinhos ....................119

Foto 4.22a-4.22d - Aspecto geral e de detalhe dos afloramentos do CCG ..............................120

Foto 4.22e-4.22i - Aspecto geral e de detalhe dos afloramentos do CCG ..............................122

Foto 4.23a-4.23c - Aspecto geral e de detalhe do granitóide Areia ..................................... 124

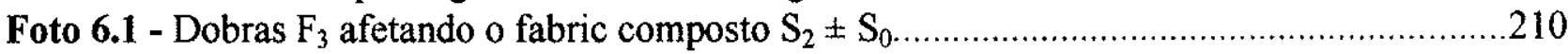

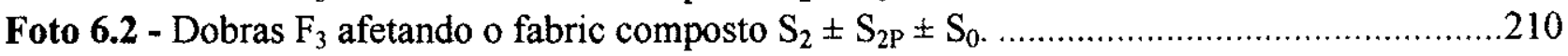

Foto 6.3a-6.3b - Aspecto geral de metassedimentos e gnaisses migmatizados e

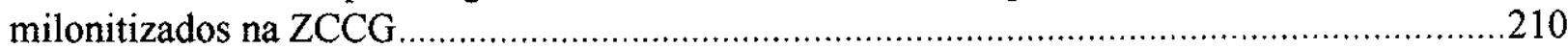

Foto 6.4 - Gnaisses bandados do embasamento migmatizados e milonitizados na ZCCG.........210

Foto 6.5 - Veios pegmatíticos sintectônicos boudinados e rotacionados com cinemática

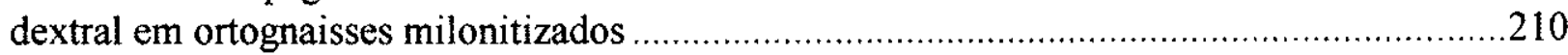

Foto 6.6 - Crescimento de clorita nos necks dos porfiroblastos de granada $\sin -\mathrm{D}_{3}$. .................219

Foto 6.7 - Crescimento de granada tardi- $\mathrm{D}_{3}$ em micaxistos miloníticos

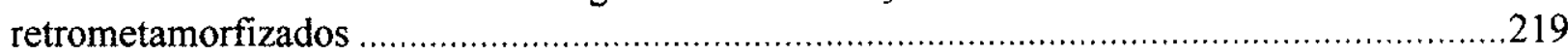

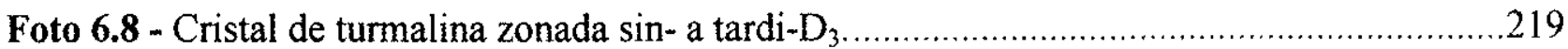

Foto 6.9 - Poiquiloblastos de estaurolita englobando cristais de granada + muscovita +

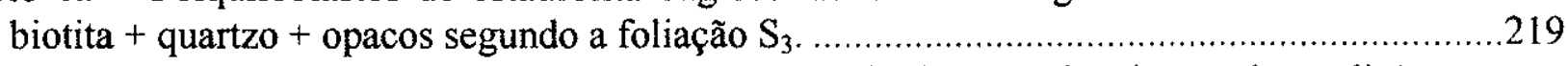

Foto 6.10 - Porfiroblastos sintectônicos dextrais de cordierita em micaxistos sob condições

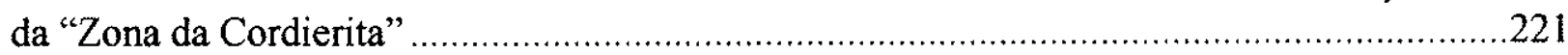

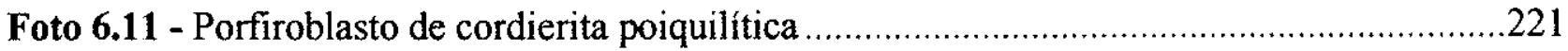

Foto 6.12 - Porfiroblastos sigmoidais sintectônicos dextrais de cordierita sob condições da "Zona Superior da Sillimanita".

Foto 6.13 - Porfiroblasto de andaluzita em micaxistos sob condições da "Zona da Andaluzita".....

Foto 6.14 - Porfiroblastos sintectônicos dextrais de andaluzita em micaxistos sob condições de transição entre a "Zona da Andaluzita" e a "Zona da Sillimanita"....................221

Foto 6.15 - Porfiroblasto sintectônico dextral de cordierita .................................................221

Foto 6.16a-6.16b - Porfiroblastos de andaluzita em micaxistos sob condições de transição entre a "Zona da Andaluzita" e a "Zona da Sillimanita".

Foto 6.17 - Crescimento de fibrolita associada a biotita vermelha ao redor e nas sombras de pressão de porfiroblastos de granada sintectônica

Foto 6.18 - Micaxistos sob condições da "Zona da Sillimanita" 225 nas sombras de pressão

.225

Foto 6.20 - Porfiroblasto sintectônico dextral de andaluzita em micaxistos migmatíticos......

Foto 6.21 - Cristal de ortopiroxênio como fase estável com hornblenda marrom-verde e biotita vermelha...

Foto 6.22 - aspecto de gnaisse do embasamento milonitizado sob condições do fácies granulito de pressão baixa a intermediária.

Foto 6.23 - Cristal de ortopiroxênio em paragênese típica do fácies granulito.

Foto 6.24 - Aspecto do ganisse do embasamento envolvido pela ZCRP com início de fusão

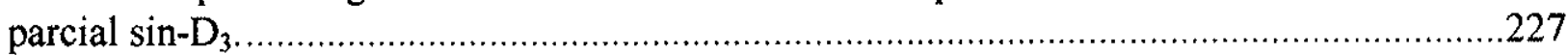

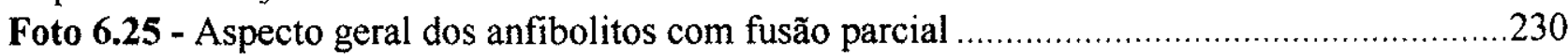

Foto 6.26 - Veios pegmatíticos sin-D3 com K-feldspato translúcido e turmalina .....................230

Foto 6.27 - Veio pegmatítico sin-D3 que intercepta micaxistos migmatíticos milonitizados

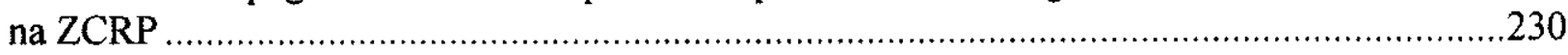

Foto 6.28 - Aspecto geral dos micaxistos migmatíticos milonitizados na ZCRP ......................230

Foto 6.29 - Micaxistos migmatíticos sob condições da "Zona Superior da Sillimanita".............230 
Foto 6.30 - Aspecto geral dos micaxistos migmatíticos milonitizados na ZCRP sob condições da "Zona Superior da Sillimanita"

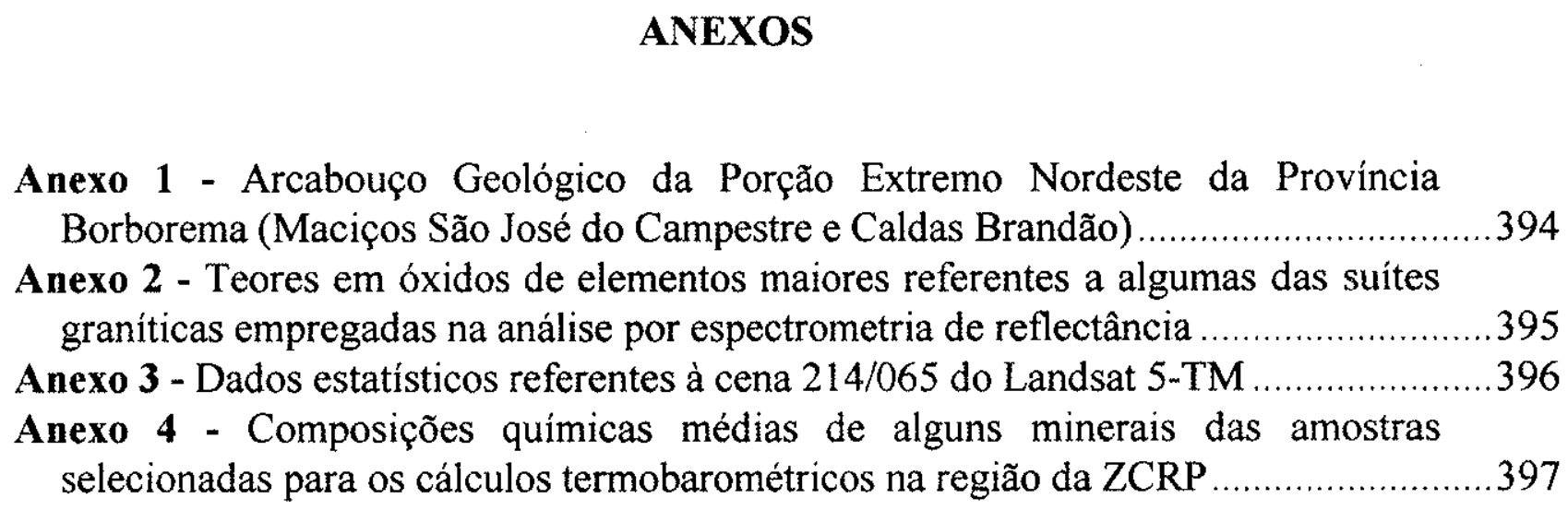




\section{1 - CONSIDERAÇÕES INICIAIS E PROPOSIÇÃO DO PROBLEMA}

\section{1 - Principais Objetivos e Justificativa da Investigação Proposta}

No Setor Extremo Nordeste da Província Borborema, o arranjo cinemático de zonas de cisalhamento de escala litosférica, desenvolvido durante a orogênese Brasiliana, promoveu a instauração de domínios transtracionais e extensionais sobre o substrato siálico composto dominantemente de rochas gnáissico-migmatíticas do Arqueano $\mathrm{e}$ Paleoproterozóico (Dantas et al. 1997). A configuração dessas estruturas denota uma integração geométrica com os sistemas de zonas de cisalhamento em regimes transpressional e transtracional nas porções Norte (Faixa Seridó) e Central (Domínio da Zona Transversal) da Província Borborema, respectivamente. A disposição geográfica desse sistema intracontinental de zonas de cisalhamento dúcteis sugere conexão com aquele na África Ocidental, numa reconstituição paleotectônica do Gondwana (Fig. 1.1). A deformação transtracional e extensional dominantes exerceram controle sobre a geometria de faixas de rochas supracrustais (p.ex. a faixa de micaxistos de Barra de Santa Rosa e Taipu-Ielmo Marinho), concomitante às condições de alta temperatura e baixa pressão do metamorfismo no fácies granulito, com extensiva migmatização e granitogênese. A variedade de suítes graníticas relacionadas às extensas zonas de cisalhamento dúcteis, com regimes combinados transcorrente e extensional, sugere o envolvimento de fontes mantélicas enriquecidas e/ou metassomatizadas canalizadas pelas zonas de cisalhamento que alcançariam profundidades do manto litosférico.

O objetivo principal da presente investigação é a análise e a integração de dados multiespectrais de sensoriamento remoto (Landsat 5-TM e GEMS/Banda X) e dados geofísicos (gravimétricos e aeromagnéticos) por métodos de processamento digital de imagens, como contribuição à cartografia geológica de reconhecimento e de semi-detalhe nesse setor da Província Borborema. O contexto geográfico desses terrenos, com amplas exposições incluídas no semi-árido do Nordeste do Brasil, favoreceram o emprego do aspecto sinóptico e multiespectral das imagens do Landsat 5-TM no aperfeiçoamento do mapeamento das unidades litoestratigráficas, com ênfase no zoneamento tectonometamórfico e na diferenciação das suites granitóides. Na abordagem estatística de seleção das composições coloridas de bandas do Landsat 5-TM com melhores desempenhos 


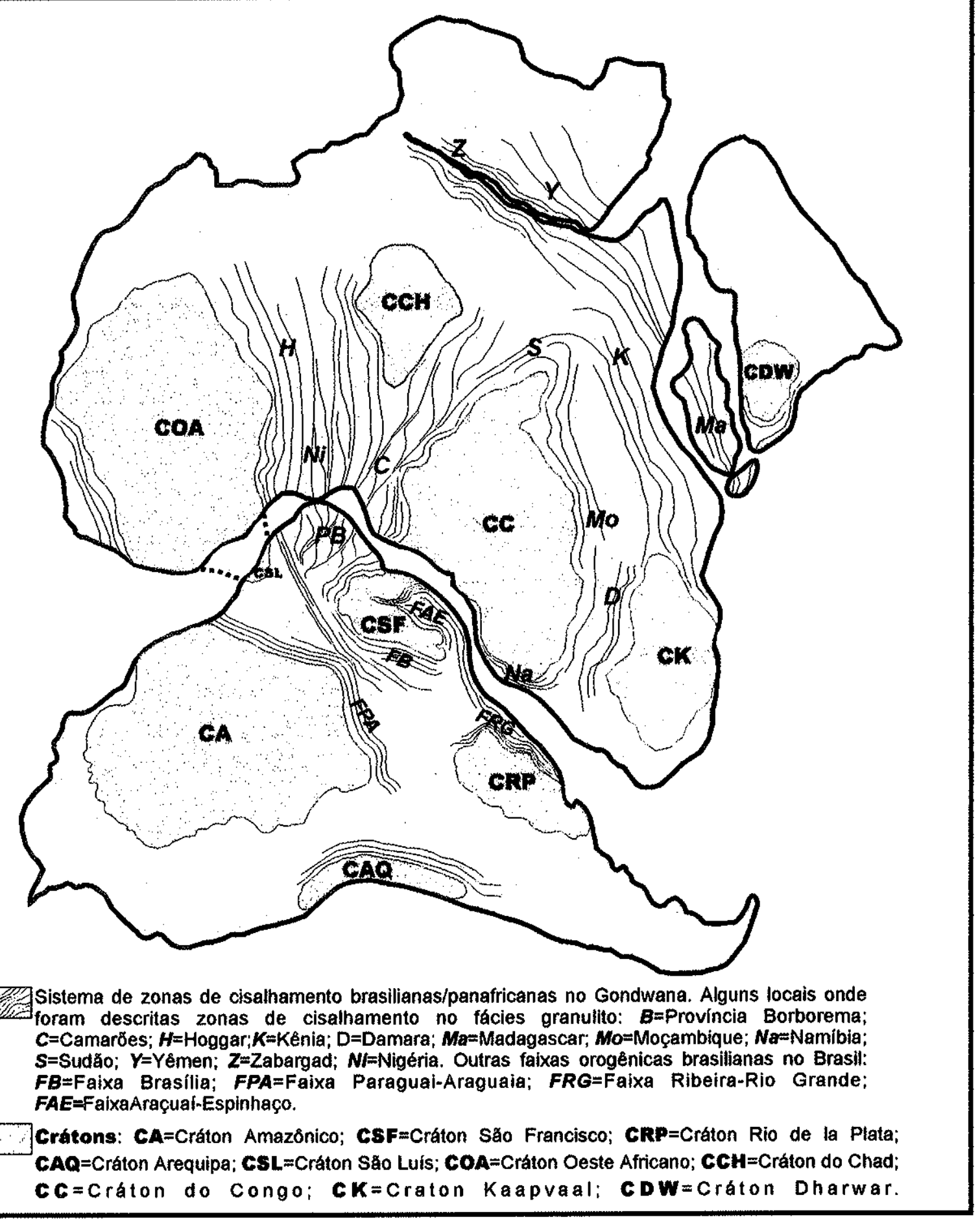

Figura 1.1 - Reconstituição pré-deriva mesozóica entre a América do Sul, África, Madagascar e Índia, integrantes do supercontinente Gondwana, mostrando as correlaçðes da rede intercontinental de zonas de cisalhamento brasilianas/pan-africanas contornando os principais crátons arqueanos a paleoproterozóicos. As faixas orogênicas brasilianas/pan-africanas com zonas de cisalhamento no fácies granulito foram destacadas. Modificado de Caby et al. (1991) e Jardim de Sá (1994). 
na diferenciação litológica e no estabelecimento das relações deformacionais, foram consideradas as assinaturas espectrais de amostras-de-mão representativas de algumas das principais unidades litológicas da área de estudo. Os espectros de reflectância demonstraram estreita correlação com os dados mineralógicos e geoquímicos de elementos maiores das suites granitóides analisadas, justificando a utilização dos espectros como elementos de distinção entre rochas com afinidades petrográficas e químicas semelhantes. Os resultados confirmaram a aplicabilidade do método às imagens Landsat 5-TM como incremento ao mapeamento geológico na região entre Barra de Santa Rosa e Campina Grande, sugerindo a extensão dos procedimentos para outros setores. Nesta região, uma estimativa termobarométrica foi realizada para o ápice do evento tectometamórfico no Brasiliano, responsável pelas condições de alta temperatura e baixa pressão (alta-T/baixa-P) contemporâneas à instalação de zonas de cisalhamento dúcteis no fácies granulito com ampla migmatização dos terrenos gnáissicos e metassedimentares, acompanhado de granitogênese alcalina e subalcalina.

Nos tratamentos dos dados geofísicos foram efetuados os realces de anomalias regionais e residuais, indicadoras de fontes em diferentes profundidades da litosfera, obtidas pela filtragem dos dados de anomalia Bouguer e intensidade magnética total-DGRF. Os métodos de filtragens empregados envolveram comprimentos de onda variados nos domínios da freqüência e espaço-temporal. A análise combinada entre as assinaturas gravimétricas e aeromagnéticas e os elementos estruturais da deformação brasiliana permitiu a caracterização de diferentes blocos crustais e/ou litosféricos delimitados por zonas de cisalhamento dúcteis com raizes mantélicas.

O emprego dessas técnicas combinado aos dados de campo, especialmente os dados estruturais, à análise cinemática e às estimativas das condições metamórficas (P-T-t), conduziram a algumas sugestões sobre a modelagem da estruturação crustal e litosférica da região, reflexo das deformações proterozóicas. A interpretação integrada desses dados, com vantagens sobre os mesmos métodos de investigação isolados e a exemplo de terrenos proterozóicos e arqueanos em outros continentes, concentrou-se no realce das feiçðes relevantes à interpretação geodinâmica do arranjo estrutural bidimensional e tridimensional da crosta continental no Brasiliano. 


\section{2 - Localização da Área e Aspectos Fisiográficos}

O estudo proposto envolve uma superfície com aproximadamente $28.000 \mathrm{~km}^{2}$ entre os estados do Rio Grande do Norte e Paraíba, circunscrita entre os paralelos $5^{\circ} 15^{\prime} 00^{\prime \prime}$ $7^{\circ} 30^{\prime} 00^{\prime \prime} \mathrm{S}$ e os meridianos $35^{\circ} 00^{\prime} 00^{\prime \prime}-36^{\circ} 15^{\prime} 00^{\prime \prime} \mathrm{W}$. Cidades como Natal/RN, Campina Grande/PB e Itabaiana/PB, entre as principais cidades da região Nordeste do Brasil, estão envolvidas pela área de estudo, como mostra a Fig. 1.2.

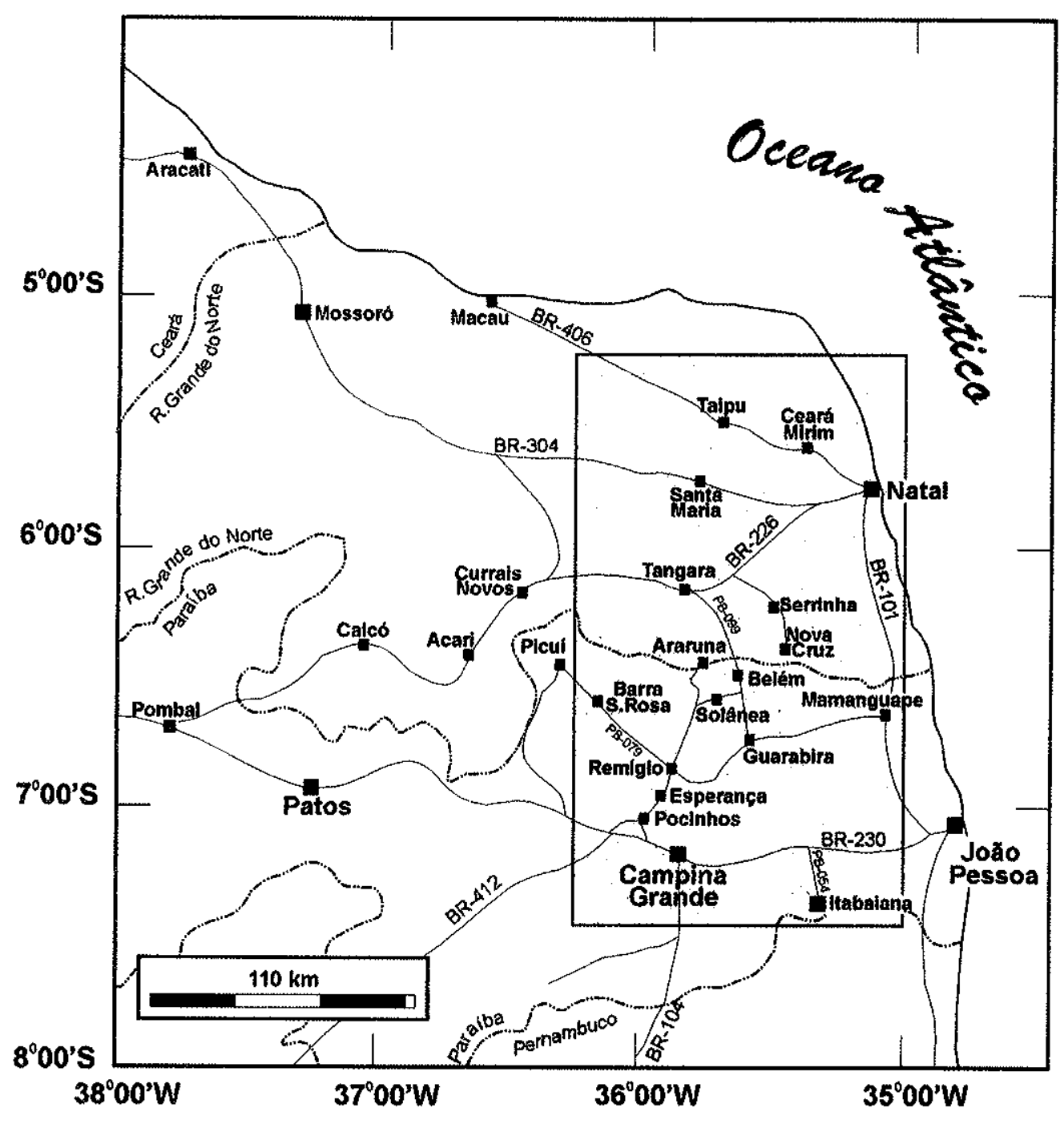

Figura 1.2 - Mapa de localização da área de estudo mostrando as principais cidades e vias de acesso.

$\mathrm{Na}$ área de estudo, os principais deslocamentos são realizados pelas rodovias federais e estaduais: (a) no setor norte pela BR-304 (Natal-Fortaleza) e BR-226 (NatalCurrais Novos); (b) no setor central pela BR-101 (Natal-João Pessoa), RN-003 (BR-101-São José do Campestre) ; (b) no setor sul pela BR-230 (João Pessoa-Patos), PB-054 (ItabaianaBR-230), PB-099 (Guarabira-São José do Campestre), PB-055 (Sapé-Guarabira), PB-079 
(Remígio-BR-230). Os demais setores são percorridos pelas estradas carroçáveis e trechos precários que interligam as pequenas cidades e vilas às estradas principais.

O clima semi-árido é dominante na região com temperaturas elevadas e escassez de chuvas. Entretanto, estão envolvidas quatro zonas fitogeográficas, diferenciadas desde a costa até o interior do continente: (a) a zona litorânea, onde dominam as coberturas arenosas (dunas e praias) e vegetação de palmeiras e combretáceas; (b) a zona da mata, onde a vegetação exuberante foi substituída por áreas de pastagens e canaviais, reduzida a pequenas áreas de preservação; (c) a zona do agreste, caracterizada por escassa vegetação de pequeno porte (mirtáceas, leguminosas e combretáceas) e solo pedregoso; (d) o sertão nordestino, com vegetação de caatinga, solo pedregoso e períodos prolongados de seca.

Os principais rios permanentes da área são os rios Potengi, Jundiai, Trairí, CearáMirim, Jacu e Curimataú no Estado do Rio Grande do Norte, e os rios Camaratuba, Mamanguape, Mirirí e Gurinhém e Paraíba no Estado da Paraiba, todos alimentados por cursos d'água secundários e intermitentes.

O relevo aplainado $(0-400 \mathrm{~m})$ domina a região, propiciando uma paisagem monótona interrompida por feições de inselbergs constituídos por rochas gnáissicomigmatíticas e plútons granitóides, e depressões com lagoas acompanhando os cursos dos rios. As maiores elevações $(400-720 \mathrm{~m})$ ocorrem na porção sudoeste da área, região da cidade de Campina Grande, onde predominam plútons granitóides envolvidos por largas e extensas faixas miloniticas.

Esse conjunto de feições permite uma distribuição favorável dos afloramentos nos setores interiores da área, em vastas exposições superficiais das principais unidades litológicas, por vezes recobertos por litossolos. Nos setores próximos às áreas costeiras, as freqüentes coberturas sedimentares meso-cenozóicas tornam os afloramentos mais esparsos.

\section{3 - Arcabouço Geotectônico}

\subsection{1 - Contexto Geodinâmico da Provincia Borborema}

A Província Borborema (Almeida et al. 1981), numa reconstrução pré-deriva mesozóica dos continentes sul-americano e africano, situa-se precisamente na junção entre os crátons Oeste Africano/São Luís e Congo/São Francisco (Fig. 1.1), envolvendo a maior parte dos terrenos do Nordeste do Brasil (Fig. 1.3). Os estudos sobre a continuidade dos 
terrenos da Provincia Borborema na África Ocidental evidenciaram similaridades com os aspectos evolutivos crustais dos escudos da Nigéria-Camarões e Hoggar (região denominada de Faixa Trans-Sahara, Cahen et al. 1984). As correlaçס̃es entre os terrenos da Faixa Borborema/Trans-Sahara sugerem a composição de uma complexa faixa colisional proterozóica gerada num contexto tectônico colisional-acrescionário (p.ex. Jardim de Sá et al. 1991, Brito Neves \& Cordani 1991, Caby et al. 1991). Esse contexto mecânico foi controlado por interações transcorrentes e oblíquas entre blocos litosféricos (incluindo os crátons Oeste Africano/São Luís e Congo/São Francisco), fragmentos de micro-continentes e terrenos alóctones de crosta antiga e juvenil, consolidada ao final do evento Brasiliano/PanAfricano (ca. 600-550 Ma).

Diversos autores sugeriram a subdivisão da Província Borborema segundo critérios relativos à evolução tectônica, litoestratigráfica, magmática e geocronológica, e unânimes reconheceram faixas de supracrustais proterozóicas intercaladas com áreas de embasamento gnáissico-migmatítico arqueano a paleoproterozóico (maciços medianos de Brito Neves 1975, 1983) de estruturação definida pela superimposição do Brasiliano aos eventos orogênicos anteriores (Brito Neves 1975, 1983, Santos \& Brito Neves 1984).

Jardim de Sá (1994) propôs a subdivisão da Província Borborema em subprovíncias estruturais (chamadas domínios ou faixas) de feições contrastantes, como sumariado abaixo (Fig.1.3):

(i) As faixas Sergipana (FS) e Riacho do Pontal (FRP), localizadas a norte do Cráton São Francisco e a sul da zona de cisalhamento Pernambuco, compostas por supracrustais monocíclicas neoproterozóicas;

(ii) A Faixa Noroeste do Ceará ou Médio Coreaú (FNC), melhor representada pela correlata Faixa Atacora na África, ocorre na margem do Cráton São Luís e está limitada a sudeste pela zona de cisalhamento Sobral-Pedro II (uma ramificação do Lineamento Transbrasiliano), constituída por supracrustais monocíclicas meso- e neoproterozóicas;

(iii) A Faixa Seridó (FSE) e o Domínio Ceará Central (DCC), dispostos a norte da zona de cisalhamento Patos, compreendem supracrustais mono- ou policíclicas proterozóicas, separadas entre si pela Faixa Orós-Jaguaribe formada por supracrustais monocíclicas mesoproterozóicas; os limites a leste e a oeste são feitos pelas zonas de cisalhamento Portalegre e Aiuaba, respectivamente; 
(iv) O Domínio da Zona Transversal (DZT), compreende os terrenos entre as zonas de cisalhamento Pernambuco e Patos, composto por um arranjo complexo de supracrustais mono e/ou policíclicas proterozóicas.

No modelo sugerido por Santos $(1995,1996)$, a Província Borborema estaria subdividida num maior número de terrenos tectonoestratigráficos (Fig.1.4), com a Faixa Seridó subdivida nos terrenos Rio Piranhas, Seridó e São José do Campestre, e o DZT, denominado de Superterreno Rio Pajeú e subdividido nos terrenos Piancó-Alto Brígida (TPB), Alto Pajeú (TAP) e Alto Moxotó (TAM). No DZT foram reconhecidos dois episódios orogênicos, os ciclos Cariris Velhos/Kibaran (1,1-0,95 Ga, Brito Neves et al. 1996) e o Brasiliano/Pan-Africano (750-570 Ma), com mecanismos de rifteamento, acresção, amalgamação e retrabalhamento intracontinental. Os terrenos referidos ao TAM envolvem sequeências clásticas aluminosas e vulcanossedimentares de arco-magmático, associadas a blocos de metabásicas alóctones e granitóides do tipo-I cordilheirano. No TAP predominam seqüências metassedimentares flyschóides, massas ofiolíticas e granitóides colisionais. O TPB (incluindo a Faixa Salgueiro-Cachoeirinha) engloba desde complexos metavulcanossedimentares do tipo rifte até os termos metaturbidíticos, compondo um ambiente do tipo bacia de ante-arco (Campos Neto et al. 1994). As isócronas obtidas

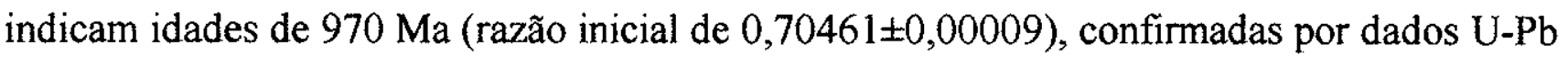
e $\mathrm{Pb}-\mathrm{Pb}$ em zircões, com idades $\mathrm{T}_{\mathrm{DM}}$ do Mesoproterozóico (Van Schmus et al. 1995). Esses dados descrevem um ambiente de convergência e amalgamação no evento Cariris Velhos, constituindo uma placa continental jovem que interagiu por colisão com os crátons do Oeste Africano/São Francisco e outras microplacas, retomadas por extensivo retrabalhamento crustal no Brasiliano.

As propostas de subdivisão apresentadas limitaram os domínios/blocos aos empurrões nas margens cratônicas e às principais zonas de cișalhamento transcorrentes intracontinentais, com ápice dos deslocamentos em alta temperatura estimados em ca.580 Ma e etapas sucessivas de resfriamento entre 550-520 Ma (Jardim de Sá 1994). A distribuição dos domínios e as principais descontinuidades foram confirmadas nos modelos gravimétricos regionais para a estruturação crustal da Província Borborema (Oliveira \& Santos 1993, Castro et al. 1997b, Jardim de Sá et al. 1997a). 


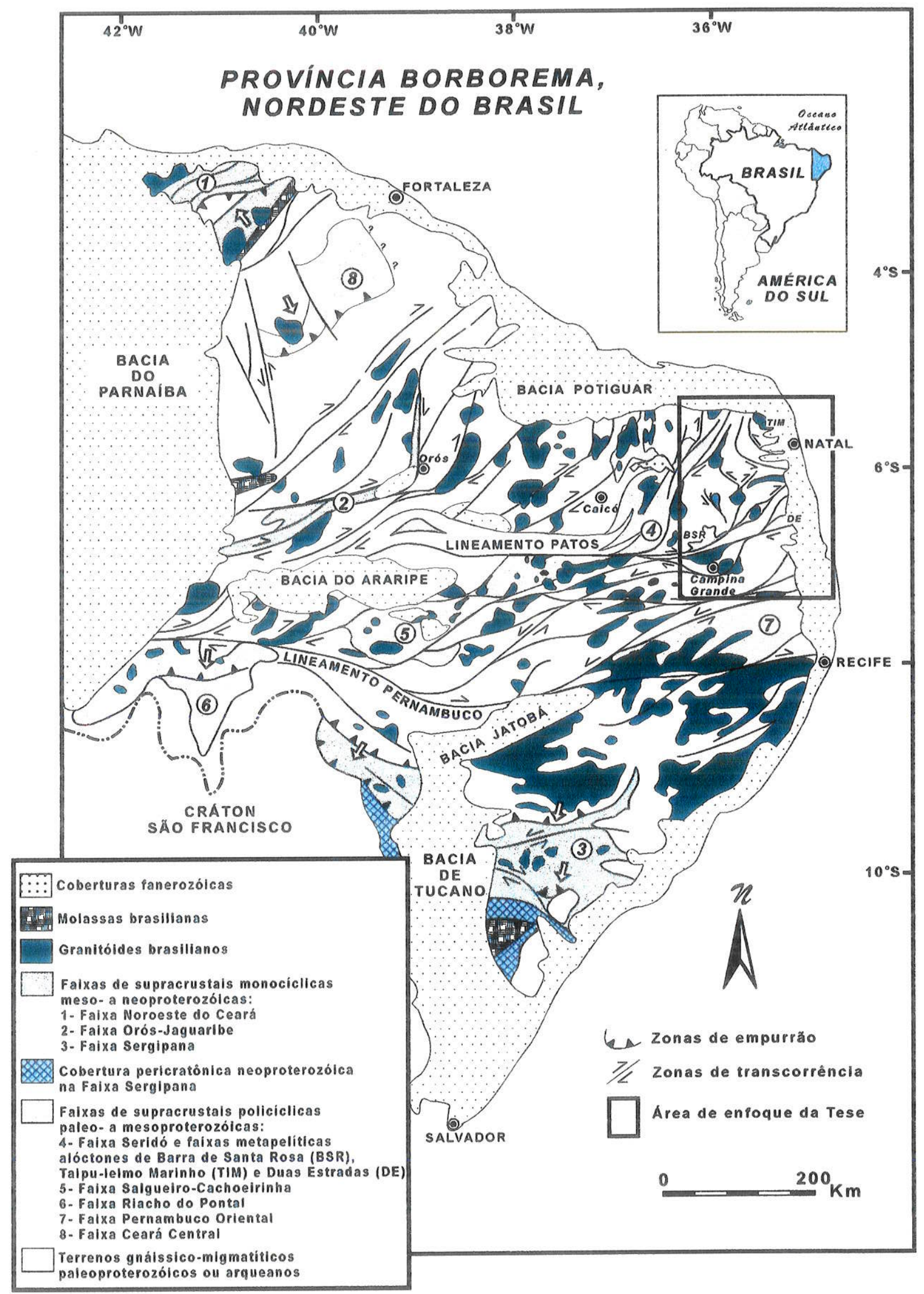

Figura 1.3 - Esboço geológico regional da Província Borborema, apresentando as principais unidades tectonoestratigráficas e a localização da área de enfoque da Tese. Modificado de Brito Neves (1983) e Jardim de Sá et al. $(1988,1991)$. 


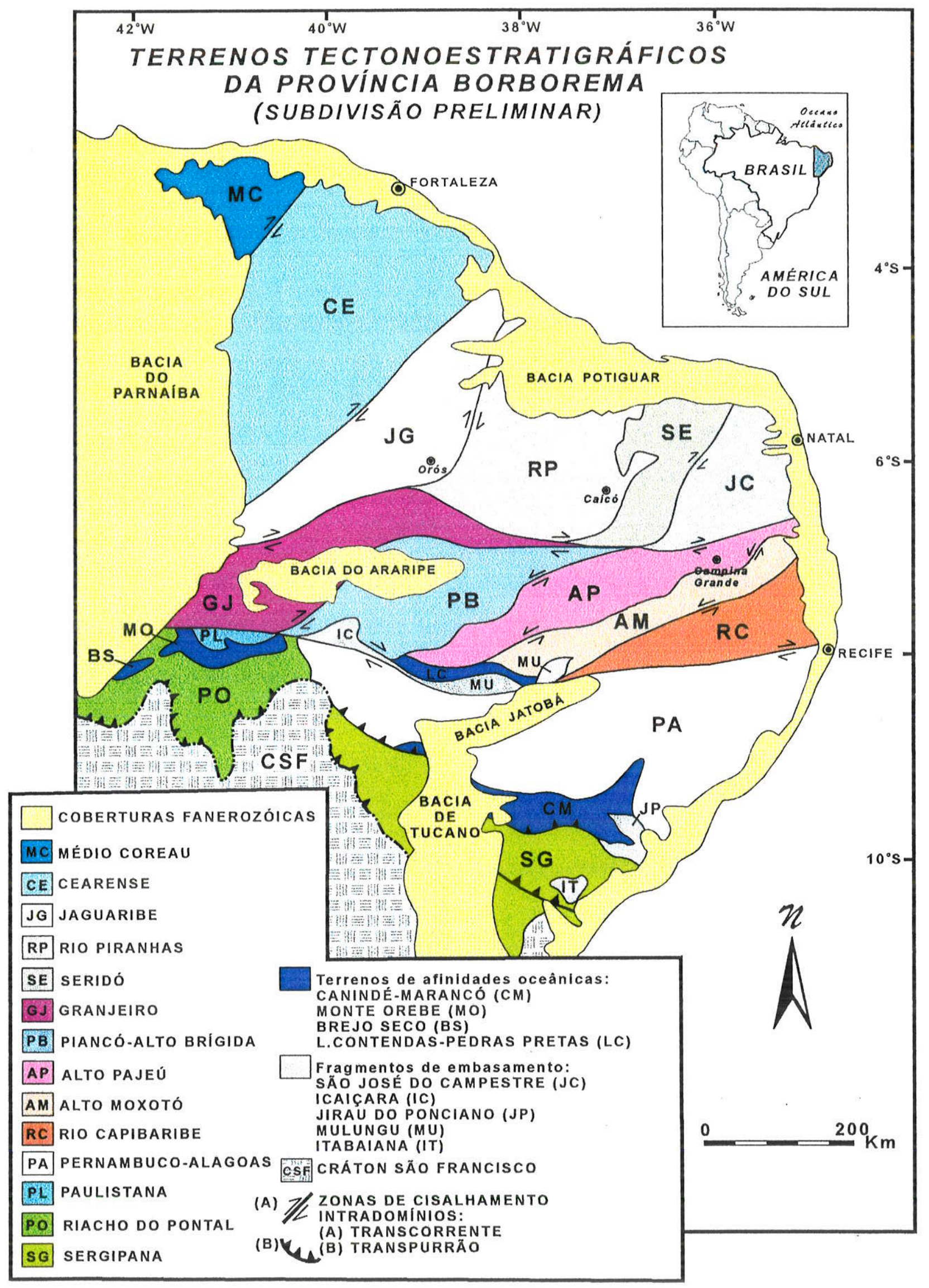

Figura 1.4 - Mapa preliminar dos terrenos tectonoestratigráficos da Província Borborema. Modificado de Brito Neves $(1975,1983)$ e Santos $(1995,1996)$. 
A correlação dos terrenos proterozóicos do Nordeste do Brasil com aqueles da África Ocidental induz à interpretação de que as zonas de cisalhamento transcorrentes intracontinentais da Faixa Borborema/Trans-Sahara constituem uma rede transcontinental de zonas de cisalhamento dúcteis de escala crustal a litosférica, instaladas na acomodação das convergências relativas dos crátons do Oeste Africano, Amazônico, São Francisco/Congo e diversos fragmentos de microcontinentes no Neoproterozóico (Jardim de Sá 1984, Caby 1989). O padrão geométrico do sistema de zonas de cisalhamento transcorrentes é formado pela coalescência entre os lineamentos de direção geral EW e extensão superior a $1000 \mathrm{~km}$ entre o Brasil e Camarões, incorporados aos lineamentos de direção geral NE com cerca de $3000 \mathrm{~km}$ de extensão entre o Brasil Central e Hoggar. Os trabalhos preliminares sugeriram o desenvolvimento das zonas de cisalhamento dúcteis sob condições tectonometamórficas de baixa pressão e alta temperatura (condições de fácies anfibolito a granulito), envolvendo intensa fusão crustal e granitogênese (Caby et al.1991, Corsini et al. 1991, Vauchez \& Egydio-Silva 1992, Vauchez et al. 1997a). As evidências geoquímicas, geofísicas e metamórficas apontam para o enraizamento profundo das zonas de cisalhamento, que favoreceria a percolação de fluidos (magmas e voláteis), a dissipação de calor e o enriquecimento geoquímico do manto litosférico, especialmente em terras raras leves (TRL). O manto litosférico subcontinental anômalo constituiria uma fonte contaminante aos fluidos astenosféricos ascendentes, resultando na geração de magmas shoshoníticos (Jardim de Sá 1994).

No estágio principal da orogênese Brasiliana $(580 \pm 30 \mathrm{Ma})$, o regime cinemático no setor a norte da zona de cisalhamento de Patos foi marcado por estruturas transpressionais dextrais de direção NE nas faixas Orós e Seridó Central, e por estruturas transtracionais e detachments extensionais no bloco a leste da Faixa Seridó (Sá et al. 1991, Jardim de Sá et al.1993c, Jardim de Sá 1994). Para o DZT, as interpretações visuais de imagens de satélite demonstraram o aspecto anastomosado do sistema de zonas de cisalhamento NE sinistrais entre os lineamentos dextrais de trend geral EW de Patos e Pernambuco, em arranjo geométrico do tipo-dominó (Jardim de Sá 1994, Jardim de Sá et al. 1995). Esse padrão difere daquele proposto anteriormente que considerava uma cinemática dextral para as zonas de cisalhamento NE (Corsini et al. 1992, Vauchez et al. 1992, Vauchez \& Egydio-Silva 1992). Nesse contexto, Amaro et al. (1991b) redefiniram a zona de 
cisalhamento Campina Grande (ZCCG) como uma faixa de alta temperatura envolvendo as zonas de cisalhamento do Congo e Afogados da Ingazeira (Brito Neves 1983). A ZCCG estaria mecanicamente integrada ao sistema transpressional Patos-Seridó numa disposição en échelon, compondo um trend estrutural que acompanha uma anomalia gravimétrica positiva (Rand \& Manso 1990) marcada por ocorrências de eclogitos nas regizes de Bodocó-Floresta/PE (Beurlen 1988) e Queimadas-Itatuba/PB (Beurlen et al. 1991). O metamorfismo eclogítico $\left(13 \pm 2 \mathrm{kbar}, 580 \pm 60^{\circ} \mathrm{C}\right.$, eclogito tipo-C) atuaria sobre rochas máfico-ultramáficas de afinidade toleitica e natureza ofiolítica. A suspeita da ocorrência de eclogitos, associados aos granitóides brasilianos de alojamento em regime colisional e à assinatura gravimétrica positiva, suporta a hipótese de que esta faixa represente uma zona de sutura do Brasiliano. Desta forma, algumas das zonas de cisalhamento representariam o retrabalhamento intracrustal de suturas dos episódios prévios de acresção. $\mathrm{O}$ arranjo do tipodominó combinado à geometria escalonada entre os lineamentos Patos e Pernambuco, com terminação progressiva em splay de direção NE do lineamento Patos próximo à costa, constituíram sítios transtracionais e favoreceram a intrusão de plútons alcalinos sin- a tarditectônicos (Jardim de Sá et al. 1995).

Durante a orogênese Brasiliana, a Província Borborema foi intrudida por enorme volume de granitóides polidiapíricos sin- a pós-tectônicos (granitóides $\mathrm{G}_{3}$ e $\mathrm{G}_{4}$, Jardim de Sá et al. 1981, 1987, Leterrier et al. 1990), cuja distribuição é parcialmente controlada pelas zonas de cisalhamento. Diversos trabalhos trataram do regime cinemático de alojamento e da deformação dos granitóides brasilianos (Jardim de Sá et al. 1986, Archanjo \& Bouchez 1992, Archanjo 1993). Os plútons ocorrem encaixados nas seqüências metassedimentares, nos gnaisses do embasamento e metaplutônicas eoproterozóicas (os granitóides $\mathrm{G}_{2}$, Jardim de Sá et al. 1987), truncando estruturas antigas relacionadas aos episódios deformacionais de idade pré-brasiliana ( $D_{1}$ e $D_{2}$, Jardim de Sá et al. 1987). Na porção central da Província Borborema predominam os granitóides porfiriticos sin- a tarditectônicos de filiação subalcalina e monzonítica dos tipos-I ou intermediários entre os tipos-I e A. Freqüentemente, os granitóides porfiríticos são contemporâneos aos granitóides básicos a intermediários de afinidades shoshoníticas. Os aspectos químicos dessas suítes, como os altos teores em TRL, valores negativos do $\mathrm{E}_{\mathrm{Nd}}^{\mathrm{t}}$ e altas razões iniciais dos isótopos de $\mathrm{Sr}$, demonstram a influência 
de processos de contaminação crustal de fontes mantélicas enriquecidas e/ou metassomatismo das fontes, decorrente da percolação de fluidos nas zonas de cisalhamento profundas. No DZT foram descritos os granitóides tonalíticos a granodioríticos precoces (tipo-Conceição), semelhantes aos granitóides do tipo-I de ambientes pós-colisionais (Sial \& Ferreira 1988), e pouco reconhecidos na FSE e no DCC. Esta suíte geralmente precede granitóides com megacristais de K-feldspato e afinidade cálcio-alcalina potássica denominados de tipo-Itaporanga. A suite de granitóides alcalinos a peralcalinos formam um corredor de plútons e diques alinhados na direção NE (Linha Sienitóide), com fontes no manto litosférico enriquecido, provavelmente composto por mica-piroxenito (Ferreira \& Sial 1986). Um grupo de afinidade trondhjemítica (tipo-Serrita) também foi reconhecido. O controle exercido pelas zonas de cisalhamento no alojamento dos plútons permitiu o zoneamento da distribuição química da granitogênese em relação à deformação brasiliana no DZT (Medeiros et al. 1996). Os granitóites cálcio-alcalinos do tipo-Conceição ocorrem nas regiões de baixo strain, enquanto os granitóides cálcio-alcalinos potássicos (tipoItaporanga) bordejam e são afetados pelas zonas de cisalhamento. Os plútons de afinidade trondhjemítica (tipo-Serrita) encontram-se alojados nos sítios transtracionais das estruturas brasilianas. Os granitóides da série alcalina foram controlados pelos deslocamentos en échelon nas zonas miloníticas NE da Linha Sienitóide (Sial \& Ferreira 1988). O controle sin- a tardi-tectônico dos granitóides na etapa de alta temperatura da orogênese Brasiliana foi confirmado nas dataçðes Rb-Sr e U-Pb, para a FSE (Galindo et al. 1991, McMurry et al. 1987a, 1987b, Leterrier et al. 1994, Jardim de Sá 1994, Galindo et al. 1995) e DZT (Mariano \& Sial 1988, Silva Filho et al. 1993, Jardim de Sá 1994).

Uma hipótese para a evolução geodinâmica da Província Borborema foi aventada como se segue: (i) uma cadeia colisional Transamazônica/Eburneana, marcada por estruturas tangenciais, nappes e metamorfismo de alta temperatura e pressão média, ao final da qual a plataforma continental estaria estável; (ii) a crosta continental foi então afetada por episódios extensionais, responsáveis pela abertura de bacias intracontinentais e pelo vulcanismo sinsedimentar no período Estateriano (ca. 1,8 Ga, Sá el al. 1991); (iii) um evento orogênico no período Toniano ( $c$. 1,0 Ga, evento Cariris Velhos), com consumo oceânico e acresção de arcos, ao menos no DZT; (iv) o evento Brasiliano seria caracterizado por dois ambientes não-excludentes e definidos por: (a) subducção oblíqua e acresção 
transformante de terrenos (Jardim de Sá et al. 1991); (b) deformação transcorrente heterogênea num contexto intracontinental, associada a um processo colisisonal obliquo ou frontal, com extrusão lateral de blocos na placa cavalgante. Durante esta colisão, a placa continental jovem, formada pela Provincia Borborema/Trans-Sahara, deslizou/colidiu entre os crátons Oeste Africano/São Luís e Congo/São Francisco, e alguns micro-continentes, desenvolvendo as zonas de cisalhamento transcorrentes EW e NE de escala litosférica, combinadas em cenários transpressionais e transtracionais, provavelmente em função do contraste reológico causado pela alternância das bacias metavulcanossedimentares e blocos continentais pré-existentes.

\subsection{2 - Evolução Crustal da Porção Extremo Nordeste da Província Borborema (Maciços}

São José do Campestre e Caldas Brandão)

As denominações de Maciço Caldas Brandão (MCB) e Maciço São José do Campestre (MSJC) foram propostas por Brito Neves $(1975,1983)$ para as unidades tectônicas compostas por gnaisses migmatiticos e granitóides anatéticos de idades arqueanas (isócrona de 2,7 Ga na região de Presidente Juscelino-RN) e paleoproterozóicas, afetadas pelo evento Brasiliano na Porção Extremo Nordeste da Província Borborema. Nesta Tese sugere-se a manutenção das denominações diferenciadas em MSJC (terrenos entre as cidades de Bom Jesus-Santa Cruz-Barra de Santa Rosa) e MCB (terrenos entre as cidades de Mari-Caldas Brandão-Boqueirão), baseada sobretudo nas informações estruturais (ver Cap. 4), geofisicas (ver Cap. 7) e geocronológicas (Brito Neves, inform. pess.).

Dantas et al. $(1995,1996)$ apresentaram uma proposta de subdivisão cronoestratigráfica dessa região em blocos crustais distintos, denominada indistintamente de $\mathrm{MCB}$, baseados na integração do mapeamento geológico, dados isotópicos (U-Pb e $\mathrm{Sm}-\mathrm{Nd}$ ) e geoquímicos (Fig.1.5, Tab. 1.1 e 1.2). No arcabouço geral sugerido foram agrupadas diversas assembléias lito-estratigráficas com idades variando desde o Paleoarqueano (idades superiores a 3,4 Ga) até o Neoproterozóico (600 Ma).

Um núcleo arqueano foi definido entre as cidades de Bom Jesus, João Câmara e São José do Campestre, no estado do Rio Grande do Norte (Tab. 1.1). As idades do Paleoarqueano ocorrem na região de Bom Jesus, nos blocos compostos por ortognaisses tonalíticos a trondhjemíticos, intercalados a anfibolitos e meta-ultramáficas, com idades de $3,45 \mathrm{Ga}$ (U-Pb em zircão). As afinidades cálcio-alcalinas de baixo potássio, o padrão 
enriquecido em TRL e as idades entre 3,6-3,7 Ga ( $E_{\mathrm{Nd}}$ negativos) apontam como fonte geradora dessas rochas uma crosta continental antiga ou manto enriquecido (Dantas 1997). No Mesoarqueano $(3,25-3,0 \mathrm{Ga})$ ocorreu a principal atividade magmática na região, representado por ortognaisses tonaliticos, trondhjemíticos e granodioríticos migmatizados, migmatitos bandados e hedenbergita ortognaisses intercalados com anfibolitos, metagabroanortositos (complexos Presidente Juscelino, Brejinho, e Senador Elói de Souza). Para o Complexo Presidente Juscelino as idades modelo entre 3,6-3,4 Ga e o $\mathrm{E}_{\mathrm{Nd}}$ negativos apontam como fonte uma crosta continental antiga retrabalhada, enquanto no Complexo Brejinho as idades $\mathrm{T}_{\mathrm{DM}}$ de $c a .3,2 \mathrm{Ga}$ e os valores positivos do $\mathrm{E}_{\mathrm{Nd}}$ sugerem como fonte uma crosta juvenil mesoarqueana (Dantas et al. 1997). No Neoarqueano, um magmatismo tardio é definido por sienogranitos com alto-K na região de São José do Campestre, com idade de $2,7 \mathrm{Ga}$ (U-Pb em zircão).

O Paleoproterozóico está representado por diferentes blocos crustais, individualizados por Dantas (1997) em complexos João Câmara e terrenos Serrinha-Pedro Velho e Santa Cruz (Fig.1.5, Tab. 1.2). No Complexo João Câmara foram descritos biotita e/ou hornblenda migmatitos bandados intercalados a granada e biotita gnaisses graníticos com idades entre 2,4-2,2 Ga (U-Pb em zircão). No Terreno Serrinha-Pedro Velho é caracterizado por rochas de alto grau metamórfico, como biotita-hornblenda migmatitos bandados, ortognaisses tonalíticos com granada, gnaisses com piroxênio, intensamente migmatizados e datados em 2,2 Ga. No Terreno Santa Cruz predominam rochas metaplutônicas cálcio-alcalinas, como biotita-hornblenda ortognaisses tonalíticos a granodioríticos, com idades variando entre 2,2-2,0 Ga. Dantas et al. (1996) sugerem um evento acrescionário em 2,2 Ga, marcado por granitogênese sin-colisional (Complexo João Câmara) e geração de crosta juvenil (Terreno Serrinha-Pedro Velho), seguido de magmatismo tardio (Terrenos Santa Cruz) que indica a amalgamação em 2,0 Ga.

As unidades neoproterozóicas no MSJC-MCB correspondem às faixas de micaxistos alóctones correlatos ao Grupo Seridó (porção superior metaturbidítica) e granitóides brasilianos intrusivos (granitóides $\mathrm{G}_{3}$ ), ambas associadas ao complexo sistema de zonas de cisalhamento brasilianas. Na porção central da Faixa Seridó, os dados Rb-Sr, U-Pb e $\mathrm{Pb}-\mathrm{Pb}$, aliados às relações estruturais, indicam idades Paleoproterozóicas ( $c a .1,9 \pm 0,1 \mathrm{Ga}$ ) para o fabric tangencial dúctil penetrativo $\left(\mathrm{D}_{2} \pm \mathrm{D}_{1}\right.$, dobras recumbentes e thrusts $)$, 

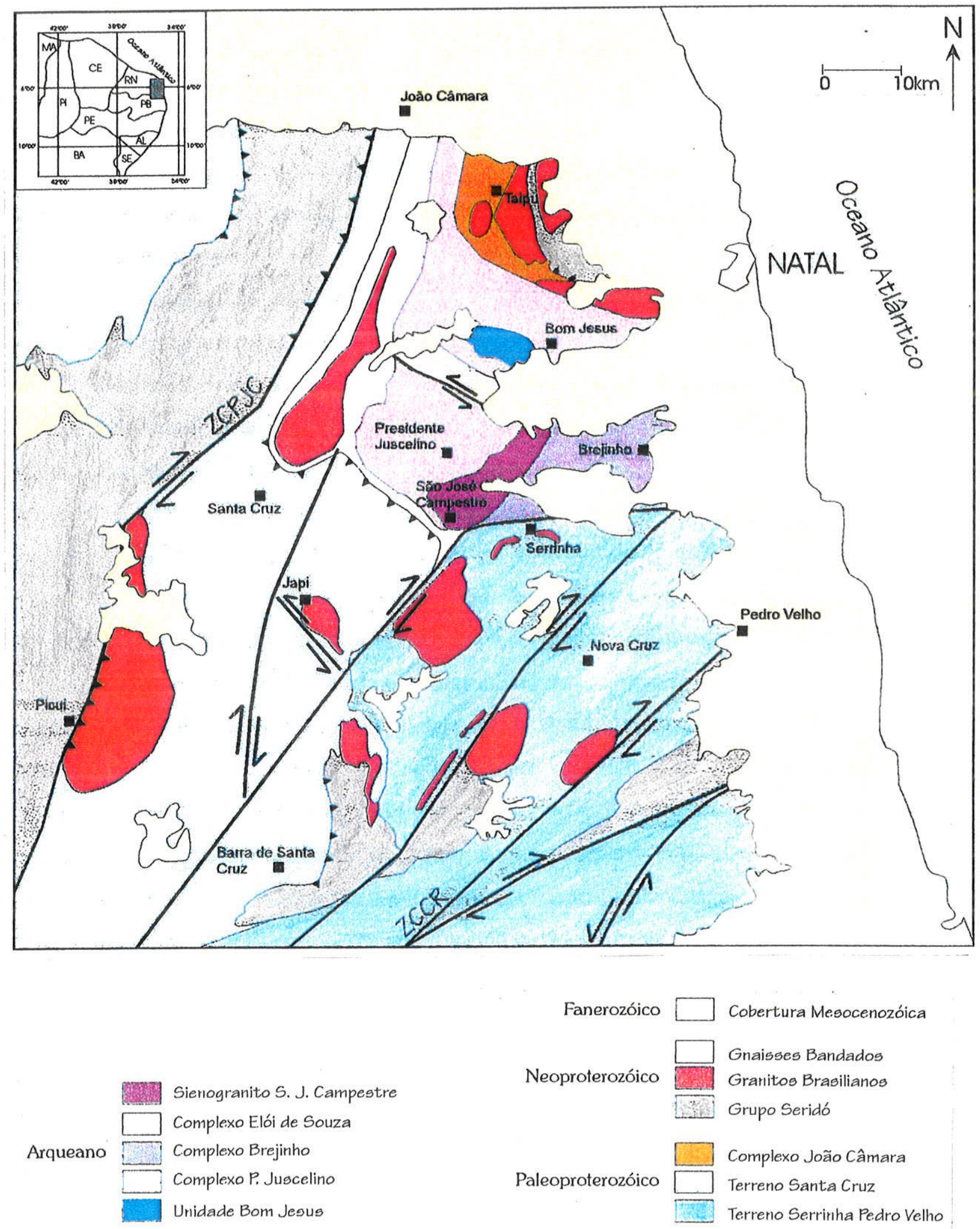

Figura 1.5 - Arcabouço geral com as principais unidades litoestratigráficas reconhecidas nos maciços São José do Campestre e Caldas Brandão, segundo Dantas (1997). ZCPJC = Zona de Cisalhamento Picui-João Câmara, ZCCR = Zona de Cisalhamento Cacerengo-Remígio. 
Tabela 1.1 - Idades arqueanas das unidades litoestratigráficas reconhecidas no Maciço São José do Campestre, conforme Van Schmus et al. (1995), Dantas et al. (1995, 1996) e Dantas (1997). A localização das unidades está descrita na Fig.

\begin{tabular}{|c|c|c|c|}
\hline UNIDADE & TDM (Ga) & $\mathcal{E N d}$ & U-Pb/Zircão (Ga) \\
\hline Unidade Bom Jesus & 3,6 & $(-)$ & 3,45 \\
\hline Complexo Pres.Juscelino & 3,4 & $(-)$ & 3,25 \\
\hline Complexo Brejinho & 3,2 & $(+)$ & 3,18 \\
\hline Complexo Elói de Souza & 3,2 & $(-)$ & 3,0 \\
\hline Sienogranito S.J.Campestre & 3,2 & $(-)$ & 2,7 \\
\hline
\end{tabular}

Tabela 1.2 - Idades paleoproterozóicas das unidades litoestratigráficas reconhecidas no Maciço São José do Campestre, conforme Van Schmus et al. (1995), Dantas et al. (1996) e Dantas (1997). A localização das unidades está descrita na Fig.

\begin{tabular}{|c|c|c|c|}
\hline UNIDADE & TDM (Ga) & $\mathcal{E}$ Nd & U-Pb/Zircão (Ga) \\
\hline Complexo João Câmara & $2,4-2,7$ ou 3,0 & $(-)$ & $2,25-2,7$ \\
\hline Terreno Serrinha-P.Velho & $2,3-2,4$ e $2,5-2,6$ & $(+)$ & 2,18 \\
\hline Terreno Santa Cruz & $2,5-2,6$ & $(-)$ & $2,0-2,23$ \\
\hline
\end{tabular}

Tabela 1.3 - Dados geocronológicos referentes aos granitóides brasilianos do Maciço São José do Campestre, compilados de McMurry et al. (1987a, b), Almeida et al. (1997), Macedo et al. (1997), Dantas (1997), Souza et al. (1998). A Fig. mostra a localização dos granitóides referidos às idades TDM (Ga) e neoproterozóicas $(\mathrm{Ma})$.

\begin{tabular}{|c|c|c|c|c|}
\hline GRANITÓIDE & Rb-Sr (Ma) & U-Pb/Zircão (Ma) & TDM (Ga) & MONAZITA (Ma) \\
\hline Monte das Gameleiras & $517 \pm 26$ & $* * *$ & 2,2 & $* * *$ \\
\hline Serrinha & $620 \pm 51$ & $599 \pm 16$ & $1,85-2,0$ & $555 \pm 10$ \\
\hline Dona Inês & $557 \pm 13$ & $* * *$ & 2,19 & $* * *$ \\
\hline CCG & $* * *$ & $581 \pm 1,6$ & 2,0 & $* * *$ \\
\hline Picuí & $* * * *$ & $* * *$ & 2,54 & $* * *$ \\
\hline Japi & $* * *$ & $* * *$ & 2,05 & $* * *$ \\
\hline Caxexa & $* * *$ & $* * *$ & 2,2 & $* * *$ \\
\hline Serraria & $* * *$ & $* * *$ & 2,1 & $* * *$ \\
\hline Taipu & $* * *$ & $* * *$ & 2,39 & $* * *$ \\
\hline Macaiba & $* * *$ & $* * *$ & 2,98 & $* * *$ \\
\hline Pitombeira & $* * *$ & $* * *$ & 2,2 & $* * *$ \\
\hline Migmatito-ZCRP & $* * *$ & $* * *$ & $* * *$ & $578 \pm 25$ \\
\hline
\end{tabular}


acompanhada por granitóides (ortognaisses $G_{2}$, Jardim de Sá et al. 1987). As estruturas da deformação brasiliana $\left(\mathrm{D}_{3}\right)$ apresentam metamorfismo de alta temperatura/baixa pressão, alta-T/baixa-P, coevo à granitogênese $G_{3}$ e sobrepostas à deformação dúctil paleoproterozóica, como reconhecido nas regiões de baixo strain $\mathrm{D}_{3} \mathrm{em}$ todas as unidades estratigráficas (complexos do embasamento, faixas supracrustais e granitóides $\mathrm{G}_{2}$ ). Para as faixas de micaxistos afetados pela fase $\mathrm{D}_{3}$ na região dos MSJC-MCB predomina um modelo geométrico extensional caracterizado por regime tangencial-extensional (faixa de micaxistos de Taipu-Ielmo Marinho, ou FTIM) e transtracional em flor negativa (faixa de micaxistos de Barra de Santa Rosa, ou BSR), integrado mecanicamente à zonas de cisalhamento de Remígio-Pocinhos (ZCRP) de caráter dextral.

$\mathrm{O}$ alojamento dos plútons granitóides ocorreu preferencialmente nos sítios extensionais e/ou transtracionais favorecidos pelo arranjo geométrico entre as zonas de cisalhamento dextrais e sinistrais brasilianas. Recentemente, diversas idades e sugestões de fontes foram realizadas para os principais plútons do MSJC-MCB (Tab.1.3): plúton Serrinha com idade de $602 \pm 22 \mathrm{Ma}$ (isócrona Rb-Sr) e Sm-Nd de 2,07 Ga (Macedo et al. 1997); plútons do Complexo Campina Grande (que engloba os plútons Massaranduba e Serra Redonda) com idade $581 \pm 1,6 \mathrm{Ma}$ (U-Pb em zircão) e Sm-Nd em ca. 2,0 Ga (Almeida et al. 1997); plútons Taipu e Cardoso com isócronas de 666 Ma (Hackspacher et al. 1987); plútons Dona Inês, com isócrona de $555 \pm 35 \mathrm{Ma}$, e Monte das Gameleiras, com isócrona $517 \pm 26 \mathrm{Ma}$ (McMurry et al. 1987a, 1987b). Para os granitóides com idades modelo de ca. 2,0-2,2 Ga (plútons Barcelona, Gameleiras, Taipu, Japi, Serrinha e Complexo Campina Grande) foram sugeridas fontes infracrustais de idade paleoproterozóica. Para os granitóides na região de João Câmara e para o plúton Picuí, com idades $T_{\mathrm{DM}}$ entre 2,9-2,7 Ga, foram sugeridas fontes mistas arqueanas e paleoproterozóicas (Dantas 1997). 


\section{2 - BASES CONCEITUAIS E SÍNTESE BIBLIOGRÁFICA}

\section{1 - O Conceito de Lineamentos e a Aplicação do Termo aos Terrenos da Província}

\section{Borborema}

A distribuição e o arranjo retilinear de diversos elementos estruturais, tais como juntas, fraturas, falhas, veios e feições topograficas (vales e cristas de montanhas), tem sido alvo de estudiosos europeus desde o início do século XIX. Os "geólogos" da época, entre os quais Sedgwick, La Beche, Hopkins, Phillips, Haughton, Daubree e Kjeruff, observaram a correspondência direta entre feições fisiográficas e o arranjo dos padrões de fraturamento no terreno. Todavia, deve-se a Hobbs (1904) a introdução do termo lineamento caracterizando a relação espacial de feições morfológicas da paisagem como "(l) cristas de cordilheiras ou limites de áreas elevadas, (2) linhas de drenagens, (3) linhas de costa, e (4) linhas limitrofes de formações, de tipos petrográficos de rochas, ou linhas de afloramentos". Hobbs (1912) apresentou uma redefinição mais ampla para o termo como "linhas significativas da paisagem que revelam a arquitetura escondida das rochas do embasamento". Entretanto, incorporou a essa redefinição uma importante conotação tectônica na afirmação "muitos lineamentos são idênticos às linhas sismotectônicas $e$ portanto permitem, até certo ponto, uma maneira de determição adiantada das linhas de maior perigo devido aos terremotos". Desse modo, os lineamentos reais no sentido de Hobbs seriam as expressões superficiais das falhas e zonas de falhas, com elementos cinemáticos associados.

Com o advento das missões orbitais de levantamento dos recursos terrestres no início da década de 70, inúmeros padrões de lineamentos foram detectados, mesmo os mais sutis e com realidade geológica de dificil precisão. Após o lançamento da série Landsat e a disponibilidade comercial do sistema GEMS/Banda $\mathrm{X}$, diversos artigos foram publicados sobre a correlação entre os lineamentos e os dados geológicos e geofísicos preliminares. Em 1974 foi realizada a primeira conferência de geociências para discussão das feições lineares da superficie terrestre (Salt Lake City, EUA), que trouxe considerável contribuição aos procedimentos de análise, classificação e interpretação tectônica dos lineamentos (p.ex. Lathram \& Albert 1974, Kowalik \& Gold 1974, Short 1974, Wertz 1974, Reeves 1974, ElEtr et al. 1974, Babcock 1974, Drahovzal 1974, Dolivo-Dobrovol'sky \& Strel'nikov 1974, 
Hodgson 1974, Gelnett 1974). A análise compilatória de alguns trabalhos que trataram do significado geológico dos lineamentos (Dennis 1967, Isachsen et al. 1973, 1974, Allen et al. 1973, Bodechtel \& Lammerer 1973, Cavelier et al. 1973, Gold et al. 1973, Lammar \& Merifield 1974, Lathram \& Albert 1974, Pickering \& Jones 1974, Scanvic 1974), baseados em informações geológicas de campo e dados geofísicos em diversas regiões do mundo, permitiu uma definição ampla do termo lineamento como "feições lineares de âmbito regional que se expressam na topografia pela morfologia de vales, cristas, segmentos de drenagens e anomalias tonais, controladas estruturalmente por foliações, juntas/fraturas $e$ falhas" (O'Leary \& Simpson 1975, Sabins 1978). Nota-se o emprego indiscriminado do termo correlato às estruturas deformacionais frágeis ou dúcteis, com ênfase apenas no caráter descritivo e cartográfico dos lineamentos, como na redefinição proposta por O'Leary et al. (1976) em que caracterizariam "feições lineares simples ou compostas da superficie terrestre com pelo menos alguns quilometros de extensão que possam ser reconhecidos nos mapas, fotos aéreas e nas imagens de satélite, que reflitam um fenômeno de subsuperficie". Esse conceito vigorou por longo tempo influenciando os procedimentos adotados na extração dos lineamentos, geralmente condicionados à obtenção do número de elementos aceitáveis para a aplicação de cálculos estatisticos, cujos resultados seriam determinantes nas interpretações sobre a gênese dos vários agrupamentos de lineamentos (Wise 1982). Os elementos da deformação frágil foram predominantemente associados aos lineamentos por serem os mais conspícuos, extensos e os principais modeladores da topografia recente (Wise et al. 1985, Hancock et al. 1987). Além disso, a história geodinâmica complexa das estruturas dúcteis mostram por vezes inúmeras reativações da crosta em ambiente frágil. O termo megalineamento refere-se aos lineamentos de extensão transregional, como aqueles que cruzam limites entre domínios cratônicos diferentes, ou que sejam correlacionáveis entre continentes anteriormente aglomerados, numa reconstituição pré-deriva.

Para os terrenos brasileiros, sobretudo na Província Borborema, foram propostos métodos para a distinção entre os lineamentos correspondentes às estruturas frágeis e dúcteis, pelo uso de feições estruturais e geomorfológicas analisadas nos atributos como densidade espacial, geometria, direção azimutal, extensão, localização espacial, interrelações de interseção e retidão (Amaro et al. 1991a, Jardim de Sá et al. 1993b). Uma revisão dos conceitos metodológicos de aplicação das informações lineares extraídas dos produtos de 
sensoriamento remoto, na interpretação das condiçð̃es cinemáticas e geodinâmicas em escala regional, tendo como exemplos as províncias estruturais Borborema e Tocantins, pode ser encontrado em Amaro e Strieder (1994) e nas referências ali contidas. Jardim de Sá et al. (1993b), baseados na interpretação visual de imagens Landsat 5-TM e GEMS/Banda X aplicadas ao mapeamento estrutural da Faixa Seridó, sugeriram a utilização dos termos fotolineações, para os traços lineares de localização abrangente na superfície topográfica correspondentes às estruturas dúcteis penetrativas (foliações e/ou lineações); e fotolineamentos, para os traços lineares de localização espacial mais precisa, referentes às estruturas frágeis ou dúcteis-frágeis. Essas feições lineares apresentam-se, geralmente, gradacionais na análise visual temática, sobretudo nos casos de estruturas decorrentes da deformação contínua e/ou reativações. Contudo, apesar da conotação genética dos termos propostos por Jardim de Sá et al. (1993b), neste trabalho optou-se pelo uso indiscriminado do termo lineamento de Hobbs (1912) e O'Leary et al. (1976), adjetivado pela correspondente conotação tectônica e genética das estruturas deformacionais (frágil, frágildúctil ou dúctil) nos diversos mapas elaborados.

\section{2 - O Conceito de Unidade de Paisagem no Procedimento de Interpretação Visual dos Produtos de Sensoriamento Remoto}

Com a considerável evolução da cartografia temática, influenciada pelo avanço tecnológico nos recursos de obtenção de imagens orbitais, ocorreu uma dicotomia entre os métodos de fotointerpretação por chaves de interpretação (Gagnon 1974) e os modelos de reconhecimento automático de objetos geomorfólogicos e geológicos (Chorowicz 1984, Chorowicz et al. 1989). Apesar da tendência das pesquisas na busca de uma automatização integral dos procedimentos cartográficos (p.ex. Fourcade 1979, Debaine et al. 1988), as técnicas de interpretação visual envolvendo as comparações entre os objetos nas imagens e os elementos nos terrenos permanecem como padrões essenciais ao mapeamento geológico em escala regional, com base nas imagens Landsat 5-TM.

Diversos trabalhos de mapeamento geológico demonstraram a aplicabilidade da combinação das características de alta resolução espacial e espectral dos satélites com as informações provenientes de documentos de outras disciplinas (p.ex. os mapas da geomorfologia, cobertura vegetal, pedologia, geoquímica, geofísica, topografia), na obtenção 
de documentos temáticos detalhados baseados em critérios múltiplos (Bonnefoy et al. 1986, Conradsen et al. 1986, Dutrarte \& King 1986, Bardinet et al. 1988, Coupez et al. 1988, EOSAT 1988). Os fatores que controlam a "interdependência entre os fenômenos" (Tricart 1978) constituem o fundamento da sistemática adotada na interpretação desses documentos temáticos produzidos nas diferentes abordagens.

$\mathrm{Na}$ estratégia metodológica definida para a Porção Extremo Nordeste da Província Borborema, após os tratamentos digitais das seis bandas ópticas do Landsat 5-TM as composições multiespectrais obtidas foram submetidas aos procedimentos de análise e interpretação visual baseadas nos critérios de unidade de paisagem (Vauzelle 1982), e então combinadas às informações de campo disponiveis, na obtenção dos mapas temáticos. $\mathrm{O}$ conceito de unidade de paisagem foi definido sobre uma imagem como "um conjunto de planos de informações apresentando características comuns, sendo as mais importantes aquelas de ordem espectral, morfológica e textural" (Vauzelle 1982). Na aplicação dos critérios de distinção das unidades de paisagem para a zona climática semi-árida do Nordeste do Brasil notou-se que, tanto quanto para zonas temperadas (Deroin 1992), os critérios espectrais estão diretamente associados à ocupação do solo, em relação estreita com a exposição do substrato geológico, a alteração pedológica do substrato e a cobertura vegetal, por menor que possa parecer sua abrangência; os critérios texturais estão relacionados à rede hidrográfica (padrão e grau de dissecação), às diversidades da cobertura vegetal e à organização na ocupação do solo, com o conjunto inteiramente dependente dos litótipos e da estruturação decorrente do estado de deformação do terreno; os critérios morfológicos traduzem a impressão na paisagem seja de um estilo tectônico frágil e dúctilfrágil, marcado por falhas abruptas ou sutis, escarpamentos ou estruturas lineares e circulares do relevo, e/ou de um estilo tectônico dúctil definido por dobramentos e pela orientação da foliação/lineação e seus mergulhos.

Todos os diferentes aspectos relacionados a esses critérios foram utilizados conjuntamente na seleção dos elementos geológicos à partir das imagens multiespectrais do Landsat 5-TM para a Porção Extremo Nordeste da Província Borborema. A abordagem baseada no conceito de unidade de paisagem esteve implícita em todo o procedimento de interpretação visual, buscando-se manter as interrelações dos critérios espectral, textural e morfológico das imagens orbitais com os dados provenientes de outras fontes orbitais 
(fotografias de avião) e não-orbitais (mapas topográficos, hidrográficos, pedológicos, geofisicos e de vegetação).

\section{3 - Noções de Espectrometria de Reflectância}

\subsection{1 - Principais Fenômenos e Feições Diagnósticas nas Assinaturas Espectrais}

As assinaturas espectrais, ou simplesmente espectros, são as medidas das interações das radiações eletromagnéticas (REM) com a matéria. Além das características químicas dos materiais, as condições físicas propiciam diferentes superficies de interação entre o espectro eletromagnético (EEM) e a matéria, de maneira a alterar a aparência do espectro, sobretudo para os sólidos que podem ser analisados como superficies naturais (rugosas), polidas ou pulverizadas.

Diversos trabalhos abordaram as principais características dos efeitos da absorção espectral nas rochas e minerais de importância geológica, geralmente em amostras pulverizadas, com controle granulométrico e químico, por Raios-X e microssonda eletrônica, e na calibração das mudanças sistemáticas da reflectância espectral com as variações composicionais (Burns 1970, Hunt \& Salisbury 1970, 1971, Hunt et al. 1971a, 1971b, 1972, 1973a, 1973b, 1974a, 1974b, Adams 1974, 1975, Hunt 1977, 1979, 1980, Singer 1981, Clark 1983, Clark \& Lucey 1984, Clark \& Roush 1984, Clark et al. 1990). As pesquisas sistemáticas das principais bandas de absorção diagnósticas dos minerais, envolvendo a definição e catalogação das propriedades espectrais, foram efetuadas a partir de espectros de transmissão seguindo os principais eixos cristalográficos de monocristais, técnica denominada de espectrometria de absorção polarizada, com controle sobre as variações composicionais dos minerais (p.ex. Hunt \& Salisbury 1970, Adams 1975). No entanto, a avaliação dos espectros de reflectância da rocha total em faces naturais, seções simples ou polidas, foi pouco abordada na literatura, pois não se tem uma compreensão ampla da maneira como o EEM interage com as superficies dielétricas (Yon \& Pieters 1988).

$\mathrm{Na}$ distribuição do EEM considerada neste trabalho $(0,25-2,35 \mu \mathrm{m})$, duas faixas estão inteiramente obscurecidas por absorções atmosféricas, devido às feições produzidas por processos vibracionais atômico-moleculares que deformam as estruturas moleculares das moléculas de $\mathrm{H}_{2} \mathrm{O}$ e $\mathrm{CO}_{2}$. Essas regiões de absorção atmosféricas ocorrem aproximadamente 
centradas em 1,4 $\mu \mathrm{m}$ e $1,9 \mu \mathrm{m}$, onde as feições espectrais dos materiais são limitadas aos propósitos diagnósticos.

\subsection{2 - Processos Atômico-Moleculares de Energia e as Aparências no EEM}

A interação entre a energia incidente e a matéria, num dado tempo, produz a absorção seletiva da REM, em função da posição relativa e do estado de energia das particulas contituintes da matéria. O sistema atômico-molecular que compõe a matéria é caracterizado por estados de energia inerentes (transicional, rotacional, vibracional e eletrônico) que absorvem a energia da radiação permitindo transições entre níveis de energia, num comprimento de onda especifico.

Na região do visível-infra vermelho próximo (VNIR, 0,4-1,0 $\mu \mathrm{m}$ ) predominam os fenômenos eletrônicos derivados dos metais de transição $\mathrm{Fe}, \mathrm{Ti}, \mathrm{Ni}, \mathrm{Cr}, \mathrm{Sc}, \mathrm{Cu}, \mathrm{Co}, \mathrm{Mn}$ e V, caracterizados por mudanças eletrônicas dos níveis de energia, cujos principais processos que acarretam absorções seletivas nas assinaturas espectrais foram sumariados:

1. Efeito de transferência de carga: a energia incidente absorvida pelo material excita $o$ elétron que migra entre íons adjacentes, não se tornando entretanto completamente móvel. Esse efeito ocorre na faixa do ultravioleta (UV) ao visível (VIS), principalmente nos óxidos de ferro. As ligações Fe-O absorvem energias de comprimentos de onda curtos provocando uma queda na assinatura espectral na faixa do azul $(0,475-0,575 \mu \mathrm{m})$ e a típica coloração avermelhada assumida por alguns materiais na faixa do vísivel.

2. Efeito de absorcão por banda de condução: ocorre em alguns semicondutores (p.ex. os sulfetos) onde os fótons de energias superiores a um valor limiar são absorvidos, incrementando a energia dos elétrons para outros níveis, produzindo espectros com faixas pronunciadas de absorção (Gupta 1991).

3. Transicão eletrônica em metais de transição: esses processos ocorrem freqüentemente nos metais de transição produzindo fortes feições de absorção para os íons $\mathrm{Fe}^{3+}$ em $0,87 \mu \mathrm{m}, 0,5$ $\mu \mathrm{m}$ e $0,35 \mu \mathrm{m} ; \mathrm{Fe}^{2+}$ em $1,0 \mu \mathrm{m}$ e nas faixas $0,55-0,57 \mu \mathrm{m}$ e $1,8-2,0 \mu \mathrm{m}$; Cu em $0,8 \mu \mathrm{m}$; $\mathrm{Ni}$ em $1,25 \mu \mathrm{m}, 0,74 \mu \mathrm{m}$ e $0,4 \mu \mathrm{m}$; e $\mathrm{Cr}$ em $0,55 \mu \mathrm{m}, 0,45 \mu \mathrm{m}$ e $0,35 \mu \mathrm{m}$.

4. Efeito de campo dos cristais: na teoria de campo dos cristais (Burns 1970) o nível de energia para o mesmo íon pode ser diferente em campos distintos do cristal. Para os elementos de transição da primeira série $\mathrm{Fe}, \mathrm{Ti}, \mathrm{Ni}, \mathrm{Cr}, \mathrm{Sc}, \mathrm{Cu}, \mathrm{Co}, \mathrm{Mn} \mathrm{e} \mathrm{V}$, os níveis de 
energia são controlados pelos elétrons do orbital 3d, e portanto fortemente influenciados pela interação com os campos eletrostáticos que cercam os íons. Tais campos são gerados pelos ânions e grupos dipolares que circundam os íons, de modo que as mudanças induzidas nesses íons dependem do tipo de ligação (p.ex. metal-oxigênio), da valência dos íons (p.ex. $\mathrm{Fe}^{2+}$ ou $\mathrm{Fe}^{3+}$ ), posição e simetria dos ligantes (Hunt 1977). Para o ion $\mathrm{Fe}^{3+}$, Hunt (1980) apresentou uma série de possiveis picos de absorção em diferentes comprimentos de onda, $\mathrm{e}$ portanto de diferentes espectros para o íon, que dependem da posição do íon no campo dos cristais. Essa é uma indicação que as assinaturas espectrais podem ser usadas na dedução dos campos dos cristais e, conseqüentemente, no diagnóstico da composição geral dos materiais (Gupta 1991), ou como um método de determinação da mineralogia a distância. Os metais de transição da primeira série e seus cátions, particularmente $\mathrm{Fe}^{3+}, \mathrm{Fe}^{2+}, \mathrm{Ti}^{3+} \mathrm{e}^{3+}$, constituem cerca de $40 \%$ dos materiais da Terra e são encontrados em abundância nos minerais silicáticos.

As regiões do infravermelho de comprimento de onda curto (SWIR) ao infravermelho médio (MIR) são caracterizadas por processos vibracionais atômicomoleculares, que resultam em pequenos deslocamentos dos átomos de suas posições originais nas estruturas moleculares, provocando o estiramento e a inclinação das moléculas (Goetz et al. 1991). Os niveis de energia nas estruturas podem ser quantificados para cada estilo vibracional, onde o número de estilos é igual a $\mathbf{3 N - 6}$, e $\mathbf{N}$ é o numero de átomos na molécula. As principais feições dos processos vibracionais são definidas como inflexões fundamentais, supra-inflexões e combinações. As inflexões fundamentais ocorrem na faixa do MIR (>3,5 $\mu \mathrm{m})$, as supra-inflexões e combinações na região do SWIR (1-3 $\mu \mathrm{m})$. Os principais grupos minerais que possuem feições espectrais decorrentes de processos vibracionais são as hidroxilas, carbonatos, silicatos, fosfatos, sulfatos, nitratos, etc.

Buckingham e Sommer (1983) avaliaram a profundidade de penetração da radiação VNIR nos materiais pela disposição em camadas de misturas de terra e óxidos de ferro, variando a proporção relativa dos componentes. Os resultados mostraram variações entre 20-30 $\mu \mathrm{m}$, para diferentes comprimentos de onda e porcentagens relativas dos componentes, indicando que a espectrometria de reflectância no VNIR apresenta informações representativas apenas da camada superficial do material. Assim, a presença 
nas superficies analisadas de pátinas de óxidos de ferro e manganês, espectralmente opacos pode impedir a discriminação entre os litótipos.

\subsection{3 - Características Espectrais dos Componentes Iônicos Comuns nos Minerais e}

\section{Rochas entre o Visivel e o Infravermelho de Curto Comprimento de Onda}

As caracteristicas espectrais dos minerais de importância geológica foram ilustrados em ampla literatura. Os espectros dos minerais são definidos pelo somatório dos espectros dos ions dominantes, dos ions traços e do efeito do campo do cristal, e medidos em laboratório por diversas técnicas (Burns 1993, Gaffey et al. 1993). Entretanto, os espectros são dificilmente modeláveis e a identificação dos minerais é feita por comparação com os espectros obtidos em laboratório à partir de amostras quimicamente conhecidas. A identificação é baseada na posição e forma (largura e profundidade) das bandas de absorção, conforme a resolução espectral empregada.

1. Óxidos de ferro (limonita, hematita, goethita): comuns como produtos de alteração dos minerais ferromagnesianos, esses minerais mostram bandas de absorção decorrentes do fenômenos de transição eletrônica do $\mathrm{Fe}^{3+}$ centradas em 0,65 $\mu \mathrm{m}$, e entre 0,86-0,94 $\mu \mathrm{m}$ segundo o óxido (hematita em 0,86-0,88 $\mu \mathrm{m}$; goethita em 0,90-0,93 $\mu \mathrm{m}$; limonita em 0,90 $0,91 \mu \mathrm{m}$, Townsend 1987).

2. Quartzo: quando composto por silicato simples em estrutura tetraédrica apresenta bandas de absorção apenas na região do MIR. Entretanto, as freqüentes impurezas e/ou inclusões com íons $\mathrm{Fe}$ e $\mathrm{H}_{2} \mathrm{O}$ controlam as bandas de absorção (em 1,4 e $1,9 \mu \mathrm{m}$ ) e a coloração dos cristais.

3. Piroxênios: apresentam bandas de absorção no VNIR decorrentes da presença do ín $\mathrm{Fe}^{2+}$ e no MIR devido ao ion silicato. O clinopiroxênio com teor elevado em $\mathrm{Ca}$ (molécula wollastonita $\mathrm{Wo}_{\mathrm{O}}>11 \%$ ), mostra geralmente absorçðes de campo do cristal devido ao $\mathrm{Fe}^{2+} \mathrm{em}$ 1,03 e $2,31 \mu \mathrm{m}$, e em 0,66 e $0,85 \mu \mathrm{m}$ devido a impurezas de $\mathrm{Cr}^{3+}\left(\sim 1 \% \mathrm{Cr}_{2} \mathrm{O}_{3}\right.$, Singer 1981). O ortopiroxênio com baixo teor em $\mathrm{Ca}(\mathrm{Wo}<11 \%)$, apresenta bandas de absorção de campo do cristal centradas em 0,90-0,93 $\mu \mathrm{m}$ e 1,80-1,95 $\mu \mathrm{m}$ decorrentes do $\mathrm{Fe}^{2+}$, com deslocamento linear das absorções em direção aos comprimentos de onda maiores a medida que aumenta o teor em $\mathrm{Fe}^{2+}$ (Burns 1970, Adams 1974). Freqüentemente ocorrem absorções em 1,4 e $2,3 \mu \mathrm{m}$ devido a processos vibracionais do $\mathrm{OH}$. A mistura entre ortopiroxênio e 
clinopiroxênio ( $50 \%$ vs. 50\%) intensifica a absorção próxima a 1,0 $\mu \mathrm{m}$ e amplia e espalha a absorção próxima a 2,0 $\mu \mathrm{m}$ (Singer 1981).

4. Anfibólios: o ferro controla as bandas de absorção na região do VNIR, e os íons $\mathrm{OH}$, moléculas $\mathrm{H}_{2} \mathrm{O}$, e combinações Al-OH e Mg-OH na região do SWIR. As absorções em 1,0 e $2,3 \mu \mathrm{m}$ são decorrentes do íon $\mathrm{Fe}^{2+}$, enquanto efeitos de transferência de carga dos íons $\mathrm{Fe}^{2+}$ e $\mathrm{Fe}^{3+}$ controlam a absorção em 0,65 e $0,75 \mu \mathrm{m}$. $\mathrm{O}$ ín $\mathrm{OH}$ causa as absorções em 1,4 e 2,3 $\mu \mathrm{m}$ e a $\mathrm{H}_{2} \mathrm{O}$ em 1,4 e 1,9 $\mu \mathrm{m}$. A banda de absorção em 1,392 $\mu \mathrm{m}$ é decorrente do $\mathrm{Mg}_{3}$, enquanto aquelas em 1,398 $\mu \mathrm{m}$ e 1,404 $\mu \mathrm{m}$ são controladas pela solução sólida $\mathrm{Mg}_{2} \mathrm{FeOH}$ e $\mathrm{MgFe}_{2} \mathrm{OH}$ (Clark et al. 1990).

5. Micas: os ions $\mathrm{Fe}^{2+}, \mathrm{Fe}^{3+}, \mathrm{Cr}^{3+} \mathrm{e} \mathrm{Ti}^{4+}$ condicionam as absorções no VNIR; mas geralmente as feições de absorção caracteristicas em 2,2 e 2,3 $\mu \mathrm{m}$ são decorrentes da presença da $\mathrm{H}_{2} \mathrm{O}$ e íns $\mathrm{OH}$ em combinações como $\mathrm{Al}-\mathrm{OH}, \mathrm{Mg}-\mathrm{OH}$ e Si-OH. Na biotita e muscovita, os processos vibracionais do $\mathrm{OH}$ causam absorções em 2,75 e 2,85 $\mu \mathrm{m}$. A clorita mostra feições de absorção devido ao $\mathrm{Fe}^{2+}$ e $\mathrm{Fe}^{3+}$ em $0,7 \mu \mathrm{m}, 0,85 \mu \mathrm{m}$ e 1,1 $\mu \mathrm{m}$. Na flogopita a $\mathrm{OH}$ produz absorção em 1,37-1,39 $\mu \mathrm{m}$ e a combinação Mg-OH em 2,32 $\mu \mathrm{m}, 2,37 \mu \mathrm{m}$ e 2,39 $\mu \mathrm{m}$.

6. Plagioclásios: o plagioclásio "puro" não possui banda de absorção, mas ínfimas quantidades de $\mathrm{Fe}^{2+}$ incorporados nas posições do $\mathrm{Al}$ (raramente do $\mathrm{Ca}$ ) causam uma ampla banda de absorção por transição eletrônica entre 1,10-1,30 $\mu \mathrm{m}$, controlada pela porcentagem de anortita, onde a absorção em 1,30 $\mu \mathrm{m}$ corresponde a An65. Abaixo de $0,60 \mu \mathrm{m}$ ocorre um decréscimo na reflectância devido à absorção por transferência de carga do $\mathrm{Fe}^{2+}$ (metaloxigênio, Adams \& Goullaud 1978).

7. Feldspato alcalino: a assinatura espectral diagnóstica é conduzida pela presença do ferro $\mathrm{e}$ $\mathrm{OH}$, freqüentemente com feições de absorção em $0,6 \mu \mathrm{m}, 1,4 \mu \mathrm{m}$ e $2,3 \mu \mathrm{m}$.

8. Granadas: geralmente apresentam três bandas de absorção centradas em $1,35 \mu \mathrm{m}, 1,7 \mu \mathrm{m}$ e 2,3 $\mu \mathrm{m}$ (Burns 1993).

9. Argilas: as feições de absorção características são definidas pelas combinações $\mathrm{Al}-\mathrm{OH}$ (em 2,2 $\mu \mathrm{m}$ ), $\mathrm{Mg}-\mathrm{OH}(\mathrm{em} 2,3 \mu \mathrm{m}$ ) e pela presença de moléculas d'água (em 0,9 e 1,4 $\mu \mathrm{m}$ ). Quando o Fe substitui o $\mathrm{Mg}$ ou $\mathrm{Al}$ ocorre um incremento das absorções na região entre 0,4$1,0 \mu \mathrm{m}$. A região entre 2,1-2,4 $\mu \mathrm{m}$ é marcada por intensa absorção (decorrentes das 
vibrações $\mathrm{Al}-\mathrm{OH}$ e $\mathrm{Mg}-\mathrm{OH}$ ), com pico de reflectância em 1,6 $\mu \mathrm{m}$, quando se trata de associação de minerais de argila em zonas de alteração hidrotermal (Gupta 1991).

As rochas apresentam assinaturas espectrais resultantes da combinação dos efeitos dos espectros individuais dos componentes poliminerálicos dominantes, traços, impurezas e produtos de alteração, das interrelações texturais e granulometria dos grãos. No entanto, a diagnose dos litologias baseada apenas no modelo aditivo linear dos componentes é bastante restrita, pois as misturas poliminerálicas apresentam feições espectrais resultantes de combinações não-lineares complexas das propriedades ópticas dos minerais (Gupta 1991). Outro aspecto importante é que a região entre o VNIR e o SWIR, faixa espectral geralmente empregada nas análises laboratoriais diagnósticas combinadas ao tratamento digital de imagens do Landsat 5-TM, é intensamente afetada pelas variações na textura e coberturas de pátinas de alterações, incrustações de liquens e poeira, comuns nas amostras naturais. Na região do VNIR as diferenças mais comuns de cores nas rochas são causadas pela presença do ferro em vários estados de oxidação e coordenação. As cores caracteristicas do ocre ao vermelho resultam das bandas de absorção típicas localizadas entre o UV e o azul, com ampliação da reflectância para as regiões do EEM com comprimentos de onda maiores.

Os principais elementos diagnósticos dos espectros de reflectância das rochas metamórficas e ígneas foram descritos a seguir. A seleção foi baseada no conjunto de rochas que apresentam características mineralógicas, texturais e cujos espectros possam ser comparados àqueles das litologias analisadas para a região de interesse:

1. Rochas metamórficas: as feições diagnósticas têm origem na presença de grupos de ânions (p.ex. carbonatos, sulfatos, fosfatos), do grupo $\mathrm{OH}$ e de moléculas de $\mathrm{H}_{2} \mathrm{O}$ (freqüente como inclusões fluidas). Geralmente, as bandas de absorção decorrentes dos processos vibracionais ocorrem nas posições próximas de $1,3 \mu \mathrm{m}$ e $2,3 \mu \mathrm{m}$, e superiores ao limite de $2,5 \mu \mathrm{m}$. As constantes absorções nas posições $0,46 \mu \mathrm{m}, 0,55 \mu \mathrm{m}, 0,85 \mu \mathrm{m}$ e $1,0 \mu \mathrm{m}$ têm origem nas transições dos íns $\mathrm{Fe}, \mathrm{Mg}$ e Ti. Nas rochas gnáissicas de granulação grossa à base de quartzo e feldspatos, com alternância de micas, anfibólios e opacos, ocorrem modificações nas localizações das absorções decorrentes dos íons $\mathrm{Fe}^{2+} \mathrm{e} \mathrm{Fe}^{3+}$ na clorita (em $0,7 \mu \mathrm{m}, 0,85 \mu \mathrm{m}$ e $1,1 \mu \mathrm{m}$ ), na sericita + clorita (em 0,325 e 1,3 $\mu \mathrm{m}$ ), nos anfibólios (em 0,6 
e $1,3 \mu \mathrm{m}$ ), na homblenda (em $0,7 \mu \mathrm{m}, 0,9 \mu \mathrm{m}$ e $1,1 \mu \mathrm{m}$ ), nas granadas (em $0,5 \mu \mathrm{m}, 0,575$ $\mu \mathrm{m}$ e $0,85 \mu \mathrm{m}$, com a almandina controlando a posição próxima a $1,3 \mu \mathrm{m})$ e na magnetita (em 1,9 e 2,5 $\mu \mathrm{m}$ ). Nas rochas xistosas a abundância dos minerais micáceos (p.ex. biotita, clorita, muscovita) controla a aparência das bandas de absorções devido ao íons $\mathrm{OH}$, enquanto os freqüentes minerais acessórios (p.ex. granada, anfibólios, sillimanita, turmalina, epidoto, oxidos de ferro) e minerais de argilas acrescentam bandas adicionais aos espectros das rochas. As posições diagnósticas das bandas de absorção do $\mathrm{OH}$ nos minerais mais comuns nas rochas xistosas foram destacadas: na clorita centrada em $2,34 \mu \mathrm{m}$; nos minerais de argila + micáceos em 1,4 $\mu \mathrm{m}$; nas micas em 1,4 $\mu \mathrm{m}$ e 2,2-2,3 $\mu \mathrm{m}$; na tremolita em 1,4 e $2,0 \mu \mathrm{m}$; na hornblenda $1,4 \mu \mathrm{m}, 2,32 \mu \mathrm{m}$ e $2,38 \mu \mathrm{m}$; na actinolita em $1,4 \mu \mathrm{m}$; no epidoto em $1,45 \mu \mathrm{m}$. A turmalina controla bandas de absorção em $0,45 \mu \mathrm{m}, 0,80 \mu \mathrm{m}$ e $1,15 \mu \mathrm{m}$, devido a transições dos íons $\mathrm{Fe}^{2+} \mathrm{e} \mathrm{Fe}^{3+}$, e entre 2,2-2,3 $\mu \mathrm{m}$ devido às vibrações da ligação $\mathrm{B}-\mathrm{O}$ (Hunt \& Salisbury 1976).

2. Rochas igneas: as principais feições de absorção diagnósticas são governadas pela composição química da rocha, e pelas relações texturais das fases minerais predominantes (Ross et al. 1969). A reflectância aumenta com a diminuição da granulometria da rocha (Adams \& Filice 1967, Ross et al. 1969). As rochas graníticas mostram nítido controle das absorções vibracionais do $\mathrm{OH}$ e $\mathrm{H}_{2} \mathrm{O}(1,4 \mu \mathrm{m}, 1,9 \mu \mathrm{m}$ e $2,2 \mu \mathrm{m})$, cuja intensidade depende da quantidade d'água nos cristais. A presença de minerais acessórios nas rochas graniticas (p.ex. magnetita, biotita, piroxênios, anfibólios), em proporções superiores a 1\% da moda, controla a ocorrência das feições de absorção típicas desses minerais na assinatura espectral das rochas, justificando o uso da espectrometria na diagnose e classificação dos litótipos. Nas rochas máficas, os minerais como piroxênios, anfibólios e magnetita, ricos nos íons $\mathrm{Fe}^{2+}$ $\mathrm{e} \mathrm{Fe}^{3+}$, mostram bandas de absorção características em 0,7 e 1,0 $\mu \mathrm{m}$. As rochas ultramáficas possuem grande quantidade de minerais ricos em íons $\mathrm{Fe}^{2+}$ com bandas de absorção intensas em $0,7 \mu \mathrm{m}, 1,0 \mu \mathrm{m}$ e $2,0 \mu \mathrm{m}$. 


\section{4 - Síntese Sobre as Assinaturas Gravimétricas das Zonas de Cisalhamento Intracontinentais e a Estruturação da Crosta Continental}

$\mathrm{Na}$ definição de modelos para a estruturação crustal em orógenos antigos (Apalaches), em zonas de suturas antigas (nos escudos Canadense e Brasileiro), em sistemas orogênicos relacionados ao Pan-Africano (Austrália, África e Brasil) e em orógenos recentes (Andes, Himalaias e Alpes), as assinaturas gravimétricas observadas estão caracterizadas por anomalias Bouguer compondo pares positivo-negativos combinados (p. ex. Gibb \& Thomas 1976, Wellman 1978, Lesquer et al. 1981, Gibb et al. 1983, Karner \& Watts 1983, LyonCaen et al. 1985, Sheffels \& McNutt 1986, Ponsard et al. 1988, Molina 1990, Marangoni 1994). Nos processos mecânicos de colisão continental, as forças horizontais resultantes induziriam à redistribuição de massas entre as placas adjacentes, sob a forma de thrusts do embasamento, nappes ofiolíticas, blocos obductados e flakes. Após o consumo completo da litosfera oceânica e a cessação do processo colisional, o rebalanceamento isostático determina a etapa final de redistribuição de massa. Nos modelos de suturas colisionais, aparentemente existe consenso nas interpretações quanto às anomalias negativas dos pares negativo-positivo como decorrente do aumento da depressão da Moho em direção à zona de sutura. Todavia, foram propostas diversas explicações para as fontes das anomalias positivas, como o aumento na espessura e densidade da placa colisional mais jovem, o excesso de massa provocado pelos blocos obductados, a exposição da crosta inferior e o soerguimento da Moho, todas baseadas na mesma origem colisional e na variedade de possibilidades dos arranjos geométricos entre os limites das placas tectônicas (Gibb \& Thomas 1976, Karner \& Watts 1983, Sheffels \& Mcnutt 1986, Pilkington 1990).

Os estudos recentes sobre a estruturação dos terrenos continentais aplicando técnicas de processamento digital de imagens para realce das anomalias de campo potencial, têm demonstrado a associação entre anomalias gravimétricas positivas e/ou gradientes íngremes positivos às zonas de cisalhamento em escalas continentais.

O mapa de anomalias Bouguer realizado por Lambeck (1983) para a região central da Austrália mostrou a correlação direta entre o extenso sistema de zonas de cisalhamento no fácies granulito (Collins \& Teyssier 1989) e os valores positivos das anomalias. A interpretação de Lambeck et al. (1988) caracterizou o controle das zonas de cisalhamento sobre a deformação da interface crosta-manto litosférico favorecendo o 
soerguimento da Moho aos niveis crustais, em processos tectônicos compressionais. $\mathrm{Na}$ mesma linha de pesquisa, no mapeamento geológico-geofisico integrado para a crosta continental da Austrália Ocidental, Whitaker (1994) destacou a intensa linearidade de anomalias gravimétricas e magnéticas positivas marcando toda a extensão das zonas de cisalhamento proterozóicas no fácies granulito (P-intermediária) contendo magnetita, na borda sul do cráton de Yilgarn. Diante das evidências, esse autor sugeriu a deformação da crosta proterozóica em regime transcorrente-compressional até pelo menos profundidades da crosta inferior.

$\mathrm{Na}$ avaliação das evidências gravimétricas pré-drift dos continentes Africano e Sul-americano, Lesquer et al. (1984) destacaram a correlação entre as anomalias gravimétricas e a estruturação tectônica das bacias sedimentares e dos falhamentos no dominio cratônico e nas margens do cráton do Oeste Africano-São Luís.

Broome (1990) utilizando imagens realçadas de dados geofisicos (gravimetria, magnetometria e gama-espectrometria) no mapeamento geológico de terrenos proterozóicos do noroeste do Canadá, destacou a presença de anomalias gravimétricas e magnéticas marcando zonas de cisalhamento em duplexes no fácies granulito, sugerindo a continuidade das rochas granulíticas de alta densidade em profundidade.

Poudjom Djomani et al. $(1995,1997)$ estudaram a espessura elástica efetiva da litosfera na África Centro-Ocidental e o mapa de anomalias gravimétricas obtido permitiu a delineação das zonas de cisalhamento da África central (ZCAC) e Sanaga (ZCSA, Fig.2.1). Essas zonas de cisalhamento são decorrentes da evolução pan-africana e se estendem desde a região nordeste do Brasil (Caby 1989, Ngako et al. 1991) até o Sudão (Ibrahim et al. 1996), perfazendo extensão superior a $4000 \mathrm{~km}$, numa reconstituição do Gondwana (Fig.1.1). A reativação contínua dessas extensas zonas de cisalhamento e a condução de processos deformacionais no manto superior pôde ser sugerido com base no controle que exerceram na colocação dos younger granites (213-141 Ma) do platô da Nigéria (Black et al. 1985) e da atividade magmática na Linha Vulcânica dos Camarões (LVC) (65 Ma ao presente), com afinidades quimicas indicativas da fusão parcial e do fracionamento no manto superior (Halliday et al. 1990). Na LVC tem sido registrado intensa atividade sísmica, com magnitudes superiores a 4.8 , relacionada à atividade magmática recente (Tabod et al. 1992). 

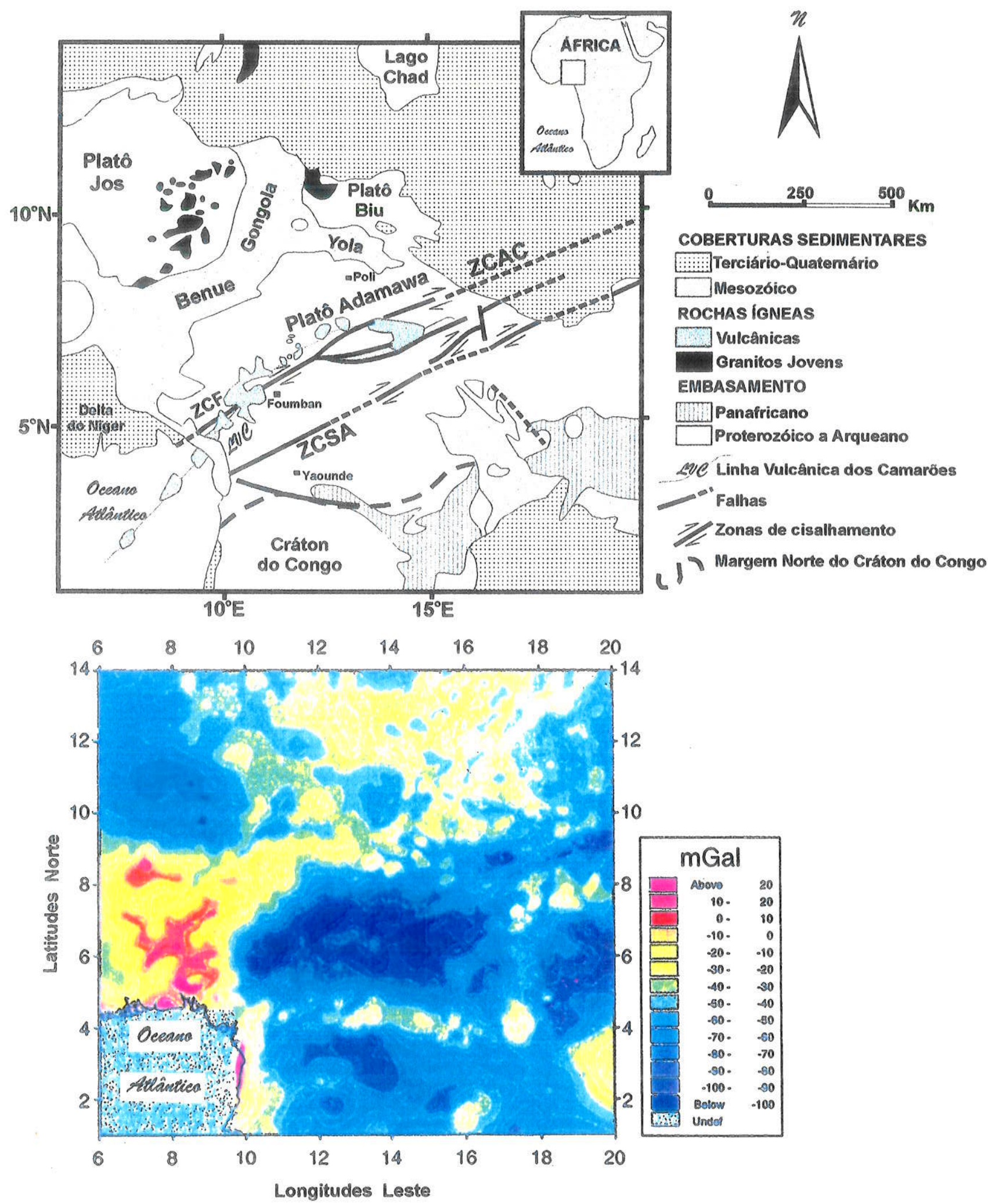

Figura 2.1 - Mapa geológico da África Centro-Oriental comparado ao mapa de anomalias Bouguer. $\mathbf{Z C A C}=$ Zona de Cisalhamento da África Central; $\mathbf{Z C S A}=$ Zona de Cisalhamento Sanaga; $\mathbb{Z C F}=$ Zona de Cisalhamento Faumban; sue = Linha Vuncânica dos Camarões. Modificado de Poudjom Djomani et al. $(1995,1997)$. 
Dorbath et al. (1986), baseados na inversão 3-D das ondas telesísmicas Presiduais e na variação azimutal das ondas residuais relativas, sugeriram a divisão da crosta e manto superior da região de Adamawa em três blocos separados por limites subverticais de direção ENE que atingem profundidades superiores a $190 \mathrm{~km}$. Os modelos apresentados mostraram expressivo afinamento sob o bloco central que corresponde à $\mathrm{ZCAC}$, com largura superior a $100 \mathrm{~km}$.

Plamerová et al. (1993), com base dos dados sobre ondas telesísmicas P-residuais e PKP, aliadas às anomalias Bouguer, definiram o afinamento da litosfera ao longo da ZCAC, com soerguimento da astenosfera de $190 \mathrm{~km}$ para $120 \mathrm{~km}$ de profundidade e largura restrita entre o rifte Garoua e a Falha do Limite Norte (FLN, Fig.2.2). Os modelos apresentados sugerem uma mudança abrupta na profundidade da Moho sob a FLN (com largura aproximada de $15 \mathrm{~km}$ ) provocando a deformação da interface litosfera-astenosfera. A FLN foi interpretada como marcadora da zona de sutura subvertical acrescionária entre blocos litosféricos com heterogeneidades tectônicas e diferentes anisotropias de resfriamento, refinando o trabalho de Dorbath et al. (1986).

Hartley et al. (1996) realizaram estudo sobre as propriedades termal e mecânica da placa litosférica africana com base na análise espectral das anomalias gravimétricas e dados topográficos. O mapa de anomalias Bouguer para a África foi obtido pelo isolamento de anomalias com comprimentos de onda entre 100 e $200 \mathrm{~km}$, e permitiu o realce das extensas zonas de cisalhamento panafricanas no fácies granulito (Camarões, Hoggar, Nigéria, Kênia, Madagascar). Na Fig.2.3, esse mapa para a África foi combinado ao mapa de anomalias Bouguer para o Brasil (Sá et al. 1993), numa reconstrução pré-deriva mesozóica dos continentes sul-americano e africano, permitindo a correspondência entre as principais anomalias gravimétricas dos terrenos da Província Borborema à Faixa Orogênica TransSahara, entre os crátons Oeste da África-São Luís e São Francisco-Congo (em destaque na Fig.2.3). Os alinhamentos das anomalias gravimétricas e/ou gradientes positivos caracterizam a rede transcontinental de zonas de cisalhamento desenvolvida no Brasiliano/Pan-africano. Esse fato indica um alinhamento dos altos e baixos gravimétricos na direção paralela à direção de movimentação absoluta da placa africana, sugerindo a movimentação mantélica sob a placa. Como ambos os mapas correspondem a comprimentos de onda longos (superiores a $100 \mathrm{~km}$ ) definidores da estruturação continental, pelo fato de 

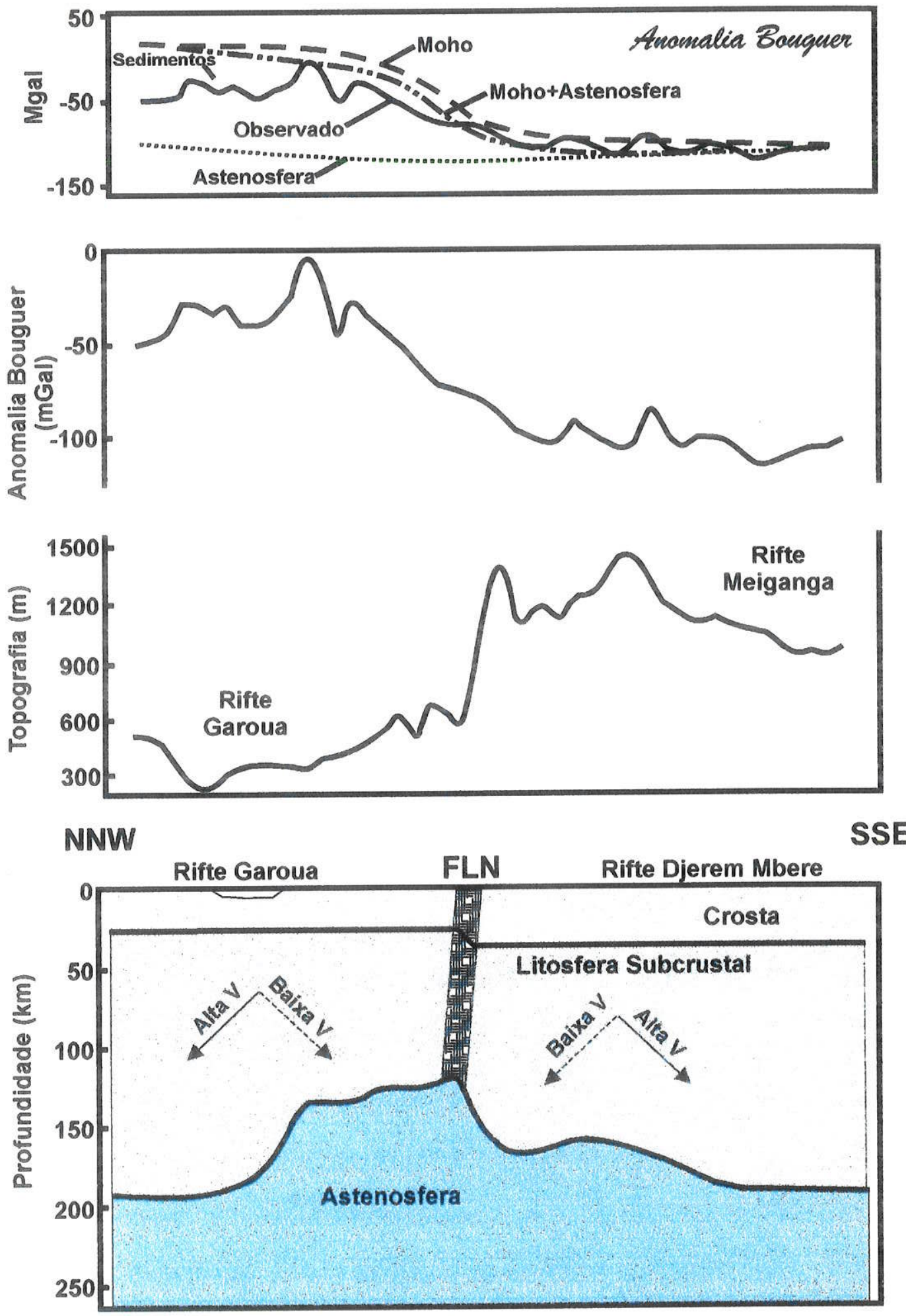

Figura 2.2- Diagramas mostrando um modelo em seção vertical da litosfera, baseado nas anomalias gravimétricas Bouguer, residuais e ondas telesísmicas. A distribuição das estações definiu dois blocos com padrões residuais opostos, onde as direções das ondas de alta- e baixa-velocidades apresentam diferentes orientações na litosfera subcrustal. Os blocos estão separados pela Falha do Limite Norte (FLN). Modificado de Plamerová et al. (1993). 


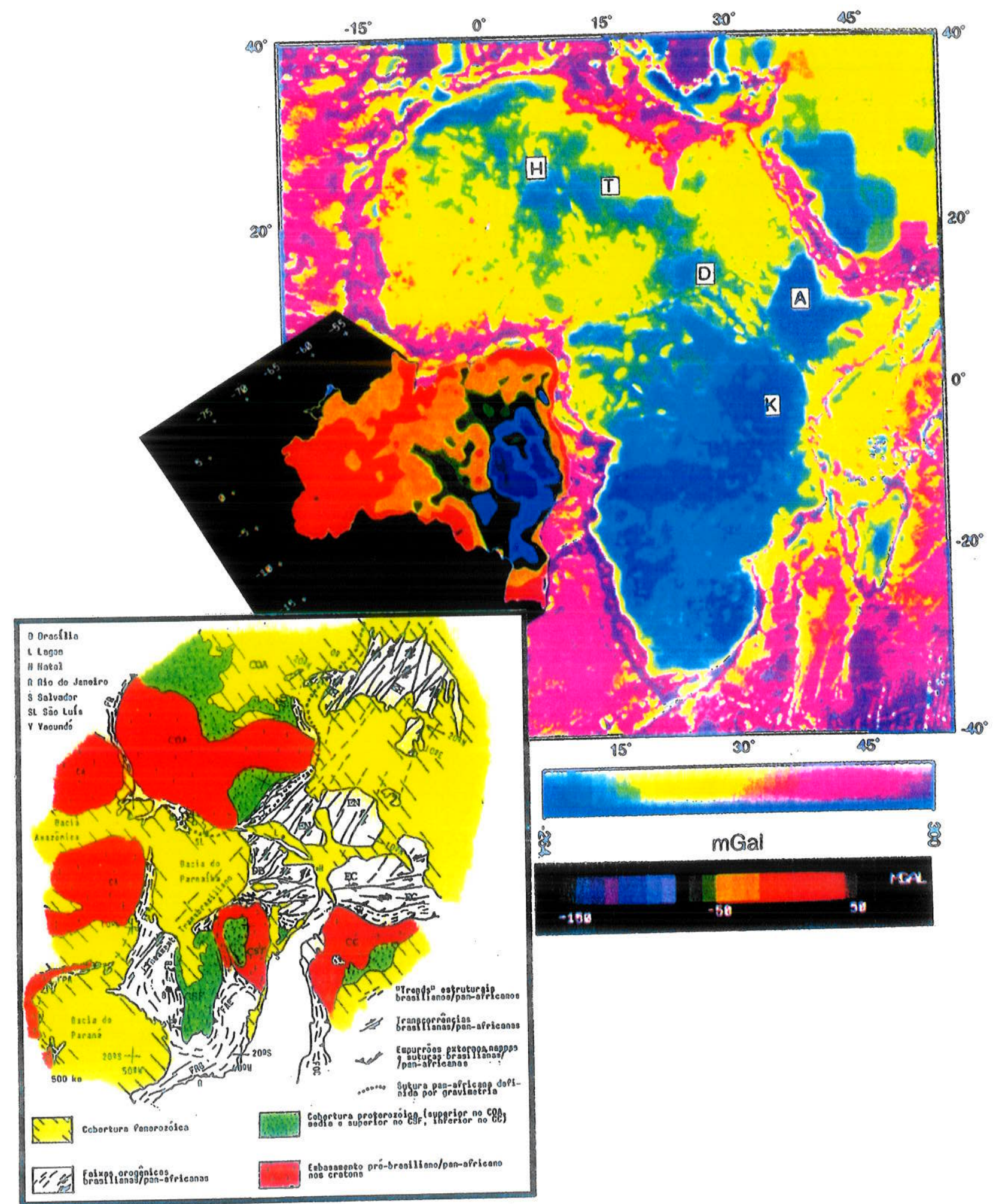

Figura 2.3 - Mapas de anomalias Bouguer da África e do Brasil combinados numa reconstituição pré-deriva mesozóica . Os cálculos consideraram uma placa simples com densidades uniformes de crosta $\left(2670 \mathrm{~kg} / \mathrm{m}^{3}\right)$ e água $\left(1030 \mathrm{~kg} / \mathrm{m}^{3}\right)$. Os principais destaques são para as assinaturas das províncias estruturais limitadas por zonas de cisalhamento em ambos os continentes. No esboço em medalhão foram enfatizados os crátons prébrasilianos/pan-africanos, as faixas orogênicas e as zonas de transcorrência e empurrões brasilianos/panafricanos. $\mathrm{CA}=$ Cráton Amazônico, $\mathrm{COA}=$ Cráton Oeste da África, $\mathrm{CSF}=$ Cráton São Francisco, $\mathrm{CC}=$ Cráton Congo, $\mathrm{PB}=$ Província Borborema, $\mathrm{EN}=$ Escudo da Nigéria, $\mathrm{EC}=$ Escudo dos Camarões, $\mathrm{EH}=$ Escudo de Hoggar, FB = Faixa Brasília, FPA = Faixa Paraguai-Araguaia, FRG = Faixa Ribeira-Rio Grande, $\mathrm{FAE}=$ Faixa Araçuaí-Espinhaço, $\mathrm{FOC}=$ Faixa Oeste do Congo, $\mathrm{H}=$ Domo de Hoggar, $\mathrm{T}=$ Domo de Tbesti, $\mathrm{D}=$ Domo de Darfur, A = Domo de Afar e K = Domo de Kening. Modificado de Sá et al. 1993, Jardim de Sá 1994 e Hartley et al. 1996. 
terem sido destacadas as anomalias referentes ao sistema de zonas de cisalhamento, sugerem que as anomalias que refletem esse sistema têm abrangência transcontinental e controlam processos de dimensões litosféricas, provavelmente desde tempos pré-cambrianos até o presente.

No estudo da distribuição e transferência de fluidos no sistema transpressional de fácies granulito de Madagascar, Pili (1997) sugeriu o soerguimento da Moho condicionada às zonas de cisalhamento principais, marcadas por anomalias gravimétricas positivas (Fig.2.4a). Dessa forma, as zonas de cisalhamento principais (>30 km de largura e extensão superior a $350 \mathrm{~km}$ ) localizariam a deformação em escala litosférica, canalizando o fluxo de carbono mantélico através da crosta. Essas anomalias gravimétricas positivas mostram correlação com as anomalias positivas presentes no eixo da depressão de Turkana no Kênia, região entre os domos de Afar e Kening, referidas como as assinaturas gravimétricas de zonas de cisalhamento litosféricas que exercem em profundidade o controle sobre a estruturação do rifte do Leste da África (Fig.2.4b, Cardon et al. 1997).

As informações compiladas até o momento conduziram a definição de alguns argumentos sobre o comportamento gravimétrico e geoquímico da crosta continental e das zonas de cisalhamento intracontinentais:

- Algumas das anomalias gravimétricas positiva estão relacionadas a colocação de corpos ígneos densos da crosta, durante processos colisionais e/ou extensionais (p. ex. modelo cisalhamento simples de Bell et al. 1988 e modelo cisalhamento simples/cisalhamento puro combinados de Buck et al. 1988);

- Cinturões de complexos máfico-ultramáficos (ofiolitos e ultramáficas do tipo alpino) possuem assinatura gravimétrica positiva, como também os cinturões magmáticos suspeitos de serem ensimáticos ou, ao menos, possuírem raízes máficas;

- Em algumas bacias os limites de gravidade lineares estão relacionadas ao uplift ou overthrusting do embasamento;

- Anomalias gravimétricas e/ou gradientes positivos delineiam toda extensão das zonas de cisalhamento intracontinentais;

- O metamorfísmo associado às zonas de cisalhamento é de alta temperatura, geralmente no fácies granulito, condicionando intensa migmatização e grande volume de fluidos magmáticos, indicando processos de fusão parcial; 


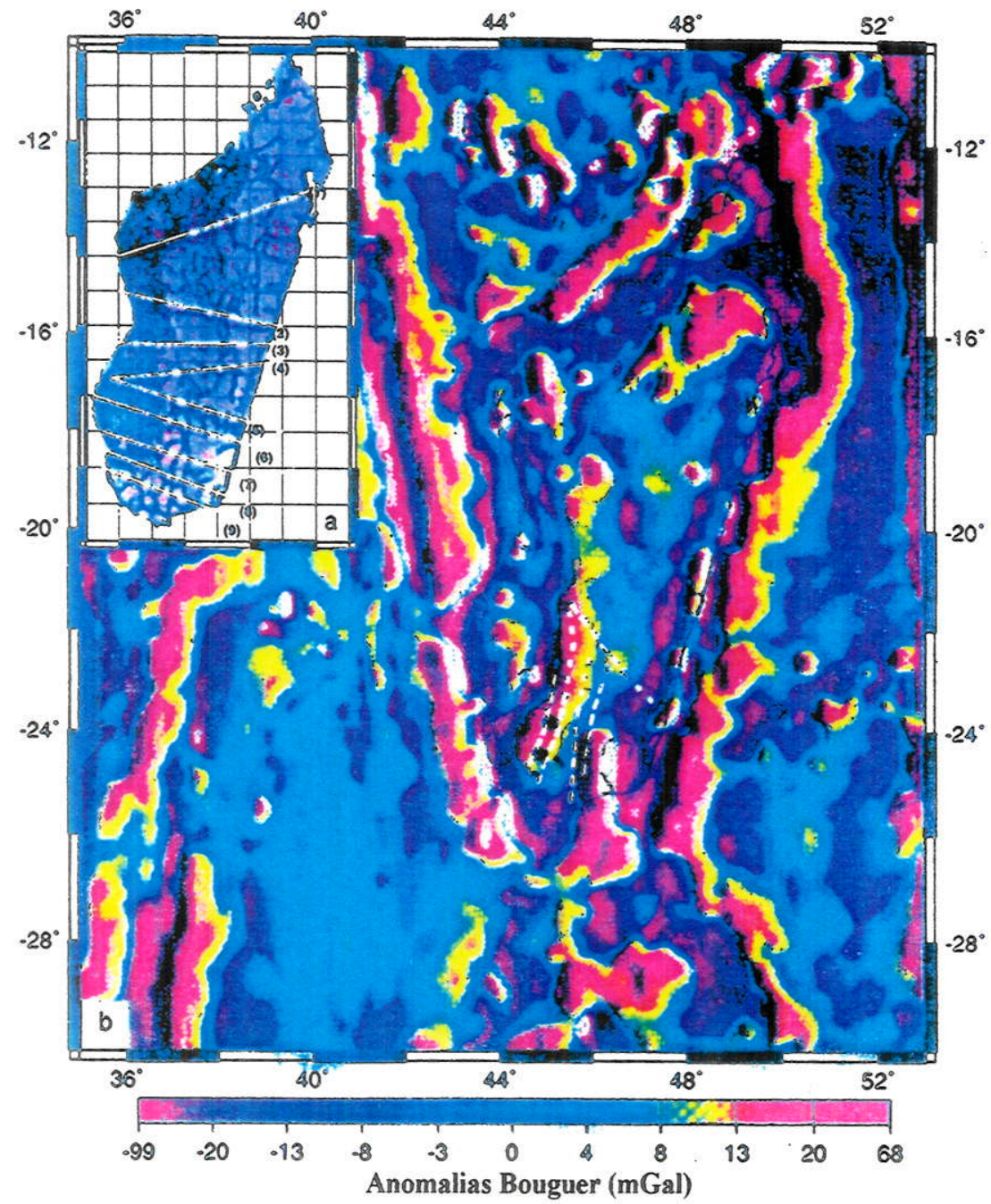

Figura 2.4a - (a) Mapa de localização das estações e perfis gravimétricos, e (b) Imagem das anomalias Bouguer para Madagascar (África) tiltradas para $80 \mathrm{~km}<\lambda<200 \mathrm{~km}$. Modificado de Pili (1997).

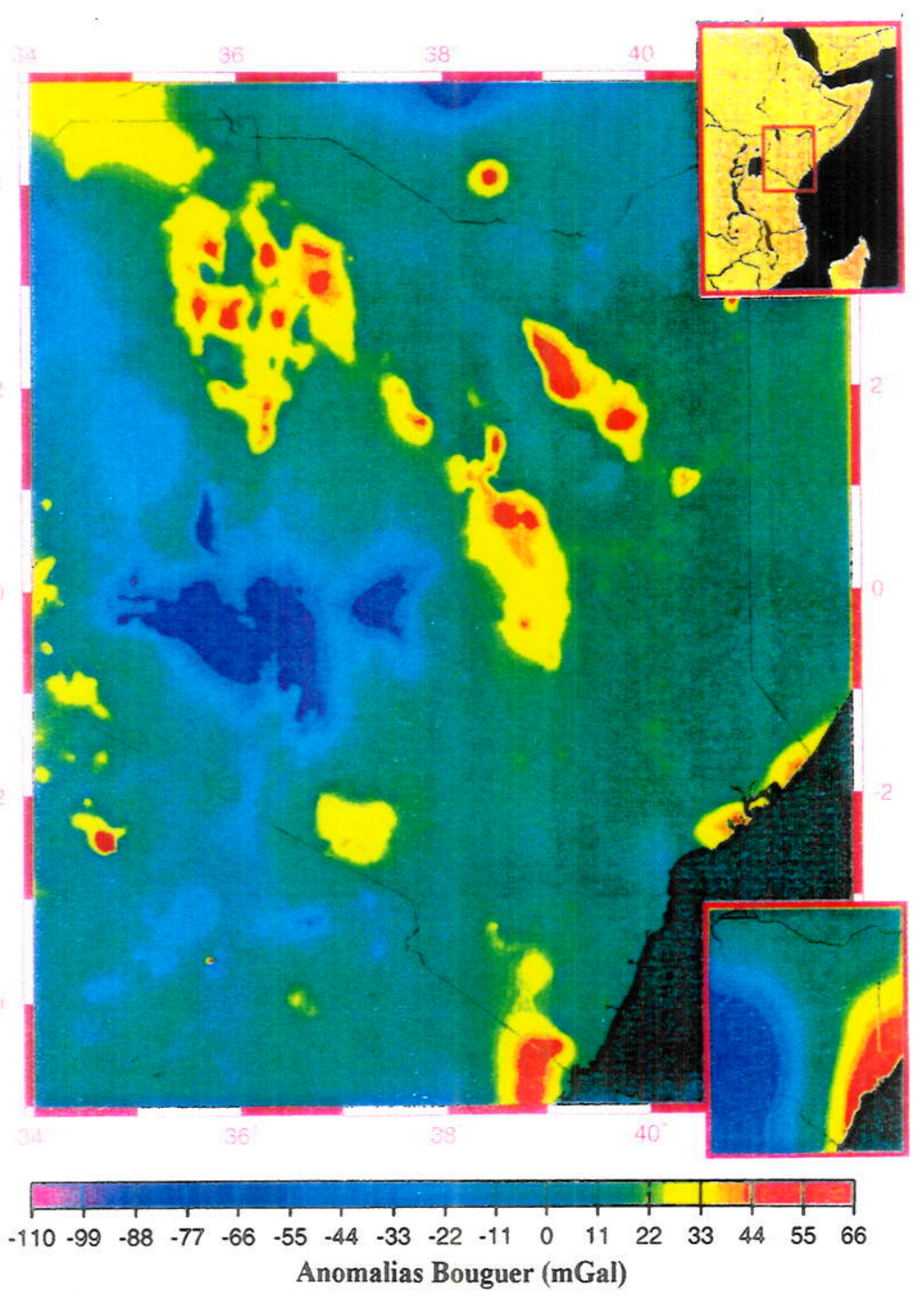

Figura 2.4b - Mapa de anomalias gravimétricas residuais para o Quênia (África, medalhão superior), obtido por filtragem no domínio espacial com filltros quadrados de $\ddot{\lambda}=550 \mathrm{~km}$ (medalhão inferior). Modificado de Cardon et al. (1997). 
- As rochas granuliticas e migmatitos são freqüentemente coevos a granitóides alcalinos;

- As zonas de cisalhamento são canalizadoras e distribuidoras de fluidos (magmas e voláteis), provenientes da crosta e manto (astenosfera ?), em escala litosférica.

Desta forma, em função das caracteristicas apresentadas, sugere-se o enraizamento litosférico das extensas zonas de cisalhamento dúcteis intracontinentais, não apenas na crosta inferior ou na interface crosta-manto litosférico, mas com deformação significativa do manto litosférico interceptado. Entretanto, algumas questões permanecem abertas:

- Qual a geometria das zonas de cisalhamento ao interceptarem o manto?;

- Qual a profundidade máxima de enraizamento dessas zonas?;

- Qual seria então a reologia da crosta inferior e do manto litosférico subcontinental interceptados por tais zonas de alto strain, extensas, largas e profundas?

\section{5 - Integração dos Dados Gravimétricos e Aeromagnéticos na Compreensão da Estruturação Crustal}

Os dados gravimétricos regionais com espaçamento entre as estações de $2-4 \mathrm{~km}$ têm se mostrado efícientes no mapeamento geológico em escala 1:250000 e na contribuição à modelagem do conjunto crosta continental/litosfera continental, enquanto as anomalias residuais como auxílio ao mapeamento geológico-estrutural detalhado, na avaliação da geometria e profundidade de unidades geológicas e depósitos minerais, e na modelagem da estruturação crustal. As limitações na compreensão das propriedades magnéticas da crosta inferior e manto superior, e as dificuldades na correlação direta das anomalias regionais e residuais com a natureza e evolução das fontes, afetaram por muito tempo o emprego adequado das anomalias magnéticas na interpretação geológica (Ravat et al. 1992, Qureshy 1982, Qureshy \& Iqbaluddin 1992). Da mesma forma que para os dados gravimétricos, diversos trabalhos demonstraram que as anomalias magnéticas produzem informações úteis à modelagem geológica da crosta, com as inerentes limitações decorrentes da "nãosingularidade" da distribuição e da geometria das fontes de campo potencial. As fontes das anomalias magnéticas de comprimentos de onda longos estão localizadas na crosta inferior (Regan et al. 1975, Wasilewski et al. 1979, Arkani-Hamed et al. 1985, Thomas 1987, Al- 
Rawi \& Brooks 1992) e manto superior (Arkani-Hamed \& Strangway 1986, Toft \& Haggerty 1986), enquanto os componentes de curtos comprimentos de onda são provenientes de fontes em diferentes profundidades na crosta (Clark 1997). Os mapas residuais resultantes das filtragens no domínio dos comprimentos de onda destacaram agrupamentos de anomalias magnéticas que, além da delimitação de domínios magnéticos, refletem uma forte correlação com a localização, trend e amplitude relativa das anomalias Bouguer e residuais, favorecendo interpretações sobre as fontes e as estruturas em diferentes niveis crustais dos terrenos pré-cambrianos e da interface crosta-manto. Os limites entre as extensas unidades tectônicas correspondem freqüentemente aos gradientes ingremes no componente de comprimentos de onda longos, freqüentemente condizentes com os gradientes gravimétricos, enquanto as feições de curtos comprimentos de onda definem unidades litologicas isoladas, falhas/fraturas ou diques (Jaques et al. 1997).

A combinação de diversas filtragens de comprimentos de onda, em diferentes domínios, tanto para os dados aeromagnéticos quanto para os gravimétricos, propicia um maior controle sobre a geometria, a localização espacial e em profundidade estimada das fontes das anomalias (Coles et al. 1976, Behrendt \& Grim 1985, Keller et al. 1985, Kane \& Godson 1985, Woodside \& Verhoef 1989, King 1990, Teskey \& Hood 1991, Whitaker 1994, Spector \& Lawler 1995, Pilkington \& Roest 1996, Gunn 1997, Tarlowski et al. 1997).

A correlação dos mapas aeromagnéticos e gravimétricos regionais e residuais para diversos comprimentos de onda permite a elaboração acurada de modelos qualitativos a semi-quantitativos em profundidade para a crosta e a litosfera. Diversos trabalhos de integração têm sido realizados com esse propósito, como por exemplo no Canadá (Broome et al. 1985, Woodside \& Verhoef 1989, Broome 1990, Feininger \& Ermanovics 1994, Cook et al.1995), na Austrália (Whiting 1988, Whitaker 1994, Tarlowski et al. 1996, Gunn et al.1997, Gunn 1997, Jaques et al. 1997), nos EUA (Keller et al. 1985, Behrendt \& Grim 1985, Yarger 1985, King 1990, Johnson et al. 1990, Spector \& Lawler 1995), na Europa (Al-Rawi \& Brooks 1982, Schlinger 1985, Zeyen et al. 1988, Miranda et al. 1989, Stefouli \& Angelopoulos 1990), na África (Lécorché et al. 1983, Fernandez-Alonso \& Tahon 1991) e na Ásia (Verma \& Subrahmanyam 1984, Shapiro et al. 1986, Atchunta Rao et al. 1992, Mishra 1992). 


\section{6 - Síntese Sobre a Susceptibilidade/Magnetismo dos Granitóides e Rochas Metamórficas de Alta Temperatura}

As rochas plutônicas em geral apresentam uma distribuição bimodal da susceptibilidade refletindo os granitóides da série-magnetita e da série-ilmenita de Ishihara (1977). Os granitóides da série-magnetita mais oxidados correspondem aos granitóides tipoI e os da série-ilmenita aos granitóides tipo-S da classificação de Chappell e White (1974). Clark (1997) apresentou uma compilação das principais características petrogenéticas dos granitóides que condicionam a magnetização/susceptibilidade das rochas, cujos principais fatos foram listados a seguir:

- Os minerais acessórios usualmente associados aos granitóides félsicos ferromagnéticos incluem o esfeno, epidoto, allanita, biotita é rica em $\mathrm{Fe}^{3+}$ e $\mathrm{Mg}$, pirita e hemoilmenita ou Mn-ilmenita;

- Os minerais acessórios associados aos granitóides paramagnéticos são a cordierita, granada ou aluminossilicatos (típicos dos granitóides do tipo-S), ilmenita (baixo $\mathrm{Fe}^{3+}$ ), pirrotita e biotita rica em $\mathrm{Fe}^{2+}$ e $\mathrm{Al}$;

- Os granodioritos com hornblenda e biotita são predominantemente ferromagnéticos, enquanto granodioritos a muscovita e biotita são paramagnéticos;

- Ocorre o aumento sistemático na susceptibilidade de granitóides félsicos com o aumento da coloração rosada do K-feldspato (Blevin 1994);

- Os granitóides com K-feldspato de coloração vermelho-tijolo usualmente indicam alteração hidrotermal (que geralmente destroi a magnetita), com baixa susceptibilidade;

- Ocorre uma correlação entre a susceptibilidade magnética dos granitóides e a mineralização (Blevin \& Chappel 1982): Cu e Au estão associados às suites intermediárias do tipo-I da série magnética; Mo com as suites do tipo-I mais fracionadas e oxidadas da série magnética; e o Sn com as séries fracionadas do tipo-I ou tipo-S paramagnéticas;

- Para rochas igneas consangüíneas ocorre uma correlação positiva entre susceptibilidade e basicidade;

- As rochas plutônicas em geral apresentam baixos valores de $\mathbf{Q}$ (razão de Königsberger, onde $\mathbf{Q}=\mathbf{J}_{\mathbf{R}} / \boldsymbol{k F}$, para $\mathbf{J}_{\mathbf{R}}=$ magnetização remanescente, $\boldsymbol{k}=$ 
susceptibilidade, $\mathbf{F}$ = campo aplicado), com exceção das intrusivas gabróicas e dioríticas que possuem magnetização remanescente predominante em função da abundância em grãos de magnetita titanífera e das inclusões de (titano)magnetita nos grãos de silicato;

- As rochas ultramáficas (piroxenitos, hornblenditos, dunitos serpentinizados, etc.) são altamente magnéticas.

Os efeitos do metamorfismo sobre as propriedades magnéticas das rochas foram avaliados em diversos trabalhos, entre os quais destacam-se os de Grant (1985), Schlinger (1985), Shive et al. (1988), Wasilewski e Warner (1988), Olesen et al. (1991), Skilbrei et al. (1991), Henkel (1991), Clark et al. (1992), Whitaker (1994) e Clark (1997). Um dos elementos de consenso nesses estudos é o fato de que o metamorfismo afeta a distribuição da magnetita, esteja ela presente como inclusões intracristalinas nos silicatos, como fase cumulus e/ou intercumulus nas rochas originais.

As rochas no fácies anfibolito apresentam, em geral, propriedades fracamente magnéticas e heterogêneas, com susceptibilidade bimodal. Nessas condições metamórficas, o magnetismo é controlado sobretudo pelas rochas máficas mais ricas em hornblenda do que em biotita e/ou clorita. Durante o metamorfismo progressivo de metabasitos o $\mathrm{Fe}^{2+}$ presente previamente na magnetita vai para a hematita, epidoto e clorita no fácies xisto-verde, para a biotita e anfibólio no fácies anfibolito, para magnetita metamórfica no fácies granulito, e para os silicatos paramagnéticos como granada e clinopiroxênio no fácies eclogito (Clark 1997). Para Schlinger (1985) o $\mathrm{Fe}^{2+}$ e o $\mathrm{Ti}$, típicos dos silicatos máficos (p.ex. biotita, clorita, anfibólio) nos fácies xisto-verde e anfibolito, sob condições metamórficas mais elevadas e com desidratação serão capturados pelo clinopiroxênio e óxidos de Fe-Ti.

O metamorfismo progradante desde o fácies anfibolito até o fácies granulito propicia a produção de magnetita como resultado da transformação dos Al-silicatos ( $\mathrm{Fe}, \mathrm{Mg}$ ) hidratados (p.ex. biotita, anfibólios, etc.) em ortosilicatos ricos em $\mathrm{Mg}$ como o piroxênio (Schlinger 1985), seguindo a reação de Grant (1985):

Al-silicatos $(\mathrm{Fe}, \mathrm{Mg})$ hidratados $+\mathrm{SiO}_{2}+\mathrm{O}_{2} \leftarrow \rightarrow$ K-feldspato + silicatos $(\mathrm{Fe}, \mathrm{Mg})+$ magnetita $+\mathrm{H}_{2} \mathrm{O}$

Os protólitos máficos submetidos ao fácies granulito produzem magnetitas secundárias e óxidos de Fe-Ti aumentando a susceptibilidade das rochas nesse fácies. Rochas gnáissicas de alto grau apresentando elevado conteúdo em magnetita e elevada susceptibilidade foram descritas na Groenlândia (Larsen 1981), Escócia (Powell 1970) e 
Noruega (Skilbrei et al. 1991). Olesen et al. (1991) sugerem para regimes metamórficos progradantes o aparecimento da isógrada da magnetita metamórfica sob condiçð̃es de fácies granulito baixo, acima da isógrada do ortopiroxênio.

No retrometamorfismo das rochas no fácies granulito, acompanhado de rápido uplift e condições de baixa- $\mathrm{P}_{\mathrm{H} 2 \mathrm{O}}$, a transformação da granada e do clinopiroxênio produzem grãos finos e espículas de magnetitas secundárias que possuem magnetização remanescente forte e estável (Skilbrei et al. 1991, Clark 1997). O retrometamorfismo com alta-P $\mathrm{P}_{\mathrm{H} 2 \mathrm{O}}$ provoca a redução no conteúdo de magnetita pela substituição da magnetita por silicatos, principalmente hornblenda e esfeno. Entretanto, a magnetita permanece estável no fácies anfibolito alto.

A correspondência positiva entre o aumento no grau metamórfico e a elevação na susceptibilidade das unidades litológicas é de extrema importância na interpretação das anomalias aeromagnéticas. As anomalias positivas de grande comprimento de onda podem ser relacionadas diretamente ao soerguimento da crosta inferior, e portanto da Moho.

\section{7 - Síntese Sobre os Estudos Geofísicos e de Sensoriamento Remoto Aplicados aos Problemas Tectônicos da Província Borborema}

\subsection{1- Trabalhos Prévios de Intepretação Visual de Produtos de Sensoriamento Remoto}

Os primeiros trabalhos foram baseados na interpretação visual monoscópica de imagens Landsat 5-TM, Spot e GEMS/Banda X em escalas 1:250000 e 1:500000, com o intuito da compreensão do padrão estrutural regional da deformação dúctil brasiliana. A estratégia metodológica desenvolvida para a região consistiu na análise de indicadores morfoestruturais dos elementos estruturais (no sentido da redefinição de Means 1993) frágeis (falhas e fraturas) e dúcteis (lineações e foliações) regionais. Esses elementos estão expressos como feições geomorfológicas positivas e/ou negativas da superficie, tais como segmentos de escarpas, cristas, vales e trechos de drenagens, organizados em padrões lineares e curvilineares, caracterizando mudanças texturais/estruturais sutis ou abruptas do terreno (unidades de paisagem, demarcadas por limites erosivos e/ou litológicos). Os resultados foram integrados e apresentados num mapa de lineamentos da porção central da Província Borborema, com abrangência de cerca de $200000 \mathrm{Km}^{2}$, em escala 1:1000000 (Fig.2.5, Amaro et al. 1991 a), que revelou a penetratividade e a complexidade dos arranjos 


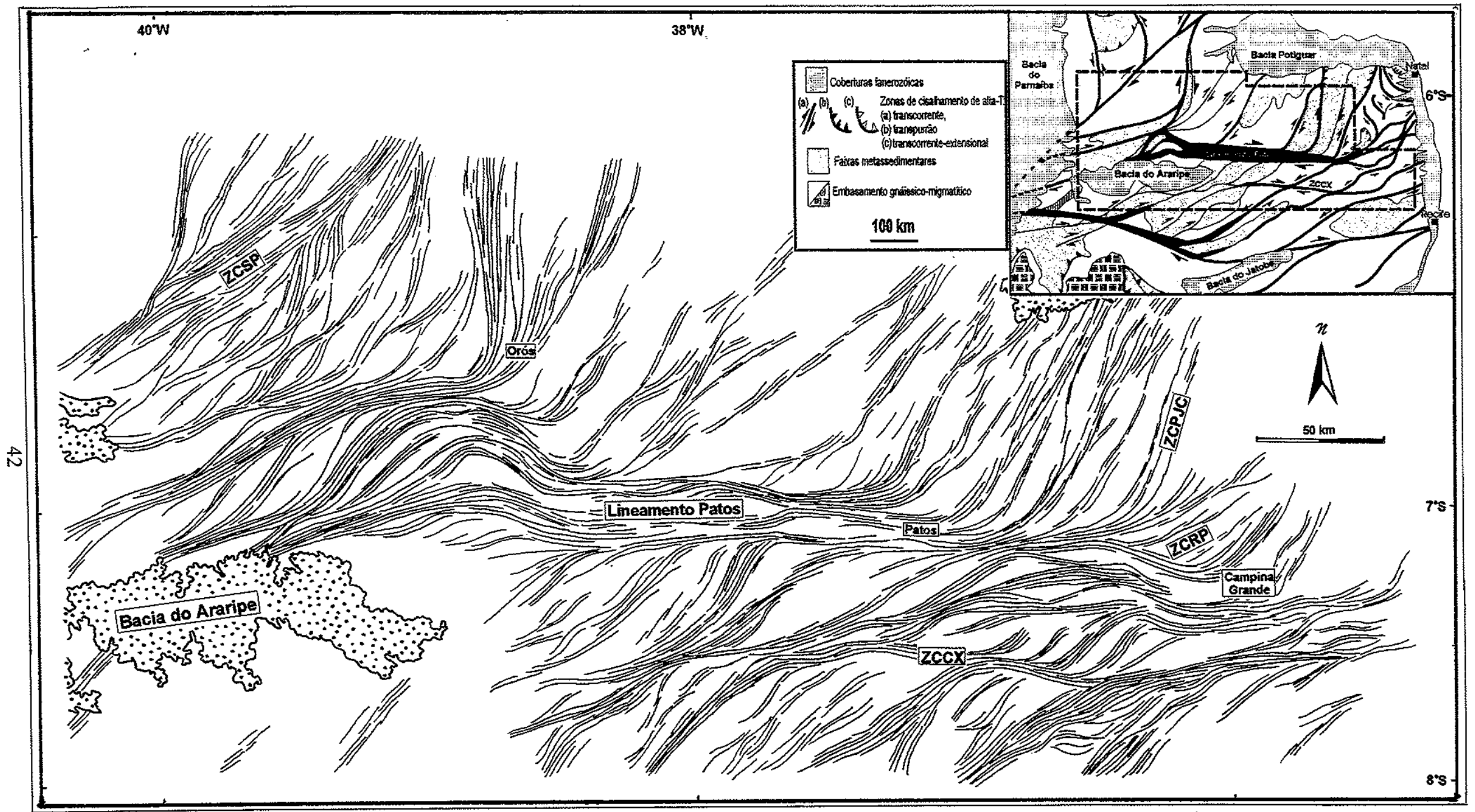

Figura 2.5 - Mapa esquemático dos lineamentos da deformação dúctil brasiliana do Setor Central da Província Borborema, realizados com base na interpretação visual monoscópica das imagens Landsat 5-TM em papel fotográfico (escalas 1:250000 e 1:100000) e produtos digitais (diversas escalas), produtos offset do radar GEMS/Banda X (escala 1:250000), produtos digitais SPOT (diversas escalas) e fotografias aéreas (escala 1:60000). A localização e a cinemática das principais zonas de cisalhamento brasilianas foram destacadas no medalhão. Modificado de Amaro $e t$ al. (1991a). Algumas abreviaturas: ZCSP = Zona de Cisalhamento Senador Pompeu, ZCPJC = Zona de Cisalhamento Picuí-João Câmara, ZCRP = Zona de Cisalhamento Remígio-Pocinhos, ZCCX = Zona de Cisalhamento Caxixola. 
da deformação dúctil na área estudada. As informações obtidas a partir desse mapa de lineamentos, com o aporte de dados estruturais de campo e mapas geológicos preliminares, propiciaram o aprimoramento das informações sobre o regime cinemático atuante no periodo de instalação dos sistemas integrados transcorrente-transpressional das porções Central e Oriental da Província Borborema (Amaro et al. 1991b, Vauchez et al. 1991, Corsini et al.1992).

A sistematização da interpretação visual dos produtos de sensoriamento remoto, diante do quadro atual de conhecimento da região, permitiram a delimitação da Faixa Seridó e seu regime tectônico, num mapa estrutural em escala 1:250000 que registra o traçado dos lineamentos, correspondentes superficiais das estruturas dúcteis penetrativas (foliações e lineações), a geometria dos plútons brasilianos e a cinemática das zonas de cisalhamento (Jardim de Sá 1994). O mapeamento da forma dos corpos graníticos brasilianos em 2D (seção cinemática $\mathrm{XZ}$ ) foi destacado no mapa estrutural, sendo enfatizadas as relações com os lineamentos marcadores das estruturas dúcteis, confirmando que o alojamento $\mathrm{e}$ deformação dos plútons na Faixa Seridó estão associados a um evento dúctil, regionalmente transcorrente-transpressional dextral (Jardim de Sá et al. 1993b).

Os estudos realizados recentemente sugeriram uma estratégia de tratamentos digitais de imagens multiespectrais do Landsat 5-TM na resolução dos problemas estruturais e na discriminação litológica, como auxilio ao mapeamento geológico básico nos terrenos semi-áridos da Província Borborema (Amaro et al. 1993a, 1993b, 1993c, Amaro 1994, Amaro \& Strieder 1994, Medeiros et al.1996). Em cada área abordada foram testados diferentes métodos de filtragens direcionais e composições coloridas de imagens realçadas e os melhores resultados obtidos produziram imagens de alta qualidade adequadas às interpretações geológicas, quanto à delimitação das descontinuidades litológicas e arranjos bidimensionais dos elementos penetrativos da deformação, que foram comparadas a mapas geológicos prévios, dados de campo e geofísicos.

\subsection{2 - Mapas de Anomalias Bouguer e Residual do Nordeste do Brasil}

A rede gravimétrica do Nordeste do Brasil foi resultante da contribuição de diversas instituições de ensino, pesquisa e exploração. Esses dados foram integrados ao banco de dados gravimétricos mantido pelo Instituto Astronômico e Geofísico da Universidade de São Paulo (IAG/USP). Os tratamentos desses dados permitiram a confecção 
de mapas de anomalias Bouguer, Ar-Livre, regionais e residuais para o Brasil (Sá et al. 1993, Ussami et al. 1993) e Província Borborema (Moreira et al. 1989a, Lins et al. 1993, Castro et al. 1997b).

O mapa de anomalias Bouguer do Nordeste Setentrional realizado por Moreira et al. (1989a) mostrou uma anomalia gravimétrica linear com gradientes positivos paralelos à margem continental, interpretada como o afinamento crustal diferenciado entre a crosta leste e norte, devido a extensão continental durante a separação dos continentes sul-americano e africano. O mapa de anomalias residuais, resultante da remoção das anomalias isostáticas regionais dos valores Bouguer, apresentou anomalias de comprimentos de onda curtos e negativos relacionados aos granitóides e faixas de metassedimentos, e positivos associados ao embasamento cristalino de alta densidade. Castro et al. (1997b), baseado no mesmo banco de dados gravimétricos, apresentaram o mapa de anomalias Bouguer do Nordeste Setentrional e margem continental adjacente, indicando a boa correlação das anomalias e lineamentos gravimétricos de curto a médio comprimentos de onda com os blocos crustais/litosféricos e os principais trends estruturais (Fig.2.6).

Rand e Manso (1990) obtiveram para a Faixa Costeira do Nordeste Oriental mapas gravimétricos (Bouguer e residual) e magnetométricos (campo vertical e residual) de referência básica para a região. As principais conclusões sugeridas pelos autores foram aquelas destacadas a seguir: (a) a subida gradativa da Moho em direção à linha litorânea, com deslocamento por falhamentos perpendiculares à costa que apresentam continuidade desde o interior do continente até as áreas de offshore; (b) estruturação da faixa costeira em blocos com anomalias positivas e negativas alternadas; (c) provável hot stop antigo na região de Lucena com ramificação para Tabatinga; (d) presença de rochas básicas subterrâneas em toda a extensão da faixa costeira.

Moreira et al. (1990), a partir do mapa residual obtido pela suavização do mapa Bouguer, destacaram uma anomalia positiva alinhada aos epicentros da falha de Samambaia, ladeada por duas anomalias negativas. A heterogeneidade de densidades da crosta na região de João Câmara foi sugerida como responsável pela localização dos hipocentros dos eventos sísmicos, concentrados na lateral oeste da anomalia positiva.

Lins et al. (1993) obtiveram o mapa de anomalias residuais da Porção Oriental da Província Borborema, pela eliminação dos grandes comprimentos de onda marcadores do 


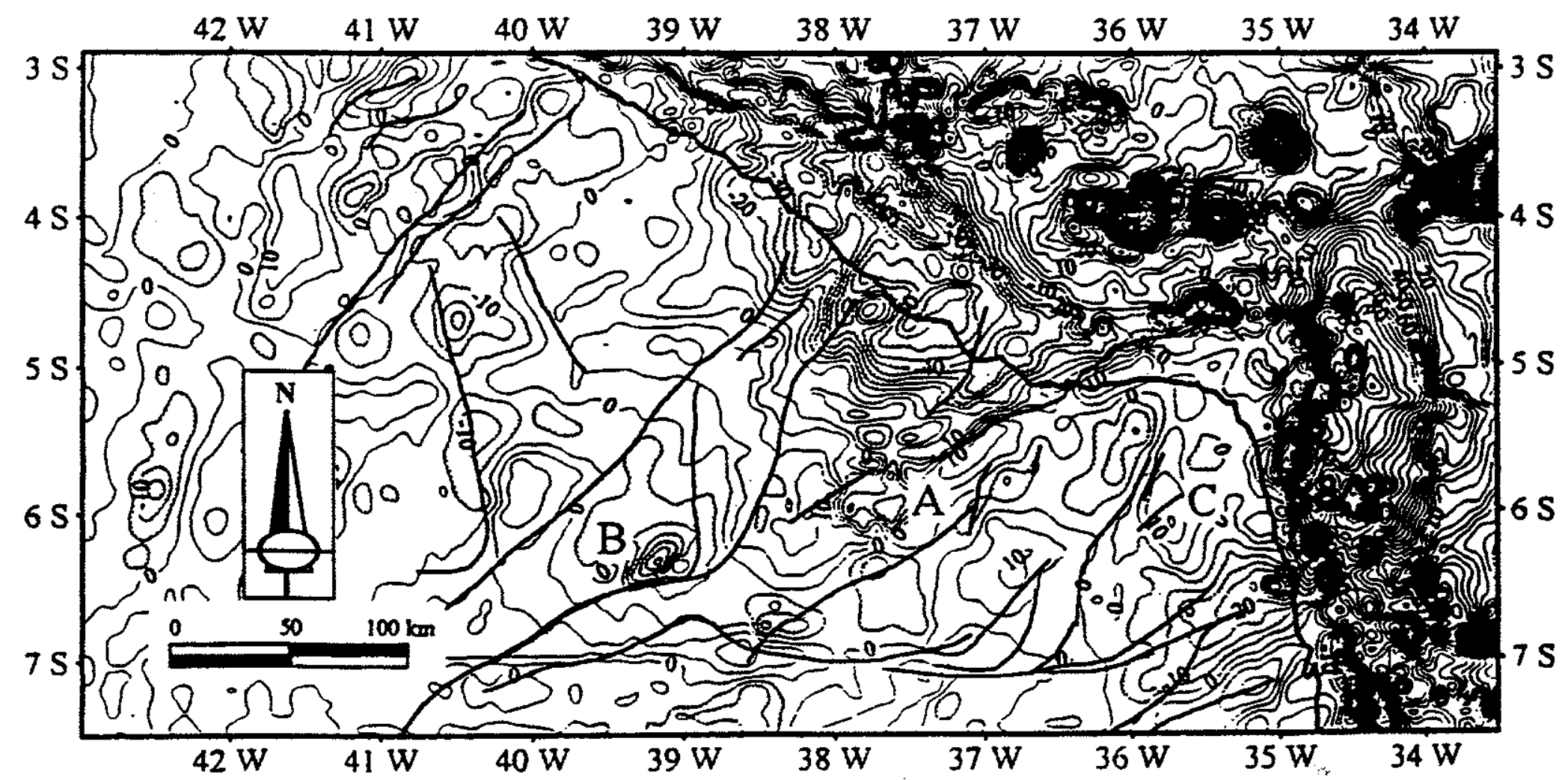

Figura 2.6 - Mapa de anomalias gravimétricas residuais para o Nordeste Setentrional do Brasil e Margem Continental Adjacente obtido pelo método de ajuste polinomial robusto (Beltrão et al. 1991). A e B = Anomalias gravimétricas negativas, e C = Anomalia gravimétrica positiva Intervalo de isolinhas de $5 \mathrm{mGal}$. Modificado de Castro et al. (1997a). 
afinamento crustal mesozóico da margem continental (Fig.2.7). Para esses autores, as anomalias isoladas, os eixos positivos e negativos seriam os representantes da última estruturação tectônica da região no Ciclo Brasiliano, enquanto algumas deflexões das anomalias próximas à costa refletiriam reativações meso-cenozóicas. O eixo $\mathrm{A}$ de anomalias negativas coincide com a porção central da Faixa Seridó, estendendo-se até o interior da Bacia Potiguar, e está consonante com os dados estruturais e metamórficos sobre o espessamento crustal nessa zona, além dos efeitos das intrusões graníticas. Os eixos B e C de anomalias negativas são marcadores de faixas de micaxistos ao longo das zonas de transcorrência e de corpos graníticos isolados (p.ex. o plúton Dona Inês). O eixo D de anomalias positivas coincide com a zona de cisalhamento Remígio-Pocinhos de movimento transtracional acompanhado de afinamento crustal, onde algumas anomalias positivas isoladas podem indicar magmas mantélicos e/ou blocos granulíticos ao longo da zona. $\mathrm{O}$ eixo $\mathrm{E}$ de trend $\mathrm{NW}$ infletindo para NNE é interpretado como uma zona de afinamento crustal causado por cisalhamentos extensionais ou transcorrentes extensionais de direção NW, a exemplo da região de Ielmo Marinho-Taipu, com forte gradiente entre a Serra de São Bento e Tangará (LSBT). A anomalia $\mathrm{X}$ de mínimos gravimétricos, no extremo NE do mapa, demarca corpos graníticos tabulares e uma fatia de micaxistos com fraco mergulho para NE, sendo as demais anomalias negativas isoladas Y (plúton Monte das Gameleiras) e Z (plúton Dona Inês) marcadoras de sítios de transtração intracrustais (Jardim de Sá et al. 1993, Jardim de Sá 1994). Um máximo gravimétrico localizado (anomalia W) pode refletir o alojamento de magmas mantélicos, como proposto por Rand \& Manso (1990).

Numa avaliação da estruturação neotectônica do litoral de Natal, Bezerra et al. (1993) demonstraram a correlação entre o mapa de anomalias Bouguer e o sistema de estruturas frágeis que afetam a rede de drenagens e os sedimentos do Grupo Barreiras. A estruturação $40^{\circ}-60^{\circ} \mathrm{NE}$ e $40^{\circ}-50^{\circ} \mathrm{NW}$ detectada independe da cobertura sedimentar e do contraste de densidade entre as unidades litológicas do embasamento e as rochas sedimentares, refletindo diretamente a estruturação do embasamento cristalino no domínio frágil. Para esses autores, os altos gravimétricos da região de Natal estariam associados a heterogeneidades de densidades em níveis profundos da crosta.

Castro et al. (1997a) apresentaram uma estimativa do relevo da Moho na Província Borborema pelos métodos do vínculo de isostasia e suavidade, mostrando em 


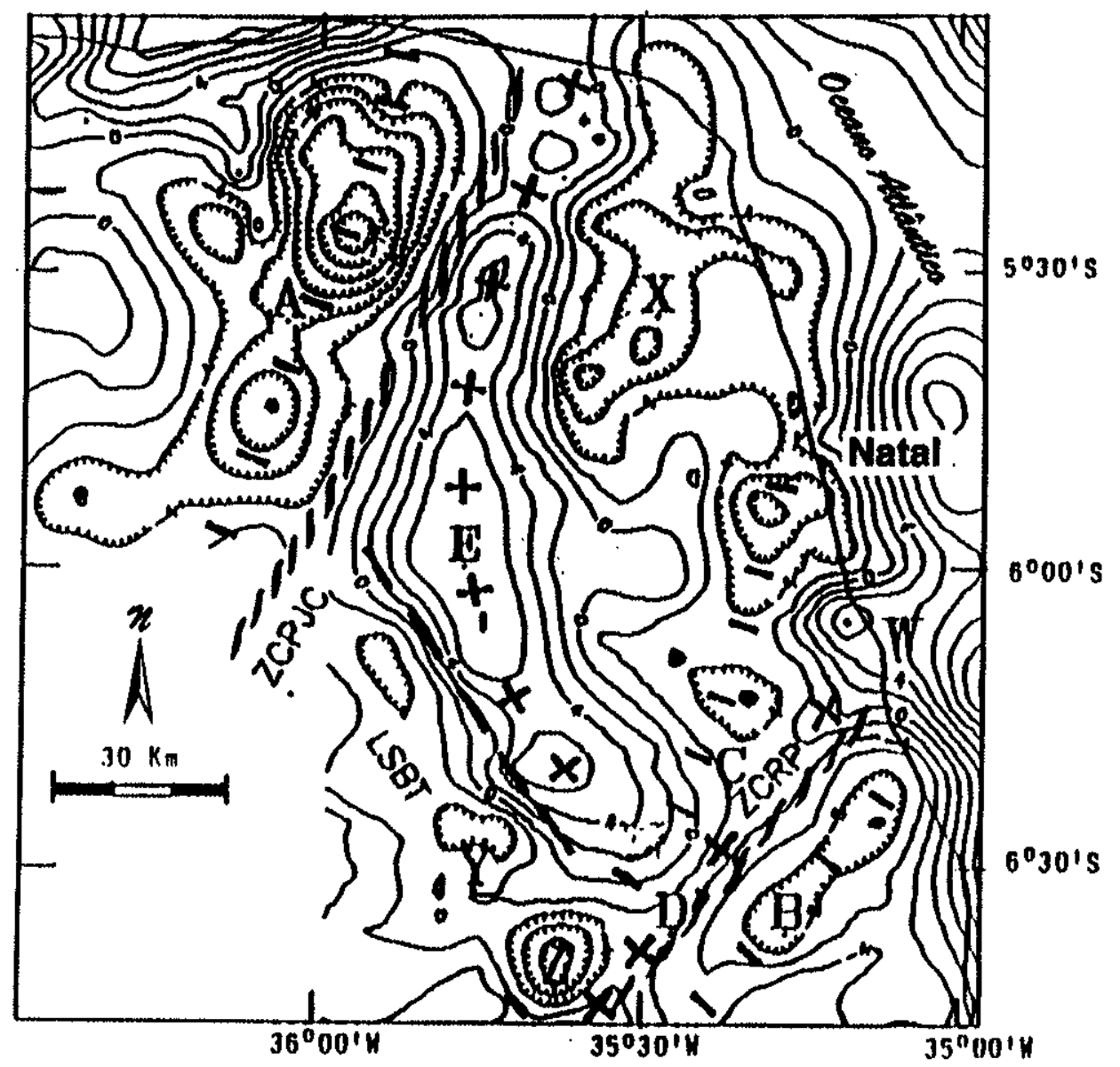

IIII A, B, C - Elxos de anomallas negatlvas

++++ D, E - Elxos de anomallas positivas

- - - Lineamento Săo Bento-Tangará (LSBT)

Zonas de clsalhamento brasillanas:

- Zona de cisalhamento Picui-Joăo Camara (ZCPJC)

- Zona de clsalhamento Remiglo-Pocinhos (ZCRP)

$X, Y, W, Z$ - Anomallas isoladas

Figura 2.7 - Mapa de anomalias gravimétricas residuais da Porção Oriental da Faixa Seridó. Intervalo de isolinhas de $2 \mathrm{mGal}$. Modificado de Lins et al. (1993). 
ambos os métodos o decréscimo progressivo de $30 \mathrm{~km}$ no continente para $10 \mathrm{~km}$ nas áreas submersas no sopé continental.

\subsection{3 - Mapas Aeromagnéticos do Nordeste Oriental}

Carneiro et al. (1988) efetuaram a compilação dos mapas dos projetos aeromagnéticos do Nordeste Oriental com intuito de caracterizar a reativação mesocenozóica de falhas antigas, a disposição de corpos ígneos aflorantes e/ou subsuperficiais e as coberturas sedimentares. No Projeto Esperança (DNPM/Nuclebrás 1976/1978) destacaram o controle das assinaturas magnéticas dos falhamentos transcorrentes de Cacerengo, Pirpirituba, Guarabira e Congo (denominação conforme os mapas da DNPM/CPRM 1974, 1978). No Projeto da Plataforma Continental do Nordeste (Petrobrás/PRAKLA 1970) interpretaram a anomalia de direção NE a leste de Arês/RN como um alto estrutural do embasamento, limite entre as bacias Pernambuco-Paraiba, a sul, e Potiguar, a norte. Na região entre Baía Formosa/RN e Recife/PE as anomalias de direção geral ENE-EW refletiriam o substrato da Bacia Pernambuco-Paraíba controlado pela estruturação do embasamento continental.

Moreira et al. (1989b) identificaram uma anomalia magnética positiva no setor sul da Faixa Seridó, com direção EW virgando para NE acompanhando a estruturação do sistema Patos-Seridó, sugerindo a correlação com um bloco máfico e magnético na crosta inferior e com granitos a magnetita alojados em níveis crustais mais rasos, esses últimos também responsáveis pelas anomalias gravimétricas negativas associadas.

Ravat et al. (1991) na determinação dos contrastes de susceptibilidades na litosfera da placa Sul-americana, baseados nas anomalias magnéticas do MAGSAT, mostraram uma extensa anomalia positiva orientada $\mathrm{N} 55^{\circ} \mathrm{W}$ para a região da Província Borborema, presente nos mapas de anomalia magnética total, de anomalias por redução-aopolo (com continuação-para-baixo de $300 \mathrm{~km}$ ) e de contraste de susceptibilidade (para camada crustal magnetizada de $40 \mathrm{~km}$ de espessura), limitada provavelment no Lineamento Transbrasiliano para NW e mantendo a mesma direção para a crosta oceânica. Na segunda derivada vertical ao longo do perfil de inversão, que intercepta a Província Borborema na direção NW (perfil AA' da Fig. 2.8), ocorre correspondência direta entre o cruzamento no nível zero e os limites das principais provincias tectônicas interceptadas. 

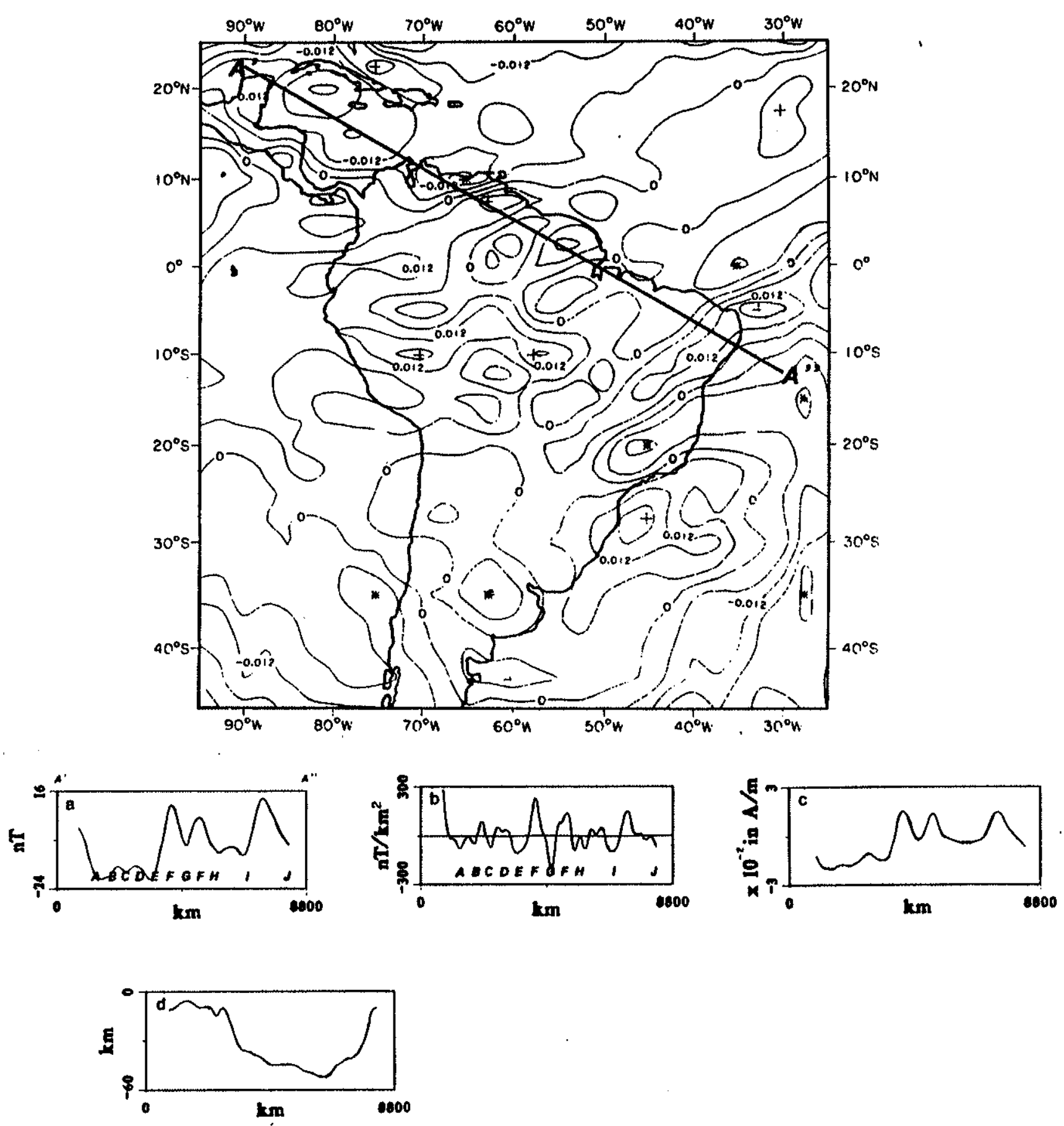

Figura 2.8 - Mapa do contraste de susceptibilidade da América do Sul assumindo uma camada crustal magnetizada de $40 \mathrm{~km}$. Intervalo de isolinhas 0,0063 (SI units). A Figura mostra a localização do perfil $\mathrm{AA}^{\prime}$ que intercepta as principais provincias tectônicas: $\mathrm{A}=$ Bacia de Yucatan, $B=$ Cadeia Nicaraguense, $C=$ Bacia Colombiana, $D=$ Faixa de Dobramentos Andina, $\mathrm{E}=$ Depressão Orinoco, $\mathrm{F}=$ escudo das Guianas, $\mathrm{G}=$ Aulacógeno Takutu, $\mathrm{H}=$ Aulacógeno Amazônico e São Luís, Bacias Amazônica e Parnaiba, I = Faixa de Dobramentos Carirís, $J=$ Bacias Brasileiras. (a) Perfil das anomalias magnéticas reduzidas ao pólo, (b) Perfil da segunda derivada vertical, (o) Perfil do contraste de susceptibilidade assumindo espessura crustal de $40 \mathrm{~km}$, (d) Espessura crustal ao longo do perfil AA'. Modificado de Ravat et al. (1991). 


\section{RECONSTRUÇĀO PRÉ-DERIVA MESOZÓICA (140 Ma)}
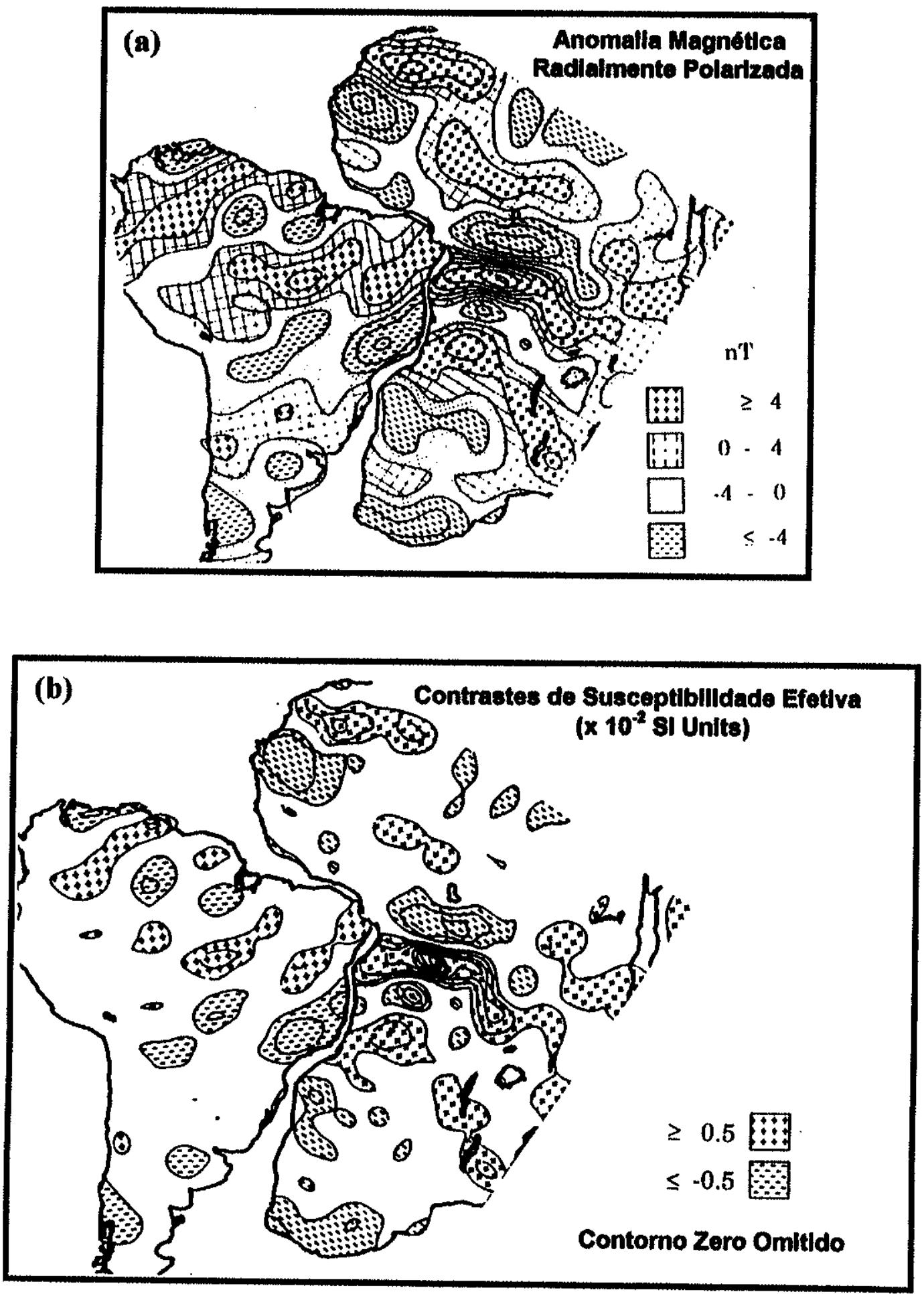

Figura 2.9 - Correlação das anomalias magnéticas para a América do Sul e África numa reconstrução pré-deriva mesozóica $(140 \mathrm{Ma})$ : (a) anomalias magnéticas radialmente polarizadas; (b) contrastes de susceptibilidade efetiva. Modificado de Ravat et al. (1992). 
Ravat et al. (1992) analisaram os contrastes das anomalias magnéticas de comprimentos de onda longos do MAGSAT entre a África e a América do Sul na compreensão da evolução de suas margens continentais (Fig. 2.9), correlacionando as estruturações pré-mesozóicas das principais províncias tectônicas. As anomalias magnéticas negativas nas províncias pan-africanas da África Ocidental (Nigéria e Camarões) indicam a desmagnetização da crosta inferior na região pelo episódio de rifteamento mesozóico (Fairhead 1988) e pela atividade intensa de hotspots no Mesozóico e Cenozóico, enquanto que para a Província Borborema a atividade relacionada a hotspots ficou restrita às proximidades da margem continental no estágio de separação dos continentes (100-120 Ma), preservando as anomalias positivas provavelmente relacionadas ao Brasiliano, principal evento tectônico gerador e modelador da crosta em tempos pré-drift. 


\section{3 - ASPECTOS METODOLÓGICOS}

\section{1 - Estratégia de Tratamentos dos Produtos de Sensoriamento Remoto Aplicados ao Mapeamento Geológico}

Nos procedimentos gerais adotados no mapeamento geológico regional e semidetalhe da área em estudo buscou-se definir os métodos mais efícientes que, além de acentuarem as descontinuidades litológicas e estruturais, permitissem a integração das áreastestes ao contexto tectônico regional. A primeira etapa da estratégia de tratamentos consistiu na interpretação visual monoscópica sistemática dos padrões de lineamentos nos produtos fotográficos do Landsat 5-TM e GEMS/Banda X, nas diversas escalas disponiveis, de forma a conduzirem à confecção do mapa geológico simplificado, conforme a metodologia definida para os terrenos semi-áridos da Província Borborema (Amaro et al. 1991a). As principais feições lineares superficiais foram reagrupadas em sistemas de lineamentos, com base em critérios como (a) a orientação azimutal, (b) os comprimentos comparativos, (c) o padrão de distribuição espacial, e (d) os espaçamentos mútuos (densidade dos sistemas).

Na segunda etapa (Amaro et al. 1993a, 1993b, 1993c), os tratamentos digitais de imagens propriamente ditos, foram aplicados métodos de síntese e realce das informações espaciais, por técnicas de filtragem direcional no domínio da imagem aplicadas às imagens monocanais (bandas 4 e 5 do Landsat 5-TM) em diversas áreas-testes com dimensões variáveis desde 50 vs. $50 \mathrm{~km}$ a 150 vs. $150 \mathrm{~km}$. Nessa etapa também foram realizados os procedimentos de análise e interpretação das assinaturas espectrais e conseqüente seleção das composições coloridas das bandas multiespectrais do Landsat 5-TM. Do conjunto de imagens coloridas foram interpretadas aquelas que proporcionaram melhor distinção das unidades litoestratigráficas regionais, apesar da complexidade dos elementos geológicos no terreno e de suas respostas radiométricas. Essas imagens coloridas, quando combinadas às imagens provenientes das filtragens direcionais, contribuiram na detecção visual de linhas e bordas, provavelmente marcadoras dos elementos estruturais e dos contatos (bordas) entre as unidades. Às imagens digitais monocanais e coloridas resultantes da segunda etapa aplicouse os procedimentos de interpretação visual da primeira etapa, na intenção de que as variações na cor, brilho e intensidade dos pixels colaborassem na determinação espacial 
detalhada do fabric estrutural. A cinemática das zonas de cisalhamento é determinada com base na comparação da geometria dos lineamentos relativos ao fabric penetrativo (no caso $\mathrm{S}_{3}$ e $\mathrm{L}_{3}$ ) em relação ao traçado das zonas de cisalhamento (plano $\mathrm{C}_{3}$ ). As formas (sigmoidal, alongada e en cornue) e o fabric (viscoso e/ou plástico) dos plútons granitóides vinculados às zonas de cisalhamento facilitam a dedução do movimento predominante na zona de cisalhamento e, no caso dos granitóides sintectônicos, do mecanismo de alojamento do plúton.

Um dos procedimentos da terceira etapa foi a comparação da complementaridade entre os diversos sistemas de lineamentos obtidos nas etapas anteriores. Os mapas foram combinados de forma que as diferentes características dos lineamentos detectados nos diversos mapas fossem compilados num único mapa de lineamentos em escala regional. Ao final, foram integrados a esse mapa as informações contidas na documentação geológica pré-existente e os parâmetros estruturais coletados em campo, que confirmam a organização espacial dos sistemas de lineamentos. Embora os resultados obtidos com as imagens interpretadas visualmente sejam altamente significativos na compreensão da estruturação regional, o acréscimo dos dados de campo favorecem a composição do arranjo tridimensional das macro-estruturas, permitindo correlações entre as estruturas em meso- e macro-escalas.

Pelo visto, o critério condutor da estratégia adotada foi a intervenção humana rigorosa em todos os procedimentos de extração das informações dos tratamentos espectrais e espaciais (Wise 1983, Wheeler 1983), com base na inspeção visual das imagens monocanais ou combinadas. A interação humana direta envolve alto nível de decisões, que favorece a preservação da coerência entre os critérios da unidade de paisagem e uma excelente determinação da correspondência geométrica dos elementos (Richards 1995). O sucesso dos procedimentos de interpretação visual em todas as etapas exigiu experiência e capacidade em explorar efetivamente os elementos espaciais, espectrais e temporais contidos nas imagens. As informações espaciais, que indicam diretamente o fabric estrutural que se pretende realçar, estão presentes na qualidade da forma, tamanho, orientação e densidade textural do conjunto de elementos das imagens multiespectrais. Algumas chaves espectrais podem ser exploradas pelo fotointérprete, de acordo com a experiência e conhecimentos $a$ priori dos tratamentos empregados e da área estudada, sobre as características de 
reflectância espectral dos objetos na superficie do terreno e a maneira como estas caracteristicas são coletadas pelo sensor orbital.

Os aspectos metodológicos para os estudos estruturais do Setor Extremo Nordeste da Província Borborema foram conduzidos parcialmente conforme a sistemática previamente adotada para a região, acrescidos da análise visual detalhada de imagens Landsat 5-TM realçadas por filtragem direcional e composições coloridas. Os resultados combinados foram interpretados para a deformação dúctil proterozóica, de acordo com a estratégia sintetizada como se segue:

(1) Investigação preliminar de campo: levantamento dos dados litológicos e estruturais em escala de afloramento, controle dos pontos baseados nos mapas geológicos preliminares, em escalas regional e semi-detalhe, e localização via GPS;

(2) Análise dos padrões de drenagens e geomorfológicos dos mapas planialtimétricos (escala 1:100000), reduzidos para a escala 1:250000;

(3) Análise visual dos produtos fotográficos das imagens Landsat 5-TM/Bandas 4 e $5 \mathrm{em}$ escalas 1:500000 e 1:250000, e GEMS/Banda X em escala 1:250000;

(4) Tratamento digital da imagens- Landsat 5-TM por filtragem direcional e composições coloridas: análise visual monoscópica das imagens digitais monocanais e combinadas;

(5) Síntese geológica e controle de campo: comparação dos diferentes mapas temáticos para interpretação geológica; combinação das diversas abordagens analíticas pela digitalização dos mapas temáticos, integrados numa única escala regional (1:250000); confirmação em campo das informações dos mapas temáticos.

A análise estatística dos lineamentos foi tratada por diversos autores, com vistas ao estudo das morfologias e orientações dos principais sistemas de lineamentos em escala regional (Blanchet 1957, Burns \& Shepard 1976, Bodechtel \& Munzer 1978, Petrorius \& Partridge 1974, Dix \& Jackson 1981, Barlow \& Odgem 1982, Scanvic 1981, Rindstad \& Follestad 1982, Koopsman 1986, Conradsen et al. 1986, Ananaba \& Ajakaie 1987). O método convencionat de apresentação dos dados estatísticos dos lineamentos, e de methor repercusão geológica, consiste em diagramas polares com "pétalas" proporcionais ao comprimento cumulativo dos lineamentos classificados conforme a orientação azimutal (p.ex. Wise et al. 1985). Contudo, nenhum dos métodos e apresentações estatisticas puderam demonstrar quantitativamente, para a área estudada, o conceito incutido no arranjo 
não-fortuito dos lineamentos (Wheeler 1983) representativo da deformação dúctil e as situações inusitadas decorrentes, como a virgação abrupta dos feixes de lineamentos (p.ex. a virgação do sistema de lineamentos Patos-Faixa Seridó, a terminação em splay do lineamento Patos na região de Campina Grande), imprescindiveis na interpretação geológica do sincronismo dos elementos dúcteis da deformação. Assim, optou-se pela análise e interpretação visual dos sistemas de lineamentos detectados nas imagens filtradas e combinadas para realces direcionais, com o intuito principal de preservar-se o arranjo simétrico e elegante dos padrões de lineamentos, segundo a proposta de "geo-arte linear" de Wise (1982).

\subsection{1 - Realce Digital do Sistema de Lineamentos e as Operações de Convolução}

Diversas metodologias foram desenvolvidas para o realce, extração e delineação dos lineamentos, principalmente pela filtragem direcional, imagens derivativas, algoritmos de realce, filtragem Fourier e algoritmos de detecção linear (Elrich 1977, 1979, Burdick \& Speirer 1980, Moore \& Waltz 1983). Os aspectos descritivos principais das imagens submetidas a esses tratamentos digitais podem ser sumariados: (a) as descrições estruturais, onde o principal critério utilizado é o controle das variações na intensidade entre o objeto e seu ambiente; (b) as descrições multiespectrais que envolvem métodos de classificação; e (c) as descrições texturais que caracterizam o grau de homogeneidade de uma superficie, baseadas em critérios pseudo-aleatórios da imagem. Nos procedimentos de realce digital dos lineamentos destacou-se sobretudo as descrições dos elementos estruturais. Todavia, todos os elementos descritivos da imagem, incrementados pelos tratamentos numéricos, foram utilizados de modo interdependente, depois de submetidos às avaliações que impedem a propagação de possíveis artefatos.

As técnicas especificas empregadas consistiram no realce e modificação geométrica detalhada das bandas 4 e 5 do Landsat 5-TM, aplicadas diretamente nos dados da imagem, e por isso chamadas de procedimentos no domínio da imagem. No recobrimento geográfico da Porção Extremo Nordeste da Província Borborema foram utilizadas a cena $214 / 065$ e os quadrantes $241 / 064 \mathrm{~A}$ e $214 / 065 \mathrm{C}$ do Landsat 5-TM. Em contraste com as técnicas pontuais de realce radiométrico, as técnicas de realce geométrico envolvem operações sobre a vizinhança mais próxima. As técnicas empregadas modificam os valores de brilho dos pixels para valores que derivam dos brilhos dos pixels nas cercanias. Nesta 
interdependência espacial dos valores dos pixels está fundamentado o detalhamento das variações geométricas da imagem (Richards 1995). Para cada imagem binária obtida foram aplicadas as metodologias de identificação e extração de lineamentos, com base na monoscopia de luz transmitida e refletida. Os mapas de lineamentos resultantes, oriundos dos diversos setores da região de estudo, foram combinados sistemáticamente entre si e com os mapas provenientes da análise das imagens fotográficas do Landsat 5-TM/bandas 4 e 5 (escala 1:250000), GEMS/Banda X (escala 1:250000), fotos aéreas (escala 1:60000) e composições coloridas descritas no item 5.6 (diversas escalas), e ao final integrados num único mapa de lineamentos, em escala 1:250000, de modo a preservar-se a visão sinóptica das imagens e a correlação regional entre os diversos sistemas de lineamentos. Este mapa de lineamentos foi então comparado e combinado aos mapas geológicos existentes nas diversas escalas e aos dados de campo previamente coletados. Com esse procedimento buscou-se avaliar a validade das feições lineares, conforme os critérios propostos por Wheeler (1983), que se seguem: (1) a objetividade das feições numa definição a priori; (2) a reprodutibilidade (persistência) das feições quanto à direção azimutal, comprimento e continuidade espacial; (3) a certeza da classificação, que distingue entre feições reais e especulativas; (4) a coincidência com elementos geológicos cartografados.

A detecção dos lineamentos nas imagens multiespectrais é função da aptidão dos captores em revelar transições sutis de reflectância ou de retrodifusão das formas topográficas e das anomalias de solo e vegetação, geralmente relacionadas aos lineamentos (Yatabe \& Howarth 1984, Soesilo \& Hoppin 1986, Desłandes \& Gwyn 1991). Os principais fatores que interferem na percepção dos lineamentos nas imagens orbitais são: (a) as propriedades de resolução espectral, espacial e radiométrica dos captores; (b) o conteúdo d'água nos solos; (c) as características da cobertura vegetal; (d) o tipo de cobertura vegetal e de uso do solo; (e) as condições atmosféricas no momento do imageamento; (f) as condições direcionais da fonte de imageamento (Deslandes \& Gwyn 1991). Alguns trabalhos demonstraram que os lineamentos são mais perceptiveis nas imagens orbitais multiespectrais e Radar quando estão fora da faixa de cerca de $20^{\circ}$ a partir da direção de iluminação, conhecida como zona de invisibilidade (Yamaguchi 1985, Bonham-Carter et al. 1985, Drudy 1986, Lowman et al. 1987). Portanto, na seleção dos melhores métodos de filtragem 
no realce dos lineamentos para análise estrutural, foi considerada a eficiência dos filtros no destaque dos lineamentos orientados em direções diferentes daquela do realce preferencial.

As principais técnicas de realce geométrico referem-se ao alisamento e ao destaque de objetos da imagem, esta última envolvendo a detecção e o realce de linhas e bordas na imagem. Estes efeitos são obtidos por técnicas de convolução em que um filtro ou kernel (matriz, box ou janela) é movido sobre a imagem, pixel a pixel, de acordo com a relação :

$$
r_{(i, j)}=\sum_{m=1}^{M} \sum_{n=1}^{N} \phi_{(m, n)} t_{(m, n)}
$$

Onde $r_{(i, j)}$ é a nova resposta de britho do pixel $(i, j)$ ao kernel, $\phi_{(m, n)}$ é o valor do britho do pixel na imagem original e $t_{(m, n)}$ é o registro do kernel naquela posição. Os valores de britho de cada pixel sobreposto pelo filtro são somados, a matriz é resolvida e o resultado é o novo valor de brilho para o pixel localizado no centro da matriz (Fig.3.1). No caso da convolução, $t$ possui largura relativamente pequena se comparado ao tamanho da imagem. Assim, o valor do pixel na posição $(i, j)$ recebe contribuição de uma pequena região ao redor do pixel em $(m, n)=(i, j)$. Para $t^{\prime}$ com dimensão de $\mathrm{W}$ linhas por $\mathrm{W}$ colunas $(\mathrm{W} \times \mathrm{W})$, a equação torna-se:

$$
r_{(i, j)}=\sum_{m} \sum_{n} \phi_{(m, n)} t_{(i-m, j-n)}^{\prime}
$$

A Fig.3.1 apresenta uma representação da convolução do filtro quadrado $t^{\prime}$ (W x W) sobre a imagem $\phi(m, n)$, de acordo com a equação. Os valores alocados em cada posição do filtro (matriz) é que determinam o realce dos pixels associados aos lineamentos. Após os cálculos realizados com todos os pixels, a imagem é modificada radiometricamente realçando ou alisando suas feições geométricas, conforme a dimensão do filtro empregado. Portanto, essas operações são do tipo "dependentes do contexto", onde o nível de cinza de um pixel é modificado em função dos níveis de cinza dos pixels na vizinhança imediata (Schowengerdt 1983).

\subsection{2 - A Filtragem Direcional na Deteç̧ão e Realce dos Lineamentos:}

Nas técnicas de realce digital por filtragem direcional são assinaladas as altas freqüências espaciais das imagens expressas petas fortes transições de níveis de cinza 


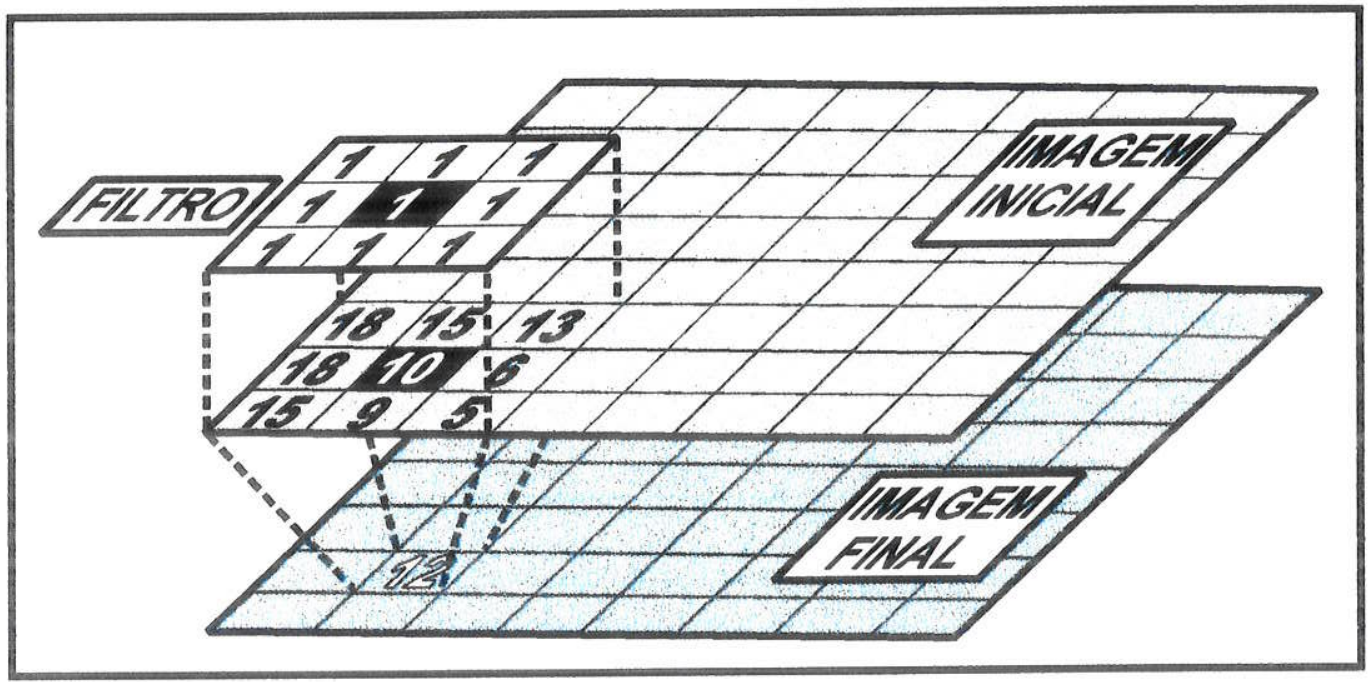

Figura 3.1 -Representação da operação de convolução por filtro de média quadrada $3 \times 3$.

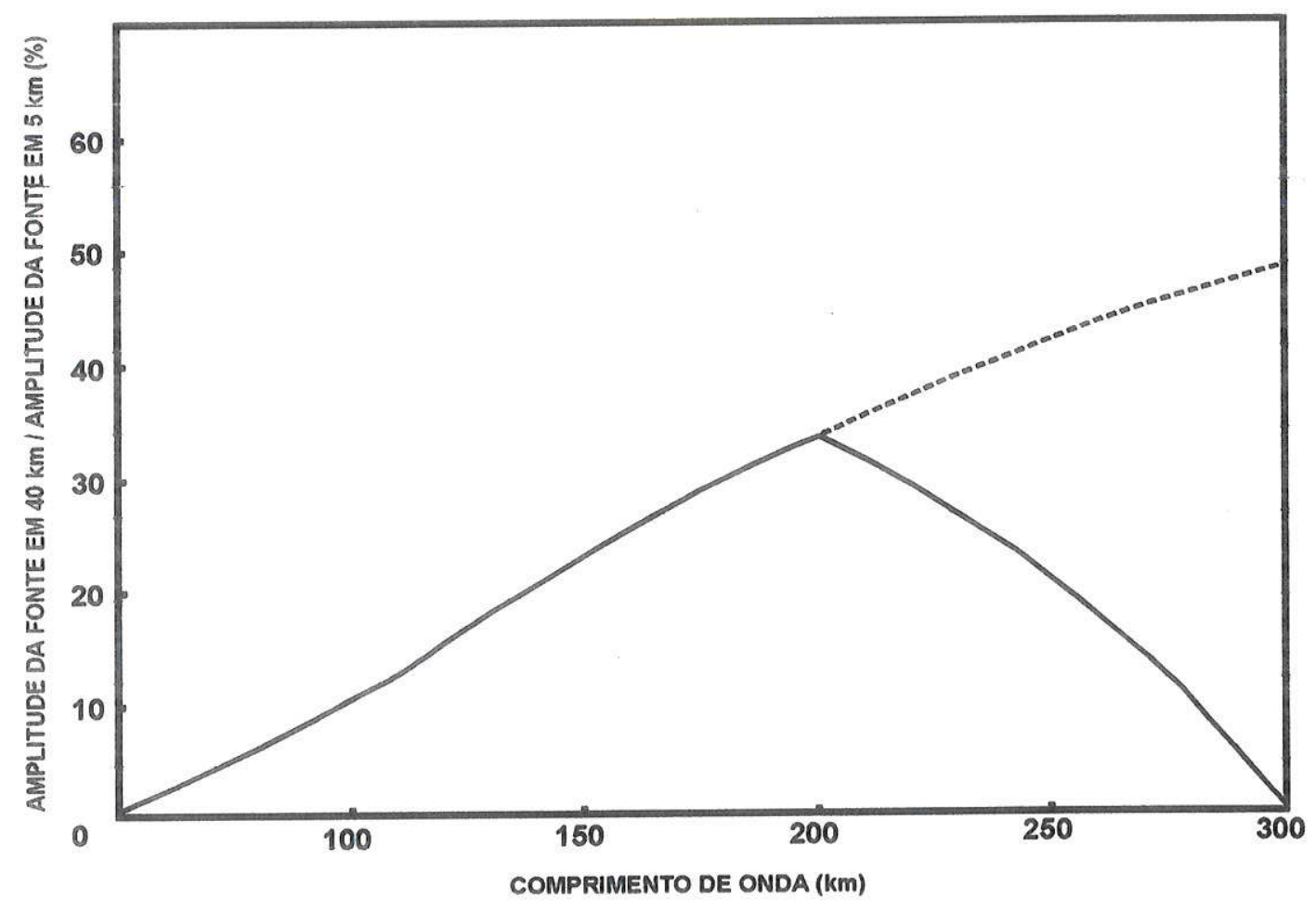

Figura 3.2- Diagrama da atenuacão dos componentes de comprimentos de onda das anomalias causadas por efeitos combinados das profundidades das fontes e o limite de cutoff das filtragens. A linha tracejada indica a projeção dos efeitos de profundidades das fontes. 
associadas aos lineamentos. $O$ cálculo para a filtragem direcional consiste na medição da primeira e segunda derivadas dos níveis de cinza da imagem, de acordo com a direção preferencial predisposta na matriz em convolução. A filtragem direcional se distingue das demais técnicas de filtragem espacial pela habilidade em evitar a tendência do realce preferencial referente à direção da fonte do imageamento, na disposição de atributos direcionais na matriz de convolução (Drudy 1986). Esse fato permite a melhoria na percepção dos lineamentos dispostos paralelamente ao imageamento, que não seriam favorecidos em condições naturais (Deslandes \& Gwyn 1991).

A segmentação é um processo de partição da imagem digital pelo reconhecimento de conjuntos conectados de pixels que assinalam as categorias de objetos componentes da imagem (Castleman 1996). Este processo é aplicado na detecção de descontinuidades marcadas por pontos, linhas ou bordas entre os objetos ou entre os objetos e o background da imagem (Gonzalez \& Woods 1992). Na abordagem para detecção dos pontos, o nível de cinza de um pixel é comparado aos pixels circunvizinhos é isolado dos demais de acordo com um peso de ponderação dos coeficientes do filtro empregado. No realce das linhas (limites alinhados entre regiões da imagem formadas por pixels com níveis de cinza contrastantes) ou bordas (conjunto de pixels interligados num arco onde os pixels fora do arco apresentam diferenças significativas de niveis de cinza) o método de diferenciação mais empregado é o gradiente máximo (Davis 1975, Schowengerdt 1983). Segundo Richards (1995), os melhores resultados na deteç̧ão de bordas e incremento dos detalhes geométricos no domínio da imagem são, geralmente, obtidos (1) pelos filtros direcionais de convolução, (2) pelo cálculo de derivadas espaciais, e (3) pela subtração dos pixels de imagens alisadas da imagem original.

No destaque das bordas e linhas das imagens do Setor Extremo Nordeste da Província Borborema, marcados por mudanças sutis no nivel de cinza de um pixel a outro, delimitando os sistemas de lineamentos, diversas abordagens foram analisadas e a combinação entre filtragem espacial de alta frequêencia e thresholding (Davis 1975, Schowengerdt 1983) foram os procedimentos que apresentaram o melhor desempenho.

Para uma imagem $f(x, y)$, o gradiente de $f$ nas coordenadas $(x, y)$ é definido pelo vetor: 


$$
\nabla f=\left|\begin{array}{l}
\delta f / \delta x \\
\delta f / \delta y
\end{array}\right|=\left|\begin{array}{l}
G x \\
G y
\end{array}\right|
$$

Na detecção de linhas e bordas é importante a quantificação da magnitude do vetor $\nabla f$ :

$$
\operatorname{mag}(\nabla f)=\left[(G x)^{2}+(G y)^{2}\right]^{1 / 2}
$$

Esse valor corresponde ao grau máximo de incremento de $f(x, y)$ por unidade na direção $\operatorname{de} \nabla f$. A função $\alpha(x, y)$ representa o ângulo do vetor $\nabla f$ em $(x, y)$ medido em relação ao eixo $x$ e expresso na relação:

$$
\alpha(x, y)=\tan ^{-1}(G y / G x)
$$

Desta forma, o gradiente de uma imagem é obtido pelo cálculo das derivadas parciais $\delta f / \delta x$ e $\delta f / \delta y$ em cada pixel. As derivadas podem ser implementadas nas imagens digitais pelos filtros direcionais de convolução (Gonzalez \& Woods 1992). Na delimitação da zona de transição de níveis de cinza, formada pelo pixel na borda do objeto e sua vizinhança na imagem, as características mais relevantes são a inclinação e a direção da transição que compõe o vetor gradiente (Castleman 1996). Os filtros de convolução examinam cada pixel na imagem, em relação a sua vizinhança, e quantificam a inclinação e a direção da transição dos níveis de cinza. Uma análise direcional completa do padrão de lineamentos da imagem requer a avaliação da posição da iluminação nos oito sentidos principais (N, NE, E, SE, S, SW, W, NW)

A área de enfoque foi dividida em áreas-testes, definidas em função do mapeamento geológico disponivel em escala de semi-detalhe. Então, os filtros demostrados como mais eficientes na deteç̧ão de lineamentos para essas áreas-teste foram aplicados às demais áreas, de forma a recobrir espacialmente toda a região de interesse. Os filtros aplicados foram do tipo Sobel, Prewitt, Kirsch e Laplaciano. À seguir, os filtros de melhor desempenho foram apresentados, após uma avaliação visual regulada por critérios como a quantidade de ruidos, nitidez das linhas e bordas, continuidade dos lineamentos realçados e aparência do alisamento. 


\section{-Filtros Sobel:}

Os filtros Sobel correspondem a uma variedade de filtros direcionais simétricos onde as posições mais próximas do pixel central da matriz de convolução interferem no resultado com peso superior àqueles nas extremidades, ajustando as variações discretas do gradiente nas direções horizontal, vertical e diagonal (Abdou \& Pratt 1979). Estes filtros têm a vantagem de aliviarem os efeitos do incremento do ruído causado pelos cálculos das derivadas propiciando tanto $o$ realce quanto o alisamento da imagem. Os melhores resultados foram obtidos com as matrizes de dimensões $3 \times 3$ e $5 \times 5$, listadas abaixo:

\begin{tabular}{|c|c|c|c|c|c|c|c|c|c|c|c|c|c|c|c|c|c|c|c|}
\hline & & -1 & -2 & -1 & & 1 & 0 & 1 & 1 & 2 & 0 & 0 & -2 & -1 & -1 & -2 & -1 & & \\
\hline & (a) & 0 & 0 & 0 & (b) & & 0 & 2 (c & 2 & 0 & -2 & (d) 2 & 0 & -2 & (e) 2 & 4 & 2 & & \\
\hline & & 1 & 2 & 1 & & -1 & 0 & 1 & 0 & -2 & -1 & 1 & 2 & 0 & -1 & -2 & -1 & & \\
\hline & & & c & -4 & $4-$ & & - & $1-$ & $\begin{array}{ll}-4 & 0\end{array}$ & & 1 & 4 & 0 & 0 & $-4-$ & & & & \\
\hline & & & (f) 4 & 9 &.- & 4 & g) - & 4 & 4 & (h) & 4 & 0 & $-4 \quad(i$ & ) 4 & - & & & & \\
\hline & & & 1 & 4 & 0 & & c & 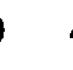 & $4 \quad 1$ & & 0 & -4 & -1 & 1 & 0 & & & & \\
\hline-3 & -2 & -2 & -1 & 0 & 1 & 1 & 0 & -1 & -1 & 0 & -1 & -2 & -2 & -3 & -1 & -2 & -3 & -2 & -1 \\
\hline-2 & -4 & -3 & 0 & 1 & 2 & 3 & 0 & -3 & -2 & 1 & 0 & -3 & -4 & -2 & -1 & -3 & -4 & -3 & \\
\hline-2 & -3 & 0 & 3 & $2(\mathbf{k}$ & 3 & 4 & 0 & -4 & $-3(I)$ & 2 & 3 & 0 & -3 & $-2(\mathbf{m}$ & a) 0 & 0 & 0 & 0 & \\
\hline-1 & 0 & 3 & 4 & 2 & 2 & 3 & 0 & -3 & -2 & 2 & 4 & 3 & 0 & -1 & 1 & 3 & 4 & 3 & \\
\hline 0 & 1 & 2 & 2 & 3 & 1 & & 0 & -1 & -1 & 3 & 2 & 2 & 1 & 0 & 1 & 2 & 3 & 2 & \\
\hline
\end{tabular}

\section{- Filtros Prewitt:}

Nos filtros Prewitt o elemento central da matriz de convolução possui maior peso no cálculo do novo valor do pixel demonstrando que, além das informações produzidas quanto ao gradiente direcional, os filtros favorecem o realce dos contornos dos objetos da imagem (Prewitt 1970). Dos filtros de dimensões $3 \times 3$ e $5 \times 5$ testados, aqueles que produziram imagens com maior destaque das feições estruturais foram:

$$
\begin{array}{lll}
-1 & -1 & -1
\end{array}
$$

(a) $0 \quad 0 \quad 0$

$\begin{array}{lll}1 & 1 & 1\end{array}$

(b) $1 \quad 0 \quad-1$

(c)

$\begin{array}{lll}1 & 0 & -1\end{array}$

(c) $1 \quad 0 \quad-1$

(d)

$\begin{array}{lll}0 & -1 & -1\end{array}$

$$
\begin{aligned}
& \text { (a) }
\end{aligned}
$$

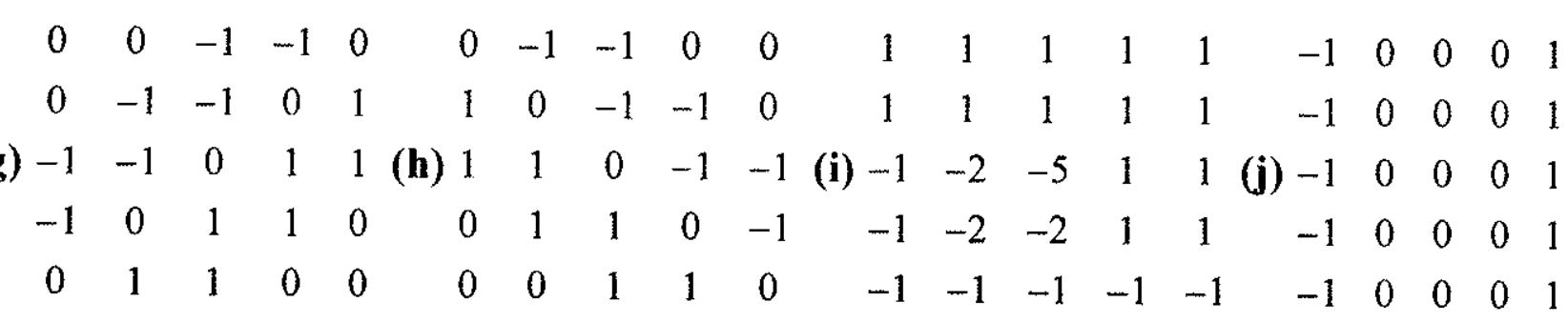




(k) $\begin{array}{ccccc}-1 & -1 & -1 & -1 & -1 \\ 0 & 0 & 0 & 0 & 0 \\ 0 & 0 & 0 & 0 & 0 \\ 1 & 1 & 1 & 1 & 1\end{array}$

Os filtros de (a) a (d), (g) e (h) destacam as estruturas na direção definida pelo alinhamento dos zeros, com o aspecto de iluminação da imagem dado pela simetria entre os valores positivos e negativos, onde o sentido da iluminação tem origem no lado onde estão os valores negativos da matriz ("posição da fonte").

\section{- Filtros Kirsch:}

As imagens das áreas-teste sofreram a convolução dos oito filtros Kirsch de dimensão 3x3 (Kirsch 1971), com excelente destaque para as feições linerares de trend geral $\mathrm{NE}$ e EW. Nesses filtros, o pixel central possui valor zero, com a matriz destacando as bordas nas oito principais orientações:

$$
\begin{aligned}
& \begin{array}{llllllllllll}
5 & 5 & 5 & -3 & 5 & 5 & -3 & -3 & 5 & -3 & -3 & -3
\end{array} \\
& \begin{array}{lllllllllllll}
\text { (a) }-3 & 0 & -3 & \text { (b) }-3 & 0 & 5 & \text { (c) }-3 & 0 & 5 & \text { (d) }-3 & 0 & 5
\end{array} \\
& \begin{array}{llllllllllll}
-3 & -3 & -3 & -3 & -3 & -3 & -3 & -3 & 5 & -3 & 5 & 5
\end{array} \\
& \begin{array}{llllllllllll}
-3 & -3 & -3 & -3 & -3 & -3 & 5 & -3 & -3 & 5 & 5 & -3
\end{array} \\
& \begin{array}{llllllllllllll}
\text { (e) }-3 & 0 & -3 & \text { (f) } 5 & 0 & -3 & \text { (g) } 5 & 0 & -3 & \text { (h) } 5 & 0 & -3
\end{array} \\
& \begin{array}{llllllllllll}
5 & 5 & 5 & 5 & 5 & -3 & 5 & -3 & -3 & -3 & -3 & -3
\end{array}
\end{aligned}
$$

\section{- Filtros Laplacianos:}

Os filtros digitais laplacianos são definidos pela associação de um coeficiente positivo ao pixel central e coeficientes negativos aos demais pixels. Como trata-se da derivada segunda de uma função bidimensional $f(x, y)$, a soma dos coeficientes é igual a zero. Esses filtros destacam transições sutis de intensidade, estabelecendo a posição do pixel (lados escuro ou claro das bordas) conforme a propriedade de zero-crossing - a derivada segunda é positiva para a parte da transição associada ao lado mais escuro da borda, negativa para a parte da borda associada ao lado mais claro e zero para áreas de níveis de cinza constantes, como mostra a equação: 


$$
\nabla^{2} f(x, y)=\partial^{2} f / \partial x^{2}+\partial^{2} f / \partial y^{2}
$$

Esta propriedade dos filtros laplacianos é importante na redução de ruídos no background da imagem, com o alisamento da imagem proporcional ao desvio-padrão, associada à delimitação precisa das bordas. Entranto, o desempenho dos filtros na proporção balanceada entre o alisamento de ruídos vs.realce de bordas é controlado pela dimensão da matriz utilizada, que define o número de pixels da vizinhança envolvidos nos cálculos e o valor estipulado para o coeficiente central da matriz, que determina a magnitude do tratamento. Para essa relação interdependente, Schowengerdt (1983) sugeriu a relação:

$$
W=\left(D^{2} * K\right)-1 \quad \begin{array}{lll}
-1 & -1 & -1 \\
-1 & W & -1 \\
-1 & -1 & -1
\end{array}
$$

Onde $W$ é o valor do coeficiente central, $D$ é a dimensão da matriz de $3 \times 3$ a $15 \times 15$, e $K$ é o fator variável de 1,0 a 2,0. No caso das áreas-teste selecionadas, o realce dos lineamentos foi inversamente proporcional a $K$, para uma dimensão fixa da matriz, onde para valores de $K$ entre 1,0 e 1,2 a imagem mostrou-se saturada, e para valores entre 1,8 e 2,0 a imagem apresentou baixo contraste. As matrizes com dimensões $3 \times 3,5 \times 5$ e $7 \times 7$ foram testadas sobre as áreas-teste, para valores de $K$ variando entre 1,2 e 1,8 (cada passo de 0,1) e os melhores resultados, numa avaliação visual das imagens monocanais, foram obtidos com matriz $5 \times 5$ e valores de $K=1,6(W=40)$.

\subsection{3 - Realce Espectral e Composições Coloridas}

$\mathrm{Na}$ última década, o incremento na qualidade e quantidade dos dados multiespectrais dos satélites de segunda geração tornou veemente o acesso à alta eficácia desses satélites para aplicações geológicas, como o mapeamento geológico básico e a detecção de zonas mineralizadas (p.ex. Abrams 1986, Rowan et al. 1987, Chorowicz et al. 1988, Abrams et al. 1988, Drury \& Hunt 1989, Drury 1984, 1990, Yésou et al. 1994, Chorowicz et al. 1994, Abdelhamid \& Rabba 1994, Macias 1995). Em todos esses trabalhos, os critérios básicos usados na avaliação dos dados de sensoriamento remoto foram: (i) o recobrimento espacial adequado das imagens, (ii) a eficiência espacial e espectral no controle estrutural e na distinção entre unidades geológicas no terreno, (iii) a precisão espacial do mapeamento resultante, (iv) a melhoria potencial do mapeamento pela 
comparação/combinação com dados de fontes distintas (geofisicas, geoquímicas, etc.), e (v) a aptidão em destacar feições geológicas em escalas variadas.

Nas pesquisas sobre a aplicação das técnicas de análise e interpretação dos produtos de sensoriamento remoto ao mapeamento geológico regional e de semi-detalhe na Província Borborema foram adotados os mesmos critérios gerais empregados para outras regiões do mundo (Loughlin \& Tawfiq 1985, Rothery 1984a, 1984b, 1987a, Davis \& Berlin 1989, Qari 1991, Glickson \& Creasey 1995), similares ao Nordeste do Brasil quanto aos aspectos climáticos e geológicos (Amaro et al. 1991a, 1991b, 1993a, 1993b, 1993c, 1994, Jardim de Sá et al. 1993b, Jardim de Sá 1994, Amaro \& Strieder 1994, Medeiros 1995, Medeiros et al. 1996). No presente trabalho foram acrescidos aos procedimentos metodológicos já testados na região, algumas das metodologias e estratégias de tratamentos digitais de imagens Landsat 5-TM envolvendo a análise e interpretação das assinaturas espectrais obtidas por equipamentos de alta sensibilidade espectral (704 canais), sob condições laboratoriais assistidas. Os resultados obtidos foram empregados no diagnóstico dos litótipos e na seleção das bandas Landsat 5-TM com melhor desempenho na distinção temática das unidades geológicas nos terrenos entre Japi-Barra de Santa Rosa-Campina Grande (BSR-CG, 06 $22^{\prime}-07^{\circ} 24^{\prime} 36^{\prime \prime} \mathrm{S} / 35^{\circ} 32^{\prime} 48^{\prime \prime}-36^{\circ} 02^{\prime} 50^{\prime \prime} \mathrm{W}$ ). Nesta porção da Província Borborema, as suítes de rochas alcalinas são contemporâneas às principais zonas de cisalhamento de alta temperatura com caráter extensional e, portanto, representantes do principal ciclo magmático em associação aos granitóides subalcalinos monzoníticos porfiriticos (tipo Itaporanga), dioritos shoshoniticos e leucogranitos tipo-S. Trata-se de uma importante feição que indica a influência do manto litosférico enriquecido como fonte em ambiente tectônico marcado por componente extensional associado ao principal evento de deformação $D_{3}$. Esta região apresenta uma cobertura de imagens digitais do Landsat 5-TM e grande acúmulo de dados petrográficos, geoquímicos, química mineral, geofisicos (gravimétricos e aeromagnéticos) que resultaram em mapeamentos geológicos nas escalas 1:250000 (DNPM/CPRM 1974, 1978, Jardim de Sá 1994, Dantas 1997) e 1:50000 (Araújo 1995, Trindade 1995, Hollanda 1996). 


\section{2 - Métodos de Filtragem dos Comprimentos de Onda Aplicados aos Dados de Campo Potencial}

Os valores do campo potencial total de uma região são produzidos pela superposição dos efeitos de várias fontes individuais de anomalias (Beltrão et al. 1991). As anomalias regionais de longos comprimentos de onda refletem estruturas profundas (crosta inferior ou manto superior), enquanto as anomalias de curtos comprimentos de onda são sobretudo causadas por contrastes de densidade e/ou susceptibilidade em níveis intracrustais mais rasos, fornecendo uma indicação da localização e da geometria das fontes causadoras das anomalias.

Segundo Henkel (1991), as anomalias de campo potencial são decorrentes de um volume especifico de rocha (ou estrutura geológica), sua localização quanto à profundidade e orientação na crosta, e propriedades físicas intrínsecas contrastantes com a circunvizinhança. Estes aspectos podem ser representados matematicamente na relação:

\section{Anomalia $=\int($ contraste $) /(\text { distância })^{\exp } J x f($ volume, orientação $)$}

Para os dados gravimétricos o valor em expoente é 2, enquanto para os dados magnéticos é de aproximadamente 3-4. De acordo com a fórmula, o conhecimento, quando possivel, das propriedades físicas das rochas pode minimizar as ambigüidades na interpretação quantitativa das anomalias.

No estudo por métodos potenciais do arranjo espacial de terrenos continentais, diversos trabalhos investigaram os limites de profundidades das fontes de anomalias regionais e residuais (Dobrin 1976, Kane \& Godson 1985, Keller et al. 1985, Behrendt \& Grimm 1985, Gupta \& Romani 1980, Wellman 1985, Debeglia \& Weber 1985, Murray et al. 1989, Murray \& Scheibner 1990, Beltrão \& Silva 1993, Hsu et al. 1996, Xia et al. 1996, Gunn 1997). Nesses trabalhos foram empregados métodos de inversão que podem ser agrupados em métodos gráficos, espectrais e polinomiais (Netleton 1976), com resultados complementares e/ou similares que propiciaram a confirmação ou redefinição da estruturação no interior e entre as unidades ou províncias geofisicas, com características geológicas diferenciadas, além da delineação da estruturação crustal sob as coberturas plataformais mais jovens. Nos trabalhos que empregaram métodos de filtragens por comprimentos de onda no realce de anomalias litosféricas e intracrustais foram sugeridos limites de corte em $2000 \mathrm{~km}, 500 \mathrm{~km}, 400 \mathrm{~km}, 300 \mathrm{~km}, 250 \mathrm{~km}, 60 \mathrm{~km}, 40 \mathrm{~km}$ e $20 \mathrm{~km}$ 
(Coles et al. 1976, Kane \& Godson 1985, Keller et al. 1985, Behrendt \& Grimm 1985, Pilkington \& Roest 1996, Tarlowski et al. 1997). Milligan e Gunn (1997) apresentaram uma revisão das técnicas de realce das anomalias de campo potencial para distinção das diferentes fontes geológicas causadoras das anomalias, mostrando que apesar de algumas limitações os resultados para a compreensão da estruturação crustal foram mais relevantes do que aqueles obtidos pela interpretação isolada da gravidade de campo total e intensidade magnética total.

\subsection{1 - Levantamento e Tratamento dos Dados Gravimétricos}

$\mathrm{Na}$ confecção do mapa Bouguer da Região Extremo Nordeste da Província Borborema foram utilizadas cerca de 3500 estações gravimétricas distribuídas pela área de longitudes $35^{\circ} 00^{\prime}-36^{\circ} 15^{\prime} \mathrm{W}$ e latitudes $05^{\circ} 5^{\prime}-7^{\circ} 15^{\prime} \mathrm{S}$, com intervalos de $2-3 \mathrm{~km}$, como mostra a Fig.3.3. Os levantamentos foram realizados em caminhamentos ao longo de estradas principais e secundárias com gravímetro La Coste \& Romberg - "Modelo G", com nivelamento barométrico, geométrico e monitorados por GPS, pelo Grupo de Geofisica do Departamento de Física Teórica e Experimental da Universidade Federal do Rio Grande do Norte. As estações foram preferencialmente estabelecidas sobre referências de nível (RN's) do IBGE, com estimativa de erro de altitude inferiores a $0,5 \mathrm{~cm}$. O conjunto de medidas gravimétricas está referenciado ao IGSN-71 e foram feitas correções de atração unisolar, latitude (GRS-67) e elevação para densidade Bouguer com valor $2,67 \mathrm{~g} / \mathrm{cm}^{3}$.

\section{- Procedimentos de Interpolação para Malha Regular dos Dados Gravimétricos:}

As medidas gravimétricas, localizadas aleatoriamente no terreno foram submetidas aos métodos de interpolação disponíveis nos programas do SURFER-Versão for Windows e GMT-Versão 3 (Wessel \& Smith 1991, 1995), para uma representação homogênea da anomalia Bouguer sobre a região de interesse. Os mapas digitais de contornos e de superfície foram gerados para os dados altimétricos ( 0 a 720 m, Fig. 3.4), anomalias Arlivre (-24 a $53 \mathrm{mGal}$, Fig. 3.5) e anomalias Bouguer (-25 a $60 \mathrm{mGal}$, Fig. 3.6).

A maioria dos métodos de interpolação do SURFER utiliza um algoritmo por média ponderada, onde quanto mais próximos os dados coletados $(x y z)$ estiverem do nó da malha, maior peso ele terá na determinação do valor de " $z$ " particular do nó da malha. Os valores são estimados para " $z$ " abaixo dos limites dados originais, como nas áreas do mapa onde não existem dados observados (bordas e "buracos" no mapa), dependendo do método 


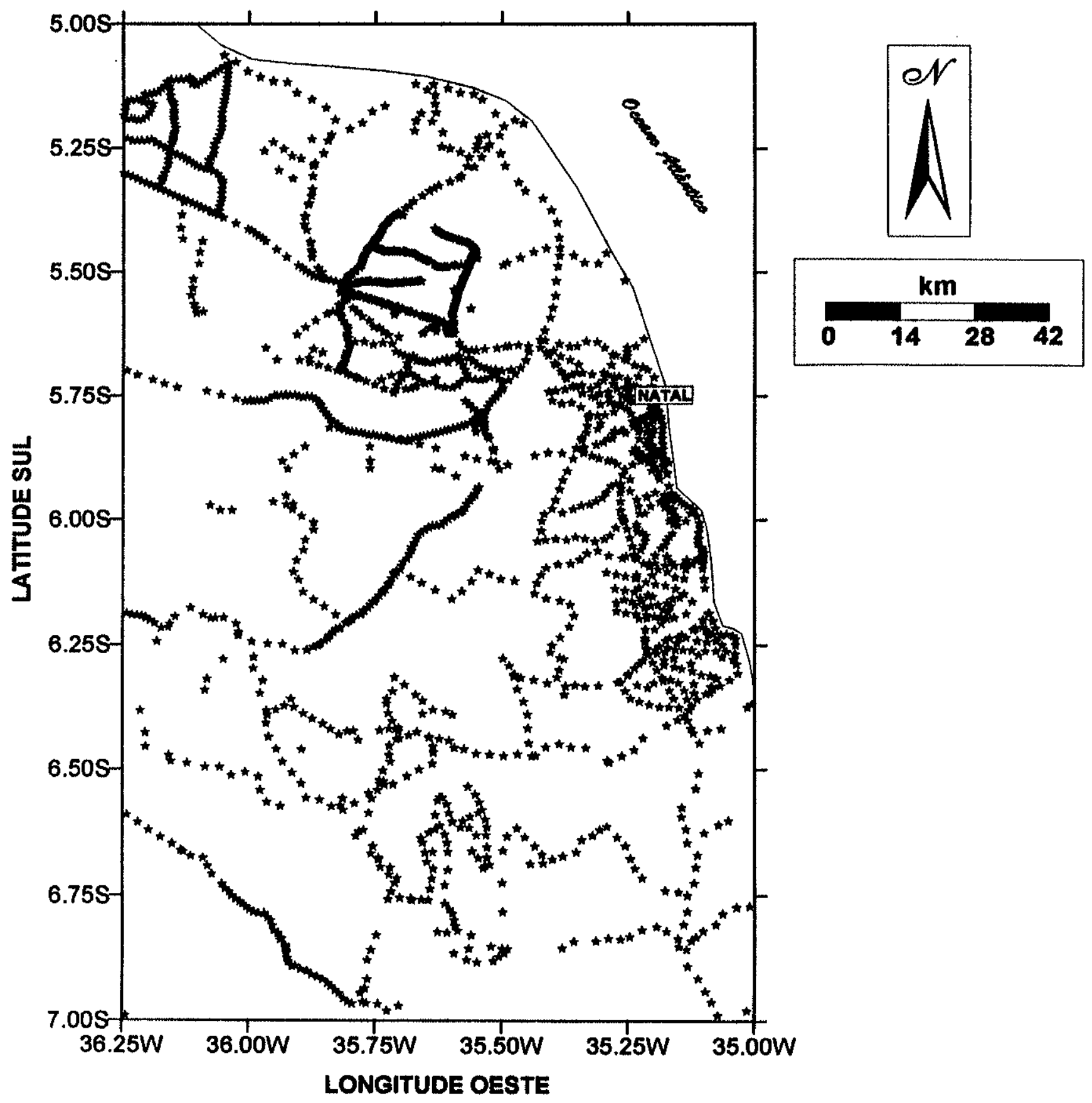

Figura 3.3 - Mapa de localização das estaçðes gravimétricas do Setor Extremo Nordeste da Província Borborema 
utilizado. Para uma avaliação preliminar dos resultados obtidos pelo SURFER foram escolhidos apenas dois métodos de interpolação por malha regular: (a) Inverso da Distância: é um método de interpolação por médias ponderadas e pode ser tanto exato quanto de alisamento, onde o peso determinado para uma medida é proporcional ao inverso da distância ao nó da malha; quando uma medida é coincidente com o nó da malha recebe o peso 1,0 e todas as demais medidas recebem pesos próximos a zero (método "quase exato"); (b) Mínima Curvatura: a superficie de interpolação gerada é análoga a uma placa fina linearmente elástica passando pelos dados observados com um mínimo arqueamento, proporcionado uma superficie alisada.

Nos métodos de interpolação do GMT-Versão 3 os dados são referenciados a uma superficie de curvatura contínua e transformados em valores $z(x y)$ pelo algoritmo spline:

$$
(1-T) * L[L(z)]+T * L(z)=0
$$

Onde $T$ é um fator de tensão disposto entre 0 e $1 ; \boldsymbol{L}$ indica o valor Laplaciano. Quanto $\boldsymbol{T}=\mathbf{1}$ a superfície é harmônica, sem máximos ou mínimos possíveis. Se $\boldsymbol{T}=\mathbf{0}$, a solução correspondente à mínima curvatura, que pode causar inúmeras oscilações locais e falsos máximos e mínimos. Para suprimir esses efeitos foi utilizado o valor de $T=\mathbf{0 , 2 5}$ (Smith \& Wessel 1990), numa malha regular de $0,01^{\circ}$, que mostrou-se eficiente na eliminação de valores redundantes e da redundância espacial dos comprimentos de onda curtos referentes aos dados gravimétricos e altimétricos na área.

Os mapas resultantes dos diferentes métodos de interpolação para malha regular (SURFER e GMT) foram avaliados quanto: (a) à consideração da superficie harmônica; (b) ao maior controle sobre a ponderação dos valores coletados; (c) à eliminação de pseudoanomalias e efeitos de bordas; (d) à eficiência na correlação direta com as informações geológicas de campo, numa análise visual. Os resultados do GMT-Versão 3 mostraram-se mais eficazes e foram selecionados para a aplicação dos métodos de filtragem dos comprimentos de onda para separação entre as anomalias regionais e residuais.

- Metodologia de Seleção das Filtragens e Comprimentos de Onda e Estimativa das Profundidades das Fontes das Anomalias Gravimétricas

$\mathrm{Na}$ filtragem dos dados de anomalia nos diferentes domínios, os comprimentos de onda foram selecionados com base nos estudos sobre a estruturação da crosta e da litosfera 


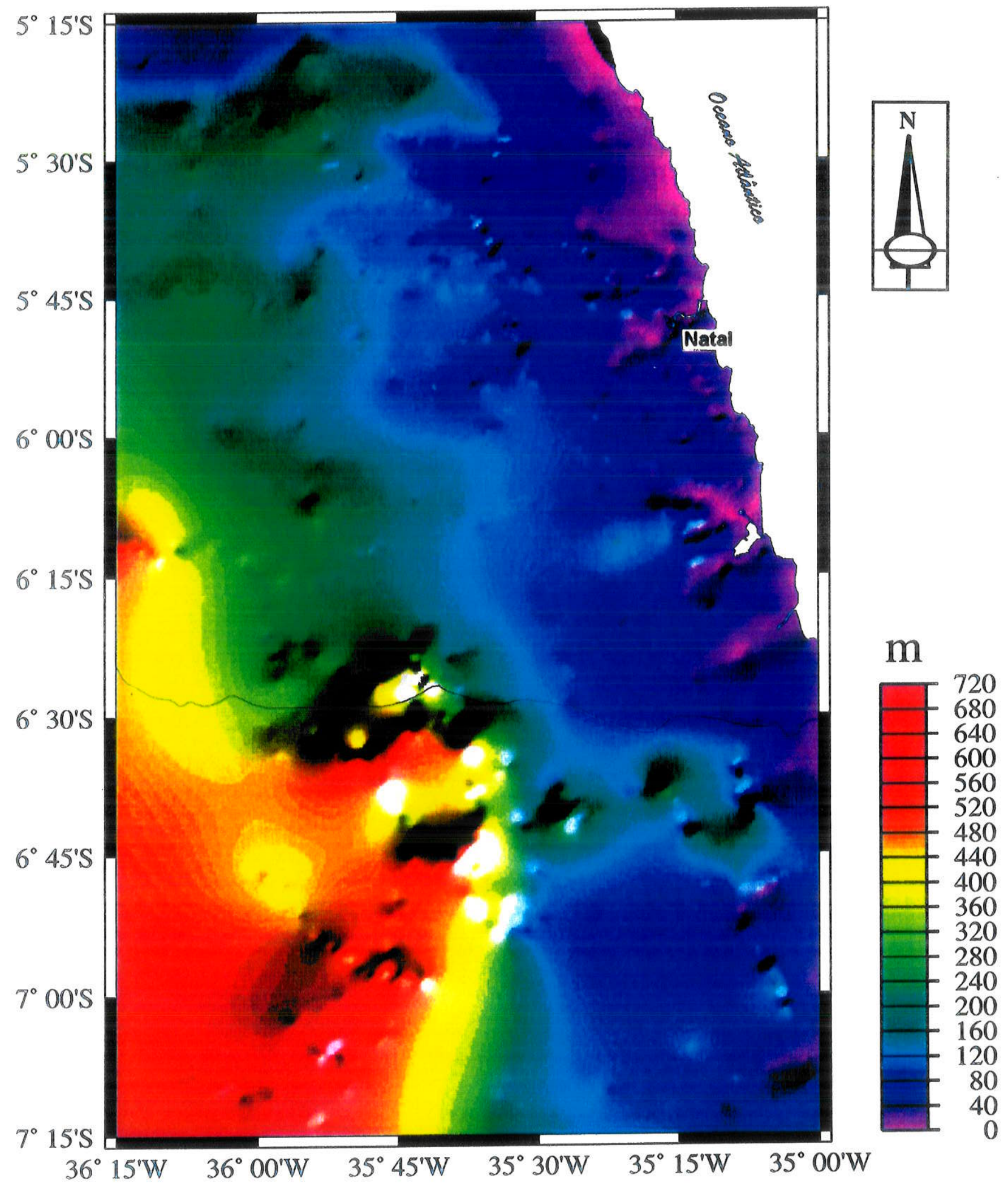

Figura 3.4 - Mapa topográfico digital com pseudo-iluminação a partir do Az $120^{\circ}$ para o Setor Extremo Nordeste da Província Borborema, elaborado a partir das medidas altimétricas nas estações gravimétricas. 


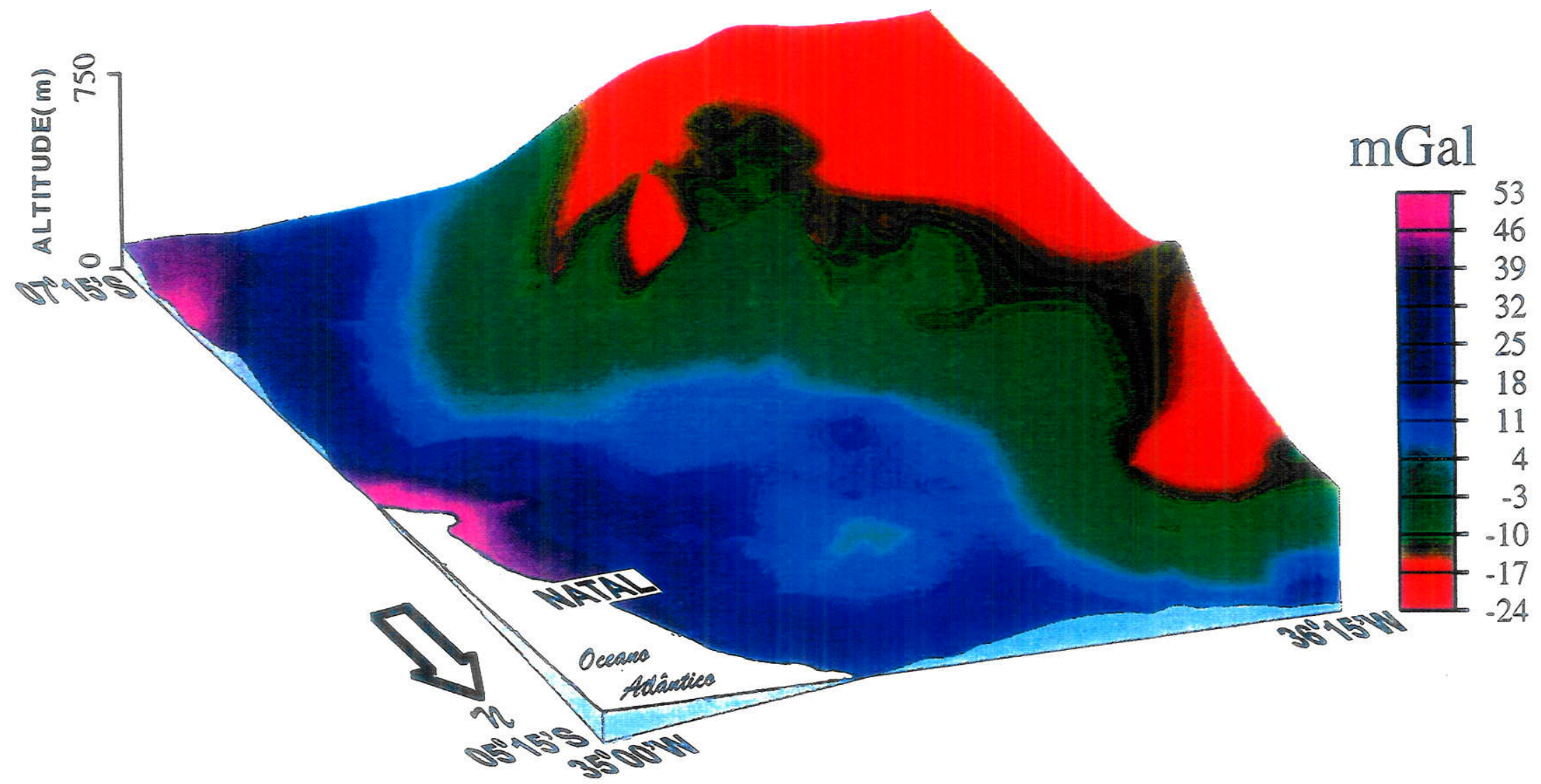

Figura 3.5 - Modelo topográfico digital combinado às anomalias gravimétricas Ar-Livre. 
(p.ex. Kane \& Godson 1985, Murray et al. 1989, Moreira et al. 1989a, 1990, Ussami et al. 1993, Whitaker 1994, Pili et al. 1997) e na avaliação das estruturas nos diferentes níveis crustais, sendo eles: $600 \mathrm{~km}, 250 \mathrm{~km}, 200 \mathrm{~km}, 80 \mathrm{~km}, 50 \mathrm{~km}, 40 \mathrm{~km}, 30 \mathrm{~km}, 20 \mathrm{~km}, 10 \mathrm{~km}$, $5 \mathrm{~km}$ e $1 \mathrm{~km}$. Os valores Bouguer filtrados foram convertidos em imagens normalizadas em 256 niveis de cinza e então codificadas entre cores equalizadas de magenta, para os valores mínimos ao vermelho, para os valores máximos, e distribuídas em projeção linear sobre a área.

Desta forma, tendo em vista os métodos de tratamentos empregados e as dimensões das filtragens utilizadas, assumiu-se profundidades crustais e litosféricas para as fontes das anomalias analisadas, provavelmente incorporadas à crosta durante o Brasiliano, último evento de geração e estruturação da crosta continental no Nordeste do Brasil.

$\mathrm{Na}$ avaliação da profundidade das fontes das anomalias gravimétricas foi considerada a relação entre amplitude e gradiente máximo para fontes em ponto, linha $\mathrm{e}$ placa (Bott \& Smith 1958, Smith 1960, Bancroft 1960, Kane \& Bromery 1968):

\section{$D_{\max }=\boldsymbol{k} A / G_{\max }$}

Onde $D_{\max }=$ profundidade máxima da fonte; $\mathrm{A}=$ amplitude da anomalia; $\boldsymbol{G}_{\max }$ $=$ gradiente horizontal máximo; $\boldsymbol{k}=$ constante (fonte em ponto $=0,32$; fonte em linha $=0,65$; fonte em placa $=0,86$ ).

Assim, foram realizadas as estimativas das profundidades máximas das fontes das principais anomalias nos mapas residuais de modo a assegurar a correlação com a profundidade crustal inferida pela filtragem e a geologia de superficie. Como as anomalias residuais possuem formas, observadas nos planos do mapa, geralmente controladas pela deformação brasiliana - que corresponde ao plano geral XZ de achatamento - foi utilizada a constante para fontes em linha 0,65 .

De acordo com Kane \& Godson (1985), na avaliação da profundidade das fontes das anomalias devem ser considerados os efeitos das filtragens nos diferentes comprimentos de onda e nas diferentes profundidades para uma mesma fonte, como na fórmula da correlação entre comprimento de onda e atenuação da amplitude na continuação-para-cima:

$$
\mathbf{D}_{\lambda}=\mathbf{A}_{\lambda} \mathbf{e}^{-2 \pi \Delta Z / \lambda}
$$


Onde $\lambda=$ comprimento de onda; $\mathbf{A}_{\lambda}=$ amplitude do $\lambda$ na profundidade original da fonte; $\mathbf{D}_{\lambda}=$ atenuação da amplitude do $\lambda$ com o aumento da profundidade da fonte; $\Delta Z=$ aumento na profundidade da fonte.

O diagrama da Fig.3.2 pôde então ser construido indicando que o aumento da profundidade da fonte tende a atenuar os componentes de comprimentos de onda de uma anomalia inversamente ao tamanho do comprimento de onda. Como a amplitude total de uma anomalia é a soma de todos os componentes atenuados por $33 \%$ ou mais (para $\lambda>200$ $\mathrm{km}$ ), então a amplitude máxima de uma fonte a $40 \mathrm{~km}$ (profundidade média do topo do manto litosférico) é menor do que $33 \%$ de uma fonte em crosta rasa equivalente a $5 \mathrm{~km}$.

$\mathrm{Na}$ avaliação das anomalias residuais, utilizadas na discriminação de diferentes niveis crustais, foram considerados os seguintes critérios: (a) trend, pois indica a direção das descontinuidades de densidade; (b) combinação entre o comprimento de onda da anomalia e sua amplitude relativa, que mostra a extensão lateral da fonte e a relação entre extensão vertical e contraste de densidade, respectivamente; (c) ruido da anomalia, que indica a ausência de uniformidade das fontes de densidades específicas.

\section{- Filtragens nos Domínios da Freqüência e Espaço-Temporal}

Os valores interpolados da anomalia Bouguer foram submetidos às transformações matemáticas bidimensionais por técnicas de Fast Fourier Transform (FFT) para conversão dos dados no domínio da frequeência e depois reconvertidos ao domínio do espaço pela transformação inversa da FFT (Syberg 1972, Gunn 1975). Os filtros utilizados foram dos tipos passa-banda, passa-alta e passa-baixa, conforme os comprimentos de onda que se pretendeu alcançar. Os mapas de anomalias residuais obtidos foram então agrupados para análise de acordo com a similaridade do conjunto das anomalias de longos e curtos comprimentos de onda, quanto à eqüidimensionalidade da geometria, amplitude e gradientes.

Aos dados gravimétricos Bouguer interpolados para malha regular foram aplicados filtros quadrados (boxcar) no domínio espaço-temporal, conforme distâncias na geometria Cartesiana. O método consiste numa filtragem passa-baixa dos dados pela convolução no domínio espacial por operadores lineares que efetuam a média dos valores, numa largura que é o diâmetro da área circular da dimensão do filtro. O filtro atua na 
decomposição do somatório dos comprimentos de onda em componentes dispostos num espaço bidimensional cujas dimensões são o tempo de ocorrência (posição) e a escala. A convolução do filtro boxcar, no tratamento para alisamento do sinal, favoreceu a localização precisa dos componentes de comprimentos de onda no espaço bidimensional, melhor do que os outros métodos de filtragem no domínio espacial. Os mapas de anomalias gravimétricas obtidos nas filtragens, de acordo com o comprimento de onda que se buscou ressaltar (10 $\mathrm{km}, 20 \mathrm{~km}, 30 \mathrm{~km}, 40 \mathrm{~km}, 50 \mathrm{~km}$ e $200 \mathrm{~km}$ ) foram subtraídos do mapa de anomalias Bouguer para obtenção dos mapas residuais finais, com anomalias gravimétricas referentes às fontes presentes em diferentes niveis verticais da crosta atual, de dimensões iguais ou inferiores ao comprimento de onda do filtro utilizado. A escolha dos filtros quadrados, em comprimentos de onda de dezenas de quilômetros na escala da crosta, foi decorrente do pressuposto de que as anomalias realçadas nos mapas correspondem às estruturas anômalas crustais cujos topos estariam localizados em profundidades iguais ou superiores à dimensão do filtro aplicado (Sharma 1986, El-Hadj et al. 1993). Todos os mapas obtidos foram agrupados para descrição e interpretação, conforme metodologia aplicada aos mapas anteriores.

\subsection{2 - Levantamento e Tratamento dos Dados Aeromagnéticos}

Os dados aeromagnéticos do Setor Extremo Nordeste da Província Borborema foram obtidos a partir das cartas em escala 1:100000 e 1:250000 do Projeto Aerogeofísico Esperança (longitudes $35^{\circ} 15^{\prime}-36^{\circ} 00^{\prime} \mathrm{W}$ e latitudes $06^{\circ} 00^{\prime}-08^{\circ} 00^{\prime} \mathrm{S}$ ), executado pelo DNPM/Nuclebrás (1976/1978) com Magnemômetro de Precessão Nuclear, numa extensão total dos perfis de $200000 \mathrm{~km}$ em área aproximada de $19000 \mathrm{~km}^{2}$. As linhas de produção foram espaçadas em intervalos de $1000 \mathrm{~m}$ na direção NS, com medidas consecutivas em intervalos de $62 \mathrm{~m}\left(1^{\prime \prime}\right)$ e altura média de vôo sobre o terreno de $150 \pm 10 \%$. Os mapas aeromagnéticos foram confeccionados em escalas 1:100000 (coordenadas geográficas de $30^{\prime}$ em 30' e coordenadas UTM de 10 em 10 km) e 1:250000 km (coordenadas geográficas de 30' em 30' e coordenadas UTM de $25 \mathrm{em} 25 \mathrm{~km}$ ) com intervalos entre isógamas de 10 gramas e intensidade magnética total média de 26200 gramas (Fig. 3.7). Os dados de

levantamento aeromagnetométrico estiveram disponíveis sob a forma de mapas de intensidade magnética total (escalas 1:100000 e 1:250000), por mais de 20 anos mas apenas recentemente os mapas foram digitalizados e recuperados numa malha que permitiu a 


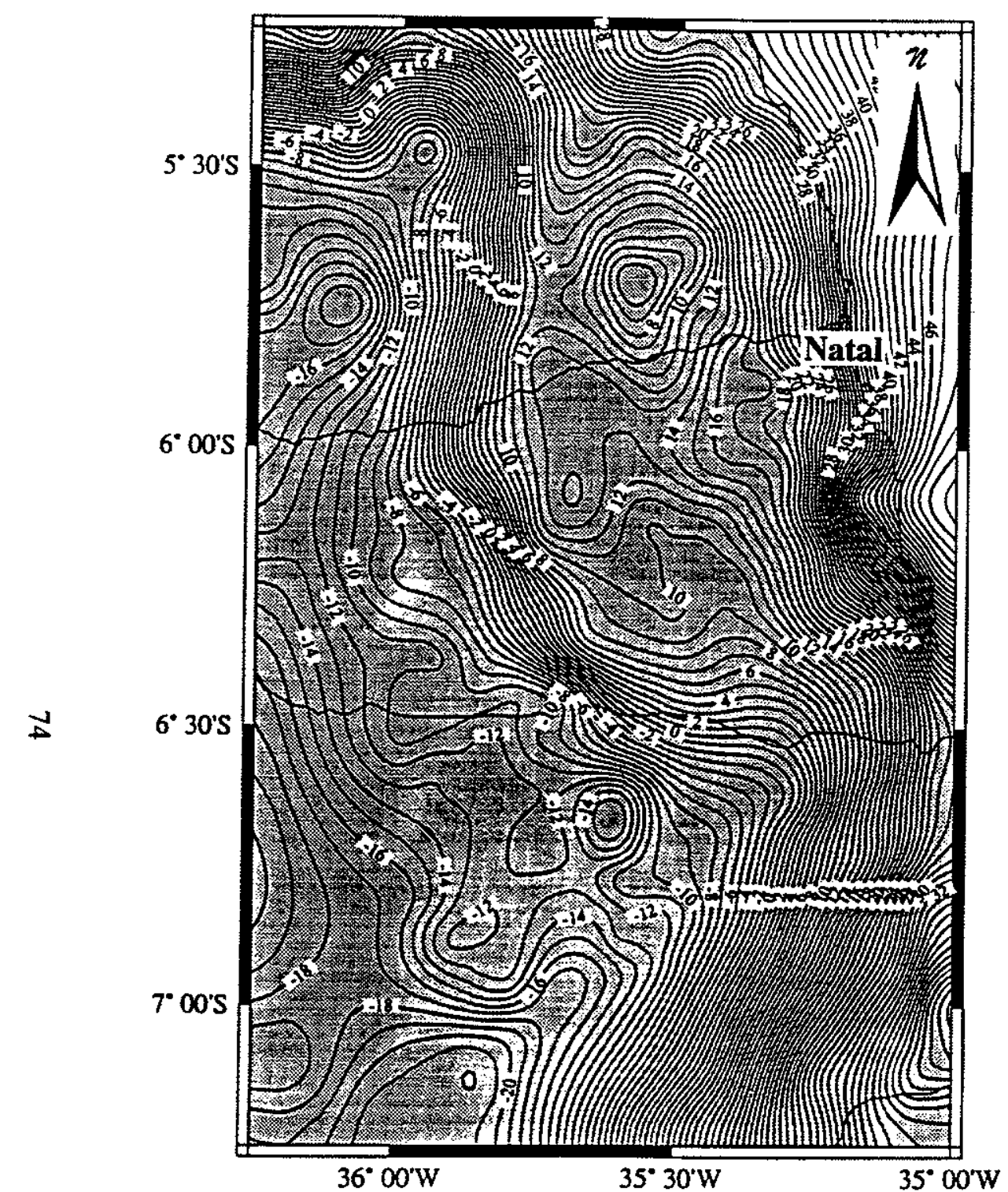

Figura 3.6 - Mapa de anomalias Bouguer para o Setor Extremo Nordeste da Provincia Borborema. Intervalo de isolinhas de $1 \mathrm{mGal}$.

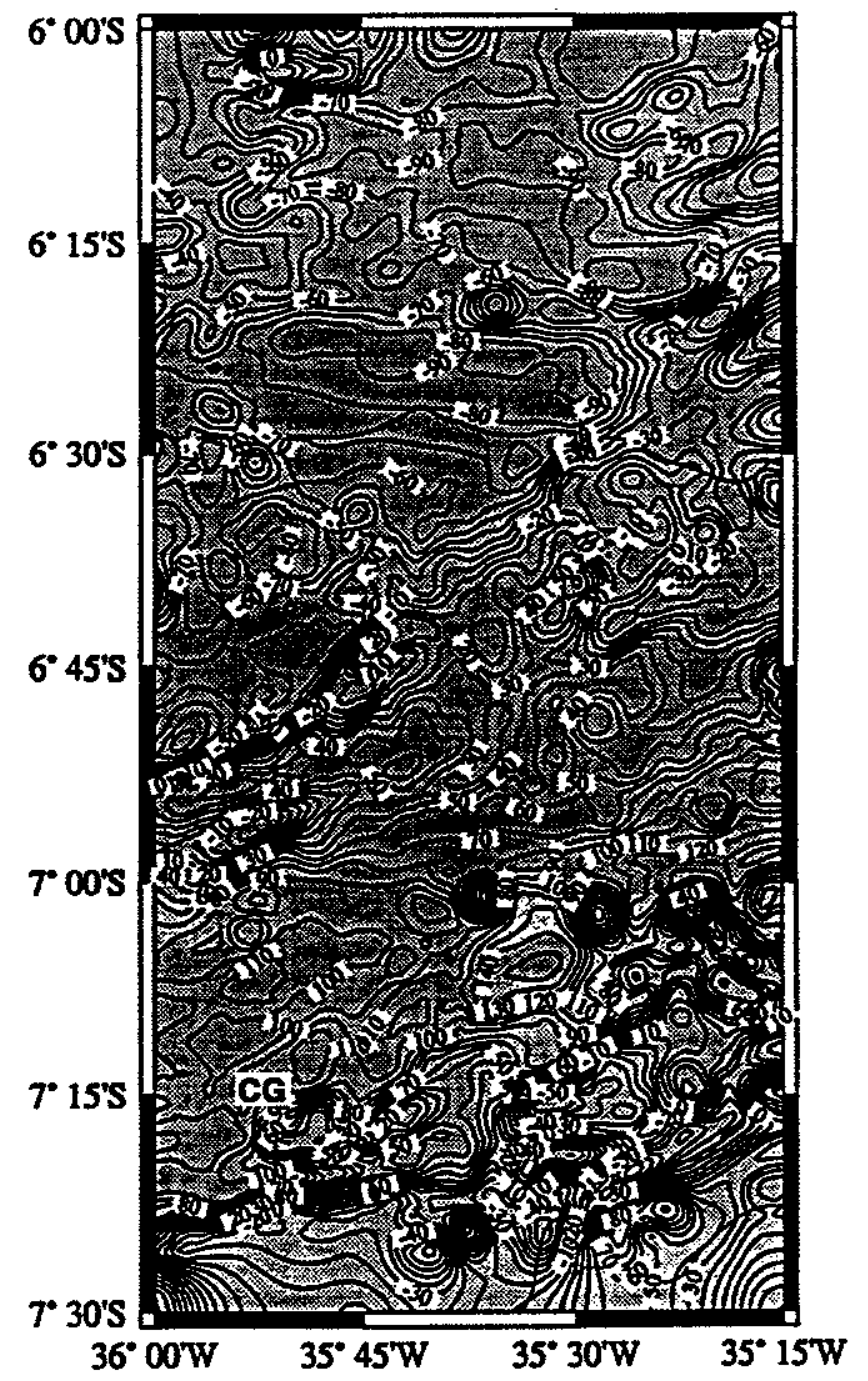

Figura 3.7 - Mapa de anomalias de intensidade magnética total-DGRF para o Setor Extremo Nordeste da Provincia Borborema. Intervalo de isolinhas de $10 \mathrm{nT}$. 
aplicação de técnicas de tratamento digital de imagens no processo interpretativo. Os valores utilizados nos tratamentos foram aqueles do campo magnético anômalo calculado sobre o modelo do DGRF. As anomalias detectadas foram aquelas com comprimentos de no mínimo $1 \mathrm{~km}$, ou seja, que puderam ser correlacionadas entre linhas de vôos adjacentes.

\section{- Procedimento de Interpolação para Malha Regular:}

Os valores do campo magnético anômalo foram interpolados por malha regular com base nos programas do SURFER, por Mínima Curvatura, e do GMT-Versão 3 (Smith Wessel 1991, 1995), por algoritmo spline com fator de tensão $\mathrm{T}=0,25$, ambos numa malha regular de $0,005^{\circ}$. Tratamentos semelhantes foram aplicados a dois setores do conjunto do Projeto Esperança, um entre $06^{\circ} 15^{\prime}-08^{\circ} 00^{\prime} \mathrm{S} / 36^{\circ} 00^{\prime}-36^{\circ} 15^{\prime} \mathrm{W}$, outro entre $06^{\circ} 00^{\prime}-$ $07^{\circ} 30^{\prime} \mathrm{S} / 35^{\circ} 15^{\prime}-36^{\circ} 00^{\prime} \mathrm{W}$ ), na tentativa de evitar o intenso artefato NS na junção dos dois setores, provavelmente decorrentes de diferentes condições no aerolevantamento dos dados originais. Uma inspeção visual preliminar no mapa de intensidade magnética total destaca as direções principais dos contrastes de susceptibilidade na região, como feições lineares definidas por agrupamentos isogâmicos numa orientação preferencial NE coincidente com as estruturas brasilianas.

\section{- Metodologia de Seleção das Filtragens e Comprimentos de Onda Aplicados aos Dados} Aeromagnéticos e a Estimativa das Profundidades das Fontes das Anomalias:

Da mesma forma que para os dados gravimétricos, os valores aeromagnéticos interpolados foram filtrados nos domínios da frequeência e espaço-temporal para comprimentos de onda definidos de acordo com trabalhos prévios de aplicação das anomalias aeromagnéticas ao estudo detalhado sobre a estruturação dos terrenos cristalinos (p. ex. Shapiro et al. 1986, Mayhew \& Johnson 1987, Woodside \& Verhoef 1989, Miranda et al. 1989, Broome 1990, Stefouli \& Angelopoulos 1990, Mariano \& Hinze 1994, Whitaker et al. 1994, Gunn et al.1997, Jaques et al. 1997).

Isles et al. $(1989,1990)$ sugeriram uma metodologia de padronização da interpretação de conjuntos de dados aeromagnéticos com base na identificação de contornos, trends e gradientes de unidades magnéticas, então comparados aos mapas geológicos preliminares, como tentativa de discriminação das unidades geológicas e da estruturação tectônica. Estes princípios têm sido amplamente aplicados e são por vezes acrescidos de técnicas que tratam das condições especificas dos terrenos, tais como as profundidades 
variáveis das fontes magnéticas, amplas variações na magnetização das unidades e a superposição das unidades magnéticas (Gunn et al. 1997).

A metodologia de interpretação empregada consistiu na inspeção de mapas aeromagnéticos regionais e residuais na definição (a) dos limites das unidades magnéticas, (b) da geometria das estruturas controladoras das unidades magnéticas, (c) da profundidade e atitude das unidades magnéticas, (d) da superposição das unidades magnéticas, e (e) das modificações químicas (metamórficas e intempéricas) das unidades litológicas.

$\mathrm{Na}$ delineação dos limites das unidades foram usados os conceitos descritos por Gunn et al.(1997), onde anomalias magnéticas grandes e isoladas são decorrentes de fontes uniformemente magnetizadas, e os limites estimados das anomalias e das fontes são coincidentes. Para agrupamentos de anomalias devido a rochas magnéticas fraturadas ou dobradas, a unidades magnéticas intemperizadas e fluxos vulcânicos irregulares, os limites são traçados de forma a envolver todas as anomalias aparentemente associadas no estilo e na distribuição espacial.

As profundidades das fontes foram estimadas qualitativamente conforme $o$ princípio de quanto mais profundas as fontes mais amplas e fortes são as anomalias. Este conceito foi combinado aos tratamentos de filtragem dos dados para diferentes profundidades da crosta que permitiu a avaliação da distribuição espacial e da superposição das anomalias para cada filtragem empregada. Como os mapas foram gerados para interpretação qualitativa das anomalias, a escolha dos melhores filtros aplicados foi também decorrente de seus aspectos visuais e das possíveis correlações com os mapas gravimétricos residuais e os dados de campo. Um fator importante na escolha da dimensão do filtro aplicado é a inferência da localização das fontes da anomalia magnética em profundidades de 1/4 dos valores dos comprimentos de onda empregados, com base na aproximação da metade-da-largura de Dobrin (1976). Assim, os comprimentos de onda definidos foram de $600 \mathrm{~km}, 250 \mathrm{~km}, 80 \mathrm{~km}, 50 \mathrm{~km}, 40 \mathrm{~km}, 30 \mathrm{~km}, 20 \mathrm{~km}, 10 \mathrm{~km}, 5 \mathrm{~km}$ e $1 \mathrm{~km}$, destacando progressivamente níveis mais rasos da crosta atual. Os mapas residuais obtidos foram normalizados para 256 níveis de cinza e então codificados em cores equalizadas no sistema RGB de magenta, para os valores mínimos, a vermelho para os valores máximos. 


\section{- Filtragens nos Dominios da Freqüência e Espaço-Temporal:}

Conforme a mesma metodologia empregada para os dados gravimétricos, os dados aeromagnéticos foram filtrados no domínio da frequêencia, pelo processamento para alisamento por FFT, retornando ao domínio do espaço pela transformação inversa de FFT (Syberg 1972, Gunn 1975), com base nos programas do GMT-Versão 3. Os filtros foram selecionados dentre aqueles que se mostraram mais eficazes na discriminação de anomalias de altas e baixas freqüências e comprimentos de onda, de acordo com o nível crustal que se pretendeu realçar, em consonância com os filtros utilizados para os dados gravimétricos.

Os valores de intensidade magnética total, interpolados pelos programas da GMT-Versão 3, foram submetidos a filtragem no dominio espaço-temporal com filtros passa-baixa do tipo boxcar para comprimentos de onda de $50 \mathrm{~km}, 40 \mathrm{~km}, 30 \mathrm{~km}, 20 \mathrm{~km}, 10$ $\mathrm{km}, 5 \mathrm{~km} \mathrm{e} 1 \mathrm{~km}$, destacando niveis progressivamente mais rasos na crosta. Desta maneira, seguindo a metodologia aplicada aos dados gravimétricos, buscou-se a avaliação do comportamento das fontes das anomalias em profundidades progressivamente mais rasas na crosta. 


\section{4 - INTERPRETAÇÃO VISUAL DOS PRODUTOS DE SENSORIAMENTO REMOTO NO MAPEAMENTO TEMÁTICO DO SISTEMA DE LINEAMENTOS}

\section{1 - Considerações Iniciais}

No mapeamento geológico da Província Borborema, a recente incorporação do processamento digital de imagens de sensoriamento remoto tem favorecido uma eficiente incrementação da análise dos elementos da deformação, principalmente pela execução integrada com a chamada "realidade do terreno" (Jardim de Sá 1994), ou seja as informações de campo, levantamentos geofísicos e geoquímicos. Este procedimento está de acordo com a atitude interdisciplinar pretendida pela proposta de interpretação visual baseada nos critérios de unidade de paisagem (Vauzele 1982, Deroin 1992). A natureza semi-árida da região oferece uma extensa e variada exposição de unidades litológicas, com feições deformacionais polifásicas complexas, tornando-a ideal para aplicação das informações multiespectrais e multitemporais do Landsat 5-TM nos estudos geológicoestruturais e das mineralizações, mesmo nas áreas próximas à costa que apresentam coberturas sedimentares conspícuas.

\section{2 - Análise Visual das Imagens Resultantes das Filtragens Direcionais: O Sistema de Lineamentos dos Maciços São José do Campestre e Caldas Brandão}

Os alvos principais dos tratamentos digitais para detecção e realce das linhas e bordas nas imagens Landsat 5-TM, com base nas filtragens direcionais, foram os lineamentos que demarcam o sistema de zonas de cisalhamento e o principal fabric tectônico $\mathrm{D}_{3}$ (foliações e lineações) da área de estudo. As dimensões dos filtros, apresentadas em número de pixels na imagem, foram estipuladas conforme a ordem de grandeza das modificações espaciais decorrentes da geometria dos lineamentos, ou seja dos tamanhos e das orientações das estruturas que se pretendeu detectar no terreno. A descrição da metodologia empregada e dos filtros com melhor desempenho na deteç̧ão dos sistemas de lineamentos foram apresentados nos itens 3.1.1 e 3.1.2. Os filtros direcionais de dimensões $5 \times 5$ foram os mais eficazes no realce dos sistemas de lineamentos da ordem de centenas de quilômetros e largura superior a alguns quilômetros nas áreas-teste com tamanho de 125 $v s .125 \mathrm{~km}$ a $150 v s .150 \mathrm{~km}$. Os filtros $3 \times 3$ mostraram melhor desempenho nas áreas-teste em 
torno de 50 vs. $50 \mathrm{~km}$, no realce de lineamentos de dezenas de quilômetros e largura superior a algumas centenas de metros. O emprego de filtros superiores a $5 \times 5$ ( $7 \times 7$ ou $9 \times 9$ ) acarretaram problemas quanto ao posicionamento dos lineamentos na imagem, decorrente do fato de que os cálculos do gradiente se estenderam a um número maior de pixels $\mathrm{e}$, dependendo das caracteristicas do filtro empregado, provocaram intenso alisamento do background e perda da nitidez das feições lineares, mesmo para áreas superiores a 150x150 $\mathrm{km}$. As diversas imagens filtradas monocanais e/ou combinadas foram analisadas visualmente e integradas para composição do mapa na escala 1:250000 (Anexo 1), apresentado de forma reduzida na Fig. 4.1. Na análise estrutural em escala regional para outros continentes, a aplicação de filtros $5 \times 5$ em imagens Landsat 5-TM foi descrita como excelente no realce das estruturas com dezenas a centenas de quilômetros de extensão (Hornsby \& Bruce 1985, Nevatia \& Babu 1980, Deslandes \& Gwyn 1991).

As correlações do sistema de lineamentos do MS.JC-MCB, dos elementos estruturais e das cinemáticas das zonas de cisalhamento dúcteis, com os mesmos elementos da deformação brasiliana em outros setores da Província Borborema, foram apresentados em mapas regionais e de semi-detalhe discutidos a seguir.

\section{3 - Mapa de Lineamentos da Porção Nordeste da Província Borborema}

O mapa da Fig. 4.2 registra o traçado dos lineamentos do setor Nordeste da Província Borborema, na região compreendida entre $05^{\circ} 30^{\prime}-08^{\circ} 00^{\prime} \mathrm{S}$ e $35^{\circ} 00^{\prime}-37^{\circ} 15^{\prime} \mathrm{W}$, envolvendo parte dos estados do RN, PB e PE. O arranjo morfoestrutural dos sistemas de lineamentos correspondem aos traços na superficie topográfica dos elementos dúcteis penetrativos neoproterozóicos, comumente foliações e lineações, distribuidos conforme seus atributos de orientação, densidade e localização espacial, condições favorecidas pela simultaneidade de exposição da seção XZ do elipsóide de strain pela superficie topográfica. O mapa ressalta, quanto ao padrão estrutural regional, a complexidade da geometria e das interrelações entre as zonas de cisalhamento neoproterozóicas, demarcados pelo elevado indice de densidade e pela continuidade dos lineamentos, contemporâneos aos dobramentos regionais $F_{3}$ e ao plutonismo brasiliano.

A Fig 4.3 demonstra a geometria e a cinemática das principais zonas de cisalhamento em relação aos prováveis limites dos terrenos tectonoestratigráficos envolvidos 


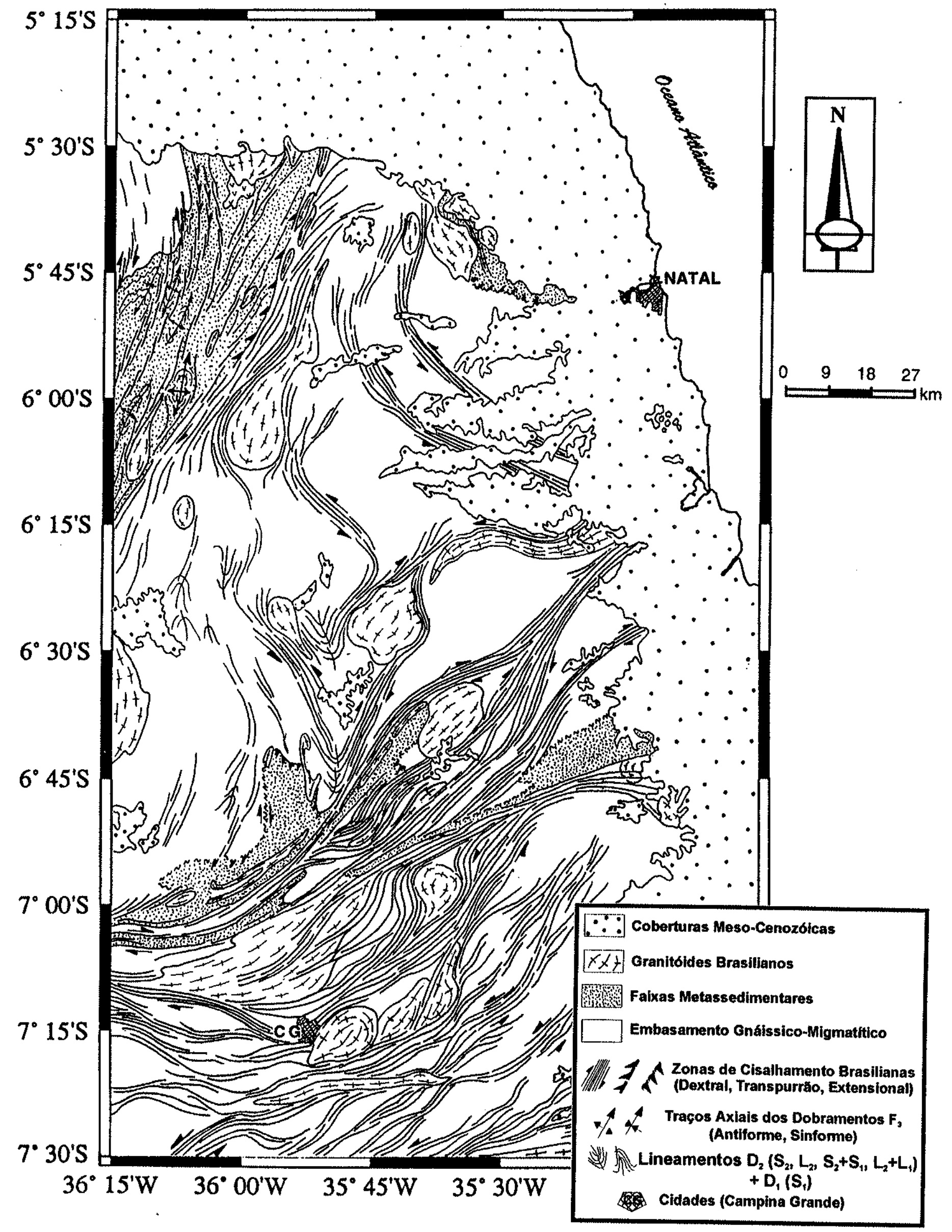

Figura 4.1 - Arcabouço geológico para o Setor Extremo Nordeste da Província Borborema, elaborado a partir da fotointerpretação das imagens digitais resultantes dos tratamentos digitais por filtragens direcionais e composições coloridas, compilação das informações cartográficas prévias e dados de campo. 
no mapa da Fig. 4.2, conforme a proposta de subdivisão da Província Borborema em domínos estruturais (Brito Neves 1983, Santos et al. 1984, Caby et al. 1991, Jardim de Sá et al. 1988, Jardim de Sá 1994, Santos 1995).

Na elaboração do mapa adotou-se a metodologia de extração dos elementos da deformação dúctil a partir dos produtos de sensoriamento remoto, combinada aos critérios interdependentes da unidade de paisagem, examinados em detalhe nos itens 1.3.2 e 3.1. Os elementos da deformação frágil, apesar de freqüentes por toda a região, foram excluídos das Fig. 4.1 e 4.2, conforme a metodologia de diferenciação proposta por Amaro e Strieder (1994), tendo sido incorporados aos mapas resultantes da interpretação visual detalhada para áreas especificas (p.ex. os setores da Faixa de Metassedimentos de Barra de Santa Rosa e de Campina Grande) e aos mapas de lineamentos para a interpretação das reativações tectônicas da deformação dúctil (ver Cap. 7, item 7.6).

A área selecionada corresponde à terminação geográfica das principais zonas de cisalhamento intracontinentais que afetaram a crosta ao final do Brasiliano, que combinadas aos prolongamentos na África Central totalizariam extensões superiores a $3000 \mathrm{~km}$. Outro fator determinante na seleção da área foi o interesse na avaliação dos tratamentos de imagens e procedimentos de análise e interpretação visual das feições lineares dos terrenos cristalinos que sofreram a extensa cobertura sedimentar recente. A proximidade da linha de costa e o clima litorâneo favorecem o intemperismo diferenciado das litologias, com desagregações físicas e químicas mais intensas e espessuras maiores dos regolitos e/ou solos do que os demais terrenos da Província Borborema. Esses fatores dificultaram o reconhecimento visual nas imagens digitais da estruturação dúctil pretérita dos terrenos cristalinos, exigindo tratamentos por realce digital das feições lineares abrangendo toda a região. Além disso, o mapa apresenta em detalhe a rede de zonas de cisalhamento da região complementar aos mapas esquemáticos para as porções Central da Província Borborema (Amaro et al. 1991a, Jardim de Sá et al. 1993b, Vauchez et al. 1995), sistema PatosCampina Grande (Amaro et al 1991b, Corsini et al. 1992), sistema Pernambuco (Vauchez \& Egydio-Silva 1992, Davison et al. 1995, Neves et al. 1996) e Domínio da Zona Transversal (Medeiros 1995, Medeiros et al. 1996), realizados com base no caráter sinóptico das imagens de satélite. 


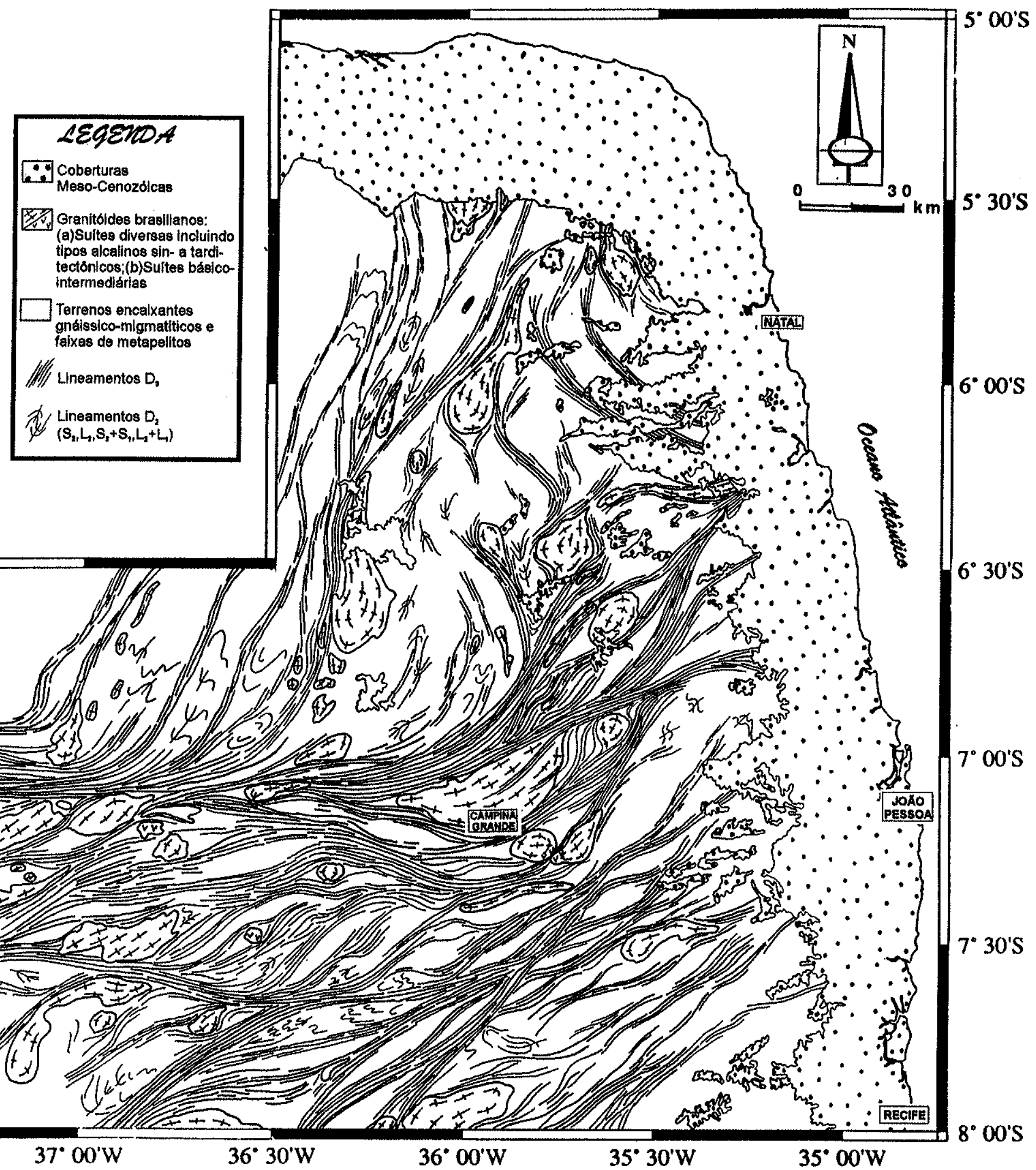

Figura 4.2 - Mapa esquemáticos dos lineamentos da deformação dúctil brasiliana do Setor Nordeste da Província Borborema, realizado com base na interpretação visual das imagens Landsat 5-TM em papel fotográfico (escalas 1:250000 e 1:100000) e produtos digitais (diversas escalas), produtos offset do radar GEMS/Banda X (escala 1:250000) e fotografias aéreas (escala 1:60000). A localização e a cinemática das principais zonas de cisalhamento brasilianas foram apresentadas na Figura 4.3. 


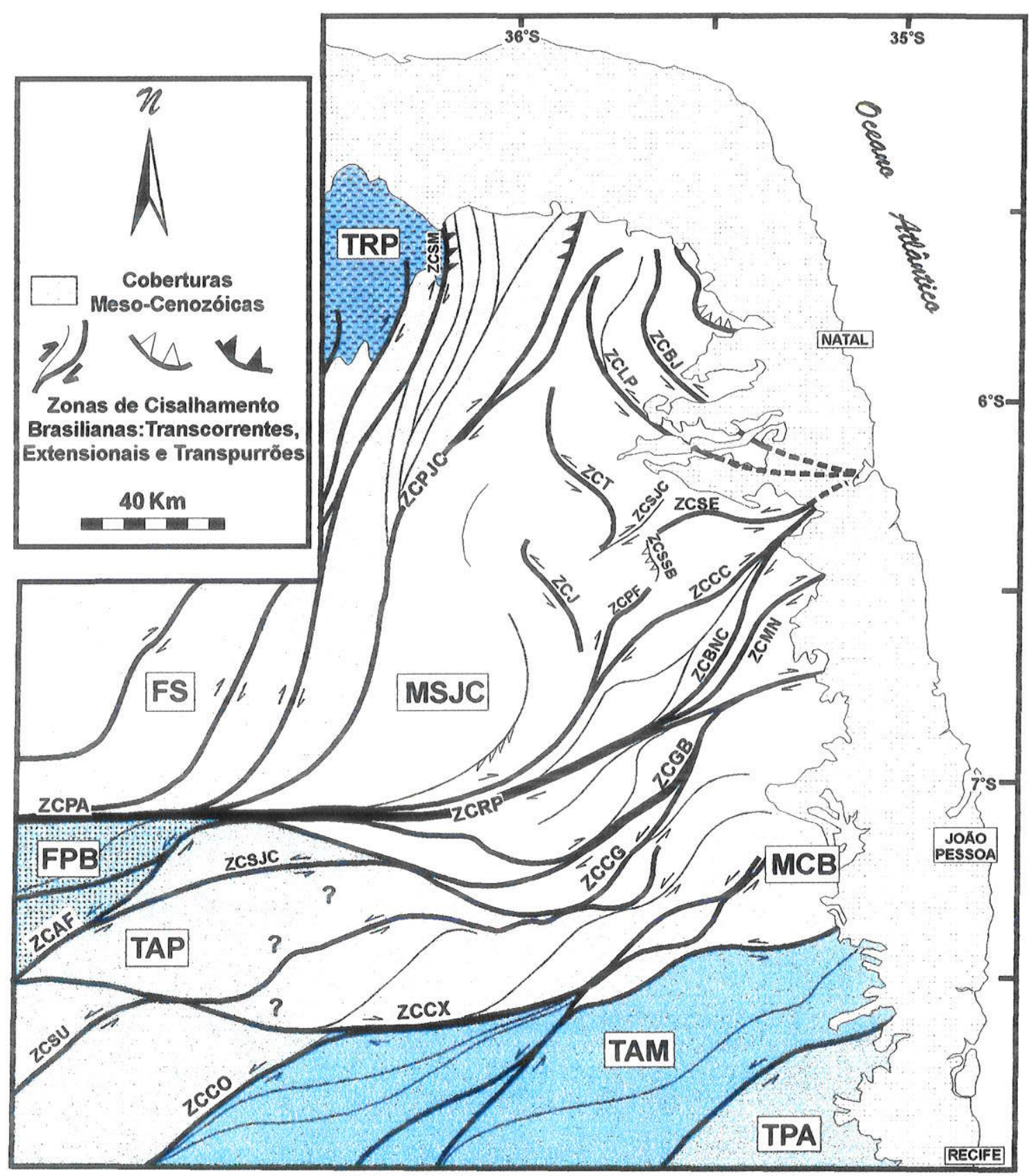

Figura 4.3 - Mapa esquemático da localização, distribuição geométrica e cinemática das principais zonas de cisalhamento brasilianas e os limites dos terrenos tectonoestratigráficos no Setor Extremo Nordeste da Província Borborema. Abreviaturas de alguns terrenos e zonas de cisalhamento: TRP $=$ Terreno Rio Piranhas, FS = Faixa Seridó, FPB = Faixa Piancó-Alto Brígida, TAP $=$ Terreno Alto Pajeú, TAM $=$ Terreno Alto Moxotó, TPA $=$ Terreno Pernambuco-Alagoas, MSJC = Maciço São José do Campestre, $\mathrm{MCB}=$ Maciço Caldas Brandão, ZCPJC = Zona de Cisalhamento Picuí-João Câmara, ZCSM = Zona de Cisalhamento Santa Maria, ZCBJ = Zona de Cisalhamento Bom Jesus, ZCLP $=$ Zona de Cisalhamento Lagoa das Pedras, $\mathrm{ZCT}=$ Zona de Cisalhamento Trairi, ZCJ $=$ Zona de Cisalhamento Japi, ZCSJC = Zona de Cisalhamento São José do Campestre, ZCSE = Zona de Cisalhamento Serrinha, ZCSSB = Zona de Cisalhamento Serra de São Bento, ZCPF = Zona de Cisalhamento Passa-e-Fica, ZCCC $=$ Zona de Cisalhamento Cacerengo, ZCBNC $=$ Zona de Cisalhamento Belém-Nova Cruz, ZCMN = Zona de Cisalhamento Montanhas, $\mathrm{ZCRP}=$ Zona de Cisalhamento Remígio-Pocinhos, $\mathrm{ZCCG}=$ Zona de Cisalhamento Campina Grande, $\mathrm{ZCGB}=$ Zona de Cisalhamento Guarabira, ZCPA = Zona de Cisalhamento Patos, $\mathrm{ZCAF}=$ Zona de Cisalhamento Afogados da Ingazeira, ZCSJC = Zona de Cisalhamento São José dos Cordeiros, $\mathrm{ZCSU}=$ Zona de Cisalhamento Sumé, $\mathrm{ZCCO}=$ Zona de Cisalhamento Congo, $\mathrm{ZCCX}=$ Zona de Cisalhamento Caxixola. 
A feição de maior destaque na Fig. 4.2 é o arranjo dos sistemas de lineamentos, indicadores de zonas de cisalhamento neoproterozoicas, numa trama penetrativa, finamente espaçada, extensa e anastomosada. Este sistema circunscreve blocos e faixas de aspectos sigmoidais compostos por granitóides neoproterozóicos e terrenos antigos (arqueanos a mesoproterozóicos), que acomodam as modificações na direção do fluxo cisalhante principal e na partição do strain $\mathrm{D}_{3}$. No interior desses blocos e faixas antigas, de estruturação anterior à instalação das zonas de cisalhamento, a deformação neoproterozóica ora está totalmente ausente, ora ocorre de forma fraca, espaçada e pouco penetrativa, freqüentemente como plano axial de dobramentos abertos e arqueamentos. A deformação brasiliana pode ainda constituir estruturas tangenciais de dificil detecção nas imagens. A delimitação das zonas de cisalhamento neoproterozóicas de regime tangencial, e a distinção das deformações tangenciais prévias, somente é possivel pela aplicação rigorosa dos critérios descritos em itens anteriores, aplicados às imagens monocanal (fotos de avião, produtos fotográficos do Radar GEMS/Banda $\mathrm{X}$ e do Landsat 5-TM/bandas 4 e 5) e combinadas aos tratamentos digitais de imagens Landsat 5-TM (composições coloridas e filtragens direcionais), imprescindivelmente comparados às informações de campo sobre as correlações estruturais, critérios cinemáticos e relações de intrusão do plutonismo associado.

$\mathrm{O}$ aspecto anastomosado dos sistemas de zonas de cisalhamento demonstra a inconveniência da representação dos lineamentos como zonas estanques e desarticuladas, aspecto freqüente na cartografia geológica regional. As principais zonas de cisalhamento neoproterozóicas ocorrem associadas espacialmente, interligadas por ramificações ou inflexões das zonas de cisalhamento subsidiárias. Estas últimas estão presentes em maior número e intensidade nas terminações em splay das zonas de cisalhamento mais largas e extensas, freqüentemente definindo o contato entre unidades litoestratigráficas e plútons granitóides.

A organização das zonas de cisalhamento em sistemas coalescentes revela a penetratividade regional da deformação $\mathrm{D}_{3}$, decorrente do intenso retrabalhamento intracontinental de uma crosta heterogênea e anisotrópica, refletindo a estruturação vista em superficie (plano XZ de achatamento do elipsóide de strain) aos niveis profundos. Deste modo, torna-se incoerente a particularização de uma única zona de cisalhamento, pela nominação especifica que não seja por motivos estritamente descritivos e localizados. Por 
isso, sugere-se o emprego informal do termo "sistema" de zonas de cisalhamento acompanhado das nominações ratificadas pela literatura geológica regional. A complexidade nas correlações entre os vários sistemas de zonas de cisalhamento de trends NE, NW e EW requer o levantamento de informações rigorosas sobre as condições metamórficas, geocronologia relativa e o regime deformacional de cada sistema na elaboração do modelo termomecânico para o conjunto da Província Borborema.

No DZT, a interpretação visual dos lineamentos em imagens de satélite (Foto 4.1) integrados às informações de campo em alguns setores (Medeiros 1995, Medeiros et al. 1996), demonstraram o caráter sinistral para a maioria das zona miloniticas de trend NE/ENE em regime do tipo cisalhamento geral (Jardim de Sá 1994, Jardim de Sá et al. 1995). No modelo transpressional de Corsini et al. (1992) e Vauchez e Egydio-Silva (1992) essas zonas possuiriam cinemática transcorrente dextral, pela transferência da movimentação no setor EW do lineamento Pernambuco para NE ao longo da ZCAF (denominada por aqueles autores de zona de cisalhamento Campina Grande, ZCCG) e outras subsidiárias, sob condições de alta temperatura. Na interpretação de Davison et al. (1995), a ZCPE apresenta traçado EW flexuoso até a costa, ocorrendo transferência de movimento dextral apenas na interligação com a ZCAF. Entretanto, a interpretação visual sistemática de imagens Landsat 5-TM combinada aos trabalhos de campo, e confirmado nos procedimentos de confeç̧ão do mapa da Fig. 4.2, demonstraram que a cinemática sinistral sob condições metamórficas de alta-T é dominante nas zonas de cisalhamento de trend geral NE, conduzida em regime de cisalhamento geral. As principais evidências que descrevem o movimento sinistral da deformação cisalhante, e estão refletidos na morfologia dos lineamentos, são os elementos do fabric $\mathrm{D}_{3}$ expressos da macro- à microescala: (a) a orientação EW e NW dos trações axiais dos dobramentos $\sin -\mathrm{D}_{3}$; (b) o padrão de inflexões das foliações e das zonas de cisalhamento subsidiárias; (c) as estruturas S-C identificáveis pelo controle exercido pelas zonas miloníticas sobre alguns plútons, e que representam as relações PFC-SPD (pre-full crystallization-subsolidus plastic deformation, Hutton 1988, Paterson et al. 1989) em macroescala; (d) a forma sigmoidal e en cornue dos plútons granitóides; (e) os levantamentos em meso- e microescalas dos indicadores cinemáticos nos corpos granitóides, faixas miloníticas e terrenos associados. No interior do DZT, algumas zonas de cisalhamento dextrais de trend EW (p.ex. as zonas de cisalhamento Caxixola, ZCCX, e Serra Talhada, 


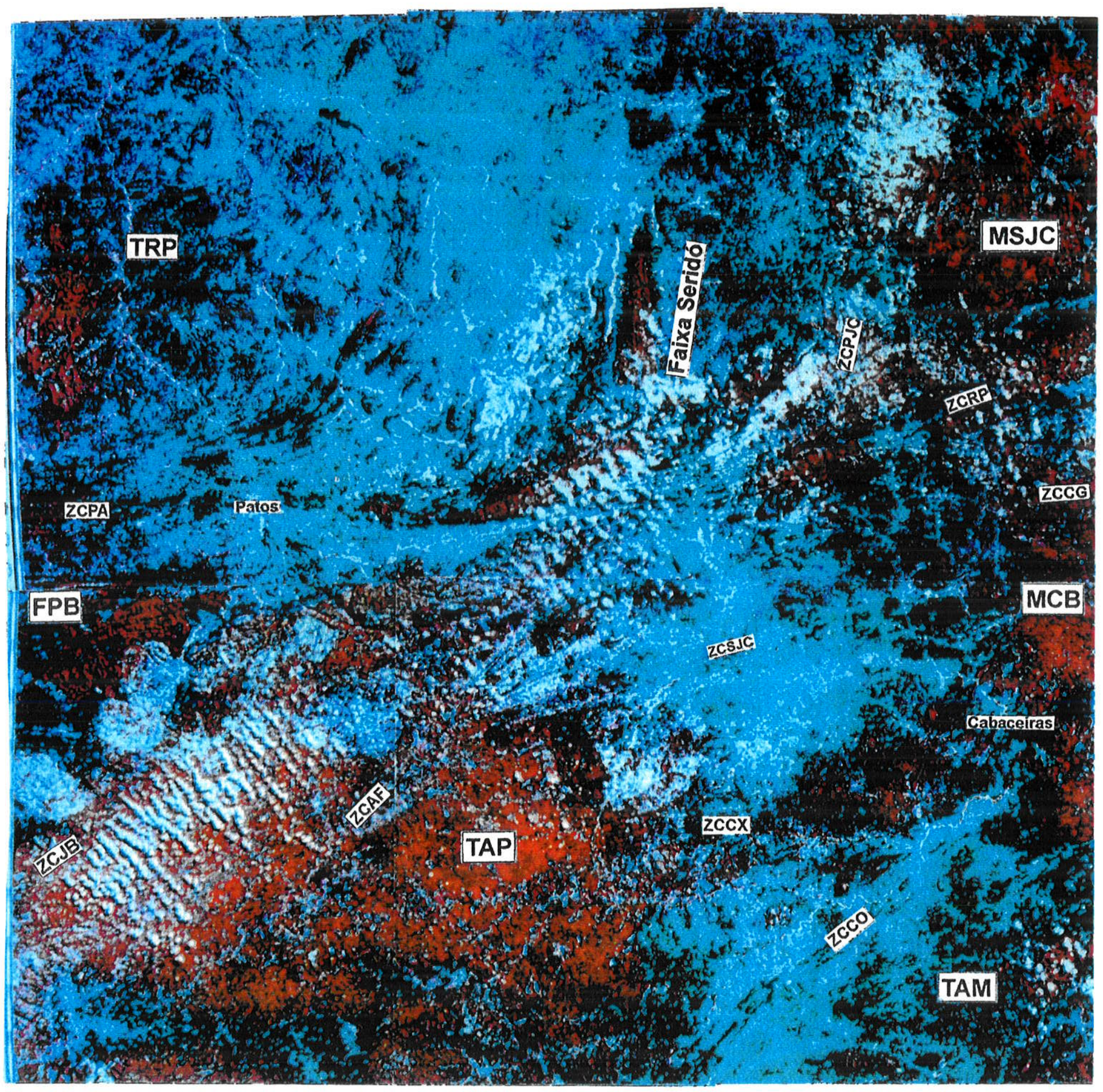

Foto 4.1 - Mosaico de imagens em composição colorida RGB das bandas 2-3-4 do Landsat-TM para o Setor Centro-Oriental da Província Borborema (limites aproximadamente entre $36^{\circ} 00^{\prime}-37^{\circ} 45^{\prime} \mathrm{W} / 6^{\circ} 00^{\prime}-8^{\circ} 00^{\prime} \mathrm{S}$ ), com destaque para algumas das principais zonas de cisalhamento e domínios estruturais envolvidos. Abreviaturas: TRP $=$ Terreno Rio Piranhas, FPB $=$ Faixa Piancó-Alto Brígida, MSJC = Maciço São José do Campestre, $\mathrm{MCB}=$ Maciço Caldas Brandão, TAP $=$ Terreno Alto Pajeú, TAM $=$ Terreno Alto Moxotó, $\mathrm{ZCPA}=$ Zona de Cisalhamento Patos, ZCPJC = Zona de Cisalhamento Picuí-João Câmara, ZCRP = Zona de Cisalhamento Remígio-Pocinhos, ZCAF = Zona de Cisalhamento Afogados da Ingazeira, ZCCX = Zona de Cisalhamento Caxixola, $\mathrm{ZCCO}=$ Zona de Cisalhamento Congo, ZCSJC = Zona de Cisalhamento São José dos Cordeiros, ZCJB $=$ Zona de Cisalhamento Juru-Belém, ZCCG $=$ Zona de Cisalhamento Campina Grande. 
ZCST) aderem em sincronismo ao movimento das zonas sinistrais de trend NE, como assinalam os traçados defletidos e coalescentes das foliações. Os movimentos sinistrais são acomodados conforme cisalhamentos antitéticos, vinculados à rotação no sentido horário dos blocos situados entre os lineamentos principais de Patos e Pernambuco (Jardim de Sá et al. 1995). O rejeito sinistral das zonas de cisalhamento de trend $\mathrm{NE}$ é contemporâneo ao movimento dextral das zonas de cisalhamento de trend $\mathrm{EW}$, em um arranjo que estabelece o "modelo em dominó" (Sylvester 1988, Tanaka \& Saka 1993) na estruturação dos terrenos do DZT. Este modelo é fortalecido pelo padrão estrutural de alojamento de alguns plútons brasilianos, conforme a orientação do fabric magmático (Archanjo 1993, Olivier \& Archanjo 1994). Os critérios sinistrais são bem descritos no alongamento EW a WNW dos plútons de Itaporanga e Triunfo, devido às zonas transcorrentes de Afogados da Ingazeira e Serra Talhada, e os dextrais no alongamento NE a ENE dos plútons de Tavares e Solidão, relacionados à zona milonítica de Juru (Medeiros et al. 1996). Os estudos de anisotropia de susceptibilidade magnética confirmam o movimento sinistral para a zona de cisalhamento de Serra Talhada de trend NE, que exerce controle na orientação EW e ENE das lineações magnéticas do sienito de Triunfo (Archanjo 1993).

Um importante aspecto do sistema de zonas de cisalhamento neste setor da Provincia Borborema é a disposição aglutinante, em direção à região costeira, das principais zonas de cisalhamento de trends NE (ZCAF, ZCC, ZCSU e ZCCO) e EW (ZCCX). Este sistema se integra ao sistema em splay do Lineamento Patos pela coalescência das zonas de cisalhamento secundárias. Este sistema anastomosado e coalescente das zonas de cisalhamento de trend EW e NE controlam a compartimentação dos terrenos tectonoestratigráficos do $\mathrm{MSJC}, \mathrm{MCB}$, Faixa Seridó, Alto Pajeú e Alto Moxotó. A estrururação do MSJC é controlada pelas zonas de cisalhamento dextrais de trend $\mathrm{NE}$ e suas subsidiárias sinistrais de trend $\mathrm{NW}$, decorrentes da total inflexão para NE do segmento EW do Lineamento Patos. Na região de Campina Grande, uma importante feição de aglutinação paraleliza a terminação em splay do Lineamento Patos, em inflexões para NE (ZCRP e ZCCG), com as zonas de cisalhamento sinistrais de trend NE provenientes do DZT. Este conjunto constitui o limite ocidental dos terrenos gnáissico-migmatíticos do MCB que para sul são delimitados por uma zona de cisalhamento NE composta da junção entre a ZCCX e a ZCCO. 
A movimentação dos setores EW dos lineamentos Patos e Pernambuco escalonados desencadearia a rotação horária progressiva das zonas de cisalhamento de trend $\mathrm{NE}$, promovendo a formação de sítios em ambiente transtacional convenientes ao alojamento de magmas. $\mathrm{O}$ grande volume de rochas alcalinas associadas às zonas de cisalhamento no DZT (Silva Filho et al. 1993, Neves et al. 1996) sugere a abrangência litosférica dessas zonas, onde as raizes possivelmente astenosféricas conduziriam os fluidos mantélicos geradores das suites alcalinas subsaturadas, proveniente de fonte anomalamente hidratada como mica piroxenito (Ferreira \& Sial 1993). Este arranjo cinemático é coerente com a distribuição e o controle estrutural da linha sienitóide descrita por Sial e Ferreira (1988). A instalação do amplo ambiente transcorrente-extensional no DZT justificaria a constância das foliações $S_{3}$ de baixo ângulo nos blocos sigmoidais entre as principais zonas de cisalhamento, em contraponto aos domínios transpressionais à norte do lineamento Patos. Num estágio tardio de movimentação em condições retrogressivas (metamorfismo de baixa temperatura), o alojamento de diques (Manaíra e Princesa Isabel) indica o prosseguimento do controle estrutural em nível crustal mais raso. Algumas das zonas de cisalhamento do DZT podem ser representantes de zonas de sutura colisional relacionadas à justaposição de terrenos alóctones, por encaixarem rochas básico-ultrabásicas com relíctos de paragênese eclogítica (Beurlen et al. 1992, Almeida et al. 1993) interpretadas como basaltos de arco ou do tipo E-MORB (Santos 1993). Posteriormente, após o amálgama dos blocos alóctones, estas zonas de sutura sofreriam reativação intracontinental com cinemática transcorrente, geralmente acompanhada de um componente compressional/extensional no regime de cisalhamento geral. Algumas destas zonas de cisalhamento estão assinaladas em sua extensão por anomalias gravimétricas positivas, que revelam a presença de escamas tectônicas de rochas de crosta oceânica e/ou mantélicas eclogitizadas (Oliveira \& Santos 1993).

\section{4 - Arcabouço Geológico da Região dos Maciços São José do Campestre e Caldas}

\section{Brandão}

A Fig. 4.1 apresenta o mapa geológico esquemático para a região dos maciços São José do Campestre (MSJC) e Caldas Brandão (MCB) entre $05^{\circ} 15^{\prime}-07^{\circ} 30^{\prime} \mathrm{S} / 35^{\circ} 00^{\prime}$ $36^{\circ} 15^{\prime} \mathrm{W}$, resultante da integração dos mapas geológicos prévios, mapas temáticos 
interpretados visualmente e dados de campo. O mapa destaca o contexto da estruturação neoproterozóica caracterizada por terrenos em regimes transtracional e extensional, definidos por zonas de cisalhamento sinistrais e dextrais, estruturas em flor negativa e zonas de detachments, contemporâneos ao regime transpressional dextral da Faixa Seridó. Os produtos de sensoriamento remoto empregados nos procedimentos interpretativos foram as imagens Landsat 5-TM 214/065 (cena de 10/julho/89), 214/064-A e 214/064-C (ambos os quadrantes de 06/agosto/1993), e as imagens GEMS/Banda X (SB.25-V-C, SB.25-Y-A, SB.25-Y-C, obtidas entre 1975-1976).

\section{- Núcleo Arqueano e Blocos Paleoproterozóicos:}

No setor correspondente aos maciços São José do Campestre e Caldas Brandão, às zonas de cisalhamento $\mathrm{NE}$ de rejeitos dextrais integram-se zonas de cisalhamento de trend NW sinistrais compondo um arranjo complexo, caracterizado por ambientes extensionais e transtracionais, que controlam o alojamento de plútons granitóides.

$\mathrm{Na}$ descrição do arranjo tectônico dos diferentes blocos crustais que compõem os MSJC-MCB foi aplicado o arcabouço geral proposto por Dantas (1997), baseado nas informações geoquimicas e isotópicas (idades modelo $\mathrm{Sm} / \mathrm{Nd}$ e U/Pb em zircão, Tab. 1.1 e 1.2). Uma feição morfológica marcante da estruturação dos terrenos, demonstrada na Fig. 4.4, é o controle exercido pelas zonas de cisalhamento neoprotrozóicas no arranjo morfológico e na delimitação entre o núcleo arqueano e os terrenos paleoproterozóicos adjacentes. O núcleo arqueano possui forma dômica ovalada parcialmente recoberto por sedimentos meso-cenozóicos a norte e leste, limitado a sul pelas zonas de cisalhamento sinistrais de Trairi e Serrinha (ZCT e ZCSE), e a oeste pela ZCPJC dextral. No setor NNE, os terrenos arqueanos constituem o substrato dos metapelitos de Ielmo Marinho-Taipu. A geometria dos terrenos paleoproterozóicos é marcado por blocos sigmoidais e elipsoidais controlados pela cinemática das principais zonas de cisalhamento de trend geral NE e EW.

Nos terrenos gnáissico-migmatíticos, o principal critério no reconhecimento do evento $D_{1}$ são os diques básicos anfibolitizados (basaltos e diabásios), presentes nos afloramentos de baixo strain $\mathrm{D}_{2}$ e $\mathrm{D}_{3}$ (Foto 4.2). Apesar dos diques estarem usualmente dobrados e boudinados pela deformação subhorizontal $\mathrm{D}_{2}$, foram reconhecidas apófíses que interceptam um bandamento metamórfico antigo (então designado $S_{1}$, Foto 4.3a e 4.3b). Esta feição descreve o caráter intrusivo de um enxame de diques em substrato previamento 


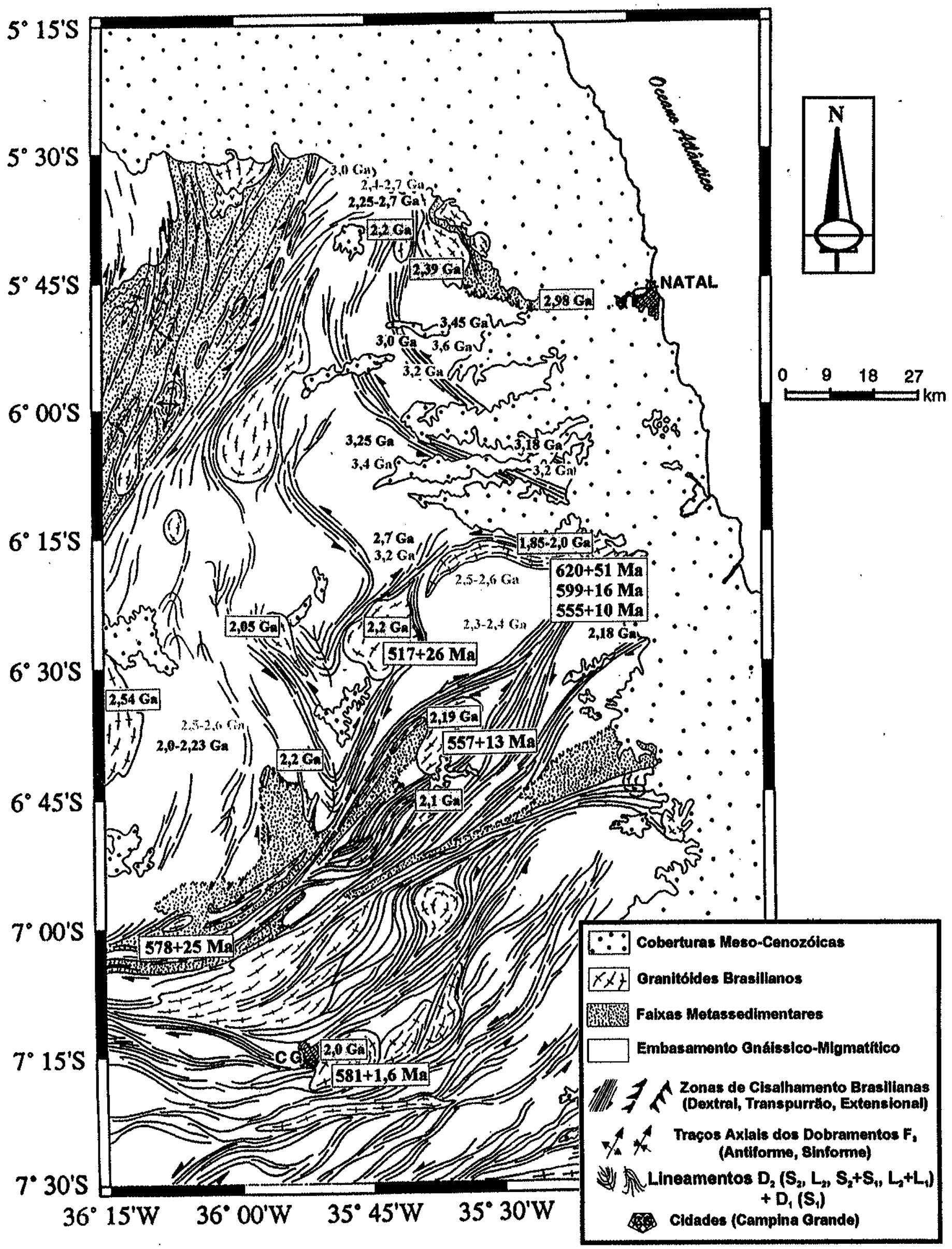

Figura 4.4 - Dados geocronológicos do Maciço São José do Campestre, Setor Extremo Nordeste da Província Borborema. As idades TDM (Ga) arqueanas e paleoproterozóicas estão definidas em cinza, e as idades' U- $\mathrm{Pb}(\mathrm{Ga})$ em zircðes estão em preto. As idades neoproterozóicas $\mathrm{Rb}-\mathrm{Sr}(\mathrm{Ma}), \mathrm{U}-\mathrm{Pb}$ em zircóes e análises químicas de monazitas estão nos quadrados brancos, enquanto as idades TDM (Ga) estão em cinza. 
deformado (bandamento $S_{1}$ ) e exumado, com os subseqüentes soterramento tectônico, deformação e metamorfismo referidos à fase $\mathrm{D}_{2}$. Esta relação de não-conformidade marca um amplo lapso temporal entre os eventos $D_{1}$ e $D_{2}$, com todo o conjunto envolvido posteriormente pelo evento $\mathrm{D}_{3}$. Segundo Jardim de Sá $(1978,1994)$, o estágio de intrusão do enxame de diques é precedente ou contemporâneo à deposição das supracrustais do Grupo Seridó.

Nas imagens interpretadas visualmente, os lineamentos representantes das estruturas $D_{2}$ (nas escalas meso- e macroscópica) formam uma trama finamente espaçada e complexa, em função da subhorizontalidade dos elementos estruturais. Nas áreas onde os terrenos estão preservados do strain $\mathrm{D}_{3}$ verifica-se que o fabric $\mathrm{D}_{2}$ é penetrativo e aliado ao alto grau metamórfico (fácies anfíbolito alto), freqüentemente numa diferenciação migmatítica de mergulho suave com remobilizados graníticos boudinados e assimétricos (Foto 4.4). Portanto, na maioria dos afloramentos a intensidade do strain $\mathrm{D}_{2}$ provoca a composição das foliações $S_{2}+S_{1}\left( \pm S_{0}\right)$. As dobras $F_{2}$ são melhor descritas em perfis verticais onde mostram a geometria recumbente e isoclinal (tipos 2 e 3 da classificação de Ramsay 1967), trend amplamente variável entre EW, NW e NE, e mergulhos suaves (Foto 4.5). A foliação $S_{2}$ comumente corresponde a um bandamento milimétrico a centimétrico, provavelmente subparalelo à superficie $S_{1}\left(S_{2} / / S_{1}\right)$, e associado a remobilizados anatéticos que denotam o caráter migmatítico. As lineações $\mathrm{L}_{2}$ correspondem a feições combinadas de estiramento $\left(\mathrm{L}_{2}^{\mathrm{X}}\right)$ e intersecção $\left(\mathrm{L}_{2}^{1}\right)$, com caimentos suaves para SSE e NNW, decorrente do alto strain $\mathrm{D}_{2}$ como descrito em outras regiões do embasamento (Complexo Caicó, Jardim de Sá 1994). A $L_{2}{ }_{2}$ é definida pelo estiramento de porfíroclastos, estiramento e boudinagem dos agregados quartzo-feldspáticos (Foto 4.4), minerais fibrosos e prismáticos, enquanto a $\mathrm{L}_{2}^{1}$ é marcada pela orientação de quartzo e biotitas na interseç̧ão das superficies $\left(S_{2} / S_{1}\right)$. Pelo exposto, a fase $D_{2}$ corresponde a um evento tangencial, onde os critérios cinemáticos indicam transporte de massa na direção NW-SE.

$O$ caráter heterogêneo e a partição do strain $\mathrm{D}_{3}$ na Província Borborema já foi descrito em diversos trabalhos (Jardim de Sá 1994 e referências ali contidas), assinalado pela alternância entre setores com dobramentos abertos, que definem o strain baixo a médio, e aqueles de alto strain (dobras fechadas a isoclinais) e zonas de cisalhamento. $O$ aumento na penetratividade do strain $\mathrm{D}_{3}$ provoca a obliteração do fabric $\mathrm{D}_{2}$ pela paralelização com a 
Foto 4.2 - Ortognaisses do embasamento com diques básicos anfibolitizados pré- $\mathrm{D}_{2}$, como sugerem as apófises, ambos mostrando fabric $\mathrm{D}_{2} \mathrm{e}$ interceptados por granitóides sintectônico $\mathrm{D}_{3}$. Afloramento no embasamento arqueano próximo a Riachuelo ( $35^{\circ} 49^{\prime} 25^{\prime \prime} \mathrm{W} / 5^{\circ} 51^{\prime} 46^{\prime \prime} \mathrm{S}$ ).

Foto 4.3 - Aspecto geral dos ortognaisses do embasamento paleoproterozóico, intercalados à Faixa de Micaxistos de Barra de Santa Rosa, migmatizados e milonitizados na ZCRP: (a) foliação milonítica $S_{3} / / C_{3}$ demonstrando o alto strain do afloramento com remobilizados graníticos sintectônicos e evidências de redobramentos do fabric $\mathrm{D}_{2}\left(+\mathrm{D}_{1}\right)$; (b) detalhe da foto anterior mostrando as apófises dos diques anfibolíticos pré- $D_{2}$, com a foliação composta $S_{2}+S_{1}$ redobrada na fase $\mathrm{F}_{3}$. Afloramento na Faixa de Micaxistos de Barra de Santa Rosa (35 $56^{\prime}$ '57' W $\left.16^{\circ} 55^{\prime} 51^{\prime \prime} \mathrm{S}\right)$.

Foto 4.4 - Remobilizados graníticos na foliação composta $S_{2}+S_{1}$ boudinados e assimétricos dextrais em ortognaisses do embasamento arqueano, truncado pelo fabric $\mathrm{D}_{3}$ que desenvolve

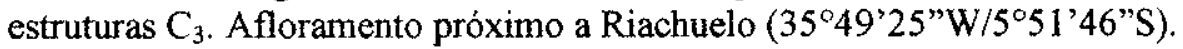

Foto 4.5 - Aspecto geral do padrão de interferência do tipo bumerangue entre as dobras $F_{3}$ (foliação vertical) e $F_{2}$ (isoclinais recumbentes) definidos em níveis quartzosos intercalados aos micaxistos sob condições da "Zona da Sillimanita". Afloramento na Faixa Seridó a sudeste de Lajes (355 $\left.58^{\prime} 41^{\prime \prime} \mathrm{W} / 5^{\circ} 45^{\prime} 36^{\prime \prime} \mathrm{S}\right)$. 
Foto 4.2

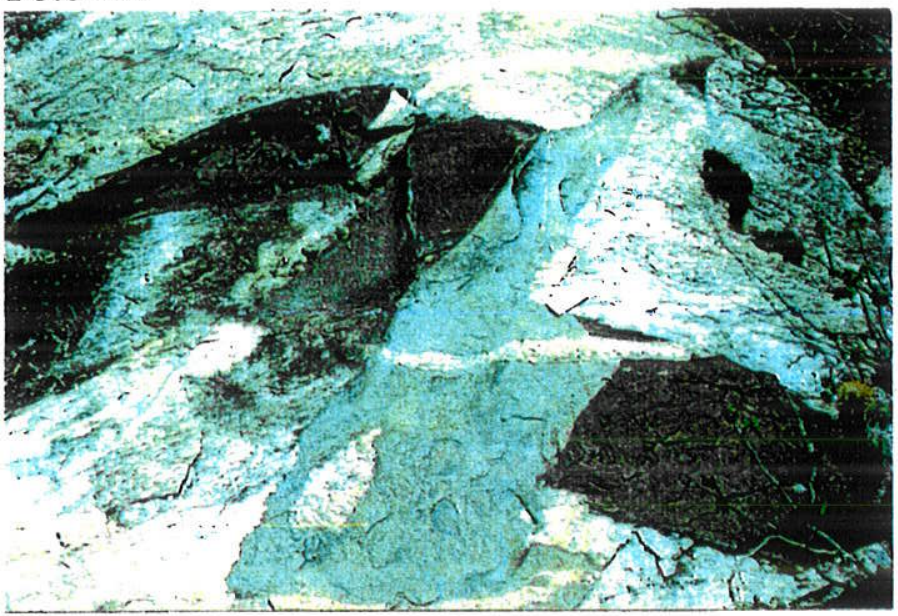

Foto $4.3 \mathrm{~b}$

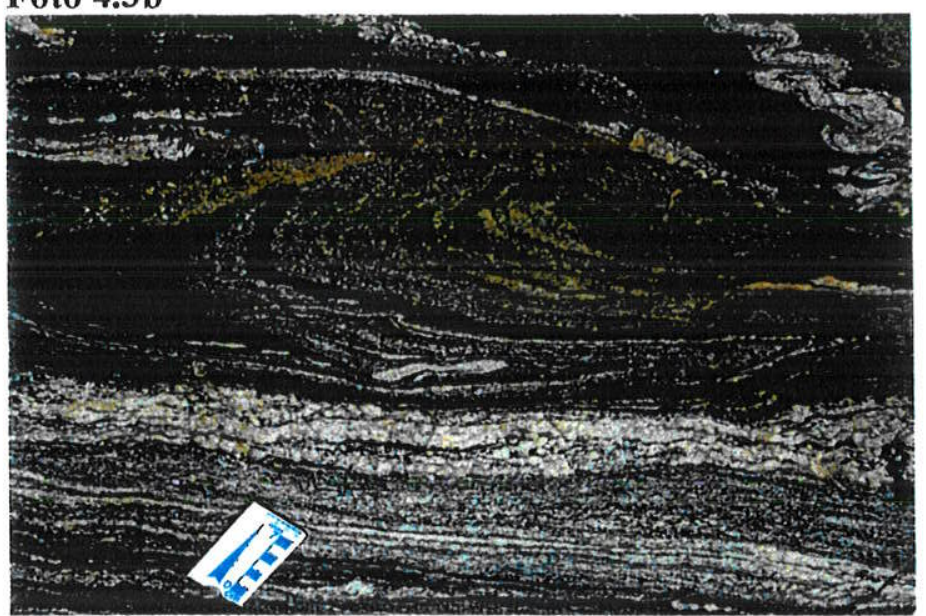

Foto 4.3a

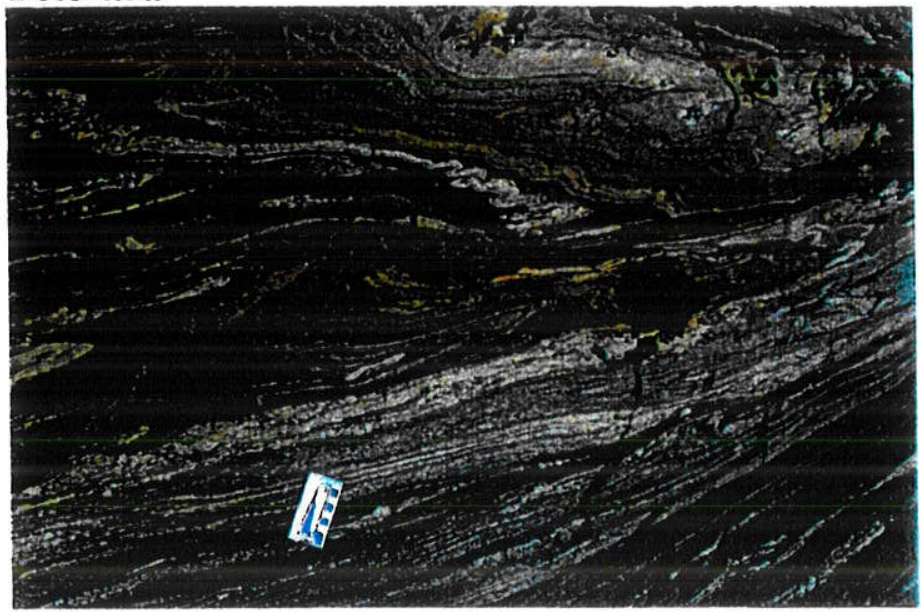

Foto 4.4

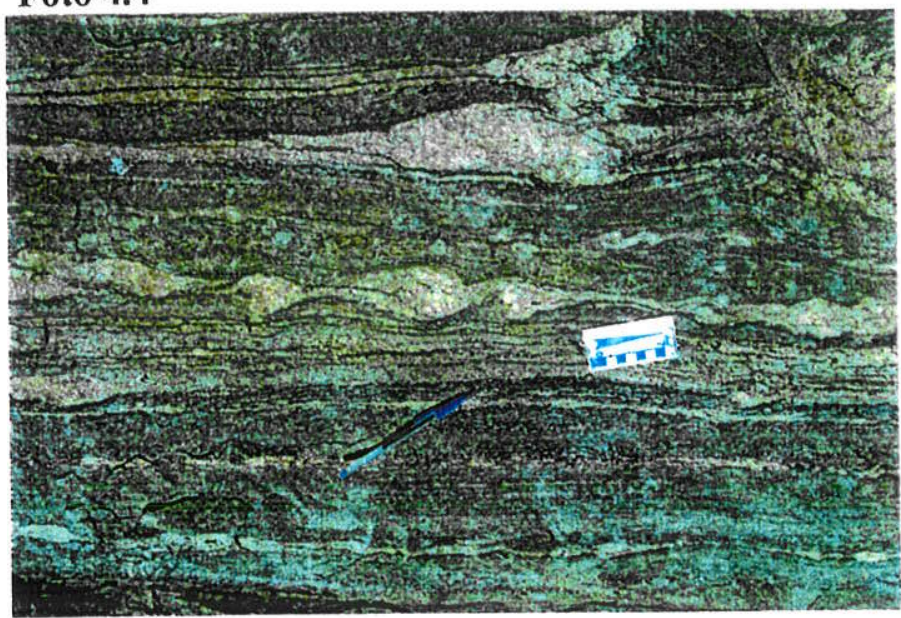

Foto 4.5

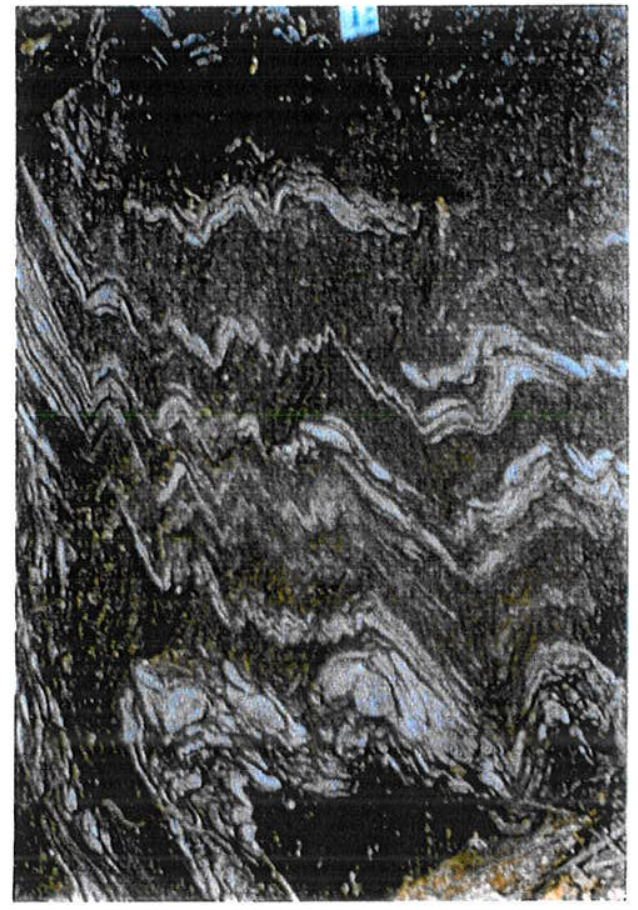


foliação $S_{3}$, e/ou retrabalhamento das foliações prévias $\left(S_{2} \pm S_{0}\right.$ ou $\left.S_{2} \pm S_{1}\right)$ como superficies de cisalhamento $\left(C_{3}\right)$. A foliação $S_{3}$ varia desde uma clivagem de crenulação até foliações miloníticas, compostas pelas associações minerais paragenéticas às condições de P-T atuantes durante a deformação (ver Cap. 6). Nos setores de alto strain $\mathrm{D}_{3}$ é gerada uma foliação composta $S_{3} / / S_{2}+S_{1}$, freqüentemente retrabalhadas por superficies de cisalhamento. A distinção entre $\mathrm{L}_{2} \mathrm{eL}^{\mathrm{X}}{ }_{3}$ é facilitada nos afloramentos onde ocorre a interseç̧ão de ambas numa mesma superficie, ou em superficies distintas $\left(S_{2}\right.$ e $\left.S_{3}\right)$ ou pela definição de $L^{X_{3}}$ presente em granitóides e pegmatóides brasilianos intrusivos e discordantes do fabric $\mathrm{D}_{2}$ (Foto 4.6a e 4.6b). Nos setores onde $S_{2}$ se paraleliza a $S_{3}$, como nas dobras $F_{3}$ apertadas a isoclinais e zonas de cisalhamento, as lineações $\mathrm{L}_{2}$ e $\mathrm{L}_{3}$ tendem à coincidência. As formas mais comuns das dobras $F_{3}$ variam desde o tipo aberto, nas áreas de baixo strain $D_{3}$, até fechado a isoclinal nas zonas de cisalhamento, normais a inclinadas, com trends gerais NW e EW de baixo caimento.

No núcleo arqueano, as estruturas $\mathrm{D}_{3}$ mostram trend geral variando de NNW a NW, acompanhando a geometria das zonas de cisalhamento de Bom Jesus e Lagoa da Pedra (ZCBJ e ZCLP), ambas sinistrais de caráter transtracional que interceptam o domo e cuja provável integração com as ZCSE e ZCRP, nas suas principais ramificações, está encoberta pelos sedimentos costeiros, na região da Lagoa Guaraíra. As foliações miloniticas possuem usualmente mergulho variando entre $40-80^{\circ}$ para $\mathrm{NE}$, contendo lineações $\mathrm{L}_{3}^{\mathrm{X}}$ com forte rake e caimentos entre $10-50^{\circ}$ para NNE, que sugere a atuação de um componente coaxial. Alguns critérios cinemáticos, como veios graníticos escalonados e sigmoidais, shear bands (Foto 4.7) e assimetria de porfiroclastos e boudins, indicam a combinação da transcorrência sinistral com movimento extensional (down dip). A migmatização é demonstrada pela freqüente segregação e migração de fundidos graníticos para as estruturas $D_{3}$ extensionais geradas no cisalhamento (Foto 4.8). Na ZCLP foram descritos granada anortositos brasilianos, associado às rochas de alto grau (Complexo Senador Elói de Souza, Dantas 1997).

Na região de São José do Campestre, uma zona transcorrente dextral de trend NE (ZCSJC, Lima 1997) limita a porção norte do granitóide Monte das Gameleiras, continuando para o interior do domo, possivelmente bordejando o sienogranito de São José do Campestre, representante do final da sequeência de diferenciação das unidades arqueanas 


\section{Foto 4.6a}

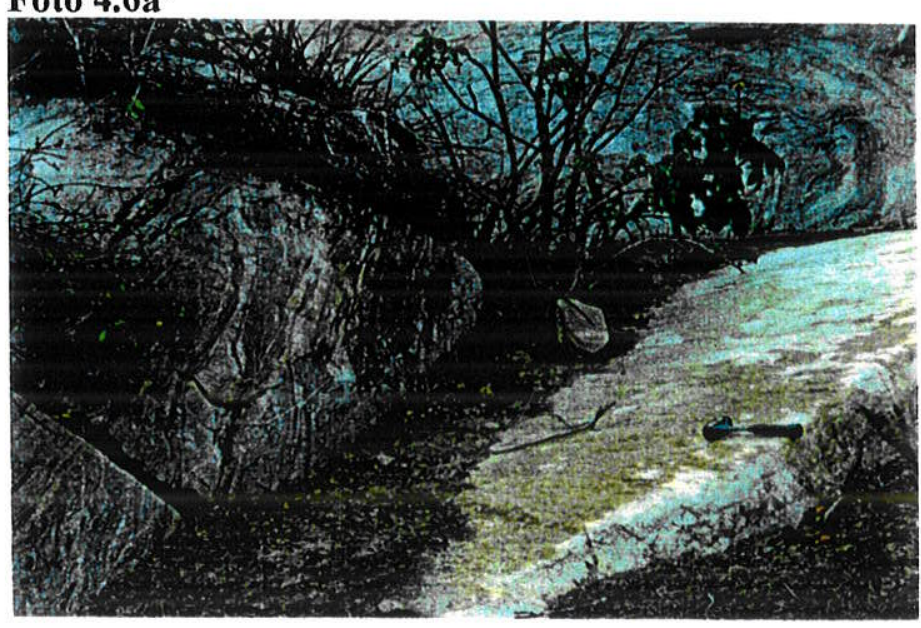

Foto 4.7

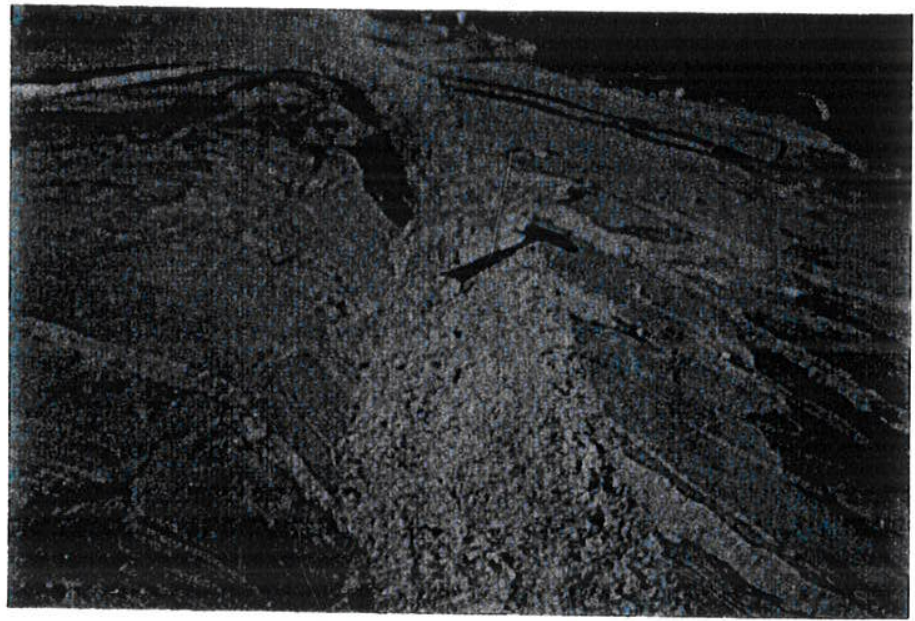

\section{Foto 4.6b}

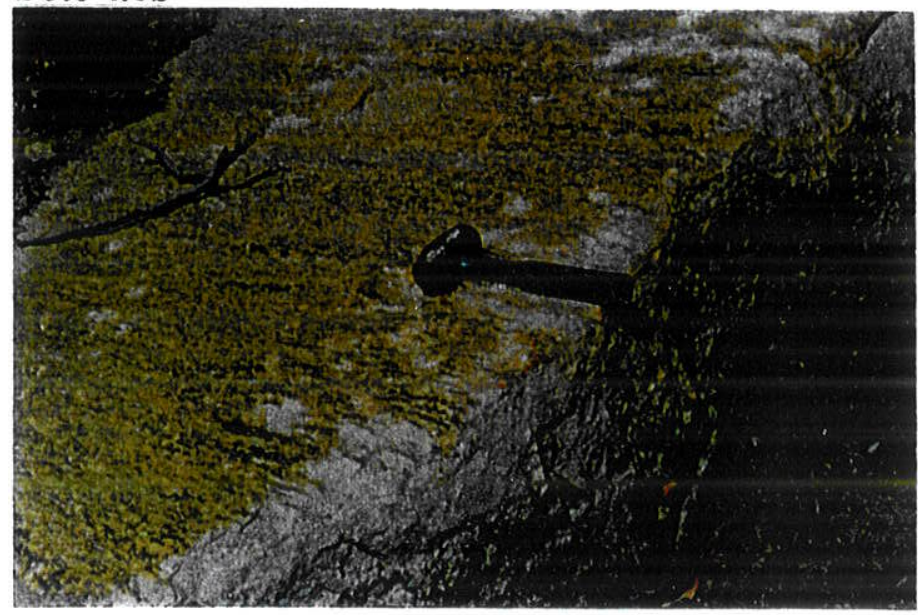

Foto 4.8

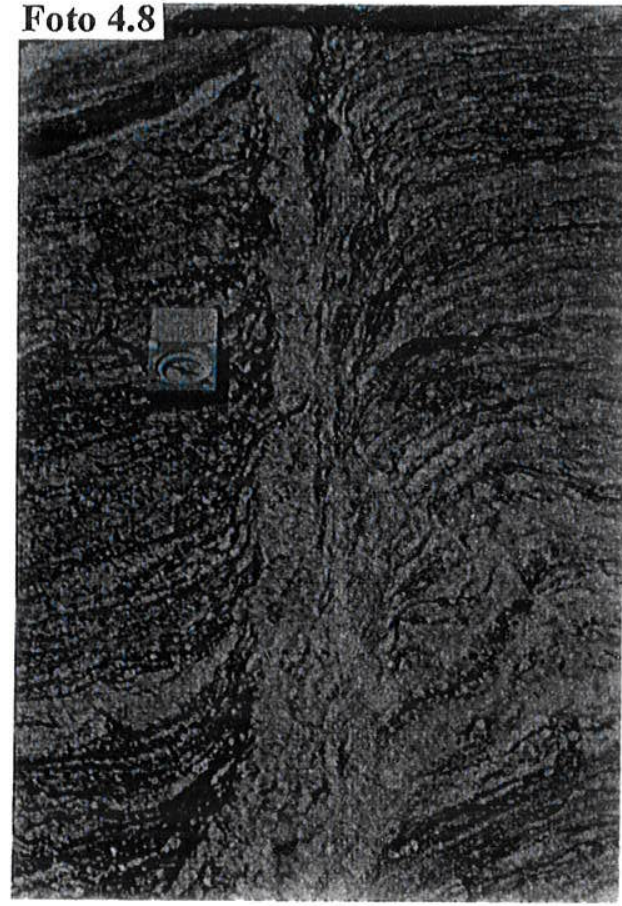

Foto 4.6 - Aspecto geral dos gnaisses do embasamento: (a) truncados por veio pegmatítico sintectônico ao fabric $\mathrm{D}_{3}$, intrusivo no plano axial de dobras recumbentes da fase $\mathrm{F}_{3}$ e com lineação de estiramento subhorizontal; (b) detalhe da foto anterior mostrando os agregados quartzo-feldspáticos + granada + silllimanita na $\mathrm{L}_{3}^{\mathrm{X}}$ subhorizontal. Afloramento no contato do embasamento gnáissico-migmatítico paleoproterozóico com a Faixa de Micaxistos de Barra de Santa Rosa.

Foto 4.7 - Gnaisses tonalíticos do embasamento afetado pelo fabric $\mathrm{D}_{3}$ que desenvolve shear bands sinistrais de alta temperatura e trend geral EW. Afloramento do embasamento gnáissicomigmatítico do embasamento arqueano envolvido pela ZCLP, próximo a Senador Elói de Souza. Foto 4.8 - Migmatitos bandados do embasamento interceptados por zona de cisalhamento sinistral $\sin -\mathrm{D}_{3}$ de trend geral $\mathrm{N} 45^{\circ} \mathrm{E}$ que coleta remobilizados de composição granítica. Afloramento do embasamento gnáissico-migmatítico do embasamento arqueano envolvido pela ZCBJ. 
(Dantas 1997). Na ZCSJC são comuns corpos de granitos porfiriticos (tipo Monte das Gameleiras) com enclaves dioríticos (tipo diorito Serrinha) alongados e boudinados com fabrics SPD e PFC subparalelos, sugerindo a intrusão sintectônica destes plútons.

A margem sul do núcleo arqueano é definida pela ZCSE de trend EW e feições de cinemática transcorrente sinistral com componente extensional, instalada sob condições de alta temperatura com ampla fusão parcial das litologias, como sugerem feições como os veios graníticos e pegmatíticos sigmoidais escalonados (Foto 4.9a), as shear bands sinistrais em seções verticais e horizontais com coleta de remobilizados graníticos (Foto 4.10), os porfiroclastos rotacionados e as assimetrias de dobras. A ZCSE se estende desde as imediações do granito Monte das Gameleiras, onde possui trend $\mathrm{NE}, \mathrm{S}_{3} / / \mathrm{C}_{3}$ com mergulhos fortes para NW, $\mathrm{L}_{3}{ }_{3}$ com caimento forte a moderado $\left(30-80^{\circ}\right)$ para $\mathrm{NW}$ e caráter extensional dominante (descrita com zona de cisalhamento Rio Jacu por Lima 1997 e Campelo 1997), onde condiciona a intrusão do corpo diorítico porfiritico de Serrinha. Diques dioríticos ocorrem comumente sincrônicos à ZCSE (Foto 4.11a), geralmente associados a estruturas de coleta de remobilizados leucocráticos (Foto 4.11b). A ZCSE afeta os gnaisses do embasamento arqueano promovendo o redobramento do fabric prévio $\left(S_{2}+S_{1}\right)$, onde localmente são descritos prováveis diques intrusivos pré- $\mathrm{D}_{2}$ (Foto $4.9 \mathrm{c}$ ). A cerca de $4 \mathrm{~km}$ para oeste da cidade de Serrinha, a ZCSE deflete para WNW e em seguida assume o trend $\mathrm{EW}$, onde $\mathrm{S}_{3} / / \mathrm{C}_{3}$ tem mergulho moderado a forte $\left(40-80^{\circ}\right)$ para $\mathrm{NNE} \mathrm{e} \mathrm{L}_{3}{ }_{3}$ com rake moderado e caimentos de $20-50^{\circ}$ para NW e NE (Foto $4.9 \mathrm{~b}$ ), até ser encoberto pelos sedimentos costeiros. Neste trajeto, a ZCSE condiciona o corpo alongado do granitóide Serrinha, de composição dominantemente sienogranitica porfiritica, que apresenta feições de intrusão sintectônica sinistral, como os fabrics PFC e SPD subparalelos, os porfiroclastos rotacionados tipo- $\sigma$, shear bands (Foto $4.12 \mathrm{~d}$ ), superficies $\mathrm{C}_{3}$ ', entelhamento de fenocristais, enclaves boudinados e rotacionados (Foto 4.12a e 4.12b). Nesta área, os indicadores cinemáticos sinistrais estão combinados a intensa fusão parcial, consumo das rochas dioríticas e produção de remobilizados graníticos a tonalíticos, que ocupam os sítios extensionais favorecidos pela cinemática sinistral da ZCSE (Foto 4.12c e 4.12e). Estas feições caracterizam o mecanismo transtracional sinistral da ZCSE sob condições de alta temperatura, provavelmente envolvendo afinamento crustal. 
Foto 4.9 - Aspecto geral do gnaisse diorítico a granodiorítico do embasamento migmatizado e milonitizado na ZCSE apresentando: (a) veios graníticos a tonalíticos intrusivos nos gnaisses do embasamento, acompanhando a foliação $\mathrm{S}_{3} / / \mathrm{C}_{3}$ em sincrônismo à ZCSE, boudinados e em escalonamento sinistral; (b) $\mathrm{L}_{3}{ }_{3}$ com rake moderado e caimento de $45-50^{\circ}$ para $\mathrm{NE}$; (c) dobras $\mathrm{F}_{3}$ sincrônicas à foliação milonítica $\left(\mathrm{S}_{3} / / \mathrm{C}_{3}\right)$ que redobram um fabric prévio $\left(\mathrm{S}_{2}+\mathrm{S}_{1}\right)$, marcado pela alternância entre o gnaisse e diques anfibolíticos provavelmente pré- $\mathrm{D}_{2}$. Afloramento na $Z \mathrm{CSE}$ (35'22'42"W/6⒈'S).

Foto 4.10 - Aspecto em seção vertical do embasamento gnáissico migmatizado na ZCSE, com coleta de material granitico em shear bands sinistrais-extensionais (componente de cisalhamento puro), conjugadas com shear bands sinistrais no plano horizontal. Afloramento na ZCSE (35'30'36"W/613'52"'s).

Foto 4.11 - Aspecto geral do gnaisse granodiorítico do embasamento envolvido pela deformação da ZCSE: (a) que afeta um fabric anterior $\left(\mathrm{S}_{2}+\mathrm{S}_{1}\right)$ e está associada a diques dioriticos; (b) detalhe da foto anterior com coleta de remobilizados graníticos nos boudins sigmoidais dextrais. Afloramento na ZCSE (3524'07'W/6' 15'26"S). 
Foto 4.9a

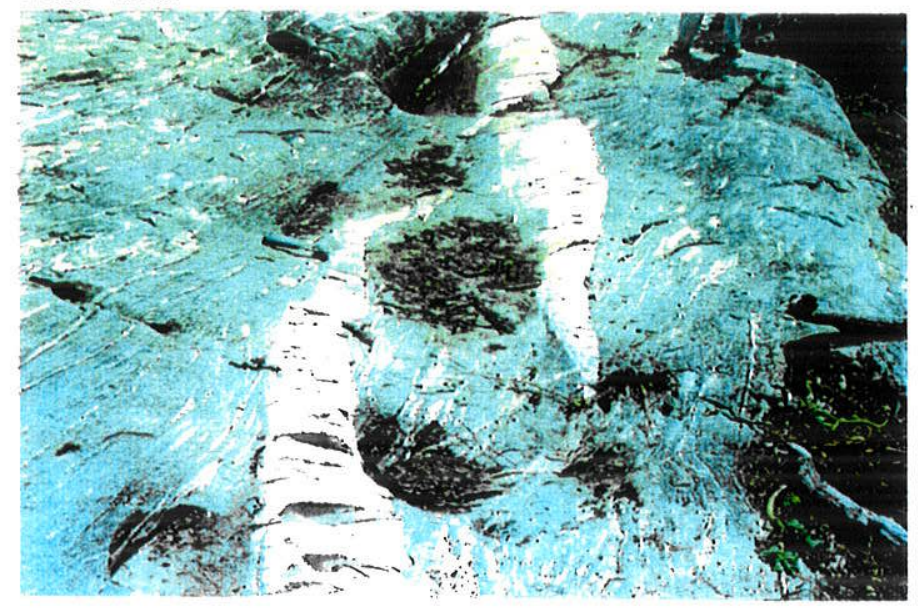

Foto $4.9 \mathrm{c}$

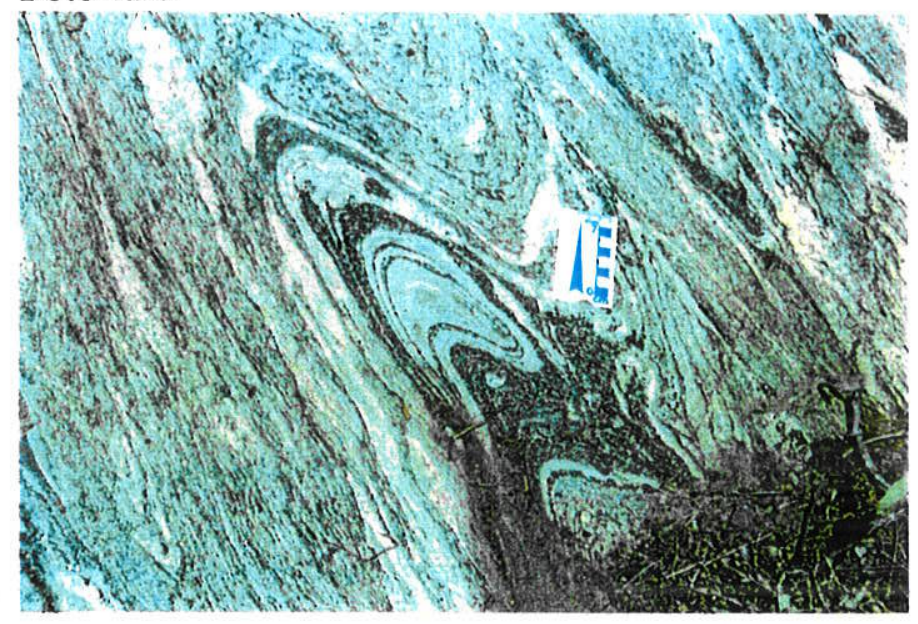

Foto $4.9 \mathrm{~b}$

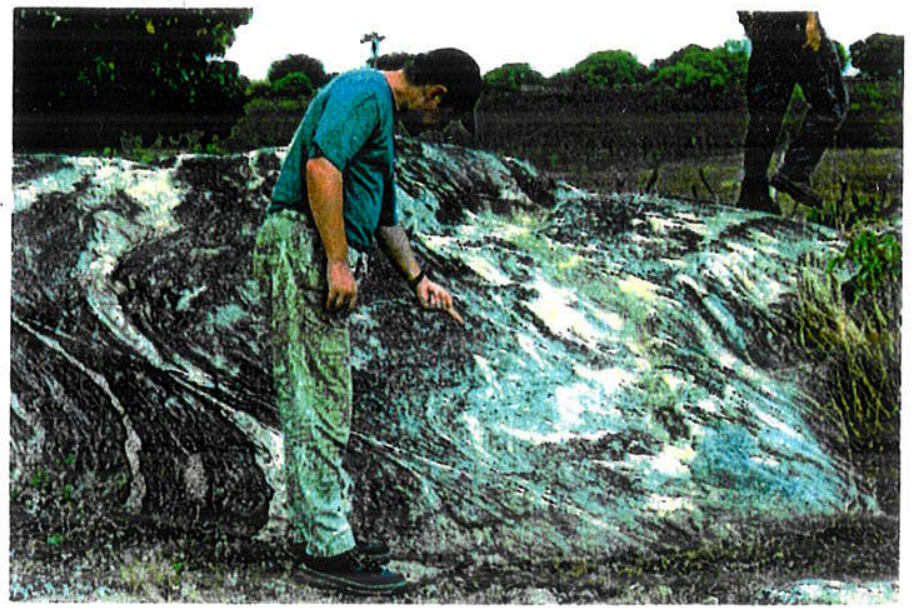

Foto 4.10

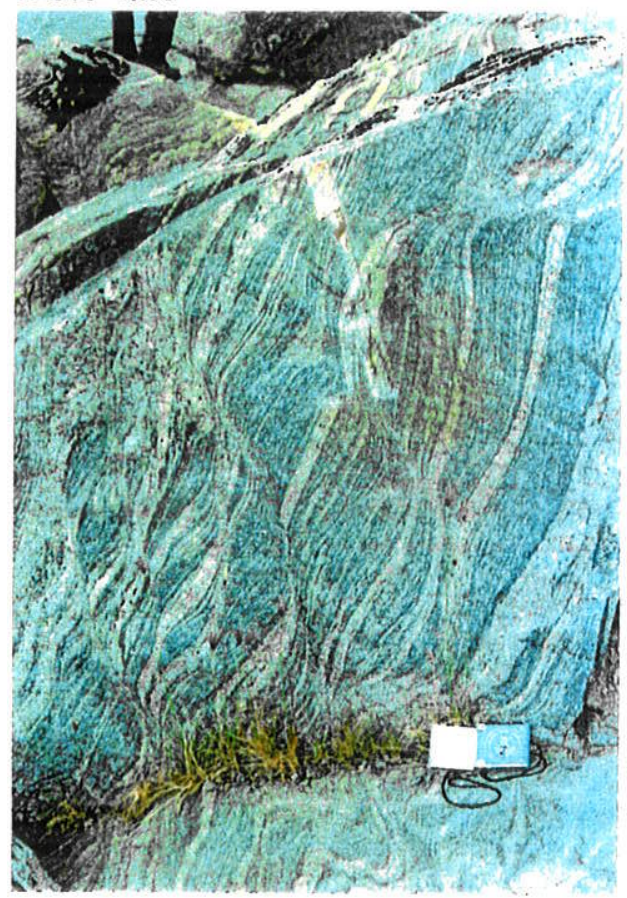

Foto $4.11 \mathrm{~b}$

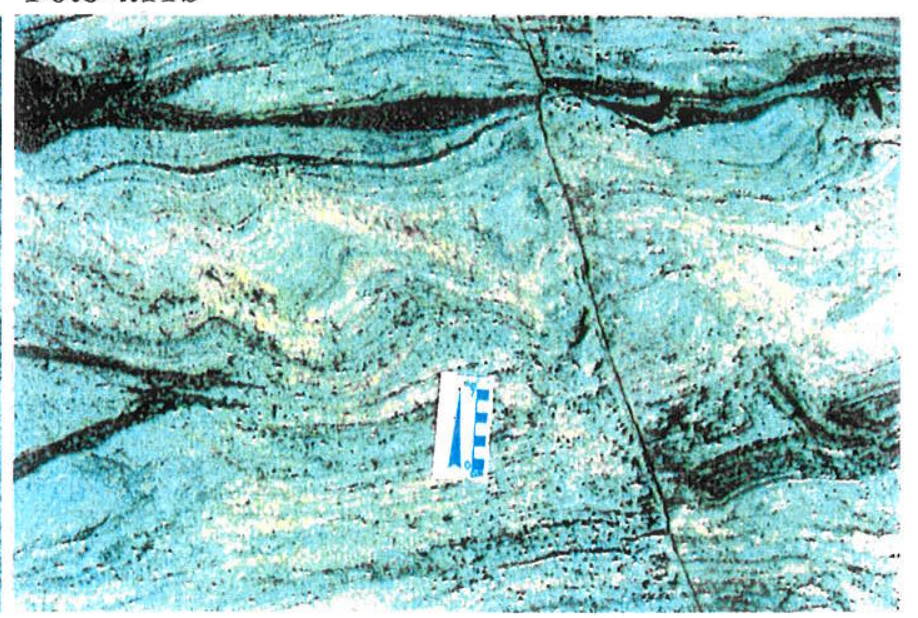

\section{Foto 4.11a}

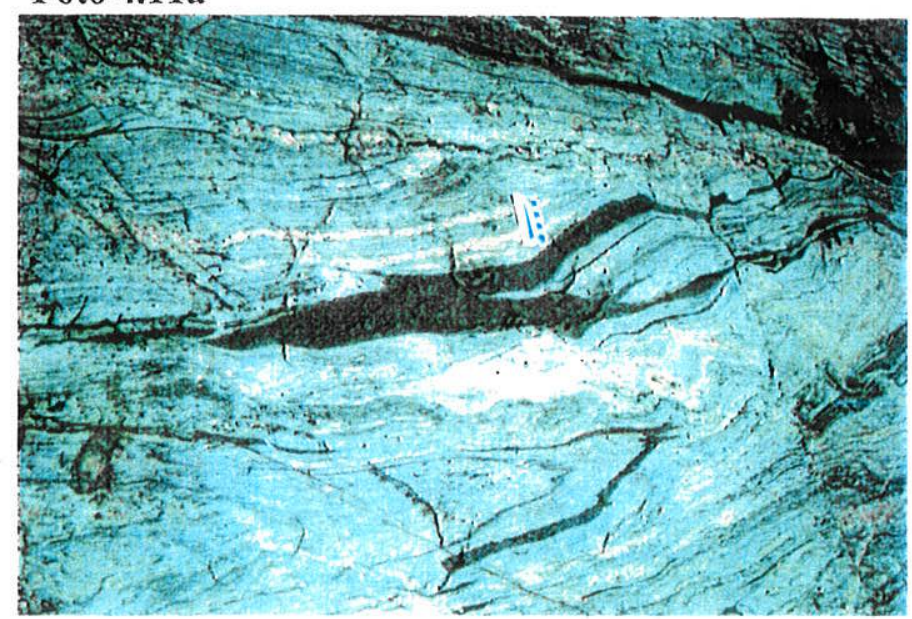



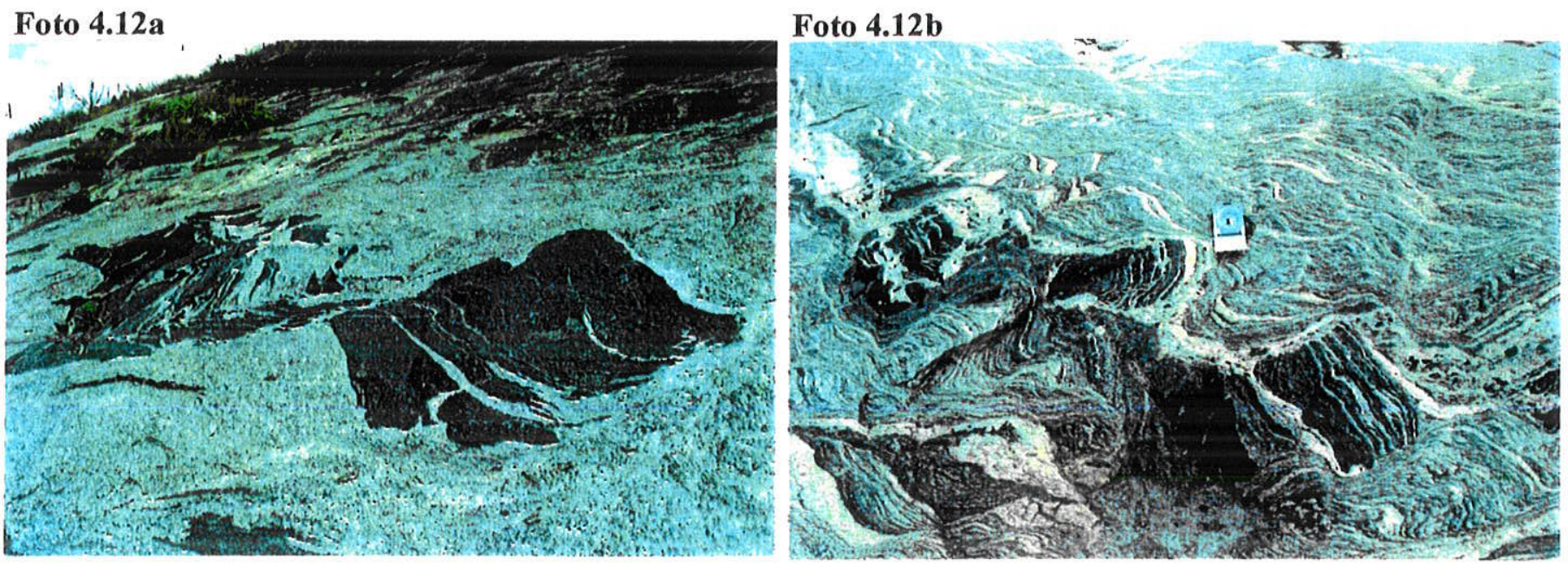

Foto $4.12 \mathrm{c}$

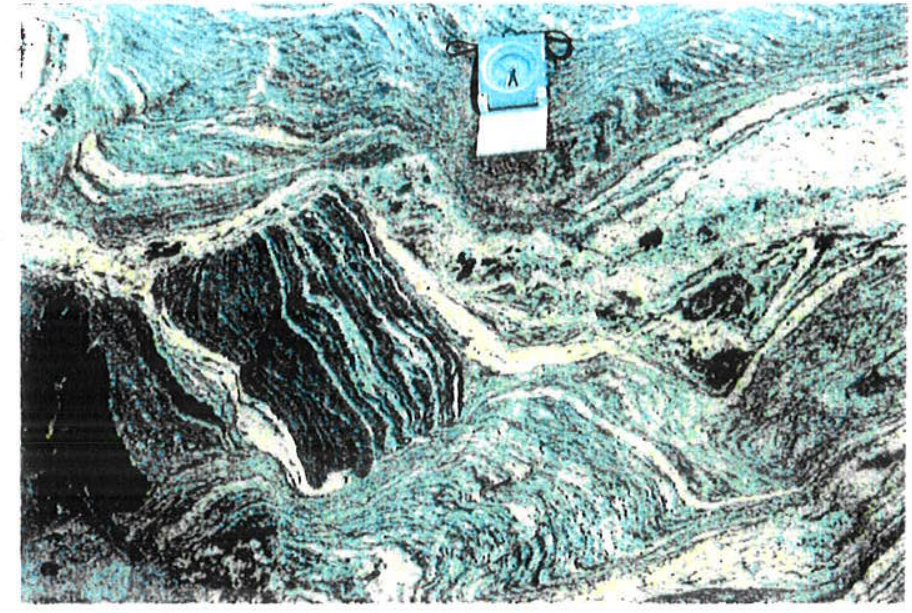

\section{Foto $4.12 d$}

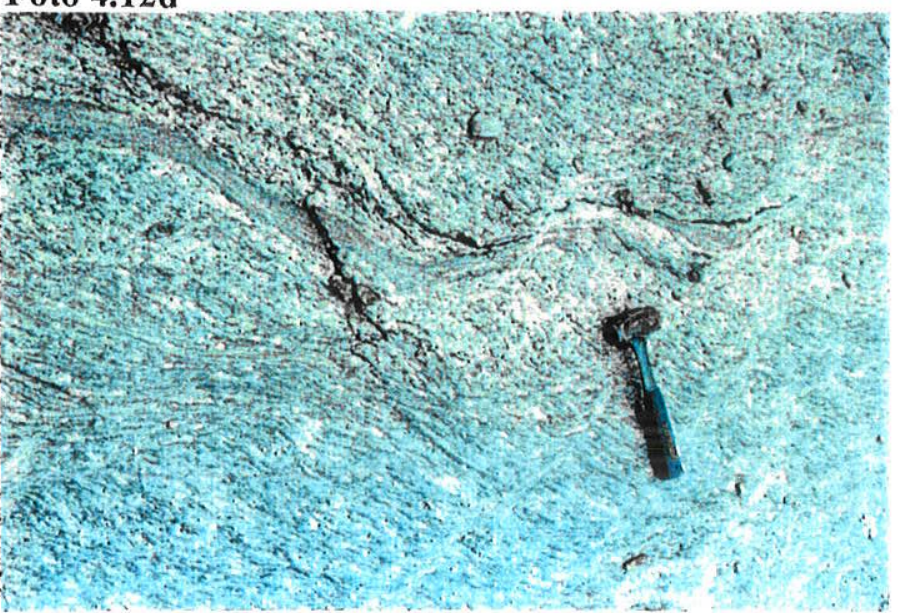

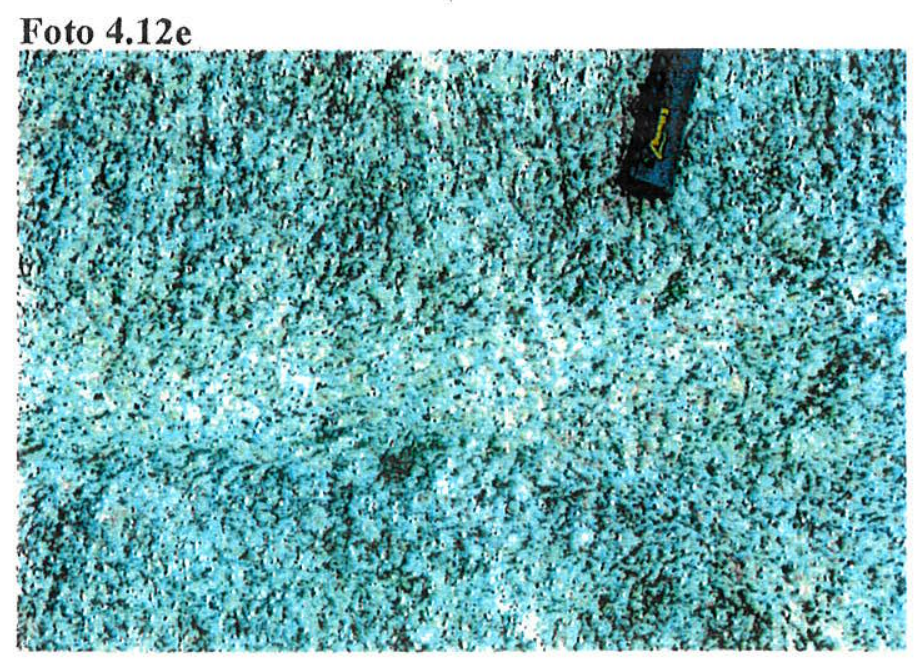

Foto 4.12 - Aspectos do Granitóide Serrinha de composição dominantemente sienogranítica: (a) com enclaves dioríticos deformados por shear bands sinistrais que coletam material de composição granítica e pegmatitos com turmalina; (b) enclaves dioríticos boudinados e rotacionados em cinemática sinistral, com remobilizados graníticos e pegmatíticos em torno e no interior dos boudins, sugerindo a refusão do material diorítico, e nos necks interboudins; (c) detalhe da foto anterior mostrando o material remobilizado de composição granítica e pegmatítica com turmalina e anfibólios, envolvendo os boudins de rocha diorítica, nos necks, nas shear bands e paralelamente à foliação magmática; (d) shear bands sinistrais que interceptam a foliação magmática e coletam remobilizados graníticos, que invadem a foliação magmatica; (e) detalhe da foto anterior mostrando os remobilizados de composição granítica a tonalítica. Afloramento próximo à cidade de Serrinha (35³0'04"W/6 $\left.16^{\prime} 48^{\prime \prime} \mathrm{S}\right)$. 
No limite sudoeste do núcleo arqueano, o contato com os terrenos paleoproterozóicos é definido pela zona de cisalhamento Trairí (ZCT) de trend NW, foliações miloniticas com mergulho suave para SW $\left(30-45^{\circ}\right), \mathrm{L}_{3}{ }_{3}$ com baixo caimento para $\mathrm{SW}\left(15-30^{\circ}\right)$ e critérios (dobras em bainha, assimetria de porfiroclastos e boudins) que indicam caráter sinistral combinado à cinemática topo para cima, com o cavalgamento dos terrenos paleoproterozóicos sobre o núcleo arqueano. Neste setor limitrofe entre o bloco arqueano e o bloco paleoproterozóico, para sudoeste, e a Faixa Seridó, para oeste, ocorre o alojamento do batólito Barcelona, com forma en cornue sintectônica a cinemática dextral da ZCPJC. Da mesma forma, a ZCPJC controla a assimetria en cornue alongada NNE do granito Picui, intrusivo no limite ente os blocos paleoproterozóicos e a Faixa Seridó. Os biotita granitos porfiriticos de composição variando desde monzo- a sienogranitos constituem o fácies dominante nesses batólitos, freqüentemente em relações de coexistência com as suites básico-intermediárias. A principal característica da deformação $D_{3}$ nesses batólitos é a transição do fabric PFC, geralmente nas porções centrais, para as feições do fabric SPD nas bordas, e sobretudo no limite afetado pela ZCPJC, preservando os indícios dos critérios cinemáticos. $\mathrm{O}$ granito Picui mostra um ângulo moderado $\left(50-70^{\circ}\right)$ da foliação $\mathrm{S}_{3}$ mergulhando para ESE, com $\mathrm{L}_{3}{ }_{3}$ subhorizontal de baixo rake, enquanto no granito Barcelona o caimento da foliação $S_{3}$ varia de subvertical a forte $\left(70-85^{\circ}\right)$ para $\mathrm{WNW}$, com $\mathrm{L}_{3}^{\mathrm{X}}$ de forte rake. Estes batólitos acompanham, de sul para norte, a variação no mergulho ao longo da ZCPJC, com manutenção do movimento transcorrente dextral, com componente de transpurrão a partir do setor do granito Barcelona.

Os terrenos paleoproterozóicos estão condicionados pelo sistema de zonas de cisalhamento dextrais de trends NE e EW (ZCPJC, ZCPA, ZCRP e ramificações) e sinistrais de trend NW (ZCT e ZCJ), que imprimem aos blocos as formas sigmoidais, cuja cinemática é reconhecida pelo comportamento assimétrico dos sistemas de lineamentos expressos nas imagens (assimetrias em " $\mathrm{S}$ ", "Z" ou simétricos). Nos MSJC-MCB, o fabric $\mathrm{D}_{2}$ de baixo ângulo e trend geral $\mathrm{NW}$, definido pelo bandamento entre níveis recristalizados de biotitas thornblenda+plagioclásio e remobilizados anatéticos, é bastante penetrativo e preservado. Na região do MSJC ocorrem dobras $\mathrm{F}_{2}$ recumbentes isoclinais com lineações de baixo caimento $\left(10-30^{\circ}\right)$ variável entre SSW e SSE, sugerindo transporte de massa nestes sentidos. As estruturas $\mathrm{D}_{3}$ constituem dobras abertas com trends dos traços axiais entre NW 
e NNE, evoluindo para as dobras fechadas e isoclinais com fabric $\mathrm{D}_{3}$ cerrado nas proximidades das zonas de cisalhamento brasilianas.

A ZCJ possui trend geral NW, com inflexões acompanhando a forma en cornue do plúton de Japi numa terminação em splay para NNE. A foliação $S_{3}-C_{3}$ possui mergulho geral médio a forte $\left(50-80^{\circ}\right)$ para NNE, enquanto $\mathrm{L}_{3}{ }_{3}$ mostra rake baixo a moderado e caimento variável desde baixo (subhorizontal) até médio para NE-SE, que aliada aos critérios cinemáticos ambíguos descrevem uma transcorrência sinistral conjugada à componente extensional (transtração). A suite alcalina constitui a suite principal e mais antiga do plúton de Japi. Nas bordas de contato com o complexo gnáissico-migmatítico, formado neste setor por ortognaisses e augen gnaisses, desenvolve um intenso fabric tipo SPD com mergulhos fortes em direção ao centro do corpo, onde o strain é menos intenso. Nos setores envolvidos pela ZCJ, e zonas miloníticas subordinadas, uma foliação composta $\left(S_{3} / S_{2}+S_{1}\right)$ é retrabalhada pela foliação milonítica $\left(C_{3}\right)$. As relações de contato com as demais suites granitóides são marcadas por feições que definem o posicionamento precoce da suite alcalina, como os freqüentes xenólitos foliados no interior das suites básicointermediária, e o truncamento do fabric SPD por diques e filões destas suites. Na suíte alcalina predominam os sienogranitos, álcali-sienitos e álcali-granitos com $85-95 \%$ de minerais félsicos na moda (plagioclásio + microclina + quartzo), onde piroxênio e anfibólio são as fases máficas dominantes em alguns fácies, enquanto os minerais opacos prevalecem em outros fácies. A suíte básico-intermediária é composta por granodioritos, quartzomonzonitos, monzodioritos e gabro-noritos distribuídos na porção centro-ocidental e na cauda do plúton, com o fabric $\mathrm{D}_{3}$ registrado apenas nas faixas afetadas pela $\mathrm{ZCJ}$, tendendo a isotrópicos a medida que se distanciam das bordas.

A borda NE do granito Monte das Gameleiras é controlada pela zona de cisalhamento da Serra de São Bento (ZCSSB), de cinemática extensional topo para SW definida pelo fabric $\mathrm{D}_{3}$ com mergulhos médios $\left(30-45^{\circ}\right)$ e a assimetria de fenocristais $\mathrm{e}$ enclaves dioriticos (Lima 1997). Na interpretação visual foi definida uma relação de intersecção da ZCSSB sobre os lineamentos de trend NE da ZCSE, que aliado aos dados de campo caracteriza dois estágios progressivos da estruturação $\mathrm{D}_{3}$ : (a) um primeiro (episódio $\mathrm{D}_{3 \mathrm{~A}}$ ) marcado pelo desenvolvimento da ZCSE e intrusão sintectônica de plúton diorítico e granito de Serrinha, e (b) um segundo estágio (episódio $\mathrm{D}_{3 \mathrm{~B}}$ ) de instalação das ZCSSB , e 
das zonas de cisalhamento dextrais de Passa e Fica (ZCPF) e São José do Campestre (ZCSIC) que controlam a intrusão do batólito de Monte das Gameleiras em local transtracional. No batólito de Monte das Gameleiras predominam os granitos porfiríticos de composição monzogranitica, com dioritos a quartzo-dioritos de textura fina a média e granodioritos equigranulares subordinados. No setor central do corpo predomina o fabric $\mathrm{PFC}$, com feições de entelhamento de fenocristais de K-feldspato, textura de fluxo e orientação preferencial de aglomerados de fenocristais e inclusões de natureza variada, enquanto o fabric SPC descreve as bordas milonitizadas, com critérios definidos por fenocristais com sombras de pressão e caudas de recristalização assimétricas, fraturados e rotacionados, enclaves estirados, boudinagem de veios e shear bands. A suite de rochas básico-intermediárias ocorre como enclaves sin-magmáticos em feições de magma mixing $\mathrm{e}$ mingling com os termos porfiriticos. Os granodioritos equigranulares interceptam os granitos porfiríticos e os dioritos, sobretudo nas porções centrais do batólito (Galindo 1984). O arranjo geométrico entre as zonas de cisalhamento dextrais (ZCSJC e ZCPF) e extensional (ZCSSB), e o padrões dos fabrics $\mathrm{D}_{3}$ nas bordas miloníticas sugerem o ambiente de afinamento crustal conduzindo a intrusão do plúton. Jardim de Sá (1994) sugeriu a colocação do batólito no setor transtracional formado pela atuação conjugada das zonas transcorrentes de Japi, sinistral de trend NW, e São José do Campestre, dextral de trend NE, favorecendo uma extensão na direção NS. No entanto, ocorre uma incompatibilidade entre este movimento e a cinemática dextral simultânea das ZCPF e ZCSJC.

No setor sul-sudeste da Fig. 4.1, o esboço anastomosado do sistema de lineamentos descreve o principal aspecto da partição da deformação $D_{3}$ entre a rede de zonas de cisalhamento dextrais de trend NE (ZCPA-ZCRP-ZCCG e ramificações), alternado extensas faixas de rochas miloníticas de alta-T e pods constituidos por granitóides e blocos gnáissicos de menor strain, por largura aproximada de $50 \mathrm{~km}$ em planta. Os mergulhos da foliação milonítica variam de subverticais a moderados $\left(>45^{\circ}\right)$ para $N W$, a $L_{3}$ é subhorizontal acompanhando a inflexão do trend das foliações $\mathrm{S}_{3}-\mathrm{C}_{3}$ ou com rake moderado a forte para SW-NW. Uma característica marcante por todo o sistema é a intensa granitogênese sincinemática, com composições variando de alcali-granitos a monzodioritos, e a migmatização que afeta as rochas envolvidas na milonitização. $O$ processo de fusão parcial sincrônico ao evento $\mathrm{D}_{3}$ é evidente na analogia entre o fabric dos migmatitos e dos 
metapelitos e gnaisses miloníticos, e na colocação dos remobilizados leucocráticos no plano axial de dobras, em shear bands e nos necks dos boudins dos gnaisses miloníticos. Os principais critérios que indicam o predomínio da cinemática dextral são as estruturas $\mathrm{S} / \mathrm{C}$, as figuras assimétricas nos porfiroclastos, veios de quartzo, boudins de granitóides e enclaves máficos. Em diversos setores os indicadores cinemáticos são simétricos e/ou conjugados dextrais e sinistrais, com preponderâncias alternadas, sugerindo um regime de fluxo em cisalhamento geral. Na região de Campina Grande, o caimento moderado a forte da $\mathrm{L}_{3}$, aliado aos critérios de assimetria que indicam movimento de topo para baixo (down dip), sobretudo nos granitóides (Foto 4.22g), indicam uma situação de fluxo conjugado transcorrente-extensional. A caracterização dos ambientes de alojamento dos granitóides sintectônicos brasilianos é freqüentemente indicada pelas formas dos corpos. As formas en cornue (Japi, Areia), ovaladas (Dona Inês, Monte das Gameleiras) e estirados (Algodão, Queimadas), descrevem o arranjo de zonas de cisalhamento em ambientes transcorrenteextensional, extensional e transcorrente, respectivamente.

\section{- Região do Domo de Lagoa D'Anta:}

Na região entre as cidades de Lagoa D'Anta, Serrinha, Santo Antônio do Salto da Onça e Nova Cruz, uma distribuição sistemática e marcante de lineamentos circulares e semi-circulares concêntricos limitados por zonas de cisalhamento transcorrentes $\mathrm{e}$ extensionais brasilianas (ZCSE, ZCSSB, ZCPF, ZCCC e ZCBNC, onde as três últimas correspondem às principais ramificações da ZCRP) compõem uma megaestrutura em forma dômica, denominada informalmente de Domo de Lagoa D'Anta (DLD). Os terrenos compreendem gnaisses bandados tonalíticos a graniticos, augen gnaisses graníticos, ortognaisses homogêneos tonalíticos a granodioriticos e sienograniticos, intensamente migmatizados. O evento Brasiliano foi responsável pelo processo de fusão parcial e pela geometria dômica do fabric principal nos terrenos migmatíticos. O controle da deformação heterogênea $D_{3}$ sobre a migmatização é assinalada pelo extenso acúmulo dos leucossomas graníticos nas estruturas referentes aos fluxos cisalhantes: shear bands e foliações $\mathrm{S}_{3}$ (Foto 4.13a), zonas de cisalhamento extensionais (Foto $4.13 \mathrm{c}$ e $4.13 \mathrm{~d}$ ), necks de boudins de rochas anfibolíticas e gnáissicas e planos axiais de dobras $\mathrm{F}_{3}$ de alto strain (Foto 4.13b). Freqüentemente, a superimposição das estruturas $D_{3}$ afetam o fabric bandado $D_{2}\left(S_{2}+S_{1}\right)$ produzindo diversas figuras de interferência (Foto 4.13e). As informações de campo 
Foto 4.13a - Gnaisses tonalíticos do embasamento afetado pelo fabric $\mathrm{D}_{3}$ sob condições de alta temperatura, que desenvolve shear bands sinistrais que coletam remobilizados graníticos e favorecem o aporte deste material através da foliação. Afloramento no Domo Lagoa D'Anta $\left(35^{\circ} 27^{\prime} 12^{\prime \prime} \mathrm{W} / 6^{\circ} 22^{\prime} 23^{\prime \prime} \mathrm{S}\right)$.

Foto $4.13 \mathrm{~b}$ - Dobras $F_{3}$ isoclinais afetando os gnaisses granodioriticos do embasamento em setor de alto strain, com remobilizados leucocráticos intrusivos no plano axial. Afloramento do embasamento arqueano envolvido pela ZCSE, nas bordas no Domo Lagoa D'Anta $\left(35^{\circ} 24^{\prime} 07^{\prime \prime} \mathrm{W} / 6^{\circ} 15^{\prime} 26^{\prime \prime} \mathrm{S}\right)$.

Foto $4.13 \mathrm{c}$ - Aspecto geral dos gnaisses tonalíticos do embasamento interceptado por zona de cisalhamento dextral que coleta remobilizado de composição granítica. Afloramento no Domo Lagoa D'Anta ( $35^{\circ} 28^{\prime} 35^{\prime \prime} \mathrm{W} / 6^{\circ} 19^{\prime} 13^{\prime \prime} \mathrm{S}$ ).

Foto 4.13d - Detalhe da foto anterior mostrando o material granitico preenchendo a zona de cisalhamento.

Foto 4.13e - Aspecto geral do padrão de interferência coaxial das fases $\mathrm{F}_{3}$ (foliação principal subvertical) e $F_{2}$ (foliação composta $S_{2}+S_{1}$ redobrada) em gnaisses tonalíticos a granodioriticos, redobrando diques anfiboliticos pré- $\mathrm{D}_{2}$, previamente paralelizados aos gnaisses pelo fabric $\mathrm{D}_{2}$. Afloramento no Domo Lagoa $D^{\prime}$ Anta afetado pela ZCBNC, próximo à Nova Cruz ( $\left.35^{\circ} 25^{\prime} 49^{\prime \prime} W / 6^{\circ} 28^{\circ} 03^{\prime \prime}\right)$. 
Foto $4.13 \mathrm{~b}$

Foto 4.13a

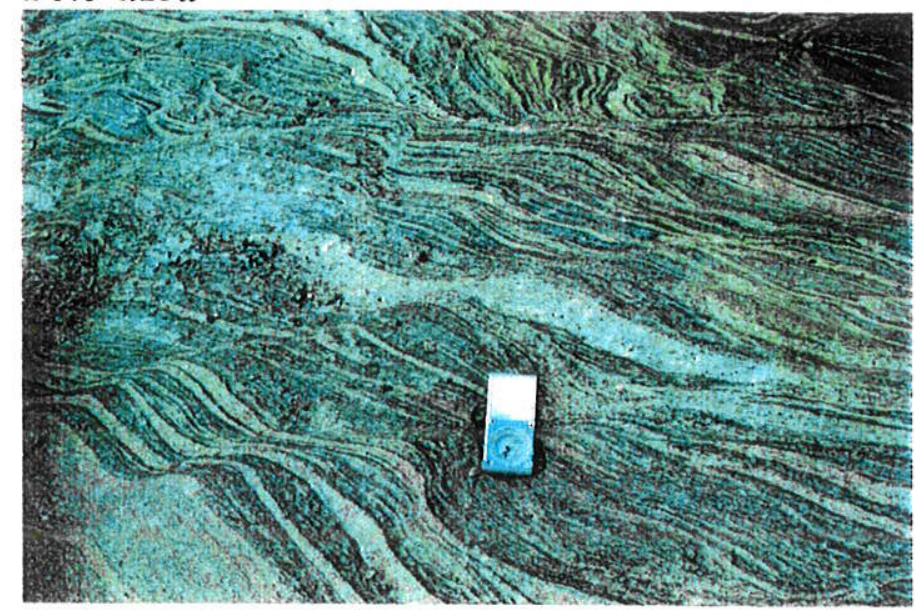

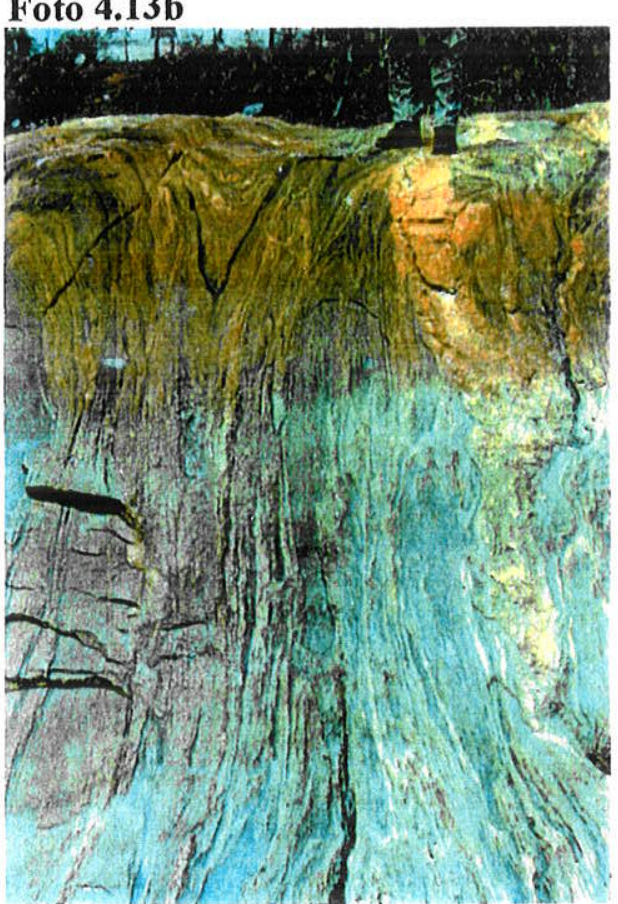

Foto 4.13d
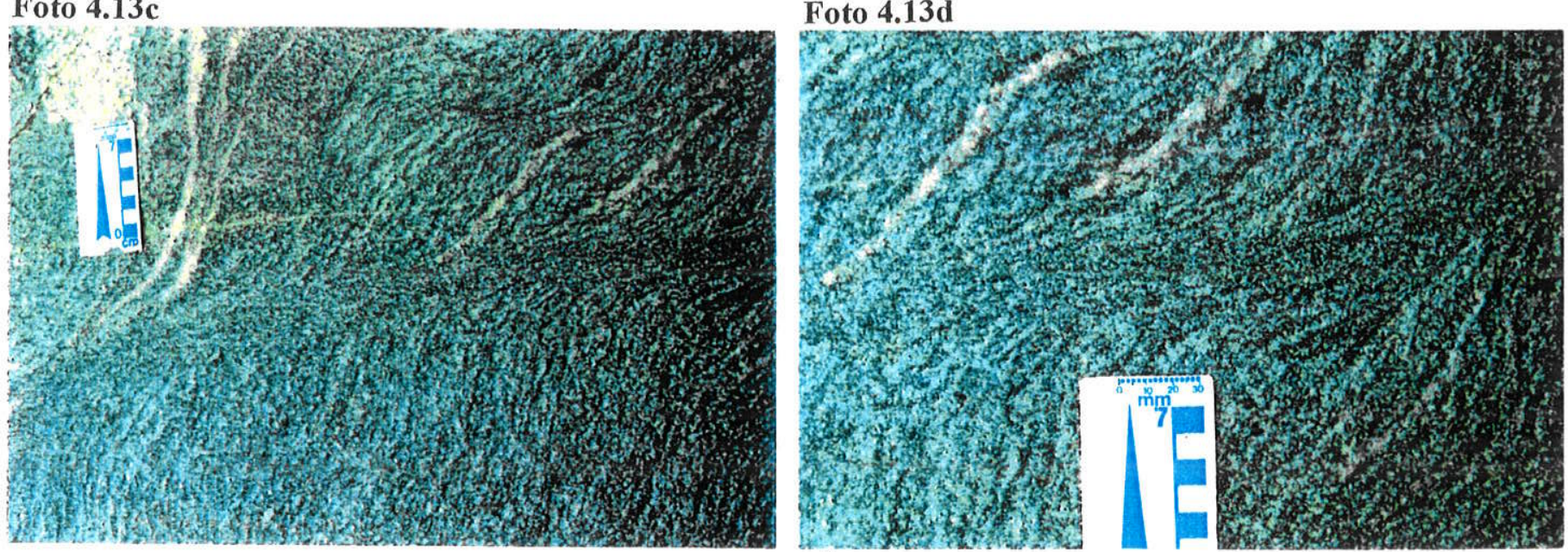

Foto $4.13 \mathrm{e}$

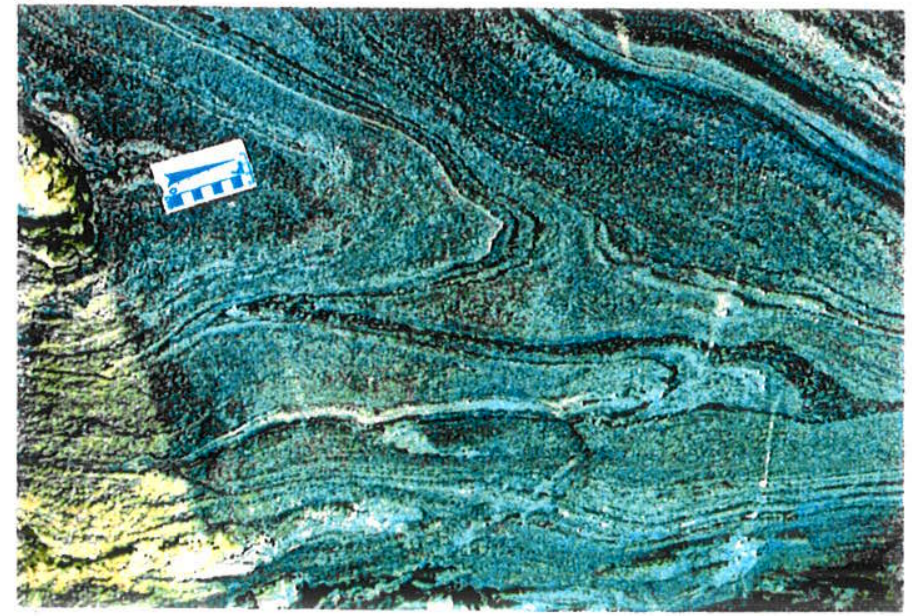


mostram que o fabric principal do domo $\left(\mathrm{S}_{3} / / \mathrm{S}_{2}+\mathrm{S}_{1}\right)$ tende a acompanhar o trend e o sentido de caimento nas proximidades das zonas de cisalhamento $\mathrm{D}_{3}$ de alta-T em suas bordas: a norte segue o trend geral EW com caimento para NNE da ZCSE, para leste o trend NW com mergulhos para SW da ZCSSB, e nos demais setores acompanha o trend NE com mergulhos para NW das ramificaçães da ZCRP (ZCPF, ZCCC e ZCBNC). Esta distribuição do fabric $\mathrm{D}_{3}$, bem expressa pelos lineamentos detectados, ilustra a feição dômica com setores onde ocorre uma gradação progressiva desde rochas gnáissicas bandadas e miloniticas até rochas migmatíticas homogêneas com textura ígnea equigranular a porfiritica, por vezes com xenólitos do protólito gnáissico. A maioria das feições descritas demostram o intenso processo de migmatização a que a região foi submetida durante o evento $D_{3}$. O regime transcorrente-extensional nas zonas de cisalhamento provavelmente favoreceu a mobilização de magmas mantélicos na base de uma crosta extensionada, envolvida em processo de afinamento crustal, com conseqüente aumento no fluxo de calor e canalização de fluidos ao longo das zonas miloníticas.

\section{- Faixa Seridó:}

A área NW do mapa corresponde à porção centro-oriental da Faixa Seridó (região de Caiçara do Rio dos Ventos) caracterizada por estruturas que configuram o regime transpressional dextral (Corsini et al. 1991, Jardim de Sá 1994): relação de baixo ângulo entre as superficies $\mathrm{S}_{3}$ e $\mathrm{C}_{3}$, duplexes transcorrentes-compressionais (transpurrões), estruturas em flor positiva, estruturas dômicas e braquidobras $F_{3}$ com traço axial $\left(S_{3}\right)$ subparalelo às zonas de cisalhamento $\left(\mathrm{C}_{3}\right)$. Os lineamentos descrevem a geometria principal da faixa, traços axiais e padrões de interferência de dobras, foliações de forte mergulho e zonas de cisalhamento, referentes à estruturação do evento $\mathrm{D}_{3}$. Os contatos entre os micaxistos Seridó e o embasamento gnáissico-migmatítico (e ortognaisses $\mathrm{G}_{2}$ ) é feito pelas zonas de cisalhamento dextrais com mergulhos para o interior da faixa: para oeste a ZCLCC, na região da Serra do Feiticeiro, e os transpurrões da ZCSM, e para leste a ZCPJC. A geometria da foliação $S_{3}$ compõe um leque de direção NS a NNE, verticalizada no centro e mergulhando para o interior da faixa nas bordas, acompanhando as zonas de cisalhamento. Os trends das lineações $\mathrm{L}_{3} \mathrm{e} \mathrm{L}^{\mathrm{X}}{ }_{3}$ são oblíquos aos trends NS e NNE das zonas de cisalhamento, com caimentos variando de NE, no setor oeste (ZCSM), a SW na região da 
ZCPJC. A geometria do fabric aliada ao rejeito dextral das zonas de cisalhamento definem uma macroestrutura em flor positiva para esta região.

Os granitóides brasilianos intrusivos na Faixa Seridó foram amplamente empregados como marcadores estruturais e geocronológicos, no detalhamento do regime tectônico dominante no evento $\mathrm{D}_{3}$ (Jardim de Sá 1978, Jardim de Sá et al. 1981). O conceito da assinatura cinemática dos plútons foi introduzida por Jardim de Sá et al. $(1986,1987)$, envolvendo a análise do estilo de fabric (PFC ou SPD), descritos em diferentes escalas (micro- a macroescala), das formas tridimensionais e das formas na seção XZ dos plútons, segundo a prerrogativa para a região da coincidência da seção $\mathrm{XZ}$ com a superfície topográfica (Jardim de Sá et al. 1993b). Estas feições são indispensáveis no reconhecimento do regime de fluxo dominante (viscoso ou plástico) e no estilo deformacional, que aliado às características geoquímicas dos granitóides apresentam indícios sobre os mecanismos deformacionais litosféricos que controlaram a geração das zonas de cisalhamento e a intrusão dos plútons. Uma revisão dos conceitos e referências específicas aos diversos granitóides relacionados à Faixa Seridó podem ser encontradas em Jardim de Sá (1994). No âmbito da Fig. 4.1, que envolve apenas o setor norte-oriental da Faixa Seridó, destacam-se os plútons Totoró e Serra Verde intrusivos exclusivamente nos metapelitos.

Na Faixa Seridó predominam as suites de granitos porfíriticos de composição monzo- a sienogranítica, com abundantes fenocristais de K-feldspato, comumente interagindo em coexistência com as suítes básico-intermediárias, compostas por uma sequência diferenciada desde os termos primitivos gabros e dioritos até os termos quartzo monzonitos e granodioritos mais evoluidos. Na região do plúton Totoró, o granito porfiritico está associado a gabronoritos de textura fina a média e equigranular, com clinopiroxênio (augita ou diopsídio) e hiperstênio, e são comuns os xenólitos de rochas granulíticas. A forma sigmoidal e a disposição do plúton de Totoró em relação à zona milonítica em sua borda oriental indica a intrusão em sítio de encurvamento transtracional (releasing bend) da zona de cisalhamento dextral. No corpo de Serra Verde, predominam os biotita monzogranitos e granodioritos com biotita \pm anfibólio, intrusivos na forma en cornue alongada na direção NNE e com feições características de contemporaneidade à deformação transcorrente-transpressional $\mathrm{D}_{3}$. 


\section{- Faixa de Metapelitos de Taipu-Ielmo Marinho:}

Na porção NE do mapa, a geometria extensional da deformação $D_{3}$ na fatia de micaxistos alóctones "tipo Seridó" de Ielmo Marinho-Taipu é mecanicamente conciliável à estrutura em flor positiva na região de Caiçara do Rio dos Ventos da Faixa Seridó, com base na correlação dos critérios cinemáticos associados às principais estruturas (Fig.4.5). A comparação entre as variações no mergulho das superficies $\mathrm{S}_{3}$ e a orientação NE conspícua das lineações $\mathrm{L}_{3}{ }_{3}$ que afetam a área desde o embasamento próximo à ZCPJC ( $\mathrm{S}_{3}$ mergulhando para SW), passando pela região do embasamento entre Riachuelo e Santa Maria ( $S_{3}$ com mergulhos de baixo ângulo, por vezes zonas de cisalhamentos subverticais) até a região de lelmo Marinho ( $S_{3}$ com mergulhos suaves a moderados para NE), definem a cinemática extensional down dip (topo para $\mathrm{NE}$ ) do fabric $\mathrm{D}_{3}$ (como mostra a seção geológica esquemática da Fig. 4.5), correlato ao regime transpressional dextral da ZCPJC (Jardim de Sá 1994). A mesma cinemática está impressa no fabric dos granitóides brasilianos sintectônicos, cuja forma ovalada é característica de intrusões em zonas de cisalhamentos de regime extensional (Taipu, Pitombeira, Gameleira, Primeira Lagoa, Matão e Nova Descoberta). As rochas miloníticas nas zonas de cisalhamento da fase $D_{3}$ desenvolvem uma foliação milonitica $\left(\mathrm{S}_{3} / / \mathrm{S}_{2}+\mathrm{S}_{0}\right)$ dada pela orientação de biotitas e $L^{\mathrm{X}}{ }_{3}$ definida pelo estiramento de fibrolita, descrevendo condições metamórficas de fácies anfibolito superior. Nestas rochas os marcadores cinemáticos mais comuns são os micafish, porfiroclastos rotacionados tipo- $\sigma$, relações S-C e boudins assimétricos, que sugerem o transporte tangencial para ENE. As dobras $\mathrm{F}_{3}$ apresentam geometria invertida com planos axiais entre EW e NW e caimento suave a moderado $\left(20-60^{\circ}\right)$ para $\mathrm{N}$ e NE. Os padrões de interferência entre as dobras $F_{2}$ e $F_{3}$ são geralmente em laço ou bumerangue (tipos 3 e 2 de Ramsay 1967), com o caimento suave de $\mathrm{L}_{3}{ }_{3}$ consistente para NE. Nos setores de baixo strain $\mathrm{D}_{3}$, as dobras $\mathrm{F}_{3}$ apresentam o acamamento $\left(\mathrm{S}_{0}\right.$, definido pela gradação composicional entre niveis pelíticos e arenosos) com face invertida (downard facing) no flanco normal. Esta feição evidência pelo menos duas fases de deformação (Fig. 4.6): (i) a primeira (evento $\mathrm{D}_{2}$ ) marcada por dobras recumbentes isoclinais responsáveis pela inversão de $\mathrm{S}_{0}$; (ii) a segunda (evento $\mathrm{D}_{3}$ ) resulta nas dobras $\mathrm{F}_{3}$ downward facing pelo redobramento das dobras $\mathrm{F}_{2}$. 


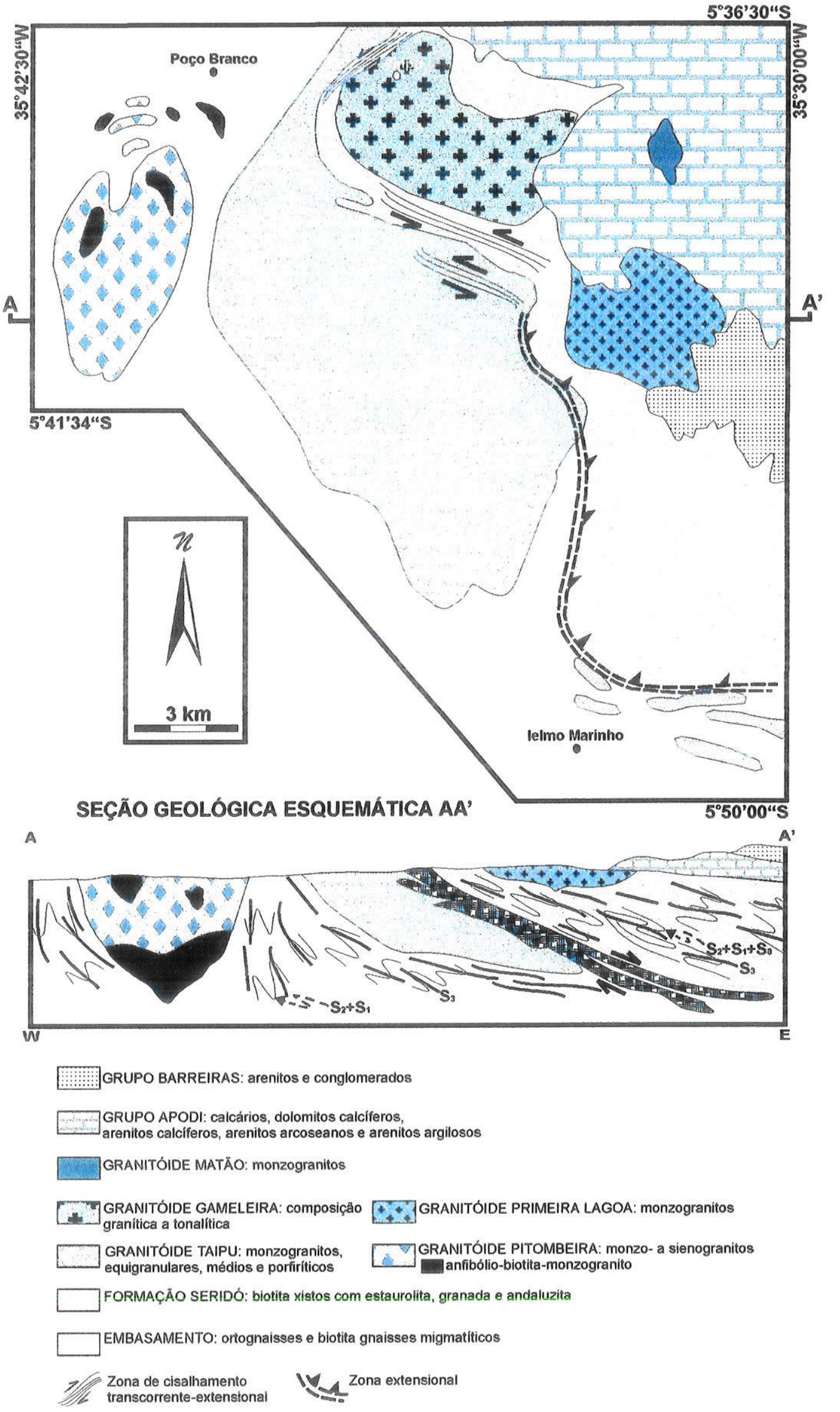

Figura 4.5 - Arcabouço geológico da região entre Taipu e Ielmo Marinho (RN). 
Os plútons granitóides brasilianos são dos tipos sintectônico (Taipu, Pitombeira e Nova Descoberta) e tarditectônicos (Gameleira, Primeira Lagoa e Matão). Os granitóides sintectônicos possuem dominantemente composições de monzo- a sienogranitos equigranulares de textura média a grossa, por vezes com hornblenda, onde as foliações PFC e SPD são subparalelas de baixo ângulo e com caimento para NNE. Nestes corpos predominam as formas ovaladas e sheets, com xenólitos estirados assimétricos dos micaxistos subparalelos à foliação $\mathrm{S}_{3}$ (Foto $4.14 \mathrm{a}$ ), porfiroclastos rotacionados e enclaves máficos estirados que indicam cinemática dextral e/ou topo para baixo (Foto 4.14b). $\mathrm{O}$ plúton Pitombeira mostra feições de stockwork entre rochas dioríticas e os fácies monzo- a sienograniticos, e enclaves de rochas gabróicas com textura cumulática e foliadas (Foto $\mathrm{PFC} / \mathrm{SPD}, 4.14 \mathrm{c}$ e 4.14d). A combinação dessas feições nos granitóides com os critérios cinemáticos nos micaxistos indica o movimento tangencial extensional (down dip) das estruturas $\mathrm{D}_{3}$, com o retralhamento do fabric $\mathrm{D}_{2}$, relacionados a um mecanismo de afinamento crustal. Os granitóides tarditectônicos têm composições tonalítica a granodioritica e monzogranítica equigranulares, onde predomina a foliação PFC, com a foliação SPD sutil e apenas nas bordas dos plútons.

Os principais critérios empregados na distinção entre os eventos $D_{2}$ e $D_{3}$ são: (i) a correlação entre o fabric $\mathrm{D}_{3}$ e indicadores cinemáticos presentes nos granitóides brasilianos $\left(\mathrm{G}_{3}\right)$ com o fabric descrito nos micaxistos; (ii) a correspondência entre os elementos do fabric e o regime metamórfico (condições PT); (iii) a comparação entre os critérios cinemáticos no embasamento e nos micaxistos. Os augen gnaisses $\mathrm{G}_{2}$ intrusivos no embasamento preservam critérios assimétricos indicando movimento tangencial para SW, enquanto nos micaxistos e plútons sintectônicos a $D_{3}$ o transporte tangencial das estruturas é para E e NE.

O posicionamento alóctone desta fatia de micaxistos é sugerido pelo contato milonítico de baixo ângulo para NE com os ortognaisses do embasamento, onde as faixas de paragnaisses e mármores, que ocorrem sotopostas aos micaxistos na Faixa Seridó, são restritas e condicionadas às zonas de cisalhamento $D_{3}$. Desta forma, a idade do posicionamento poderia ser atribuida ao evento $\mathrm{D}_{3}$, opção favorecida pela intrusão sincinemática de granitóides brasilianos. No entanto, a geometria recumbente e invertida das 
Figura 4.6 - Relações mesoscópicas entre as fases de dobramentos $F_{3}$ e $F_{2}$ em zonas de deformação tangencial onde as dobras $F_{3}$ mostram geometria invertida e afetam $S_{2}$ e $S_{0}$ : o dobramento $\mathrm{F} 2$ promove a inversão prévia do acamamento em alguns setores, resultando em dobras F3 "downward facing". O esboço apresenta os critérios cinemáticos na face paralela a $\mathrm{L}_{3}{ }_{3}$ e o baixo ângulo de $S_{3}$, baseados na região a norte de Ielmo Marinho. A seta de ponta preta indica o sentido normal do acamamento, identificado nos estratos por niveis claros (quartzosos) na base escuros (micáceos) no topo. Modificado de Jardim de Sá (1994).

Foto 4.14a - Xenólitos de micaxistos parcialmente fundidos, à base de biotita + quartzo + Kfeldspato, e estirados subparalelos à foliação $S_{3}$ no granitóide Taipu. No interior do xenólito notase a foliação composta $S_{2}+S_{0}$ redobrada pelo fabric $D_{3}$ e os agregados quartzo-feldspáticos formando dobras assimétricas e sigmóides dextrais. Afloramento próximo a Taipu $\left(35^{\circ} 35^{\prime} 26^{\prime \prime} \mathrm{W} / 5^{\circ} 41^{\prime} 39^{\prime \prime} \mathrm{S}\right)$.

Foto 4.14b - Enclave máfico sigmoidal dextral e pegmatitos tardi- $\mathrm{D}_{3}$ dobrados, indicando intrusão no plano $\mathrm{YZ}$ da elipsóide de strain, em setor de alto strain no anfibólio granodiorio sintectônico ao fabric $\mathrm{D}_{3}$ em regime de cisalhamento geral. Afloramento próximo à pedreira de

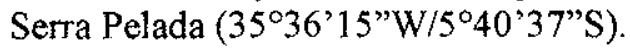

Foto 4.14c - Enclaves magmáticos angulosos de dioritos e gabros imersos em rocha leucogranítica. Os contatos abruptos com finas bordas de reação indicam a cristalização prévia das rochas máficas (base da crosta?) anterior à invasão do leucogranito. Afloramento nas

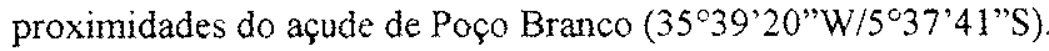

Foto 4.14d - Enclaves gabróicos de textura inequigranular média a dois piroxênios, mostrando um fabric PFC dominante, por vezes uma concentração estratiforme dos minerais máficos que sugere aspecto de textura cumulática. Foto de detalhe no afloramento anterior. 


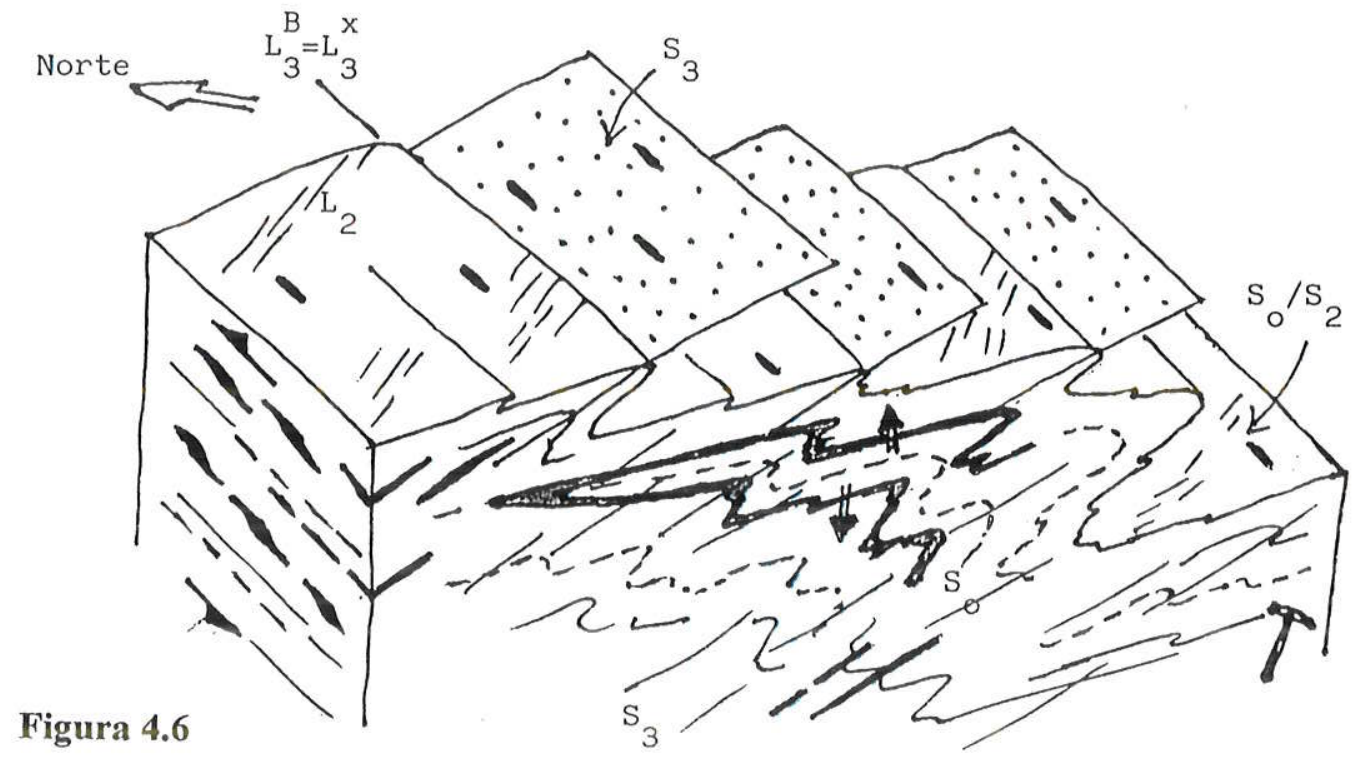

Foto $4.14 \mathrm{a}$

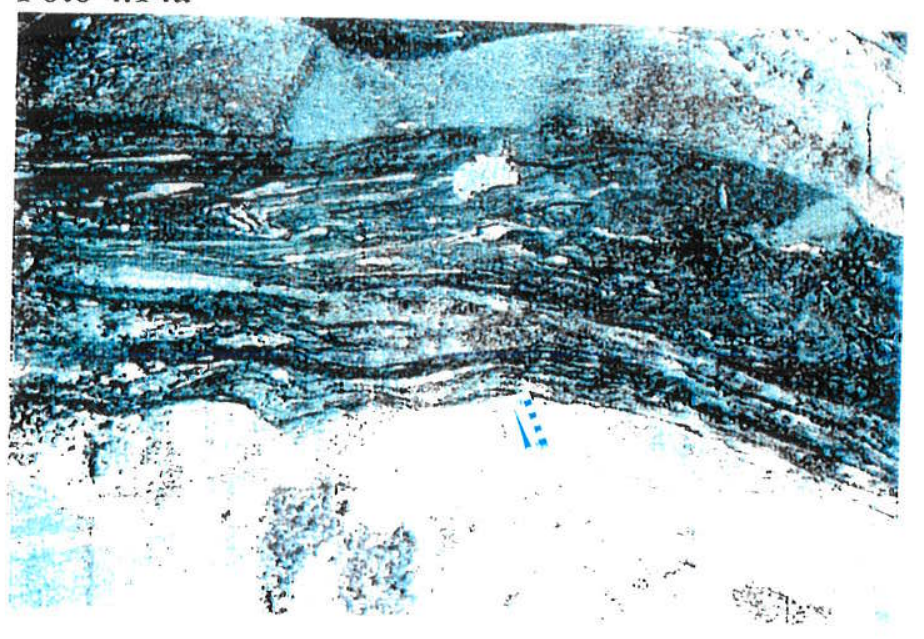

Foto $4.14 \mathrm{~b}$

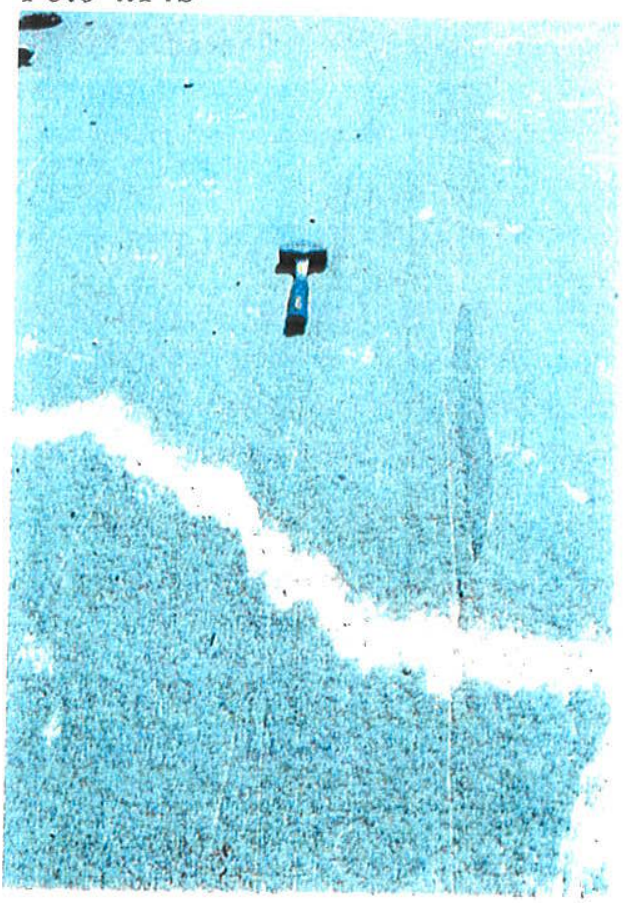

Foto $4.14 \mathrm{c}$
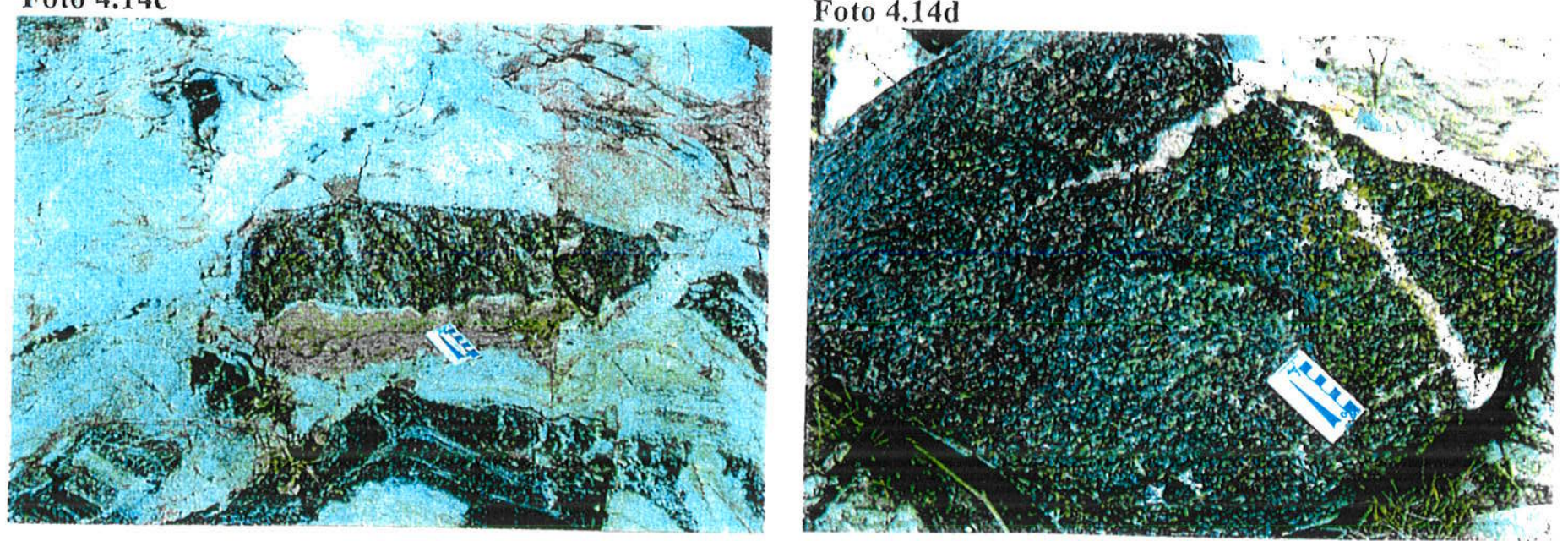
dobras $F_{2}$ sugere a atuação de empurrões que poderiam ser os responsáveis pela colocação alóctone dos micaxistos, com subseqüente retrabalhamento pelo evento $D_{3}$.

Jardim de Sá (1994) sugeriu a compatibilidade mecânica entre esta faixa de micaxistos e a porção central da Faixa Seridó, baseado na consistência dos critérios cinemáticos e dos fabrics, com caimentos para W e SW na Faixa Seridó, e para E e NE em Ielmo Marinho-Taipu. Neste caso, o movimento tangencial com escape NE em lelmo Marinho-Taipu estaria enraizado na ZCPJC, compondo uma estrutura em flor positiva, onde a denudação tectônica na Faixa Seridó estaria acomodada pelo alívio gravitacional em Ielmo Marinho-Taipu. Outra hipótese, correlaciona a fatia de micaxistos tangencial com zonas de cisalhamento extensionais de trend $\mathrm{NW}$, comuns na área mapeada, constituindo um ambiente transtracional formado na junção entre a ZCPJC e uma zona de trend EW em offshore sugerida por dados geofisicos (Fortes 1986, 1988).

\section{- Faixa de Metapelitos de Barra de Santa Rosa:}

A porção sudoeste do mapa mostra a ZCRP associada em regime transtracional à faixa de micaxistos alóctones de Barra de Santa Rosa numa megaestrutura em semi-flor negativa. A faixa de micaxistos está em contato milonitico com o gnaisses do embasamento e exibe superficies $S_{3}$ de baixo ângulo $\left(25-45^{\circ}\right)$ mergulhando para $S$ e $S E$, progressivamente verticalizadas em direção à ZCRP, como ilustram o mapa e as seções geológicas esquemáticas da Fig. 4.7. Um aumento no strain $\mathrm{D}_{3}$ de $\mathrm{NW}$ para $\mathrm{SE}$, relacionado à verticalização das estruturas em direção à ZCRP (Fig. 4.8), acompanha o aumento no metamorfismo $\mathrm{M}_{3}$ desde o fácies anfibolito baixo ("Zona da Granada") até o fácies granulito ("Zona Superior da Sillimanita") com extensiva migmatização (ver Cap. 6), que afeta os micaxistos e os ortognaisses do embasamento. $O$ caimento moderado da foliação $S_{3}$ afeta desde a ZCPJC na região de Picui/RN, onde a deformação PFC do granitóide Picuí descreve uma cinemática dextral-topo para sul, passa pelo bloco paleoproterozóico, com poucas zonas de cisalhamento subverticalizadas, e persiste até a região da faixa de micaxistos de Barra de Santa Rosa (Fig. 4.8).

$\mathrm{Na}$ área que envolve o bloco gnássico paleoproterozóico e a faixa de micaxistos de Barra de Santa Rosa, o fabric $\mathrm{D}_{2}$ é penetrativo e marcado por dobras recumbentes fechadas e isoclinais, com assembléia paragenética do fácies anfibolito alto. $O$ estilo do dobramento $F_{2}$ é inferido nos micaxistos, em setores com baixa penetratividade de $D_{3}$, pela 


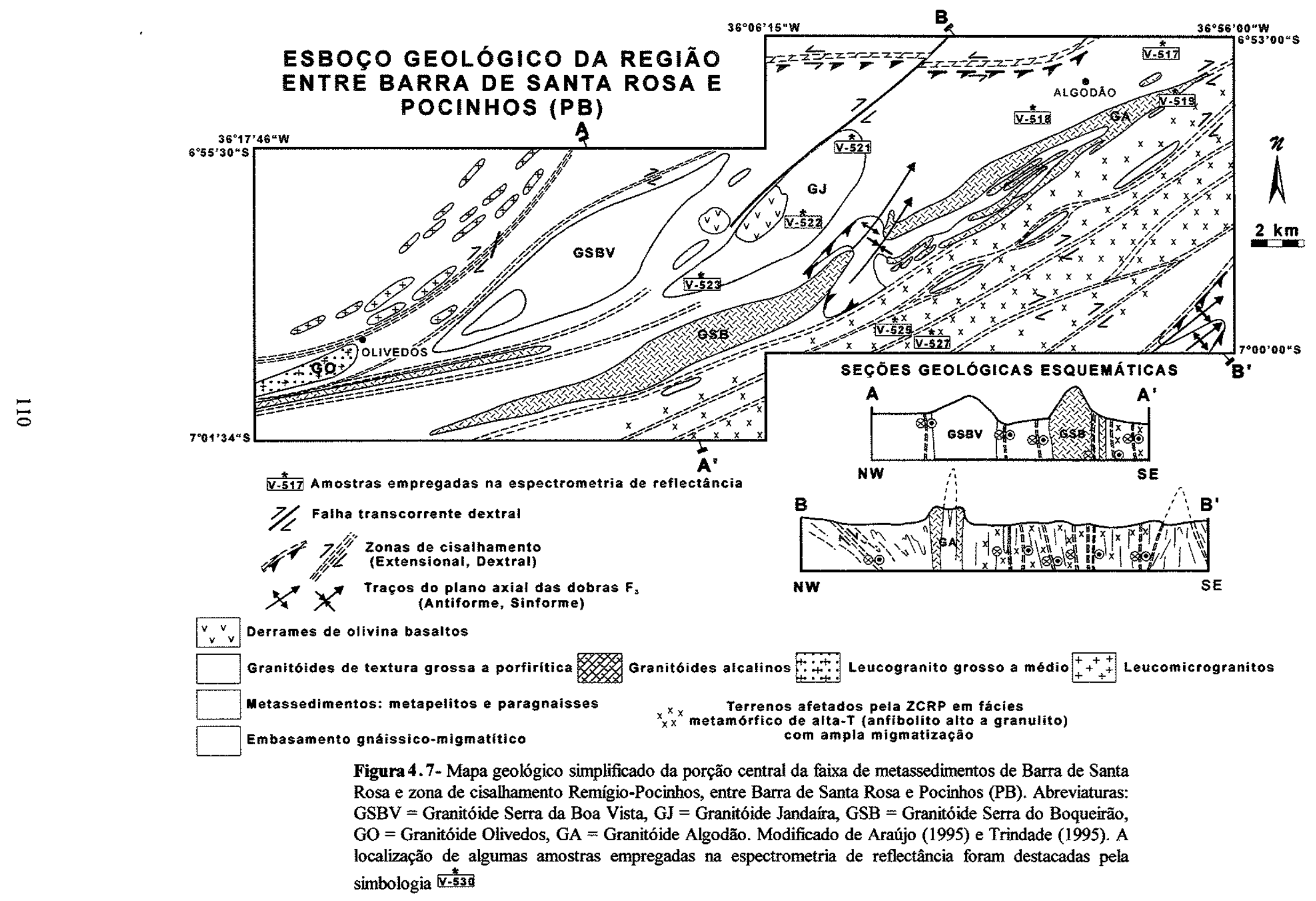


inversão da polaridade de $S_{0}$ e pela incongruidade na assimetria de minidobras parasiticas nos flancos de dobras $F_{3}$. Entretanto, é comum o processo de retrabalhamento da foliação tangencial $S_{2}$ durante o evento $D_{3}$, gerando estruturas com foliação composta $S_{2}+S_{3}$ de trend geral NE. Este processo é freqüente nas proximidades dos contatos miloníticos subhorizontalizados dos micaxistos com o embasamento, onde as foliações $S_{2} / C_{2}$ são retomadas pelo desenvolvimento de $\mathrm{S}_{3} / \mathrm{C}_{3}$ (Foto $4.13 \mathrm{~b}$ ). Nessas zonas de cisalhamento de baixo ângulo, dispostas na porção central e na borda ocidental da faixa de micaxistos, o movimento transcorrente-extensional para S-SW, sob condiçð̃es de alta-T/baixa-P é evidenciada por indicadores cinemáticos como: os porfiroblastos rotacionados de cordierita, as assimetria de dobras e os boudins $\mathrm{S}-\mathrm{C}$ de veios de quartzo e leucogranitos. Na borda norte e oriental da faixa, a foliação $S_{3}$ possui caimento forte e alternado, ora para WSW, ora para ENE, e o movimento é sinistral, marcado nos indicadores cinemáticos dos micaxistos e no granito Caxexa, provavelmente integrado à $\mathrm{ZCJ}$ para noroeste. As lineações $\mathrm{L}_{3}{ }_{3}$ são definidas por sillimanita ou agregados de biotita+quartzo recristalizados, com geometria variando gradualmente desde o alto rake e caimento entre $15-45^{\circ}$ para $\mathrm{SSW}$, na porção centro-ocidental da faixa, até baixo rake subhorizontalizada $\left(<15^{\circ}\right)$ no interior da ZCRP (Foto 4.15). $O$ estilo dos dobramentos $F_{3}$, afetando as superficies $S_{2}\left( \pm S_{0}, S_{1}\right)$, varia desde formas fechadas a apertadas, com pequeno ângulo entre $S_{3}$ e o fabric $D_{2}$ nas porções menos deformadas (Foto 4.16a), até dobras em bainha e isoclinais com eixos subparalelos à $\mathrm{L}_{3}^{\mathrm{X}} \mathrm{e}$ transposição do fabric $D_{2}$ por $S_{3}\left(S_{3} / / S_{2} / / S_{0}\right)$ nas faixas miloniticas (Foto $4.16 b$ ). Nos micaxistos, o padrão de interferência mais comum entre os dobramentos $F_{2}$ e $F_{3}$ é do tipo laço (tipo 3 de Ramsay 1967).

$\mathrm{Na}$ ZCRP, a partição do strain $\mathrm{D}_{3}$ gera blocos anastomosados ("cavalos"), compostos por fatias de micaxistos e ortognaisses sigmoidais alóctones, bordejados por faixas miloníticas transcorrentes com larguras variando de decamétricas a quilométricas. Os critérios cinemáticos indicam movimentação dominantemente dextral, registrados nos porfiroblastos rotacionados tipos $\sigma$ e $\delta$ (Foto 4.17), superficies S-C e C' (Foto 4.18), dobras assimétricas veios de quartzo e neossomas boudinados sigmoidais (Foto 4.19),. Para sudoeste, o fabric $\mathrm{D}_{3}$ e as estruturas de trend NE da ZCRP defletem gradativamente para EW, integrando ao Lineamento Patos. Em sua continuidade para NE, a ZCRP apresenta uma repartição em splay do strain heterogêneo, constituindo as zonas de cisalhamento de Passa e 
Foto 4.15 - Veio de quartzo $\sin -\mathrm{D}_{3}$ em micaxistos miloníticos de alta temperatura mostrando a lineaçâo de estiramento $L^{x}{ }_{3}$ dada por sillimanita + granada + quartzo como agregados recristalizados. Afloramento em zona de cisalhamento no contato entre a Faixa de Micaxistos de Barra de Santa Rosa e o embasamento (35 $58^{\prime} 08^{\prime \prime W} / 6^{\circ} 50^{\prime} 17^{\prime \prime} S$ ).

Foto 4.16a - Aspecto geral dos micaxistos onde se observa o paralelismo entre $S_{2}$ e $S_{0}$, este fabric composto $\mathrm{S}_{2}+\mathrm{S}_{0}$ definido pela intercalação entre os estratos claros (quartzosos) e escuros (micáceos + calciossilicáticas) e truncado pelo fabric $\mathrm{D}_{3}$ que desenvolve veios de quartzo escalonados em cinemática dextral. A mão do Prof. Jardim de Sá, no canto direito da foto, indica o sentido do caimento da $\mathrm{L}_{3}{ }_{3}$. Afloramento na Faixa de Micaxistos de Barra de Santa Rosa próximo ao açude de Algodão ( $36^{\circ} 00^{\prime} 02^{\prime \prime} \mathrm{W} / 6^{\circ} 54^{\prime} 08^{\prime \prime} \mathrm{S}$ ).

Foto 4.16b - Aspecto geral dos micaxistos envolvidos em zona de cisalhamento $\mathrm{D}_{3}$ sob condições da "Zona da Sillimanita", onde ocorre a transposição do fabric $\mathrm{D}_{2}$ pelo fabric $\mathrm{D}_{3}$ gerando o paralelismo de $\mathrm{S}_{3} / / \mathrm{S}_{2} / / \mathrm{S}_{0}$, com boudinagem sigmoidal dextral dos veios de quartzo. Afloramento a algumas dezenas de metros do afloramento da foto anterior.

Foto 4.17 - Porfiroclasto rotacionado dextral de K-feldspato com cauda de recristalização do tipo$\delta$ em micaxistos migmatizados e ultramilonitizados na ZCRP. Os micaxistos apresentam retrometamorfismo no fácies xisto verde. Afloramento na Faixa de Metassedimentos de Barra de Santa Rosa (36 $\left.14^{\prime} 48^{\prime \prime} \mathrm{W} / 7^{\circ} 00^{\prime} 16^{\prime \prime} \mathrm{S}\right)$.

Figura 4.8 - Relaçôes mesoscópicas das variações na geometria das dobras da fase $F_{3}$, num perfil a sudeste de Barra de Santa Rosa e noroeste de Remígio, mostrando a disposição em leque da foliação $S_{3}$ com verticalização progressiva em direção à ZCRP. A foliação $S_{3}$ afeta as dobras $F_{2}$, que provocaram a inversão prévia dos estratos $\left(\mathrm{S}_{0}\right)$, acompanhada de granitóides brasilianos. A identificação do fabric nos granitóides brasilianos favorece a caracterização dos elementos estruturais da fase deformacional $D_{3}$ na região. Modificado de Jardim de Sá (1994). 


\section{Foto 4.15}

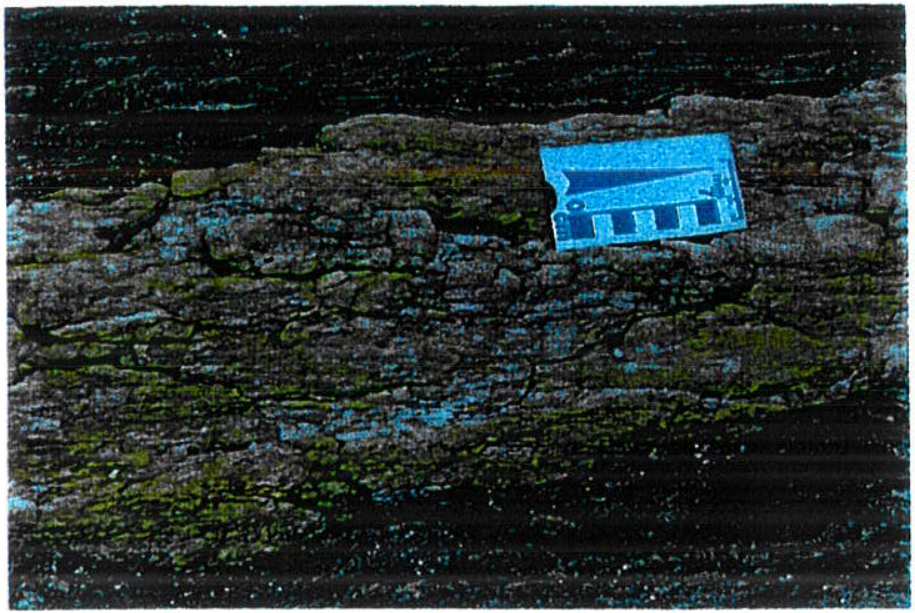

Foto $4.16 \mathrm{~b}$

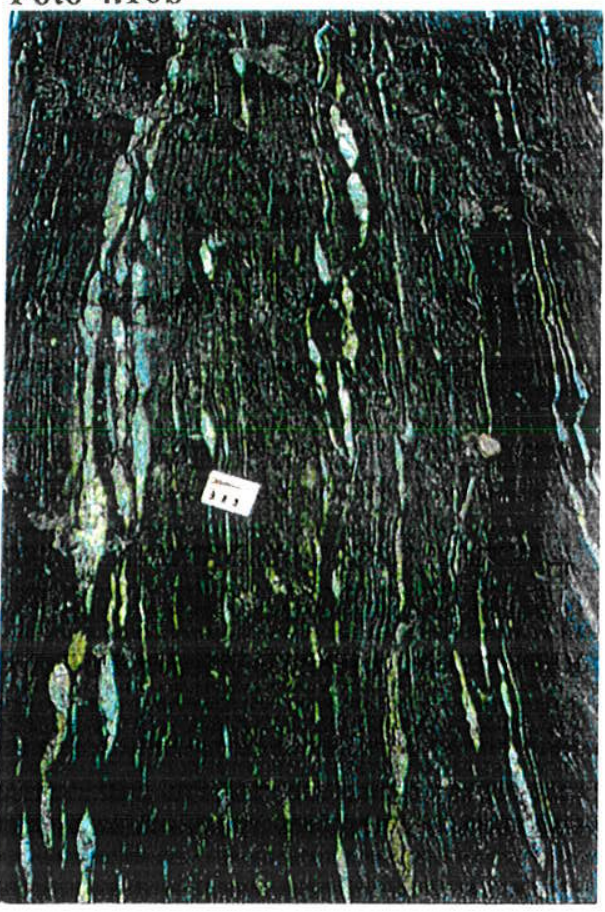

\section{Foto $4.16 \mathrm{a}$}

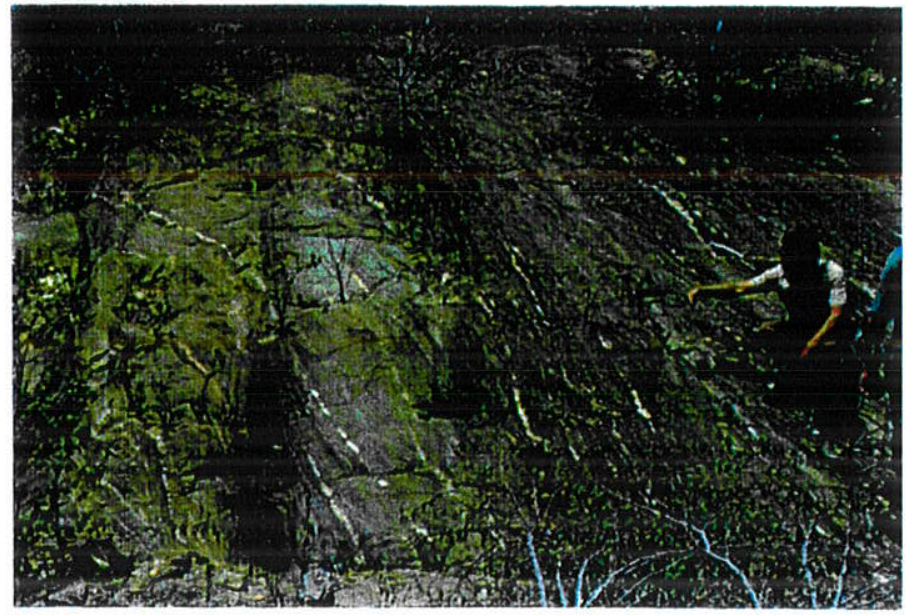

Foto 4.17

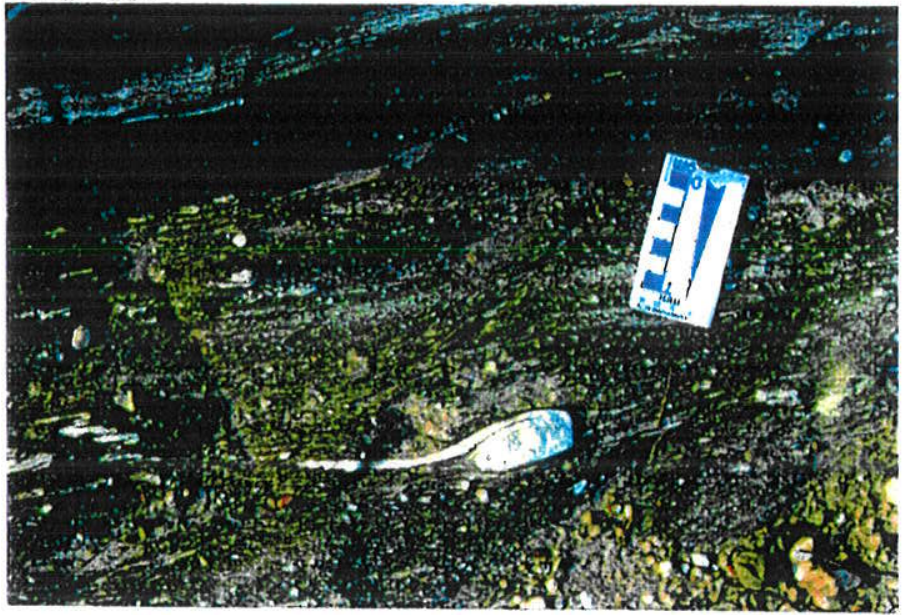

Figura 4.8

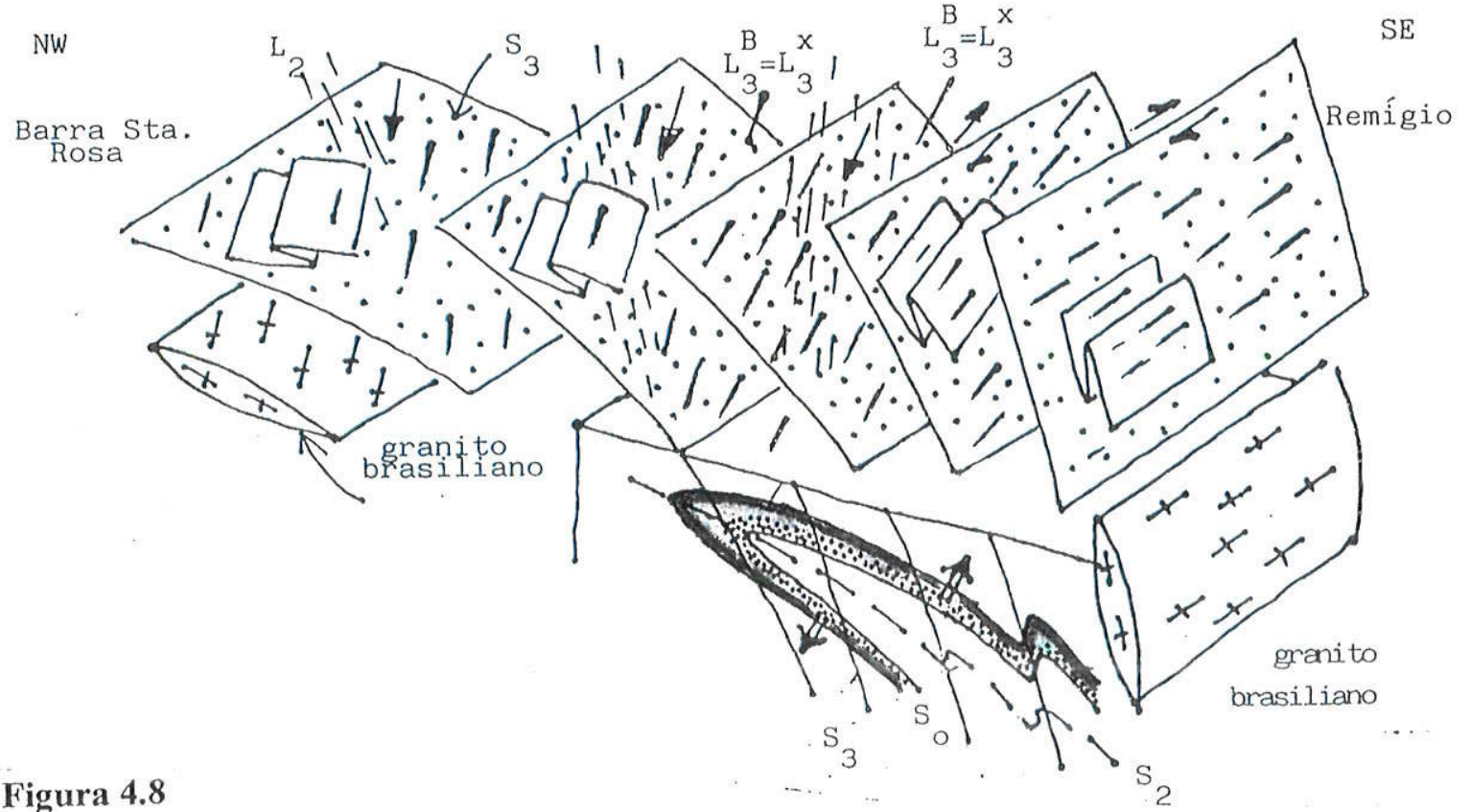


Foto 4.18

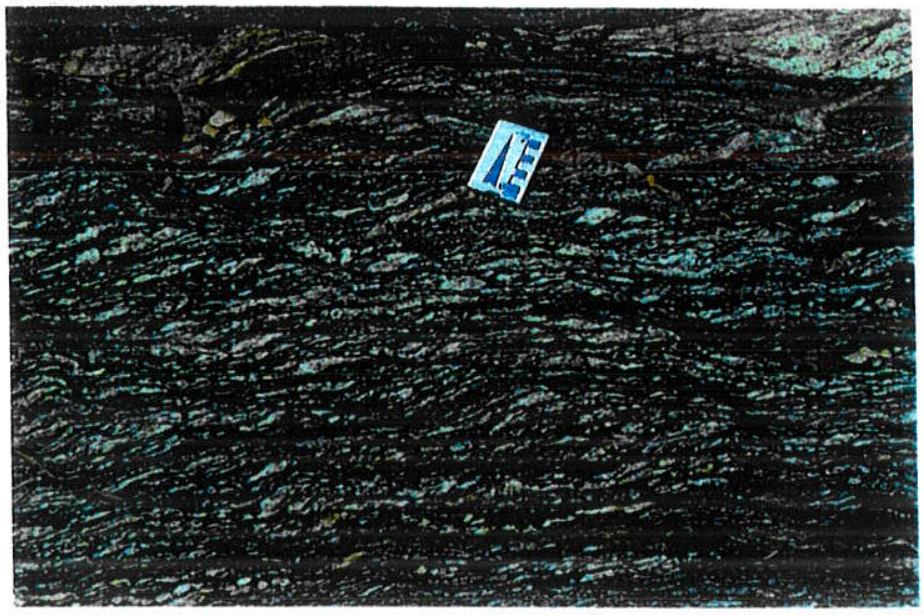

Foto 4.20

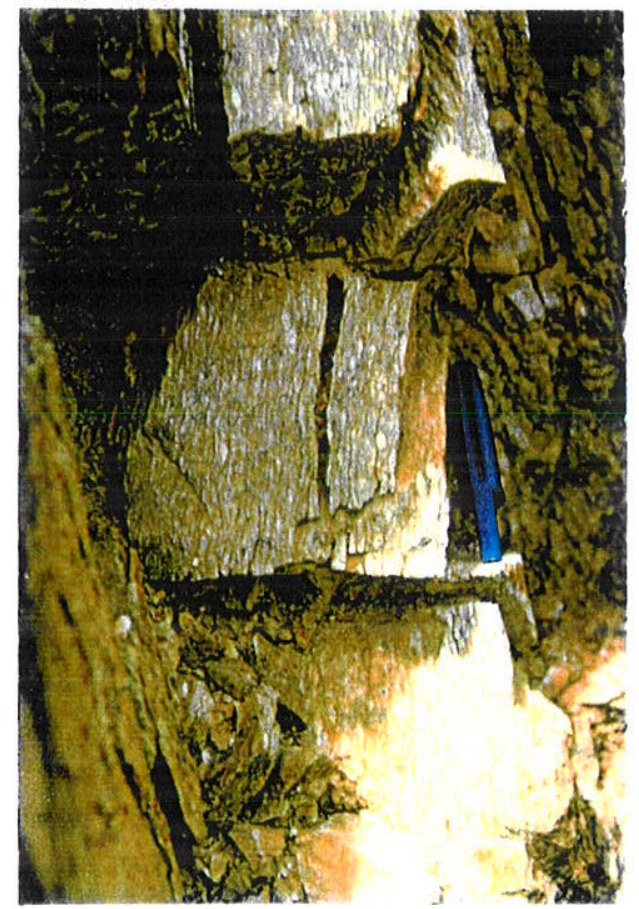

Foto 4.19

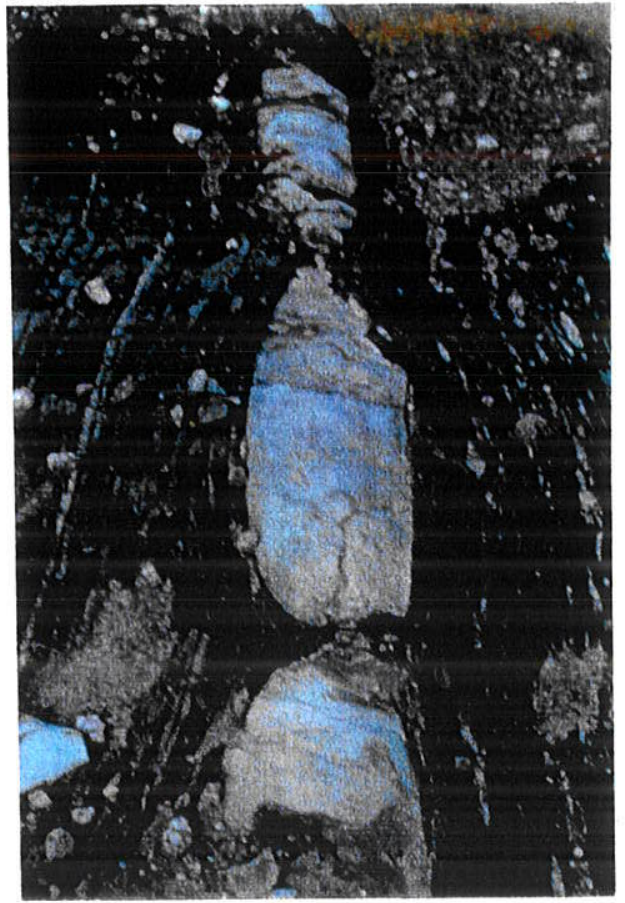

Foto 4.18 - Estruturas S-C, C', veios de quartzo e de neossomas com granada boudinados sigmoidais rotacionados indicando cinemática dextral em micaxistos migmatizados e milonitizados em zona de cisalhamento $\mathrm{D}_{3}$. Afloramento na Faixa de Micaxistos de Barra de Santa Rosa envolvida na ZCRP (35'58'18'W/655'36"S).

Foto 4.19 - Veio de leucogranito boudinado sigmoidal dextral em micaxistos migmatizados e milonitizados na ZCRP. Afloramento na Faixa de Micaxistos de Barra de Santa Rosa envolvidos pela ZCRP.

Foto 4.20 - Paragnaisses granolepidoblásticos porfiríticos finos com porfiroclastos de feldspatos e agregados quartzo-feldspáticos com cinemática dextral sin- $\mathrm{D}_{3}$. Afloramento intercalado ao corredor de micaxistos entre Pirpirituba e Sertãozinho, na continuidade para nordeste da ZCRP. 
Fica (ZCPF), Cacerengo (ZCCC) e Belém-Nova Cruz (ZCBNC), denominadas conforme a proximidade de cidades homônimas. Estas zonas miloníticas preservam as características inerentes ao Lineamento Patos e à ZCRP, com transcorrência dextral sob condições metamórficas de alta-T/baixa-P e migmatização associada. Entretanto, apesar das ramificações infletidas, os lineamentos de trend geral $\mathrm{N} 60-65^{\circ} \mathrm{E}$ que delimitam a ZCRP permanecem contínuos, passando pela cidade de Pirpirituba até o recobrimento pelos sedimentos costeiros na região da Lagoa Guaraíra, no ramo denominado informalmente de ZCBNC. Estes lineamentos interceptam uma ampla fatia de micaxistos (tipo Seridó) encaixados na zona de cisalhamento, que a partir da cidade de Sertãozinho ampliam para NNE, envolvendo as cidades de Lagoa de Dentro e Duas Estradas. Ao longo do corredor $\mathrm{N} 60-65^{\circ} \mathrm{E}$, a foliação $\mathrm{S}_{3}$ tem caimento forte $\left(60-85^{\circ}\right)$ para NW, a $\mathrm{L}_{3}{ }_{3}$ tem baixo rake com caimento subhorizontal (até $30^{\circ}$ ) para $\mathrm{SW}$, e os indicadores cinemáticos são dominantemente dextrais (Foto 4.20).

A fatia de micaxistos alóctones da região de Duas Estradas apresenta fabric $\mathrm{D}_{3}$ com trend geral $\mathrm{NE}$, superimposto à uma foliação $\mathrm{S}_{2}\left( \pm \mathrm{S}_{0}\right)$ subhorizontal, definido por assembléia metamórfica de alta-T. No interior da faixa de micaxistos a foliação $S_{3}$ possui caimentos moderados formando dobramentos abertos a fechados com planos axiais de trend geral NE, e lineações $\mathrm{L}_{3}{ }_{3}$ de rake baixo a moderado com caimentos $\left(5-45^{\circ}\right)$ para $\mathrm{SW}$. Na borda noroente da faixa, a foliação $S_{3}$ tem caimentos moderados a fortes para $S E$, seguindo a ZCMN (zona de cisalhamento Serra da Raiz-Montanhas), uma ramificação da ZCRP, de caráter dextral e alta-T (migmatização $\sin -\mathrm{D}_{3}$ ). Neste setor, a $\mathrm{L}_{3}{ }_{3}$ possui rake moderado $\mathrm{e}$ caimentos $\left(20-45^{\circ}\right)$ para $\mathrm{SW}$, sugerindo movimentos combinados transcorrente-extensional. Em direção à $Z C R P$, a foliação $S_{3}$ tende à verticalização, as lineações $L_{3}$ e $L^{X}{ }_{3}$ mostra caimentos subhorizontais $\left(<15^{\circ}\right)$ e os critérios são dextrais, designados por estruturas S-C, veios de quartzo e leucogranitos boudinados e assimétricos e porfiroclastos de feldspatos rotacionados em granitóides $\sin -\mathrm{D}_{3}$.

Outra fatia de micaxistos alóctones ocorre na região de Araras e Cacerengo associada às transcorrências dextrais das ZCCC e ZCBNC, compondo uma cinemática transcorrente-extensional. O fabric $\mathrm{D}_{3}$ acompanha o trend geral $\mathrm{NE}$ das zonas de cisalhamento, onde as foliações $S_{3}$ apresentam mergulhos moderados a fortes $\left(50-85^{\circ}\right)$ para $\mathrm{NW}$, por vezes para $\mathrm{SE}$, e as lineações $\mathrm{L}_{3}$ e $\mathrm{L}_{3}{ }_{3}$ com baixo rake têm caimentos moderados a 
fracos $\left(5-45^{\circ}\right)$ para SW. Nos micaxistos afetados pelas zonas de cisalhamento, a lineação $\mathrm{L}_{3}^{\mathrm{X}}$ é dada pela orientação de sillimanita, enquanto o processo de fusão parcial é marcado por remobilizados leucograníticos ocupando as estruturas $D_{3}$ (foliações $S_{3}$, cisalhamentos $C_{3}$ ' e $\mathrm{C}_{3}$, shear bands). Os principais critérios cinemáticos assinalam os movimentos extensionaistranscorrentes dextrais efetivos sob condições de alta-T $\left(>550^{\circ} \mathrm{C}\right)$ : porfiroblastos rotacionados, comumente de estaurolita e cordierita, estruturas S-C, micafish, sigmóides dextrais em mobilizados leucograníticos e pegmatóides.

Nas faixas de micaxistos e sistemas de zonas de cisalhamento de alta- $\mathrm{T}$ (sistema Patos-Campina Grande, ZCRP e ramificações) ocorre amplo plutonismo granitóide coetâneo às estruturas $D_{3}$. As relações entre os traçados dos lineamentos interpretados e a forma dos plútons, aliado aos principais critérios petrográficos e cinemáticos das rochas, permitiram estabelecer o caráter sin- a tarditectônicos em relação às zonas de cisalhamento $D_{3}$. Os granitóides porfiriticos incluem composições de sieno- a monzogranitos (granitóides Serra da Boa Vista, Jandaira, Olivedos, Serraria), com formas en cornue, alongadas e em sheets encaixados nos ortognaisses do embasamento e nos micaxistos, comumente associados a corpos gabro-dioríticos em feições de magma mixing e magma mingling. Os corpos apresentam deformação com intensidade variada, desenvolvendo desde o fabric PFC até exclusivamente SPD, freqüentemente subparalelos e acompanhando o fabric milonítico das zonas de cisalhamento. Nas bordas dos plútons são comuns os xenólitos e roof pendants das rochas encaixantes, e enclaves máficos (gabro-dioritos) deformados segundo o fabric predominante. As relações de contato entre as rochas porfiriticas hospedeiras e os enclaves máficos, como contatos irregulares e a incorporação mecânica de fenocristais de feldspato pela fração máfica, indica baixo contraste de viscosidade, prevalecendo os processos de magma mingling sobre o magma mixing. Os critérios cinemáticos caracterizam a sincronia da intrusão desses granitóides com o principal estágio da deformação cisalhante: a continuidade entre o fabric PFC (foliação magmática) no interior dos corpos granitóides e o fabric SPD (foliações $\mathrm{S}_{3} / \mathrm{C}_{3}$ ) nas bordas afetadas pelas zonas de cisalhamento, o entelhamento de fenocristais de caráter dextral similar à assimetria de porfiroblastos e veios de quarto e remobilizados leucocráticos sigmoidais.

Os granitóides de afinidades alcalinas (Algodão, Caxexa, Serra do Boqueirão) compreendem álcali-granitos a álcali-sienitos com aegirina-augita e pirocloro, cujas formas 
variam conforme a intensidade e a geometria do strain $\mathrm{D}_{3}$, desde o antiforme isoclinal boudinado do plúton Algodão, até corpos sigmoidais e alongados (plútons Caxexa e Serra do Boqueirão), e sheets sigmoidais deformados acompanhando as zonas miloníticas. A coloração rósea a esbranquiçada e a textura fina a média equigranular, descrita nas proporções elevadas de K-feldspato, dificultam a observação dos indicadores cinemáticos. No entanto, os principais critérios descritos foram: xenólitos de micaxistos formando boudins assimétricos, niveis máficos (ricos em piroxênios e anfibólios) como dobras assimétricas e boudins, fenocristais de feldspatos estirados e microfraturados, agregados policristalinos sigmoidais, que também constituem a $\mathrm{L}_{3}{ }_{3}$.

Como na região da faixa de Barra de Santa Rosa as principais feições cinemáticas do evento $D_{2}$ indicam transporte tangencial para NW-SE, e aquelas do evento $D_{3}$ assinalam transporte para S-SW, o mecanismo de colocação da fatia de micaxistos foi efetuado, provavelmente, durante os estágios de tectônica tangencial $\mathrm{D}_{2}$, e ulteriormente retrabalhada no evento $D_{3}$ (Jardim de Sá 1994). O funcionamento em regime trantracional da faixa de micaxistos foi decorrente, possivelmente, das magnitudes de deformações diferenciadas e/ou diacronismos episódicos entre o ramo dextral de trend EW-ESE do Lineamento Patos e a deflexão para NE da ZCRP, na região de Campina Grande. As informações geofisicas assinalam os gradientes gravimétricos e aeromagnéticos positivos que acompanham o trend das principais estruturas dúcteis, dos plútons porfiriticos e alcalinos nesse setor.

\section{- Sistema de Zonas de Cisalhamento de Patos-Campina Grande e o MCB:}

No setor a sul das cidades de Pocinhos e Campina Grande, as zonas miloniticas que formam o Lineamento Patos coalescem com zonas de cisalhamento de larguras quilométricas $(\sim 1-5 \mathrm{~km})$ e trend geral NE (ZCAF, ZCSJC, ZCCX e ZCCO), provenientes da região do DZT, compondo um arranjo complexo de zonas de cisalhamento de alta-T. A Fig. 4.2 demonstra que os lineamentos do corredor EW do Lineamento Patos infletem progressivamente para NNE e NE, gerando as principais zonas de cisalhamento de alta-T nos terrenos do MSJC (ZCPJC e ZCRP, e suas ramificações). No entanto, a interpretação visual da distribuição e continuidade dos lineamentos, complementada com informações de campo sobre a persistência do fabric de alta-T e indicadores cinemáticos, demonstra que a zona de cisalhamento de trend WNW com trajetória passando a sul do granitóide Pocinhos e defletindo para NE na cidade de Campina Grande corresponde à última inflexão do sistema 
de Lineamentos Patos. Esta feição é comprovada pelo caráter dextral e intensa migmatização deste setor, conforme descrito por Amaro et al. (1991b) e Corsini et al. (1992) que denominaram de zona de cisalhamento de Campina Grande (ZCCG, Foto 6.3a a Foto 6.5). Todavia, em contraponto a esses trabalhos que a estenderam incluindo os domínios da ZCAF, sugere-se a denominação de ZCCG apenas para esta ramificação.

A área de abrangência do MCB (Fig. 4.3) envolve desde a região das cidades de Mari, Caldas Brandão e Mulungu, no setor sudeste da Fig. 4.1, passando pela região entre Queimadas e Itabaiana, a sul-sudeste de Campina Grande, até a região entre Boqueirão e São João do Cariri. Esta disposição tem forma sigmoidal alongada na direção NE, conforme o traçado dos lineamentos que correspondem às zonas miloníticas limitrofes: a virgação da zona de cisalhamento de Patos (ZCRP e ZCCG) nos limites norte e ocidental do MCB e a ZCCO nos limites oriental e sul. Os terrenos do MCB estão amplamente migmatizados em fabric subhorizontal (aqui descrito como $\mathrm{D}_{2}$ ), compostos dominantemente por gnaisses bandados com granada (metassedimentos migmatizados), ortognaisses bandados e augen gnaisses. As unidades ocorrem intercaladas entre si, por vezes limitadas por faixas miloniticas que circunscrevem principalmente os ortognaisses numa forma sigmoidal. Estas faixas miloniticas possuem dimensões variando de algumas dezenas a centenas de metros, de trend geral NE, mergulhos moderados a fortes $\left(50-85^{\circ}\right)$ e cinemáticas sinistrais dominantes, comumente acompanhadas por corpos alongados de granitóides porfííticos, e constituem zonas subsidiárias à $\mathrm{ZCCO}$. No setor norte do $\mathrm{MCB}$, entre Mulungu e Guarabira, foram descritas algumas faixas miloníticas de alta- $\mathrm{T}$, trend geral $\mathrm{EW}$, mergulhos moderados para NW e NE, com movimentos dominantemente dextrais, que aparentemente correspondem ao splay da ZCCG que ocorre a partir das proximidades de Guarabira. A foliação $S_{2}$ é geralmente subhorizontal com caimentos variados, tendendo ao paralelismo com a foliação $\mathrm{S}_{3}$ nas proximidades das faixas miloniticas. As lineações $\mathrm{L}_{3} / \mathrm{L}^{\mathrm{X}}{ }_{3}$ nas principais faixas miloníticas sinistrais mostram caimento fraco a moderado $\left(5-35^{\circ}\right)$ para $\mathrm{SW}$, que integradas à cinemática topo para baixo em alguns granitóides, compõem um movimento transtracional com transporte para sul.

No setor a noroeste de Campina Grande, o granitóide Pocinhos constitui um batólito elipsoidal alongado e infletido de EW para NE, com as bordas controladas pelas zonas de cisalhamento formadas pelo splay do Lineamento Patos (ZCRP e sistema Patos- 
Campina Grande). O corpo é constituído por pelo menos três fácies composicionais distintos: monzo- a sienogranitos, monzonitos e monzodioritos. Contudo, não foi realizada a diferenciação cartográfica do batólito. Os materiais máficos de natureza diorítica são freqüentes, desde individualizados como enclaves envoltos pela matriz granítica porfirítica, até em associações de magma mixing e magma mingling (Foto 4.21a). As bordas do batólito são intensamente deformadas, desenvolvendo proeminente fabric SPD, onde as foliações $\mathrm{S}_{3} / \mathrm{C}_{3}$ são definidas por minerais máficos com mergulhos para NW e $\mathrm{SE}$, e a lineação $L^{X}$ com caimentos baixo a moderado $\left(5-35^{\circ}\right)$ para SW e SE. No centro do corpo o strain é mais fraco, com faixas de alto strain restritas às zonas miloníticas subparalelas à ZCRP. O fabric SPD é caracterizado por fenocristais de feldspatos estirados e rotacionados (tipo $\sigma$ ), com sombras de pressão e mantos de recristalização, assimetria de boudins, veios e sheets pegmatíticos, dominantemente de cinemática dextral e/ou topo para baixo (Foto $4.21 \mathrm{~b}$ ). Todavia, os critérios sinistrais e simétricos são comuns indicando um importante componente de achatamento e, portanto, o caráter transtracional da deformação. O fabric PFC, geralmente paralelo ao SPD, é marcado pela assimetria de enclaves máficos e entelhamento de fenocristais euédricos de feldspato, caracterizando a continuidade entre o fluxo viscoso e o plástico $\mathrm{D}_{3}$ (Foto $4.21 \mathrm{c}$ ).

O Complexo Campina Grande (CCG, Almeida et al. 1997) corresponde aos plútons gotiformes de Massaranduba e Serra Redonda localizados próximos à cidade de Campina Grande, abrangendo quartzo monzonitos, granodioritos e quartzo-monzodioritos porfiríticos, freqüentemente associados em magma mingling e mixing a enclaves máficos de composições variando de dioritos a quartzo-dioritos (Foto 4.22a). As rochas são, comumente, mesocráticas de coloração cinza a rósea, inequigranulares e porfiríticas. $\mathrm{O}$ caráter sintectônico dos plútons e definida pela congruência entre o fabric $\mathrm{PFC}$, definido por feições de entelhamento de pórfiros e enclaves distorcidos por fluxo, e SPD, fenocristais rotacionados (tipo $\sigma$ ) com sombras de pressão de quartzo + feldspatos recristalizados, relações $\mathrm{S}-\mathrm{C}$ e shear-bands. $\mathrm{Na}$ borda ocidental do complexo, os indicadores assimétricos mostram dominância do caráter dextral, com presença constante de critérios simétricos e sinistrais, relacionado à ZCCG. Neste setor, a foliação $S_{3}$ apresenta mergulho forte $\left(65-85^{\circ}\right)$ para NW e $\mathrm{L}_{3}{ }_{3}$ com caimento moderado $\left(15-40^{\circ}\right.$ ) para SW (Foto $4.22 \mathrm{~b}$ ), com predomínio de indicadores dextrais como fenocristais com sombras de recristalização assimétricas, enclaves 


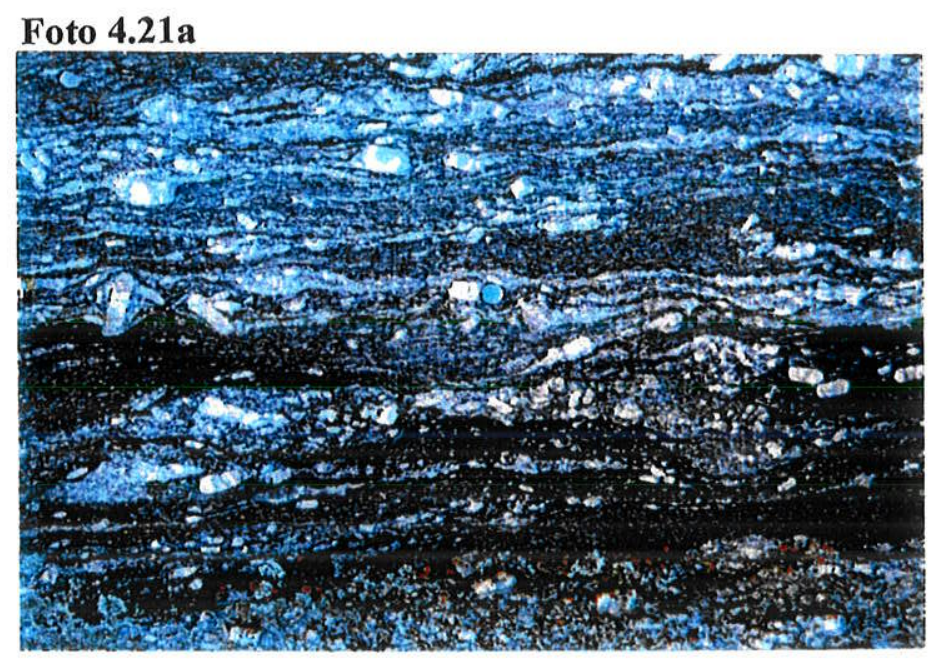

Foto $4.21 \mathrm{~b}$

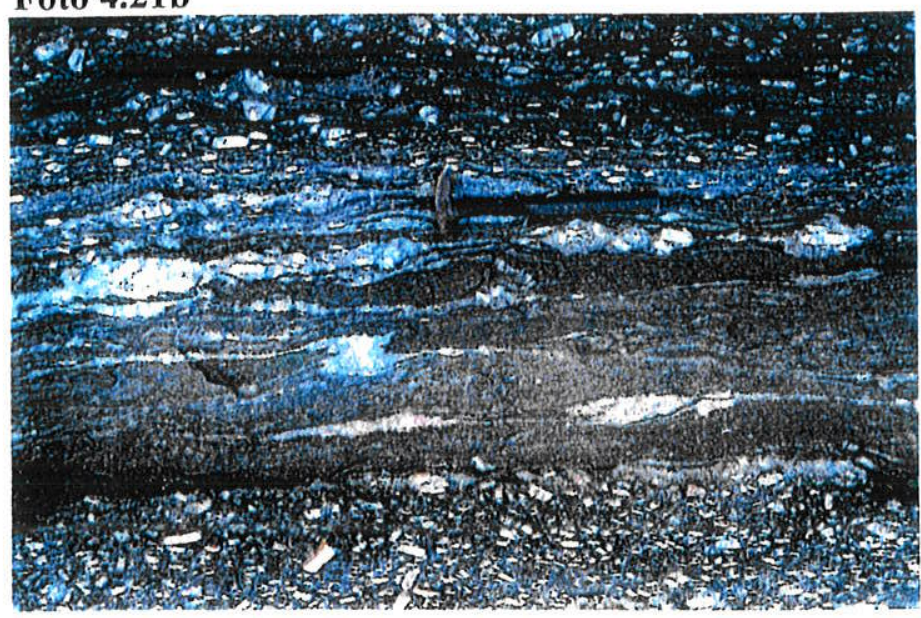

Foto $4.21 \mathrm{c}$

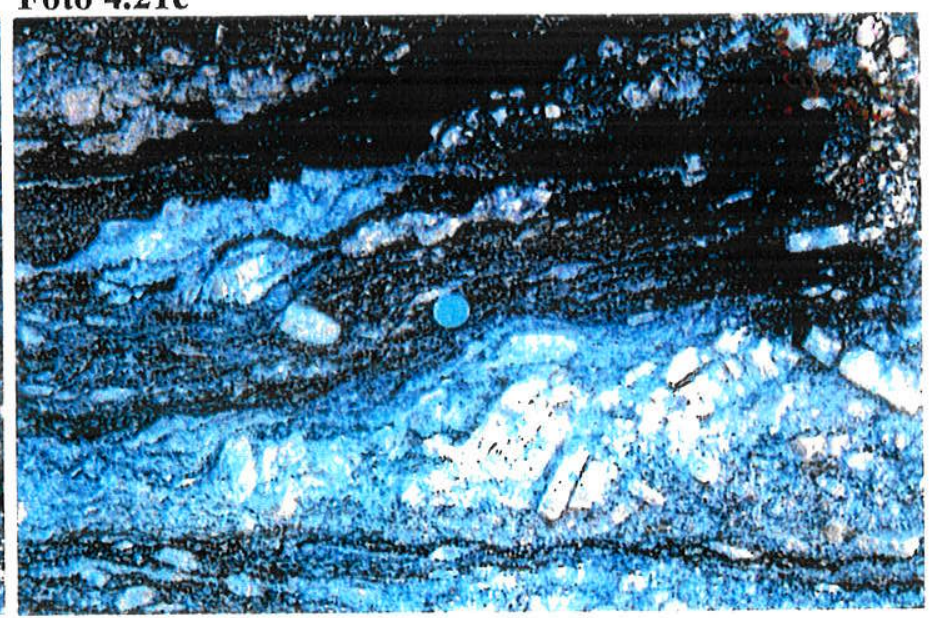

Foto 4.21a - Contato interdigitado entre os fácies monzo- a sienogranítico porfirítico e diorítico fino indicando a contemporaneidade entre os magmas, com captura de fenocristais de K-feldspato pelo diorito conforme o fluxo PFC da rocha e feicões de rolamento de fenocristais. A orientação do fabric magmático da rocha coincide com aquele dos gnaisses do embasamento milonitizados nas ZCRP-ZCCG. Afloramento no Granitóide Pocinhos próximo a Alagoa Nova.

Foto 4.21b - Aspecto geral de afloramento em setor de baixo strain com fabric misto PFC + SPD, predominando o fluxo PFC, com componente não-coaxial dextral definido nos boudins sigmoidais, entelhamento de $\mathrm{K}$-feldspatos, assimetrias de dobras e aglomerados quartzofeldspáticos,. Afloramento a algumas dezenas de metros do afloramento da foto anterior.

Foto $4.21 \mathrm{c}$ - Aspecto geral de afloramento onde predominam deformação viscosa indicada pelo entelhamento de fenocristais de K-feldspato e os aglomerados sigmoidais de fenocristais de feldspatos em regime de fluxo viscoso com cinemática dextral. Afloramento a algumas dezenas de metros do afloramento da foto anterior. 


\section{Foto 4.22a}
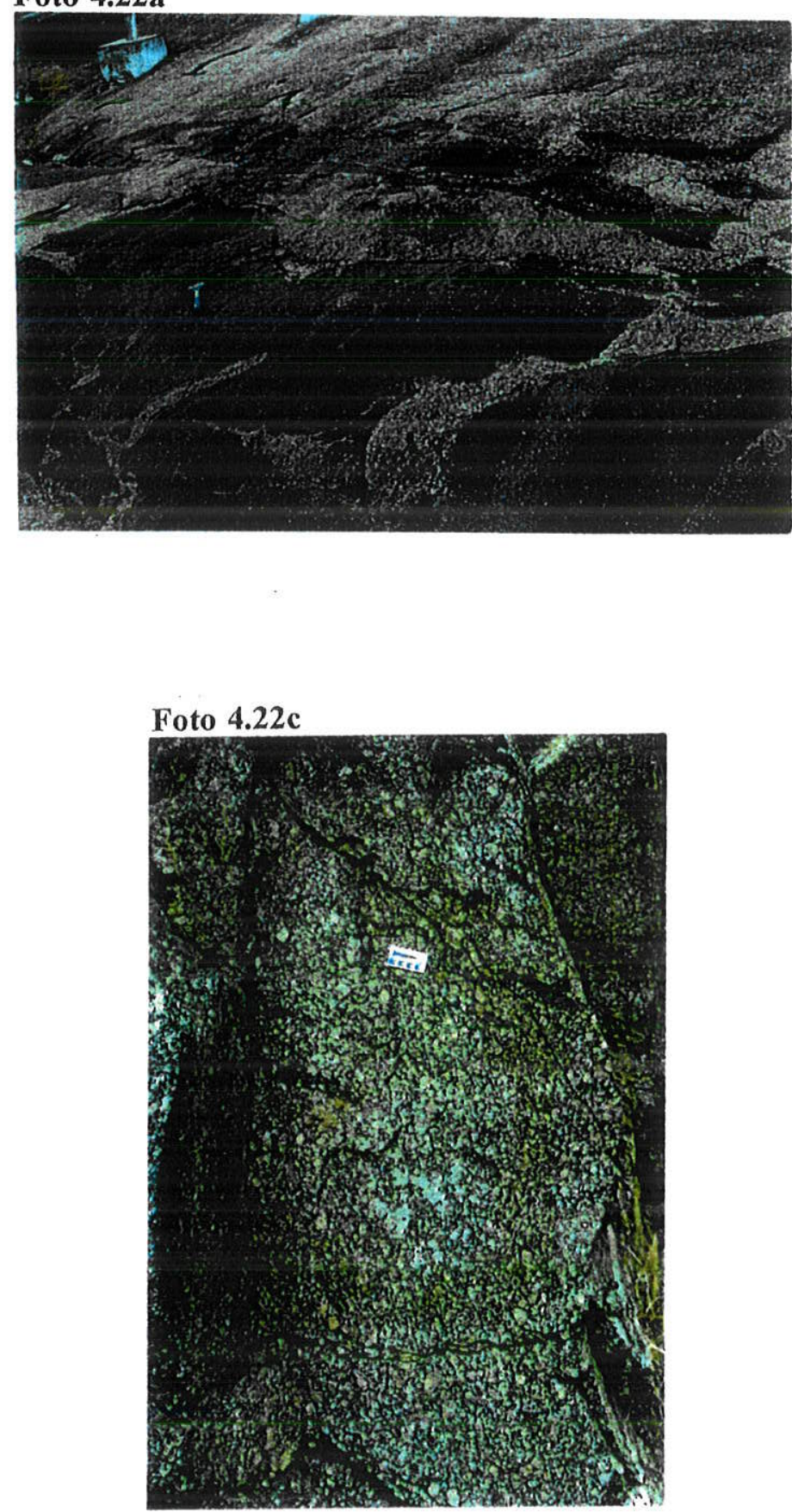

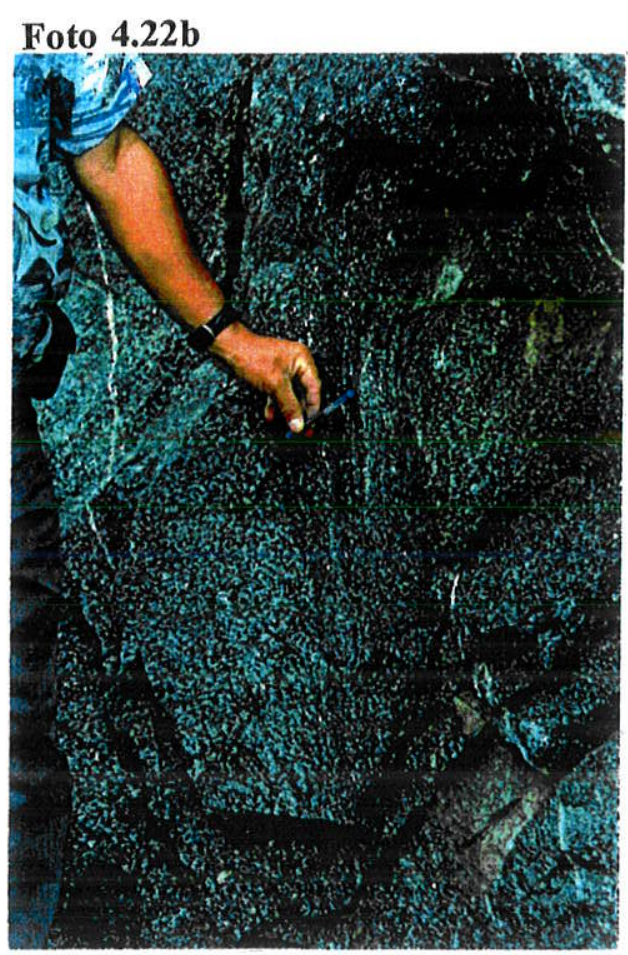

\section{Foto $4.22 d$}

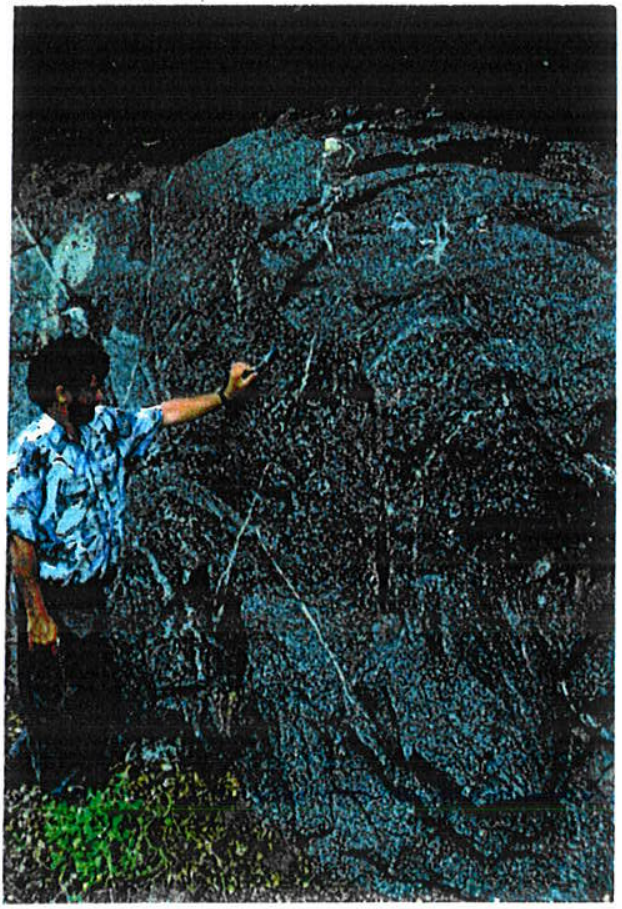

Foto 4.22a - Contato interdigitado entre o fácies granodiorítico porfirítico e os enclaves dioríticos mostrando feições de captura de fenocristais de K-feldspato pelo diorito durante o fluxo viscoso, indicando coexistência e mistura dos magmas. Afloramento no Complexo Campina Grande (CCG) próximo a Campina Grande (3548'39"W/7¹5'30”S).

Foto 4.22b - Aspecto geral de gabro-norito isotrópico interceptado por zona milonítica dextral de alta temperatura com o fabric $\mathrm{D}_{3}$ (SPC) evidenciado pela cominuição, estiramento e reorientação dos grãos. A caneta indica a orientação da $\mathrm{L}_{3}{ }_{3}$ com caimento moderado $\left(\sim 30^{\circ}\right)$ para SE. Afloramento na BR-230 entre Campina Grande e João Pessoa (3544'54"W/7¹6'28"S).

Foto 4.22c - Quartzo monzonito com enclaves de metabásicas (granulitos ?) estirados segundo a foliação magmática (marcada pela seta), truncado pelo fabric $\mathrm{D}_{3}$ subvertical definido na matriz pela reorientação de micáceos, estiramento e recristalização de quartzo. Afloramento na BR-230 entre Campina Grande e João Pessoa (3546'24"W/7¹6'38"S).

Foto 4.22d - Aspecto geral do stock de gabro-norito isotrópico, associado aos quartzo monzonitos e granodioritos porfiríticos dominantes no complexo, truncado por zona de cisalhamento dextral de alta temperatura, com geração de remobilizados leucocráticos que sugerem o aporte de fluidos.

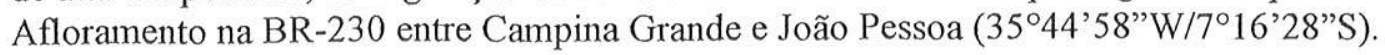


sigmoidais e fenocristais boudinados e rotacionados. Para o centro do corpo, foram preservadas feições da foliação magmática em baixo ângulo definida pela orientação de enclaves máficos e xenólitos de rocha metabásica a dois piroxênios (granulitos da base da crosta?), interceptada por $S_{3}$ subvertical marcada pela recristalização e estiramento do quartzo e feldspato (Foto 4.22c). Em alguns setores do CCG predominam rochas gabróides (monzo-gabros a gabro-noritos, Foto $4.22 \mathrm{~d}$ ), por vezes interceptadas por zonas de cisalhamento métricas de cinemática dextral e $L_{3}{ }_{3}$ de baixo caimento $\left(<30^{\circ}\right)$, e diversos veios pegmatíticos com anfibólio (Foto 4.22e), que sugerem o grande aporte de fluidos e processos de difereciação a partir de rochas mantélicas. Alguns critérios de fluxo viscoso, como o entelhamento de fenocristais e desvio ao redor de enclaves máficos sigmoidais, ainda são percebidos nos afloramentos onde a deformação plástica é incipiente e sugerem cinemática sinistral (Foto 4.22f). Na borda oriental, onde a foliação $S_{3}$ é moderada (50-70 $)$ e a $\mathrm{L}_{3}{ }_{3}$ de alto rake, dominam os critérios sinistrais com componente topo para baixo, como enclaves sigmoidais (Foto 4.22g), shear bands (Foto 4.22h), fenocristais com caudas recristalizadas e assimétricas, fraturados e rotacionados (Foto 4.22i). A assimetria dos enclaves máficos freqüentemente indica movimento de topo para baixo (Foto 4.22g), acompanhando o alto rake da lineação, por vezes parcialmente absorvidos e orientados segundo o fabric $\mathrm{D}_{3}$. A freqüente alternância de critérios dextrais e sinistrais, em associação com feições simétricas, denotam a intrusão sob regime de cisalhamento geral de caráter transtracional. As feições de transição entre os fluxos PFC e SPD, freqüentemente de caráter sin-cinemático, denotam acristalização do plúton durante a atuação de deformação transcorrente e/ou transtracional nas zonas de cisalhamento $D_{3}$.

O plúton de Dona Inês apresenta forma ovalada de eixo principal $\mathrm{NE}$, controlada pelas zonas transcorrentes ZCCC e ZCBNC, ambas ramificações do principal corredor milonítico da ZCRP. A disposição geométrica das zonas ZCCC e ZCBNC, subparalelas e com movimentos dextrais, favorece o alojamento do plúton Dona Inês em sítio transtracional. O corpo é composto por leucogranitos de composição monzogranítica, com fabric SPD e PFC subparalelos e pouco penetrativos, geralmente com foliações de mergulho forte e lineações de baixo rake.

$O$ tratamento digital das imagens Landsat 5-TM, com filtragem direcional para o traçado das foliações e faixas miloníticas, e as composições coloridas para o realce 
Foto 4.22e - Detalhe da foto anterior evidenciando os veios pegmatíticos com anfibólios e bordas de reação com a encaixante, indicando a canalização de fluidos de alta temperatura através de zonas de cisalhamento dextrais ou sinistrais. A origem das rochas granodioriticas dominantes estaria relacionada a processo de diferenciação com aporte de fluidos às rochas gabróicas.

Foto 4.22f - Quartzo monzonitos porfiriticos de granulação grossa com estruturas S-C indicando cinemática sinistral, em setor de fabrics PFC e SPD contemporâneos (baixo strain). A foliação magmática é definida pela caneta com tarja colorida, que acompanha a orientação de enclaves máficos, e o fabric SPD pela caneta de ponta amarela, marcada pelos fenocristais com caudas de recristalização e quartzo estirados na matriz. Os fenocristais arredondados indicam o reequilíbrio de K-feldspato com fluidos de alta temperatura. Afloramento a poucos metros da BR-230 entre Campina Grande e João Pessoa (35 $43^{\prime} 24^{\prime \prime} \mathrm{W} / 7^{\circ} 16^{\prime} 18^{\prime \prime} \mathrm{S}$ ).

Foto $4.22 \mathrm{~g}$ - Quartzo monzonitos porfiríticos em setor com predominância de fluxo PFC mostrando enclaves máficos sigmoidais em cinemática topo para baixo (down dip), acompanhando o fabric $\mathrm{D}_{3}$ da zona de cisalhamento nas bordas do plúton. Afloramento na $\mathrm{BR}$ 230 entre Campina Grande e João Pessoa ( $35^{\circ} 43^{\prime} 24^{\prime \prime W} / 76^{\circ} 16^{\prime} 18^{\prime \prime}$ ).

Foto $4.22 \mathrm{~h}$ - Granodiorito porfiritico com shear bands sinistrais acompanhando $\mathrm{L}_{3}{ }_{3}$ de alto rake e cinemática topo para baixo (down dip) no plano $\mathrm{XY}$, em setor envolvido por zona de cisalhamento sinistral. Afloramento na BR-230 entre Campina Grande e João Pessoa $\left(35^{\circ} 47^{\prime} 32^{\prime \prime} \mathrm{W} / 7^{\circ} 16^{\prime} 12^{\prime \prime} \mathrm{S}\right)$.

Foto 4.22i - Quartzo monzonitos porfiriticos mostrando fenocristais de $\mathrm{K}$-feldspato com caudas de recristalização dinâmica em assimetria sinistral, associado a quartzo recristalizado e estirado na matriz. Afloramento na borda sudeste do $\mathrm{CCG}$, envolvida por zona de cisalhamento sinistral (35 $\left.35^{\prime} 20^{\prime \prime} \mathrm{W} / 7^{\circ} 15^{\prime} \mathrm{S}\right)$. 
Foto $4.22 \mathrm{e}$

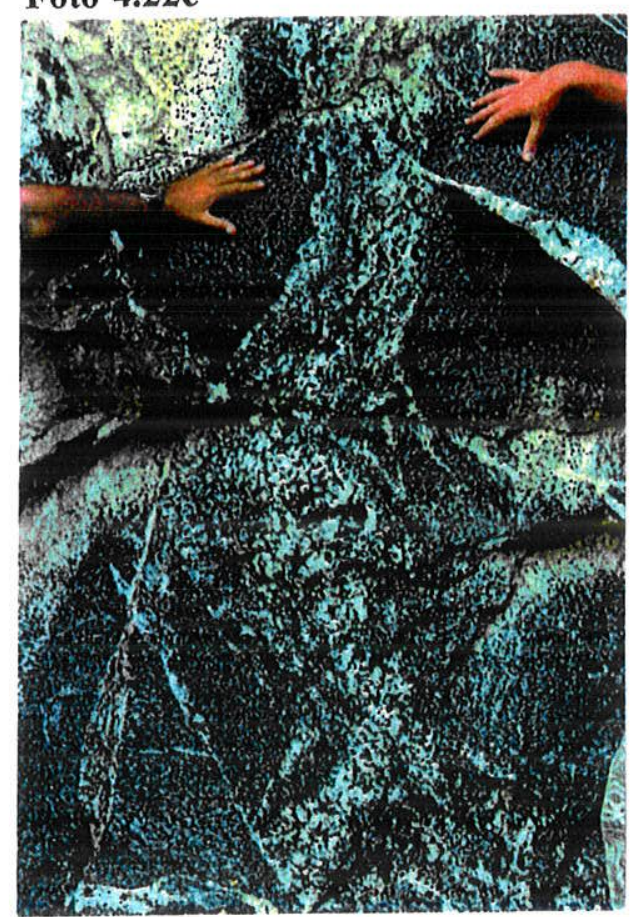

Foto $4.22 \mathrm{f}$

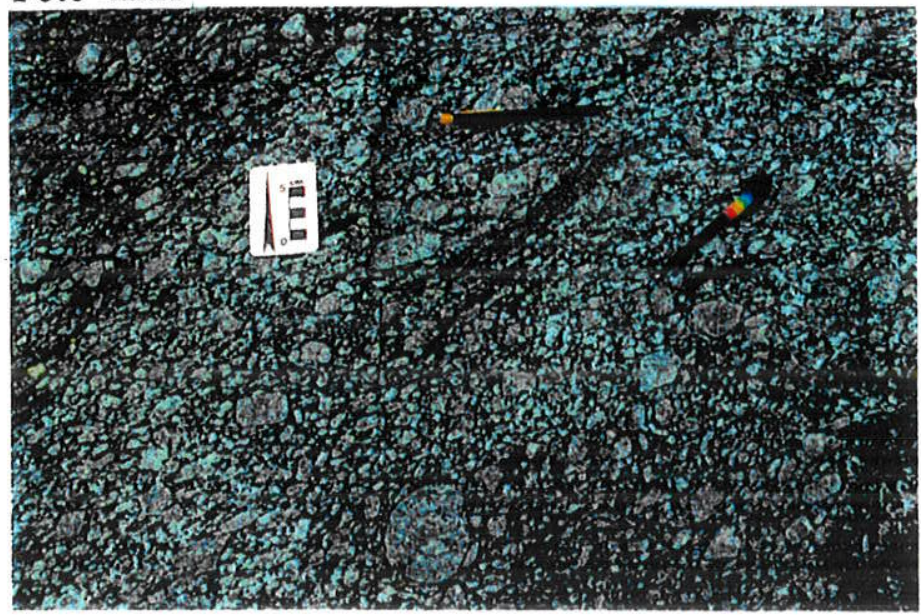

Foto $4.22 \mathrm{~g}$

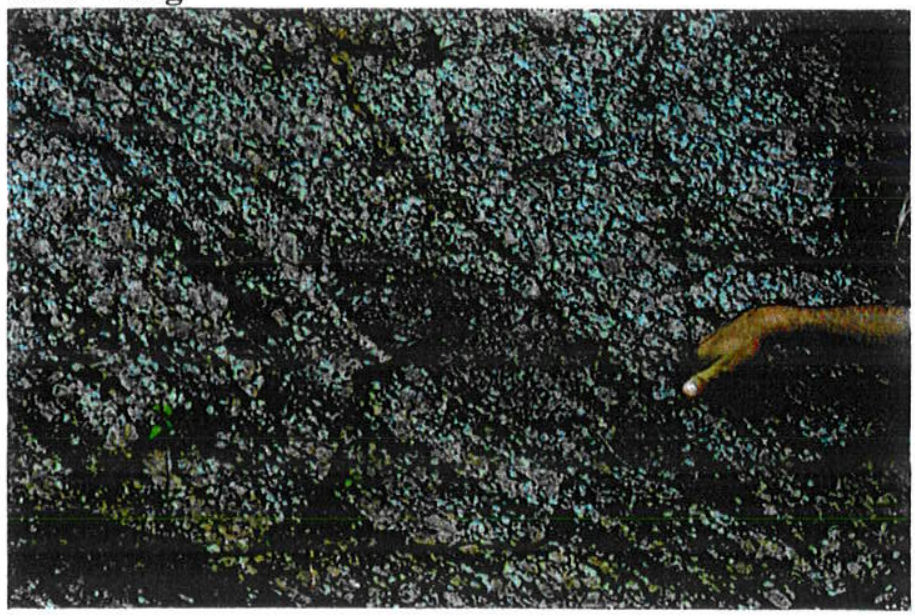

Foto $4.22 \mathrm{~h}$

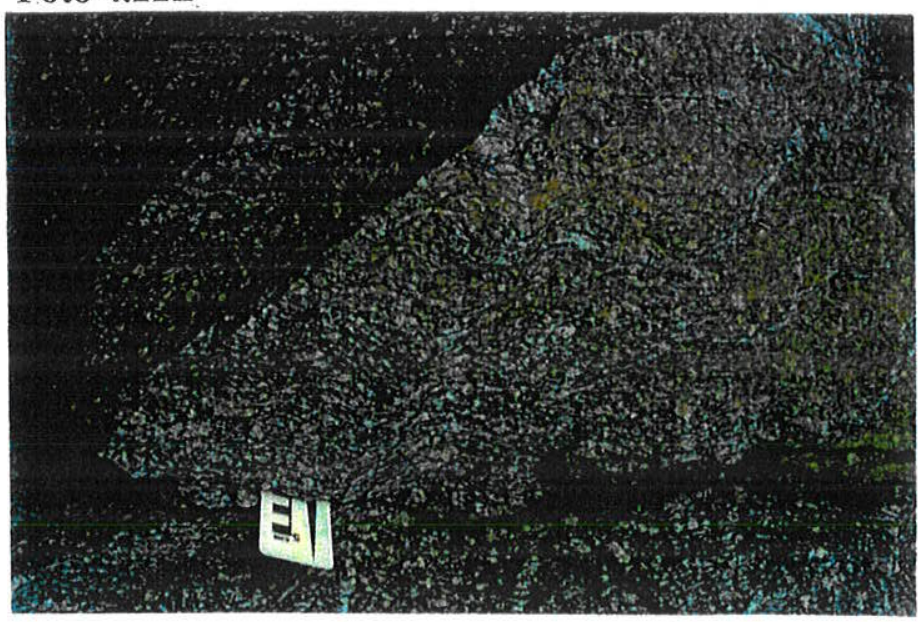

Foto $4.22 \mathrm{i}$

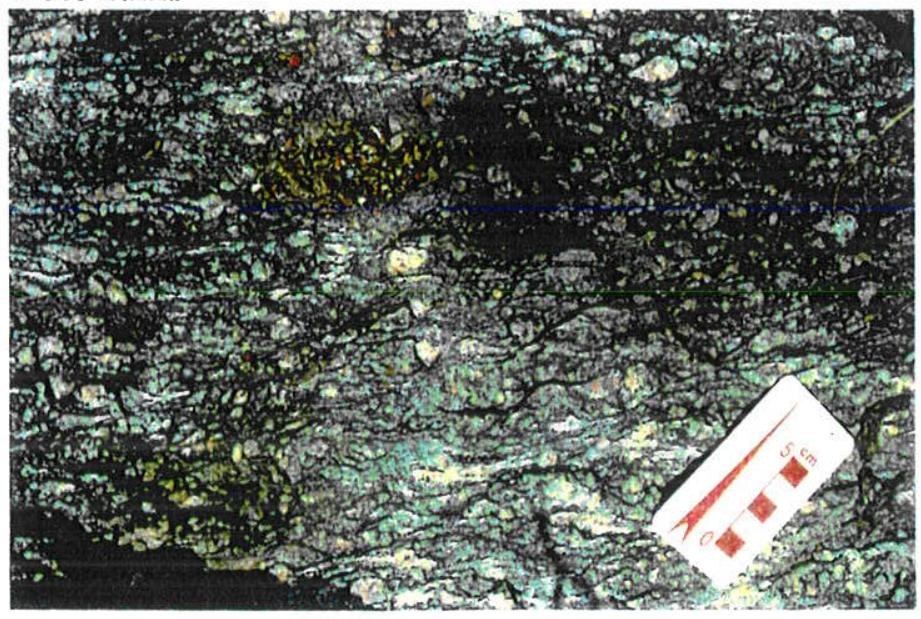


diferenciado das litologias, destacou um plúton de forma sigmoidal na região de Areia, denominado informalmente de granitóide Areia. A forma sigmoidal com caudas assimétricas do plúton, é evidente no plano superficial (plano XZ da elipsóide de strain); caracterizando o movimento dextral das faixas miloniticas nas bordas. O corpo é composto por rochas leuco- a mesocráticas, inequigranulares, com textura porfiritica média a grossa, compreendendo desde biotita monzogranitos a hornblenda-biotita granodioritos. Nas bordas do plúton predomina o fabric SPD relacionado ao alto strain das zonas de cisalhamento dextrais, com $\mathrm{S}_{3}$ de trend $\mathrm{N} 45-65^{\circ} \mathrm{E}$ e megulho moderado a forte $\left(60-85^{\circ}\right)$ para $\mathrm{NW}$ e $\mathrm{SE}$, com $\mathrm{L}_{3}{ }_{3}$ de caimento baixo a moderado $\left(5-40^{\circ}\right)$ para SE e SW. O fabric SPD está marcado por indicadores cinemáticos como caudas de recristalização assimétricas nos fenocristais (Foto 4.23a), shear bands e faixas miloníticas dextrais (Foto 4.23b). Na borda SW do plúton a faixa milonitica de trend $\mathrm{N} 35-45^{\circ} \mathrm{W}$ tem $\mathrm{S}_{3}$ com mergulho para $\mathrm{NE}$ e $\mathrm{L}_{3}{ }_{3}$ de caimento baixo $\left(5-15^{\circ}\right)$. Em direção ao centro do plúton predomina o fabric $\mathrm{PFC} \pm \mathrm{SPD}$, onde feições como o entelhamento de fenocristais e inclusões magmáticas sigmoidais estão acompanhados por quartzo estirado na matriz, falhas antitéticas, shear bands e sombras de pressão assimétricas em fenocristais de feldspato (Foto 4.23c). A maioria dos critérios descreve uma cinemática dextral para o fabric $\mathrm{D}_{3}$, mas indicadores simétricos e sinistrais são freqüentes, e até predominantes em alguns afloramentos, sugerindo a participação de um componente coaxial. Provavelmente, o alojamento do plúton ocorreu em ambiente transtracional, controlado pelas cinemáticas dextrais das ZCRP e ZCCG, de forma semelhante ao plúton Dona Inês, ou em pontes transtracionais constituidas por cisalhamentos tipo $P$.

O emprego da fotointepretação dos lineamentos nas imagens Landsat 5-TM, permitiu a definição sistemática dos sistemas de zonas de alto strain e faixas miloníticas distribuidas nos arranjos anastomosados dos blocos gnáissicos, faixas metapelíticas e plútons graníticos. Esta análise, integrada aos aspectos geométricos, cinemáticos, metamórficos e geocronológicos, favoreceu a avaliação das estruturas e do mecanismo deformacional $D_{3}$. Desta forma, a continuidade das estruturas entre os regimes de transpressão (Faixa Seridó) e transtração (MSJC-MCB), em padrões de fluxo em cisalhamento geral, são complementares numa disposição mecânica tridimensional envolvendo a litosfera. A ampla granitogênese de afinidades variadas, destacando-se os termos alcalinos e as associações em magma mixing e 


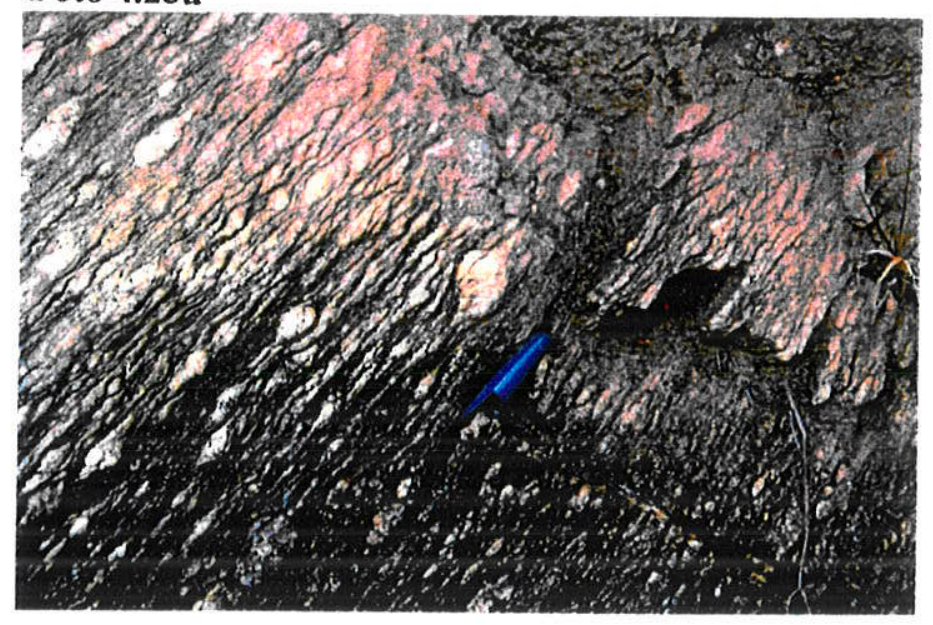

\section{Foto $4.23 \mathrm{c}$}
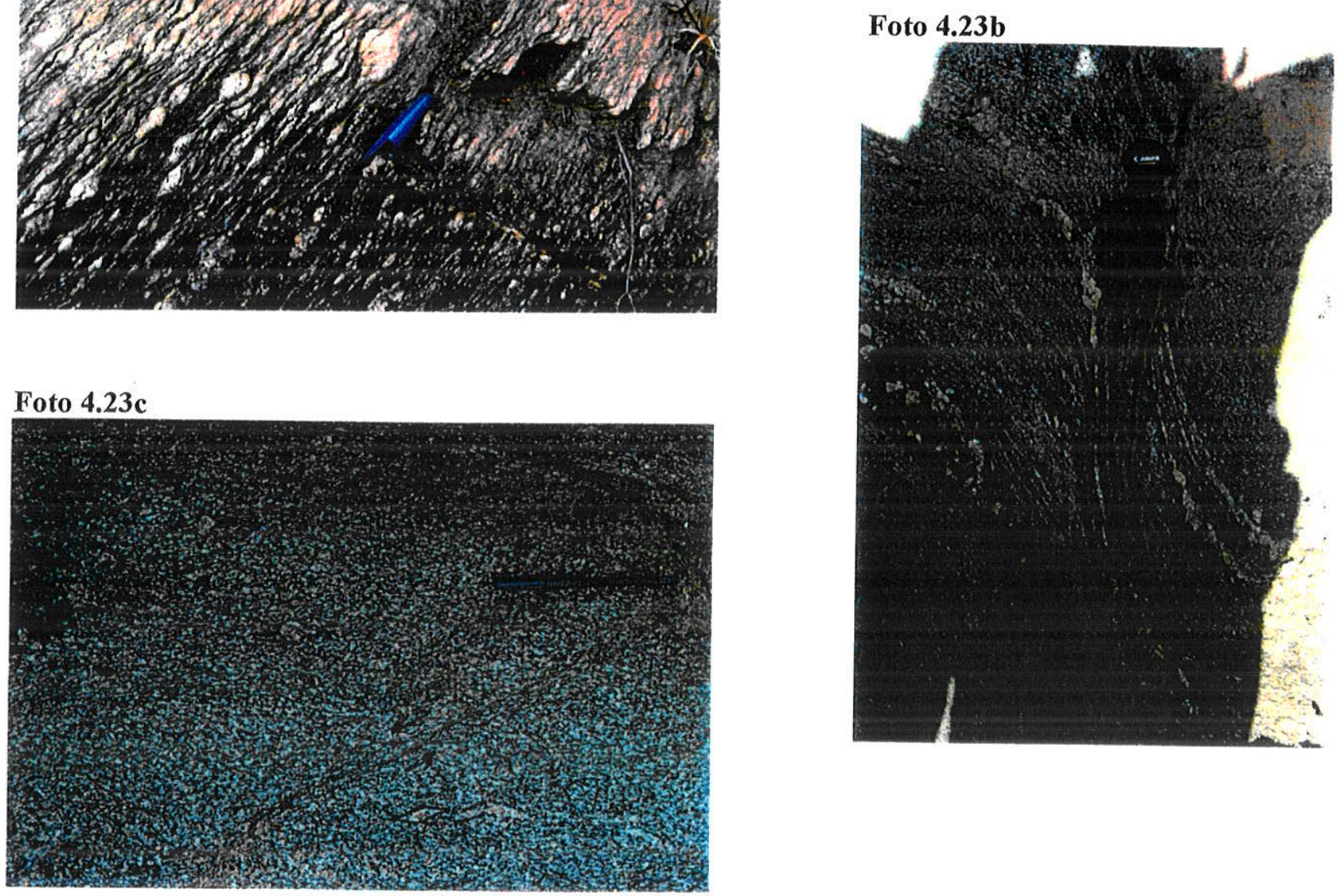

Foto 4.23a - Porfiroclastos de K-feldspatos com caudas de recristalização assimétricas dextrais, associados à recristalização e estiramento de quartzo na matriz, indicando a predominância do fabric SPD $\sin -\mathrm{D}_{3}$ em rocha granitóide porfirítica do Granitóide Areia envolvido na ZCCG. A tampa de caneta azul indica a orientação da $\mathrm{L}_{3}^{\mathrm{X}}$. Afloramento no Granitóide Areia próximo a Alogoa Grande.

Foto 4.23b - Zona de cisalhamento dextral $\sin -\mathrm{D}_{3}$ mesoscópica na borda do Granitóide Areia envolvida pela ZCCG. Afloramento próximo a Guarabira.

Foto 4.23 c - Porfiroclastos com caudas de recristalização assimétricas dextrais, agregados quartzo-feldspáticos assimétricos dextrais e shear bands sinistrais, em rocha ortoderivada porfirítica, com quartzo recristalizado e estirado na matriz, definindo o fabric SPD dextral dominante. Afloramento a cerca de $2 \mathrm{~km}$ a sul do afloramento da foto anterior, próximo à borda do Granitóide Areia envolvida pela ZCCG. 
mingling com rochas dioriticas, sobretudo no setor entre Barra de Santa Rosa e Campina Grande, sugere a canalização de fluidos mantélicos pelo sistema de zonas de cisalhamento dextrais e sinistrais, que alcançariam as profundidades mantélicas das fontes.

\section{5 - Mapa Esquemático do Sistema de Zonas de Cisalhamento Dúcteis de Alta- Temperatura da Província Borborema}

A Fig. 4.9 apresenta o mapa esquemático do sistema de zonas de cisalhamento neoproterozóicas da Borborema (Jardim de Sá 1994, Vauchez et al. 1995, Neves et al. 1996), ao qual foram acrescentadas as informações que resultaram nos mapas de lineamentos das Fig. 4.1 e 4.2, com maior detalhamento da região do MSJC-MCB. A análise dos indicadores cinemáticos incorporados aos dados metamórficos $\mathrm{e}$ as medidas termobarométricas contribuiram na caracterização do arranjo do sistema de zonas de cisalhamento brasilianas de alta-T. A disposição geométrica regional enfatiza as largas e extensas zonas de cisalhamento transcorrentes dextrais de orientação EW e NE coalescentes ao Lineamento Transbrasiliano nos limites oeste e noroeste do Cráton São Francisco (CSF). A partir do Lineamento Transbrasiliano ramificam-se as principais zonas de cisalhamento dextrais de Patos e Pernambuco, de trend geral EW e divisoras da Província Borborema nas porções setentrional e central. Estas zonas de cisalhamento estão caracterizadas por deslocamentos EW sinuosos e terminações em splay (ou tipo rabo-de-cavalo), associadas às faixas metassedimentares de estilos deformacionais transpressional (Faixa Seridó) e trantracional-extensional (faixas de Barra de Santa Rosa e Ielmo Marinho-Taipu). Esta alternância entre setores de strain $\mathrm{D}_{3}$ baixo a médio e de estilos cinemáticos diversos, limitados por zonas miloníticas em regime de cisalhamento geral ou simples e volumosa granitogênese, denota a heterogeneidade do fabric e a repartição do strain no evento deformacional $\mathrm{D}_{3}$. A integração das informações de campo, geoquímicas, geocronológicas e geofisicas, comparadas aos homólogos na África Ocidental, favoreceu a interpretação do evento $D_{3}$ como típico de retrabalhamento intracontinental (orogênese ensiálica, Kröner 1981) atuante sobre crosta em aquecimento (Bell 1981, Gapais 1989, Black \& Liégeois 1993, Jardim de Sá 1994).

A inflexão mecânica das zonas de cisalhamento EW e NE está marcada pela rotação progressiva dos elementos da deformação plástica (foliações e lineações), que 


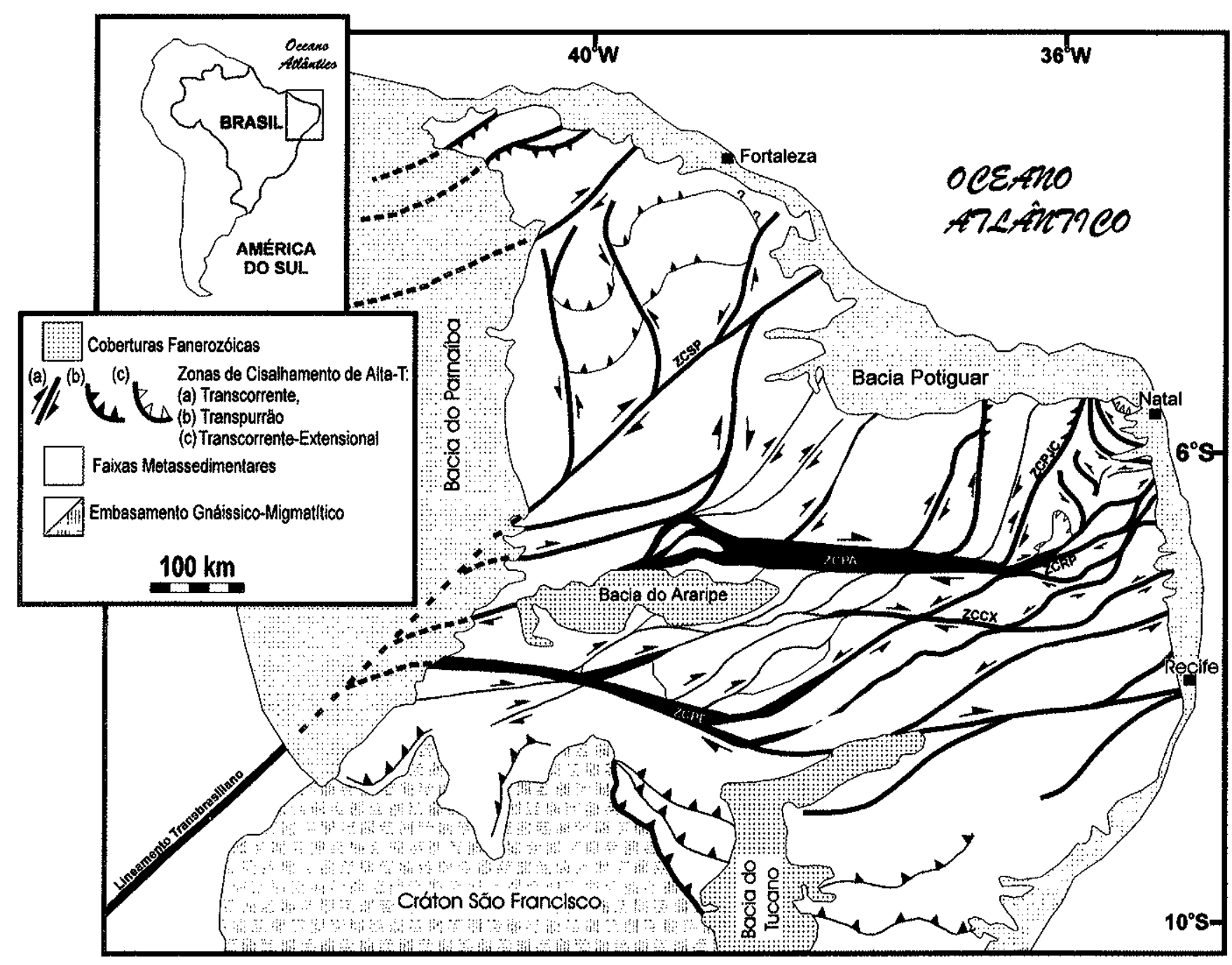

Figura 4.9 - Mapa esquemático da localização, distribuição geométrica e cinemática do sistema de zonas de cisalhamento brasilianas e faixas metassedimentares da Província Borborema. Abreviaturas de algumas zonas de cisalhamento: ZCSP = Zona de Cisalhamento Senador Pompeu, ZCPA = Zona de Cisalhamento Patos, ZCPE $=$ Zona de Cisalhamento Pernambuco, ZCPJC $=$ Zona de Cisalhamento Picuí-João Câmara, ZCRP = Zona de Cisalhamento RemígioPocinhos, ZCCX = Zona de Cisalhamento Caxixola. Modificado de Vauchez et al. (1995) e Tommasi e Vauchez (1997). 
denotam o sincronismo do regime deformacional entre as diversas zonas de alto strain e os dobramentos nas faixas metassedimentares. Para alguns setores estudados preliminarmente (Orós-Tatajuba, Patos-Seridó, Pernambuco-Cachoeirinha, Patos-Campina Grande), além da continuidade dos lineamentos expressa nas imagens de satélite, os fatores que ratificam a continuidade mecânica das estruturas são os que se seguem: (i) os dados de campo confirmam a contemporaneidade dos elementos estruturais e a coerência cinemática entre as diversas ramificações do sistema (Corsini et al.1991, Vauchez \& Egydio-Silva 1992, Leterrier et al. 1994, Jardim de Sá 1994); (ii) as estimativas do metamorfismo (alta temperatura/baixa pressão) coevo à deformação sugerem condições similares de PT para o conjunto do sistema (Vauchez et al. 1995); (iii) as idades disponíveis indicam o sincronismo da deformação iniciando entre 600-570 Ma, atuando de maneira intermitente por todo o sistema, com resfriamento lento até aproximadamente $500 \mathrm{Ma}$ (Sá 1991, Figueiredo et al. 1992, Féraud et al. 1993, Leterrier et al. 1994); (iv) os dados gravimétricos e aeromagnéticos mostram a curvatura progressiva das anomalias geofisicas acompanhando o fabric tectônico das zonas de cisalhamento (Moreira et al. 1989a, Lins et al. 1993).

O desenvolvimento do sistema de zonas de cisalhamento da Província Borborema foi induzido pela atuação de esforços compressionais sobre uma litosfera continental de intensa heterogeneidade reológica, como mostra a alternância entre terrenos ortognáissicos e faixas de supracrustais com fabric tectônico variado (Jardim de Sá 1994, Vauchez et al. 1995, Tommasi et al. 1995). Os dados geocronológicos recentes sugerem a instalação do evento de retrabalhamento, em estilo transcorrente acrescionário, sobre litosfera continental formada pela justaposição de terrenos alóctones de idades arqueanas a neoproterozóicas (Jardim de Sá 1994, Van Schmus et al. 1994, 1995, Brito Neves et al. 1995, Dantas 1997). As zonas de cisalhamento dúcteis, que freqüentemente ocorrem na interface entre as unidades litoestratigráficas e os plútons granitóides, permitem inferir duas associações contrastantes: (a) as unidades são alóctones e foram dispostas em contato pelo cisalhamento; (b) os cisalhamentos foram nucleados ao longo do contato prévio entre as unidades, com possibilidade de preservação das feições intrusivas ou estratigráficas originais nas áreas de menor strain.

A influência efetiva do estilo de deformação, e estruturas associadas em cada domínio alóctone, depende de fatores como (a) a geometria dos blocos envolvidos, (b) de 
suas propriedades reológicas, e (c) da cronologia relativa dos movimentos. Para a Província Borborema, o campo de strain finito é altamente heterogêneo devido à interação desses fatores, resultando em padrões cinemáticos complexos e conduzindo à formação do sistema ramificado de zonas de cisalhamento, com diferenciação lateral e vertical na intensidade do strain, no regime deformacional e metamórfico.

No setor norte do lineamento de Patos, preponderam as zonas de cisalhamento de direções gerais NE e NNE desde a Faixa Seridó até a Faixa Noroeste do Ceará (Caby et al. 1991), enquanto aquelas de direção NW são de caráter sinistral e extensional. Nas faixas de supracrustais de direção NE (faixas Seridó e Orós-Jaguaribe) os dados estruturais indicam o strain resultante da combinação dos padrões cinemáticos dos tipos cisalhamento simples e puro (Archanjo \& Bouchez 1991, Sá \& Bertrand 1992), consistente com o regime transpressional, decorrente da movimentação sincrônica das zonas de cisalhamento NE/NNE e do lineamento Patos (Corsini et al 1991, Vauchez et al. 1992). Uma evidência típica do regime transpressional ocorre na região de Caiçara do Rio dos Ventos, onde as zonas de cisalhamento dextrais verticalizadas no centro, mergulham para o interior da faixa no contato com embasamento feito pela ZCPJC. Os caimentos da lineação $\mathrm{L}_{3}$, em ângulo com a direção NS-NNE das zonas miloniticas, variam de NE a SW na ZCPJC. Esses elementos definem a movimetação contracional inversa característica de zonas de cisalhamento do tipo transpurrão da macroestrutura em flor positiva (Jardim de Sá 1994). O contraste reológico entre as faixas supracrustais mais dúcteis alternadas com os blocos gnáissicos menos dúcteis é o principal controlador da partição do strain em escala regional. Estas variações no regime deformacional subordinadas à orientação preferencial das zonas de cisalhamento são condizentes ao campo de magnitude do stress definido por compressão EW (Corsini et al. 1991, Vauchez et al. 1995). O contato tectônico entre a limite leste da Faixa Seridó e o embasamento gnáissico é marcada pela intrusão de corpos granitóides sintectônicos brasilianos, entre os quais os plútons de Picuí e Barcelona que apresentam a forma sigmoidal típica do alojamento forçado no regime cinemático transpressional dextral da ZCPJC (Jardim de Sá et al. 1993a). As estruturas de empurrão com transporte para NW do DCC (Pessoa \& Archanjo 1984, Arthaud \& Hartmann 1986) são integráveis ao arranjo geométrico para o modelo tectônico. No entanto, Jardim de Sá (1994) sugeriu modificações ao modelo transpressional de Corsini et al. (1991), com base na continuidade da zona de 
cisalhamento de Patos em direção à costa envolvendo ramificaçðes com trend ENE/NE (ZCRP) a EW/ESE (zonas de cisalhamento integradas ao sistema Patos-Campina Grande). A região entre as principais ramificações dextrais de trend NNE/ENE da ZCPA (ZCPJC e ZCRP) é caracterizada por regimes transtracionais (regiões de e lelmo Marinho-Taipu) e zonas de cisalhamento sinistrais. No ramo EW da ZCPA foram descritos critérios sinistrais e simétricos, sem crononologia sistemática com o critério dextral dominante, que sugerem um componente de transpressão. Estas evidências sugerem, ao menos, um padrão de fluxo de cisalhamento geral (transpressional e transtracional) na integração do diferentes domínios (Jardim de Sá 1994).

\section{6 - Geometria dos Sistemas de Lineamentos e a Dimensionalidade das Zonas de Cisalhamento Dúcteis Brasilianas}

O principal objetivo da cartografia sistemática dos padrões geométricos dos sistemas de lineamentos é a correlação entre a rede de zonas de cisalhamento e o comportamento anisotrópico e heterogêneo da litosfera, determinando a natureza das conecções entre a crosta e o manto litosférico. Para isso, os estudos abrangem o caráter sinóptico das imagens de satélite integrado às informações geofisicas e aos dados de campo sobre a intensidade do strain, cinemática, fácies metamórfico e granitogênese.

A avaliação da dimensionalidade das zonas de cisalhamento tem implicação direta na estimativa do rejeito relativo e do enraizamento profundo dessas estruturas. Apesar de que as correlações entre largura, extensão e profundidade para zonas de falhas ainda não sejam amplamente estabelecidas, Sankov (1989) admitiu a proporcionalidade entre a extensão vs. profundidade, onde megalineamentos representariam falhas profundas que penetrariam a base da crosta e em alguns casos o manto litosférico. Para Peyve (1990) as zonas de falhas com larguras superiores a dezenas de quilômetros apresentam como feições estruturais essenciais: (a) grande extensão; (b) profundidades que alcançam pelo menos a base da crosta; (c) desenvolvimento multifásico, às vezes com inversão de movimentos. Alguns estudos sobre zonas de cisalhamento avaliaram as relações largura vs. tempo (Means 1984), largura vs. deslocamento (Hull 1988), comprimento vs. deslocamento (Ranalli 1987) e largura $v s$. comprimento (Pili 1997), mas a abrangência dos resultados ainda é controversa. 
Jardim de Sá (1994), considerando as dimensões das zonas de cisalhamento de trend NE dos setores central e norte da Província Borborema, as diferenças relativas nas colunas estratigráficas entre os blocos interceptados e o controle estrutural dos plútons brasilianos associados, sugeriu o enraizamento profundo (crosta inferior a manto litosférico) e deslocamentos direcionais expressivos para essas zonas. Nos diagramas relacionando deslocamentos vs. comprimento (Ranalli 1987) e deslocamento vs. largura (Otsuki 1978, apud. Vauchez 1987) essas zonas de cisalhamento apresentaram, respectivamente, deslocamentos variando desde dezenas a centenas de quilômetros até milhares de quilômetros. No entanto, as principais zonas de cisalhamento da Província Borborema apresentam ampla heterogeneidade do strain, constituindo setores de pontes e pods de baixo strain que mascaram as medidas de largura das zonas e alteram as estimativas de rejeito direcional e profundidade baseadas neste critério (Jardim de Sá 1994). Além disso, os comprimentos observados correspondem aos valores mínimos, pois as estruturas estão freqüentemente truncadas pelos limites do continente e recobertos por depósitos sedimentares, descaracterizando a utilização isolada dos parâmetros geométricos das zonas de cisalhamento para estimativas regionalizadas do strain e do comportamento 3-D.

Pili et al. (1997) apresentaram o diagrama largura vs. comprimento (Fig. 4.10) para as zonas de cisalhamento neoproterozóicas de Madagascar, baseados na interpretação visual de imagens Spot às quais foram associados dados gravimétricos e dados estruturais de campo. Neste diagrama foram definidos três grupos de zonas de cisalhamentos: (a) zonas de cisalhamento menores, com razão comprimento/largura de cerca de 17 , passando pela origem; (b) zonas de cisalhamento maiores com razão comprimento/largura superior a 60; (c) zonas de cisalhamento intermediárias cujo comprimento não ultrapassa $450 \mathrm{~km}$ e razão comprimento/largura equivalente às zonas de cisalhamento menores. A combinação desses resultados com a gravimetria permitiu aos autores sugerirem a correspondência direta entre a dimensão das zonas de cisalhamento e a profundidade, com as zonas de cisalhamento menores enraizadas inteiramente na crosta e as zonas de cisalhamento maiores e intermediárias alcançando, pelo menos, profundidades de manto litosférico.

Algumas zonas de cisalhamento de trend NE (ZCPJC, ZCRP, ZCC) e NW (ZCLP, ZCBJ, ZCJ) da rede de zonas de cisalhamento da porção Extremo Nordeste da Província Borborema foram dispostas no diagrama da Fig. 4.10 juntamente com os 


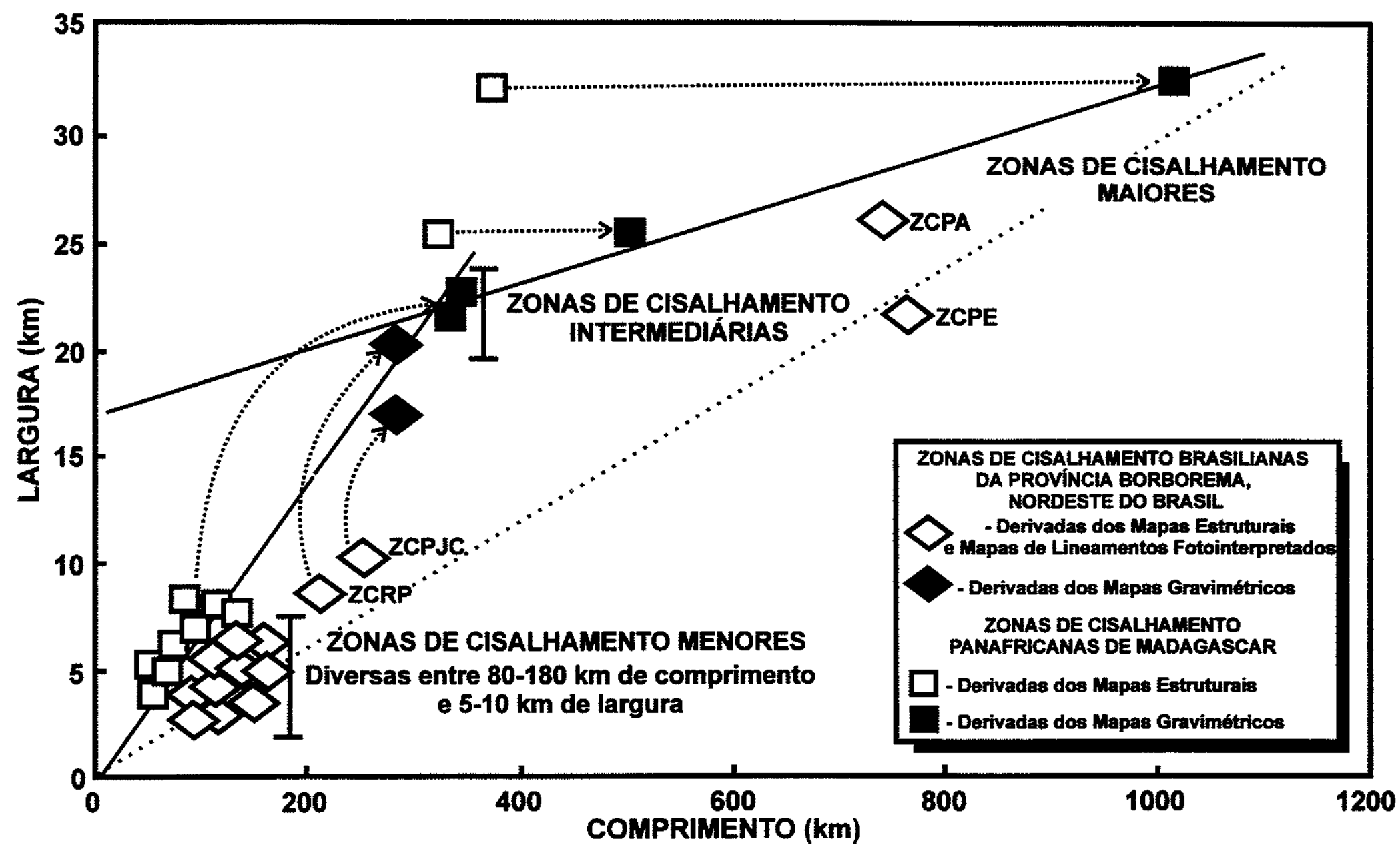

Figura 4.10 - Diagrama da largura vs. comprimento (ambos em $\mathrm{km}$ ) para as zonas de cisalhamento brasilianas. $O$ comprimento medido das zonas de cisalhamento é apenas aparente, uma vez que esta estruturas podem estar truncadas pelo limite da costa e/ou encobertas por sedimentos. Os conjuntos de símbolos abertos correspondem às estruturas derivadas dos mapas geológicos, enquanto os símbolos preenchidos correspondem às estruturas derivadas da análise dos mapas gravimétricos. Abreviaturas: ZCPA $=$ Zona de Cisalhamento Patos, $Z C P E=Z$ Zona de Cisalhamento Pernambuco, $Z$ CPJC $=$ Zona de Cisalhamento Picuí-João Câmara, ZCRP = Zona de Cisalhamento Remigio-Pocinhos. 
lineamentos Patos e Pernambuco. As ZCJ e ZCBJ de trend NW mostraram relações equivalentes às zonas menores (razoes comprimento/largura entre 10-25), as demais entre menores e intermediárias (ZCRP, ZCPJC, ZCC e ZCLP, com razões próximas a 30), enquanto os lineamentos Patos e Pernambuco como zonas maiores (razão de cerca de 40), talvez mais longos se correlacionados aos lineamentos equivalentes na África pré-deriva. Em contraponto à proposta de Pili (1997) para as zonas de cisalhamento de Madagascar, o diagrama indica o alinhamento passando pela origem dos conjuntos de zonas de cisalhamento da Província Borborema, sugerindo que mecanismos deformacionais integrados foram os responsáveis pelas zonas de cisalhamento desde menores até maiores. Independente da classificação dimensional das zonas de cisalhamento, outros argumentos apontam para a interpretação de que a deformação responsável pela instalação do arranjo de zonas de cisalhamento brasilianas foi controlada pelo manto superior, associada à coleta $\mathrm{e}$ canalização de fluidos (magma $+\mathrm{H}_{2} \mathrm{O}+\mathrm{CO}_{2}$ ) mantélicos e crustais, e à deformação da Moho:

(a) O controle estrutural das zonas de cisalhamento sobre o alojamento dos plútons brasilianos; a maioria dos granitóides têm origem na anatexia da crosta inferior e estão freqüentemente associados à corpos gabro-dioríticos e seus diferenciados de fonte mantélica;

(b) O condicionamento da distribuição espacial do metamorfismo de alta-T/baixa$\mathrm{P}$ às zonas de cisalhamento, alcançando paragêneses do fácies granulito e migmatização, comprovando a importância do fluxo térmico anômalo e da canalização de fluidos profundos e quentes pelas zonas de cisalhamento (Lima 1987, Souza \& Jardim de Sá 1993);

(c) As anomalias gravimétricas e aeromagnéticas profundas controladas pelas zonas de cisalhamento, evidências dos mecanismos de afinamento e espessamento crustal (Lins et al. 1993, Cap. 7 desta Tese).

Estes fatos, aliados aos dados geofisicos e de campo, permitiram a sugestão do modelo esquemático da distribuição mecânica em profundidade das zonas de cisalhamento da porção Nordeste da Província Borborema (Fig. 4.11). As zonas de cisalhamento intermediárias a maiores de trend NE e alto ângulo (ZCPJC, ZCRP, ZCCC, lineamentos Patos e Pernambuco) teriam raízes mantélicas demarcando sítios de transtração (p.ex. ZCRP) e transpressão (p.ex. ZCPJC). As zonas menores de trend NW e baixo ângulo (ZCLP, ZCBJ, ZCJ) ocorreriam diretamente enraizadas no manto litosférico ou integradas às 


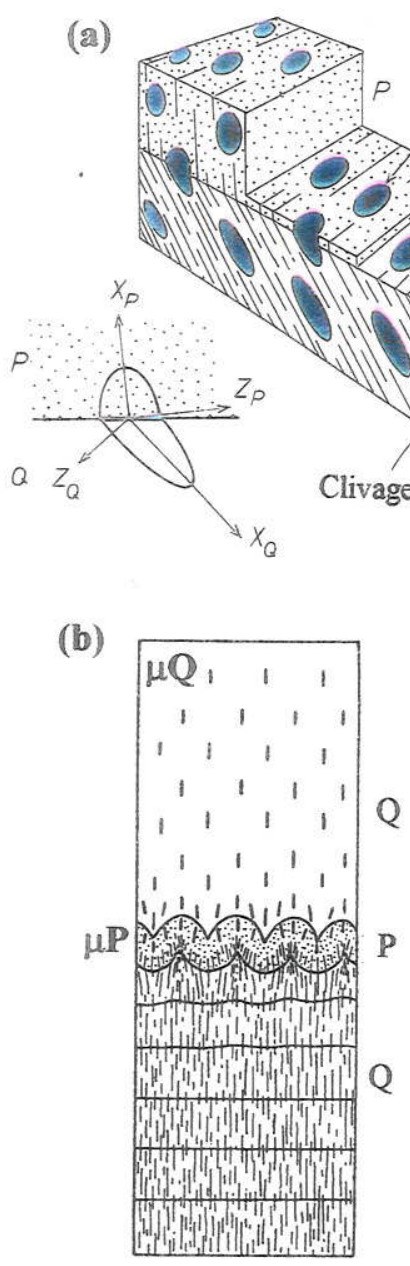

Elipses de Strain

Finito Identi

(c)
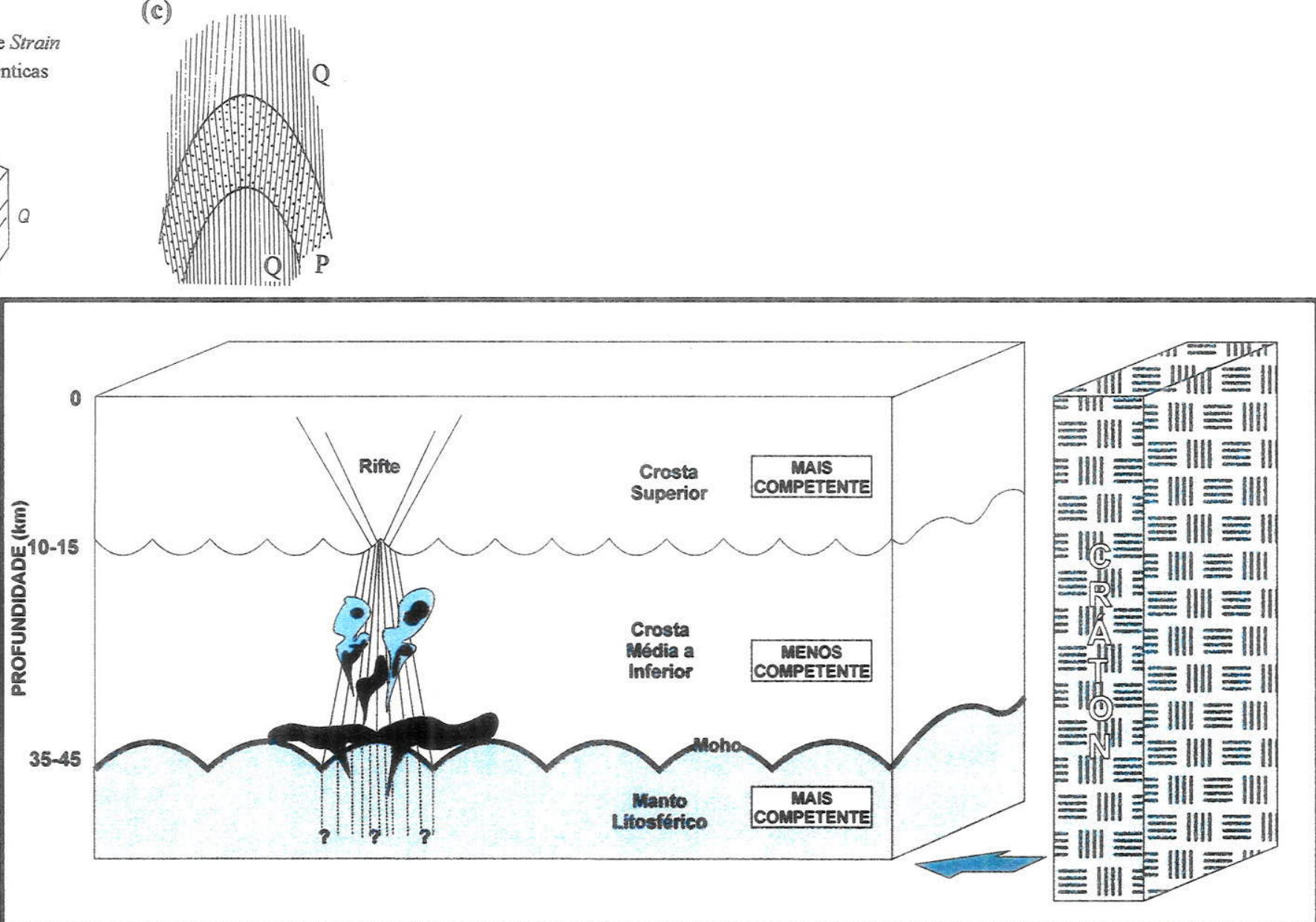

Figura 4.11 - Modelo hipotético para a deformacão da litosfera continental representante das microplacas em convergência com as placas litosféricas (crátons), durante a orogênese Brasiliana/Pan-Africana na Província Borborema. A crosta superior deforma por boudinagem acompanhando comprimentos de onda de segunda ordem. No manto litosferico, a deformação por boudinagem ou flambagem segue comprimentos de onda de primeira ordem que produzem lóbulos em direção à crosta inferior, indicando o soerguimento da Moho e da astenosfera. O fluxo de calor anomalo e as heterogeneidades mecanicas favoreceriam a nucleacão e a propagaçáo das zonas de cisalhamento litosféricas, que canalizariam fluidos (magmas e voláteis) desde as raizes mantelicas (astenosfericas ?) ate a crosta. Essa advecção do calor facilitaria a fusão parcial vertical progressiva da crosta, o alto grau metamórfico (alta-T/baixa-P) nas zonas de cisalhamento e proximidades dos corpos plutônicos sintectônicos. Em destaque, figuras modificadas de Ramsay e Huber (1987): (a) a relacão entre as elípses de strain de camadas mais e menos competentes, mostrando a refração da clivagem decorrente da mudança na elipsóide de strain, mas com elípse de strain finito comum $(P=$ camada competente, $Q=$ camada incompetente): (b) padrões do strain finito e variacões na clivagem de uma camada modificac̃̃o na nornd act pla (sendo duas camadas ativas) de Ricard e Froidevaux (1986), Allemand e Brun (1991), Burg et al. (1994). 
zonas de cisalhamento maiores/intermediárias através de zonas sub-horizontais de detachment, que acomodariam a geometria do movimento nos blocos crustais e/ou litosféricos aglutinantes. $\mathrm{O}$ arranjo dos sistemas de zonas de cisalhamento instalados nas bordas de blocos litosféricos heterogêneos, definidos pela alternância de domínios mais e menos rígidos (p.ex. terrenos gnáissicos arqueanos a paleoproterozóicos, e faixas metassedimentares, respectivamente) e a distribuição espacial periódica das anomalias gravimétricas ("ondulações" do mapas regionais e residuais) definem componentes remanescentes dos processos de extensão (boudinagem, Ricard \& Froidevaux 1986, Allemand \& Brun 1991) e compressão (buckling ou flambagem, Martinod 1991) na deformação da litosfera. Nesses modelos, os mecanismos de deformação da litosfera são uma combinação de instabilidades induzidas pelo crosta e manto. No modelo de Martinod (1991), a camada mantélica plástica conduz a mecanismos de deformação com comprimentos de onda longos de 150-300 km, enquanto a flambagem da crosta superior gera comprimentos de onda curtos de 40-60 km. O modelo de extensão, ou compressão, da litosfera subdividida em três camadas reológicas (crosta superior competente, crosta inferior menos competente e manto litosférico competente), sugere a atuação simultânea de alguns comprimentos de onda preferenciais $(30-35 \mathrm{~km}, 50 \mathrm{~km}, 70-80 \mathrm{~km}, 150 \mathrm{~km}$ e $200 \mathrm{~km}$ ), conduzindo à boudinagem da crosta superior e à alternância entre boudinagem e flambagem do manto litosférico (Ricard \& Froidevaux 1986). Os domínios convergentes (p.ex. ÍndiaÁsia) são caracterizados por processos de partição do strain em diversos ambientes e concentração da deformação em zonas de cisalhamento (Vauchez \& Nicolas 1991), geralmente thrusts na porção frontal, zonas transcorrentes e ambientes extensionais nos domínios externos (Peltzer \& Tapponier 1988).

No modelo mecânico esquemático proposto (Fig.4.11) foi considerado o buckling (ou boudinagem) da litosfera com três camada reológicas e baixo contraste de viscosidade. As nucleções das zonas de cisalhamento principais teriam origem no manto litosférico submetido a boudinagem (comprimentos de onda $>200 \mathrm{~km}$, Ricard \& Froidevaux 1986), provocando a ampla deformação na crosta inferior. Esta deformação se propaga até a interface de transição dúctil-frágil onde pode controlar a propagação de falhas conjugadas que se encontram nesta profundida e, conseqüentemente, a geração de um rifte (comprimentos de onda $<40 \mathrm{~km}$, Allemand \& Brun 1991). A ampla instabilidade reológica 
na crosta inferior (menos competente) efetua a combinação entre os comprimentos de onda da ordem de 40-200 km e favorece a nucleação de zonas de cisalhamento menores e intermediárias. Estas zonas de cisalhamento podem estar interligadas às zonas de cisalhamento principais ou permanecer individualizadas até a Moho. Este modelo mecânico proposto sugere o soerguimento da Moho por alguns quilômetros ao longo das zonas de cisalhamento, com a periodicidade controlado pelos comprimentos de onda do manto litosférico. Alguns estudos revelaram evidências da presença de amplas anomalias de densidade em profundidade ao longo das zonas de cisalhamento, e da canalização de fluidos contendo $\mathrm{CO}_{2}$ de origem mantélica. No entanto, conforme discutido por Pili (1997), permanece como questão aberta se as anomalias representam o soerguimento do manto em estado sólido ou de magmas de origem mantélica (fusão parcial do manto litosférico) canalizados ao longo das zonas de cisalhamento. A Fig. 4.11 sugere a atuação de ambos os processos, onde o manto soerguido produziria a fusão da crosta inferior e geração de magmas na base da crosta, que aliados à intensidade e concentração da deformação (strain heterogêneo) propiciaria a transposição nos limites da Moho (ver Fig.8.4 e 8.5). 


\section{5 - ESPECTROMETRIA DE REFLECTÂNCIA APLICADA AO MAPEAMENTO GEOLÓGICO DOS MACIÇOS SÃO JOSÉ DO CAMPESTRE E CALDAS BRANDÃO}

\section{1 - Considerações Iniciais}

Com a variedade de imagens multiespectrais e sensores disponíveis tornou-se imprescindivel a compreensão da qualidade dos dados obtidos e o amplo acesso ao bom desempenho destes produtos para aplicações geológicas. No caso do Landsat 5-TM, o investigador é confrontado com o desafio de obter das seis bandas não-termais (bandas 1-5 e 7) as melhores informações, geralmente a partir de três bandas combinadas num sistema de cores. As formas de representações mais freqüentes das cores são: (1) a designação dos digital numbers (DN's) nas cores primárias do sistema $\mathrm{RGB}(\mathrm{R}=$ Vermelho, $\mathrm{G}=$ Verde, $\mathrm{B}=$ azul), e (2) o sistema IHS ( $I=$ Intensity, $\mathrm{H}=$ Hue $\mathrm{S}=$ Saturation), usado na definição matemática da cor em coordenadas cilíndricas ou esféricas (Edwards \& Davis 1994).

Os procedimentos empreendidos nos tratamentos digitais das imagens do Landsat 5-TM seguiram dois estágios, anteriores à análise e interpretação visual das imagens resultantes. O primeiro estágio foi a seleção dos conjuntos de três bandas para aplicação no sistema RGB, que pode ser realizada por processos de decisões a priori ou por métodos estatísticos (Yésou et al. 1993a), como empregado neste trabalho. No segundo estágio foi efetuada a redução da dimensionalidade das informações contidas nas bandas com base nos métodos de razão de bandas e análise fatorial, onde os tratamentos usados foram a Análise por Principais Componentes (APC ou PC), IHS e HRGB (Hue/Red/Green/Blue, Liu \& Moore 1990), aplicados ao conjunto das seis bandas (bandas $1-5$ e 7) e/ou num grupo selecionado previamente com base na análise estatística da redundância entre as bandas.

Nos tratamentos digitais baseados nas medidas de espectrometria de reflectância de diversas litologias, foram usadas seis bandas do Landsat 5-TM (bandas 1-5 e 7) da cena 214/065 do Landsat 5-TM de 10/julho/1989, com resolução espacial de $30 \mathrm{~m}$. A principal área selecionada possui cerca de $3850 \mathrm{~km}^{2}$, entre os meridianos $35^{\circ} 32^{\prime} 50^{\prime \prime}-36^{\circ} 02^{\prime} 50^{\prime \prime} \mathrm{W}$ e paralelos $06^{\circ} 46^{\prime} 22^{\prime \prime}-07^{\circ} 24^{\prime} 36^{\prime \prime} \mathrm{S}$, com a cidade de Campina Grande/PB localizada próximo ao centro da área, e envolvendo parcialmente a região de coleta das amostras para as análises espectrométricas. A partir desta área foram destacadas outras subáreas para maior 
detalhamento, com enfoque na distinção das principais unidades litológicas e realce das feiçð̃es deformacionais. Os processamentos digitais foram realizados com o software ERMapper v.5.2-UNIX da Earth Resource Mapping Pty Ltd., disponivel no Centre for Remote Sensing do Imperial College-University College of London (Londres, Inglaterra).

Para a região estudada, sempre se considerando as questões temporais na análise dos fatores geológicos, as imagens foram avaliadas quanto à eficiência que apresentaram: (1) na identificação e discriminação entre as diferentes unidades de paisagem (solos, vegetação, litologias, estruturas, etc.), principalmente das litologias que tiveram os espectros de reflectância analisados; (2) no realce dos elementos estruturais do terreno (foliações, lineações, falhas); (3) na produção de imagens com boa resolução espacial, e que não tenham gerado artefatos que interfiram na análise visual.

\section{2 - Aspectos Petrográficos e Geoquímicos das Amostras Submetidas à Espectrometria de Reflectância}

Para os procedimentos de espectrometria de reflectância foram selecionadas amostras representativas dos ortognaisses migmatíticos do embasamento, dos micaxistos $\mathrm{e}$ paragnaisses da Faixa de Micaxistos de Barra de Santa Rosa, dos fácies alcalinos dos plútons de Japi, Algodão e Caxexa, e os fácies porfiriticos dos granitóides Jandaíra, Pocinhos e Complexo Campina Grande (CCG). A análise das relações texturais (interrelações e granulometria dos grãos) e composição química permitiu a compreensão das formas das assinaturas espectrais das amostras-de-mão e grãos minerais específicos destas rochas. A análise desses elementos, aliados aos fatores geomorfológicos e estruturais condicionantes das amostras, favorece a correlação das observações pontuais à escala regional do mapeamento e a interpretação das imagens nos tratamentos digitais. Os índices de catalogações das amostras foram dispostos entre parênteses e as localizações das amostras podem ser acompanhadas nos mapas das Fig. 4.7, 5.22 e 5.26. Os principais aspectos de campo, petrográficos e geoquímicos das litologias analisadas foram descritos a seguir.

\section{Aspectos de Campo e Petrográficos:}

\section{- Ortognaisses Migmatíticos do Embasamento (V-514, V-526):}

As amostras selecionadas para análise espectral correspondem às litologias típicas do complexo gnáissico-migmatítico do setor oeste, próximo ao contato com a porção norte 
da faixa de micaxistos de Barra de Santa Rosa (Fig. 5.26) Os ortognaisses compreendem rochas, principalmente, granodioríticas a tonaliticas equigranulares médias a grossas, leucoa mesocráticas, textura granolepidoblástica a granonematoblástica, com bandamento definido por faixas máficas (biotita + anfibólio) e félsicas (quartzo + feldspatos) intercaladas. A mineralogia é essencialmente definida por quartzo (40-45\%), plagioclásio (25-30\%), microclina (10-15\%), anfibólio (20-25\%) e biotita (5-10\%). Os minerais acessórios mais freqüentes são apatita, zircão e alanita, e como secundários o epídoto, titanita, clorita, mica branca, carbonatos e opacos. O quartzo ocorre como cristais xenomórficos com extinção ondulante e diâmetro médio de $1,0 \mathrm{~mm}$, ribbons de largura entre 0,5-1,0 mm e agregados policristalinos. O plagioclásio (An40-45) constitui grãos idio- a hipidiomórficos de até $4,0 \mathrm{~mm}$ de diâmetro médio, por vezes com intensa saussuritização ou sericitização. Os cristais de microclina pertítica são xeno- a hipidiomórficos e maiores que 1,0 mm. A hornblenda xeno- a hipidiomórfica poiquiloblástica (inclusões de quartzo, apatita e zircão) de dimensões entre $2,0-6,0 \mathrm{~mm}$ estão orientados e estirados na foliação $\mathrm{S}_{2}$ formando microboudins. A biotita ocorre como palhetas isoladas (até $2,0 \mathrm{~mm}$ de eixo maior) poiquiloblásticas (inclusões de titanita, zircão, quartzo e opacos) ou em agregados com anfibólios e opacos e constitui o principal marcador do fabric da rocha. Uma biotita verde a castanho claro hipidiomórfica com contatos retos e serrilhados trunca a biotita mais antiga (foliação $S_{1}$ ), definindo a foliação $S_{2}$, juntamente com hornblenda e os agregados policristalinos. Os minerais acessórios (zircão, apatita e titanita) formam grãos inferiores a $0,3 \mathrm{~mm}$ geralmente como inclusões na biotita, anfibólios e microclina. Os opacos representam comumente seções quadrangulares da magnetita $(0,2-5,0 \mathrm{~mm})$.

\section{- Micaxistos (V-516, V-517, V-518):}

Os micaxistos da porção centro-norte da faixa de Barra de Santa Rosa foram selecionados por apresentarem paragêneses no fácies anfibolito (Foto 4.16a). Desta forma, foi possível a comparação das respostas espectrais das paragêneses metamórficas na evolução desde o fácies anfibolito até o fácies granulito (Foto 4.16b), nos paragnaisses migmatíticos (Foto 6.26), entre a área com $\mathrm{S}_{3}$ de baixo ângulo para SE e a ZCRP. Os micaxistos apresentam textura lepidogranoblástica a lepidonematoblástica, que define a foliação principal da rocha $\left(\mathrm{S}_{0}+\mathrm{S}_{2} / \mathrm{S}_{3}\right)$, coloração cinza esverdeada a cinza escuro, compostos essencialmente por biotita (30-50\%), quartzo (20-40\%), plagioclásio (5-15\%), 
granada (2-5\%), clorita (0-2\%) e sillimanita (0-3\%) e proporçðes variadas de K-felsdapato, andaluzita, estaurolita, muscovita, turmalina e opacos. O quartzo $(0,3-1,0 \mathrm{~mm})$ forma agregados em ribbons associado à biotita e granada. Três gerações de biotitas podem ser observadas, com predomínio daquela que condiciona a foliação $\mathrm{S}_{3}$ : (i) a biotita mais antiga é geralmente mais fina (menor que $0,5 \mathrm{~mm}$ ) marcando a foliação $\mathrm{S}_{2}$; (ii) a biotita $\sin -\mathrm{S}_{3} \mathrm{em}$ palhetas de 0,1-4.0 mm (eixo maior) com inclusões de quartzo, apatita, zircão e opacos, geralmente acompanhada de sillimanita, andaluzita, granada e estaurolita; (iii) a biotita que define o fabric nos ultramilonitos $\mathrm{e}$ as superficies tardi- $\mathrm{S}_{3}$ e $\mathrm{C}_{3}$, freqüentemente desestabilizada para clorita + muscovita + opacos. O plagioclásio (An30-24) forma cristais xeno- a hipidiomórficos $(0,2-2,0 \mathrm{~mm})$ parcialmente transformados para mica branca. A granada $(0,5-2,5 \mathrm{~mm})$ ocorre em grãos xeno- a hipidiomórficos com inclusões de quartzo e biotita. As geraçðes de granadas envolvem episódios cedo-, sin- e tardi- $S_{3}$. Os mais comuns são os grãos alongados pré- a $\sin -S_{3}$ que defletem a foliação $S_{3}$ da biotita, com freqüentes fibras de sillimanita nas sombras de pressão e textura helicítica. As granadas tardi- $\mathrm{S}_{3}$ estão sempre defletindo a foliação milonítica tardia. A andaluzita forma cristais xenomórficos de até $1,5 \mathrm{~mm}$, freqüentemente poiquiloblásticos (inclusões de quartzo e biotita). A sillimanita constitui agregados fibrosos acompanhando as biotitas $\sin -\mathrm{S}_{3}$ e nas sombras de pressão dos porfiroblastos de granada e nos necks de andaluzitas boudinadas.

\section{- Paragnaisses (V-525, V-527):}

Os paragnaisses ocorrem no corredor central da ZCRP, geralmente com bandamento milonitico definido por faixas de biotita-sillimanita-granada (paleossoma) e remobilizados quartzo-feldspáticos (neossoma), com muscovita, turmalina e granada intercalados (Foto 6.26). A assembléia metamórfica correlacionada aos critérios texturais e cinemáticos caracteriza condições metamórficas de fácies granulito e migmatização sincisalhamento $\mathrm{D}_{3}$. Intercalados aos migmatitos pelíticos ocorrem granulitos máficos com ortopiroxênio + clinopiroxênio + granada em equilibrio com hornblenda verde escura e biotita marrom, que definem a foliação $\mathrm{S}_{3}$. A mineralogia essencial nas faixas máficas é composta por biotita (40-45\%), plagioclásio (15-20\%), quartzo (15-20\%), granada (10-15 $\%$ ), sillimanita (5-10\%). Os minerais acessórios são comumente clorita, muscovita, turmalina e opacos. A biotita $\left(\mathrm{TiO}_{2}=2,04 \%\right)$ ocorre em palhetas de coloração marrom escuro (até 2,0 mm de eixo maior), interdigitadas à sillimanita compondo o fabric milonítico 
de alta temperatura. A transformação típica é para muscovita rica em $\mathrm{Al}$ e Ti $\left(\mathrm{Al}_{2} \mathrm{O}_{3}=35,1\right.$ $\%, \mathrm{TiO}_{2}=0,80 \%$ ), clorita e opacos. As inclusões mais freqủentes são de zircão, quartzo, opacos e sillimanita. O plagioclásio mirmequítico (An20) forma porfiroclastos xeno- a hipidiomórficos (2,0 a $6,0 \mathrm{~mm})$. O quartzo xenomórfico comumente acompanha a foliação milonítica como ribbons $(\sim 2,0 \mathrm{~mm})$. A microclina pertítica é xeno- a hipidiomórfica, com geminação em xadrez e dimensões entre 0,2 e 3,5 mm e associados a quartzo e plagioclásio. A granada é xeno- a hipidiomórfica $(0,4 \mathrm{a} 5,0 \mathrm{~mm})$, freqüentemente estiradas e boudinadas. A sillimanita é geralmente fibrosa acompanhando o fabric de alta temperatura. A turmalina prismática com até $2,0 \mathrm{~mm}$ (eixo maior) é freqüente nas zonas de alto strain, compondo até $5 \%$ da rocha e associadas à muscovita, clorita e relictos de biotita e sillimanita.

\section{- Suíte Alcalina do Plúton de Japi (MH-107, VMH-1):}

No plúton de Japi, a suite alcalina é composta por sienogranitos, álcali-sienitos e álcali-granitos, onde os minerais félsicos predominam na moda ( $85-95 \%$ de plagioclásio + microclina + quartzo), com piroxênio e anfibólio são as fases máficas dominantes em alguns fácies, enquanto os minerais opacos prevalecem em outros. O fabric SPD (SL ou S>L) é marcado pelo estiramento do quartzo e minerais máficos. O plagioclásio (An24-28), por vezes mirmequitico, apresenta transformação para mica branca + epidoto granular + carbonato. A microclina pertítica (tipo string e stringlets) forma cristais anédricos a subédricos $(\sim 2,0 \mathrm{~mm})$. O quartzo é anédrico e forma agregados quartzo-feldspáticos recristalizados e ribbons. O clinopiroxênio (augita sódica) constitui a fase máfica dominante, caracterizando a afinidade alcalina da suíte. Os cristais são subédricos a euédricos $(\sim 2,0 \mathrm{~mm})$ com inclusões de opacos e plagioclásio, e freqüente transformação para anfibólio. $O$ anfibólio primário tem forma euédrica a subédrica do tipo hornblenda magnesiana e sofre transformação parcial para clorita. A biotita está cloritizada, com geração de epídoto e opacos finos nos planos de clivagem. A apatita e zircão ocorrem como cristais prismáticos alongados. Os minerais opacos ocorrem como cristais euédricos (magnetita) ou anédricos (Ti-magnetita), em geral com coroas de titanita indicando esfenitização tardia.

\section{- Granitóides Caxexa e Serra do Algodão (MC-12, VC-1, V-515, V-519):}

Os plútons de Caxexa e Serra do Algodão mostram uma ampla semelhança petrográfica e textural, relacionados ao contexto transtracional da ZCRP. O plúton Caxexa ocorre como corpo tabular alongado intrusivo na zona de transferência (rampa oblíqua) de 
baixo ângulo entre a estrutura em flor negativa extensional e a ZCRP dextral, que justapõe os gnaisses do embasamento e os micaxistos de Barra de Santa Rosa. O plúton Algodão constitui um antiforme isoclinal intrusivo nos augen gnaisses e ortognaisses do embasamento, presentes no núcleo do antiforme, e nos metassedimentos da faixa de Barra de Santa Rosa envolvidos pela ZCRP com cinemática transcorrente dextral, no setor central de alto mergulho da estrutura em flor negativa. Os granitóides apresentam fabric PFC e SPD dispostos paralelamente à ZCRP e interceptando os elementos da deformação $\mathrm{D}_{2}$ mais antiga, com freqüentes xenólitos de rochas encaixantes milonitizadas.

As rochas alcalinas compreendem álcali-granitos a álcali-sienitos com aegirinaaugita e pirocloro de textura fina, leucocráticas $(<15 \%$ de minerais máficos) de coloração rósea a cinza esbranquiçada. A microclina, o plagioclásio e o quartzo constituem a mineralogia dominante, em proporções superiores a $85 \%$ da moda, sendo os minerais secundários clinopiroxênio, anfibólios, granada, pirocloro, titanita, zircão, apatita e epídoto. A microclina pertítica forma cristais subédricos a anédricos de até $4,0 \mathrm{~mm}$. O plagioclásio (An25-30) é subédrico a anédrico $(0,5$ a $3,5 \mathrm{~mm})$, com transformação incipiente para mica branca + epídoto + carbonatos. O quartzo constitui grãos anédricos de dimensões inferiores a 3,0 mm e agregados policristalinos estirados e ribbons. O clinopiroxênio da série aegirinaaugita é a fase máfica dominante, como cristais subédricos prismáticos e anédricos esqueletais (forma "em atol") de dimensões inferiores a 1,0 mm. Uma orientação incipiente dos cristais define possivelmente um fabric magmático (PFC). A transformação mais freqüente é para anfibólio, carbonatos, epídotos e opacos. $\mathrm{O}$ anfibólio primário (riebequita) apresenta grãos anédricos, com dimensões entre 0,1 e $0,5 \mathrm{~mm}$. A granada (almandina) forma grãos subédricos a euédricos de coloração amarelada e ocorre associada à titanita. A titanita ocorre em grãos euédricos a subédricos de seções losangulares menores que $0,5 \mathrm{~mm}$. A apatita e o zircão formam cristais subédricos prismáticos menores que $0,3 \mathrm{~mm}$. Os opacos apresentam seções quadrangulares (magnetita) e anédricas dispostas nas clivagens dos piroxênios ou estiradas com coronas de titanita.

\section{- Suíte Porfirítica do Plúton Jandaíra (V-521, V-522, V-523):}

$\mathrm{O}$ plúton Jandaíra abrange monzogranitos a granodioritos com granada, mesocráticos e inequigranulares intrusivos nos micaxistos, de coloração cinza claro a róseo, com fabric PFC bem desenvolvido em todo o plúton, e um fabric SPD quando interceptado 
por faixas miloniticas métricas a decamétricas. Enclaves magmáticos máficos, desenvolvendo relações de magma mingling com as rochas granitóides predominantes, ocorrem de maneira conspicua pelo plúton.

A mineralogia principal (liquidus) é composta por quartzo (30-35\%), K-feldspato (25-30\%), plagioclásio (30-35\%) e biotita (15-20\%), tendo como acessórios hornblenda, titanita, zircão, apatita, alanita, epídoto, e opacos. Os minerais secundários (subsolidus) mais comuns são mica branca, clorita, carbonato, albita, titanita e epídoto granular. O quartzo é anédrico com até $4,0 \mathrm{~mm}$. Os grão menores $(0,3$ a $0,5 \mathrm{~mm})$ formam agregados policristalinos, associados ao plagioclásio fino na foliação milonítica. A microclina pertítica é subédrica a anédrica $(0,4$ a $1,0 \mathrm{~cm})$, freqüentemente como pórfiros orientados na deformação de fluxo viscoso (PFC) e típicas feições de entelhamento. Nas faixas miloníticas constituem os porfiroclastos com dimensões de até $1,0 \mathrm{~cm}$ circundados por quartzo estirado. O plagioclásio mirmequitico (tipo bulbo) forma cristais subédricos $(<4,0 \mathrm{~mm}$ ), e freqüentes transformaç̃es para mica branca + carbonato. A biotita constitui a fase máfica principal, como palhetas orientadas de até $3,0 \mathrm{~mm}$, ou formando agregados com anfibólio, opacos e titanita. Alguns cristais com kinks denotam o fabric SPD, comumente contornando cristais de granada e quartzo estirados. A transformação parcial para clorita e o intercrescimento vermiforme de quartzo são freqüentes. Os anfibólio (hornblenda edenítica) são subédricos. A sillimanita forma cristais fibrosos aleatórios pela rocha, provavelmente como xenocristal das fases metapeliticas. O zircão, a titanita e a apatita estão geralmente inclusos na biotita e nos feldspatos. Os opacos possuem cristais euédricos quadráticos (magnetita) e anédricos nas clivagens da biotita e clorita.

- Granitóide Pocinhos (V-510, V-511, V-528, V-530):

Os principais fácies descritos para o granitóide Pocinhos foram monzo- a sienogranitos, monzonitos e monzodioritos (Foto 4.21). Todavia, não foi empreendido o mapeamento faciológico detalhado do batólito. $\mathrm{O}$ corpo tem as bordas controladas por zonas de cisalhamento dominado pelo fabric SPD. No centro do corpo predomina o fabric PFC, geralmente subparalelo ao SPD, com o alto strain restrito às zonas de cisalhamento secundárias. Os indicadores cinemáticos do fabric SPD assinalam movimentos alternados dextral e topo para baixo. Diversos critérios sinistrais e simétricos foram descritos, sugerindo a participação de um componente de achatamento simultâneo à transcorrência. 
O plagioclásio mirmequitico (An30-35) tem formas euédricas a subédricas $(0,3-$ $5,0 \mathrm{~mm}$ ), por vezes transformado para mica branca, carbonatos e epidoto. A microclina é subédrica, comumente com fenocristais $(>5,0 \mathrm{~mm}$ ) pertíticos (tipo filetes e gotas) e com textura mortar. A biotita forma palhetas euédricas, marrom avermelhada, poiquilítica (inclusões de titanita, opacos e anfibólio) e alterada para clorita, muscovita e epidoto. A hornblenda forma cristais prismáticos $(0,5-3,0 \mathrm{~mm})$ em textura simplectítica com quartzo, inclusões de titanita, opacos, zircão e apatita. Os minerais acessórios subédricos a euédricos mais comuns são a titanita, apatita, opacos e zircão.

\section{- Granodiorito e Quartzo-Monzonito do CCG (V-534, V-535, V-539, V-540):}

O Complexo Campina Grande (CCG) compreende quartzo monzonitos, granodioritos e quartzo-monzodioritos porfiríticos mesocráticos, freqüentemente associados em magma mingling e mixing a enclaves máficos de composições varjando de dioritos a quartzo-dioritos (Foto 4.22). Estas rochas são mesocráticas de coloração cinza a rósea, inequigranulares e porfiríticas. O caráter sintectônico dos plútons e definida pela coerência entre os fabrics PFC e SPD, onde os indicadores cinemáticos indicam predominância do caráter dextral nas bordas. Entretanto, a presença constante de critérios simétricos e sinistrais denota um regime de cisalhamento geral, provavelmente de caráter transtracional.

Os fácies granodiorítico a monzonítico são compostos por plagioclásio (40-50\%), microclina (30-40\%), hornblenda (20-25\%), quartzo (10-20\%), com acessórios de ortopiroxênio, clinopiroxênio, biotita, titanita, zircão, apatita, monazita e opacos. O plagioclásio mirmequítico (An25-30) é subédrico com diâmetros de até 2,0 mm, por vezes saussuritizado. A microclina pertítica ocorre como cristais subédricos a anédricos de até 5,0 $\mathrm{mm}$, e como porfiroclástos centimétricos. A magnésio hornblenda $(1,0-5,0 \mathrm{~mm})$ ocorre em formas subédricas de coloração verde oliva a amarelada. O quartzo mostra-se anédrico $(0,1-$ $2,0 \mathrm{~mm}$ ) com textura em ribbons e poligonal. O clinopiroxênio (diopsídio) forma cristais subéricos a anédricos de tamanhos variados $(<3,0 \mathrm{~mm})$ comumente transformado para anfibólios. Os minerais acessórios (enstatita, biotita, titanita, zircão, apatita, monazita) formam cristais subédricos a euédricos de dimensões variando de 0,1 a $1,0 \mathrm{~mm}$, isolados ou agregados segundo os planos de foliação da rocha. Os opacos formam seções quadráticas (magnetita) de até 2,0 mm e anédricas (Ti-magnetita?), geralmente associados à hornblenda, 
clinopiroxênio e biotita. Por vezes, as titanitas formam coroas envolvendo os opacos, indicando processos tardios de esfenitização.

\section{Afinidades Geoquímicas das Suítes Graníticas:}

As análises quimicas das rochas das suites alcalinas de Japi, Caxexa, Algodão e da suite porfirítica de Jandaíra foram realizadas com Fluorescência de Raios-X no Laboratoire de Pétrologie et Tectonique da Université Claude Bernard-Lyon 1 (Lyon, França) e os resultados encontram-se listados no Anexo 2. Com esta avaliação buscou-se caracterizar a influência dos óxidos de elementos maiores nos aspectos diagnósticos definidos pelas assinaturas espectrais das rochas analisadas, inclusive no aporte de informações sobre variações químicas discriminatórias entre aquelas de aspectos petrográficos similares, caso das rochas das suites alcalinas.

As amostras analisadas mostraram extensa variação nos teores de $\mathrm{SiO}_{2}(60,59-$ $76,86 \%)$ e forte enriquecimento em álcalis $\left(\mathrm{Na}_{2} \mathrm{O}+\mathrm{K}_{2} \mathrm{O}\right.$, entre 8,0-14,74\%), com marcante empobrecimento em $\mathrm{CaO}(0,17-3,42 \%)$ e $\mathrm{MgO}$ (valores $<1,55 \%$ ).

No diagrama QP (Fig. 5.1) de Debon e Le Fort $(1983,1988)$ a suite porfiritica Jandaira mostrou trends de transição entre rochas subalcalinas escuras (SALKD, equivalente a shoshoníticas) e cálcio-alcalinas (CALK), numa associação químico-mineralógica de quartzo-monzonitos e granitos. Para as suites de Japi, Caxexa e Algodão o arranjo desordenado das amostras caracterizaram trends variáveis entre alcalinos supersaturados (ALKOS) e cálcio-alcalinos (CALK). No mesmo diagrama, as suítes de Japi e Caxexa foram classificadas predominantemente como monzogranitos e sienogranitos, com granodioritos e quartzo-sienitos subordinados. A maioria das amostras de Algodão ocupam os campos dos monzogranitos e sienogranitos, duas amostras o campo dos granodioritos, duas amostras indicam quartzo-sienitos, enquanto três amostras não se classificaram.

Nos diagramas de variações dos óxidos de elementos maiores vs. $\mathrm{SiO}_{2}$ de Harker

(Fig. 5.2) ficaram evidentes as principais diferenças químicas entre a suíte porfiritica Jandaíra e as suites alcalinas, dispostas em trends distintos, refletindo a $s$ diferenças petrográficas e texturais. No diagrama $\mathrm{K}_{2} \mathrm{O}$ vs. $\mathrm{SiO}_{2}$, observando as linhas divisórias de Pecerillo e Taylor (1976), a suíte Jandaíra foi considerada como cálcio-alcalina de alto-K, enquanto as suítes alcalinas foram identificadas como transicionais entre a série shoshonítica e alcalinas de alto-K. Na suíte Jandaíra os trends, em típicas trajetórias curvilíneas e 


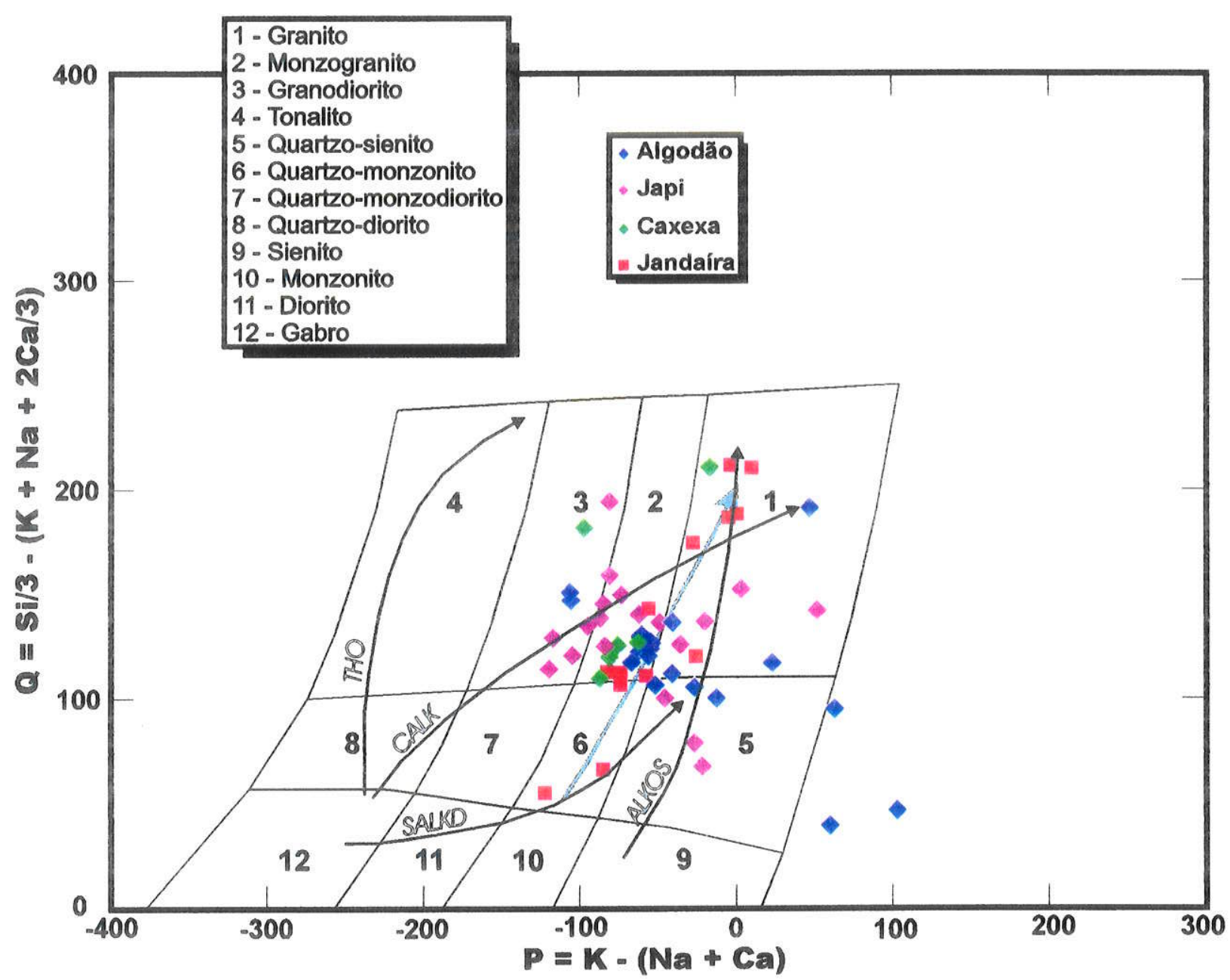

Figura 5.1 - Diagrama discriminante QP (Debon \& Lefort 1983) para a caracterização geoquímica das rochas graníticas. A seta cinza contínua marca o trend da suíte porfirítica de Jandaíra. Abreviaturas dos trends: THO $=$ Toleítica, CALK $=$ Cálcio-alcalina, SALKD $=$ Subalcalina escura, ALKOS = Alcalina supersaturada. 


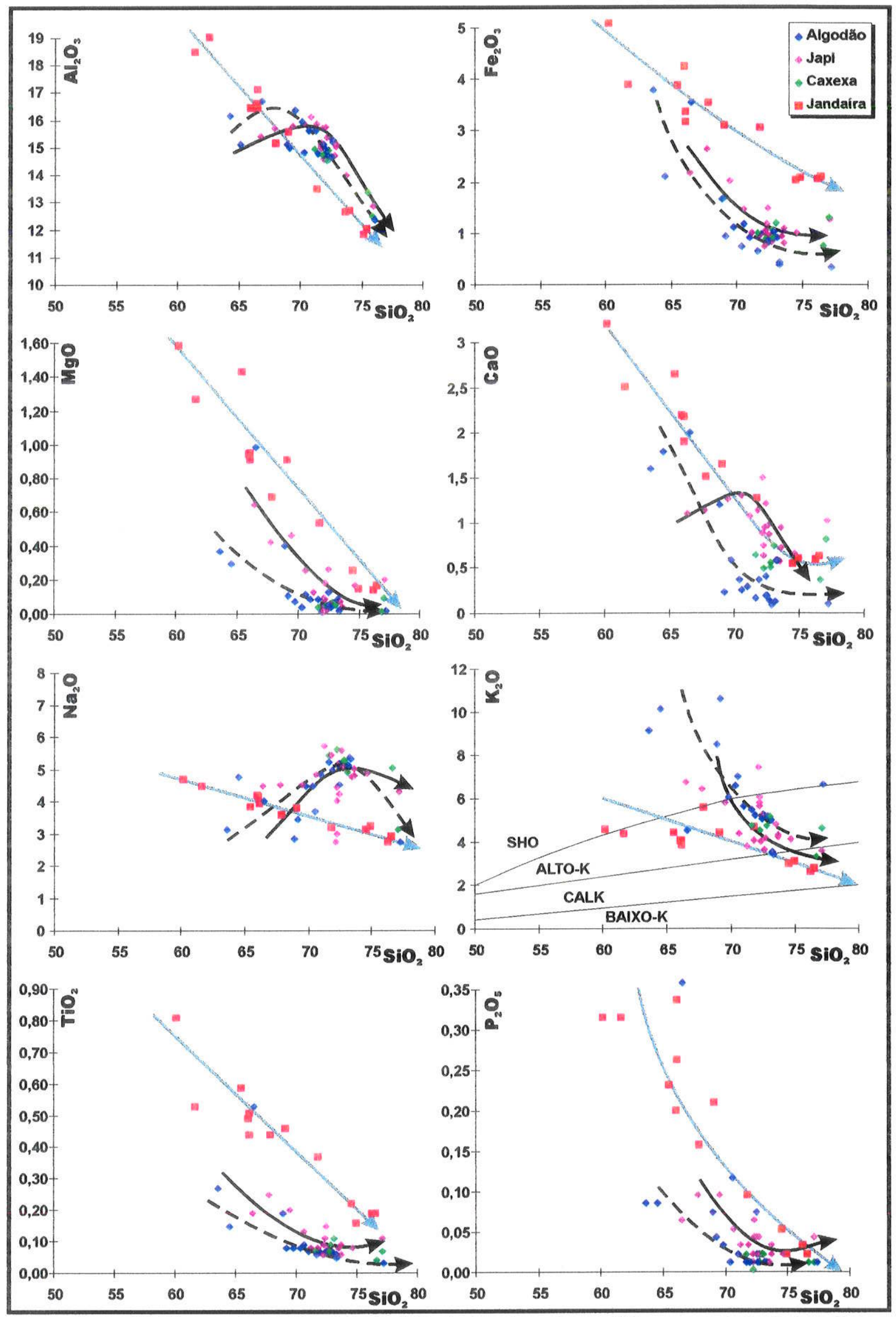

Figura 5.2 - Diagramas de variação química dos óxidos de eiementos maiores vs. $\mathrm{SiO}_{2}$ para a caracterização das rochas graniticas. A seta continua preta marca o trend da suite alcalina de Japi, a seta cinza contínua marca o trend da suite porfiritica de Jandaira e a seta tracejada preta marca o trend das suites alcalinas de Caxexa e Algodão. No diagrama $\mathrm{K}_{2} \mathrm{O}$ vs. $\mathrm{SiO}_{2}$, a definição dos campos de composição das séries é de Pecerillo e Taylor (1976) e Ewart (1982). Abreviaturas dos campos no diagrama $\mathrm{K}_{2} \mathrm{O}$ vs. $\mathrm{SiO}_{2}: \mathrm{SHO}=$ Shoshonítica, Alto-K = Alto-potássio, CALK = Cálcio-alcalina, Baixo-K = Baixo-potássio. 
ingremes, mostram a relação inversamente proporcional entre $\mathrm{SiO}_{2}$ e os óxidos $\mathrm{Al}_{2} \mathrm{O}_{3}$, $\mathrm{Fe}_{2} \mathrm{O}_{3}, \mathrm{MgO}, \mathrm{CaO}, \mathrm{TiO}_{2}$ e $\mathrm{P}_{2} \mathrm{O}_{5}$, com trajetórias retilíneas e suaves para $\mathrm{Na}_{2} \mathrm{O}$ e $\mathrm{K}_{2} \mathrm{O}$, refletindo pequenas variações nos processos de fracionamento de fenocristais de $\mathrm{K}$ feldspato. Os teores de $\mathrm{Fe}_{2} \mathrm{O}_{3 \mathrm{t}}, \mathrm{CaO}, \mathrm{MgO}, \mathrm{TiO}_{2}$ e $\mathrm{P}_{2} \mathrm{O}_{5}$ são superiores na suite Jandaíra do que nas suites alcalinas, ocorrendo o inverso para os teores de $\mathrm{Na}_{2} \mathrm{O}$ e $\mathrm{K}_{2} \mathrm{O}$. As rochas das suítes alcalinas apresentaram decréscimos bem definidos em trajetórias curvas, em relação ao $\mathrm{SiO}_{2}$, para os óxidos de $\mathrm{Fe}_{2} \mathrm{O}_{3}, \mathrm{MgO}, \mathrm{K}_{2} \mathrm{O}, \mathrm{TiO}_{2}$ e $\mathrm{P}_{2} \mathrm{O}_{5}$. Para os $\mathrm{Al}_{2} \mathrm{O}_{3}$ e $\mathrm{Na}_{2} \mathrm{O}$, as suítes alcalinas descrevem uma trajetória curva inicialmente aumentando os teores e diminuindo em seguida, fato que se repete para o $\mathrm{CaO}$ na suite de Japi. A dispersão das suítes alcalinas em alguns desses gráficos $\left(\mathrm{CaO}, \mathrm{Na}_{2} \mathrm{O}\right.$ e $\left.\mathrm{K}_{2} \mathrm{O}\right)$ denota a heterogeneidade dos magmas. Os diagramas destacam os trends diferenciados entre as suites alcalinas de Japi e Algodão + Caxexa, mostrando Japi com teores relativamente enriquecidos em $\mathrm{Al}_{2} \mathrm{O}_{3}, \mathrm{Fe}_{2} \mathrm{O}_{3}, \mathrm{MgO}$, $\mathrm{CaO}$ e $\mathrm{P}_{2} \mathrm{O}_{5}$. Estes teores podem ser correlacionadas às diferenças nas associações paragenéticas desses granitóides, com a ocorrência na suíte alcalina de Japi de hornblenda magnesiana $(\mathrm{Fe}>18 \%, \mathrm{Mg}>10 \%, \mathrm{Ca}<11 \%$ ) como mineral máfico primário dominante, com a augita sódica $\left(\mathrm{Fe}>9 \%, \mathrm{Mg}>11 \%\right.$ ), elevando os teores em $\mathrm{CaO}, \mathrm{MgO}$ e $\mathrm{FeO}_{\mathrm{t}}$, enquanto em Algodão + Caxexa predominam os cristais de aegirina-augita e os anfibólios são sobretudo resultantes da transformação do piroxênio.

Os diagramas discriminantes TAS e R1-R2 (Fig. 5.3 e 5.4, respectivamente) foram empregados na caracterização complementar das afinidades geoquímicas das suites analisadas. No diagrama TAS, exibindo a linha divisória proposta por Irvine e Baragar (1971), a suíte Jandaíra acompanha o trend monzonítico ou subalcalino, enquanto as suites alcalinas seguem trends alcalinos não coincidentes subparalelos para Japi e Algodão, com as amostras de Caxexa correlacionadas ao trend de Algodão, que indica teores sutilmente mais elevados em álcalis. O diagrama R1-R2 (De La Roche et al. 1980, Batchelor \& Bowden 1985) compara as suítes alcalinas e porfirítica analisadas às associações modernas de tendências tardi-orogênica a anorogênica, com as amostras de Jandaíra definindo um trend subalcalino, enquanto as suites alcalinas de Japi e Algodão + Caxexa ocorrem diferenciadas em dois trends alcalinos distintos e convergentes.

No contexto de séries magmáticas, os trends diferenciados das suites alcalinas de Japi e Algodão + Caxexa, além daquele para a suíte Jandaíra, presentes em todos os 


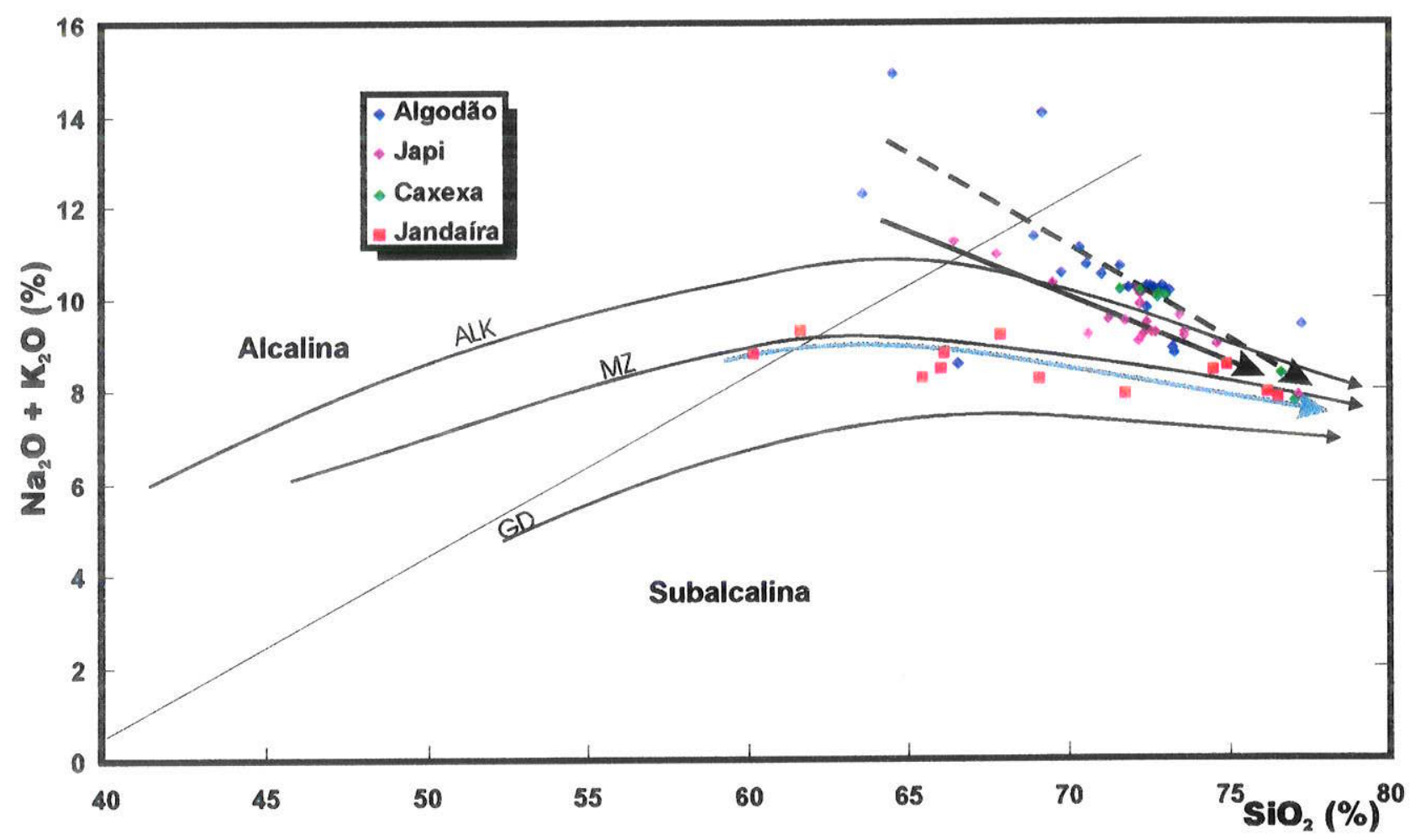

Figura 5.3 - Diagrama discriminante TAS para a caracterização geoquímica das rochas graníticas, com a linha divisoria de Irvine e Baragar (1971) e trends de Lameyre (1987). A seta continua preta marca o trend da suíte alcalina de Japi, a seta cinza marca o trend da suíte porfirítica de Jandaíra e a seta tracejada preta marca o trend das suites alcalinas de Caxexa e Algodão. Abreviaturas dos trends: ALK = Alcalina, MZ = Monzonítica, GD = Granodiorítica. 


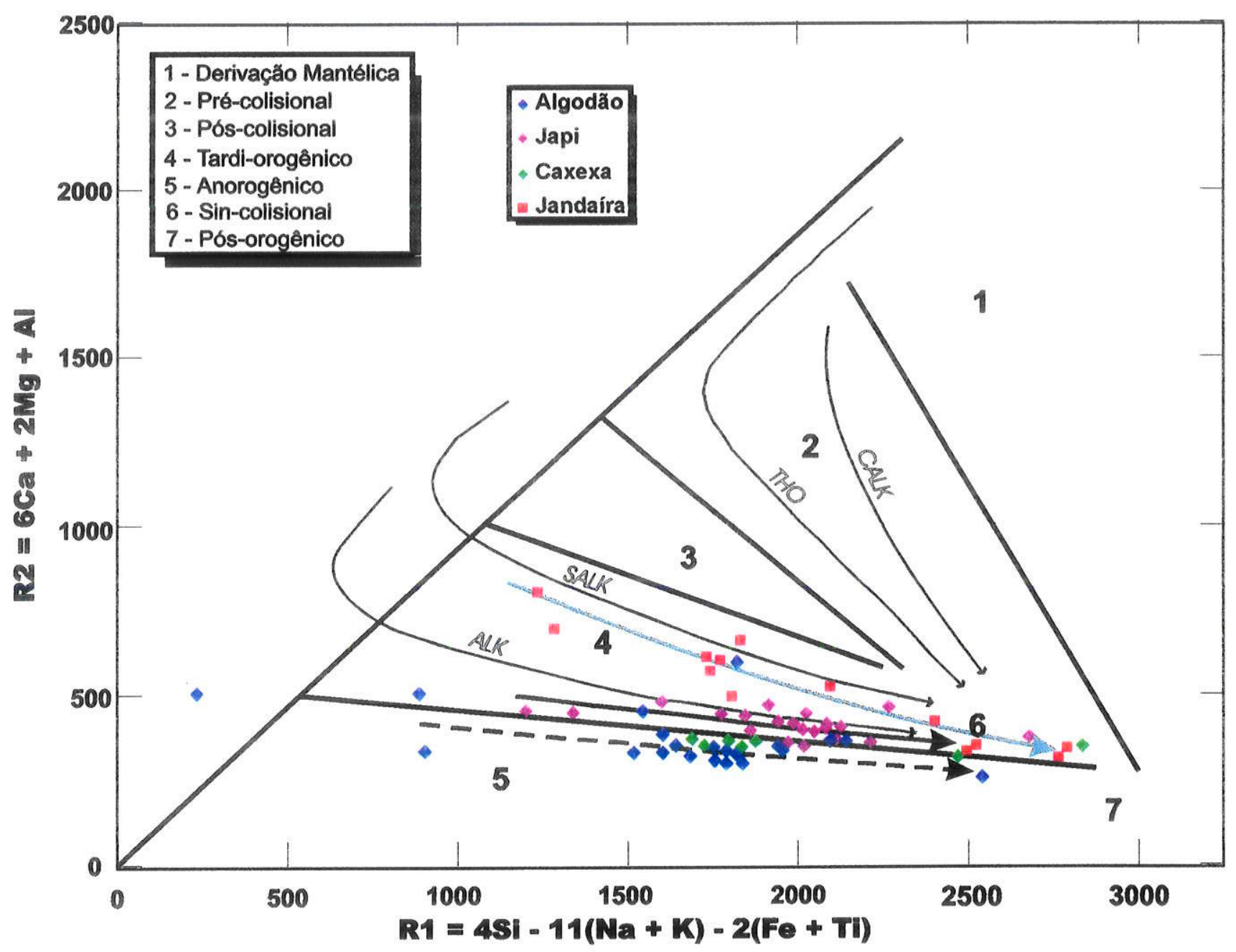

Figura 5.4 - Diagrama discriminante R1 vs. R2 (De La Roche 1980) para a caracterização geoquímica das rochas graníticas, com diferenciação dos campos para as associações orogênicas e ambientes modernos de Batchelor e Bowden (1985). A seta contínua preta marca o trend da suíte alcalina de Japi, a seta cinza contínua marca o trend da suíte porfirítica de Jandaira e a seta tracejada preta marca o trend das suítes alcalinas de Caxexa e Algodão. Abreviaturas dos trends: CALK = Cálcio-alcalina, THO = Toleítica, SALK $=$ Subalcalina, ALK $=$ Alcalina . 
diagramas empregados, caracterizam a natureza subalcalina-monzonítica da suite porfirítica Jandaíra e a tendência alcalina supersaturada das suítes de Japi, Algodão e Caxexa, provavelmente provenientes de magmas parentais distintos e/ou processos evolutivos diferenciados para os magmas.

Apesar da classificação orogênica no diagrama R1-R2, as suites alcalinas analisadas não representam intrusð̃es tardias ao ciclo magmático principal, ou anorogênicas, mas acompanham contemporâneamente os granitóides porfiriticos subalcalinos monzoníticos porfíriticos (o tipo Itaporanga, Almeida et al. 1967), os dioritos shoshoníticos (Hollanda 1996) e os leucogranitos aluminosos do tipo-S. As suítes analisadas mostram critérios de colocação sintectônicas às principais estruturas transcorrentes-extensionais (Jardim de Sá et al. 1997b), que incluem: (a) correlação da geometria dos plútons com as estruturas $\mathrm{D}_{3}$ regionais; (b) sheets e diques de granitos intrusivos no plano axial de dobras $\mathrm{F}_{3}$ e cisalhamentos extensionais tipo-C'; (c) fabrics SPD e PFC paralelos entre si e com as trajetórias regionais de $\mathrm{S}_{3}+\mathrm{L}_{3}$. A combinação destas feições com as informações geoquímicas sugere, como modelo petrogenético gerador das suítes alcalinas durante o principal evento de deformação $D_{3}$ neste setor da Província Borborema, o envolvimento: (i) de fontes de manto litosférico enriquecido e/ou metassomatizado pela percolação de fluidos por meio das zonas de cisalhamento profundas, em ambientes tectônicos de caráter extensional; (ii) soerguimento da astenosfera quente, decorrente do afinamento litosférico ao longo das zonas de cisalhamento produzindo os magmas básicos parentais que instalados na crosta inferior e/ou na base da crosta (underplating) induziriam a fusão crustal.

\section{3 - Resultados e Discussões Sobre as Assinaturas Espectrais}

Os dados espectrais apresentados foram obtidos no Laboratoire de Pétrologie Structurale da Université de Nantes (Nantes, França), onde as amostras-de-mão foram analisadas no espectrorradiômetro GER-3700 da Geophysical \& Environmental Research Corp., que atua na banda espectral entre $0,25 \mathrm{~mm}$ e $2,5 \mathrm{~mm}$ (UV a SWIR) com três conjuntos de detetores (512 Si, $128 \mathrm{PbS}, 64 \mathrm{PbS}$ ) integrados em 704 canais. O espectrorradiômetro dispunha de calibração automática conforme a iluminação da fonte natural, fibra óptica de captação para medidas em partículas com dimensões superiores a 3,0 mm e suporte do software SIGNATURE $^{\mathcal{C}}$ para visualização dos espectros em tempo-real. 
Para as análises espectrais foram selecionadas de três a quatro faces por amostra, entre faces frescas e com pátina de alteração, com pelo menos duas medidas por face e de três a quatro amostras por litologia. Nas análises espectrais dos minerais foram selecionados os grãos ou agregados policristalinos com dimensões superiores a $5,0 \mathrm{~mm}$, conforme as especificações da fibra óptica de captação, presentes nas amostras do ortognaisse do embasamento (V-514), micaxisto (V-517, V-518), granodioritos e quartzo-monzonito do CCG (V-539, V-540), suítes alcalinas de Japi (MH-107) e Algodão (V-519, V-520), suite porfiritica de Jandaíra (V-521) e Pocinhos (V-510, V-528). As medidas foram adquiridas ao ar-livre no mês de abril/1997 (primavera), sob condições de temperatura entre $28-30^{\circ} \mathrm{C}$, umidade do ar entre $40-50 \%$ RH e irradiação solar do horário entre 12 e $14 \mathrm{~h}$.

O diagrama da Fig. 5.5 apresenta os espectros de reflectância para o conjunto de amostras analisadas, que representam a relação entre o valor percentual medido da reflectância do material na faixa do EEM abrangida pelo espectroradiômetro $(0,25$ a 2,5 $\mu \mathrm{m})$. As assinaturas espectrais apresentadas correspondem ao somatório das médias aritméticas das assinaturas obtidas para cada uma das faces das amostras analisadas, onde os aspectos peculiares de cada face, como cobertura de pátina e presença de liquens, constituiram os critérios de seleção das curvas. As faixas de comprimentos de onda das bandas do Landsat 5-TM que atuam no VNIR e SWIR (bandas 1-5 e 7) e a principal feição de absorção da clorofila (coluna verde em $0,675 \mu \mathrm{m}$, banda 3 ) foram discriminadas no diagrama. As áreas com vazios marcam as faixas onde ocorrem as principais feições de absorção da $\mathrm{H}_{2} \mathrm{O}$ na atmosfera, centradas em 1,4 e $1,9 \mu \mathrm{m}$, definidas por queda intensa na reflectância das curvas espectrais.

A totalidade das assinaturas espectrais demonstram um tênue crescimento da reflectância em direção aos maiores comprimentos de onda (inclinação positiva da curva cspectral), principalmente na faixa do visível do EEM (cntrc 0,4 c $0,7 \mu \mathrm{m}$ ), causado sobretudo pela presença do ferro em vários estados de oxidação e coordenação produzindo as tonalidades variando do marrom ao róseo avermelhado presente nas rochas analisadas. Para a região do espectro além de $0,65 \mu \mathrm{m}$, os espectros de reflectância das rochas com predominância de minerais máficos tendem a permanecer constantes, enquanto que para as 

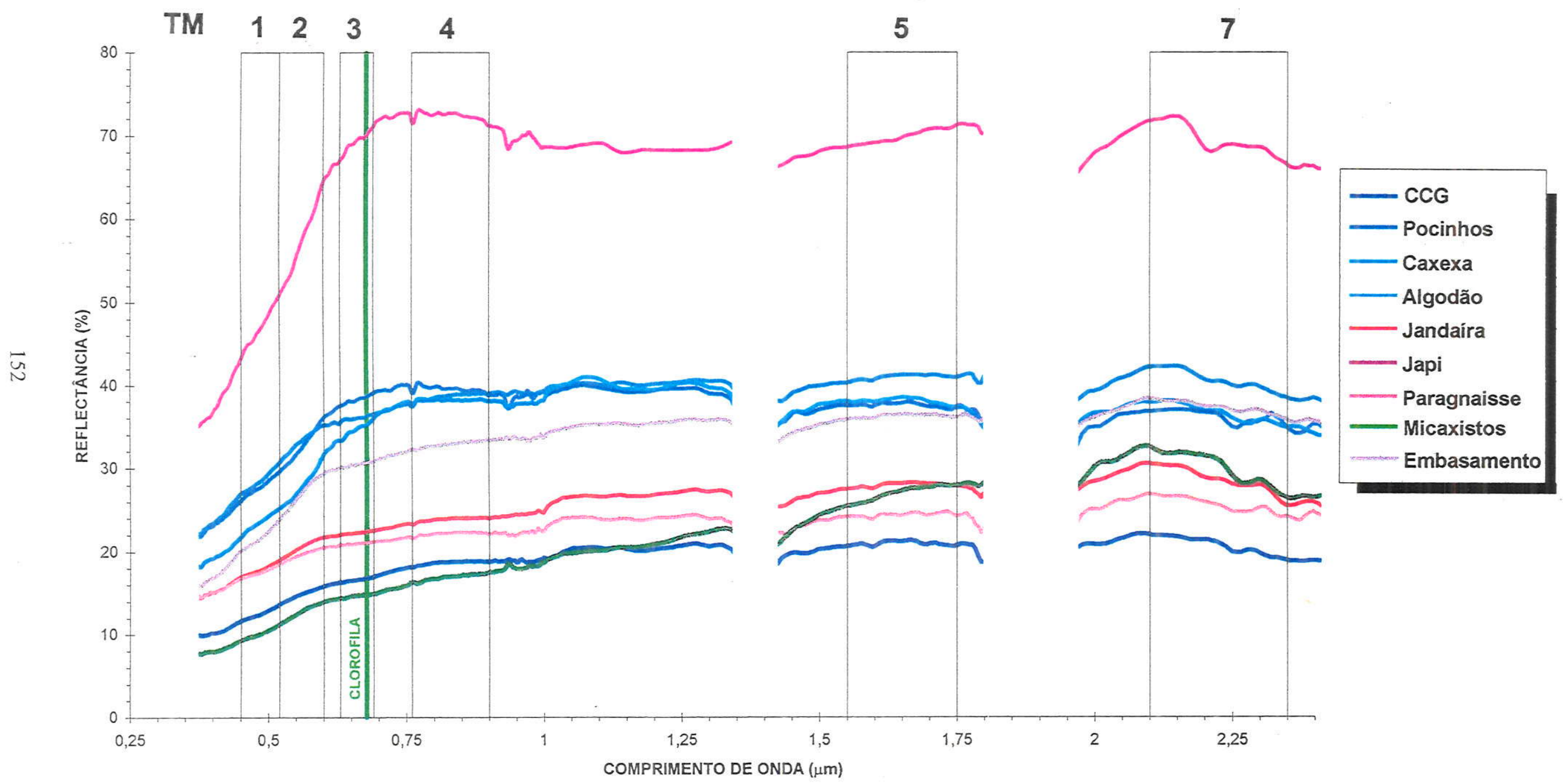

Figura 5.5 - Curvas espectrais de reflectância para o conjunto de litologias do Setor Extremo Nordeste da Província Borborema selecionadas para as medidas espectrométricas de reflectância

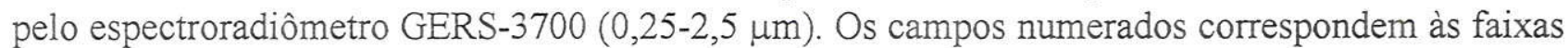
de atuação das bandas do Landsat 5-TM no espectro eletromagnético. A coluna verde marca a principal faixa de absorção da clorofila. 
rochas félsicas mantém uma inclinação positiva. A ampliação dos contrastes de reflectância entre as litologias ocorre principalmente na região do NIR (banda 4).

As amostras foram reunidas em duas categorias, com base na variação da reflectância no EEM: (A) a categoria das rochas granitóides com predominância em minerais félsicos e valores de reflectância variando entre 20-75 \% (granitóides Japi, Caxexa, Algodão, Pocinhos e ortognaisse do embasamento), e (B) a categoria de rochas com minerais máficos variando entre $10-28 \%$, ou proporções similares entre máficos e félsicos (micaxisto, paragnaisse, granitóides Jandaíra e CCG). Os principais minerais formadores das rochas graníticas, como o K-feldspato, quartzo e plagioclásio, são pobres em íons $\mathrm{Fe}$ provocando a ampla variação dos valores da reflectância nas curvas espectrais, desde os menores até os maiores comprimentos de onda no EEM. Para as rochas ricas em minerais máficos, como anfibólios, biotita, piroxênios e opacos, as assinaturas espectrais sofrem baixos incrementos na reflectância, e até decréscimos, devido às absorções decorrentes dos ions $\mathrm{Fe}$ e $\mathrm{OH}$, sobretudo nas faixas entre 0,85 e $1,1 \mu \mathrm{m}$ e além de $2,1 \mu \mathrm{m}$. Outra feição diagnóstica dessas categorias de assinaturas espectrais, e conseqüentemente diferenciação das diversas litologias, são as altas reflectâncias das rochas graniticas em torno de 1,6 $\mu \mathrm{m}$ caracterizando a presença de íons $\mathrm{Fe}^{3+}$, marcado pela intensa coloração rósea avermelhada dos $\mathrm{K}$-feldspatos, em contraste com a depressão da curva de reflectância para as demais rochas cuja mineralogia comporta maiores proporções em íons $\mathrm{Fe}^{2+}$. $\mathrm{Na}$ descrição das assinaturas espectrais das amostras analisadas optou-se pelo tratamento das duas categorias separadamente ( $\mathrm{A}$ e $\mathrm{B}$ ), na tentativa de detecção de feições diagnósticas entre as curvas espectrais similares.

\section{A. Rochas com predomínio de minerais félsicos:}

As Fig. 5.6a e 5.6b mostram a alta reflectância e a semelhança entre as formas suavemente côncavas das curvas espectrais das suites alcalinas de Japi, Algodão e Caxexa, distintamente da assinatura espectral de inclinação positiva do ortognaisse. O diagrama da Fig. 5.6b representa a disposição simplificada das assinaturas espectrais referidas aos pontos médios das faixas de atuação das bandas do Landsat 5-TM no EEM, de forma a favorecer a distinção de agrupamentos das assinaturas espectrais, as variações no valor médio da reflectância em cada banda e a comparação do comportamento espectral das amostras em cada banda do Landsat 5-TM. Apesar da grande semelhança petrográfica entre as amostras 

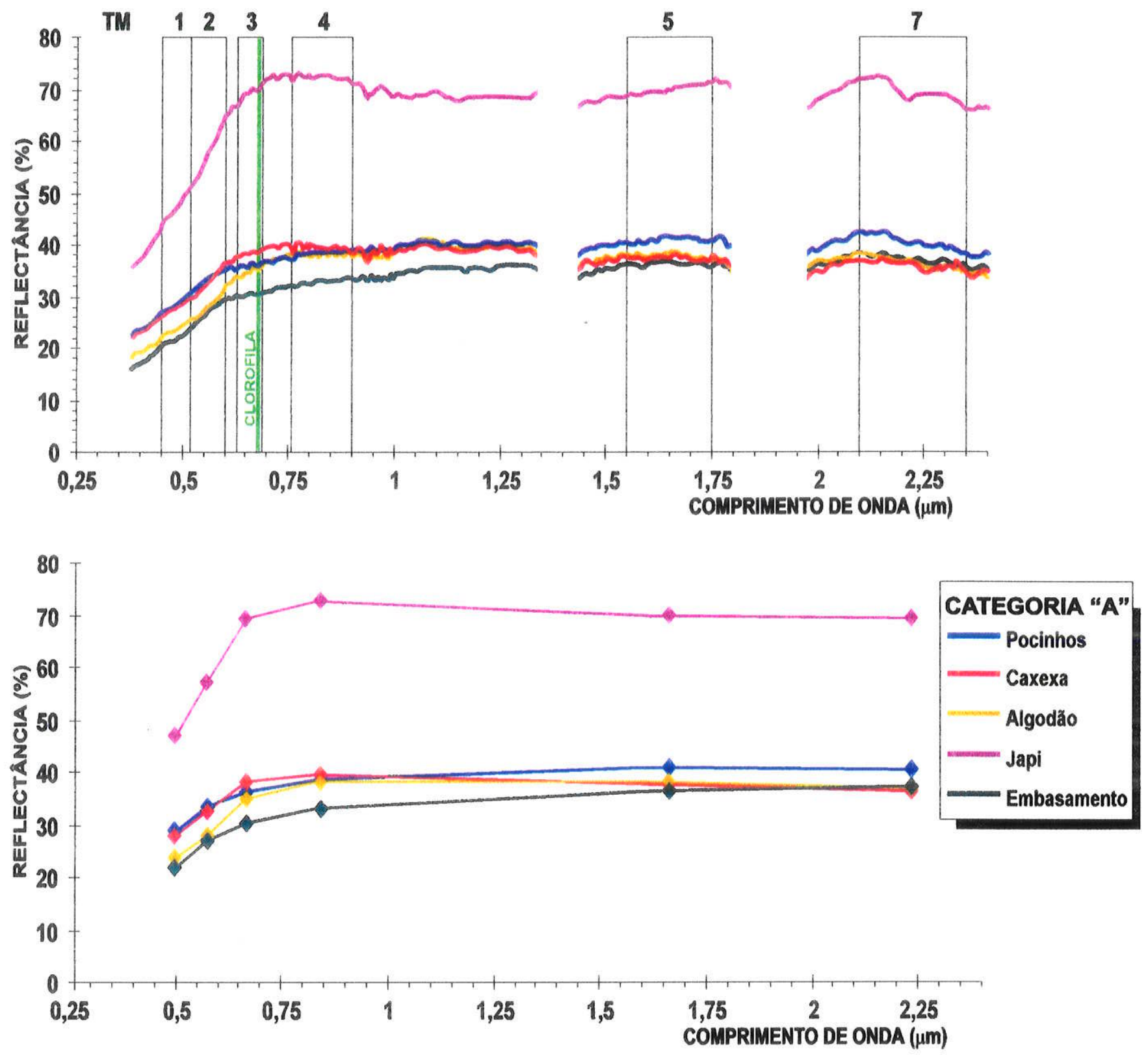

Figura 5.6 - (a) Curvas espectrais de reflectância para a "Categoria A" de litologias do setor Extremo Nordeste da Província Borborema. (b) Disposição simplificada das mesmas assinaturas espectrais em relação aos pontos médios das faixas abrangidas pelas bandas do Landsat 5-TM. 
das suites alcalinas, o diagrama evidencia como feição diagnóstica marcante entre elas a alta reflectância das rochas de Japi, superior as demais entre 20-40\%, decorrente da coloração cinza rosado a róseo avermelhado das amostras compostas por $90-95 \%$ de minerais félsicos na moda, essencialmente plagioclásio, microclina e quartzo.

O albedo em Japi tem contribuição do elevado teor modal de 25-35\% de quartzo, enquanto os valores são inferiores a $20 \%$ nas demais suítes. As curvas de reflectância das suítes alcalinas de Algodão e Caxexa são idênticas quanto à forma, intensidade de albedo e feições de absorção, aspectos que refletem as semelhanças mineralógicas e geoquímicas destas suites, distintas daquelas da suite de Japi.

A forma da curva espectral média das amostras de Japi está controlada pela resposta espectral dos minerais félsicos, como indica a Fig. 5.7 de comparação entre as assinaturas espectrais médias da rocha e dos minerais. A elevação ingreme da assinatura espectral na faixa do visível entre 0,55 e $0,65 \mu \mathrm{m}$, atingindo máximos de reflectância na faixa do vermelho e em torno de $1,6 \mu \mathrm{m}$, define a coloração róseo avermelhada das amostras decorrente do efeito de transferência de carga do $\mathrm{Fe}^{3+}$. As feições de absorção em $0,66 \mathrm{e}$ $0,75 \mu \mathrm{m}$, presentes nas curvas da rocha e dos minerais félsicos, indicam os fenômenos de transição do $\mathrm{Fe}^{3+}$ pela presença de impurezas de óxidos de ferro nos minerais félsicos. A amplitude e intensidade da absorção em $0,75 \mu \mathrm{m}$ indica a participação de efeitos de transferência de cargas entre os íons $\mathrm{Fe}^{2+}$ e $\mathrm{Fe}^{3+}$ comuns nos anfibólios. A pronunciada banda de absorção em $0,93 \mu \mathrm{m}$ é, provavelmente, decorrente do $\mathrm{Fe}^{2+}$ em transições de campo do cristal no clinopiroxênio com baixos teores de $\mathrm{Ca}$ (augita sódica com $\mathrm{Fe}>9 \% \mathrm{e}$ $\mathrm{Mg}>11 \%$ ). A ampla banda de absorção centrada em $1,15 \mu \mathrm{m}$ é controlada por efeitos de transição eletrônica do $\mathrm{Fe}^{2+}$ substituindo o $\mathrm{Al}$ no plagioclásio, feição notória no espectro do minerais félsicos. A banda de absorção centrada em $2,2 \mu \mathrm{m}$ indica os fenômenos vibracionais do Al-OH nos anfibólios, combinados à absorção em 2,35 $\mu \mathrm{m}$ do $\mathrm{Mg}-\mathrm{OH}$, e nos minerais de argila produzidos nas transformações dos feldspatos. A forma do espectro dos minerais félsicos indica o predomínio do $\mathrm{K}$-feldspato, de coloração rósea devido às substituições de $\mathrm{Fe}^{3+}$, com inclusões de óxidos de ferro (transições de $\mathrm{Fe}^{3+}-\mathrm{Fe}^{2+}$ em $0,9 \mu \mathrm{m}$ ) e plagioclásio (banda de absorção entre 1,1-1,25 $\mu \mathrm{m}$ ). A banda de absorção centrada em 1,6 


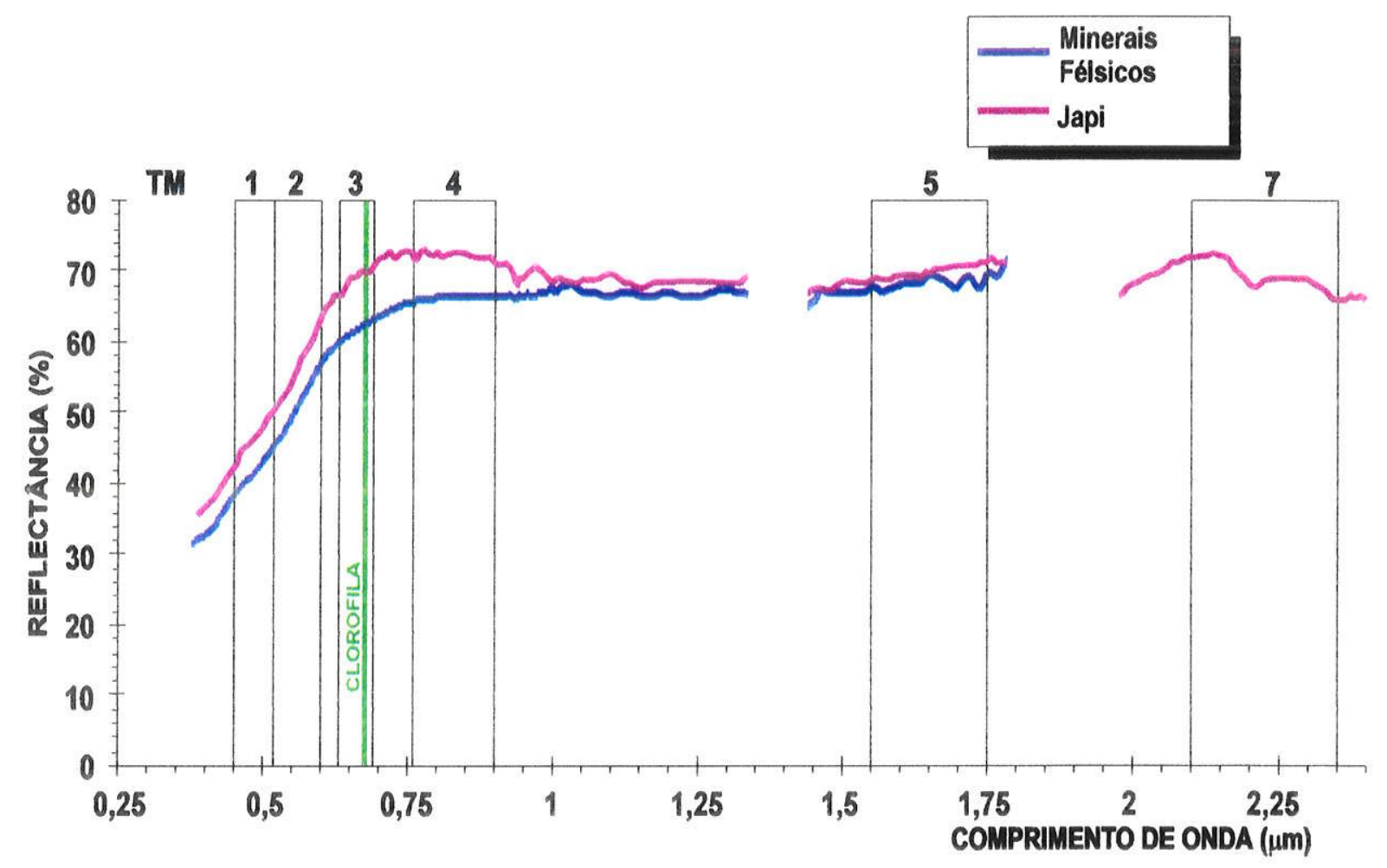

Figura 5.7 - Diagrama comparativo entre as assinaturas espectrais médias das rochas da suite alcalina do plúton Japi e dos principais componentes minerais félsicos.
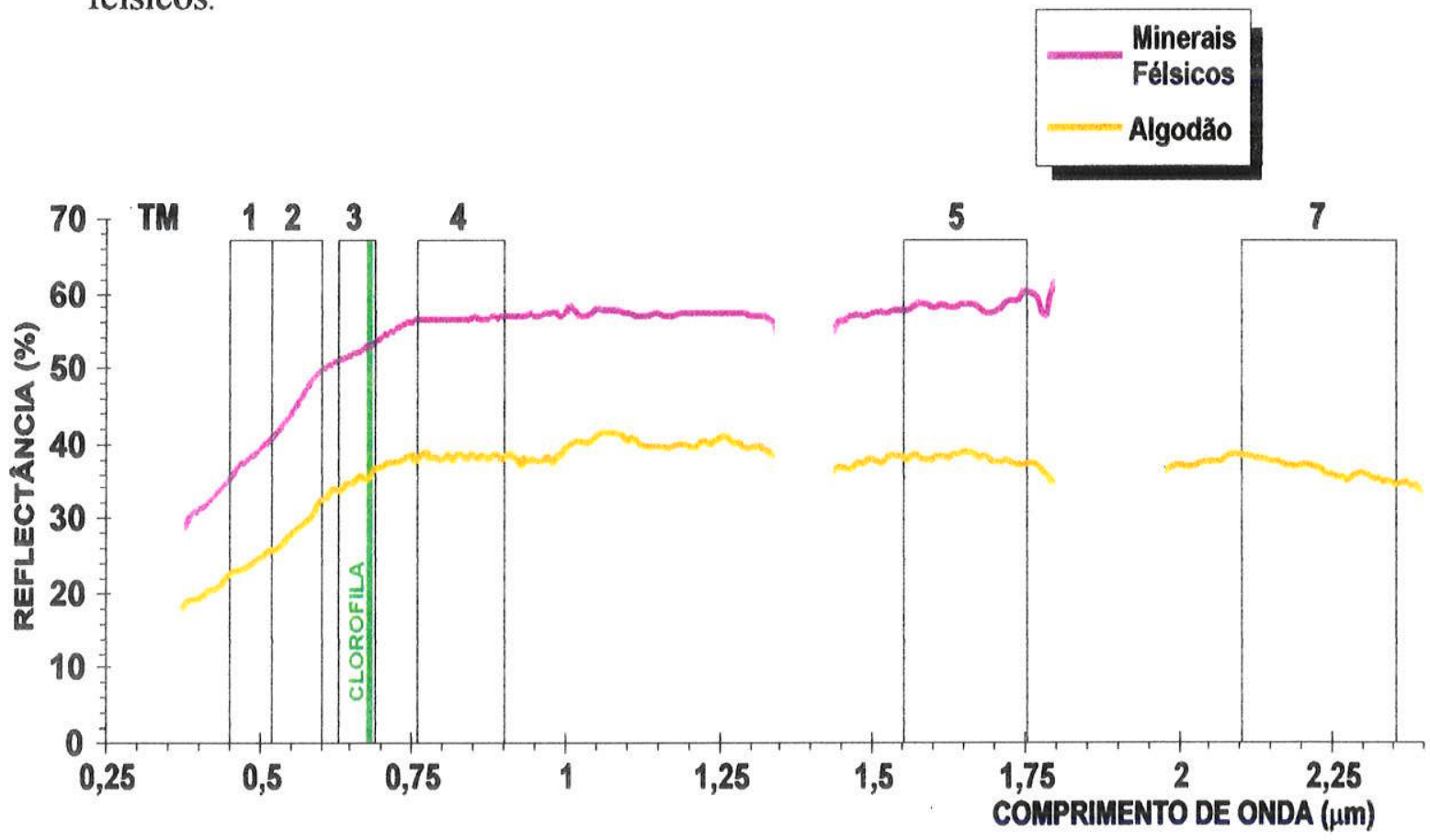

Figura 5.8 - Diagrama comparativo entre as assinaturas espectrais médias das rochas da suíte alcalina do plúton Algodão e dos principais componentes minerais félsicos. 
$\mu \mathrm{m}$ é decorrente de efeitos vibracionais do $\mathrm{OH}$ e $\mathrm{H}_{2} \mathrm{O}$ e indica a transformação parcial dos plagioclásios em argilo minerais.

Na suite de Caxexa, a principal absorção na faixa do visível está centrada em $0,66 \mu \mathrm{m}$ devido à transição eletrônica do $\mathrm{Fe}^{3+}$, complementadas pelas absorções em $0,86 \mu \mathrm{m}$ e $0,91 \mu \mathrm{m}$ que marcam a presença de hematita e limonita. Para a suite de Algodão as transições eletrônicas do $\mathrm{Fe}^{3+}$ produzem absorção em $0,64 \mu \mathrm{m}$, decorrente de inclusões de óxidos de ferro no K-feldspato, como mostra a assinatura espectral dos minerais félsicos do Algodão, com a forma controlada pelo K-feldspato (Fig. 5.8). O pico de absorção centrada em $0,94 \mu \mathrm{m}$, provavelmente devido aos efeitos do campo do cristal do $\mathrm{Fe}^{2+}$ nos clinopiroxênios, é mais intensa no Caxexa. Os efeitos de absorção por campo do cristal do $\mathrm{Fe}^{2+}$ em $1,0 \mu \mathrm{m}$ define a presença de minerais máficos como anfibólio e piroxênio nas amostras. A banda de absorção entre 1,05 e 1,25 $\mu \mathrm{m}$ é mais intensa no Algodão do que no Caxexa, indicando maiores proporções de substituições de $\mathrm{Al}$ por $\mathrm{Fe}^{2 !}$. As absorções decorrentes dos efeitos vibracionais do $\mathrm{OH}$ são mais intensas no Caxexa, centradas em 2,25 e 2,36 $\mu \mathrm{m}$, do que a absorção em $2,28 \mu \mathrm{m}$ no Algodão, provavelmente indicativo de maiores proporções de anfibólios no Caxexa.

No sienogranito de Pocinhos, a forma da curva espectral é definida pelos minerais félsicos no VNIR, e pelos máficos na faixa do SWIR entre 2,1 e 2,35 $\mu \mathrm{m}$ do EEM (Fig. 5.9). Os picos de absorção em $0,63 \mu \mathrm{m}, 0,75 \mu \mathrm{m}$ e centrado em $1,0 \mu \mathrm{m}$, marcando as transferências $\mathrm{Fe}^{2+}-\mathrm{Fe}^{3+}$ e os efeitos de campo dos cristais do $\mathrm{Fe}^{2+}$, são comuns nos minerais como anfibólio, biotita, e óxidos de ferro, enquanto aquela em $2,31 \mu \mathrm{m}$ pode ser relacionada ao $\mathrm{Fe}^{2+}$ no piroxênio. A presença de plagioclásio com teores próximos a An65 pode ser definida pela sutil banda de absorção centrada em $1.3 \mu \mathrm{m}$, provavelmente substituido parcialmente por argilo minerais, como indica o pico de absorção em $1,6 \mu \mathrm{m}$ presente na assinatura dos minerais félsicos. A ampla absorção assimétrica em torno de 2,35 $\mu \mathrm{m}$ é típica de minerais com $\mathrm{Mg}-\mathrm{OH}$ como biotita e anfibólios.

Os ortognaisses migmatíticos do embasamento mostram picos de absorções tênues no VNIR, característica dos minerais félsicos que controlam a curva nessa faixa do EEM (Fig. 5.10). As principais bandas de absorçào ocorrem centradas em 1,0 $\mu \mathrm{m}, 2,27 \mu \mathrm{m} \mathrm{e}$ $2,36 \mu \mathrm{m}$, indicadoras do controle da assinatura dos ortognaisses pelos minerais máficos 


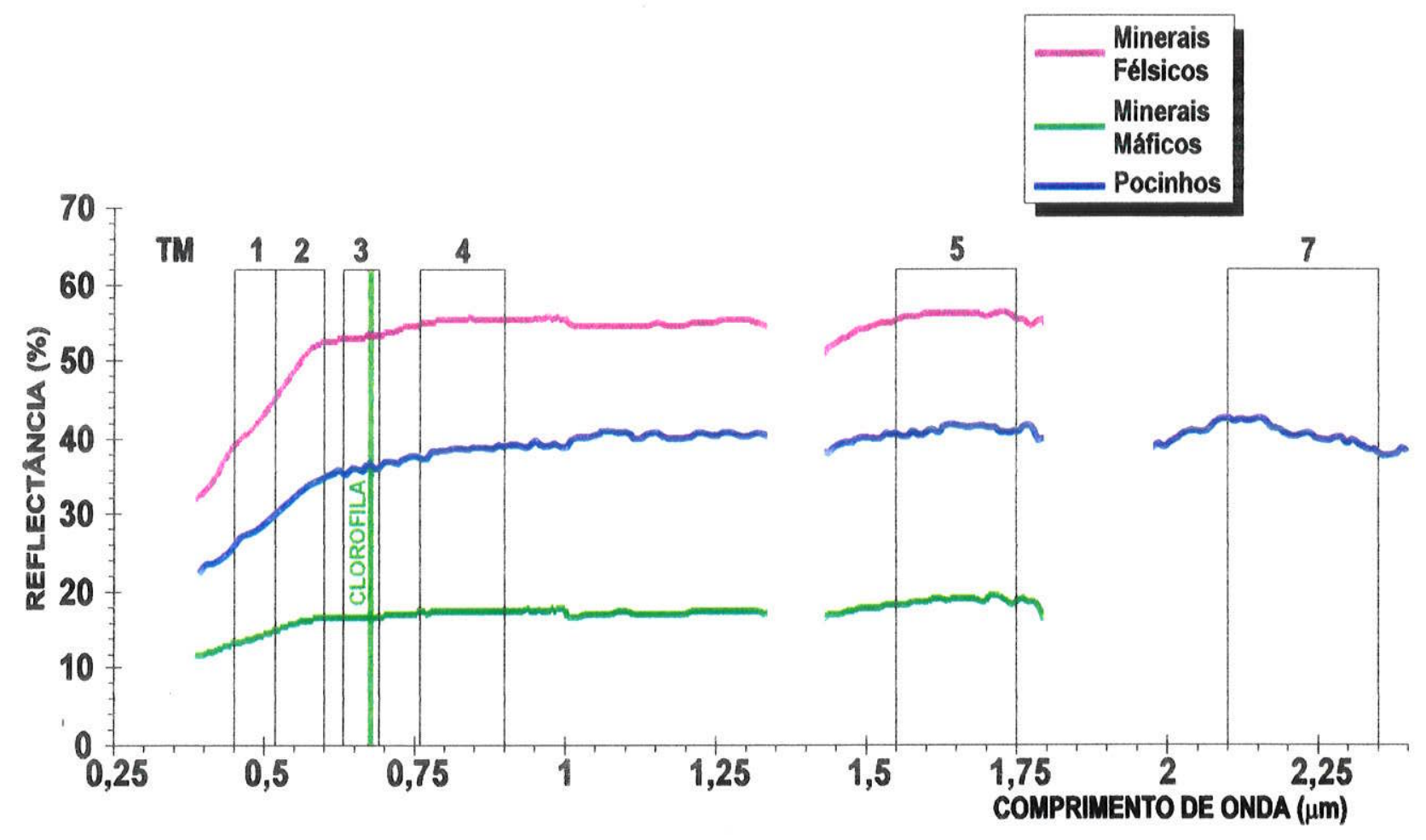

Figura 5.9 - Diagrama comparativo entre as assinaturas espectrais médias das rochas do plúton Pocinhos e dos principais componentes minerais máficos e félsicos. 


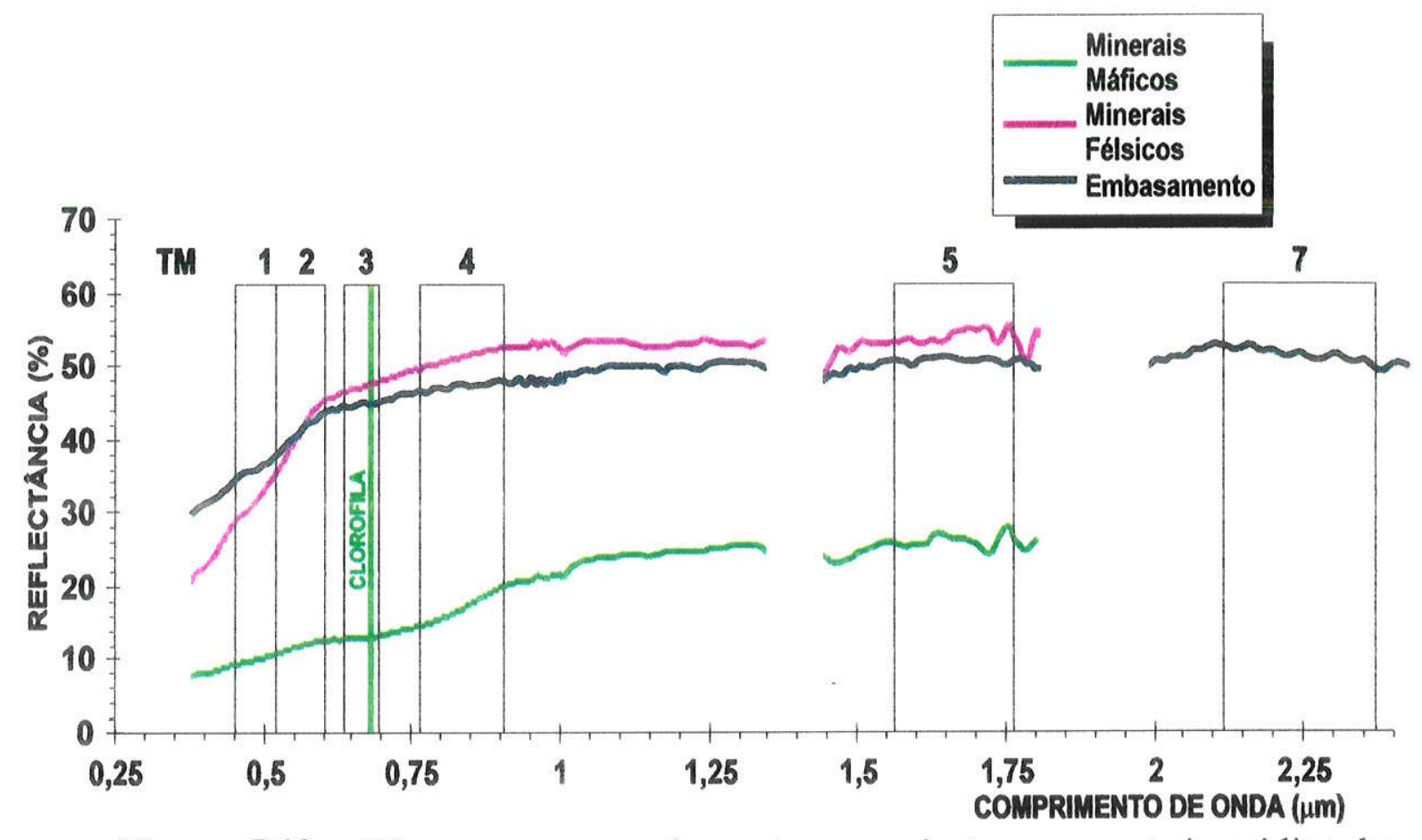

Figura 5.10 - Diagrama comparativo entre as assinaturas espectrais médias das rochas gnáissico-migmatíticas do embasamento e dos principais componentes minerais máficos e félsicos.

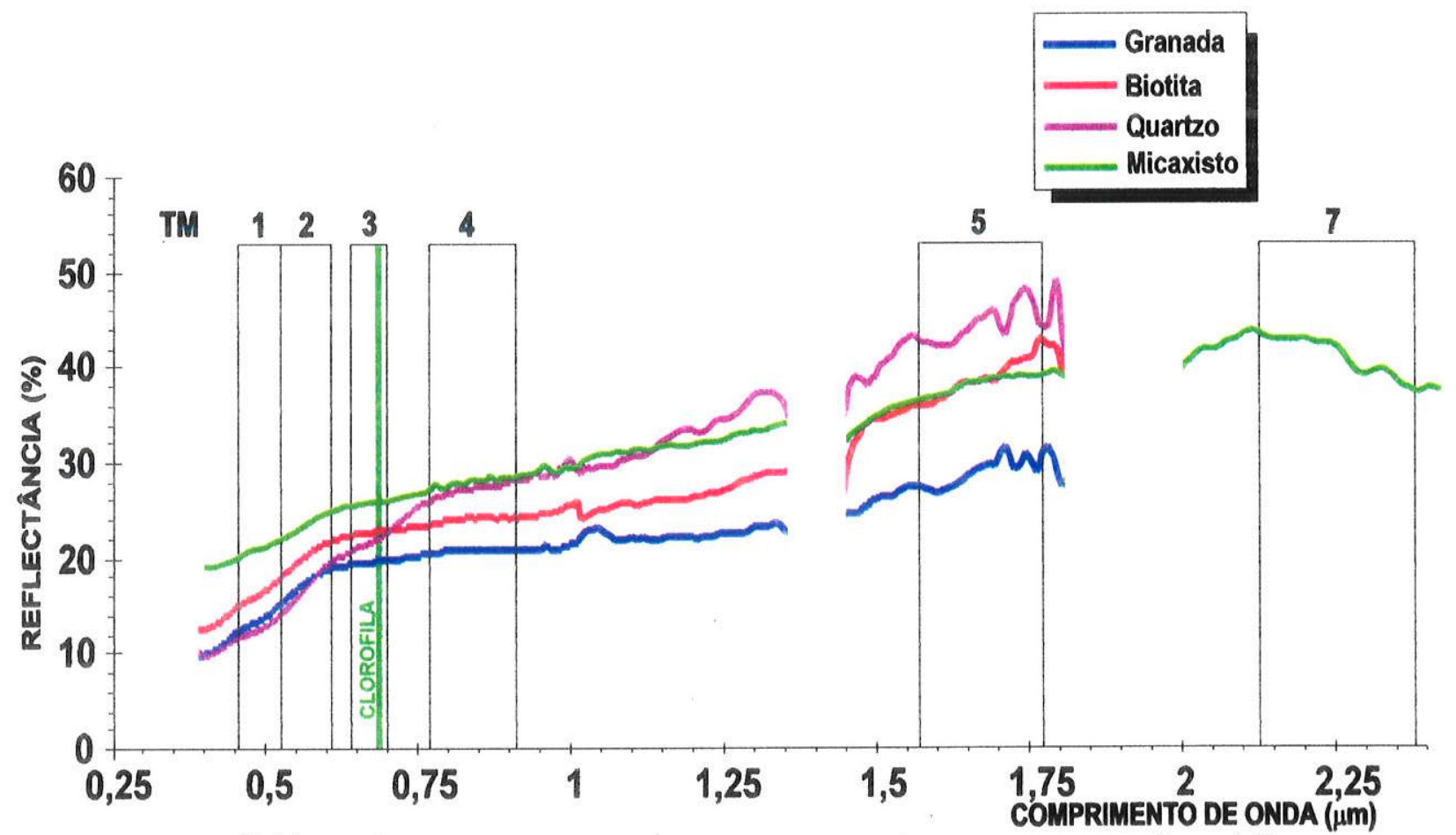

Figura 5.11 - Diagrama comparativo entre as assinaturas espectrais médias dos micaxistos da Faixa de Metassedimentos de Barra de Santa Rosa e dos principais componentes minerais: granada, biotita e quartzo. 
como a biotita e os anfibólios, com absorções nestas faixas devido às transiç̃es eletrônicas e vibracionais do $\mathrm{Fe}^{2+}$ e $\mathrm{Mg}-\mathrm{OH}$.

\section{B. Rochas com minerais máficos em proporções superiores a $15 \%$ :}

As Fig. 5.11a e 5.11b apresentam as assinaturas espectrais para o micaxisto, paragnaisse, granitóides Jandaira e $\mathrm{CCG}$, que possuem em comum o baixo albedo. A forma da assinatura espectral dos micaxistos é inteiramente controlada pela presença de biotita, como indica a semelhança entre as curvas espectrais (Fig. 5.12). A forma do espectro do quartzo, apesar do albedo mais elevado, mostra a intensa influência da biotita sugerido que o quartzo seja praticamente transparente à iluminação incidente, permitindo a reflectância da biotita como mineral predominante. Os picos de absorção em 0,63 e $0,76 \mu \mathrm{m}$ marcam as transições de $\mathrm{Fe}^{2+}-\mathrm{Fe}^{3+}$ relativas à biotita, óxidos de ferro e clorita, e em $0,96 \mu \mathrm{m}$ indicam efeitos de campo do cristal do $\mathrm{Fe}^{2+}$ na biotita e granada. As bandas de absorção devido aos efeitos vibracionais do $\mathrm{OH}$ são intensos e centrados em $2,25 \mu \mathrm{m}$ (Al-OH em muscovita e clorita) e $2,32 \mu \mathrm{m}$ (Mg-OH em biotita e clorita). A presença de $\mathrm{H}_{2} \mathrm{O}$ nos retículos dos cristais de quartzo e granada pode ser responsável pelos picos de absorção em 2,03 e 2,12 $\mu \mathrm{m}$, como mostra a comparação entre as assinaturas desses minerais e da rocha.

Nos paragnaisses, os picos de absorção por fenômenos de transição eletrônica do $\mathrm{Fe}^{2+}-\mathrm{Fe}^{3+}$ estão centradas em 0,65 e $0,75 \mu \mathrm{m}$, sobretudo decorrentes da presença de magnetita em grandes proporções na amostra. As bandas de absorção centradas em $0,96 \mu \mathrm{m}$ definem o $\mathrm{Fe}^{2+}$ no anfibólio, e em $1,03 \mu \mathrm{m}$ no piroxênio. A banda de absorção ampla e sutil entre 1,1 e $1,2 \mu \mathrm{m}$ pode ser relacionada à presença de plagioclásio com alguma substituição do $\mathrm{Al}$ por $\mathrm{Fe}^{2+}$, com evidências de transformação para minerais de argila como sugere o pico em 1,6 $\mu \mathrm{m}$. As absorções vibracionais do $\mathrm{OH}$ marcam bandas centradas em 2,25 $\mu \mathrm{m}$ (Al$\mathrm{OH})$ relacionada à presença de clorita e muscovita, e 2,35 $\mu \mathrm{m}(\mathrm{Mg}-\mathrm{OH})$ decorrente da biotita e anfibólios. O pico assimétrico centrado em $2,32 \mu \mathrm{m}$ pode ser indicativo de efeitos de campo do cristal do $\mathrm{Fe}^{2+}$ em cristais de piroxênio presentes na amostra analisada.

A forma da assinatura espectral da suite porfiritica de Jandaíra é controlada pelos minerais félsicos na faixa do VNIR (Fig. 5.13). As absorcões por transições eletrônicas $\mathrm{Fe}^{2+}$ $\mathrm{Fe}^{3+}$ no VNIR são bastante sutis centradas em 0,6 e $0,75 \mu \mathrm{m}$, provavelmente decorrentes da biotita, óxidos e anfibólios. A presença de plagioclásio (teores próximos a An65) define 

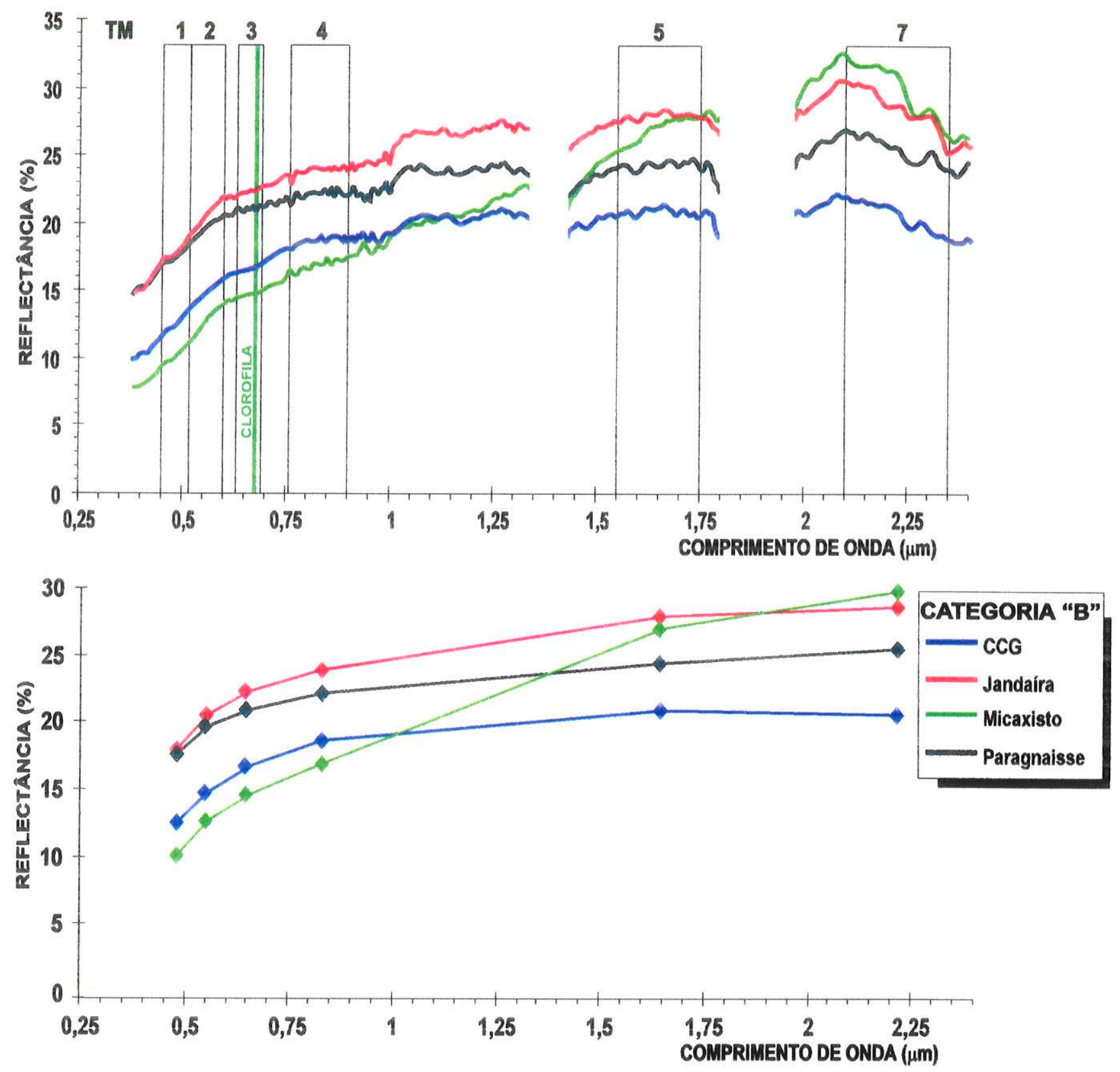

Figura5.11- (a) Curvas espectrais de reflectância para a "Categoria B" de litologias do setor Extremo Nordeste da Província Borborema. (b) Disposição simplificada das mesmas assinaturas espectrais em relação aos pontos médios das faixas abrangidas pelas bandas do Landsat 5-TM. 


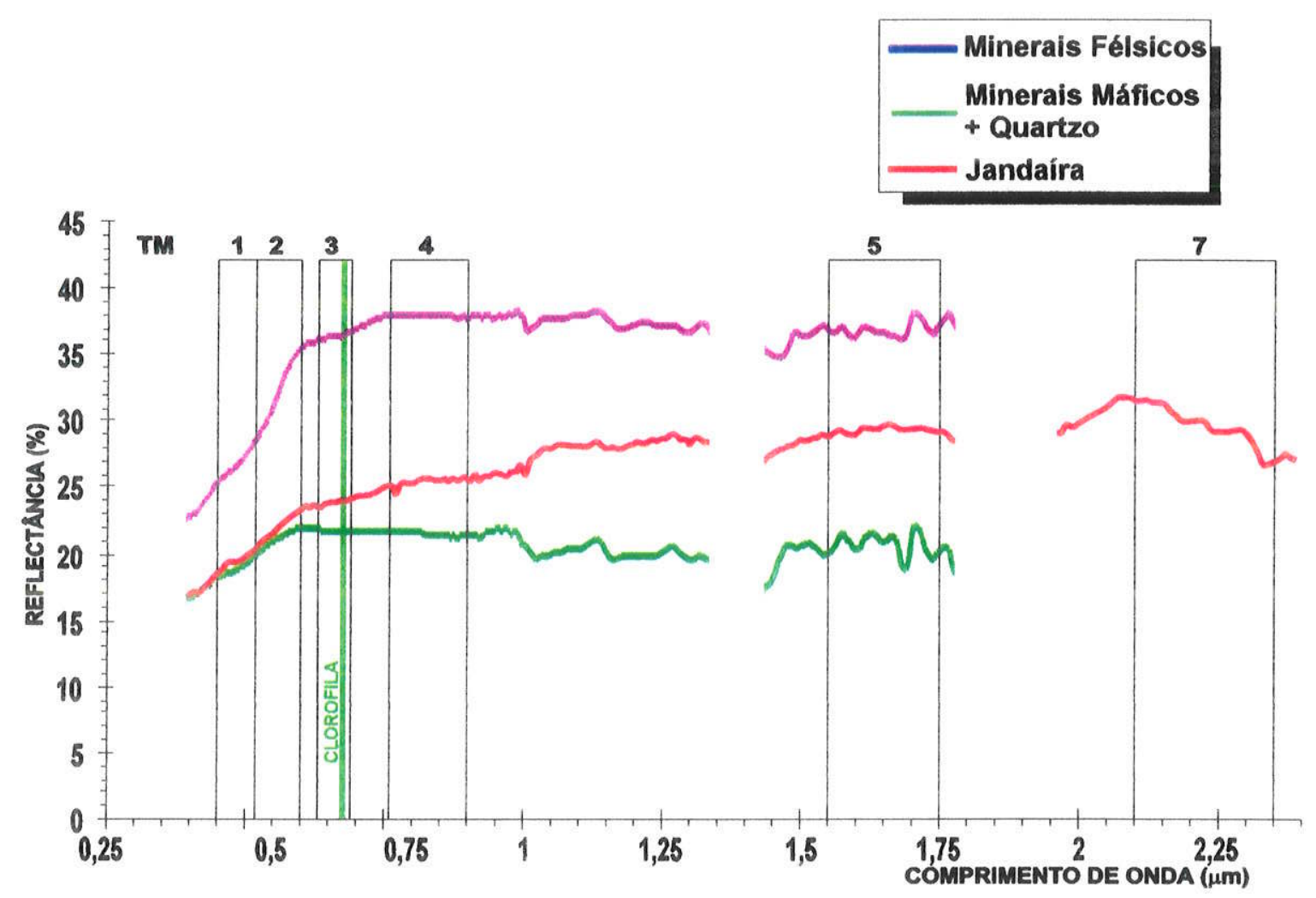

Figura 5.13 - Diagrama comparativo entre as assinaturas espectrais médias das rochas da suíte porfirítica do plúton Jandaíra e dos principais componentes minerais máficos e félsicos.
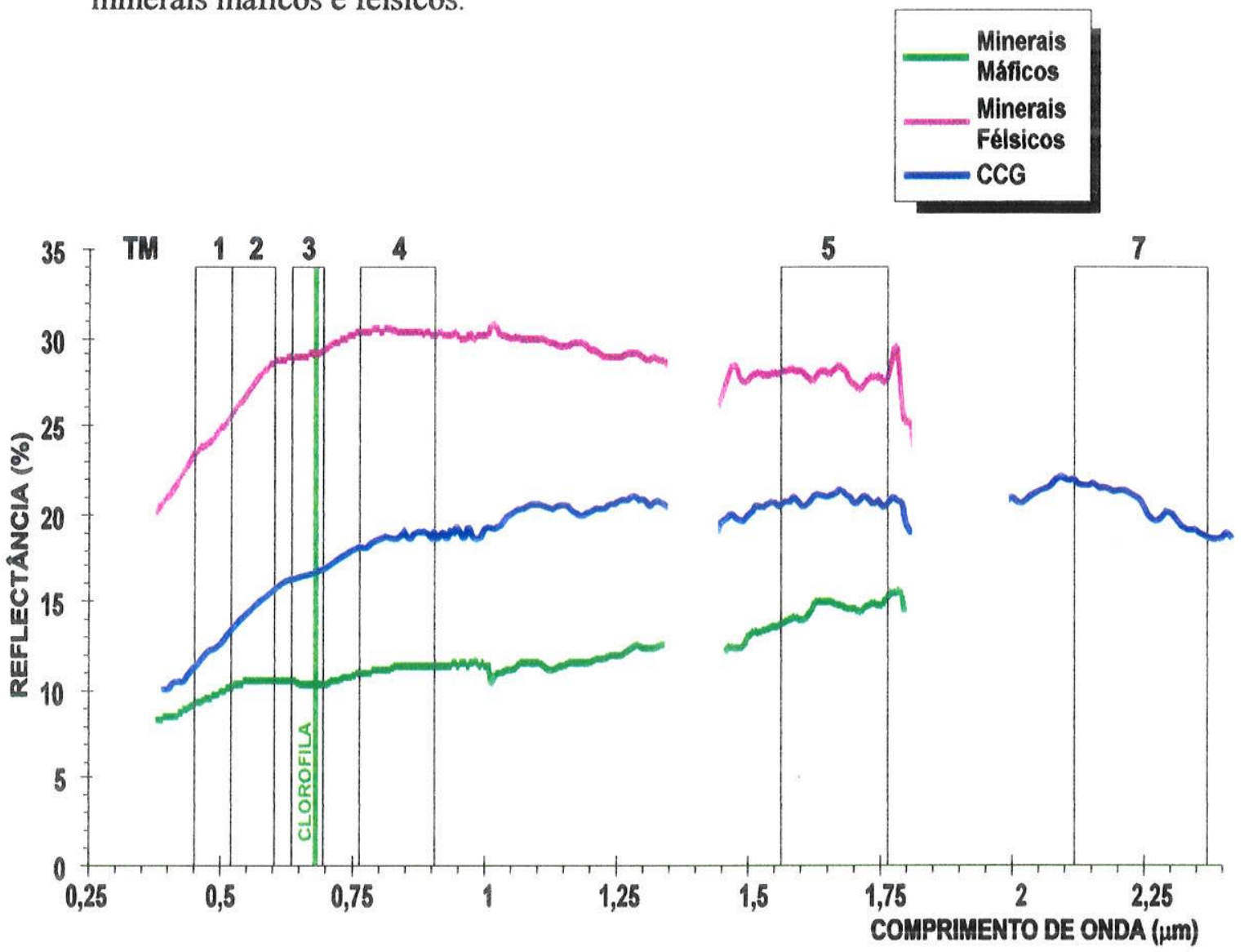

Figura 5.14 - Diagrama comparativo entre as assinaturas espectrais médias das rochas do Complexo Campina Grande (CCG) e dos principais componentes minerais máficos e félsicos. 
bandas de absorção centradas em 1,3 $\mu \mathrm{m}$ na assinatura para os minerais félsicos, marcado de forma tênue e ampla na assinatura da rocha, com as típicas transformações para minerais de argila (pico centrado em 1,6 $\mu \mathrm{m}$ ). Os anfibólios caracterizam as absorções em 1,0 $\mu \mathrm{m}\left(\mathrm{Fe}^{2+}\right.$ ) e 2,35 $\mu \mathrm{m}(\mathrm{Mg}-\mathrm{OH})$, com a biotita provavelmente substituida por clorita e/ou muscovita definindo o pico de absorção centrado em $2,25 \mu \mathrm{m}$.

As rochas do CCG, comparado às demais litologias analisadas, possuem a menor reflectância (18-21\%) na faixa do SWIR, inferior apenas aos micaxistos no VNIR (Fig. 5.14). Na faixa do VNIR, a forma da curva espectral é controlada pelos minerais félsicos, enquanto no SWIR os minerais máficos determinam os principais picos de absorção e a forma da curva. Os picos de absorção no visivel são sutis em 0,63 e $0,75 \mu \mathrm{m}$, relacionados às transferências eletrônicas entre $\mathrm{Fe}^{2+}-\mathrm{Fe}^{3+}$. No NIR, as principais bandas de absorção são aquelas centradas em 0,95 e $1,0 \mu \mathrm{m}$ decorrentes das transições de campo do cristal do $\mathrm{Fe}^{2+}$ nos anfibólios, piroxênios e magnetita. Os plagioclásios estão definidos pela banda de absorção centrada em $1,3 \mu \mathrm{m}$, provavelmente transformados para minerais de argila, como indica a absorção em 1,6 $\mu \mathrm{m}$. No SWIR as bandas de absorção vibracionais estão centradas em 2,25 e $2,3 \mu \mathrm{m}$, marcando a presença de $\mathrm{Al}-\mathrm{OH}$ e $\mathrm{Mg}-\mathrm{OH}$ em anfibólios, biotita e piroxênios.

\section{4 - Síntese das Principais Feições Espectrais Diagnósticas das Amostras Analisadas}

Como visto no item $\mathbf{5 . 3}$, as amostras analisadas foram agrupadas em duas categorias em função dos valores percentuais de reflectância (albedo). A forma e a inclinação das curvas espectrais nas faixas do VNIR e SWIR são resultantes das propriedades mineralógicas e químicas inerentes e peculiares das amostras analisadas, e portanto diagnósticas do material analisado. As assinaturas espectrais dos diferentes materiais são comparadas nas faixas do EEM referentes às bandas do Landsat 5-TM, favorecendo a seleção das melhores bandas a serem empregadas nos tratamentos digitais para diagnose e discriminação das litologias. A inspeção visual das curvas espectrais das Fig. 5.6 e 5.11 mostra similaridades entre as formas e inclinações das curvas em algumas faixas do EEM, sobretudo para os granitóides agrupados numa mesma categoria de variação da reflectância, que poderiam dificultar a discriminação entre as litologias baseada nos 
tratamentos digitais das bandas do Landsat 5-TM. Entretanto, algumas feiç̃es espectrais distintivas, como a localização e a intensidade dos picos de absorção, ou a ausência de absorção numa faixa específica do EEM, permitem a caracterização das litologias, com base nos dados mineralógicos e químicos, e sugerem a discriminação entre aquelas com grandes semelhanças.

Entre as suites alcalinas de Algodão, Caxexa e Japi, apesar das semelhanças petrográficas e geoquímicas, as assinaturas espectrais mostram importantes feições especificas que definem a singularidade petrológica dos plútons, permitindo a discriminação entre as suites com base nas bandas do Landsat 5-TM:

- A reflectância mais elevada em Japi é controlada pela porcentagem modal dos minerais félsicos, principalmente pelo quartzo modal (25-35\%) maior que os teores de quartzo em Caxexa e Algodão, ambos inferiores a $20 \%$, já que os teores em álcalis nesses últimos são sutilmente superiores que em Japi (Fig. 5.2 e 5.3);

- As absorções das transições eletrônicas do Fe2+-Fe3+ são mais acentuadas em Japi, devido aos teores de $\mathrm{Fe}$ mais elevados nos anfibólios (hornblenda magnesiana com $\mathrm{Fe}>18$ \%) e piroxênios (augita sódica com $\mathrm{Fe}>9 \%$ ) de Japi, do que em Caxexa e Algodão (aegirina-augita com $\mathrm{Fe}<8 \%$ ). As rochas alcalinas de Japi mostram teores médios de $\mathrm{Fe} 2 \mathrm{O} 3(0,82-2,65 \%)$ maiores que em Caxexa $(0,85-1,37 \%)$ e Algodão $(0,44-1,71 \%)$, como mostra a Fig. 5.2;

- No VNIR (bandas 1 a 4 do Landsat 5-TM) a assinatura espectral de Japi é positiva com inclinação marcante (reflectância variando de 34 a 74 \%, do azul ao vermelho), indicando maiores teores de ions $\mathrm{Fe}^{2+}-\mathrm{Fe}^{3+}$; as curvas para Caxexa e Algodão são positivas com inclinações moderadas (reflectância variando de 20 a $42 \%$ );

- Na faixa espectral entre 1,55 e 1,75 $\mu$ m (banda 5 do Landsat 5-TM) e entre 2,15 e 2,35 $\mu \mathrm{m}$ (banda 7 do Landsat 5-TM) os niveis de reflectância de Caxexa e Algodão são idênticos $(40 \%)$ e inferiores ao de Japi $(70 \%)$, provavelmente relacionados aos teores médios de $\mathrm{CaO}, \mathrm{MgO}$ e $\mathrm{Al}_{2} \mathrm{O}_{3}$ superiores em Japi do que em Caxexa e Algodão, como sugerem os diagramas de Harker e R1-R2 (Fig. 5.2 e 5.4, respectivamente);

- Na faixa entre 2,1 e 2,35 $\mu \mathrm{m}$ (banda 7 do Landsat 5-TM) a curva espectral de Japi mostra intensas absorções vibracionais do $\mathrm{Al}-\mathrm{OH}(2,2 \mu \mathrm{m})$ e $\mathrm{Mg}-\mathrm{OH}(2,35 \mu \mathrm{m})$, sugerindo 
processos vibracionais mais pronunciados, provavelmente devido aos teores médios de $\mathrm{Al}_{2} \mathrm{O}_{3}(13,01-16,11 \%)$ e $\mathrm{MgO}(0,08-0,65 \%)$ superiores aos de Caxexa $\left(\mathrm{Al}_{2} \mathrm{O}_{3}=12,66\right.$ $15,01 \%, \mathrm{MgO}=0,08-0,13 \%)$ e Algodão $\left(\mathrm{Al}_{2} \mathrm{O}_{3}=12,54-16,16 \%, \mathrm{MgO}=0,01-0,42 \%\right)$;

- A curva espectral de Algodão mostra bandas de absorção muito sutis, quando comparadas àquelas dos demais granitóides, devido ao baixo percentual modal de minerais máficos (anfibólios, piroxênio e magnetita).

As rochas graniticas analisadas exibiram características espectrais especificas no VNIR em função dos conteúdos de $\mathrm{Fe}, \mathrm{Ca}, \mathrm{Mg}, \mathrm{Al}$ e $\mathrm{OH}$. Estes elementos associados na mineralogia dominante e refletidos nas propriedades quimicas das rochas causam diferenças sutis no índice de cor e albedos das rochas, resultando na assinatura espectral com aumento da reflectância para os maiores comprimentos de onda do EEM.

As principais feições espectrais úteis como critérios distintivos entre as assinaturas espectrais dos granitóides de Pocinhos, CCG e Jandaíra, foram listadas:

- A reflectância é mais elevada nas amostras analisadas de Pocinhos (sienogranitos), do que naquelas de Jandaíra e CCG, provavelmente controlada pela porcentagem modal de minerais félsicos (40-50\%), que condicionam inclusive a forma da curva (Fig.5.9), e de máficos em proporções inferiores a $15 \%$;

- A inclinação da curva de Pocinhos na faixa do VNIR (bandas 1 a 4 do Landsat 5-TM) é positiva e mais acentuada (reflectância variando de 22 a $40 \%$ ), sugerindo maior proporção de íons $\mathrm{Fe}^{2+}-\mathrm{Fe}^{3+}$, como mostram os picos de absorção mais acentuados em 0,63 e 0,75 $\mu \mathrm{m}$;

- Na faixa entre 1,55 e 1,75 $\mu \mathrm{m}$ do SWIR (banda 5 do Landsat 5-TM), permanece a reflectância do Pocinhos em torno de $40 \%$, seguido por Jandaira (28 \%) e CCG (21\%), este último mostrando pico de absorção em 1,6 $\mu \mathrm{m}$ mais acentuado, provavelmente devido à maior proporção de substituições do plagioclásio;

- Na faixa entre 2,1 e $2,35 \mu \mathrm{m}$ do SWIR (banda 7 do Landsat 5-TM), as curvas são negativas, permanecendo as diferenças nos valores relativos das reflectâncias. As posições e intensidades das bandas de absorção provocada pelo ín $\mathrm{OH}$ nos minerais máficos indicam elementos distintivas: o granitóide Jandaíra apresenta bandas de absorção do Al-OH $(2,25$ $\mu \mathrm{m})$ e $\mathrm{Mg}-\mathrm{OH}(2,35 \mu \mathrm{m})$, mais intensas do que Pocinhos e CCG; 
- As mais altas reflectâncias para os granitóides Japi, Caxexa, Algodão estão em 0,85 $\mu \mathrm{m}$; para os granitóides Pocinhos e CCG em 1,65 $\mu \mathrm{m}$; para o granitóide Jandaíra e ortognaisse do embasamento em $2,2 \mu \mathrm{m}$. Estas propriedades refletem a correlação entre a assinaturas espectrais e a alcalinidade dos granitóides.

Os dados apresentados demonstram que algumas peculiaridades mineralógicas e químicas das litologias podem ser discriminadas nas assinaturas espectrais das superficies naturais das rochas e minerais, sejam esses componentes dominantes e originais, produtos de alteração ou impurezas menores, e que algumas feiç̃̃es espectrais podem ser úteis no diagnóstico de litologias petrologicamente análogas. Com base nessa prerrogativa buscou-se a diferenciação das litologias que tiveram ou não os espectros analisados, através das bandas isoladas e/ou combinadas do Landsat 5-TM, como abordagem metodológica de incrementação do mapeamento geológico na região de Barra de Santa Rosa-Campina Grande.

De maneira suscinta, a comparação dos espectros das superfícies naturais das rochas e minerais da região de Barra de Santa Rosa-Campina Grande nas faixas espectrais correspondentes às seis bandas do Landsat 5-TM no visivel-infravermelho permitiram a correlação das bandas com alguns aspectos diagnósticos freqüentemente expressos na composição superficial dos terrenos geológicos:

- Nas bandas de 1 a 4 (VNIR) estão as informações sobre os minerais que contém ferro : na banda 1 ocorrem as feições de transfência de carga $\mathrm{Fe}^{2+}-\mathrm{Fe}^{3+}$; as bandas 2 e 3 mostram alta correlação relacionada à rampa de reflectância do $\mathrm{Fe}^{3+}$; na banda 3 ocorre a principal feição de absorção da clorofila e os altos índices de reflectância dos óxidos de ferro no VIS; na banda 4 estão as absorções decorrentes dos efeitos de campo do cristal do $\mathrm{Fe}^{3+}$, além das altas reflectâncias da vegetação seca e de alguns minerais de argila; os minerais de argila alcançam o patamar de alta reflectância no VNIR, enquanto os óxidos de ferro causam absorção no VIS, favorecendo a distinção entre materiais com proporções variadas entre argila/óxidos de ferro; a sílica e o quartzo livre alcançam alta reflectância, geralmente entre as bandas 1 e 2, e prosseguem por todo o EEM;

- As bandas 5 e 7 (SWIR) mostram as principais evidências da presença dos minerais hidroxilados; a banda 5 caracteriza o albedo geral dos materiais, destacando a alta 
reflectância dos ions $\mathrm{Fe}^{3+}$ na região próxima a $1,6 \mu \mathrm{m}$, enquanto o $\mathrm{Fe}^{2+}$ provoca absorção nessa região, além de alguns picos de alta reflectância e absorção das argilas; o emprego da banda 5 geralmente favorece a distinção entre os materiais ferruginosos e aqueles ricos em argila; as posições variadas das feições de absorção do $\mathrm{Al}-\mathrm{OH}, \mathrm{Mg}-\mathrm{OH}$ e $\mathrm{H}_{2} \mathrm{O}$ na banda 7 provocam uma redução na reflectância dos minerais hidroxilados.

\section{5 - Avaliação Estatística das Combinações de Bandas do Landsat 5-TM}

A diversidade de litologias as assinaturas espectrais medidas favoreceu o emprego dos métodos de análise e interpretação dos dados do Landsat 5-TM na discriminação litológica e estrutural na região de Japi-Barra de Santa Rosa-Campina Grande. $\mathrm{Na}$ avaliação da exeqüibilidade do método, três questões fundamentais devem ser apresentadas e respondidas: (i) quais são as principais bandas do Landsat 5-TM ou combinação de bandas mais eficientes na discriminação das unidades litológicas mapeadas previamente ?; (ii) quais as combinações de bandas mais eficazes no diagnóstico das litologias similares, com variações mineralógicas e geoquímicas sutis ?; (iii) como as bandas e/ou combinação de bandas podem tornar-se mais eficazes na detecção detalhada de novas unidades e/ou alterações localizadas nas unidades litológicas?

Nos estudos sobre o emprego do Landsat 5-TM na discriminação litológica e realce das feições deformacionais, o senso comum sobre as melhores combinações coloridas de bandas ainda não está plenamente estabelecido. Com as seis bandas do espectro refletido, excluída a banda 6 com baixa resolução espacial $(120 \mathrm{~m})$, existem 20 possibilidades de combinações de três bandas com 120 permutações para disposição no sistema RGB. A avaliação sobre quais seriam as melhores bandas do Landsat 5-TM depende, parcialmente, das feições espectrais diagnósticas dos diferentes materiais em estudo, e da combinação entre a experiência e a lógica do intérprete. Após a decisão de quais bandas (ou razões de bandas) a serem usadas, outra decisão a ser tomada é como combiná-las em cores. A escolha de qual banda dispor em cada cor nos sistemas cromáticos (RGB ou IHS) depende das informações contidas nas bandas e da forma como o sistema visual humano percebe as informações coloridas, uma vez que não é igualmente sensivel a toda REM.

Alguns autores apresentaram argumentos favoráveis à seleção e combinação de três bandas baseados numa abordagem estatística multiespectral das cenas ou subcenas 
(áreas-teste), considerando as variâncias e as correlações entre as diferentes bandas (Chavez et al. 1982, 1984, Sheffield 1985, Hunt et al. 1986, Crippen 1989). A variância entre as bandas, indicada pelo desvio padrão, está relacionada ao conteúdo de informações contido na banda, e os coeficientes de correlação são indicadores da redundância entre as bandas. Sheffield (1985) alegou que o método mais rigoroso de selecção das três bandas é aquela baseado no determinante da matriz de variância-covariância $3 \times 3$ disposto num espaço de sétima dimensão. O determinante é uma medida de volume do elipsóide das três bandas, relativo à entropia da imagem multiespectral onde a melhor combinação apresenta o maior volume. Este autor destacou a combinação das bandas 1, 4, 5 do Landsat 5-TM como possuindo a máxima entropia multiespectral e, portanto, o melhor conjunto de bandas na diagnose de unidades de paisagem.

Chavez et al. (1982) desenvolveram o Fator Índice Ótimo (FIO) para cada combinação possivel de três bandas, expresso na Eq.(1). Crippen (1989) apresentou outro indice (INDEX) relacionado à raiz quadrada do determinante da matriz de correlação, como mostra a Eq.(2):

$$
\begin{aligned}
& F I O=\frac{\sigma_{1}+\sigma_{2}+\sigma_{3}}{\left|r_{(1,2)}\right|+\left|r_{(1,3)}\right|+\left|r_{(2,3}\right|} \\
& I N D E X=\sqrt{1+2\left[r_{(1,2)} r_{(1,3)} r_{(2,3)}\right]-\left[r_{(1,2)}\right]^{2}-\left[r_{(1,3)}\right]^{2}-\left[r_{(2,3)}\right]^{2}}
\end{aligned}
$$

Onde $\sigma_{i}$ é o desvio padrão para a banda $i$, e $r_{(i, j)}$ é o coeficiente de correlação entre as bandas $i$ e $j$. Esses dois tratamentos estatísticos foram aplicados às bandas Landsat 5-TM da região de Barra de Santa Rosa-Campina Grande, como mostra a Tab.5.1, calculados com base nas informações estatísticas das seis bandas do Landsat 5-TM apresentadas no Anexo 3.

Os resultados obtidos pelo método de Chavez et al. (1982) indicam que as combinações 1-4-5, 2-4-5, 1-4-7, 3-4-5 e 2-4-7, principalmente, são conjuntos informativos. Pelo método de Crippen (1989), o melhor conjunto é 1-4-5, seguido por 2-4-5, 1-4-7, 3-4-5, 2-4-7 e 3-4-7. Ambos os métodos apresentam resultados similares para as primeiras combinações, enquanto a classificação dos demais conjuntos de bandas é controversa. A banda 4 ocorre em todos os conjuntos provavelmente devido ao fato de que contém as 
absorções de campo do cristal do $\mathrm{Fe}^{3+}$. As bandas 1, 2 e 3 predominam nos conjuntos de piores classificações, indicando serem altamente correlacionadas e afetadas pelos efeitos atmosféricos, e portanto de baixo desempenho como combinaçðes coloridas.

Tabela 5.1 - Valores calculados do Fator Índice Ótimo (FIO, Chavez et al. 1982) e INDEX (Crippen 1989) para os 20 conjuntos de trios de bandas Landsat

5-TM. Comparação entre as diferentes classificações derivadas desses indices.

\begin{tabular}{|c|c|c|c|c|}
\hline BANDAS & FIO & RANK & INDEX & RANK \\
\hline $1-2-3$ & 7,583 & 20 & 0,1565 & 20 \\
\hline 1-2-4 & 25,187 & 9 & 0,41 & 8 \\
\hline $1-2-5$ & 12,489 & 15 & 0,305 & 11 \\
\hline $1-2-7$ & 8,195 & 19 & 0,265 & 15 \\
\hline $1-3-4$ & 26,63 & 8 & 0,4136 & 7 \\
\hline $1-3-5$ & 12,522 & 14 & 0,2968 & 12 \\
\hline $1-3-7$ & 9,429 & 17 & 0,222 & 18 \\
\hline $1-4-5$ & 40,26 & 1 & 0,706 & 1 \\
\hline $1-4-7$ & 32,41 & 5 & 0,6207 & 3 \\
\hline $1-5-7$ & 13,719 & 12 & 0,288 & 13 \\
\hline $2-3-4$ & 24,07 & 10 & 0,312 & 10 \\
\hline $2-3-5$ & 13,259 & 13 & 0,260 & 16 \\
\hline 2-3-7 & 8,636 & 18 & 0,2068 & 19 \\
\hline $2-4-5$ & 34,41 & 3 & 0,652 & 2 \\
\hline $2-4-7$ & 29,35 & 6 & 0,5971 & 5 \\
\hline $2-5-7$ & 12,47 & 16 & 0,2846 & 14 \\
\hline $3-4-5$ & 36,09 & 2 & 0,599 & 4 \\
\hline 3-4-7 & 29,223 & 7 & 0,5184 & 6 \\
\hline 3-5-7 & 13,775 & 11 & 0,2449 & 17 \\
\hline $4-5-7$ & 33,53 & 4 & 0,3756 & 9 \\
\hline
\end{tabular}

$\mathrm{Na}$ avaliação estatística comparativa da forma e intensidade das curvas espectrais para os conjuntos de trios de bandas do Landsat 5-TM foi empregado um método onde o maior indice percentual (positivo ou negativo) obtido para as amostras analisadas indica a melhor correlação das curvas entre os canais. Os cálculos foram realizados com os valores médios da assinatura espectral do material analisado em .cada banda do Landsat 5-TM, ponderados pela média nas três bandas empregadas numa distribuição gaussiana. Quanto maior o grau de afastamento entre os valores percentuais de cada material analisado para as 20 combinações de três bandas maior a distinção entre eles na composição colorida entre as três bandas. Os melhores resultados obtidas para as 20 combinações das seis bandas do Landsat 5-TM (1-5 e 7) para distinção de todos as litologias analisadas por espectrometria foram os conjuntos 1-3-5, 1-2-5, 1-3-7 e 2-3-5. Os conjuntos 1-2-3 e 2-3-4, freqüentemente empregados nos trabalhos de mapeamento geológico por envolverem as bandas no VNIR, mostraram os piores resultados na distinção das litologias, sendo os demais conjuntos úteis 
para comparaç̃es específicas envolvendo até três litologias, conforme as maiores diferenças entre os indices.

Os diagramas de dispersão comparativos para as categorias A e B foram apresentados nas Fig. 5.15a e 5.15b, respectivamente, de acordo com os resultados expressos na Tab. 5.2. Estes diagramas indicam a habilidade dos 20 conjuntos de trios de bandas na distinção entre as litologias, agrupando-as em categorias segundo as proporções de minerais máficos e félsicos. Para a categoria $\mathrm{A}$, o diagrama (Fig. 5.15a) mostra a dificuldade de distinção das litologias individualmente. Os melhores conjuntos, ou seja aqueles onde a maioria das litologias analisados estão individualizadas, foram 1-2-5, 1-3-5, 1-2-7 e 2-3-7, com afastamentos variando de $3 \%$ a $40 \%$. Nos demais conjuntos de bandas ocorre sobreposição entre as litologias, sobretudo entre Caxexa, Japi e Algodão, evidenciando a proximidade mineralógica e geoquimica destes granitóides. Entretanto, a distinção entre os granitóides alcalinos, o ortognaisse do embasamento e Pocinhos pode ser obtida sutilmente nos conjuntos 2-3-4, 3-4-5, 1-4-7, 2-4-7 e 3-4-7. No diagrama para a categoria B (Fig. 5.15b) os conjuntos 1-5-7, 2-4-5, 2-5-7, 3-4-5, 3-4-7 e 3-5-7 foram os mais distintivos para todas as litologias analisadas, com variações entre $5 \%$ e $40 \%$. As litologias com maiores sobreposições e semelhanças na assinatura espectrais são Pocinhos e o paragnaisse, cuja melhor distinção pode ser obtida nos conjuntos 1-5-7, 2-5-7 e 3-5-7.

Os quatro melhores conjuntos na distinção entre a totalidade das litologias (1-2-5, 1-3-5, 1-3-7 e 2-3-5) foram combinados dois a dois num diagrama de dispersão 2-D (Fig. 5.16), de forma a evidenciar o grau de dispersão entre as litologias submetidos ao tratamento de apenas duas das quatro melhores combinações possiveis. Os diagramas da Fig. 5.16 mostram que nas combinações $1-2-5|2-3-5,1-3-5| 2-3-5$ e $1-3-7 \mid 2-3-5$ as litologias foram diferenciados em três grupos: (a) o micaxisto; (b) o grupo formado pelos granitóides alcalinos (Japi, Algodão e Caxexa); e (d) o grupo formado pelas demais litologias (Jandaíra, CCG, paragnaisse, Pocinhos e ortognaisse do embasamento). Desta forma, o emprego desses conjuntos permite apenas a distinção entre os grupos, ocorrendo freqüentes sobreposições entre os granitóides de Caxexa e Japi, e entre Pocinhos e o ortognaisse. O evidente alinhamento entre os pontos nos diagramas, com inclinação próxima a $45^{\circ}$, marca a forte correlação entre as bandas empregadas. A dispersão é mais acentuada para as combinações $1-2-5 \mid 1-3-5$ e 1-2-5|1-3-7, onde não ocorre nem mesmo alinhamentos entre os pontos, 
Talbella 5.2 - Valores estatísticos das dispersð̃es nos 20 conjuntos de trios de bandas TM calculados conforme as respostas espectrais das litologias do Setor Extremo Nordeste da Província Borborema.

\begin{tabular}{|c|c|c|c|c|c|c|c|c|c|}
\hline & cco & Caxexa & Pocinhos & Algodå० & Jandaira & Japi & Paragnaisse & Embasamento & Micaxisto \\
\hline$T M 123$ & $5 \%$ & $-4 \%$ & $7 \%$ & $-12 \%$ & $6 \%$ & $-5 \%$ & $5 \%$ & $8 \%$ & $7 \%$ \\
\hline TM 234 & $-2 \%$ & $16 \%$ & $1 \%$ & $13 \%$ & $1 \%$ & $18 \%$ & $1 \%$. & $5 \%$ & $-3 \%$ \\
\hline TM 345 & $-1 \%$ & $12 \%$ & $1 \%$ & $13 \%$ & $-13 \%$ & $11 \%$ & $-6 \%$ & $-4 \%$ & $-54 \%$ \\
\hline$T M 457$ & $17 \%$ & $-3 \%$ & $9 \%$ & $5 \%$ & $17 \%$ & $-4 \%$ & $6 \%$ & $9 \%$ & $39 \%$ \\
\hline TM 235 & $-19 \%$ & $24 \%$ & $-8 \%$ & $14 \%$ & $-22 \%$ & $24 \%$ & $-12 \%$ & $-9 \%$ & $-76 \%$ \\
\hline TM 125 & $-31 \%$ & $-1 \%$ & $-12 \%$ & $-26 \%$ & $-29 \%$ & $-7 \%$ & $-17 \%$ & $-20 \%$ & $-93 \%$ \\
\hline TM 135 & $-2 \%$ & $43 \%$ & $9 \%$ & $32 \%$ & $-8 \%$ & $46 \%$ & $0 \%$ & $13 \%$ & $-60 \%$ \\
\hline TM 145 & $30 \%$ & $52 \%$ & $28 \%$ & $59 \%$ & $11 \%$ & $59 \%$ & $15 \%$ & $34 \%$ & $-25 \%$ \\
\hline TM 147 & $14 \%$ & $38 \%$ & $12 \%$ & $47 \%$ & $-7 \%$ & $37 \%$ & $-5 \%$ & $7 \%$ & $-59 \%$ \\
\hline TM 157 & $64 \%$ & $43 \%$ & $46 \%$ & $65 \%$ & $51 \%$ & $50 \%$ & $33 \%$ & $56 \%$ & $83 \%$ \\
\hline TM 245 & $12 \%$ & $33 \%$ & $11 \%$ & $40 \%$ & $-4 \%$ & $36 \%$ & $2 \%$ & $11 \%$ & $-42 \%$ \\
\hline TM 247 & $14 \%$ & $38 \%$ & $12 \%$ & $47 \%$ & $-7 \%$ & $37 \%$ & $-5 \%$ & $7 \%$ & $-59 \%$ \\
\hline TM 257 & $45 \%$ & $23 \%$ & $28 \%$ & $45 \%$ & $35 \%$ & $27 \%$ & $20 \%$ & $33 \%$ & $65 \%$ \\
\hline TM 357 & $31 \%$ & $2 \%$ & $18 \%$ & $18 \%$ & $26 \%$ & $2 \%$ & $12 \%$ & $18 \%$ & $53 \%$ \\
\hline TM 124 & $-13 \%$ & $-9 \%$ & $-3 \%$ & $-27 \%$ & $-5 \%$ & $-12 \%$ & $-3 \%$ & $-4 \%$ & $-16 \%$ \\
\hline $\operatorname{TM} 127$ & $-28 \%$ & $5 \%$ & $-11 \%$ & $-20 \%$ & $-32 \%$ & $-6 \%$ & $-24 \%$ & $-24 \%$ & $-110 \%$ \\
\hline TM 134 & $17 \%$ & $34 \%$ & $19 \%$ & $31 \%$ & $17 \%$ & $40 \%$ & $15 \%$ & $29 \%$ & $22 \%$ \\
\hline TM 137 & $1 \%$ & $49 \%$ & $11 \%$ & $39 \%$ & $-11 \%$ & $47 \%$ & $-7 \%$ & $8 \%$ & $-78 \%$ \\
\hline TM 237 & $-17 \%$ & $29 \%$ & $-6 \%$ & $20 \%$ & $-25 \%$ & $25 \%$ & $-19 \%$ & $-14 \%$ & $-92 \%$ \\
\hline TM 347 & $1 \%$ & $17 \%$ & $2 \%$ & $19 \%$ & $-16 \%$ & $11 \%$ & $-13 \%$ & $-8 \%$ & $-70 \%$ \\
\hline
\end{tabular}

Tabela 5.4 - Valores estatísticos das dispersões nos 13 conjuntos de razões de bandas TM calculados conforme as respostas espectrais das litologias do Setor Extremo Nordeste da Província Borborema.

\begin{tabular}{lrrrrrrrrr} 
& CCG & Caxexa & Pocinhos & Algodå० & Jandaira & \multicolumn{2}{c}{ Japi } & Paragnalsse Embasamento & Micaxisto \\
TM 5 / TM 1 & $66 \%$ & $34 \%$ & $43 \%$ & $61 \%$ & $56 \%$ & $48 \%$ & $38 \%$ & $66 \%$ & $165 \%$ \\
TM 2 / TM 1 & $18 \%$ & $17 \%$ & $16 \%$ & $18 \%$ & $15 \%$ & $21 \%$ & $12 \%$ & $24 \%$ & $25 \%$ \\
TM 3 / TM 2 & $12 \%$ & $17 \%$ & $8 \%$ & $24 \%$ & $8 \%$ & $21 \%$ & $7 \%$ & $13 \%$ & $15 \%$ \\
TM 4 / TM 3 & $12 \%$ & $3 \%$ & $7 \%$ & $10 \%$ & $7 \%$ & $4 \%$ & $6 \%$ & $8 \%$ & $15 \%$ \\
TM 5 / TM 4 & $12 \%$ & $-5 \%$ & $6 \%$ & $-0 \%$ & $17 \%$ & $-3 \%$ & $10 \%$ & $10 \%$ & $60 \%$ \\
TM 7 / TM 5 & $-2 \%$ & $-4 \%$ & $-1 \%$ & $-4 \%$ & $2 \%$ & $-1 \%$ & $5 \%$ & $3 \%$ & $11 \%$ \\
TM 3 / TM 1 & $32 \%$ & $37 \%$ & $26 \%$ & $47 \%$ & $24 \%$ & $47 \%$ & $19 \%$ & $40 \%$ & $44 \%$ \\
TM 4 / TM 2 & $26 \%$ & $21 \%$ & $16 \%$ & $37 \%$ & $16 \%$ & $27 \%$ & $13 \%$ & $22 \%$ & $33 \%$ \\
TM 4 / TM 7 & $-9 \%$ & $9 \%$ & $-5 \%$ & $5 \%$ & $-16 \%$ & $4 \%$ & $-13 \%$ & $-12 \%$ & $-43 \%$ \\
TM 5 / TM 3 & $26 \%$ & $-2 \%$ & $14 \%$ & $10 \%$ & $25 \%$ & $1 \%$ & $16 \%$ & $19 \%$ & $84 \%$ \\
TM 7 / TM 4 & $10 \%$ & $-9 \%$ & $5 \%$ & $-4 \%$ & $19 \%$ & $-4 \%$ & $15 \%$ & $13 \%$ & $76 \%$ \\
TM 5 / TM 7 & $2 \%$ & $4 \%$ & $1 \%$ & $4 \%$ & $-2 \%$ & $1 \%$ & $-4 \%$ & $-3 \%$ & $-10 \%$ \\
TM 3 / TM 4 & $-11 \%$ & $-3 \%$ & $-7 \%$ & $-9 \%$ & $-7 \%$ & $-4 \%$ & $-5 \%$ & $-7 \%$ & $-13 \%$
\end{tabular}


(a)

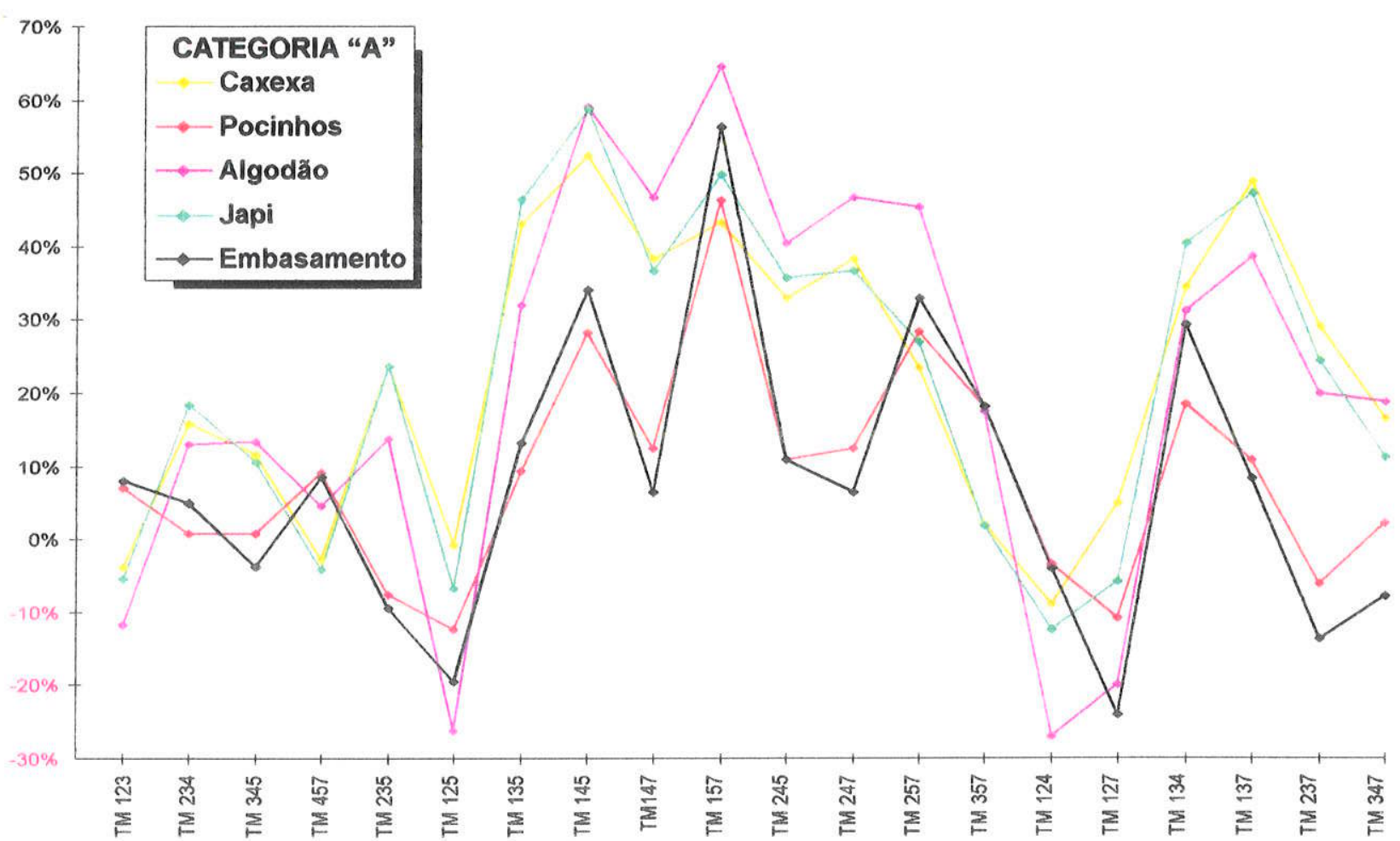

(b)

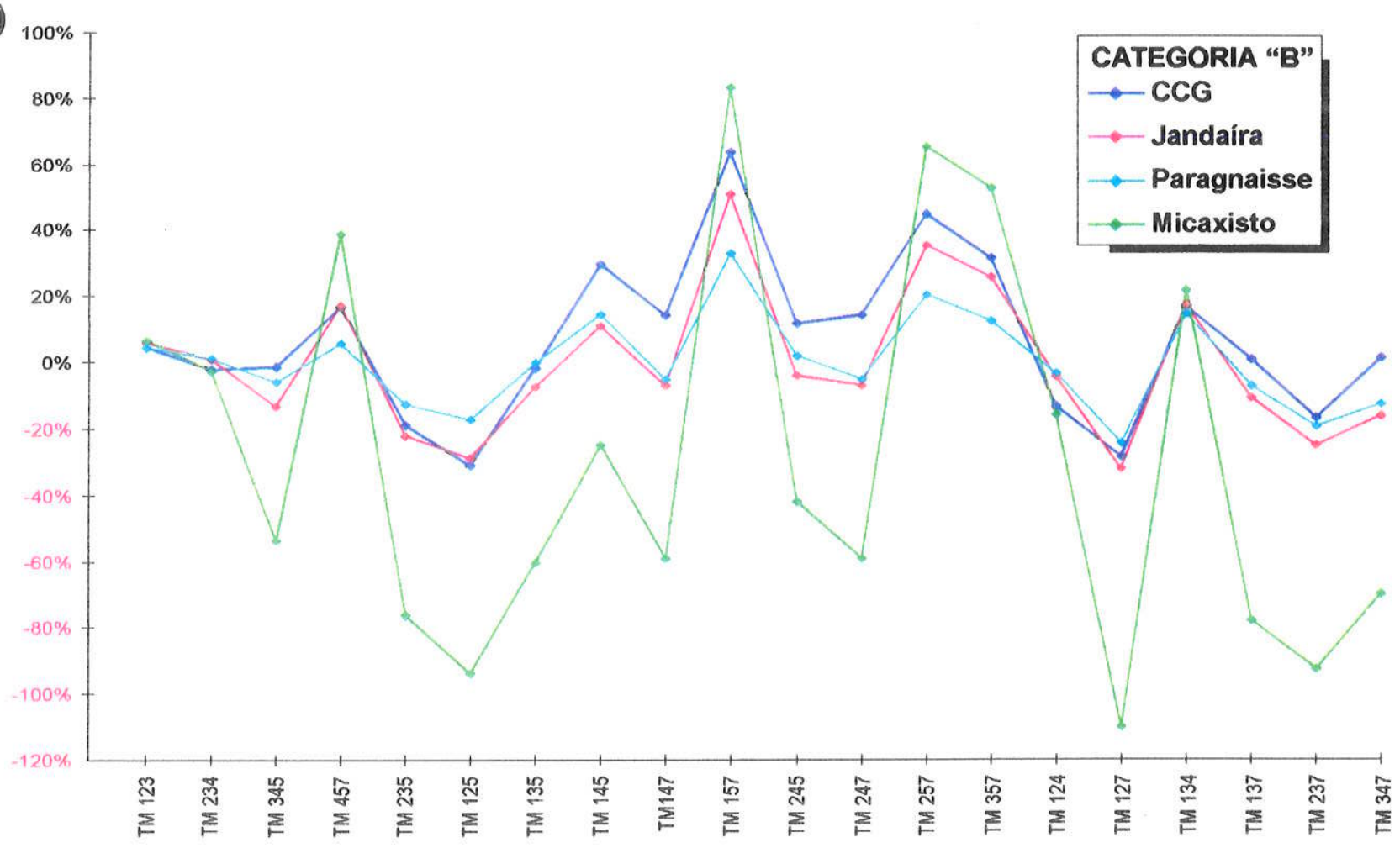

Figura 5.15- Diagramas comparativos da dispersão nos 20 conjuntos de bandas combinadas três a três do Landsat 5-TM das litologias que tiveram os espectros de reflectância analisados: (a) Categoria "A" e (b) Categoria "B". 


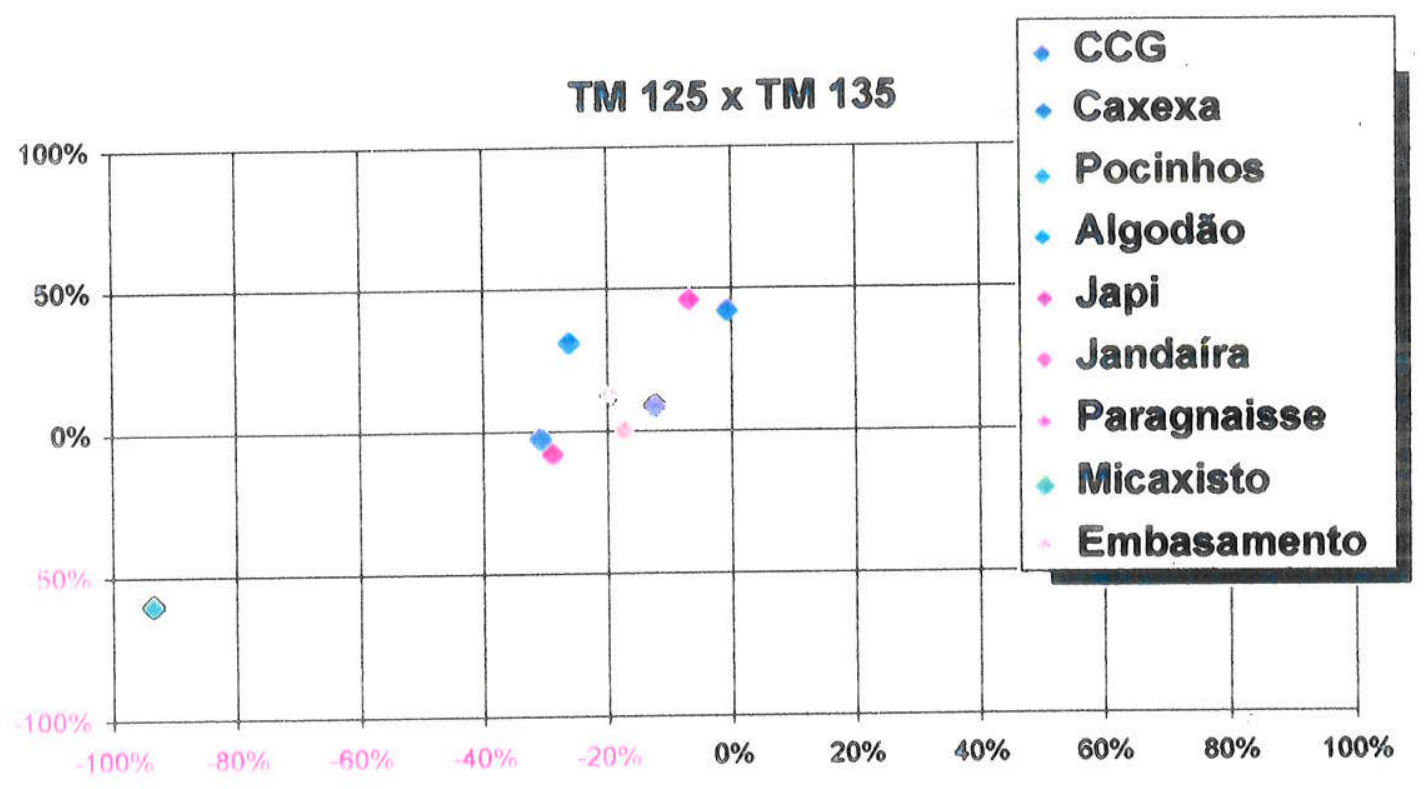

TM $125 \times$ TM 137

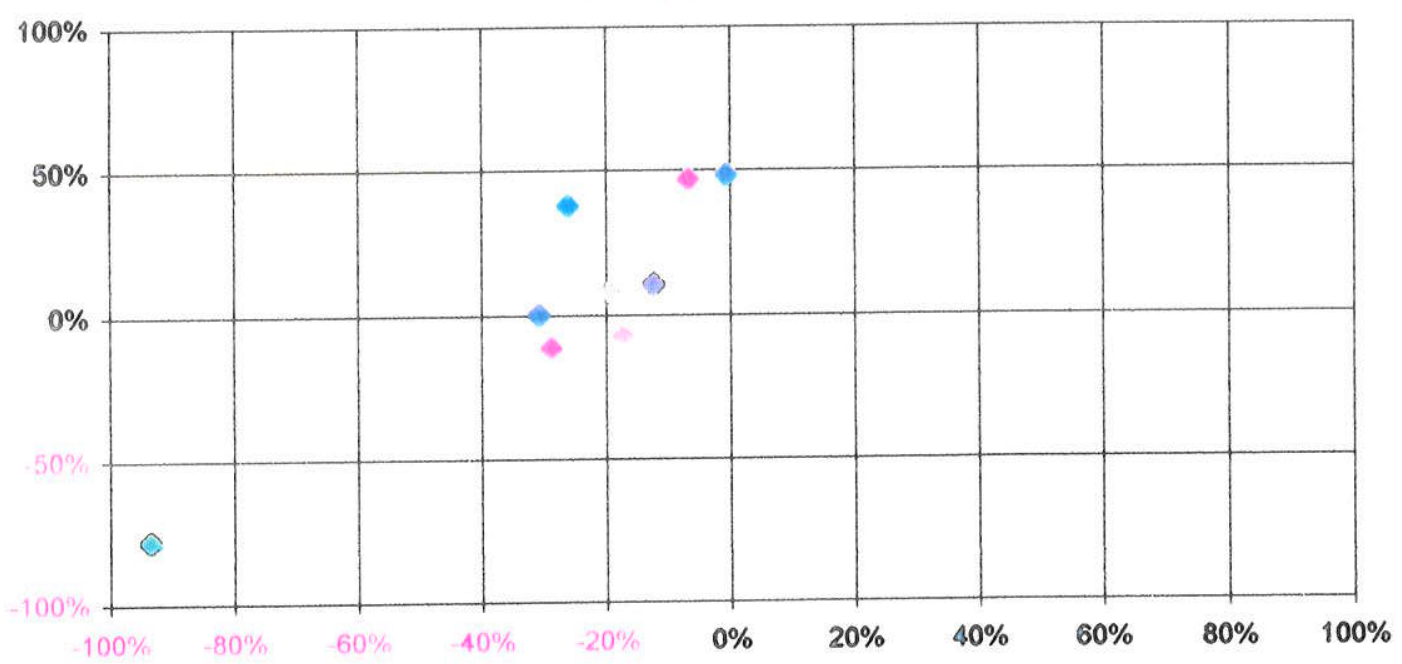

TM $135 \times$ TM 137

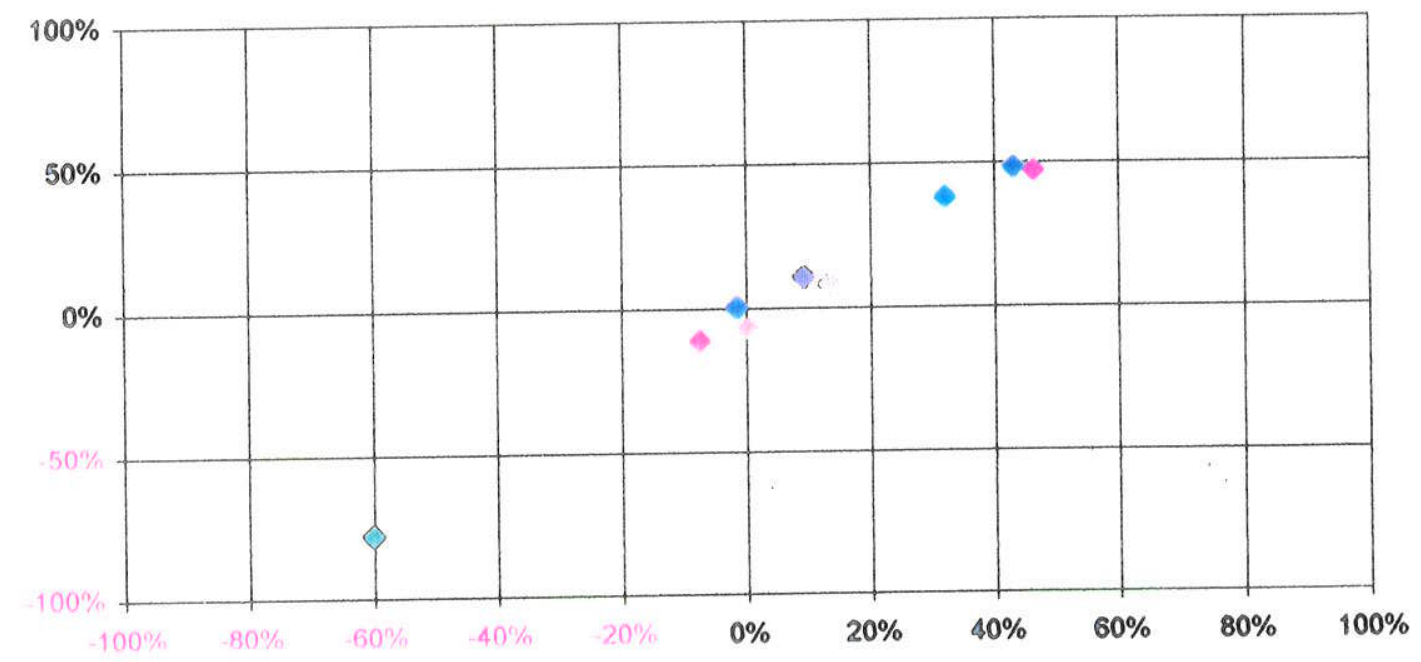

Figura 5.16 - Legenda na próxima página. 


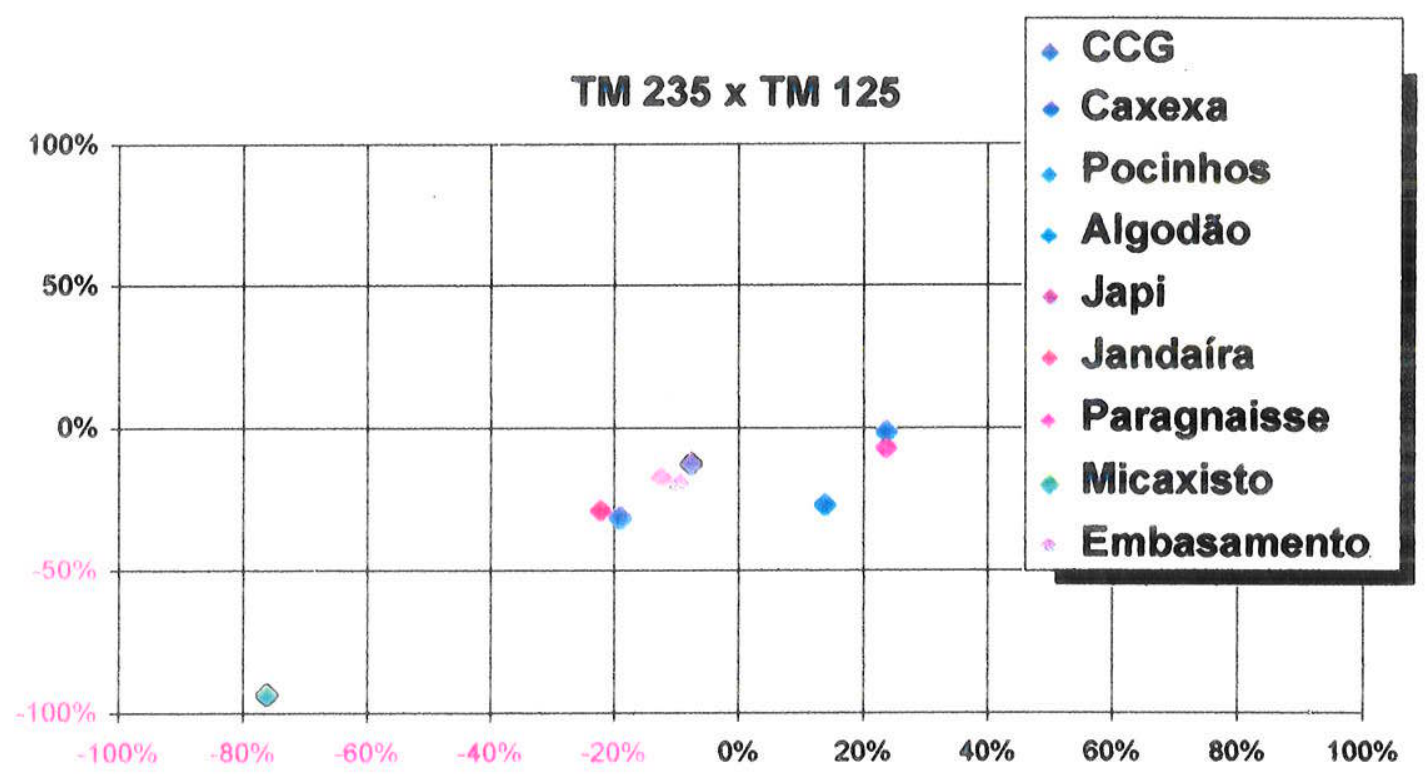

TM $235 \times$ TM 135

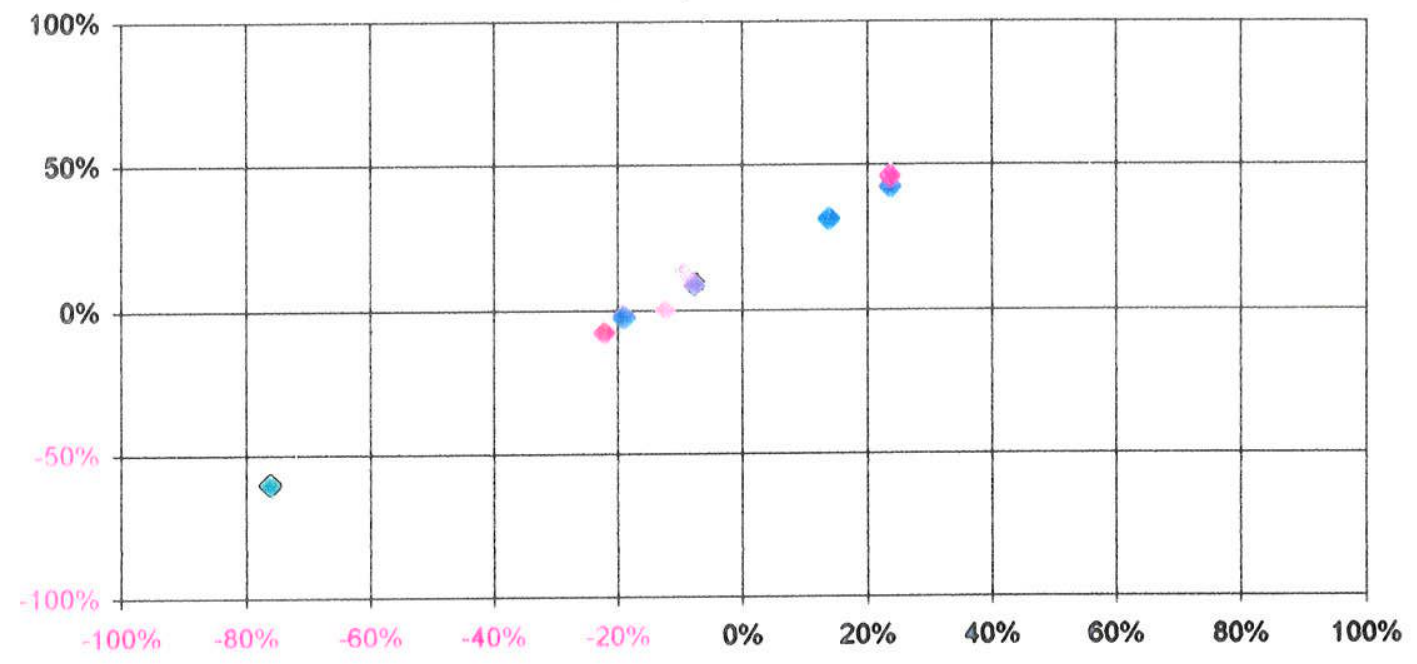

TM $235 \times$ TM 137

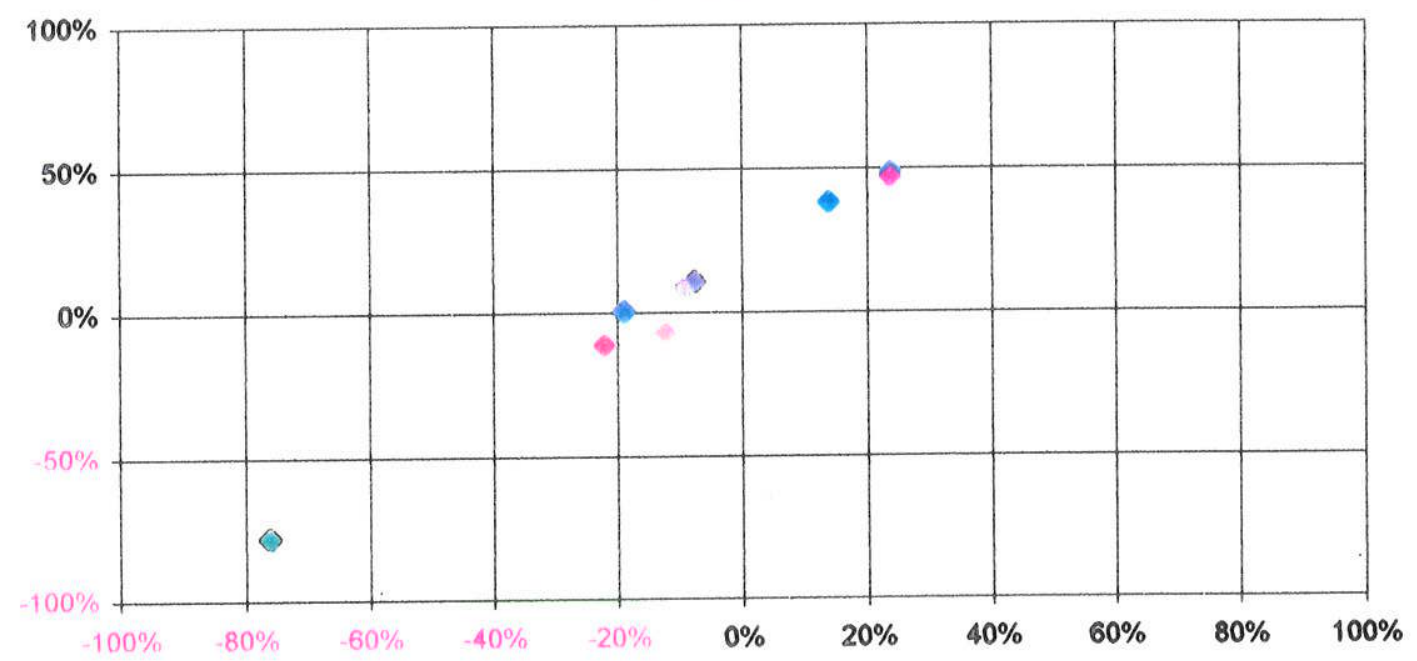

Figura 5.16 - Diagrama de dispersão 2-D comparativo dos quatro melhores conjuntos de trios de bandas TM (1-2-5, 1-3-5, 1-3-7 e 2-3-5) combinados dois a dois, para o conjunto de litologias do Setor Extremo Nordeste da Província Borborema que tiveram a respostas espectrais analisadas. 
tratando-se, portanto, dos conjuntos de bandas combinados dois a dois de melhor desempenho na distinção entre a totalidade das litologias. Nesses diagramas ficaram evidentes as similaridades petrográficas e geoquimicas entre os granitóides de Caxexa, Japi e Algodão, principalmente entre Japi e Caxexa, que aparecem quase sempre sobrepostos ou muito próximos em todos os diagramas, indicando a dificuldade de distinção baseada nos conjuntos de bandas. Entre todas as amostras analisadas, o micaxisto constitui a litologia de mais fácil distinção nas combinações de bandas.

Entretanto, o principal problema na aplicação de métodos puramente estatísticos é que eles ignoram a distinção entre variações geologicamente significantes, como diferenças de cores nas/entre as unidades litológicas, e os fatores não-geológicos, como as variações topográficas e as sombras nas superficies com valores alto ou baixo de albedo (Rothery 1987b). Assim, na prática, a melhor decisão é aquela tomada pelo intérprete após inspeção visual do trio de bandas combinadas num sistema de cores (6 permutações possíveis em RGB), considerando as principais feições espectrais diagnósticas dos materiais alvos em cada banda do Landsat 5-TM, e usando para isso um sistema de processamento de imagens bastante interativo que favoreça a velocidade do processamento.

O método estatístico comparativo aplicado, baseado nas formas e posição das bandas de absorção das assinaturas espectrais, permitiu a seleção dos conjuntos de bandas com melhores desempenhos na caracterização individualizada e na discriminação de grupos entre as categorias de litologias. Desta forma, a partir desse pressuposto estatístico, esses conjuntos de bandas com melhores desempenhos foram empregadas na incrementação do mapeamento geológico da região entre Barra de Santa Rosa-Campina Grande. Este procedimento teve o intuito de facilitar a seleção dos conjuntos de bandas empregadas nos processamentos digitais, confirmando ou não a validade dos tratamento estatísticos para áreas de maior abrangência espacial.

\section{6 - Processamento Digital de Imagens do Landsat 5-TM}

Nos trabalhos envolvendo a aplicação das bandas do Landsat 5-TM no mapeamento geológico em terrenos áridos, semi-áridos e temperados, diversos autores propuseram procedimentos básicos de escolha do melhor subconjunto de imagens, adotados em função de fatores como: (a) a habilidade na discriminação de diferentes unidades da 
paisagem, correlacionáveis às unidades geológicas; (b) o realce das estruturas geológicas correspondentes às fases tectônicas distintas; (c) a identificação e discriminação entre diferentes tipos de cobertura vegetal e ocupação do solo (florestas, solos expostos, culturas, etc.); (d) a obtenção de excelente resolução espacial nas imagens resultantes. As melhores opções assinaladas para a discriminação litológica foram resumidas:

- Composições em RGB: 742 (Loughlin \& Tawfiq 1985); 754 (Rothery 1987a, Drury \& Hunt 1989); 145 e 147 (Davis \& Berlin 1989); 4/2 4/7 5/7 (Drury \& Hunt 1989); $5 / 47 / 5$ e uma das razões $2 / 1,3 / 1,4 / 1,4 / 2$ ou $3 / 2$ (Davis \& Berlin 1989); segunda PC resultante das razões $4 / 3$ e $5 / 7$, razão $5 / 4$ e resultante de $[1+3+5+7]$ (Glikson \& Creasey 1995); 752 na discriminação de alterações argilosas e ferruginosas;

- Método de Decorrelação: transformação do trio de bandas 754 combinadas em RGB (Abrams et al. 1988, Qari 1991);

- Método de APC: três primeiras componentes das seis bandas no visívelinfravermelho combinadas em RGB (Qari 1991); três componentes de 147 em RGB (Davis \& Berlin 1989).

\subsection{1 - Interpretação Visual das Composições Coloridas em RGB}

Os principais conjuntos de trios de bandas do Landsat 5-TM, destacados nos métodos estatísticos, foram dispostos em composições coloridas no sistema RGB, apresentados segundo a seqüência como foram dispostos nos canais R-G-B. As imagens foram submetidas às modificações de contrastes dos histogramas, de forma a aperfeiçoar a distinção visual de diferentes aspectos na imagem resultante. Os métodos empregados envolveram transformações lineares (Aumento Linear de Contraste) e não-lineares (Gaussiana, Logaritmica, Equalização) correntes no ER-Mapper v.5.2, aplicadas para o realce da dinâmica visual de cada banda individualmente.

\section{- Composição 5-2-1:}

A Fig. 5.17 apresenta a composição em RGB das bandas 5-2-1 do Landsat 5-TM. A imagem resultante propiciou uma excelente discriminação das principais litologias presentes na área, como sugere a interpretação visual dos aspectos geológicos decorrentes (Fig. 5.18). Algumas das litologias da região de Barra de Santa Rosa-Campina Grande que tiveram os espectros de reflectância analisados, foram diferenciados entre si e dos demais terrenos que compõem a área de estudo. Os ortognaisses migmatíticos da porção $\mathrm{NW}$ da 


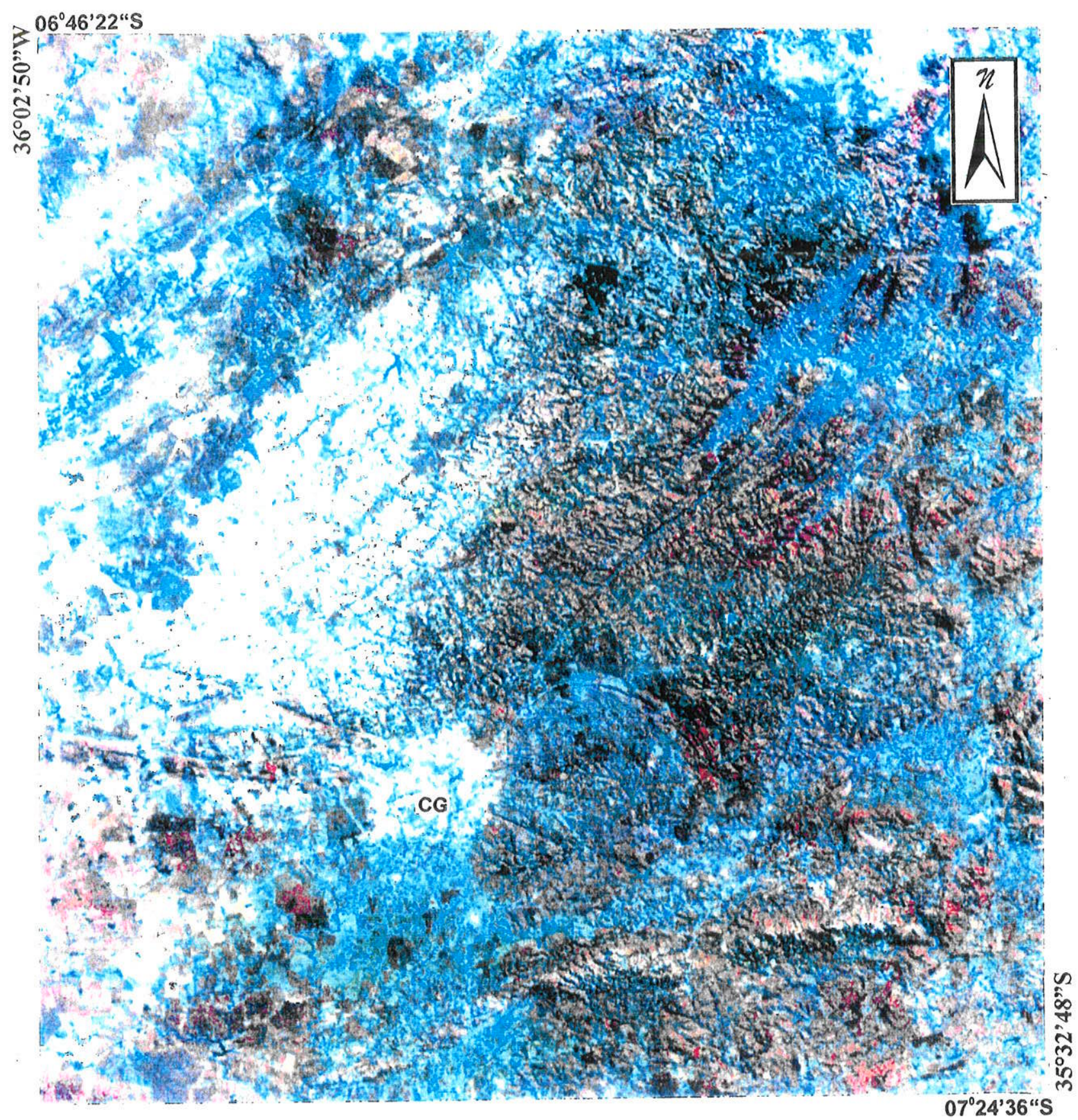

Figura 5.17 - Imagem da composição colorida das bandas 5-2-1 do Landsat 5TM combinadas em RGB. O mapa indica a localização da cidade de Campina Grande/PB marcada por CG. 


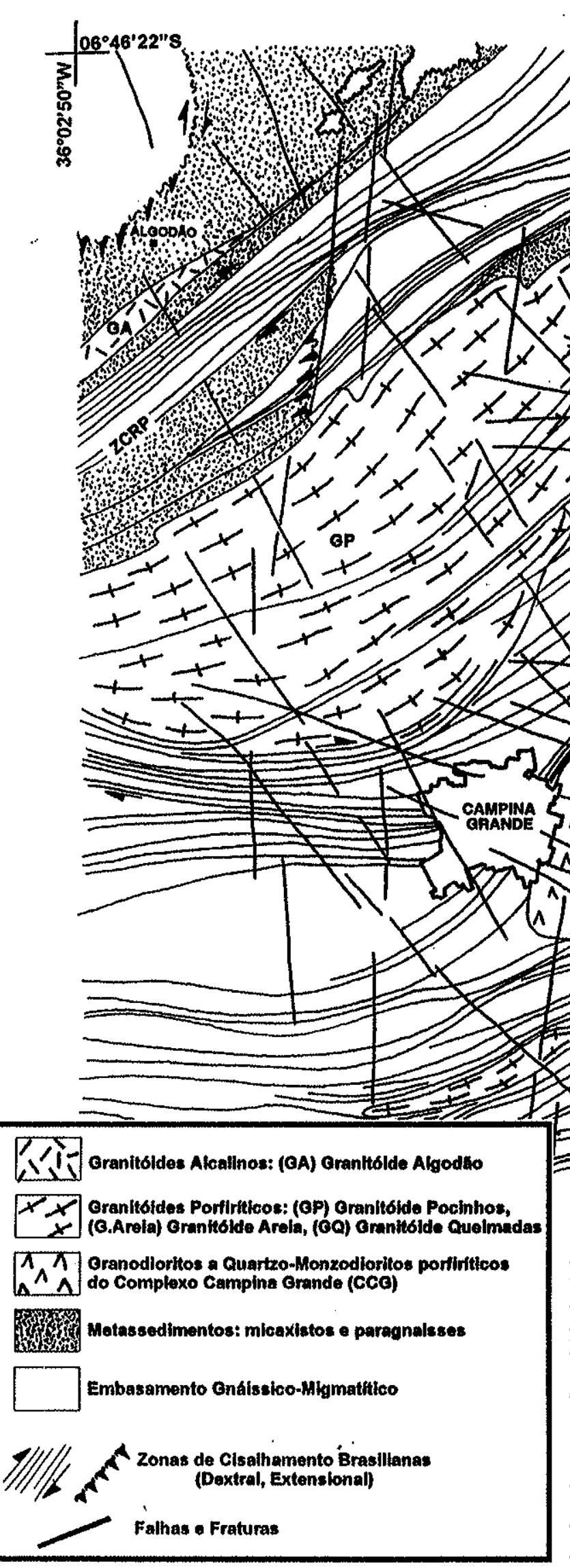


área, embasamento da faixa de matassedimentos de Barra de Santa Rosa, mostraram cores entre o vermelho e vermelho-acastanhado devido ao elevado albedo produzido pela predominância de minerais félsicos, a alta reflectância dos ions $\mathrm{Fe}^{3+}$ centrada em 1,6 $\mu \mathrm{m}$, dos óxidos de ferro na banda 3 e à intensa banda de absorção por transição eletrônica dos íons $\mathrm{Fe}^{2+}-\mathrm{Fe}^{3+}$ no VIS (bandas 1 e 2). Os micaxistos de Barra de Santa Rosa apresentaram colorações variando entre marrom-amarelado e marrom-avermelhado, respectivamente em função do aumento do grau metamórfico (fácies xisto-verde a granulito com migmatização), conforme o surgimento de piroxênios e $o$ aumento no volume de magnetita nos paragnaisses granulíticos e metapelitos migmatíticos da porção central da faixa (ZCRP). As suites alcalinas de Algodão e Caxexa. mostraram cores análogas variando entre róseoesbranquiçado e branco-azulado decorrentes da predominância de minerais félsicos (quartzo e feldspatos parcialmente alterados para argilo-minerais), dos picos dos minerais de argila que elevam o albedo na banda 5 e no VIS, do ápice de reflectância em torno de $1,6 \mu \mathrm{m}$ do $\mathrm{Fe}^{3+}$ de alteração e das bandas de absorção no VIS devido às transições eletrônicas dos íons $\mathrm{Fe}^{3+}-\mathrm{Fe}^{2+}$, comuns nos minerais máficos. O granitóide de Pocinhos mostrou coloração amarelo-esbranquiçada (quase branco), homogeneamente distribuida, que define a predominância dos feldspatos parcialmente substituídos por argilo-minerais, como indicam as características de albedo elevado na banda 5 e alta reflectância nas bandas 1 e 2 , relativo às feições de absorção das transferências $\mathrm{Fe}^{2+}-\mathrm{Fe}^{3+}$ e do campo dos cristais do $\mathrm{Fe}^{2+}$ no VIS, comuns aos minerais máficos. O granitóide é interceptado por estreitas faixas marromavermelhadas marcando zonas de cisalhamento de direção NE originadas da distribuição em splay do sistema ZCRP-ZCCG. A coloração marrom-avermelhada nessas faixas indica aumento nos teores de íons ferro, provavelmente devido ao aumento nos teores de magnetita e/ou limonita, dos argilo-minerais e da cominuição dos grãos freqüentes nas zonas de cisalhamento. O CCG apresentou cores entre magenta-escuro e azul-escuro decorrentes do baixo albedo, da associação entre a maior reflectância dos minerais máficos com $\mathrm{OH}$ na faixa do VIS e aqueles ricos em óxidos de ferro na banda 5 .

A interpretação visual da Fig. 5.17 favoreceu ainda a caracterização geológica das demais porções do terreno, das quais não se dispõe de informações espectrais. As unidades de paisagem, delimitadas na interpretação visual das imagens, foram confirmadas pelos dados de campo e serviram até mesmo como mapa-guia. De maneira geral, os terrenos 
do embasamento puderam ser discriminados entre áreas de coloração vermelho a vermelhoamarelado, caracterizadas por ortognaisses migmatíticos de composição tonalítica a granodiorítica, predominantes na porção a N-NW da cidade de Campina Grande, limitada pela ZCCG e ZCGB (zonas de cisalhamento de Campina Grande e Guarabira), e áreas verde-azuladas a verde-amareladas compostas por granada-biotita-hornblenda gnaisses bandados e migmatiticos que ocupam a porção S-SE da área. Duas faixas de coloração cinza-azulado compostas por micaxistos migmatíticos foram destacadas na região de Alagoa Grande, formando vales alongados e constituidos por regolito (espessura $>3 \mathrm{~m}$ ) e solo marrom escuro. Estas faixas estão envolvidas pela ZCGB e intercaladas aos granitóides e ortognaisses milonitizados do embasamento formando serras que delimitam os vales. A estreita faixa de micaxistos dispostas ao longo da ZCP (zona de cisalhamento Pirpirituba) destacou-se pela coloração variando entre marrom-azulado e marrom-avermelhado e textura semelhante àquela das faixas de Alagoa Grande. O granitóide de Queimadas, a SSE de Campina Grande, apresentou cores variando entre róseo e róseo-amarelado controladas pelas bandas 5 e 2 , que caracterizam a predominância de minerais félsicos definidos pelo albedo $\mathrm{e}$ ápices de reflectância do $\mathrm{Fe}^{3+}$, que freqüentemente acompanham os minerais hidroxilados de alteração. A forma sigmoidal e estirada do corpo segue a terminação EW-NE do sistema de zonas de cisalhamento do lineamento Patos-Campina Grande. Trata-se de um granitóide cinza rosado predominantemente porfirítico de natureza monzogranítica a granodiorítica (tipo Itaporanga), com fabric ora preferencialmente PFC, definido pela orientação dos fenocristais de feldspatos em fluxo viscoso, ora SPD em faixas miloníticas e nas bordas do plúton, com cominuição dos grãos e critérios cinemáticos dextrais.

A Fig. 5.17 permitiu a caracterização do granitóide de Areia, que compõe a Serra do Jacu entre as cidades de Areia e Guarabira, de aspecto sigmoidal rotacionado entre a ZCP dextral e a ZCGB de caráter sinistral. Trata-se de granitóide mesocrático a leucocrático de coloração cinza claro a cinza rosado, granulação média a grosseira, de textura microporfirítica a porfiritica e composição granítica a granodiorítica. Freqüentemente, apresenta fabric PFC, dada pela orientação dos fenocristais de $\mathrm{K}$-feldspato e das fases máficas, evoluindo para o tipo SPD, marcada pelas caudas de recristalização dos feldspatos e pelos grãos de quartzo e máficos estirados e, com cinemática dextral indicada pelas estruturas $\mathrm{S}-\mathrm{C}$ e $\mathrm{C}^{\prime}$, e porfiroclastos assimétricos rotacionados. O granitóide mostrou 
coloração cinza escura a cinza azulado na Fig. 5.17, com intercalações vermelho escuro a rosado, provavelmente devido às proporçðes de feldspatos parcialmente substituídos por argilo-minerais e minerais máficos como anfibólio e biotita presentes na matriz.

A avaliação integrada dos critérios morfológicos e texturais dos terrenos, aliados às colorações assumidas pelas unidades geológicas, possibilitaram a caracterização dos aspectos deformacionais da área, marcada pela terminação em splay do lineamento Patos, desdobrado no sistema formado pela ZCRP, e as subsidiárias ZCP e ZCCC (zonas de cisalhamento Pirpirituba e Cacerengo), e pelas ZCCG e ZCGB (zona de cisalhamento Guarabira). Nos corredores de mais alto strain das zonas de cisalhamento de direção geral EW e NE, tanto as principais como as secundárias, os lineamentos constituem sistemas extensos e densos, de aspecto intensamente ramificado nas terminações, marcadores da foliação milonitica de mergulho mediano a forte. $O$ traçado anastomosado da deformação dúctil e a forma sigmoidal assimétrica rotacionada e/ou estirada dos plútons granitóides, intrusivos nas zonas de cisalhamento, permitiram a determinação do principal caráter cinemático das zonas de cisalhamento, confirmado pelas informações de campo. Um padrão de extensas zonas de falhas com direção geral EW e NW interceptam a área condicionando preferencialmente as drenagens secundárias, como mostram os lineamentos de geometria linear a curvilinear e localização espacial bem definida. Um conjunto de lineamentos de mesmo estilo e direção geral EW a NE, reciprocamente gradacionais com os lineamentos marcadores da deformação dúctil, provavelmente decorrentes de reativações nos ambientes dúctil-frágil e frágil, condicionam as principais drenagens primárias da região.

\section{-Composição 5-3-1:}

A composição 5-3-1 mostra poucas variações quanto aos aspectos destacados pela composição 5-2-1, destacando os mesmos elementos geológicos descritos anteriormente. Entretanto, a substituição da banda 2 pela banda $3 \mathrm{em} \mathrm{G}$ produziu maior contraste no matiz e na saturação das cores, em função da alta reflectância dos óxidos de ferro na banda 3 , favorecendo a maior distinção entre variações sutis nos atributos espectrais das unidades de paisagem. Por esse motivo, as áreas de Barra de Santa Rosa e Japi foram selecionadas para maior detalhamento (Fig. 5.19 e 5.21 , respectivamente), onde foram coletadas as amostras para análise dos espectros. As Fig. 5.20 mostra a interpretação visual da imagem da região de Barra de Santa Rosa destacando a geometria da deformação e as 


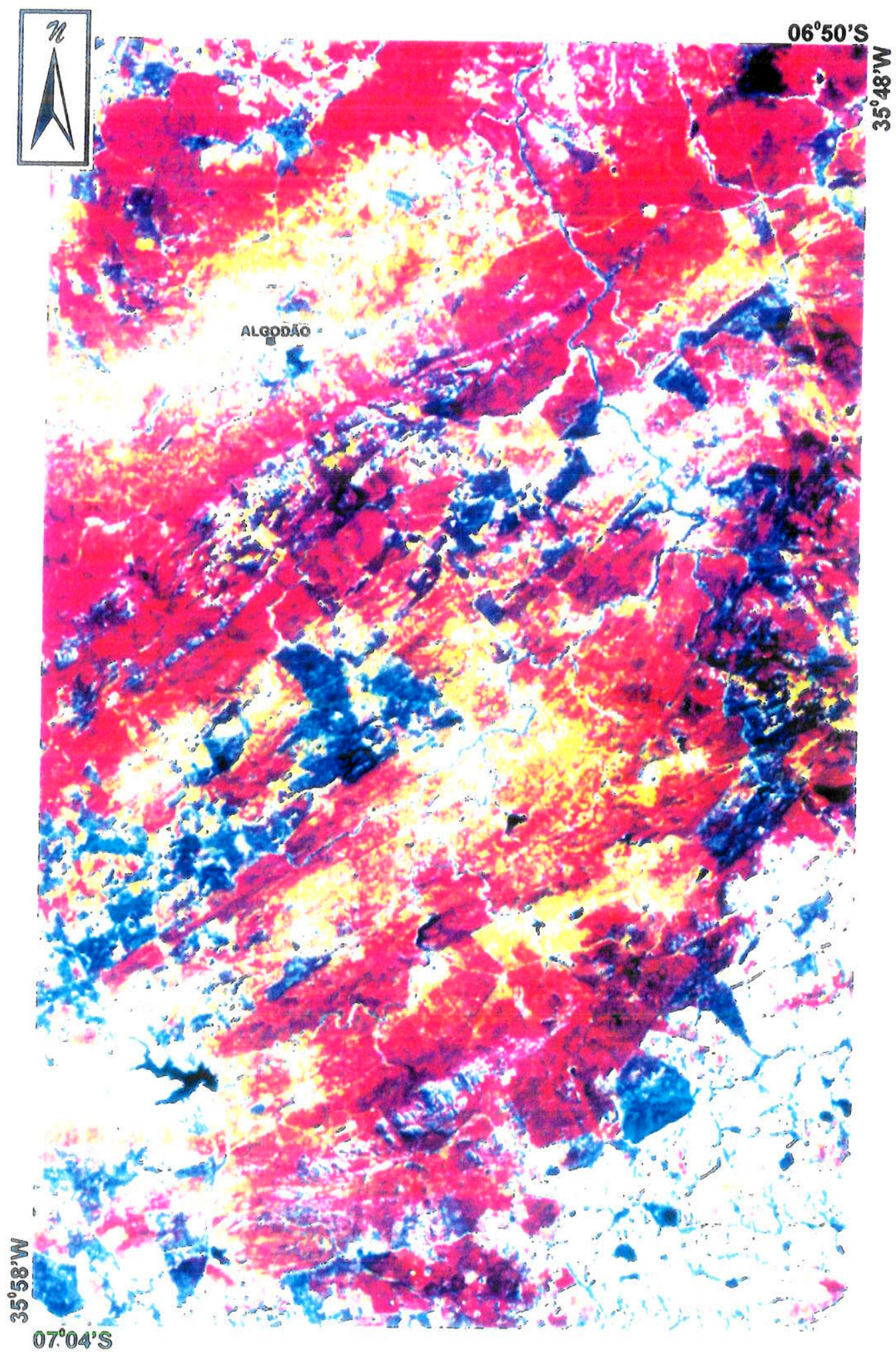

Figura 5.19 - Imagem da composição colorida das bandas 5-3-1 do Landsat 5-TM combinadas em RGB para a porção central da Faixa de Metassedimentos de Barra de Santa Rosa e da zona de cisalhamento Remígio-Pocinhos 


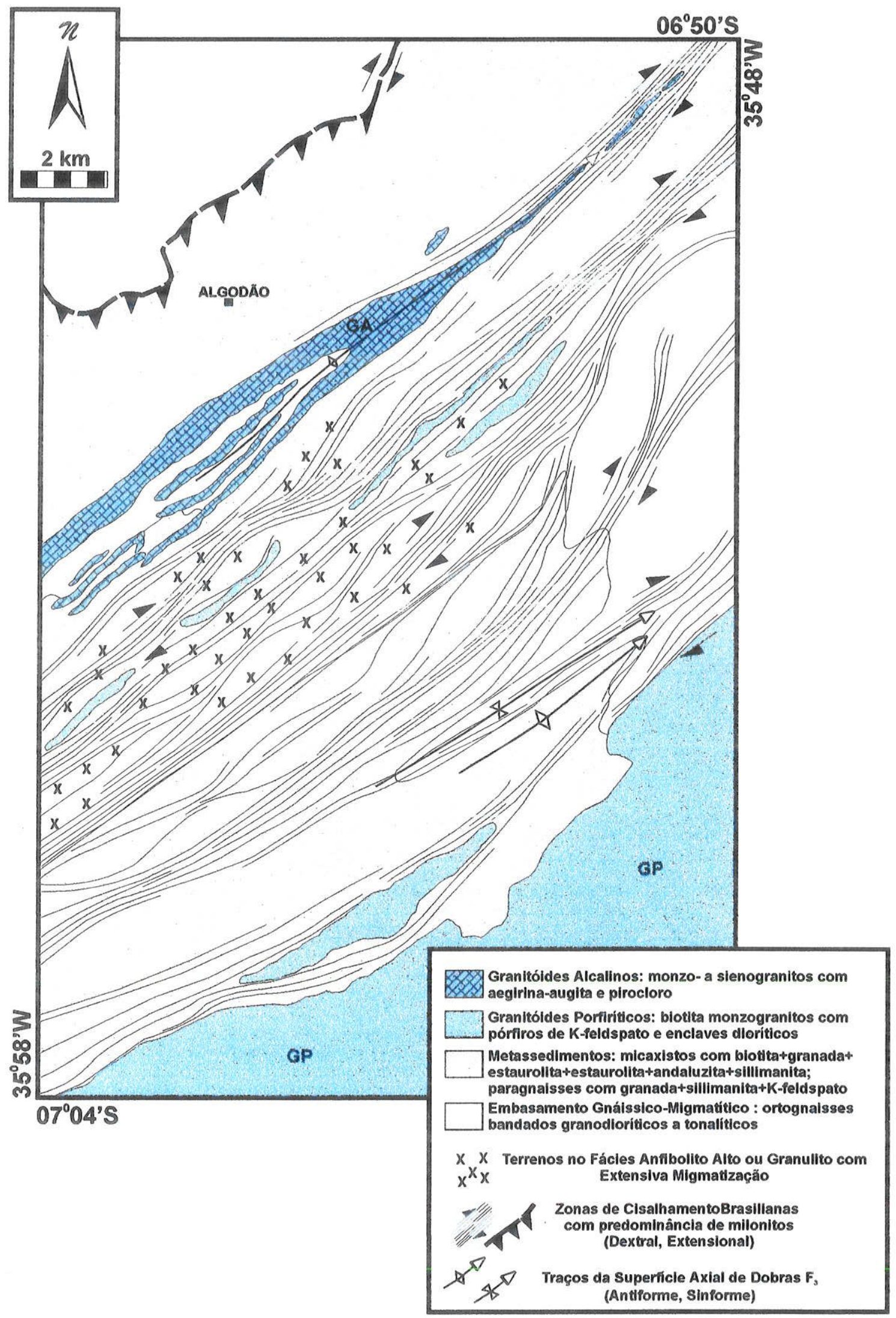

Figura 5.20 - Arcabouço geológico interpretado visualmente a partir da imagem colorida das bandas 5-3-1 do Landsat 5-TM combinadas em RGB da Figura 5.19, para a porção central da faixa de metassedimentos de Barra de Santa Rosa e da zona de cisalhamento Remígio-Pocinhos. Abreviaturas: GA = Granitóide Algodão, GP = Granitóide Pocinhos. 
principais características das unidades geológicas. Na extremidade NE do mapa ocorrem os ortognaisses migmatíticos do embasamento com coloração vermelho a marrom-avermelhado e rugosidade média, distinto da faixa de micaxistos a $\mathrm{SW}$ em contato pelas zonas de ultamilonitos tangenciais de mergulho para SE. Para a faixa de micaxistos, a variação na coloração de amarelo a amarelo-avermelhado para vermelho a vermelho-amarronzado acompanha o aumento no grau metamórfico do fácies xisto verde/anfibolito baixo, nas áreas a NW do granitóide de Algodão, para anfibolito alto/granulito com migmatização, nas áreas do corredor central da ZCRP, como mostra a Fig. 6.1. Nas áreas de micaxistos com baixo grau metamórfico, os aspectos morfológicos mostram uma organização mal definida em função do domínio extensional marcado por zonas de cisalhamento tangenciais, e portanto de expressão irregular na superficie topográfica, enquanto no corredor central com alto ângulo da ZCRP foi possivel individualizar os cavalos transcorrentes formados por fatias de gnaisses e micaxistos, justapostas por faixas miloníticas dextrais, onde o alto strain desenvolve uma foliação milonítica $\left(\mathrm{S}_{3} / \mathrm{C}_{3}\right)$ responsável pela densidade e extensão do sistema de lineamentos que a representa. $O$ granitóide de Algodão mostrou-se estruturado em antiforme isoclinal com coloração cinza claro a cinza-rosado, acompanhado por diversos sheets alcalinos, estirados e boudinados ao longo da ZCRP. No núcleo do granitóide a coloração vermelho escuro que caracteriza esta área, diferenciada das rochas alcalinas do corpo principal e dos sheets, indica a ocorrência de ortognaisses bandados granodioriticos a tonalíticos e augen gnaisses (Trindade 1995). O granitóide Pocinhos, com típica coloração amarelo-esbranquiçado (quase branco) a amarelo-rosado, ocupa a região SE da Fig. 5.19, mostrando blocos boudinados, estirados e as bordas parcialmente afetadas pela ZCRP.

A Fig. 5.21 envolve a terminação norte-nordeste da faixa de micaxistos de Barra de Santa Rosa de coloração amarelo-avermelhado que caracterizam as condiçðes de baixo a médio grau metamórfico, com as zonas de cisalhamento tangenciais definindo os limites com os terrenos gnáissicos do embasamento. $\mathrm{O}$ arcabouço geológico interpretado a partir da imagem foi apresentado na Fig. 5.22. Os terrenos gnáissicos do embasamento apresentaram características de coloração, aspectos texturais e morfológicos que permitiram a diferenciação entre duas áreas, conforme os dados de campo e as sugestões de Dantas (1997). Na porção SW da área, a SW da ZCJ (zona de cisalhamento Japi) e envolvendo a faixa de micaxistos de Barra de Santa Rosa, os terrenos apresentaram coloração vermelho a 


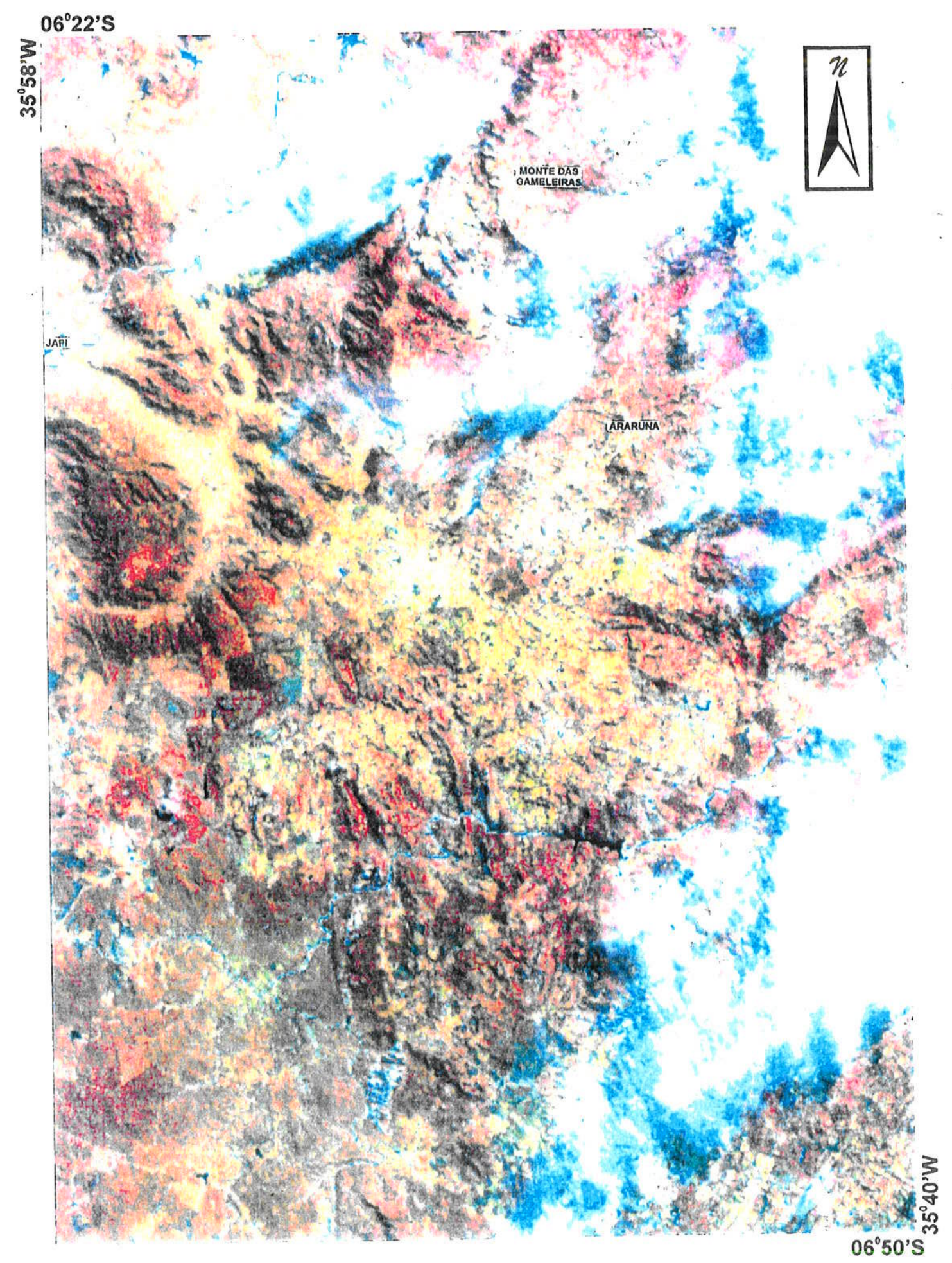

Figura 5.21 - Imagem da composição colorida das bandas 5-3-1 do Landsat 5-TM combinadas em RGB para a região entre Japi, Monte das Gameleiras e a Porção Norte da Faixa de Metassedimentos de Barra de Santa Rosa. 
$06^{0} 22 ' s$

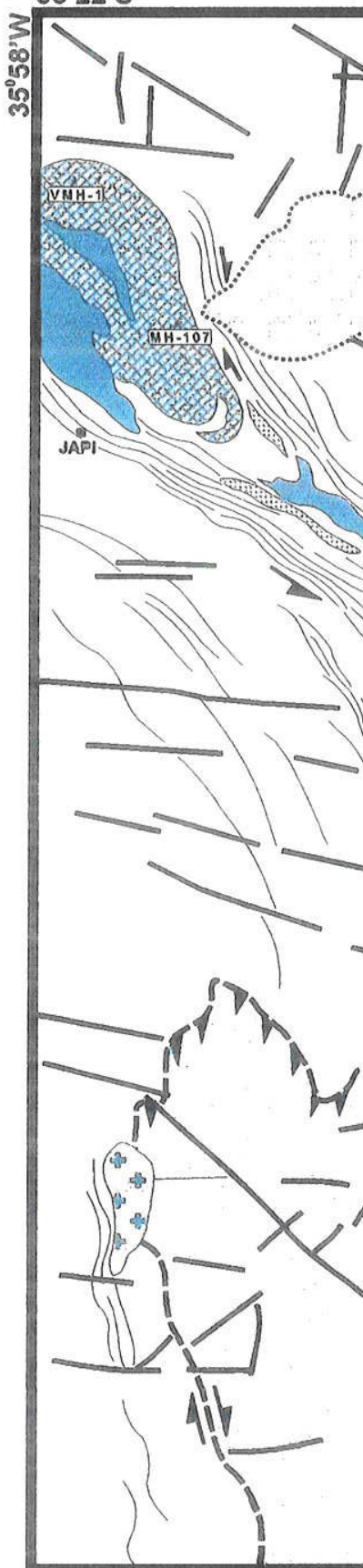

Coberturas Meso-Cenozóicas

Sufte Microgranitica: blottita granodioritos. hornblenda-blotita granodiorito

Sufte de Granithóldes Porfiriticos: hornblenda-blotita -quartzo monzonitos, blotita monzogranito e hornblenda-biotita granodioritos Sufte Básico-Intermediária: granodioritos, gabro-noritos e ollivina gabro-noritos suite de Granitoides Alcalinos: monzogranitos, quarto monzonitos e slenogranitos anaugit

Matassedimentos: micaxistos e paragnaisses

Embasamento Onâlssico-Migmađititco

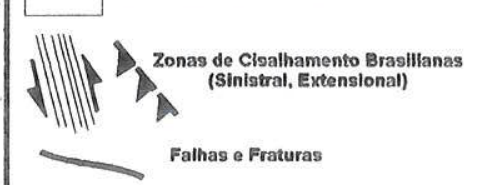


marrom-avermelhado e aspectos texturais típicos dos biotita-hornblenda-ortognaisses graníticos a tonalíticos. O restante dos terrenos gnáissicos, envolvendo os granitóides de Japi e Monte das Gameleiras, mostraram coloração amarelho-avermelhado a róseo-amarelado, textura fina e grau de dissecação médio a alto, onde predominam biotita gnaisses trondhjemíticos parcialmente migmatizados (Terreno Serrinha-Pedro Velho, Dantas 1997).

$O$ plúton de Japi ocorre sob forma en cornue controlado pela zona de cisalhamento sinistral da ZCJ, com coloração vermelho a róseo delimitando a suíte principal de monzo- a sienogranitos com afinidades alcalinas, e a coloração amarelo avermelhada definindo a suíte básica-intermediária, composta principalmente por termos monzoníticos com biotita e anfibólio, e gabros-noritos tendo forsterita + augita-ferroaugita + hiperstênio como máficos dominantes (Hollanda 1996). O corpo alcalino principal de forma elipsoidal mostra um arranjo anelar concêntrico da morfologia, acompanhando o fabric tectônico (SL ou $\mathrm{S}>\mathrm{L}$ ), em contato a sudoeste com o corpo básico-intermediário de morfologia mais plana. Para sudeste outro corpo básico-intermediário constitui a calda do plúton, ladeado por sheets de microgranitos granodioríticos. Contíguo ao plúton de Japi, um extenso sistema de lineamentos de largura e densidade variável, assinalado pela morfologia de cristas, delimita a $Z C J$ que envolve rochas do embasamento e granitóides com foliação $\left(\mathrm{S}_{3} / \mathrm{C}_{3}\right)$ de mergulho médio a forte, aliada a uma lineação de estiramento de baixo rake. A ZCJ foi definida como uma estrutura de cinemática transtracional sinistral cujo caráter extensional, conjugado às zonas de cisalhamento ESE-WNW dextrais, favoreceria a abertura de espaço para a ascenção e alojamento do plúton de Japi (Jardim de Sá 1994, Hollanda 1996). O granitóide de Monte das Gameleiras, composto predominantemente por monzo- a sienogranitos porfiriticos com enclaves dioríticos sin-magmáticos (Galindo 1982, 1984), ocorre na porção NNE da Fig. 5.21, mostrando coloração rósea-avermelhada e estruturação morfológica semicircular concêntrica, limitado na borda NW pela zona de cisalhamento dextral de São José do Campestre (ZCSJC) conjugada à ZCJ, como indica a assimetria nos lineamentos. Uma grande área do plúton está encoberta por nuvens. O granitóide de Caxexa de coloração cinza claro a cinza-rosado, semelhante ao granitóide de Algodão, foi definido numa forma estirada diferente daquela apresentada nos mapas geológicos prévios.

Os principais sistemas de lineamentos detectados controlam cristas orientadas e correspondem à deformação dúctil $\mathrm{D}_{3}$, caracterizada por condições de strain heterogêneo 
que condicionam a penetratividade e a intensidade do fabric $\mathrm{S}_{3} / \mathrm{L}_{3}$ (foliações/lineações) em diferentes setores da área (Fig. 5.22). A heterogeneidade no fabric e distribuição do strain $\mathrm{D}_{3}$ é evidente no setor a NE do granitóide de Caxexa, marcado pelo dobramento da foliação pré- $\mathrm{D}_{3}\left(\mathrm{~S}_{2}\right.$ ou $\left.\mathrm{S} 1 / / \mathrm{S}_{2}\right)$ e tendo a foliação $\mathrm{S}_{3}$ como plano axial. Em locais sob condicões de alto strain (fabric milonítico, $\mathrm{S}_{3} / \mathrm{C}_{3}$ ), os lineamentos são assimétricos, extensos e adensados, descrevendo as zonas de cisalhamento transcorrentes e seus caracteres cinemáticos, como a ZCJ e ZCSJC, ambas aparentemente conjugadas (ou en relais) e integradas num único sistema de trend geral NW-EW. A sul do granitóide de Gameleiras, este sistema inflete para $\mathrm{NE}$ integrando-se ao sistema de zonas de cisalhamento dextrais que correspondem às ramificações da ZCRP. As principais zonas de falhas estão expressas como lineamentos bem definidos, espaçados e transversais aos trends principais das estruturas dúcteis, principalmente nas direções NW-WEW, subordinadamente NE e NS.

\section{-Composições 7-5-2 e 7-5-3:}

A composição 7-5-2 favoreceu a discriminação dos principais elementos geológicos, sobretudo das unidades correlatas aos espectros dos materiais da categoria $\mathrm{B}$ (granitóide Jandaíra, CCG, metapelitos e paragnaisses migmatíticos), como mostra a Fig. 5.23. A análise combinada com a composição 7-5-3 (Fig. 5.24) permitiu enfatizar as feições geológicas da área que engloba parcialmente a faixa de micaxistos de Barra de Santa Rosa e seu embasamento (Fig. 5.25), os granitóides Caxexa e Pocinhos e a ZCRP, conduzindo a confecção do mapa da Fig. 5.26. A substituição pela banda 3 ampliou o contraste entre os matizes e ressaltou os aspectos morfológicos da imagem, favorecendo a deteç̧ão das unidades de pouco destaque na composição 7-5-2, além da geometria anastomosada da ZCRP com os cavalos de baixo strain justapostos a zonas miloníticas subverticalizadas, definidas pelo adensamento do sistema de lineamentos em faixas de cores verde a verde azulados. Os ortognaisses do embasamento da faixa de micaxistos de Barra de Santa Rosa mostraram cores entre o amarelo e o verde claro, devido à disposição da banda $5 \mathrm{em} \mathrm{G}$, indicando elevado albedo e a alta reflectância dos argilo-minerais, controlados pela predominância de minerais félsicos, e a contribuição dos minerais máficos na banda $7 \mathrm{em} \mathrm{R}$. Nos demais setores dos terrenos do embasamento, em que predominam granada-biotitahornblenda gnaisses migmatíticos bandados, a coloração varia entre azul escuro e verde azulado, condizente com o predomínio de minerais máficos com absorções intensas e baixa 


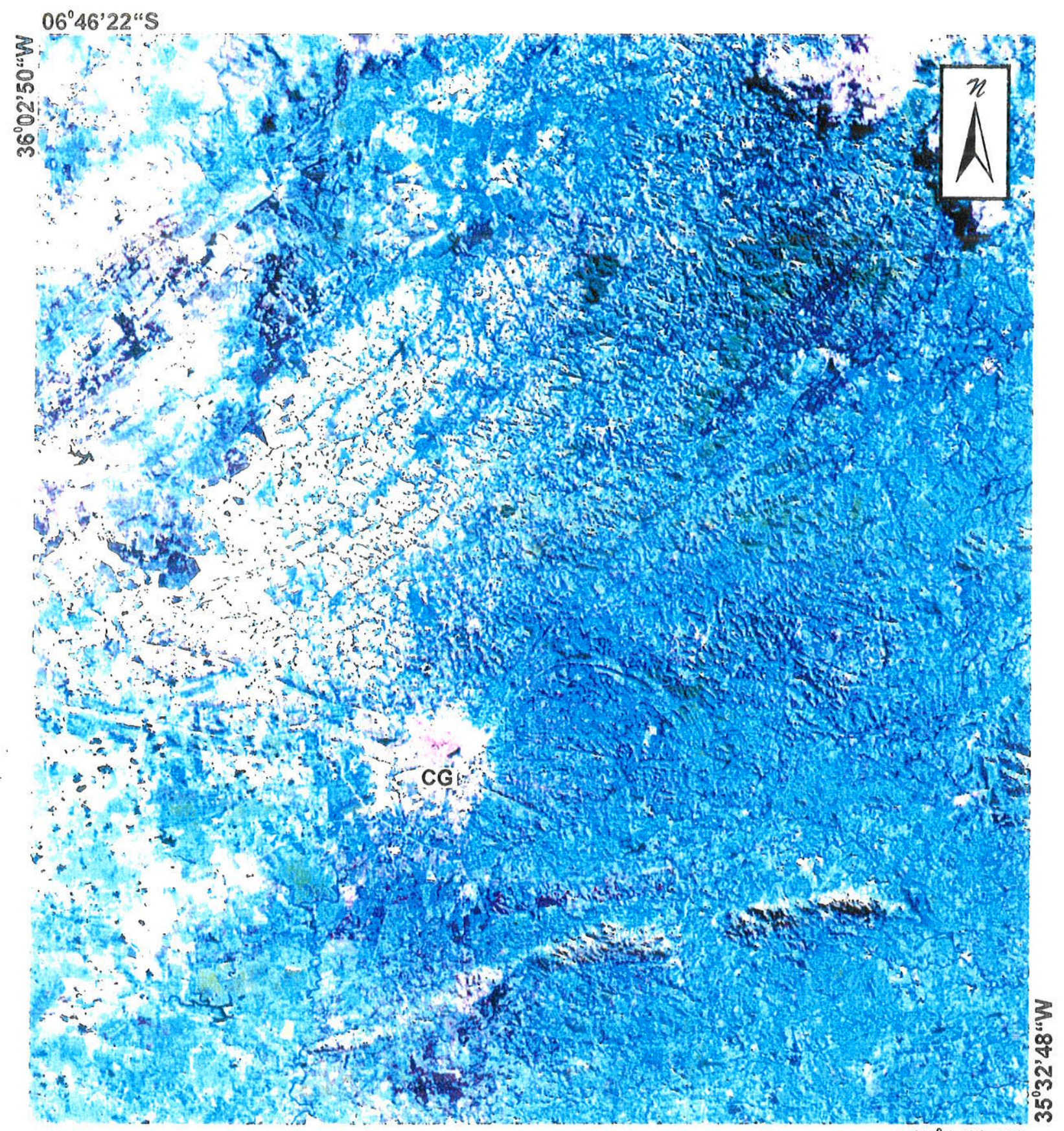

$07^{\circ} 24^{\prime} 36^{\prime \prime S}$

Figura 5.23 - Imagem da composição colorida das bandas 7-5-2 do Landsat 5TM combinadas em RGB. O mapa indica a localização da cidade de Campina Grande/PB marçada por CG. 




Figura 5.24 - Imagem da composição colorida das bandas 7-5-3 do Landsat 5TM combinadas em RGB. O mapa indica a localização da cidade de Campina Grande/PB marcada por CG. 
reflectância na banda 7, e às altas reflectâncias dos minerais hidroxilados no VIS e por vezes na banda 5. A faixa de micaxistos de Barra de Santa Rosa mostrou colorações variando entre amarelo esverdeado e marrom amarelado decorrente do controle dos ions do ferro e $\mathrm{OH}$ na biotita e clorita, além do elevado albedo do quartzo na banda 5. Nas faixas de metassedimentos granulitizados e/ou migmatizados as cores variaram de marrom amarelado a marrom, como indica a Fig. 5.24, marcando o predomínio dos máficos (anfibólios, piroxênios, biotita e magnetita), e consequente aumento nas transferências de carga dos íons $\mathrm{Fe}^{2+} \mathrm{e} \mathrm{Fe}^{3+}$ no VIS. As faixas de metapelitos migmatíticos da região de Alagoa Grande e da ZCP apresentaram coloração azul escuro provavelmente devido aos argilo-minerais e minerais máficos, inclusivo no solo espesso e regolito que recobrem a área, com absorção na banda 7 e reflectância relativamente elevada no VIS.

Nas composições 7-5-2 e 7-5-3, as cores amarelo claro a amarelo rosado do granitóide de Algodão não é distintiva de outras áreas na faixa de micaxistos de Barra de Santa Rosa Entretanto, o aspecto morfológico de antiforme boudinado foi acentuado na composicão 7-5-3 (Fig. 5.24) permitindo a delimitação do plúton. O granitóide de Pocinhos mostrou a típica coloração amarelo claro devido à predominância de minerais félsicos com $\mathrm{Fe}^{3+}$ de albedo elevado na banda 5. A Fig. 5.25 salientou o sistema de lineamentos de direção NNE que intercepta o batólito marcado por faixas na cor verde azulado, decorrente do aumento na proporção de óxidos de ferro e minerais hidroxilados, correspondentes às zonas de cisalhamento dextrais.

Nas Fig. 5.23 e 5.24, o granitóide de Areia e o CCG apresentaram colorações azul escuro a megenta escuro que caracterizam rochas com predominância de minerais máficos e óxidos de ferro, com as típicas alterações para minerais hidroxilados. O granitóide porfirítico de Queimadas apresentou cor amarela definindo a geometria sigmoidal estirada e boudinada do plúton, em razão do realce na banda 5 dos minerais félsicos, freqüentemente alterados, e aos óxidos de ferro que são definidos pela rampa de reflectância do $\mathrm{Fe}^{3+}$ na banda 2 . 


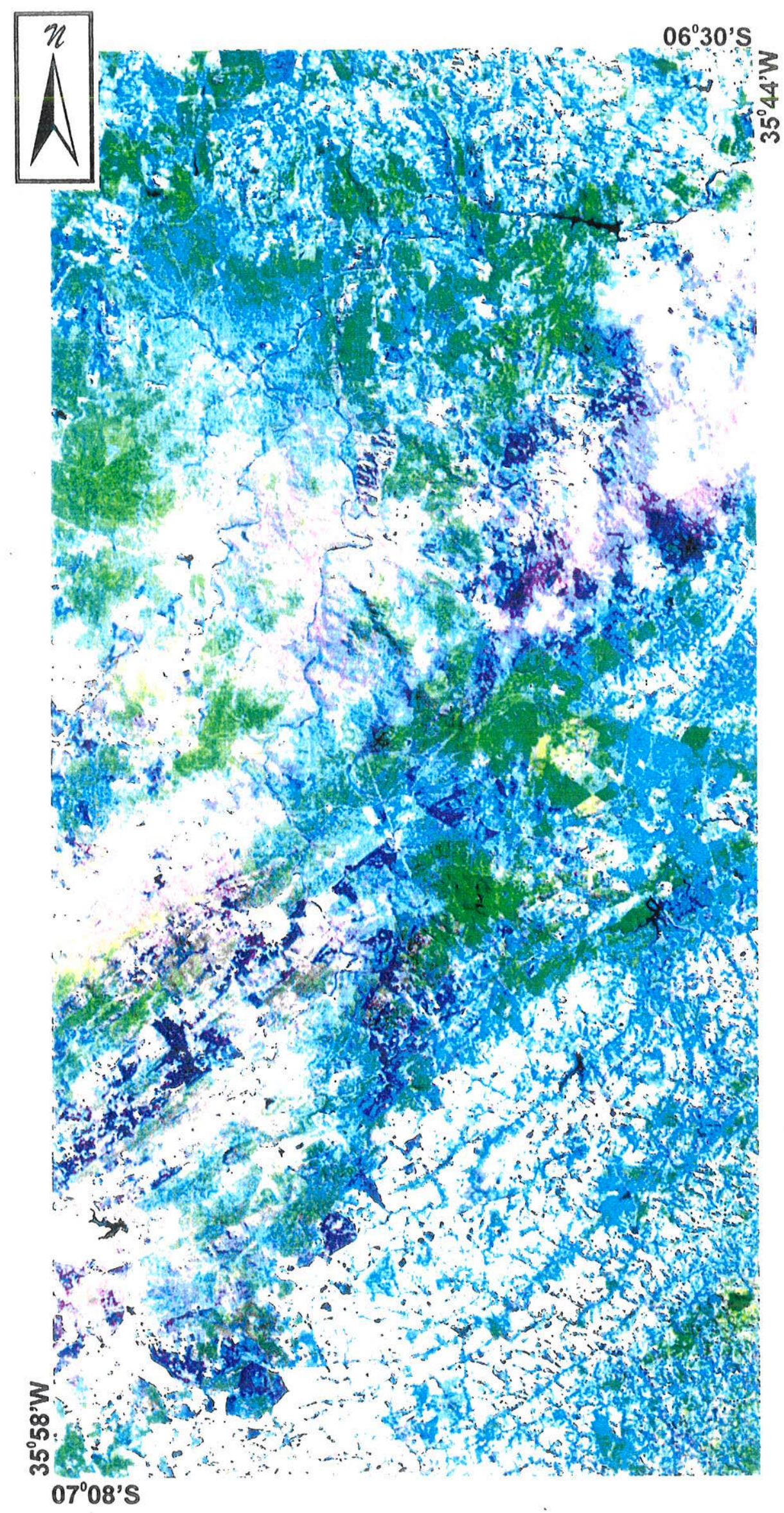

Figura 5.25 - Imagem da composição colorida das bandas 7-5-2 do Landsat 5TM combinadas em RGB para a região da faixa de metassedimentos de Barra de Santa Rosa, zona de cisalhamento Remígio-Pocinhos e o granitóide Pocinhos. 


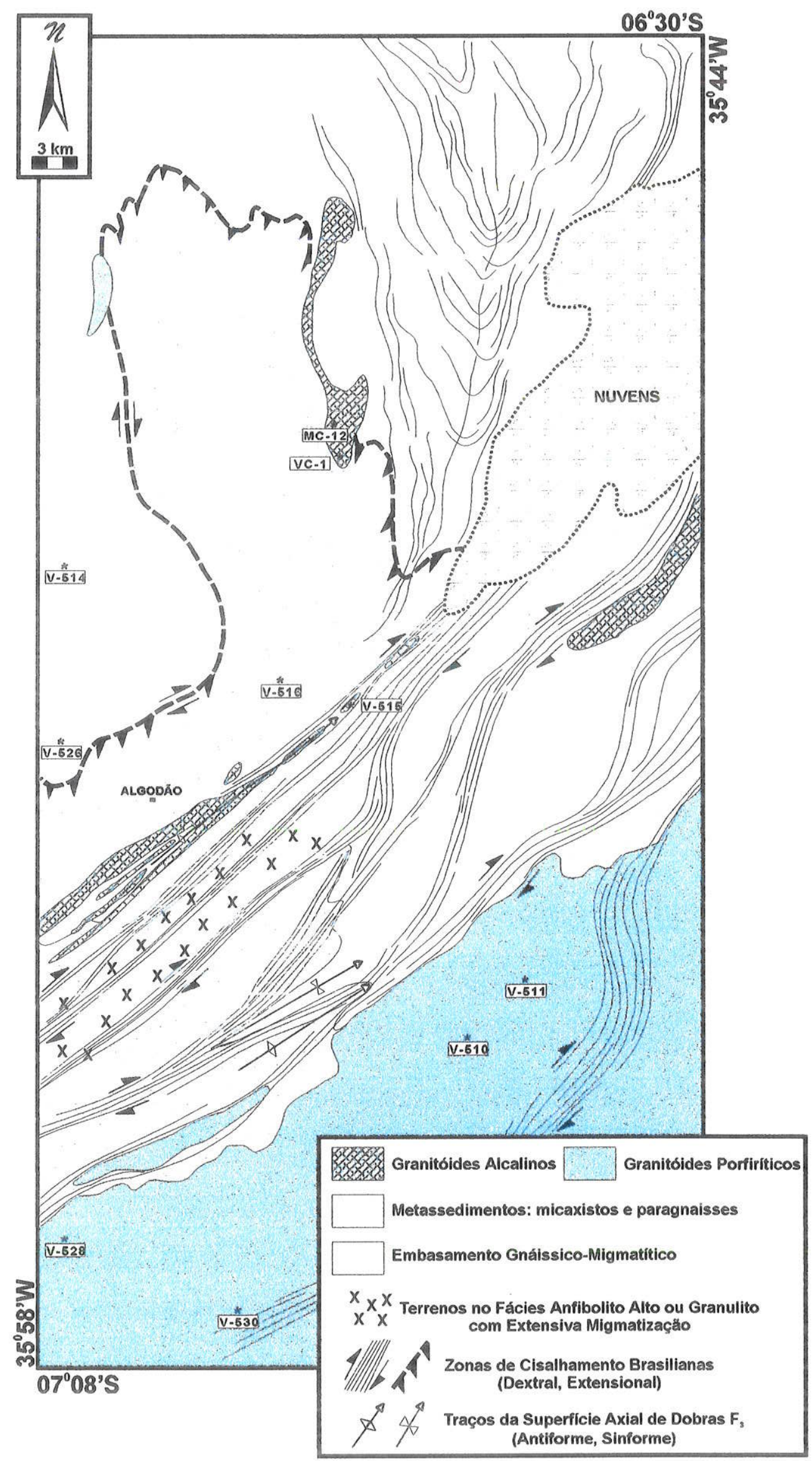

Figura 5.26 - Arcabouço geológico interpretado visualmente a partir da imagem colorida das bandas 7-5-2 do Landsat 5-TM combinadas em RGB da Figura 5.25, para a região da faixa de metassedimentos de Barra de Santa Rosa, zona de cisalhamento Remígio-Pocinhos e o granitóide Pocinhos. A localização de algumas amostras empregadas na espectrometria de reflectância foram destacadas pela simbologia $\frac{k}{V-530}$ 


\subsection{2 - Interpretação Visual das Principais Componentes Combinadas em RGB}

Diversos trabalhos destacaram o uso das três primeiras imagens resultantes do processamento por APC no realce de feições diagnósticas e na compressão das informações das imagens digitais (Taylor 1974, Marembeck et al. 1977, Blodget et al. 1978, Soha \& Schwartz 1978, Richards 1984). Este método foi baseado nas definições paramétricas de análise por auto-vetores e matrizes de variância e covariância (Swain \& Davis 1978), onde as interpretações dos resultados são complexas, uma vez que os valores de ponderação dos vetores podem ter mais de um significado (Mausel et al. 1990). A combinação das três PC's no sistema RGB permite a análise da maior quantidade de informações contidas na cena ou subcena. Entretanto, apesar da eficiência comprovada deste método, o fato de transformar as variáveis intercorrelacionadas originais num sistema de referência de variáveis nãocorrelacionadas tende a complicar a aplicação adequada de experiências prévias sobre a correlação entre as cores da superficie e das imagens (Sheffield 1985, Fung 1987, Chavez \& Kwarteng 1989). Assim, os métodos paramétricos não são efetivos para a avaliação de conjuntos de bandas, exigindo nos procedimentos de análise a combinação com métodos não-paramétricos, como o processo de interpretação visual (Skidmore \& Turner 1988, Conese \& Maselli 1993)

O cálculo das PC's para a área de Barra de Santa Rosa-Campina Grande foi efetuado com base nas seis bandas espectrais do Landsat 5-TM (bandas 1-5 e 7), conforme as informações estatística listadas no Anexo 3. As Tab. A3.2 e A3.3 mostram as correlações lineares e a covariância entre as bandas, enquanto as Tab. A3.4 e A3.5 apresentam os pesos dos auto-valores e auto-vetores usados nas transformações dos dados brutos das imagens em PC's. As três primeiras PC's perfazem 96,5 \% da variância (Tab. A3.1). A primeira principal componente (PC1) é composta pelos valores positivos das seis bandas, com $71,03 \%$ da variância dos dados brutos, contendo mais informações das faixas MIR (bandas 5 e 7) e NIR (banda 4) do EEM. A segunda principal componente (PC2) recebe mais informações dos domínios VIS (bandas 1 e 3) e MIR (banda 7), enquanto a terceira principal componente (PC3) contém dominantemente informações do VIS (bandas 1, 2 e 3) e NIR (banda 4). Portanto, as três primeiras PC's representam o resultado da compressão da totalidade do conteúdo espectral das imagens, enquanto as demais componentes participam com apenas 2,9 \% da variância e não foram usadas nas análises. Desta forma, as principais feições 
geológicas e aspectos diagnósticas estão contidas nas três primeiras PC's. Geralmente, o albedo é o responsável pela forte correlação entre as bandas multiespectrais no NIR e MIR, que nos cálculos de PC's está concentrado na PCl. As rochas com predominância de minerais félsicos e óxidos de ferro controlam os altos valores de DN. A PC2 descreve diferenças entre as bandas do VIS e do MIR, onde materiais com alta reflectância no VIS (p.ex. minerais hidroxilados, quartzo) terão altos valores de DN (pixels claros) e aqueles com alta reflectância no MIR (p.ex. óxidos de ferro) corresponderão aos pixels escuros da imagem. Alguns minerais hidroxilados podem assumir pixels escuros na PC2, em função da contribuição negativa da banda 5 e positiva da banda 7, pois os íons $\mathrm{OH}$ apresentam alta reflectância na banda 5 e absorções (baixa reflectância) na banda 7 . A correlação negativa das bandas 5 e 7 na PC3 permite a distinção entre os materiais ricos em óxidos de ferro daqueles hidroxilados, beneficiando o destaque dos terrenos alterados hidrotermalmente, apesar de representar apenas $7,02 \%$ da variância dos dados brutos numa imagem com baixo contraste e ruidosa.

A Fig. 5.27 apresenta a composição das PC1-PC2-PC3 em RGB. A análise e extração das informações geológicas foram mais eficientes que nas PC's isoladas, sobretudo pelo destaque às feições estruturais dos terrenos. A maioria das unidades geológicas e seus contatos, descritos anteriormente, foram bem definidas por cores mutuamente distinguiveis. Os biotita ortognaisses da porção extremo NW da área apresentaram cores entre o verde e o amarelo limão indistintos da faixa de micaxistos de Barra de Santa Rosa. Entretanto, os terrenos na porção a N-NW de Campina Grande, onde predominam ortognaisses tonaliticos a granodioríticos migmatizados, mostraram cores amarelo e rósea avermelhada intercaladas conforme as foliações do fabric $\mathrm{D}_{3}$. Para S-SE de Campina Grande, limitados pela ZCCG e $\mathrm{ZCGB}$, as áreas onde prevalecem granada-biotita-hornblenda gnaisses migmatiticos bandados apresentaram cores variando entre violeta pálido e amarelo claro a amarelo esverdeado. Os micaxistos de Barra de Santa Rosa mostraram cores amarelo a verde distribuídos indistintamente pela área de afloramento, sem relação com as variações na magnitude do strain e no grau metamórfico. Os vales alongados formados pelas faixas de metapelitos migmatíticos da região de Alagoa Grande mostraram coloração cinza escuro a cinza esverdeado distinguíveis dos granitóides e ortognaisses envolvidas pela ZCGB de 


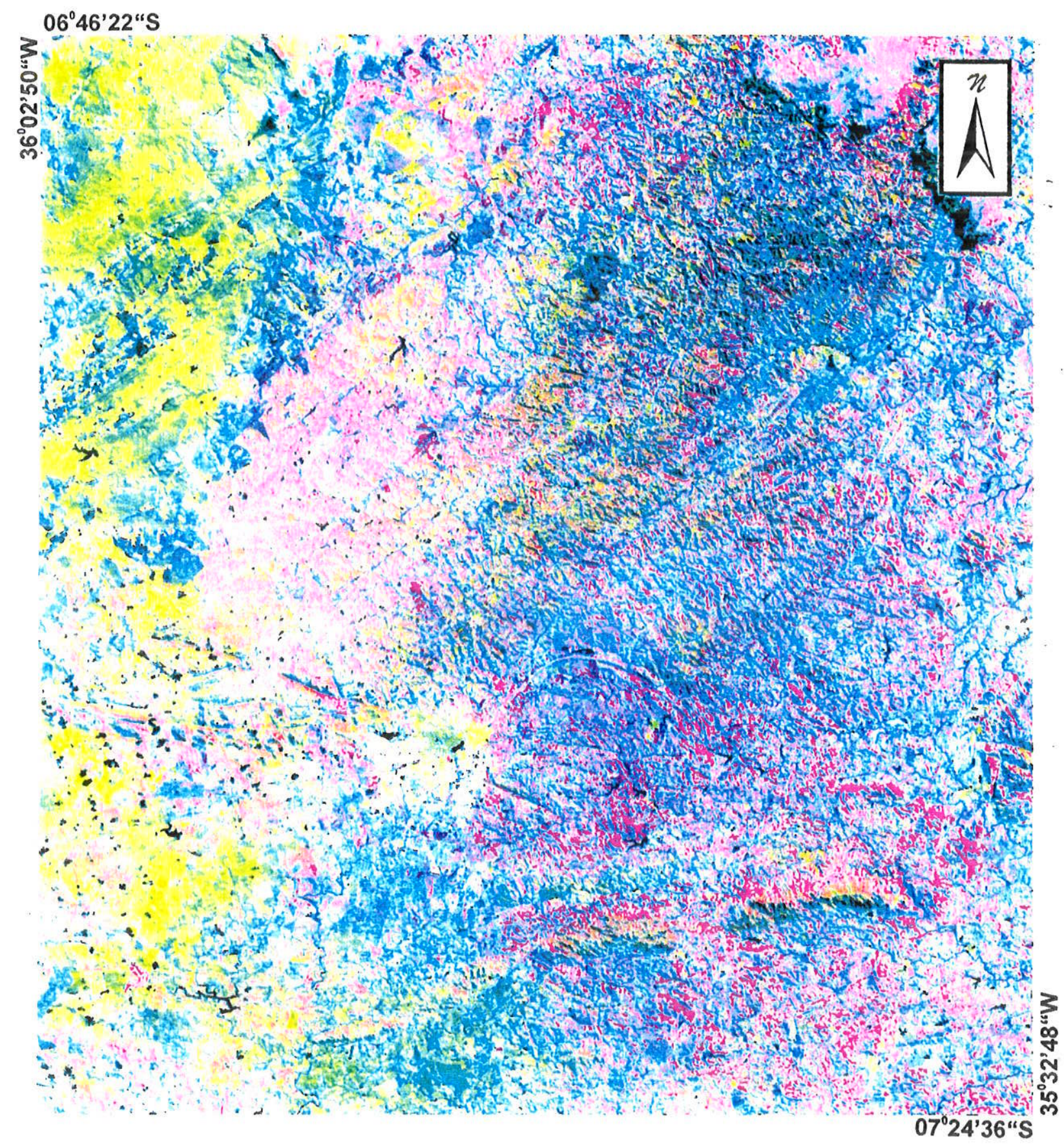

Figura 5.27 - Imagem da composição colorida das principais componentes PC1-PC2-PC3 das seis bandas não-termais do Landsat 5-TM (bandas 1-5 e 7) combinadas em RGB. O mapa indica a localização da cidade de Campina Grande/PB marcada por CG. 
coloração rósea escura. A fatia de micaxistos ao longo da ZCP não apresentou cores distintivas das rochas miloniticas associadas.

O plúton alcalino de Algodão mostrou cor rósea clara contrastante com a cor verde escuro dos ortognaisses bandados, augen gnaisses e micaxistos no núcleo do antiforme. $\mathrm{O}$ granitóide de Pocinhos apresentou cores rósea a amarelo distintas dos terrenos circunjascentes, com a estruturação NE bem marcada pelas zonas de cisalhamento de larguras variadas, que interceptam o plúton nas cores cinza esverdeada a púrpura. O CCG de cores rósea escura a violeta teve os contatos bem salientados com os terrenos adjacentes, constituídos por gnaisses migmatíticos milonitizados. O granitóide Queimadas tem a cor amarela escura homogeneamente distribuida pela forma alongada do corpo. A forma sigmoidal assimétrica do granitóide Areia foi bem delimitada pela contraste da coloração cinza escuro com rósea, acompanhando a geometria circular concêntrica do plúton, com as cores rósea e amarelo dos terrenos circunvizinhos.

\subsection{3 - Interpretação Visual das Razões de Bandas Combinadas em RGB}

As razões de bandas são tipicamente empregadas na supressão das variações de brilho relacionados à topografia, reduzindo os efeitos do ângulo do zênite solar, e às variações do tamanho dos grãos, enfatizando as tênues diferenças espectrais entre as superfícies. As bandas no numerador e denominador são em regra escolhidas para expressar diferenças de radiâncias nas bandas relacionadas às feições espectrais especificas (Tab. 5.3).

Uma avaliação estatística comparativa foi realizada para as principais razões de bandas, baseada nos valores médios das assinaturas espectrais dos materiais analisados para a região de Barra de Santa Rosa-Campina Grande (Tab. 5.4). Os indices percentuais (positivos ou negativos) são diretamente proporcionais ao grau de entropia das amostras analisadas para cada razão de banda. Quanto maior a diferença entre os índices percentuais numa razão de bandas, maior a propensão da razão de bandas na distição entre os materias. A Fig. 5.28 mostra a correlação entre os materiais para cada razão de bandas, segundo os valores da Tab. 5.4, indicando as melhores razões de bandas no caso especifico da região de Barra de Santa Rosa-Campina Grande. Aquelas que propiciaram as melhores diferenciações entre os materiais foram $5 / 4,3 / 1,4 / 2,4 / 7,5 / 3,7 / 4$ e $5 / 1$. No entanto, de acordo com as sugestões de Macias (1995) e Glikson e Creasey (1995) para distinção entre rochas félsicas e máficas, a razão $5 / 7$ foi acrescentada ao conjunto. As 21 combinações dos trios de razões 
(a)

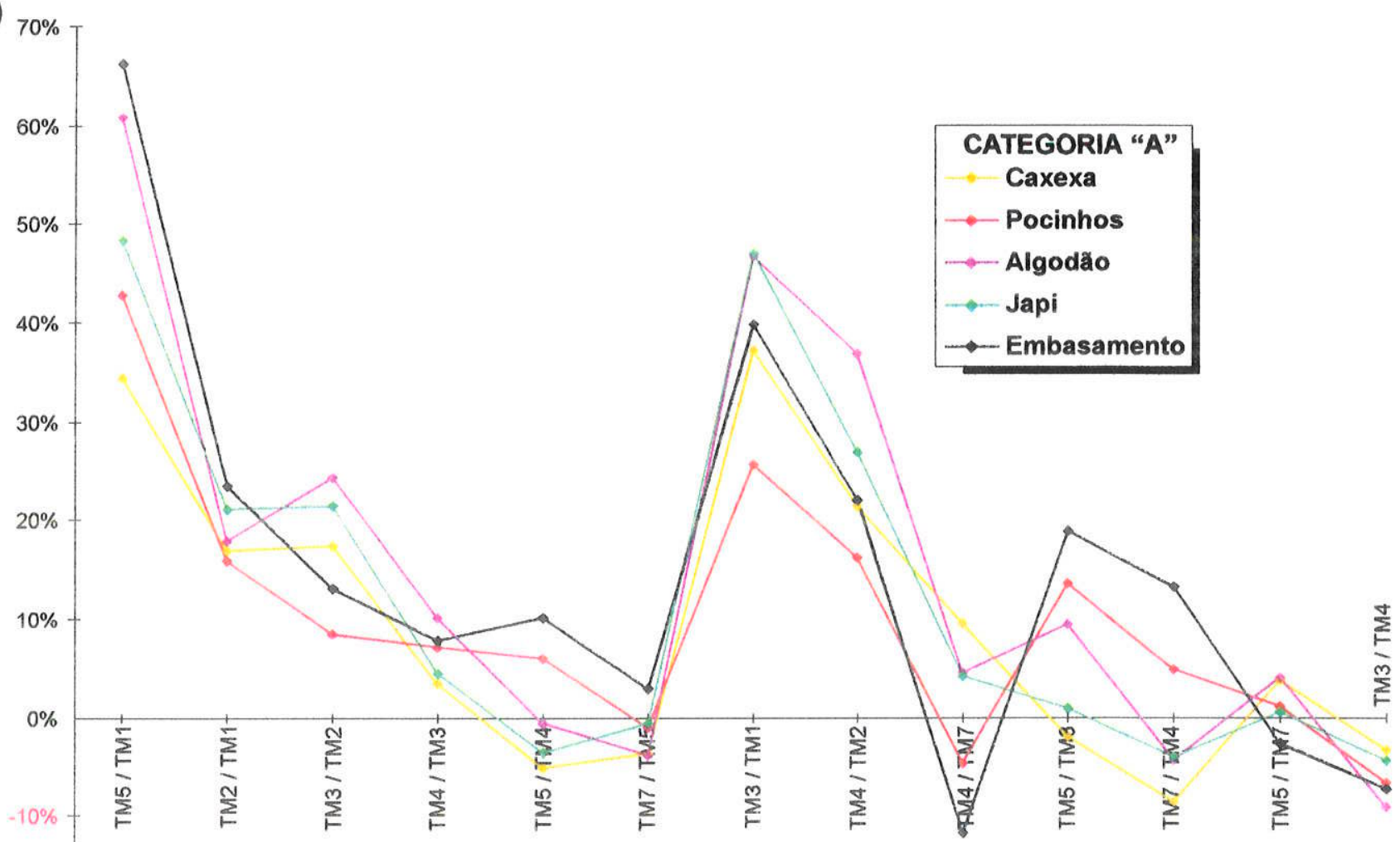

(b)

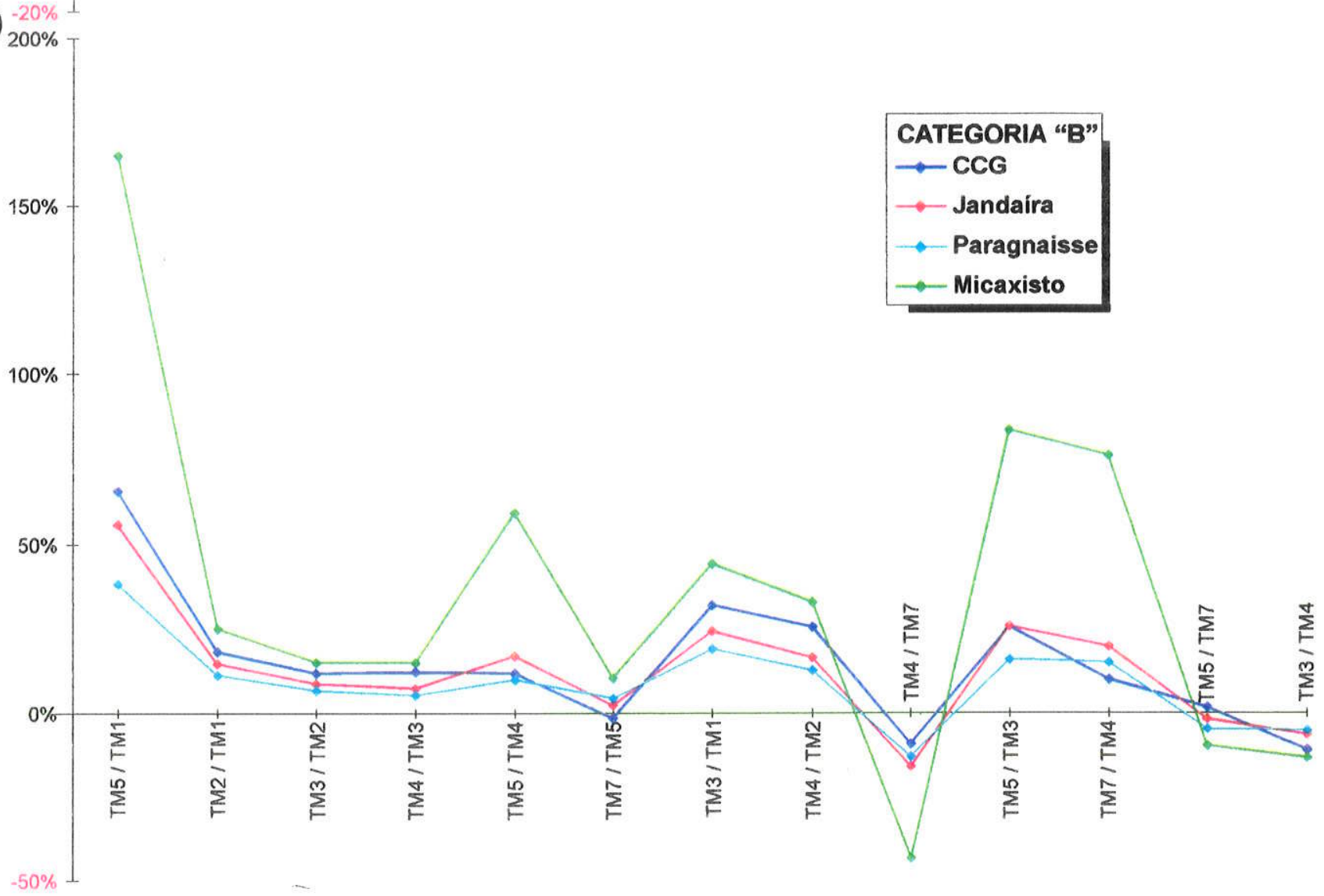

Figura 5.28- Diagramas comparativos da dispersão nos 13 conjuntos de razões de bandas do Landsat 5-TM das litologias que tiveram os espectros de reflectância analisados: (a) Categoria "A" e (b) Categoria "B". 
de bandas em RGB foram visualmente examinadas e os melhores resultados foram obtidos com as combinações 5/7|5/3|7/4 e 5/7|3/1|5/4 (Fig. 5.29). A razão 7/4 permite a detecção de áreas com coberturas de solos, enquanto a razão $3 / 1$ pode ter as correlações com os óxidos de ferro mascaradas pelos altos valores de DN da vegetação verde. Em ambas as composições, as áreas de elevada ação antrópica (cidades, povoados e estradas) assumiram coloração azul. A combinação 5/7|3/1|5/4 mostrou que o efeito da vegetação (3/1) está restrito às áreas de culturas e algumas encostas.

Tabela 5.3 - Razões de bandas do Landsat 5-TM comuns na discriminação composicional de superficies (Drury \& Hunt 1989, Macias 1995, Glikson \& Creasey 1995).

\begin{tabular}{|c|c|}
\hline RAZÓOES DE BANDAS & APLICAÇÕES \\
\hline $3 / 1$ & Materiais com Óxidos de Ferro e Vegetação \\
\hline $3 / 4$ & Rochas vs. Vegetação \\
\hline $4 / 2$ & Materiais com $\mathrm{Fe}^{2+}$ vs. Materiais sem $\mathrm{Fe}^{2+}$ \\
\hline $4 / 3$ & Vegetação Verde \\
\hline $4 / 7$ & Materiais Argilosos vs. $\mathrm{Fe}^{3+}$ \\
\hline $5 / 1$ & $\mathrm{Fe}^{3+}+\mathrm{Fe}^{2+}$ vs. Fe-livre \\
\hline $5 / 3$ & Materiais com Óxidos de Ferro \\
\hline $5 / 4$ & Materiais Argilosos vs. $\mathrm{Fe}^{2+}$ \\
\hline $5 / 7$ & Materiais Argilosos e carbonáticos \\
\hline $7 / 4$ & Materiais Argilosos e com Oxidos de Ferro \\
\hline $7 / 5$ & Materiais Argilosos vs. Não-argilosos \\
\hline
\end{tabular}

A combinação $5 / 7|5 / 3| 7 / 4$ possibilitou a caracterização das principais unidades geológicas, de acordo com as proporções entre os minerais de argilas e nos óxidos de $\mathrm{Fe}^{2+} \mathrm{e}$ $\mathrm{Fe}^{3+}$, minimizando o efeito da vegetação nas áreas com coberturas de solo. Nos terrenos do embasamento, as áreas com predominância de ortognaisses migmatíticos mostraram cores entre o verde claro e o ciano indicando a resposta combinada de materiais com óxidos de ferro (5/3) e produtos de alteração (7/4). Nas áreas dos granada-biotita-hornblenda gnaisses bandados a cor preodominante é amarela, destacando o domínio de minerais máficos e seus produtos de alteração, evoluindo para áreas com tonalidade rósea a rósea violeta relacionada, provavelmente, ao aumento da migmatização e/ou alteração. O CCG apresentou as mesmas colorações desses gnaisses. Os micaxistos de Barra de Santa Rosa mostraram cores variando entre azul e o azul-esverdeado, indistintas nas faixas de alto grau metamórfico e do granitóide Algodão. As faixas de micaxistos de Alagoa Grande e o granitóide de Areia mostraram cores entre o marrom e o róseo, indicando a predominância das respostas das argilas. No granitóide Pocinhos predominou a cor azul, com mistura de 


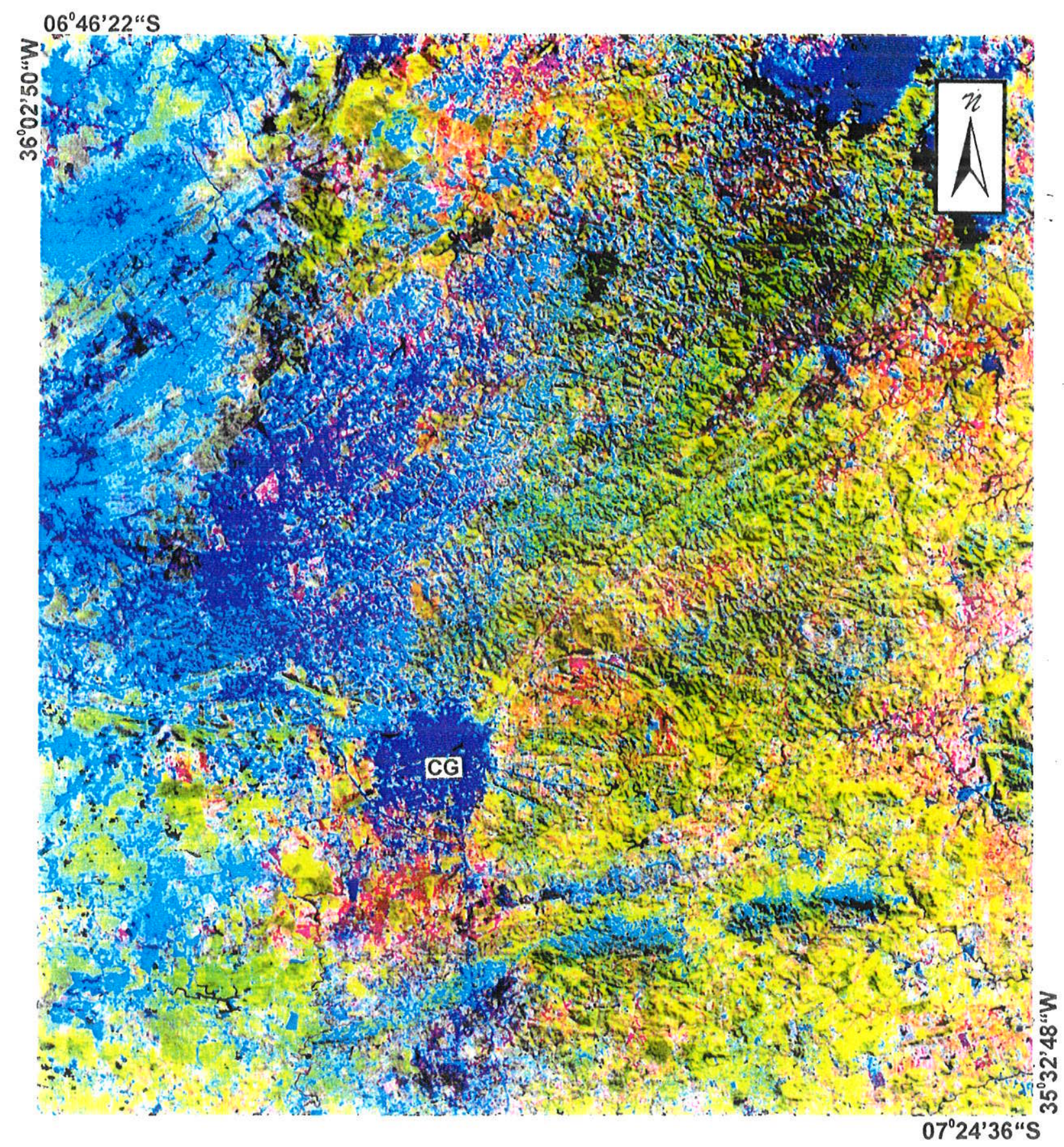

Figura 5.29 - Imagem da composição colorida das razões de bandas 5/7-5/3-7/4 combinadas em RGB. O mapa indica a localização da cidade de Campina Grande/PB marcada por CGr. 
áreas róseas, caracterizando as argilas e os óxidos de ferro, provenientes da alteração da mineralogia primária da rocha. No granitóide Queimadas, predominou o ciano a azul esverdeado, descrevendo a forma do corpo diferenciada do embasamento, indicando à predominância de minerais félsicos e de argila.

\subsection{4 - Interpretação Visual das Composições Coloridas em IHS e HRGB:}

Os principais conceitos do IHS foram revisados por Carper et al. (1990), e as transformações dos pixels das coordenadas RGB para as coordenadas IHS foram descritas por Siegal e Gillespie (1980), e revisadas por Gillespie et al. (1986). A transformação colorida em IHS é um procedimento padrão na análise de imagens para destaque de feições geológicas (Daily 1983), no realce de cores em imagens altamente correlatas (Kaufmann 1988), na combinação de dados multiespectrais de diferentes sistemas imageadores (Carper et al. 1990), dados geofisicos e geoquímicos (Baker \& Henderson 1987, Chavez et al. 1991, Yésou et al. 1993b).

A combinação das bandas espectrais adjacentes 5-4-3, respectivamente em IHS, apresentou bom resultado na caracterização de algumas das principais unidades geológicas descritas anteriormente (Fig. 5.30). Entretanto, a imagem não distingue os micaxistos de Barra de Santa Rosa e os terrenos do embasamento a sul-sudoeste de Campina Grande, ambas unidades em cores vermelho e alaranjado. Os demais terrenos gnáissico-migmatíticos mostraram coloração azul claro a ciano, numa distribuição monótona, não permitindo nenhum detalhamento. No granitóide Pocinhos dominaram cores fortes numa mistura entre amarelo, verde e alaranjado. Os granitóides de Areia, Queimadas e o CCG não são distinguíveis dos terrenos do embasamento. A uniformidade fastidiosa dos tons não favoreceram a percepção do arranjo dos lineamentos. As cidades mostraram cores vermelho a alaranjado bem destacadas do substrato.

Liu e Moore (1990) propuseram o método HRGB para eliminação das sombras e na incorporação das informações espectrais contidas em nove bandas empregadas no método, numa única imagem. No método, três imagens $H$ são obtidas a partir de três diferentes trios de bandas e depois combinadas em RGB. As cores na imagem HRGB estão correlacionadas às formas das assinaturas espectrais dos materiais nas bandas originais, não distinguindo entre espectros com a mesma forma mas albedos diferentes. A imagem HRGB 


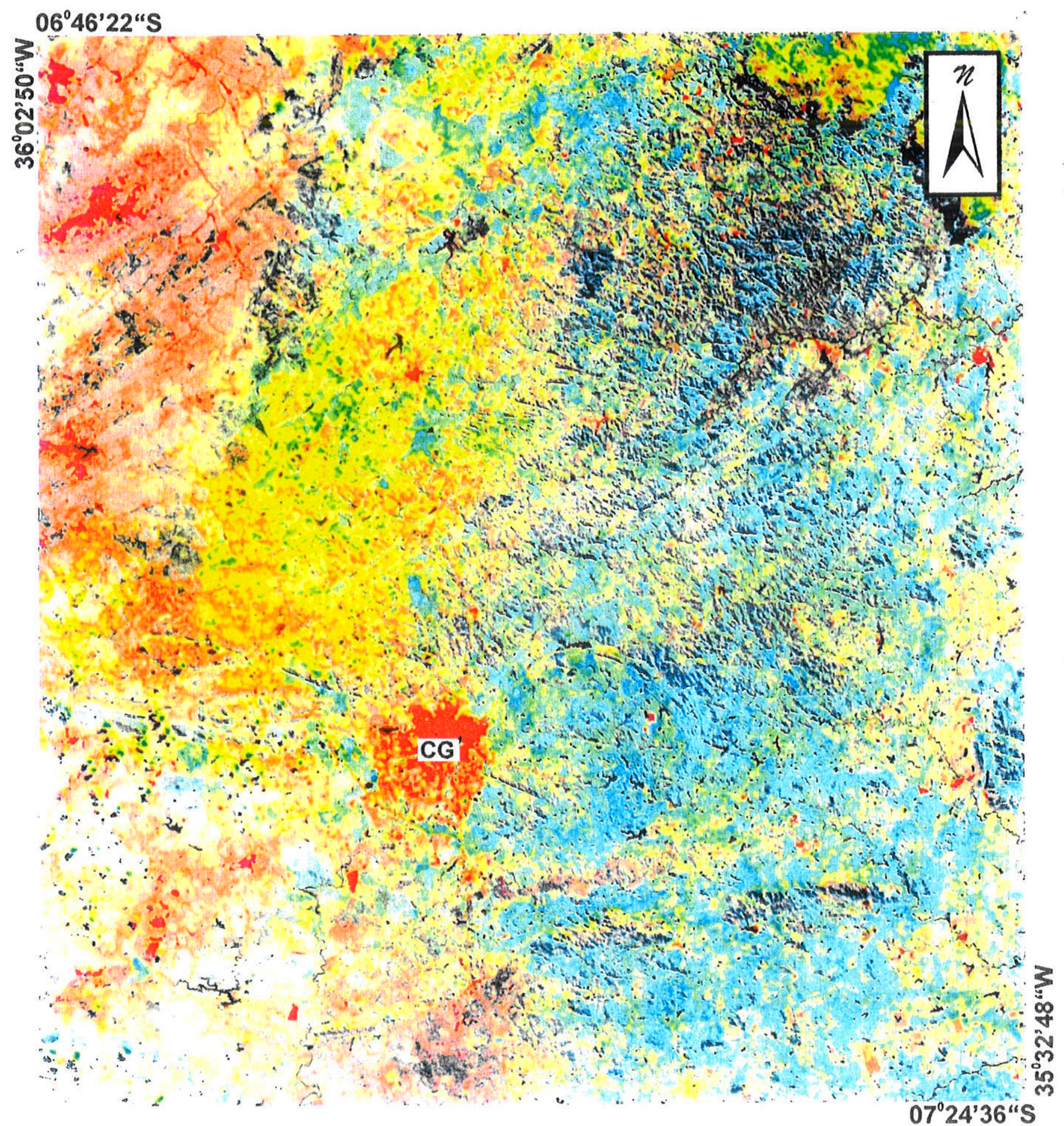

Figura 5.30 - Imagem da composição colorida das bandas 5-4-3 do Landsat 5TM combinadas em IHS. O mapa indica a localização da cidade de Campina Grande/PB marcada por CG. 


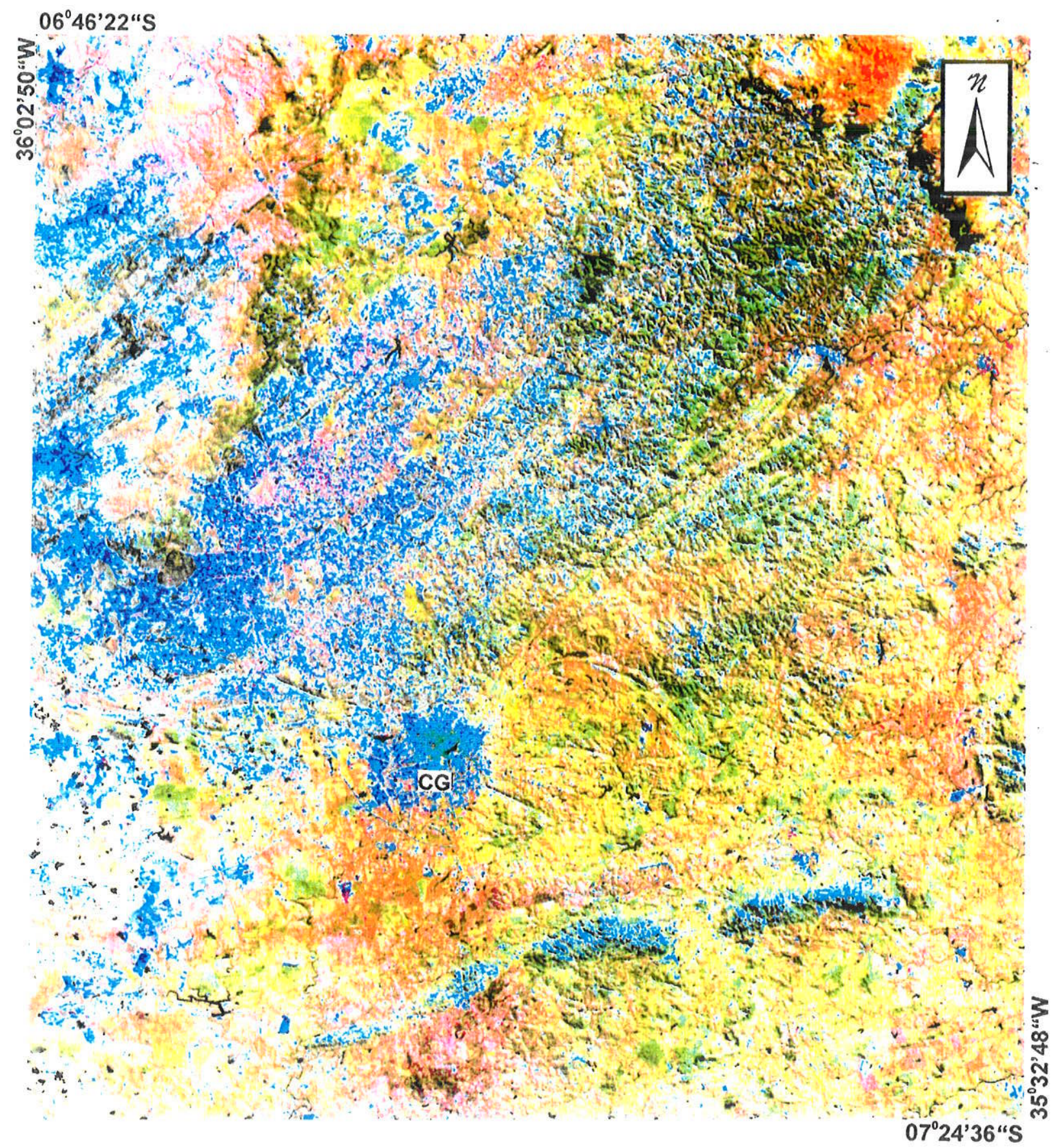

Figura 5.31 - Imagem da composição colorida em HRGB produzida pela disposição das imagens Hue em RGB, derivadas das combinações em IHS dos trios 7-5-2, 5-4-3 e 5-4-2. O mapa indica a localização da cidade de Campina Grande/PB marcada por CG. 
resultante do conjunto $752|543| 542$ apresentou bom resultado na diferenciação litológica da região de Barra de Santa Rosa-Campina Grande (Fig. 5.31). Nos terrenos do embasamento foram diferenciadas as áreas com predomínio de ortognaisses em cores verde a marrom esverdeado, dos gnaisses bandados em cores variando entre verde claro a rósea. Os micaxistos de Barra de Santa Rosa assumiram cor rósea amarelada nas áreas de baixo a médio grau metamórfico, até cores marrom esverdeado nas áreas envolvidas pela ZCRP. As faixas de micaxistos de Alagoa Grande também apresentaram cores marrom a marrom esverdeado. O granitóide Pocinhos mostrou cores azul e rósea para a área de maior abrangência do corpo, com as zonas de cisalhamento que o interceptam em cores semelhantes aos ortognaisses. No CCG, a mistura entre verde claro, amarelo e rósea permitiu a diferenciação dos ganisses migmatiticos bandados do embasamento. A forma en cornue do granitóide de Areia foi bem definida pela cor marrom, contrastante com o verde claro do embasamento. O granitóide Queimadas apresentou cores verde claro e azul misturadas. As áreas cultivadas mostraram cores verde ou azul, e as cidades e estradas cores azul e verde escuro. Quando comparada à Fig. 5.30 (HSI), a Fig. 5.31 favoreceu o melhor contraste entre as unidades geológicas, com maior definição das áreas de ocorrências dos granitóides e maior contraste no traçado dos lineamentos das áreas de alto strain. 


\section{6 - METAMORFISMO E DEFORMAÇÃO}

\section{1 - Considerações Iniciais}

A Fig. 6.1 apresenta o mapeamento regional esquemático do metamorfismo neoproterozóico $\left(\mathrm{M}_{3}\right)$ relacionando às paragêneses sin- a tardi- $\mathrm{D}_{3}$ na Porção Extremo Nordeste da Província Borborema, região dos maciços São José do Campestre e Caldas Brandão (MSJC-MCB). Esse mapa envolve o setor centro-norte da Faixa Seridó e é complementar ao mapa de distribuição das isógradas metamórficas proposto por Lima (1992). A metodologia adotada considerou as condições metamórficas estimadas a partir das relações entre as fases minerais no fabric do evento Brasiliano, com destaque para: (i) as áreas constituidas por seqüências metapelíticas, pela ampla diversidade mineralógica e sensibilidade às variações nas condições de pressão-temperatura (P-T) dessas rochas; (ii) as áreas com evidências de deformação sinanatética (fusão crustal), refletida na extensiva migmatização e anatexia dos protólitos crustais; e (iii) as zonas de cisalhamento dúcteis relacionadas ao principal evento termometamórfico.

$\mathrm{Na}$ abordagem sistemática das condições P-T, essencial no reconhecimento dos processos geodinâmicos atuantes no Brasiliano, foram avaliados aspectos referentes: (a) à caracterização espacial do metamorfismo em relação aos plútons granitóides e principais elementos estruturais brasilianos; (b) às relações texturais das paragêneses metamórficas, que indicam o controle deformacional em micro-escala; (c) às evidências de segregação e migração de fusões para as estruturas formadas pela deformação dos protólitos anisotrópicos (p.ex. a migmatização e coleta de fundidos graníticos nas zonas de cisalhamento); (d) à calibração termobarométrica (estimativas de P-T) das rochas granuliticas das ZCRP e ZCCG.

A caracterização das condições metamórficas relacionadas aos eventos deformacionais, com base na definição das paragêneses que controlam o fabric das rochas, foi assunto amplamente descrito na literatura (Yardley 1989, Bell \& Johnson 1989, 1992, Barker 1990). Os aspectos cinemáticos do metamorfismo, como as combinações entre os minerais constituintes da foliação ou lineação e dos porfiroblastos, foram controlados cronologicamente pela comparação com o fabric das rochas plutônicas nas imediações, conforme metodologia adotada para a região (Archanjo 1987, Jardim de Sá 1994). A 


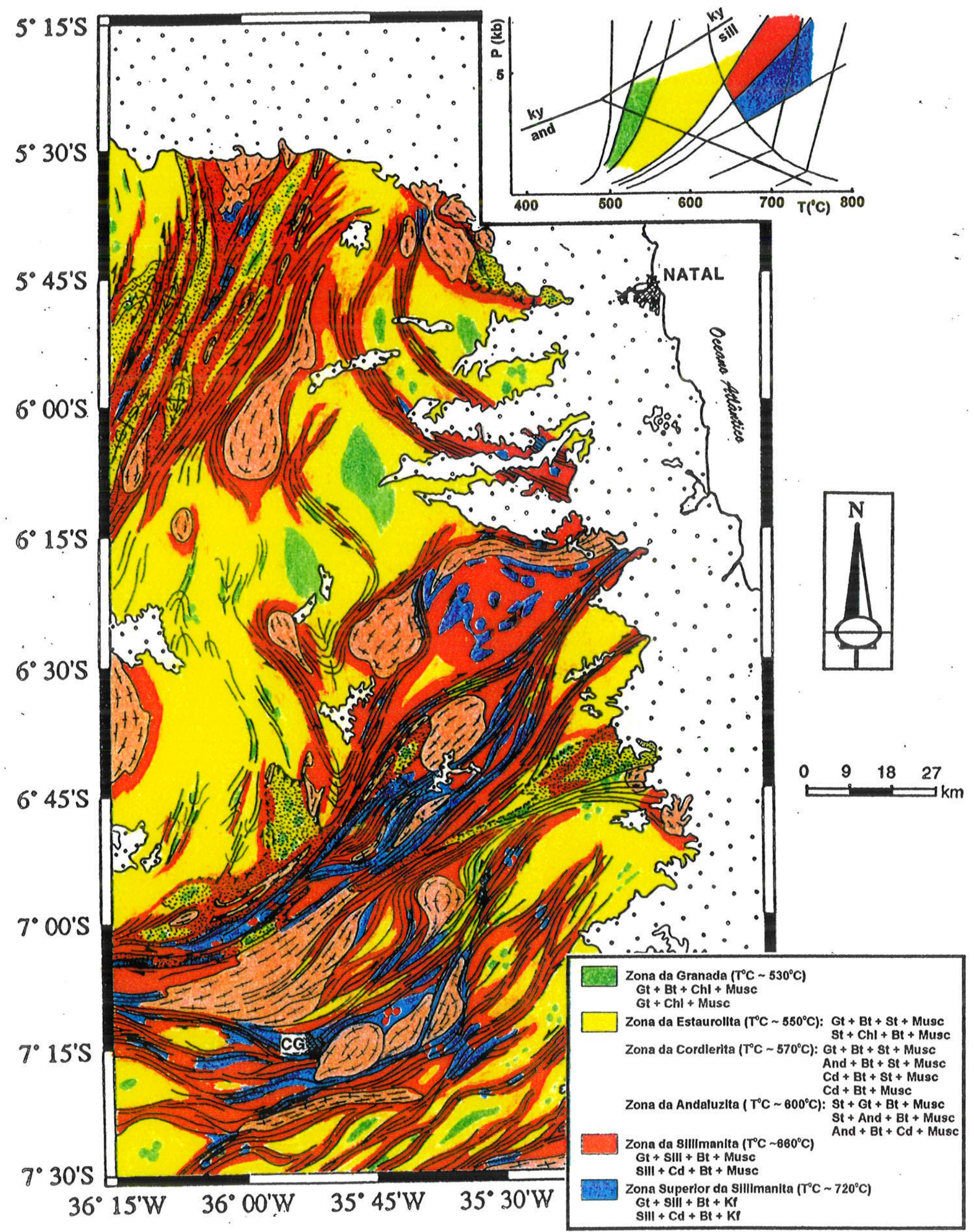

Figura 6.1 - Zoneamento metamórfico simplificado referente ao Evento Brasiliano combinado ao mapa geológico esquemático do Setor Extremo Nordeste da Província Borborema. Convenções geológicas:

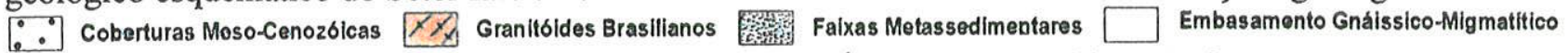
1. I Zonas de Cisalhamento Brasillianas 4 Traģos Axiais dos Dobramentos $F$. 
designação cronológica dos eventos metamórficos $\left(\mathrm{M}_{1}, \mathrm{M}_{2}, \mathrm{M}_{3}\right)$ e as correlaç̃es com os eventos seqüenciais de deformação $\left(D_{1}, D_{2}, D_{3}\right)$ segue a nomenclatura amplamente difundida nos estudos sobre a evolução pré-cambriana da região. As descriçø̃es das paragêneses metamórficas foram adequadas ao conceito de fases progressivas $\mathrm{e}$ retrogressivas (estruturas precoces, principais e tardias) num único episódio cinemático, de distribuição espacial variada (strain partitioning) e por isso nem sempre presentes e/ou seqüentes nos afloramentos.

\section{2 - Condições Metamórficas dos Eventos Pré-Brasilianos}

A obliteração dos elementos estruturais $D_{1}$ pelo intenso retrabalhamento dos eventos deformacionais posteriores $\left(\mathrm{D}_{2}\right.$ e $\left.\mathrm{D}_{3}\right)$ comumente inviabiliza a descrição das fases metamórficas características do evento mais antigo $M_{1}$. Entretanto, nas regiões do embasamento de atuação branda das deformações subseqüentes, foram descritas paragêneses reliquiares acompanhando os ortognaisses, augen-gnaisses bandados e migmatitos, definido pelo bandamento $\left(\mathrm{S}_{1}\right)$ freqüentemente anastomosado, alternando níveis máficos e félsicos com paragêneses de hornblenda + biotita \pm granada e quartzo + plagioclásio, respectivamente. $\mathrm{O}$ diagnóstico de $\mathrm{S}_{1}$ é facilitado nos afloramentos onde ocorre truncada por diques de anfíbolito pré- $\mathrm{D}_{2}$ (Foto 4.2, 4.3a e 4.3b). Os freqüentes remobilizados félsicos de composição tonalítica a granítica relacionados a este evento e, geralmente, subparalelizados à $S_{2}$, sugerem condições metamórficas de fácies anfibolito alto, com condições minimas de anatexia. Nos ortognaisses e migmatitos do núcleo arqueano foram descritas feições de extensiva migmatização aliada à possiveis estruturas de deformação PFC nos remobilizados anatéticos, como fenocristais rotacionados e recristalização de microclina, hornblenda e plagioclásio. Estas evidências caracterizariam um evento deformacional de alta temperatura no Arqueano, responsável pela geração de migmatitos e pela desestabilização da biotita + quartzo para geração de microclina + granada dos remobilizados tonalíticos.

A distribuição regional do evento $\mathrm{M}_{2}$ está relacionada aos elementos deformacionais da tectônica tangencial (nappes e zonas de cisalhamento tangenciais), com a foliação $S_{2}$ de baixo ângulo e subparalela ao acamamento e à superficie $S_{1}\left(S_{0} / / S_{1} / / S_{2}\right.$, Foto 4.5), freqüentemente obliterados pelo alto strain da fase $D_{3}$ (Foto 6.1). Entretanto, nas áreas de baixo strain $D_{3}$ constata-se que as estruturas do fabric $D_{2}$ são penetrativas e intensas nos 
complexos gnáissico-migmatíticos do embasamento e nas faixas de metassedimentos. Nas rochas do embasamento gnáissico-migmatítico a diferenciação metamórfica em $\mathbf{M}_{2}$ gerou um bandamento migmatítico $S_{2}$ definido por hornblenda + biotita + plagioclásio $(\mathrm{An}>20)$, caracterizando o fácies anfibolito como predominante nos ortognaisses bandados de composição tonalítica a granítica, augen-gnaisses e diques anfibolíticos pré- $\mathrm{D}_{2}$. A presença constante de remobilizados leucocráticos com texturas granoblásticas poligonais nos feldspatos e mirmequitas no fabric $\mathrm{S}_{2}$ ratificam as condições do fácies anfibolito alto com anatexia. Nos augen-gnaisses e ortognaisses são comuns nódulos de calciossilicáticas e anfibolitos em paragênese granada + clinopiroxênio + plagioclásio (An>50), com texturas em coroa de granada envolvendo o clinopiroxênio, sugestivas das condições iniciais do fácies granulito sob pressão intermediária a alta (Yardley 1989).

A paragênese $\mathrm{M}_{2}$ mais freqüente nos micaxistos é definida por micas + anfibólios \pm quartzo, associada a veios e remobilizados anatéticos no fabric $\mathrm{S}_{2}$. Em afloramentos de baixos strain e grau metamórfico, como no sinforme de Cruzeta e na faixa de micaxistos de Taipu-Ielmo Marinho, foi descrita uma fina alternância de bandas quartzosas e micáceas anastomosadas por mecanismo de solução por pressão (bandamento $\mathrm{S}_{2 \mathrm{p}}$ ), marcando um incremento precoce da deformação $\mathrm{D}_{2}$ sob condições do fácies xisto verde $\left(250-300^{\circ} \mathrm{C}\right.$, Jardim de Sá 1994). O strain principal $F_{2}$ paraleliza $S_{2 p}$ e $S_{2}$ gerando uma superfície composta $S_{2 p}+S_{2}$, freqüentemente paralela ao acamamento $S_{0}$ definido pelos niveis quartzosos e aluminosos intercalados (Foto 6.2). Nos setores de fraca recristalização pelo evento $M_{3}$ foi definida a paragênese do estágio principal $M_{2}$ composta por biotita + muscovita + andaluzita + granada + estaurolita, por vezes com sillimanita descrevendo a $L_{2}{ }_{2}$, indicando condições do fácies anfibolito alto de baixa pressão. Nos metassedimentos aluminosos de algumas áreas do Grupo Seridó foi descrita a paragênese reliquiar pré- $\mathrm{D}_{3}$ de cianita \pm estaurolita, sob a forma de inclusões nos porfiroblastos de andaluzita e cordierita cedo- a sin-S S $_{3}$ (Ś \& Legrand 1983, Souza 1987, Fonseca et al. 1991). De acordo com Fonseca et al. (1991), a inclusão da estaurolita pela cianita ocorre numa evolução progressiva de $\mathbf{M}_{2}$, conforme a reação: estaurolita + muscovita + quartzo $\rightarrow$ cianita + biotita $+\mathrm{H}_{2} \mathrm{O}$ (Yardley 1989). Desta maneira, as condições mais elevadas de P-T requeridas pela evolução de $M_{2}$ seriam obtidas no espessamento crustal gerados pelas estruturas $D_{2}$ 
(empurrões e nappes), com subseqüente descompressão e aquecimento relacionado às intrusões granitóides associadas (ortognaisses $\mathrm{G}_{2}$, Jardim de Sá 1994).

\section{3 - Evolução Metamórfica da Faixa Seridó no Brasiliano}

Diversos estudos abordaram a evolução metamórfica da Faixa Seridó, favorecidos pela ampla exposição de micaxistos pelíticos com fases minerais preservadas. Mello e Mello (1974) aplicaram o conceito de fácies metamórfico na descrição mineralógica dessas rochas, reconhecendo o regime de baixa pressão/alta temperatura (baixa-P/alta-T) do tipo Abukuma em gradiente progradante de oeste para leste.

$\mathrm{Na}$ análise detalhada das paragêneses metamórficas, outras contribuições relacionaram o metamorfismo aos eventos deformacionais (Gama \& Albuquerque 1979, Legrand \& Salim 1980, Lima et al. 1980, Sá \& Legrand 1983, Hackspacher \& Sá 1984, Souza 1987) e às condições precisas de P-T do metamorfismo (Gama 1981, Legrand \& Sá 1986). Gama (1981), baseado no termobarômetro granada-cordierita, estimou condições de P-T do fácies anfibolito baixo a médio $-820-856^{\circ} \mathrm{C} / 3,2-3,5$ kbar na calibração de Currie (1971), 550 ${ }^{\circ} \mathrm{C} / 4,0$ kbar na calibração de Thompson (1976) - sugerindo um único evento metamórfico. Uma explicação plausível para a diferença de $300^{\circ} \mathrm{C}$ obtido por Gama (1981) seria o desequilibrio dos minerais analisados, refletindo provavelmente um estado de alta temperatura $\left(\sim 850^{\circ} \mathrm{C}\right)$ e um de temperatura média $\left(550^{\circ} \mathrm{C}\right)$ retrometamórfico. No entanto, a maioria dos autores reconheceu uma evolução polimetamórfica integrada à evolução tectônica da região, tanto para o embasamento (Complexo Caicó) quanto para os metassedimentos (Grupo Seridó), alcançando o ápice das condições P-T durante a deformação $D_{2}$ (evento Transamazônico), com a deformação brasiliana $\left(D_{3}\right)$ descrita como retrometamórfica.

Lima $(1986,1987)$ estabeleceu um zoneamento regional do metamorfismo brasiliano, com aumento das condições P-T de oeste para leste (condições mínimas de $550^{\circ} \mathrm{C} / 2-2,5$ kbar e máximas de $600^{\circ} \mathrm{C} / 4 \mathrm{kbar}$ ) e ápice na Porção Central da Faixa Seridó. Lima (1992) sugeriu o reequilíbrio químico dos minerais estáveis no primeiro evento metamórfico na Faixa Seridó, parcial para a granada e total para a biotita, com gradiente metamórfico de $30-40^{\circ} \mathrm{C} / \mathrm{km}$ e incremento metamórfico regional de oeste para leste. Essa região coincide com um feixe de zonas de cisalhamento e granitóides associados no núcleo 
Foto 6.1- Dobras $F_{3}$ afetando o fabric composto $S_{2}+S_{0}$, indicada pela alternância de níveis claros (quartzosos) e escuros (micáceos) subhorizontalizados, em micaxistos sob condiçóes da "Zona da

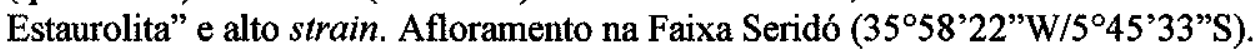

Foto 6.2 - Dobras $F_{3}$ afetando o fabric composto $S_{2}+S_{2 p}+S_{0}$, definido pela alternância entre níveis claros (quartzosos) e escuros (micáceos) formando dobras isoclinais subhorizontais $\mathrm{F}_{2}$, interceptadas por veios de quartzo precoces em $\mathrm{F}_{3}$, escalonados sinistrais e dobrados em $\mathrm{F}_{3}$. $\mathrm{O}$ fino bandamento $\mathrm{S}_{2 \mathrm{p}}$ é caracterizado pelo baixo ângulo com relação a $\mathrm{S}_{0}$. Afloramento na Faixa Seridó a sul de

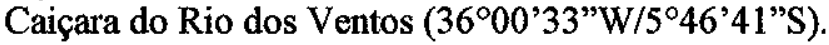

Foto 6.3 - Aspecto geral de metassedimentos e gnaisses migmatizados e milonitizados na ZCCG: (a) dobras $\mathrm{F}_{3}$ isoclinais sintectônicos à $\mathrm{D}_{3}$ com ampla geração de remobilizados leucocráticos segundo a foliação milonítica e injetados no plano axial das dobras; (b) granitóide anatético com xenólito dos metassedimentos dobrados, com aspecto que sugere anatexia em níveis profundos da crosta. Afloramento nas proximidades de Campina Grande.

Foto 6.4 - Gnaisses bandados do embasamento, migmatizados e milonitizados na ZCCG, mostrando níveis de composição granítica com boudinagem sintectônica dextral. Afloramento nas proximidades de Campina Grande.

Foto 6.5 - Veios pegmatíticos sintectônicos boudinados e rotacionados com cinemática dextral em ortognaisses milonitizados, mostrando as estruturas antitéticas no interior dos boudins e veios de quartzo ocupando os interboudins. 
Foto 6.1

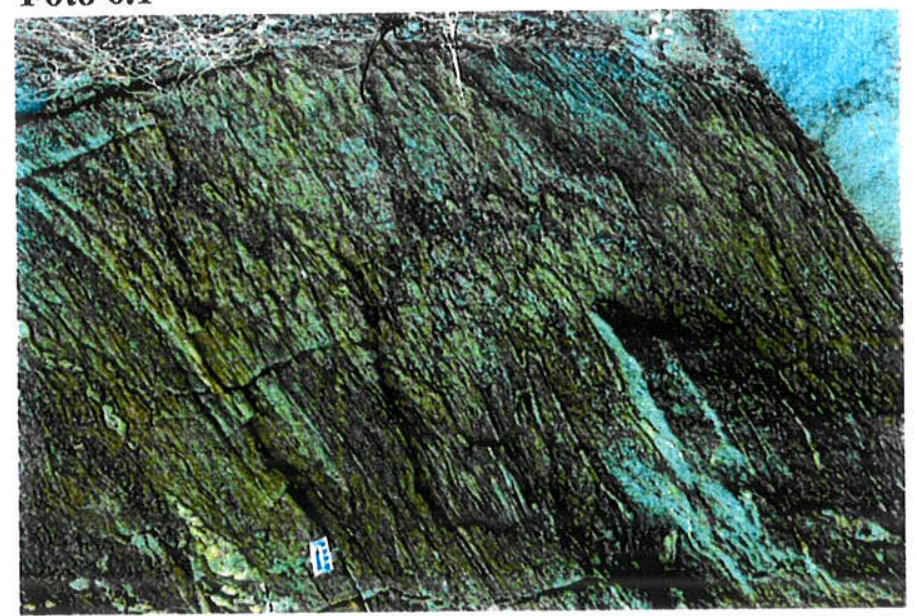

Foto $6.3 \mathrm{a}$

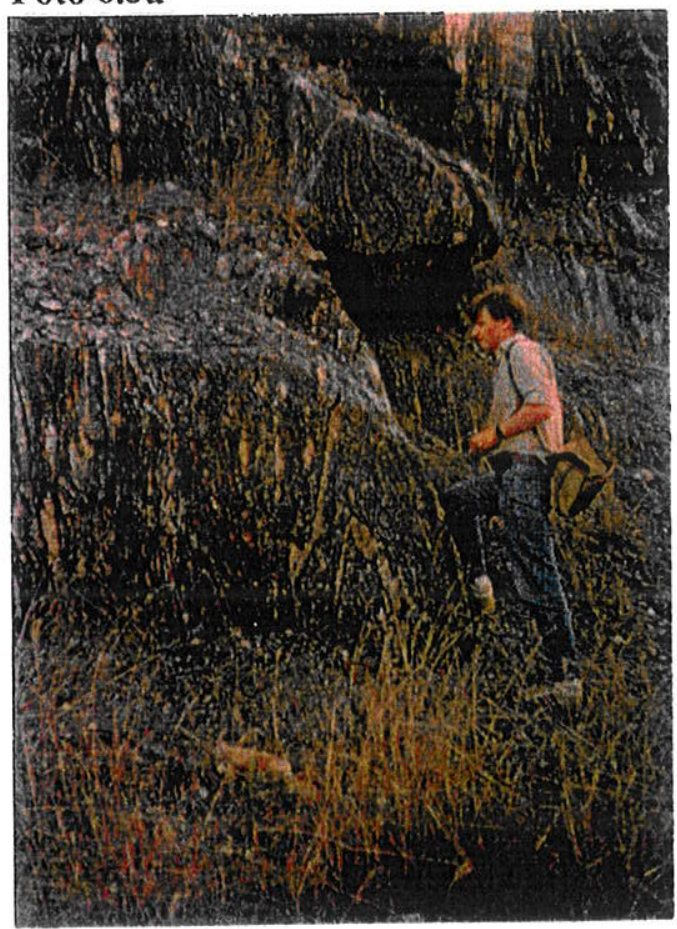

Foto 6.4

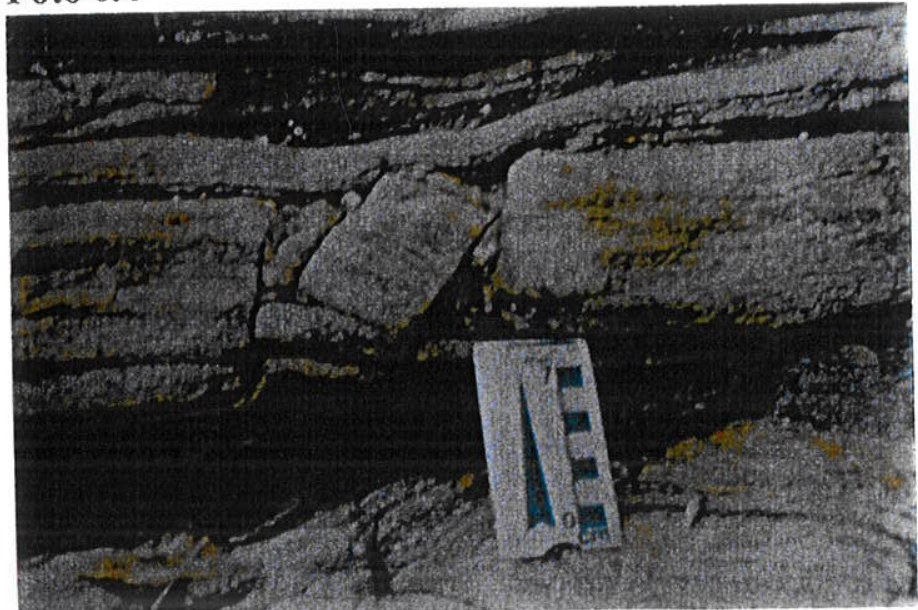

Foto 6.2

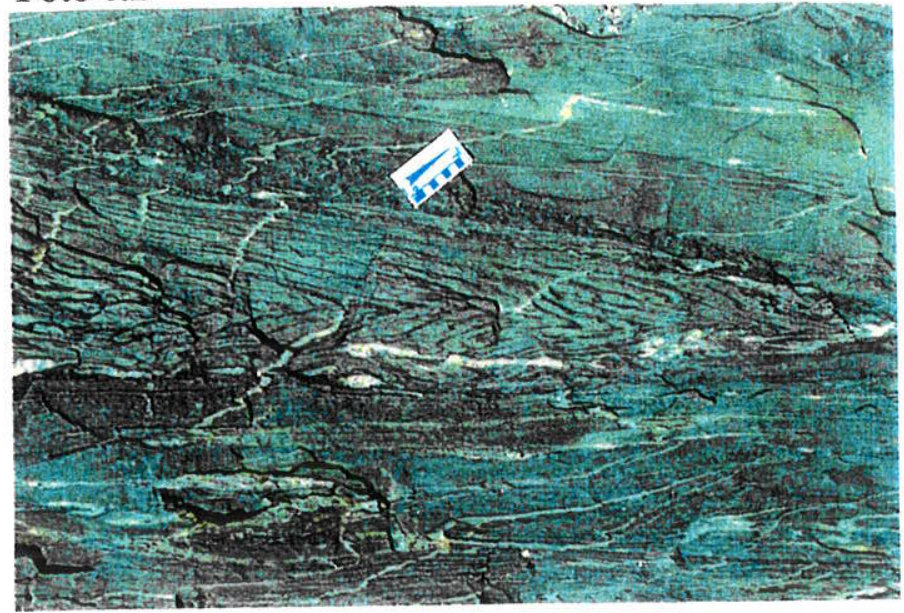

Foto $6.3 \mathrm{~b}$

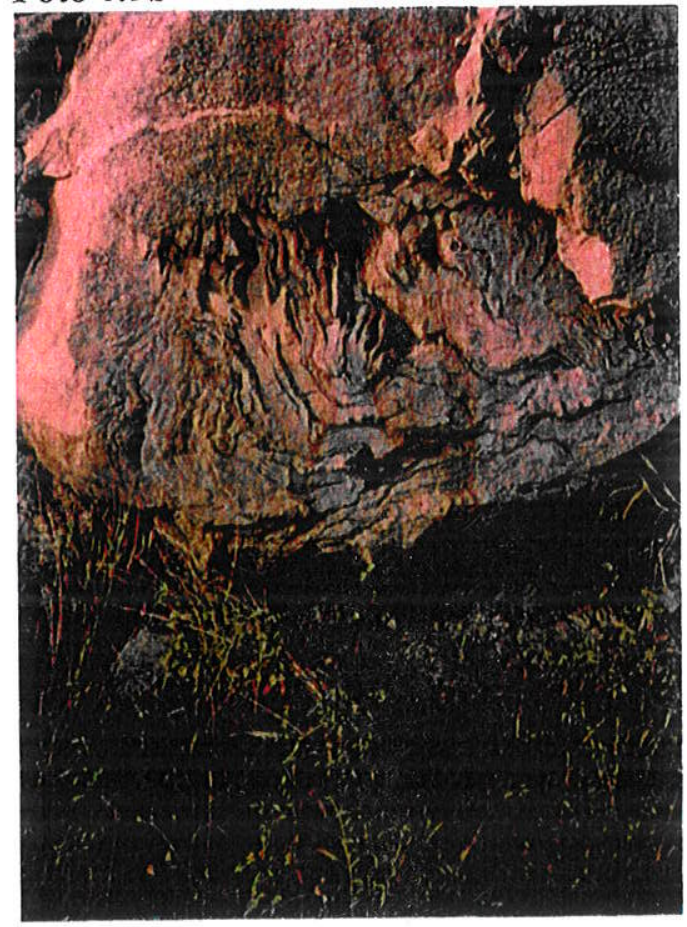

Foto 6.5

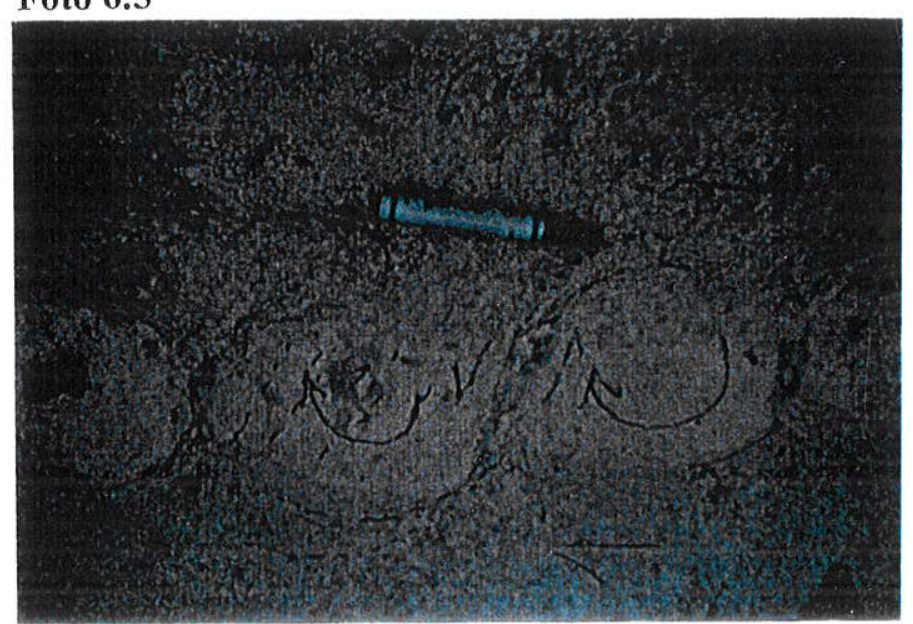


da estrutura em flor positiva (região de Caiçara do Rio dos Ventos), ambiente de espessamento crustal para a região (Jardim de Sá 1994). Nas áreas interceptadas por zonas de cisalhamento (como na inflexão N-NE do lineamento Patos na região de Santa Luzia e da ZCCG na região de Campina Grande) ocorre ampla migmatização dos micaxistos e dos gnaisses do embasamento coeva ao fabric $\mathrm{D}_{3}$ dextral (Foto 6.3a), acompanhados por sheets de leucogranitos que guardam xenólitos dos micaxistos migmatíticos (Foto 6.3b) sugerindo anatexia nos niveis profundos crosta (Corsini et al. 1992). De maneira geral, a foliação milonítica na ZCCG possui forte mergulho acompanhando paragênese metamórficas de alta$\mathrm{T}$ até ampla migmatização. A lineação de estiramento é definida por agregados quartzofeldspáticos e sillimanita, com caimento variável desde moderado $\left(\sim 45^{\circ}\right)$ a subhorizontal, freqüentemente mostrando boudinagem nos metassedimentos $\mathrm{e}$ gnaisses bandados migmatizados (Foto 6.4 e 6.5). Os milonitos de alta-T gradam a granitos anatéticos $\mathrm{e}$ migmatitos com estruturas nebulíticas e estromatíticas, que acompanham ofabric $\mathrm{D}_{3}$ (Amaro et al. 1991b).

$\mathrm{Na}$ datação direta do evento tectonometamórfico $\mathrm{D}_{3}$ pelo método $\mathrm{K}-\mathrm{Ar}$, foram sugeridas idades mínimas de 500 Ma nas micas e entre 550-600 Ma nos anfibólios (Brito Neves et al. 1975, McReath \& Jardim de Sá 1979, Galindo 1981). As datações ${ }^{40} \mathrm{Ar} /{ }^{39} \mathrm{Ar}$ realizadas em micas e anfibólios foram interpretadas como referentes a um evento de alta temperatura com idade mínima de $544 \pm 3$ Ma e um evento retrometamórfico com idade mínima 505-500 Ma (Figueiredo et al. 1992). Os valores recalculados para as temperaturas de fechamento dos minerais empregados na análise sugerem o ápice das condições P-T em 570-580 Ma. Figueiredo (1992) calculou as taxas de resfriamento em $3-9^{\circ} \mathrm{C} / \mathrm{Ma}$, refletindo um processo de soerguimento lento, em desacordo com os regimes de colisão frontal de placas (Jardim de Sá 1994). Souza et al. (Submet.) dataram o evento de migmatização que acompanha a deformação dúctil extensional nas ZCRP e ZCSE em ca.555 $\pm 10 \mathrm{Ma}$, com base na análise por microssonda eletrônica dos teores do sistema U-Th-Pb em monazitas (método descrito em Montel et al. 1996), sugerida como idade da intrusão de plútons granitóides e básicos coevos (granitóides e básicas de Serrinha, Monte das Gameleiras, Japi). Nas monazitas dos metapelitos migmatíticos da ZCRP, uma idade de $403 \pm 28$ Ma foi interpretada como referente ao evento deformacional tardio no fácies xisto verde. Esses 
autores estimaram um período inferior a $25 \mathrm{Ma}$ para os estágios de soerguimento, resfriamento e exumação dos terrenos do MSJC-MCB

\section{4 - Distribuição Regional do Metamorfismo Brasiliano nos MSJC-MCB}

\subsection{1 - Malha Petrogenética e Diagramas AFM}

De acordo com Spear (1993), as diversas sugestões de malhas petrogenéticas para os metapelitos podem ser divididas em dois grupos: (a) aqueles que assumem composições fixas de Fe-Mg nos minerais, simplificando as reações contínuas de Fe-Mg durante o metamorfismo (Albee 1965, Hess 1969, Brown 1975, Labotka 1981); (b) aqueles que consideram uma solução sólida de Fe-Mg, com controle experimental da malha pelas determinações das reações no sistema $\mathrm{KFMASH}\left(\mathrm{K}_{2} \mathrm{O}-\mathrm{FeO}-\mathrm{MgO}-\mathrm{Al}_{2} \mathrm{O}_{3}-\mathrm{SiO}_{2}-\mathrm{H}_{2} \mathrm{O}\right.$, Thompson 1976, Harte \& Hudson 1979, Bickle \& Archibald 1984, Spear \& Cheney 1989). Para a Faixa Seridó, os trabalhos de Lima $(1987,1992)$ seguiram a metodologia proposta por Albee (1965) e Hess (1969), produzindo linhas aproximadas das relações P-T.

No presente trabalho é sugerida o diagrama petrogenético P-T parcial calibrado no sistema KFMASH para as rochas pelíticas (Fig. 6.2), conforme as propostas de Harte e Hudson (1979), Clarke et al. (1987), Spear e Cheney (1989) e Spear (1993). O sistema KFMASH foi empregado devido à ocorrência extensiva de faixas de metapelitos na região, onde as paragêneses metamórficas foram caracterizadas com maior detalhe. Contudo, foram incluidas algumas das relações de fases metamórficas no sistema $\mathrm{CKNASH}\left(\mathrm{CaO}-\mathrm{K}_{2} \mathrm{O}-\right.$ $\mathrm{Na}_{2} \mathrm{O}-\mathrm{Al}_{2} \mathrm{O}_{3}-\mathrm{SiO}_{2}-\mathrm{H}_{2} \mathrm{O}$ ), que representa as principais condições $\mathrm{P}-\mathrm{T}$ de equilíbrio para composições variadas de gnaisses quartzo-feldspáticos, e é considerado como subconjunto para os metapelitos de composições amplas, sobretudo quando acompanhados de anatexia (Thompson 1974, Spear 1993). Os processos iniciais de fusão parcial das rochas crustais é controlado pelo sistema CKNASH (Thompson \& Angor 1977, Thompson \& Tracy 1979). O diagrama de fases $\mathrm{Al}_{2} \mathrm{SiO}_{5}$ apresentado pela linha contínua preta e ponto tríplice $\mathrm{H}\left(501^{\circ} \mathrm{C} \mathrm{e}\right.$ $3,8 \mathrm{kbar}$ ) foi sugerido por Holdaway (1971), enquanto a linha contínua vermelha e ponto tríplice $\mathrm{R}\left(620^{\circ} \mathrm{C}\right.$ e $\left.6 \mathrm{kbar}\right)$ foi proposto por Richardson et al. $(1968,1969)$. O ponto tríplice de Richardson et al. $(1968,1969)$ é especialmente correto para as relações de equilibrio andaluzita=sillimanita, principal transformação polimórfica do $\mathrm{Al}_{2} \mathrm{SiO}_{5}$ descrita na região estudada. A pequena diferença de energia livre entre as fases $\mathrm{Al}_{2} \mathrm{SiO}_{5}$ (reações lentas) e as 


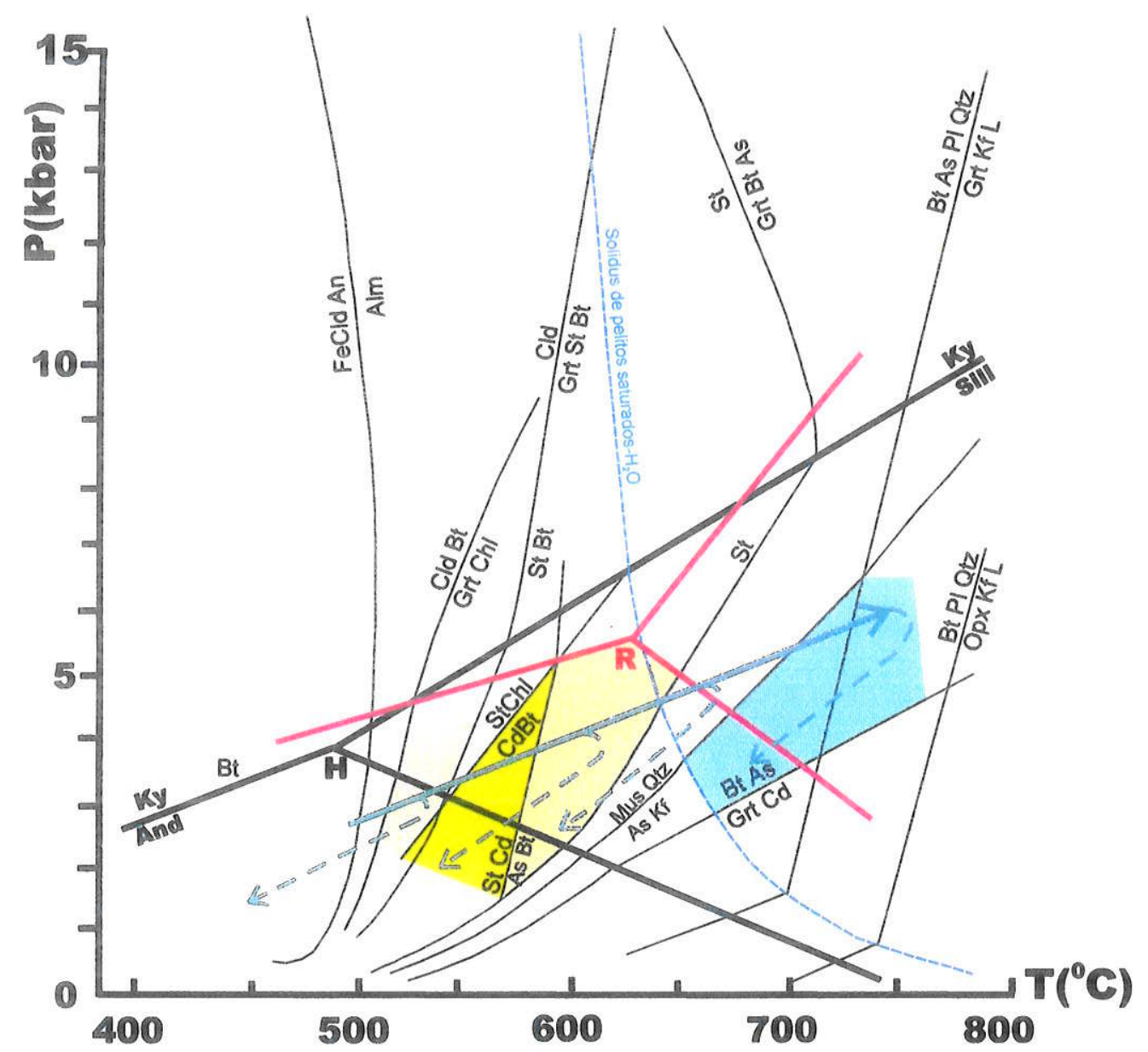

Figura 6.2 - Diagrama petrogenético P-T calibrado no sistema KFMASH para os metapelitos. $\mathrm{O}$ diagrama de fases do $\mathrm{Al}_{2} \mathrm{SiO}_{5}$ definido pela linha contínua preta e ponto tríplice $\mathrm{H}\left(501^{\circ} \mathrm{C}\right.$ e $\left.3,8 \mathrm{kbar}\right)$ foi sugerido por Holdaway (1971), e a linha contínua vermelha e ponto tríplice $\mathrm{R}\left(620^{\circ} \mathrm{C}\right.$ e $\left.6 \mathrm{kbar}\right)$ foi proposto por Richardson et al. $(1968,1969)$. As áreas coloridas representam as assembléias minerais descritas na Figura 6.3. As setas contínua e tracejadas representam caminhos P-T-t hipotéticos envolvendo M3 e M3t. Modificado de Harte e Hudson (1979), Clarke et al. (1987), Spear e Cheney (1989) e Spear (1993). Abreviaturas dos minerais: Ky = Cianita, And $=$ Andaluzita, Sill $=$ Sillimanita, $\mathrm{Bt}=$ Biotita, $\mathrm{Chl}=$ Clorita, Musc $=$ Muscovita, Grt $=$ Granada, $\mathrm{St}=$ Estaurolita, $\mathrm{Cld}=$ Cloritóide, $\mathrm{FeCld}=$ Ferrocloritóide, $\mathrm{Cd}=$ Cordierita, $\mathrm{Qtz}=$ Quartzo, $\mathrm{Pl}=$ Plagioclásio, $\mathrm{Kf}=\mathrm{K}$-feldspato, $\mathrm{An}=$ Anortita, $\mathrm{Opx}=$ Ortopiroxênio, $\mathrm{Cpx}=\mathrm{Ca}$-clinopiroxênio, $\mathrm{As}=$ Aluminossilicato, $\mathrm{Alm}=$ Almandina, $\mathrm{L}=$ Líquido (fundido silicático). 
relações de ordem/desordem na ligação $\mathrm{Al}-\mathrm{Si}$, além das freqüentes impurezas de $\mathrm{Fe}_{2} \mathrm{O}_{3}$ e $\mathrm{Mn}_{2} \mathrm{O}_{3}$ na sillimanita e andaluzita, podem influenciar as condiç̃̃es de P-T nos limites das reações de equilibrio (Spear 1993). Salje (1986) sugeriu o deslocamento de aproximadamente $200^{\circ} \mathrm{C}$ para o equilíbrio da reação andaluzita=sillimanita quando a sillimanita é a fibrolita, tipo predominante na região estudada. Portanto, o ponto tríplice para a sillimanita fibrolitica ocorre próximo ao proposto por Richardson et al. (1968, 1969), enquanto para a sillimanita prismática aproxima-se do valor sugerido por Holdaway (1971).

O sistema KFMASH foi projetado no plano AFM $\left(\mathrm{Al}_{2} \mathrm{O}_{3}-\mathrm{FeO}-\mathrm{MgO}\right)$ a partir da muscovita (Thompson 1957), removendo assim o $\mathrm{K}_{2} \mathrm{O}$ do sistema sem alterar a posição dos minerais. Os diagramas AFM da Fig. 6.3 mostram a evolução das paragêneses metamórficas durante o metamorfísmo progressivo das rochas pelíticas, relacionando as reações químicas e as assembléias minerais (campos coloridos), em correspondência com os campos coloridos distribuidos pela área. Os campos coloridos indicam o zoneamento aparente do metamorfismo regional $\mathrm{M}_{3}$, distribuídos espacialmente no mapa regional esquemático da deformação $\mathrm{D}_{3}$ (Fig. 6.1), de acordo com a correlação entre as paragêneses metamórficas e 0 fabric do evento tectonomagmático $\mathrm{D}_{3}$. Desta forma, foi proposto um esquema da evolução metamórfica para a região com as estimativas de aumento das condições P-T nas proximidades das zonas de cisalhamento e plútons granitóides.

\subsection{2 - Reações Metamórficas e a Trajetória PTt do Metamorfismo $M_{3}$}

A combinação espacial entre as assembléias minerais $M_{3}$ (Fig. 6.3) e o desenvolvimento do fabric $\mathrm{D}_{3}$ (Fig. 6.1), numa seqüência temporal, permitiu a elaboração da trajetória de pressão-temperatura-deformação-tempo (P-T-D-t) para os terrenos estudados. A elucidação da evolução tectonotermal dos terrenos foi baseada em investigações de campo e laboratório sobre as microestruturas na inferência das reações metamórficas e trajetória PTt (Vernon 1996). As principais reações minerais responsáveis pela caracterização das zonas metamórficas nas rochas metapelíticas e gnáissicas, na ordem do incremento do grau metamórfico, foram descritas e vinculadas às relações texturais entre as fases minerais.

As paragêneses de baixo grau, como representantes das condiç̃̃es P-T culminantes, foram descritas em áreas restritas das seqüências metapelíticas e núcleos dos terrenos arqueanos, caracterizados por feições de baixo strain $\mathrm{D}_{3}$ (Jardim de Sá 1994, Dantas 1997). As assembléias minerais do fácies xisto verde demarcam, sobretudo, os 

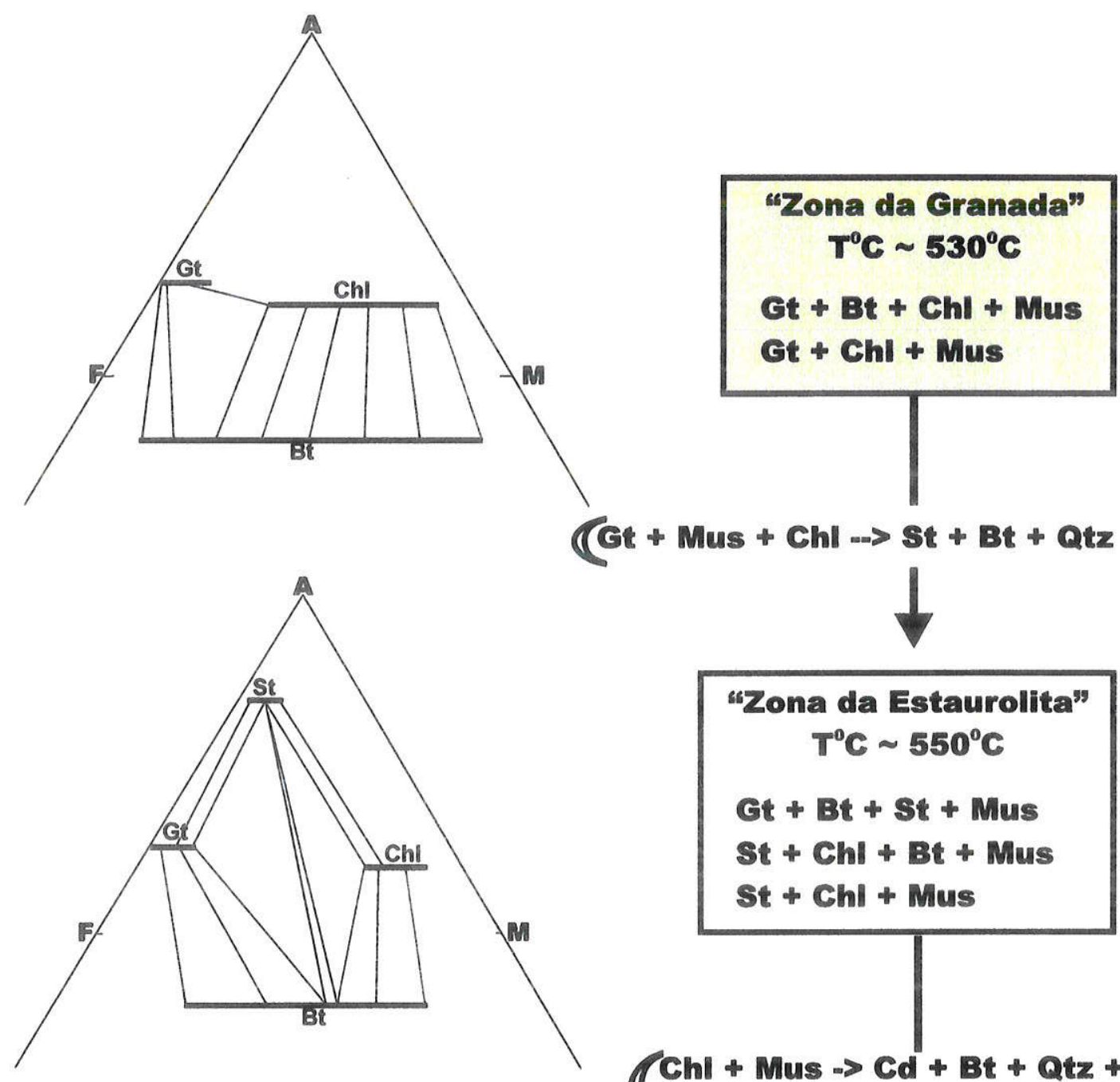

$\left(\mathrm{Gt}+\mathrm{Mus}+\mathrm{Chl} \rightarrow \mathrm{St}+\mathrm{Bt}+\mathrm{Qtz}+\mathrm{H}_{2} \mathrm{O}\right)$

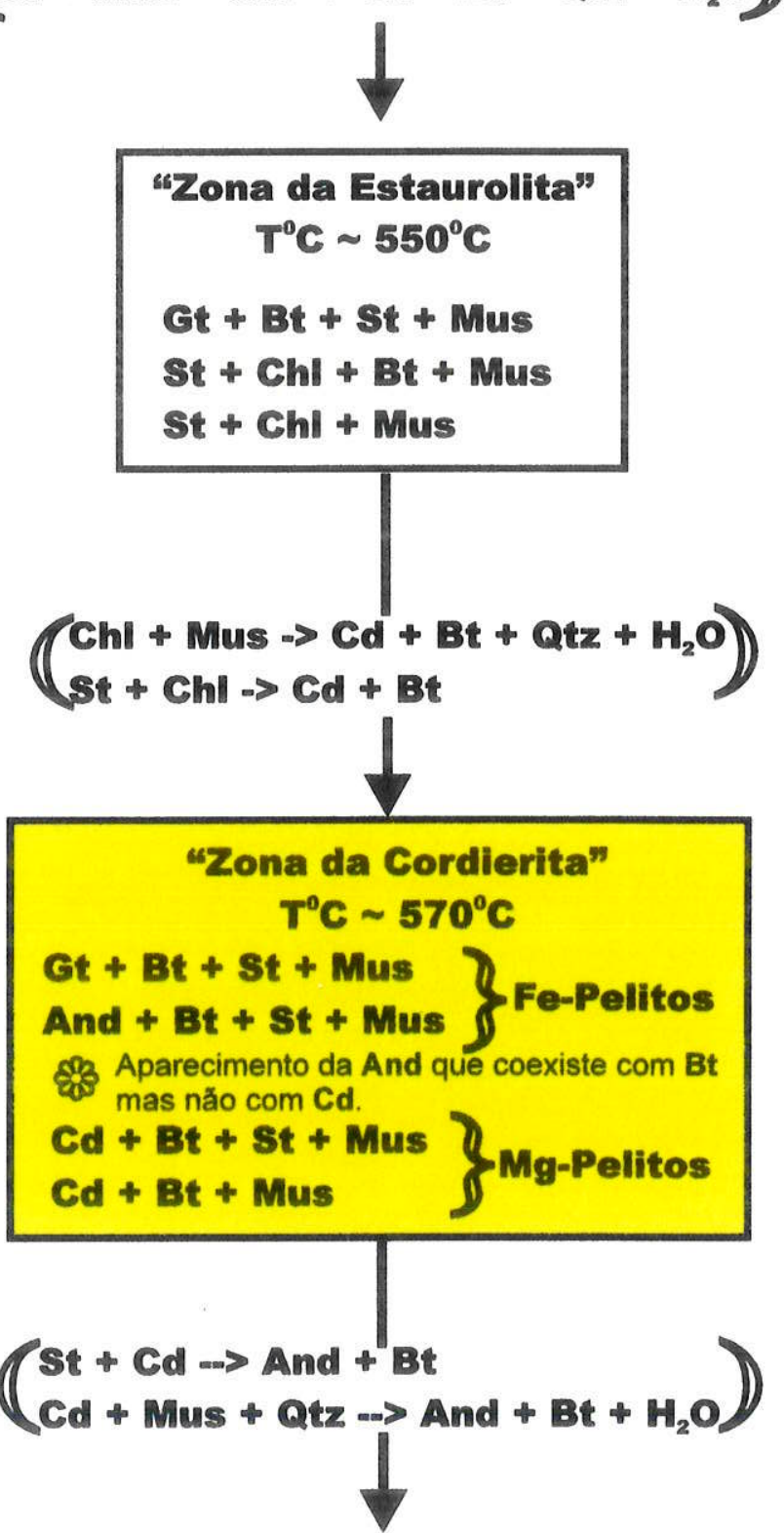

Figura 6.3 - Legenda na próxima página. 


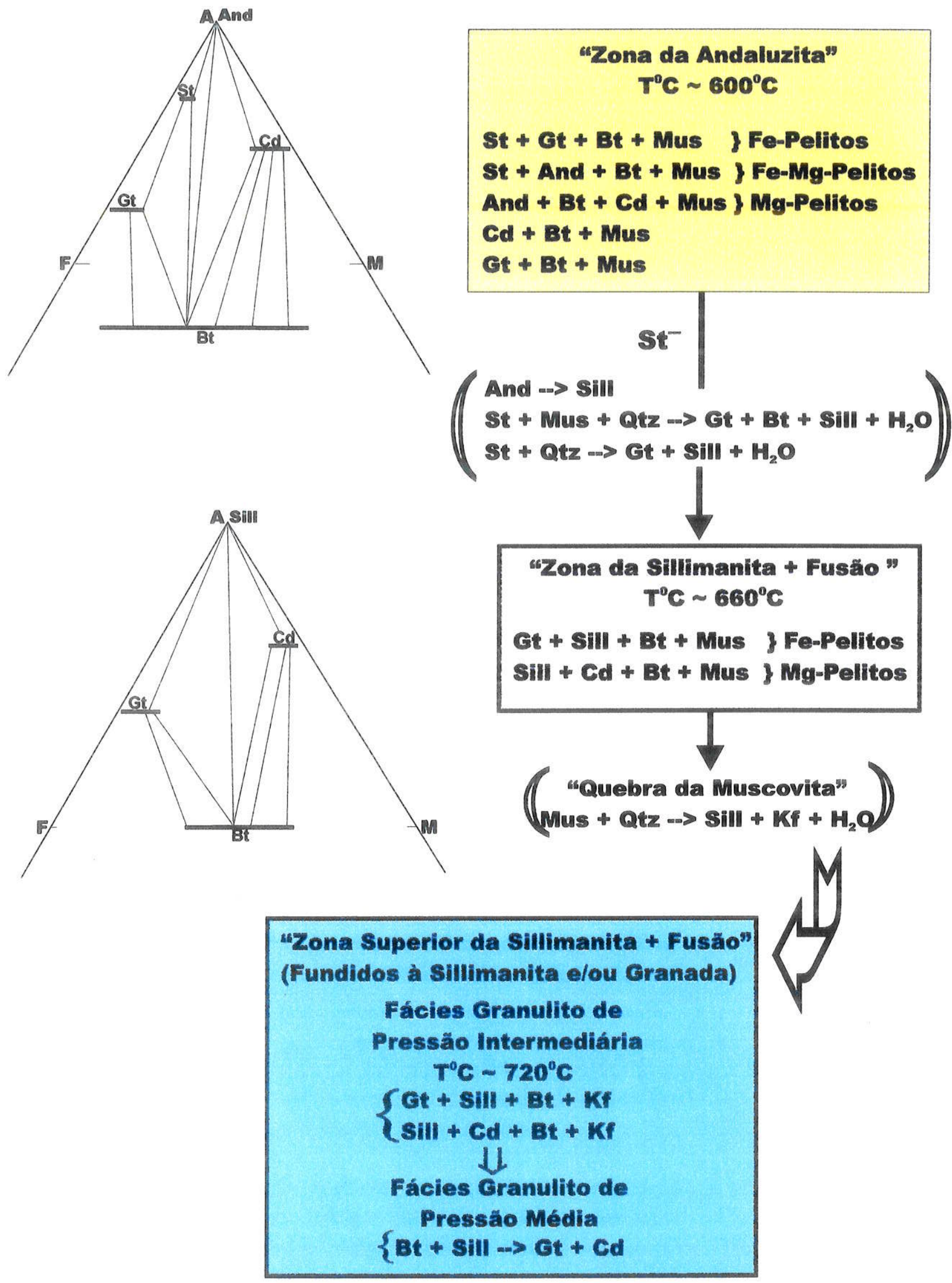

Figura 6.3 - Diagramas de projeção AFM de Thompson (1957) para as faixas de metapelitos estudadas, representando as assembléias minerais nos metapelitos de pressão baixa a intermediária. Os diagramas foram combinados às zonas metamórficas definidas pelas assembléias paragenéticas (quadrados coloridos) e às principais reações metamórficas (entre parênteses) durante metamorfismo progressivo (setas descontínuas). As abreviaturas dos minerais estão listadas na Figura 6.2. 
estágios retrometamórficos de $\mathrm{M}_{3}$ amplamente distribuídos pela região e intensificados nas zonas de cisalhamento tardias. Por vezes, refletem os estágios precoces de $\mathbf{M}_{3}$, como sugerido por algumas relações texturais e conseqüente inferência das reações de geração das assembléias minerais. Jardim de Sá (1994) descreveu micaxistos com paragêneses que indicam pico do metamorfismo sob condições do fácies xisto verde nos sinformes de Cruzeta e SW de Angicos (Faixa Seridó). As paragêneses, retrometamórficas ou não, encontradas nos metapelitos de alto-Al e baixo-Al foram:

- $g t+b t+c h l+$ mus

- gt + chl + mus

A associação $\mathbf{g t}+\mathbf{b t}+\mathbf{c h l}+\mathbf{m u s} \pm \mathbf{q t z}$, apesar de freqüente nos metapelitos de grau médio a baixo, não é controlada exclusivamente pelas relações de fase do sistema KFMASH, devido ao campo de estabilidade restrito da $\mathbf{g t}+\mathbf{c h l}$, que em reação produz bt + st. A adição ao sistema de $\mathrm{MnO}(+\mathrm{CaO})$ abaixa a temperatura de estabilidade da gt $+\mathbf{c h l}$ de $525^{\circ} \mathrm{C}$ no sistema $\mathrm{KFMASH}$ para $440-470^{\circ} \mathrm{C}$, expandindo o campo de estabilidade da granada para $\mathrm{T}<450^{\circ} \mathrm{C}$ (Albee 1968).

As condições de estabilidade da paragênese $\mathbf{g t}+\mathbf{c h l}$, que definem a "Zona da Granada" ( $\mathrm{T} \sim 530^{\circ} \mathrm{C}$, zona verde nas Fig. 6.2 e 6.3), são geralmente alcançadas no sistema KFMASH pela reação:

- cld + bt $+\mathrm{H}_{2} \mathrm{O} \rightarrow \mathrm{gt}+\mathrm{chl}$

Nas faixas de metapelitos e terrenos gnáissicos interceptados pelas estruturas tardias do evento $D_{3}$, o reajuste das paragêneses de alta-T às condições de fácies xisto verde é controlado pelas transformações (Yardley 1989):

- $\mathrm{gt}+\mathrm{Al}_{2} \mathrm{O}_{5}+\mathrm{bt}+\mathrm{H}_{2} \mathrm{O} \rightarrow \mathrm{chl}+$ mus + qtz

- $\mathrm{gt}+\mathrm{bt}+\mathrm{H}_{2} \mathrm{O} \rightarrow \mathrm{chl}+$ mus + epídoto

- $\mathrm{gt}+\mathrm{bt}+\mathrm{H}_{2} \mathrm{O} \rightarrow \mathbf{b t}+\mathbf{c h l}+\mathbf{q t z}$

- hrn $+\mathrm{Ca}-\mathrm{pl}+\mathrm{H}_{2} \mathrm{O}+\mathrm{CO}_{2} \rightarrow$ chl + epídoto + albita + calcita + opacos

- hrn + anortita $+\mathrm{H}_{2} \mathrm{O} \rightarrow$ chl + epídoto + qtz

Estas reações refletem a ampla circulação de fluidos aquosos acompanhando as condiçžes de strain decrescente, evidenciado pela progressiva concentração da deformação desde as amplas zonas de cisalhamento de alta-T, passando pela faixas de ultramilonitos e filonitos retrometamórficos, até as estreitas faixas cataclásticas. Uma evidência ubíqua e 
inconteste da canalização de fluidos ao longo das descontinuidades reológicas é a associação das paragêneses metamórficas, progressivamente de baixo grau, com veios pegmatóides, quartzosos e carbonáticos. As principais feições texturais descritas para o metamorfismo retrogressivo, que indicam condições extremas próximas à isógrada da biotita $\left(300-400^{\circ} \mathrm{C}\right)$, foram: cloritização da biotita, anfibólios, cordierita e granada, com a clorita ocupando os necks dos porfiroblastos boudinados (Foto 6.6); muscovitização da andaluzita, sillimanita e biotita; sericitização dos K-feldspatos e saussuritização dos plagioclásios; pinitização da cordierita; transformações das biotitas e hornblendas ricas em $\mathrm{Ti}$ para titanita; desestabilização do ortopiroxênio e hornblenda marrom para biotita e opacos. O amplo campo de estabilidade da granada favorece a cristalização cedo-, sin- e tardi- $\mathrm{S}_{3}$ (Foto 6.7), normalmente poiquiloblástica, com inclusões de quartzo, biotita e opacos, e contornada pela foliação milonítica tardia (bt + chl + mus). A presença de turmalina zonada nos estágios sina tardi- $\mathrm{D}_{3}$ (Foto 6.8), com inclusões de quartzo e opacos, acompanhada de biotita e muscovita, revelam a incursão de fluidos (ricos em boro e flúor) no metamorfísmo progressivo, geralmente canalizados nas zonas de cisalhamento. Estas feições revelam a evolução metamórfica acompanhando o regime dúctil, dúctil-frágil e frágil, durante a progressiva exumação dos terrenos.

Nos metapelitos, a estaurolita forma poiquiloblastos englobando cristais de granada + muscovita + biotita + quartzo que acompanham a foliação $S_{3}$ (Foto 6.9), onde as formas corroídas da granada e muscovita marcam as reações de desestabilização destes minerais. Comumente, ocorrem cristais boudinados e rotacionados de estaurolita acompanhando a foliação $S_{3}$ da matriz (biotita + granada + muscovita + quartzo), descrevendo as relações cedo- a sintectônicas. A estabilidade da associação st + bt define a "Zona da Estaurolita" ( $\mathrm{T} \sim 550^{\circ} \mathrm{C}$, zona amarelo claro nas Fig. 6.2 e 6.3), controlada pela reação:

\section{- $\mathrm{gt}+\mathrm{chl}+$ mus $\rightarrow \mathrm{st}+\mathrm{bt}+\mathrm{qtz}+\mathrm{H}_{2} \mathrm{O}$}

Para Winkler (1976) o primeiro aparecimento da estaurolita marca o ínicio do fácies anfibolito. Esta reação pode ser expandida em $10-20^{\circ} \mathrm{C}$ conforme o teor de $\mathrm{MnO}$ na rocha (Spear 1993). As paragêneses estáveis descritas nos metapelitos estudados foram: 
Foto 6.6

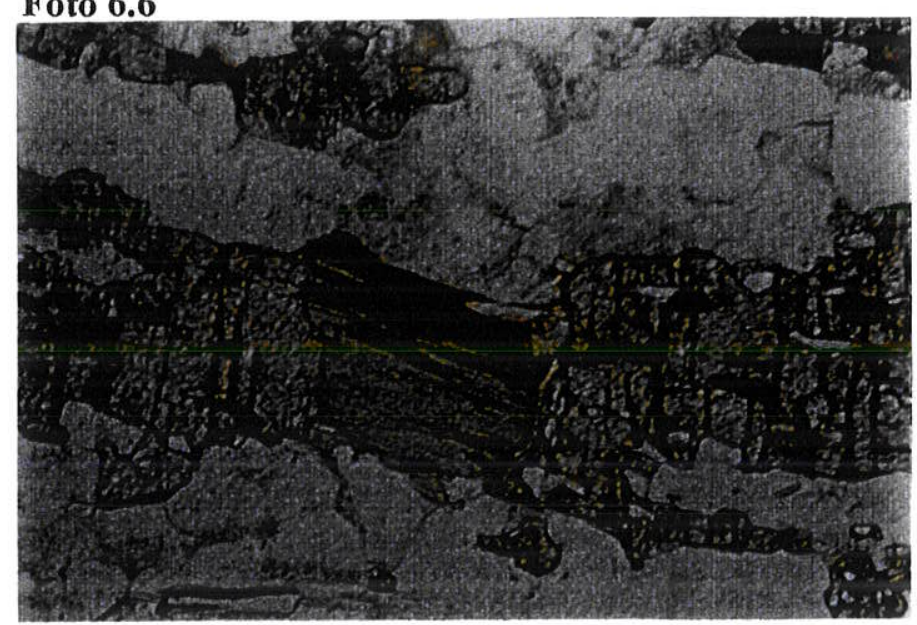

Foto 6.8

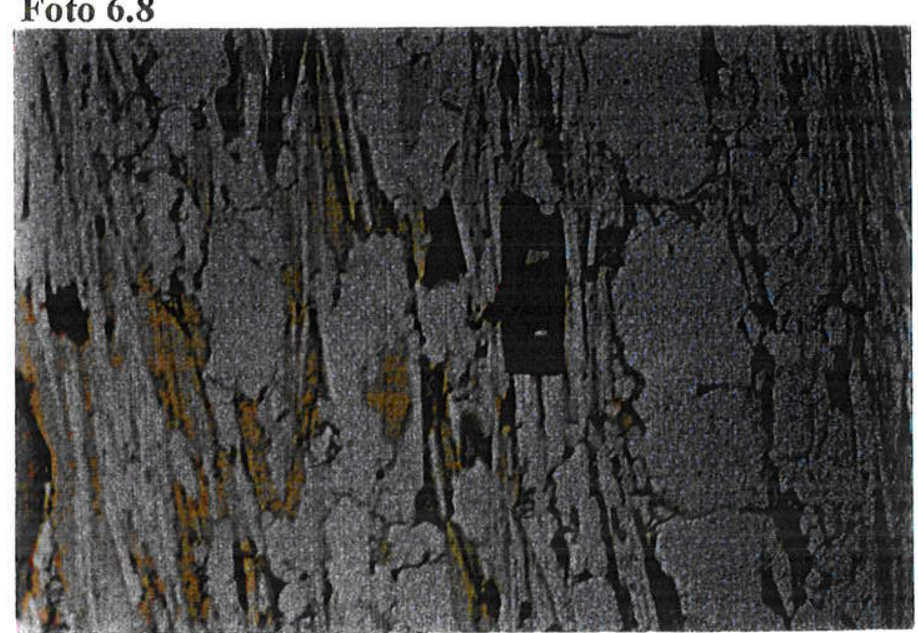

\section{Foto 6.7}
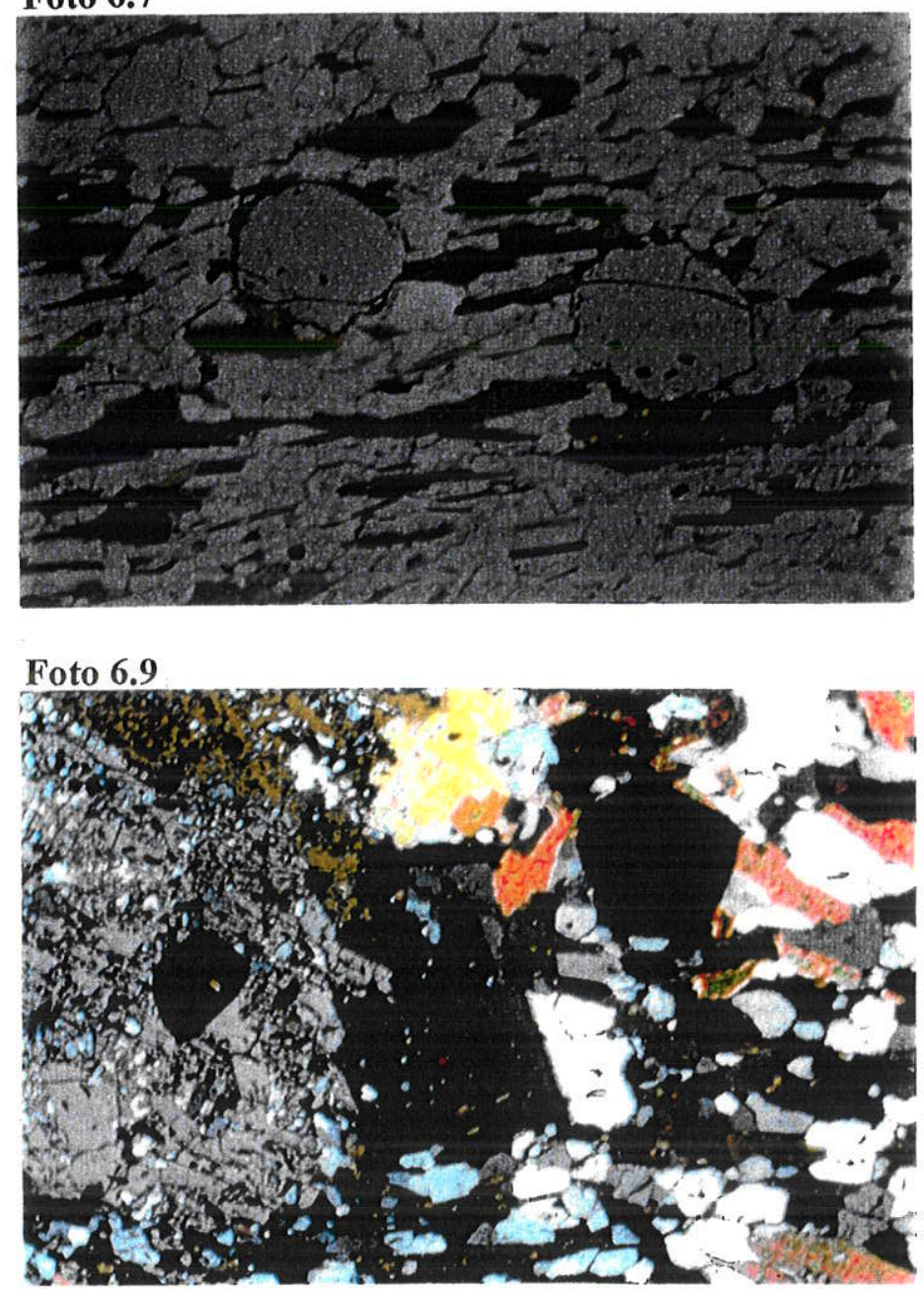

Foto 6.6 - Crescimento de clorita nos necks dos porfiroblastos de granada sin- $\mathrm{D}_{3}$ boudinados em micaxistos miloníticos retrometamorfizados para condições da "Zona da Granada" da Faixa de Micaxistos de Barra de Santa Rosa. Fotomicrografia com aumento de 160x e NP.

Foto 6.7 - Crescimento de granadas tardi- $\mathrm{D}_{3}$ em micaxistos miloníticos retrometamorfizados para condições da "Zona da Granada", com paragênese granada + biotita + clorita + muscovita \pm quartzo, da Faixa de Micaxistos de Barra de Santa Rosa. Fotomicrografia com aumento de 40x e NP.

Foto 6.8 - Cristal de turmalina zonada sin- a tardi- $\mathrm{D}_{3}$, com inclusões de quartzo e opacos, acompanhada de biotita + muscovita na foliação milonítica $\mathrm{S}_{3} / / \mathrm{C}_{3}$, em micaxistos envolvidos nas zonas de cisalhamento que interceptam a Faixa de Micaxistos de Barra de Santa Rosa. Fotomicrografia com aumento de 40x e NP.

Foto 6.9 - Poiquiloblastos de estaurolita englobando cristais de granada + muscovita + biotita + quartzo + opacos segundo a foliação $\mathrm{S}_{3}$ sob condições da "Zona da Estaurolita", mostrando feições de corrosão da granada e muscovita, que caracterizam reações de desestabilização, em micaxistos da Faixa de Micaxistos de Barra de Santa Rosa. Fotomicrografia com aumento de 40x e NX 
- st $+\mathbf{c h l}+\mathbf{b t}+\mathbf{m u s}$

- st + chl + mus

O aquecimento contínuo resulta no estabelecimento da "Zona da Cordierita" (T $570^{\circ} \mathrm{C}$, zona amarelo ouro nas Fig. 6.2 e 6.3 ), sob condições de baixa-P (< 5 kbar), controladas pelas reações no sistema KFMASH:

- $\mathbf{c h l}+$ mus $\rightarrow$ cd + bt + qtz $+\mathbf{H}_{2} \mathrm{O}$ (No sistema KMASH: Mg-chl + mus $\rightarrow$ Mg-cd + flogopita $+q \mathrm{tz}+\mathrm{H}_{2} \mathrm{O}$ )

- st $+\mathrm{chl} \rightarrow \mathrm{cd}+\mathrm{bt}+\mathrm{H}_{2} \mathrm{O}$

- chl + mus $\rightarrow$ cd + bt + and $+\mathrm{H}_{2} \mathrm{O}$

Esta última reação marca as condições máximas de estabilidade da assembléia chl + mus, acima da qual a clorita desaparece do diagrama AFM (Yardley et al. 1990). Contudo, nas rochas com muscovita ausente a clorita é estável em condições de mais alta temperatura (Spear 1993). A reação $\mathbf{s t}+\mathbf{c h l} \rightarrow \mathbf{b t}+$ and $+\mathbf{H}_{2} \mathbf{O}$ descreve o primeiro aparecimento da andaluzita em coexistência com a biotita nos Fe-metapelitos, mas em desequilíbrio com a cordierita nos metapelitos aluminosos sob baixa-P (<3 kbar). Nos micaxistos Seridó, o caráter sintectônico a $\mathrm{S}_{3}$ dos cristais de cordierita é evidente nos porfiroblastos rotacionados, com traços internos de biotita + quartzo \pm muscovita \pm granada em continuidade com a foliação $S_{3}$ da matriz (Foto 6.10). Nos metapelitos da assembléia cd + and são comuns inclusões de turmalina zonada + opacos + muscovita + quartzo (Foto 6.11). Nas faixas de metapelitos estudadas foram descritas as paragêneses relacionadas aos Fe-metapelitos e Mg-metapelitos:

- $\mathbf{g t}+\mathbf{b t}+\mathbf{s t}+\mathbf{m u s}($ Fe-metapelitos)

- and + bt + st + mus (Fe-metapelitos)

- $\mathbf{c d}+\mathbf{b t}+\mathbf{s t}+\mathbf{m u s}(\mathrm{Mg}-$ metapelitos $)$

- $\mathbf{c d}+\mathbf{b t}+$ mus (Mg-metapelitos)

A "Zona da Andaluzita" ( $\mathrm{T} \sim 600^{\circ} \mathrm{C}$, zona alaranjada nas Fig. 6.2 e 6.3) é marcado pelas reações de desestabilização da cordierita com estaurolita e muscovita produzindo as fases andaluzita + biotita em equilíbrio:

- st $+\mathbf{c d} \rightarrow$ and + bt

- $\mathrm{cd}+\mathrm{mus}+\mathrm{qtz} \rightarrow$ and $+\mathrm{bt}+\mathrm{H}_{2} \mathrm{O}$ 
Foto 6.10 - Porfiroblastos sintectônicos dextrais de cordierita em micaxistos sob condições da "Zona da Cordierita". A foliação interna está em continuidade com a foliação $S_{3}$ da matriz, composta por biotita + quartzo + granada \pm muscovita. Afloramento na Faixa Seridó a sul de Caiçara do Rio dos Ventos/RN ( $\left.36^{\circ} 00^{\prime} 33^{\prime \prime} \mathrm{W} / 5^{\circ} 46^{\prime} 41^{\prime \prime S}\right)$.

Foto 6.11 - Porfiroblasto de cordierita poiquilítica com inclusões de turmalina zonada + biotita + opacos + muscovita + quartzo, em paragnaisses da "Zona da Andaluzita". Fotomicrografia com aumento de 40x e NX.

Foto 6.12 - Porfiroblastos sigmoidais sintectônicos dextrais de cordierita com inclusões de andaluzita e nas sombras de pressão são comuns sillimanita $+\mathrm{K}$-feldspato \pm granada em micaxistos sob condições da "Zona Superior da Sillimanita". A assimetria dextral dos porfiroblastos está combinada a um componente de movimento topo para cima, caracterizando uma zona de transpurrão. Afloramento na Faixa Seridó a sul de Currais Novos/RN $\left(36^{\circ} 18^{\prime} 24^{\prime \prime} \mathrm{W} / 6^{\circ} 12^{\prime} 36^{\prime \prime} \mathrm{S}\right)$.

Foto 6.13 - Porfiroblasto de andaluzita em micaxistos sob condições da "Zona da Andaluzita". O porfiroblasto possui inclusões de granada e estaurolita e está envolta por cordierita + biotita + granada. Afloramento na Faixa Seridó entre Cruzeta e Picui/RN (36 $\left.44^{\prime} 24^{\prime \prime} \mathrm{W} / 6^{\circ} 25^{\prime} 12^{\prime \prime} \mathrm{S}\right)$.

Foto 6.14 - Porfiroblastos sintectônicos dextrais de andaluzita em micaxistos sob condições de transição entre a "Zona da Andaluzita" e a "Zona da Sillimanita" $\left(600<\mathrm{T}<700^{\circ} \mathrm{C}, \mathrm{P} \sim 2-4 \mathrm{kbar}\right)$, com a foliação interna marcada por biotita + sillimanita \pm granada \pm turmalina em continuidade com a foliação $S_{3}$ da matriz, e crescimento de fibrolita + quartzo nas sombras de pressão. Afloramento no setor centro-norte da Faixa de Metassedimentos de Barra de Santa Rosa.

Foto 6.15 - Porfiroblasto sintectônico dextral de cordierita com inclusões de andaluzita e sillimanita $+\mathrm{K}$-feldspato + quartzo nas sombras de pressão, geralmente associado a veios de remobilizados com granada. Afloramento na Faixa Seridó próximo a Acari/RN

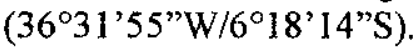

Foto 6.16 - Porfiroblastos de andaluzita em micaxistos sob condições de transição entre a "Zona da Andaluzita" e a "Zona da Sillimanita" $\left(600<\mathrm{T}<700^{\circ} \mathrm{C}, \mathrm{P} \sim 2-4 \mathrm{kbar}\right)$ : (a) porfiroblasto boudinado de andaluzita poiquiloblástica de aproximadamente $50 \mathrm{~cm}$ de comprimento, com inclusões de granada e biotita, e crescimento de sillimanita fibrolítica nos necks dos boudins e acompanhando a $\mathrm{L}_{3}$; (b) detalhe do afloramento da foto anterior mostrando porfiroblasto de andaluzita boudinado com crescimento de fibrolita nos necks dos boudins, junto a porfiroblastos sintectônicos dextrais de andaluzita onde a foliação interna acompanha a foliação $S_{3}$ da matriz, composta de biotita + sillimanita + muscovita \pm granada. Afloramento no setor centro-norte da Faixa de Micaxistos de Barra de Santa Rosa. 
Foto 6.10

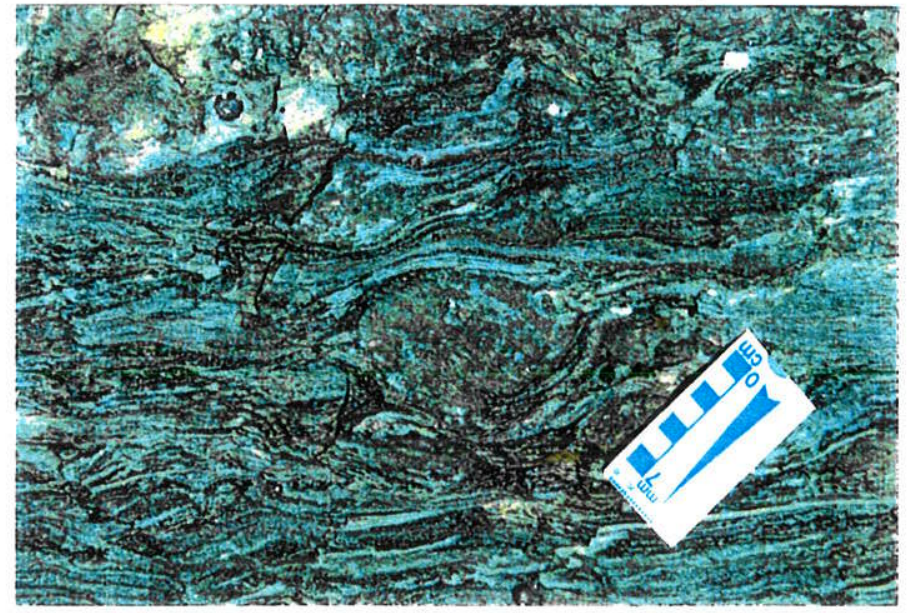

Foto 6.12

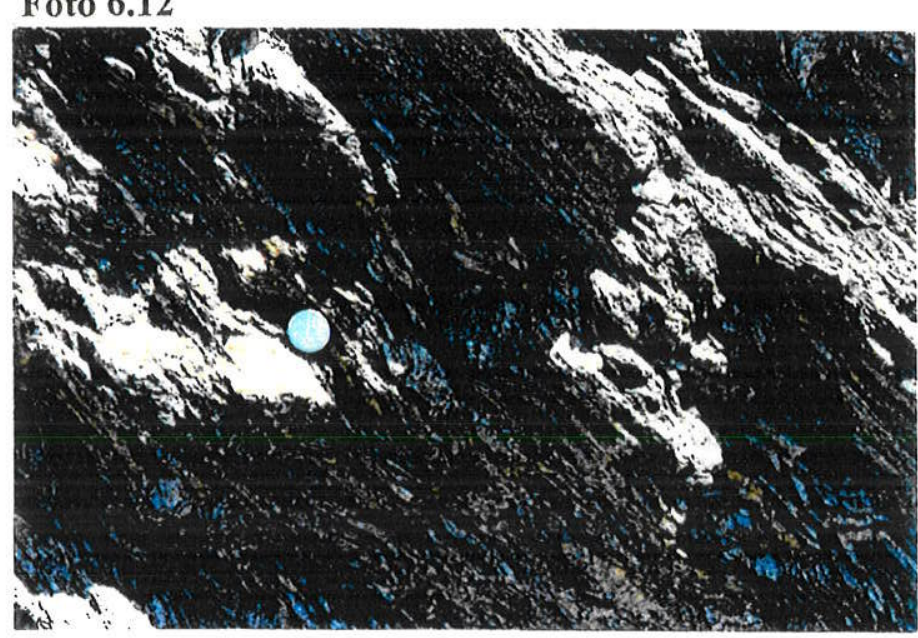

Foto 6.14

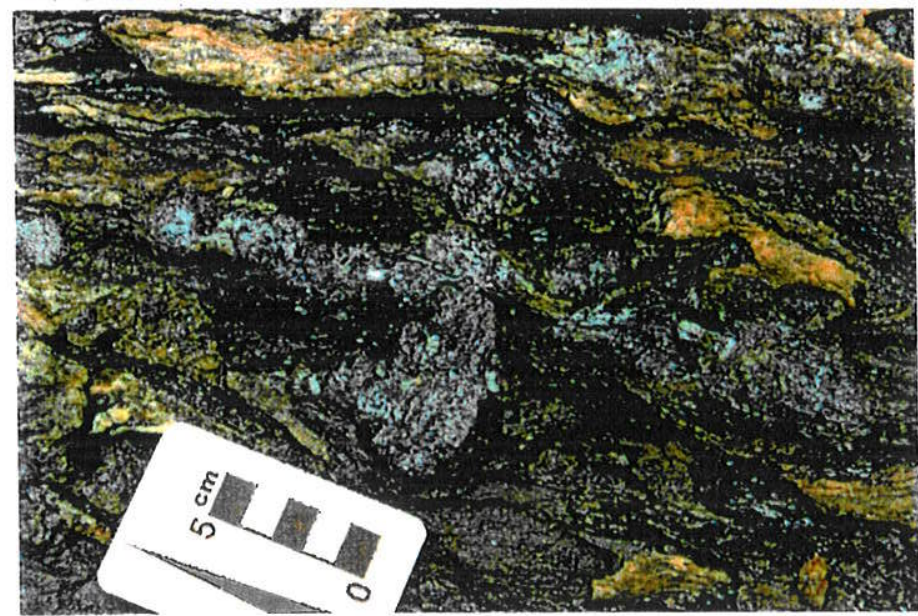

Foto 6.11

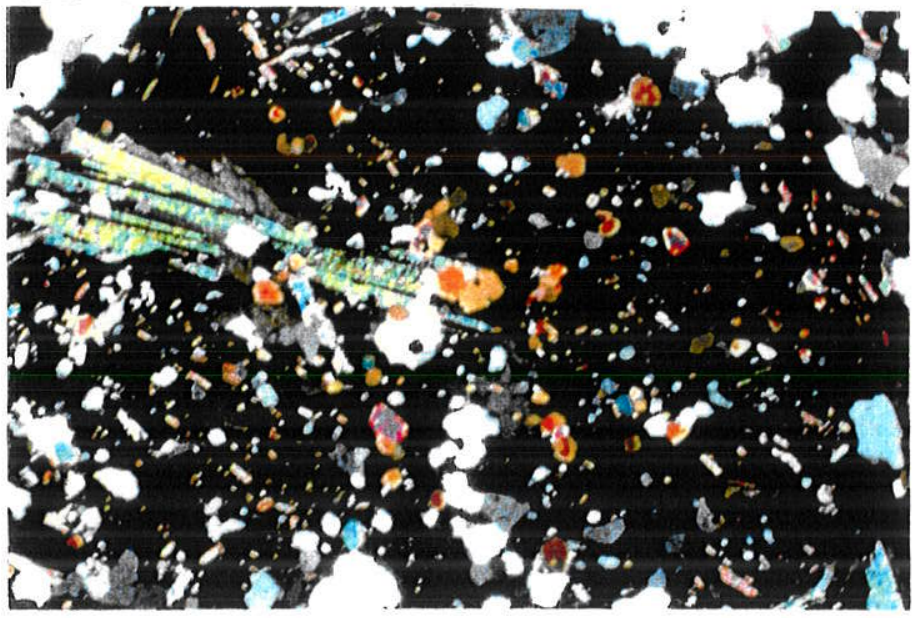

Foto 6.13

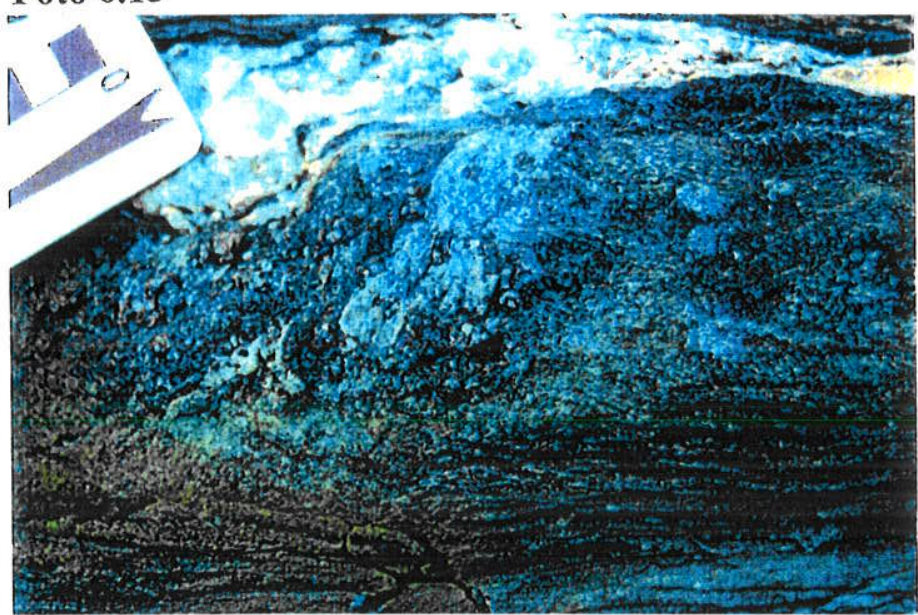

Foto 6.15

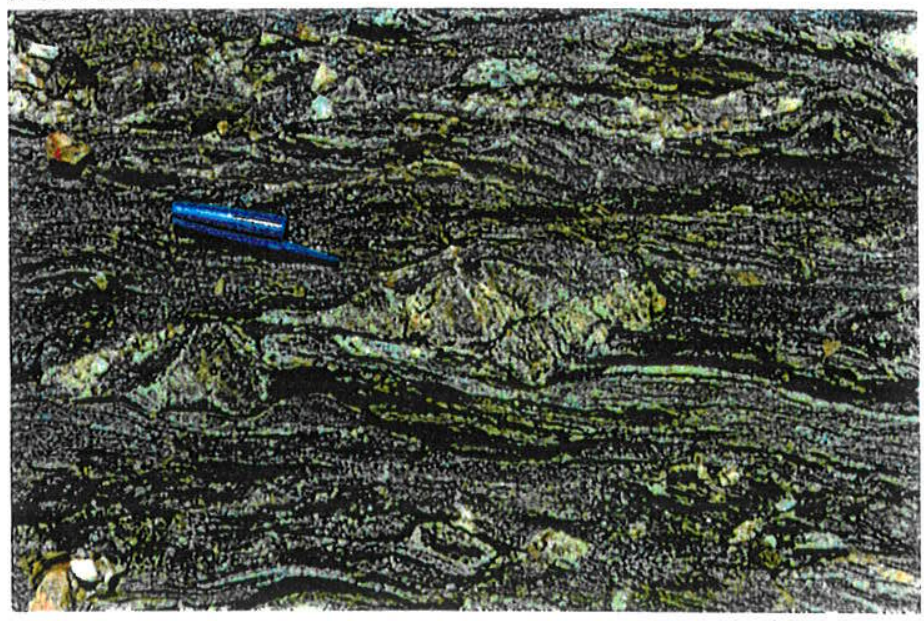

Foto $6.16 \mathrm{a}$

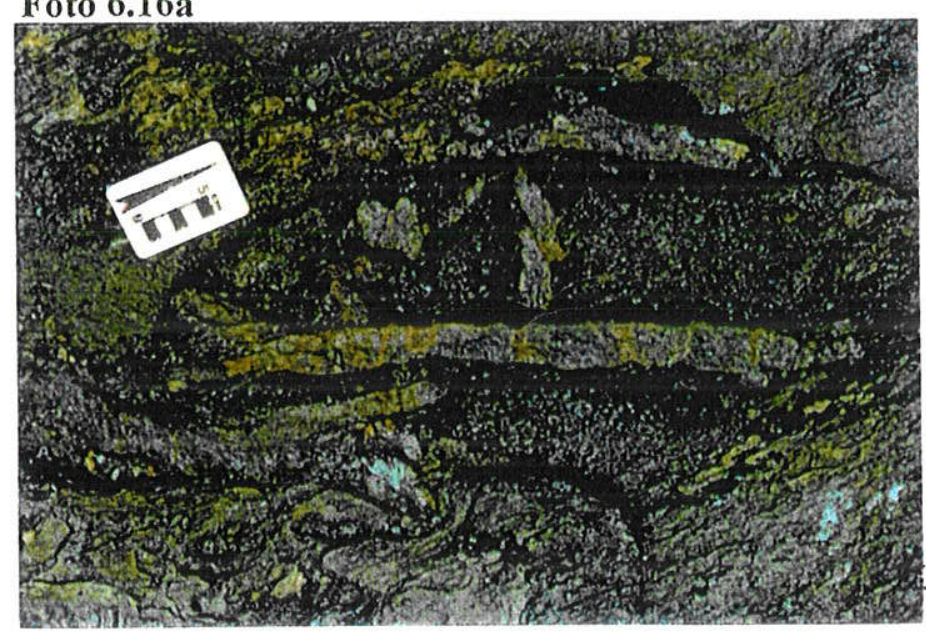

Foto $6.16 \mathrm{~b}$

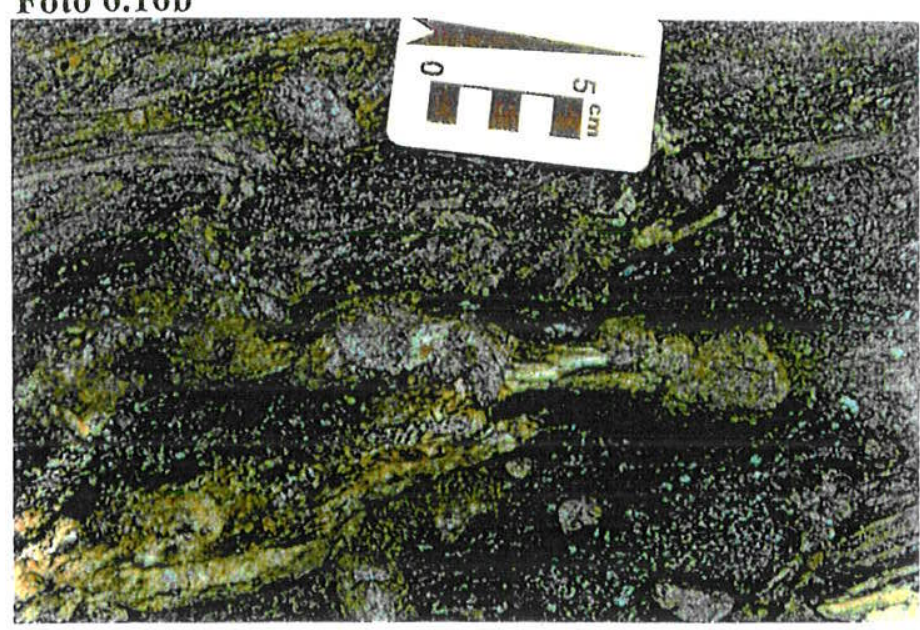


As principais paragêneses envolvendo a cordierita + andaluzita + granada, comumente como porfiroblastos sigmoidais $\sin -\mathrm{S}_{3}$ nos metapelitos estudados (Foto $6.10 \mathrm{e}$ 6.12), são as seguintes:

- $\mathbf{s t}+\mathbf{g t}+\mathbf{b t}+$ mus (Fe-metapelitos)

- st + and + bt + mus (Fe-Mg-metapelitos)

- and + bt + cd + mus (Mg-metapelitos)

- $c d+$ bt + mus

- $\mathbf{g t}+\mathbf{b t}+\mathbf{m u s}$

Os cristais de cordierita e andaluzita formam porfiroblastos sintectônicos sigmoidais, onde a andaluzita ocorre como porfiroblastos isolados e/ou como inclusões e nas sombras de pressão dos porfiroblastos de cordierita (Foto 6.13). Nos poiquiloblastos sigmoidais e agregados de andaluzita é comum a continuidade da foliação $S_{3}$ da matriz, definida pelas inclusões alinhadas de granada + biotita + quartzo \pm estaurolita (Foto 6.14).

$\mathrm{O}$ incremento da temperatura provoca a substituição da andaluzita pelo polimorfo estável sillimanita, pela reação: andaluzita=sillimanita. Esta substituicão simples freqüentemente produz sillimanita fibrolítica intercrescida com muscovita e biotita. A estabilidade terminal da estaurolita no diagrama AFM do sistema KFMASH, que resulta na remoção da estaurolita dos metapelitos nessas condições metamórficas, é descrita nas reações:

- st + mus + qtz $\rightarrow$ gt + bt + sill $+\mathrm{H}_{2} \mathrm{O}$

- st + qtz $\rightarrow$ gt + sill $+\mathrm{H}_{2} \mathrm{O}$

O primeiro aparecimento da sillimanita como polimorfo estável e a remoção da estaurolita do diagrama AFM definem a "Zona da Sillimanita" $\left(\mathrm{T} \sim 660^{\circ} \mathrm{C}\right.$, zona rósea das Fig. 6.2 e 6.3). A sillimanita prismática e/ou fibrolítica ocorrem associadas à granada + biotita + quartzo constituindo o fabric $\mathrm{F}_{3}$ na matriz dos metapelitos, geralmente contornando e/ou nas sombras de pressão dos porfiroblastos de cordierita, andaluzita e granada (Foto 6.15). Freqüentemente, a fibrolita ocorre preenchendo os necks dos megaporfiroblastos de andaluzita boudinados cedo- a sin- $S_{3}$ (Fotos 6.16a e 6.16b), nas sombras de pressão dos porfiroblastos de cordierita, andaluzita e granada, por vezes associada a biotita vermelha (Foto 6.17), e intercrescida com a cordierita (Foto 6.15). A fibrolita normalmente define a 
lineação $\mathrm{L}_{3}$ nas áreas de strain alto e nas principais zonas de cisalhamento de alta-T (Foto 4.15), acompanhando a cominuição da biotita + quartzo + granada na formação da foliação milonítica e demais superficies $\left(\mathrm{C}_{3}, \mathrm{~S}-\mathrm{C}, \mathrm{C}^{\prime}\right)$. Outras vezes, compõe agregados fibrosos que interceptam a foliação $S_{3}$, sugerindo crescimento tardio provavelmente relacionado aos incrementos de stress tardi- $\mathrm{D}_{3}$ e à participação de fluidos metassomáticos (Wintsch \& Andrews 1988). As fases paragenéticas biotita + granada + sillimanita \pm muscovita descrevem freqüentemente o fabric milonítico, acompanhando o aparecimento dos remobilizados granitóides com granada $\left(\mathrm{T} \sim 650^{\circ} \mathrm{C} / \mathrm{P}>3,5 \mathrm{kbar}\right.$, Foto 6.18). As diferenças nos hábitos da sillimanita comumente refletem a partição do strain (Vernon 1996). As principais paragêneses estáveis para a região estudada:

- $\mathbf{g t}+\mathbf{s i l l}+\mathbf{b t}+$ mus (Fe-metapelitos)

- sill + cd + bt + mus (Mg-metapelitos)

O desintegração da muscovita e a produção de K-feldspato definem a "Zona Superior da Sillimanita" ( $\mathrm{T} \sim 720^{\circ} \mathrm{C}$ zona azul nas Fig. 6.2 e 6.3 ), também chamada de Segunda Isógrada da Sillimanita (Hengeson et al. 1978), controlada pela reação contínua no sistema KASH:

- mus + qtz $\rightarrow$ sill $+\mathrm{Kf}+\mathrm{H}_{2} \mathrm{O}$

Esta reação descreve a produção de $\mathrm{K}$-feldspato em coexistência com $\mathrm{Al}_{2} \mathrm{O}_{5}$ e o primeiro aparecimento do K-feldspato em metapelitos aluminosos, sendo responsável pela produção abundante de sillimanita fibrolítica (Yardley et al. 1990). A reação marca o desaparecimento da muscovita nas rochas com razões $\mathrm{K} / \mathrm{Na}$ intermediárias e uma redução considerável na proporção modal da muscovita nas rochas ricas em K (Spear 1993). Com a remoção da muscovita da assembléia mineral, a projeção no diagrama AFM passa a ser feita a partir do K-feldspato. Assim, a biotita passa a participar do triângulo AFM diferindo dos diagramas prévios (Fig. 6.3). Nas rochas que contém $\mathrm{Ca}$, o aparecimento de $\mathbf{A l}_{\mathbf{2}} \mathbf{O}_{\mathbf{5}}+\mathbf{K}$ feldspato ("Segunda Isógrada da Sillimanita") ocorre em temperaturas cerca de $30^{\circ} \mathrm{C}$ acima da reação do sistema sem Ca (Thompson \& Tracy 1979). O aumento da T estende a assembléia $\mathbf{A l}_{\mathbf{2}} \mathbf{O}_{\mathbf{5}}+\mathbf{p l}+\mathbf{K} \mathbf{f}+$ mus para composições mais ricas em Ca (sistema CKNASH), comumente resultando na reação mus + anortita $+\mathbf{q t z} \rightarrow \mathbf{K f}+$ sill $+\mathbf{H}_{2} \mathbf{O}$. Entretanto, pela descrição de Thompson e Tracy (1979), esta reação também pode ocorrer a alguns graus abaixo da reação mus $+\mathbf{q t z} \rightarrow$ sill $+\mathbf{K f}+\mathbf{H}_{2} \mathbf{O}$ conforme a solubilidade do $\mathrm{Ca}$ na 
muscovita. Contudo, a cordierita é estável na presença de muscovita apenas sob condições de baixa-P. O sistema KMASH controla a reação para os Mg-metapelitos:

\section{- flogopita + sill $\rightarrow$ Mg-cd + mus}

Nos metapelitos envolvidos pelo fabric milonítico de alta-T é comum a presença de sillimanita + K-feldspato nas sombras de pressão e como auréolas dos porfiroblastos de cordierita, e associados aos agregados granoblásticos de K-feldspato + quartzo e remobilizados anatéticos sintectônicos (Foto 6.19). A cordierita presente nos metapelitos de alto grau, em paragênese com granada + biotita + sillimanita + quartzo, ocorre associada a fundidos leucocráticos $\left(\mathrm{T} \sim 700-750^{\circ} \mathrm{C} / \mathrm{P} \sim 4 \mathrm{kbar}\right.$, Fig. 6.2), e por vezes intercrescida com sillimanita (Foto 6.20).

No sistema KFMASH, a associação granada + cordierita em alta-T decorre da reação:

$$
\text { - bt }+ \text { sill } \rightarrow \text { grt }+ \text { cd }+\mathrm{H}_{2} \mathrm{O}
$$

A assembléia envolvendo as quatro fases $\mathbf{b t}+\mathbf{s i l l}+\mathbf{g r t}+\mathbf{c d}$, corriqueira nas faixas metapelíticas da região estudada, é preferencialmente encontrada nos metapelitos de baixa-P, do que apenas as assembléias com três fases $(\mathbf{g r t}+\mathbf{c d}+\mathbf{b t}$ ou $\mathbf{g r t}+\mathbf{c d}+\mathbf{s i l l})$, como implica o controle exercido pelo diagrama AFM. Este fato é explicado (1) pela presença de componentes extras na granada, como $\mathrm{MnO}$, que torna divariante a assembléia de quatro fases, em detrimento de univariante como pela reação no sistema KFMASH; (2) a água pura não está presente como fase mineral o que faz com que a reação seja preferencialmente divariante. A profusão de cordierita nos metapelitos de baixa-P decorre da mudança de posição dos triângulos trifásicos para composições mais ricas em $\mathrm{Fe}$ no diagrama AFM, com o decréscimo da P (Spear 1993).

As relações de fases das rochas metapelíticas demonstram que foram alcançadas condições do fácies granulito de pressão intermediária $\left(\mathrm{T}>720^{\circ} \mathrm{C}\right.$, zona azul da Fig. 6.2) com paragêneses estáveis:

- $g t+$ sill $+b t+K f$

- sill $+\mathbf{c d}+\mathbf{b t}+\mathbf{K f}$

Nos metapelitos estudados estão presentes as fases minerais típicas do fácies granulito no sistema FMAS (grt + cd + qtz \pm sill \pm opx) e no sistema KFMAS (grt + cd + $\mathbf{q t z} \pm \mathbf{K f} \pm$ sill $\pm \mathbf{o p x})$. No entanto, a paragênese opx $+\mathbf{p l}+\mathbf{b t}+\mathbf{h r b}+\mathbf{g r t}+\mathbf{K f} \pm \mathbf{c p x}$ 
Foto 6.17

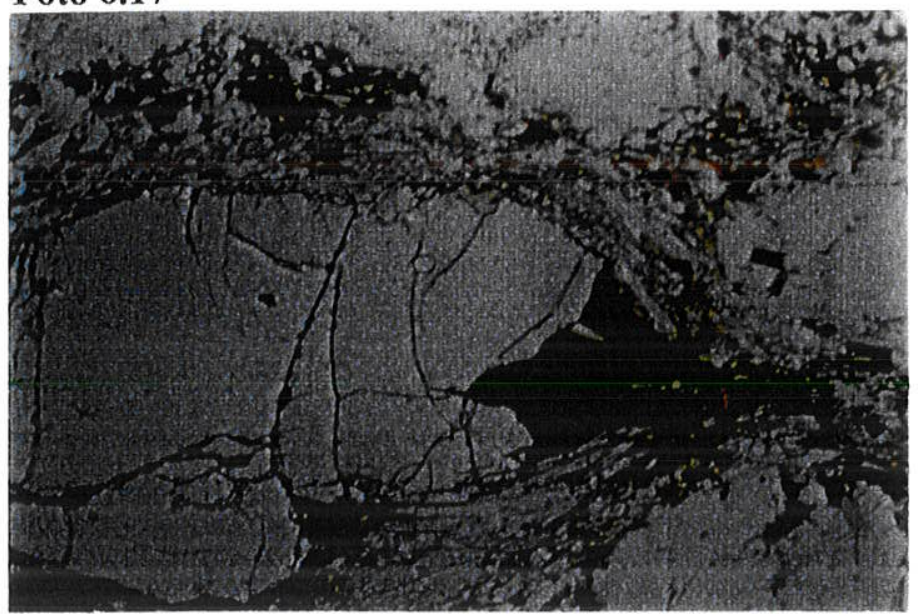

Foto 6.19

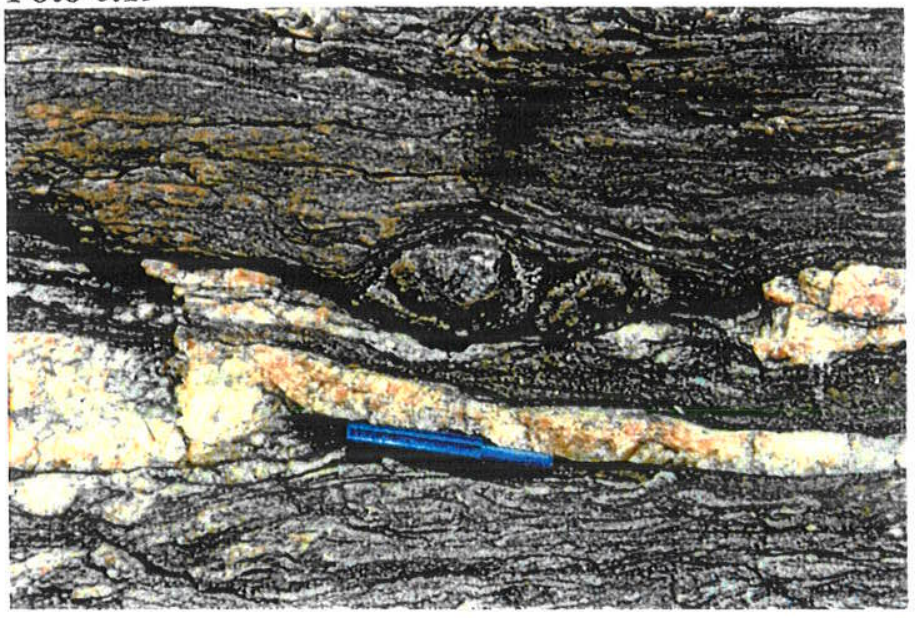

\section{Foto 6.18}

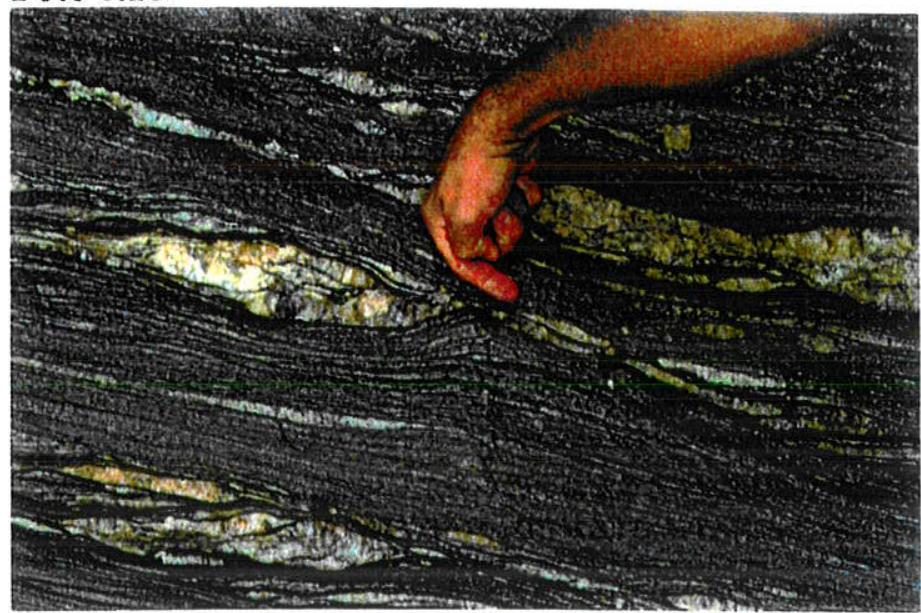

\section{Foto 6.20}

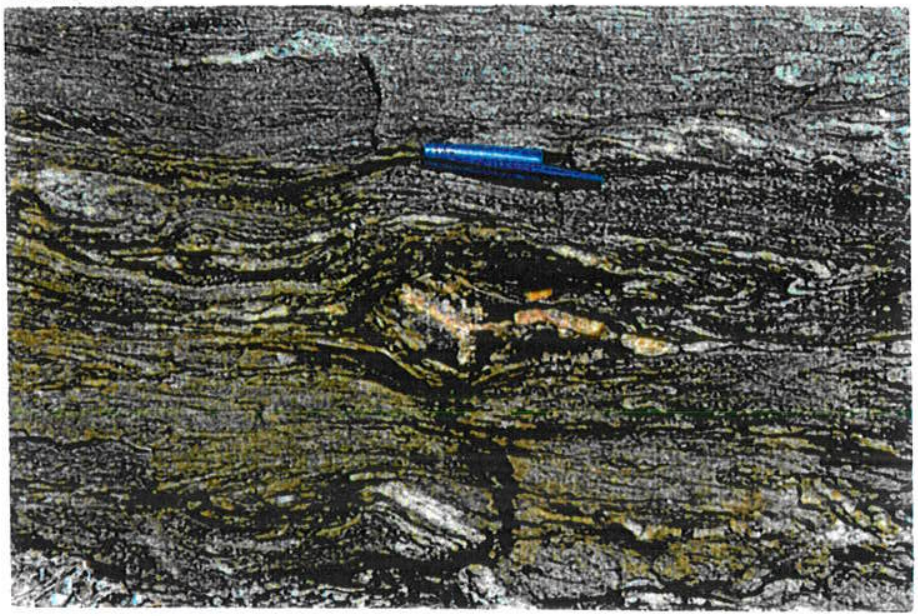

Foto 6.17 - Crescimento de fibrolita associada a biotita vermelha ao redor e nas sombras de pressão de porfiroblasto de granada sintectônica, em micaxistos da "Zona da Sillimanita" da Faixa de Micaxistos de Barra de Santa Rosa. Fotomicrografia com aumento de 40x e NP.

Foto 6.18 - Micaxistos sob condições da "Zona da Sillimanita" na zona de cisalhamento de baixo ângulo transcorrente-extensional da borda oeste da Faixa de Metassedimentos de Barra de Santa Rosa $\left(35^{\circ} 58^{\prime} 08^{\prime \prime} \mathrm{W} / 6^{\circ} 50^{\prime} 17^{\prime \prime} \mathrm{S}\right)$, onde os veios de quartzo com granada constituem boudins sigmoidais indicando movimento topo para baixo.

Foto 6.19 - Porfiroblasto sintectônico dextral de cordierita com sillimanita + K-feldspato nas sombras de pressão e auréolas de agregados granoblásticos de K-feldspato + quartzo \pm sillimanita, associados a remobilizados anatéticos sintectônicos. Afloramento nos metapelitos da "Zona da Sillimanita", envolvidos pelo fabric milonítico $\mathrm{D}_{3}$ de alta-T/baixa-P (36⒊'55"W/618'14"S)

Foto 6.20 - Porfiroblasto sintectônico dextral de andaluzita em micaxistos migmatíticos sob condições da zona de transição definida pela "Quebra da Muscovita" $\left(660<\mathrm{T}<720^{\circ} \mathrm{C}, \mathrm{P} \sim 2-4\right.$ kbar), onde sillimanita + K-feldspato ocorrem intercrescidos em substituição à andaluzita e nas sombras de pressão associados à biotita, acompanhando remobilizados anatéticos. 
envolvendo ortopiroxênio como fase estável com hornblenda marrom-verde e biotita vermelha (enriquecida em Ti, Foto 6.21) foi descrita apenas nos terrenos gnáissicos, rochas metabásicas e nos ortognaisses envolvidos pela ZCRP, estes últimos justapostos aos metapelitos da faixa de Barra de Santa Rosa progressivamente nas zonas da andaluzita a sillimanita. Nas rochas envolvidas pela ZCRP são freqüentes níveis com concentrações de turmalina $+\mathbf{c p x} \pm \mathbf{o p x} \pm$ flogopita segundo a foliação milonítica principal $\left(\mathrm{S}_{3} / / \mathrm{C}_{3}\right.$, Foto 6.22), associadas a leucossomas graníticos. De Waard (1965) descreveu o equilibrio entre ortopiroxênio e as fases hidratadas (hornblenda e biotita) como indicativa dos "granulitos hidratados" (fácies hornblenda-ortopiroxênio-plagioclásio), ou seja, não houve consumo total da bitotita e/ou hornblenda para geração do ortopiroxênio. Em mármores intercalados aos paragnaisses migmatiticos do corredor central da ZCRP foi descrita a paragênese diopsídio + flogopita + forsterita + espinélio (Souza \& Jardim de Sá 1993). Ainda na ZCRP, as metabásicas intercaladas aos metapelitos e gnaisses migmatíticos apresentaram paragêneses pl + opx $+\mathbf{c p x}+$ bt (flogopita) + turmalina $+\mathbf{h r b} \pm$ grt $\pm \mathbf{q t z} \pm$ ilmenita típicas do fácies granulito (Foto 6.23). Geralmente, essas rochas metabásicas apresentam-se boudinadas e estiradas em $S_{3} / / C_{3}$ (Foto 6.24), redobrando o fabric prévio $\left(S_{2}+S_{1}\right.$, Foto 6.22), com evidências do início da fusão parcial $\sin -\mathrm{D}_{3}$ e geração de grande volume de remobilizados contendo turmalina e relictos de piroxênios (Foto 6.25).

Nos metapelitos, foi descrita a ocorrência ostensiva de porfiroblastos de turmalina englobados por cordierita $\sin -\mathrm{S}_{3}$ (Foto 6.11), nas zonas de cisalhamentos de alta-T e migmatitos. As feições de porfiroblastos rotacionados de turmalina $\sin -\mathrm{S}_{3} / / \mathrm{C}_{3}$, associados a megacristais de K-feldspato translúcidos e remobilizados anatéticos (Foto 6.26) e acompanhando a $L_{3}$ nos pegmatitos sin- $\mathrm{D}_{3}$ (Foto 6.27). Tais relações sugerem o aporte de soluções magmáticas ricas em flúor e boro durante $\mathrm{M}_{3}$ canalizadas nas zonas de cisalhamento, que contribuiram na migmatização dos metapelitos e ortognaisses nos niveis de crosta inferior (Foto 6.28). Desta forma, os migmatitos seriam os produtos da fusão parcial dos protólitos anisotrópicos da crosta continental, submetida a deformação heterogênea e stress diferencial, como indica a migração dos fundidos leucocráticos segregados para estruturas dilatantes (Brown et al. 1995). 
Foto 6.21
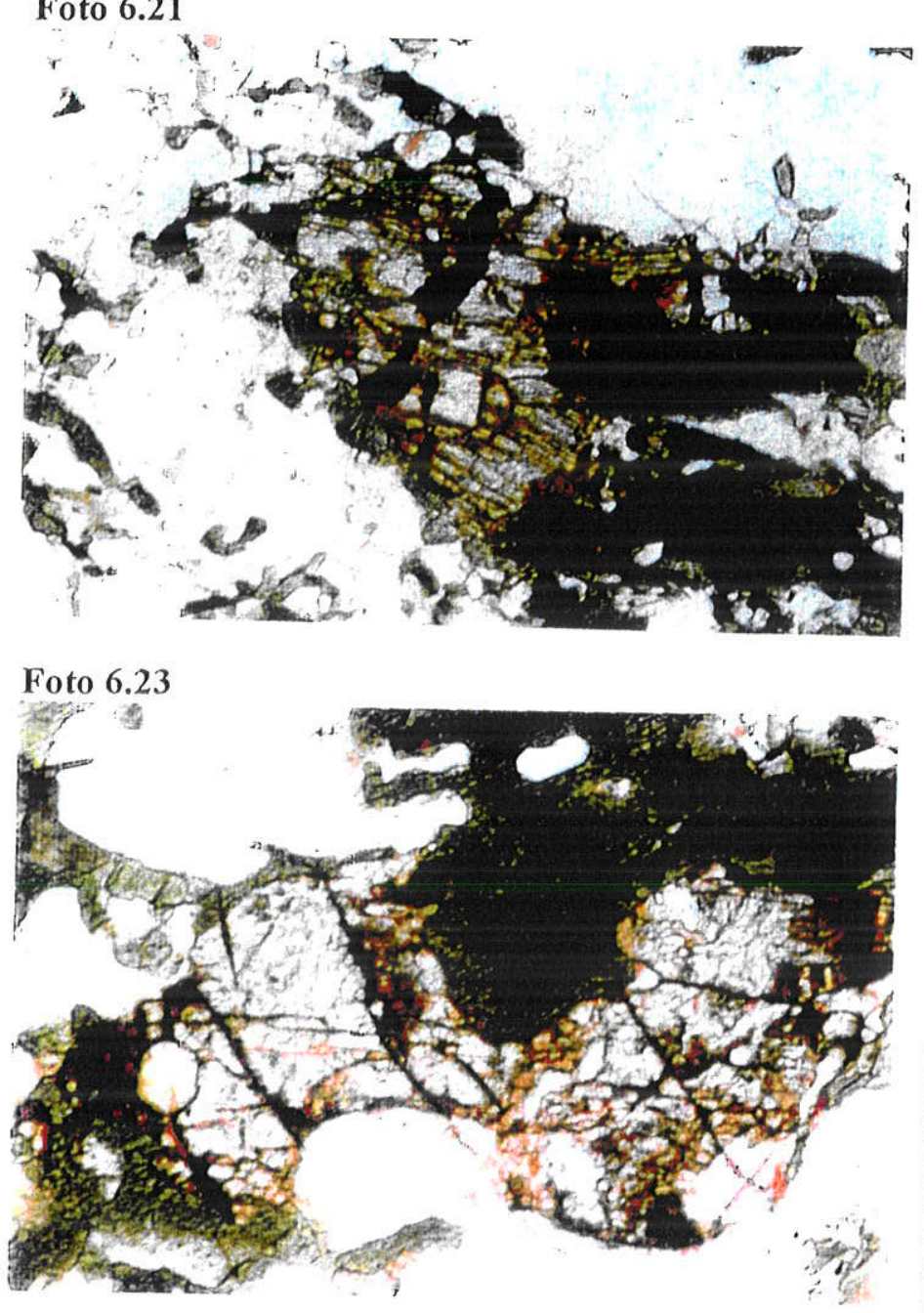

Foto 6.22

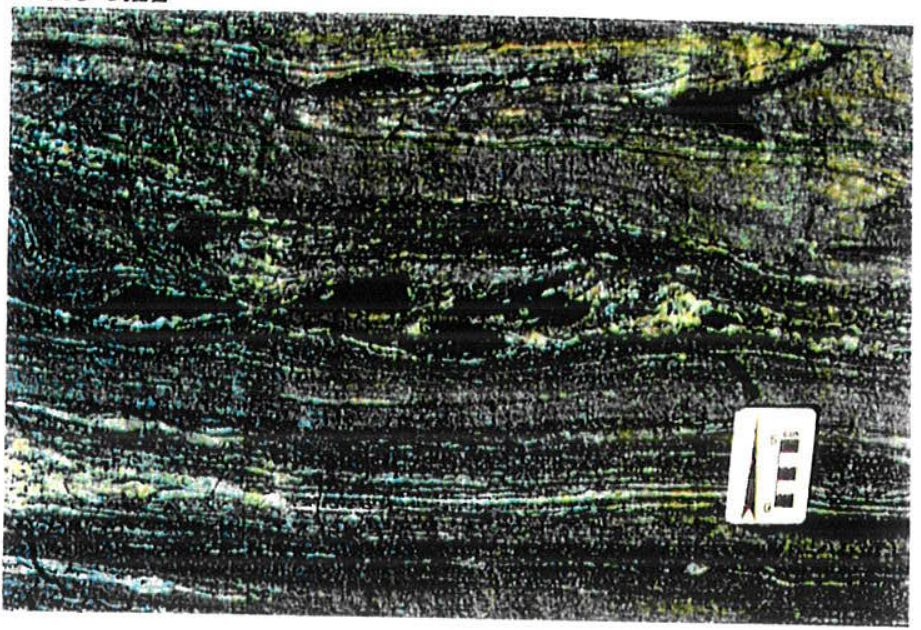

Foto 6.24

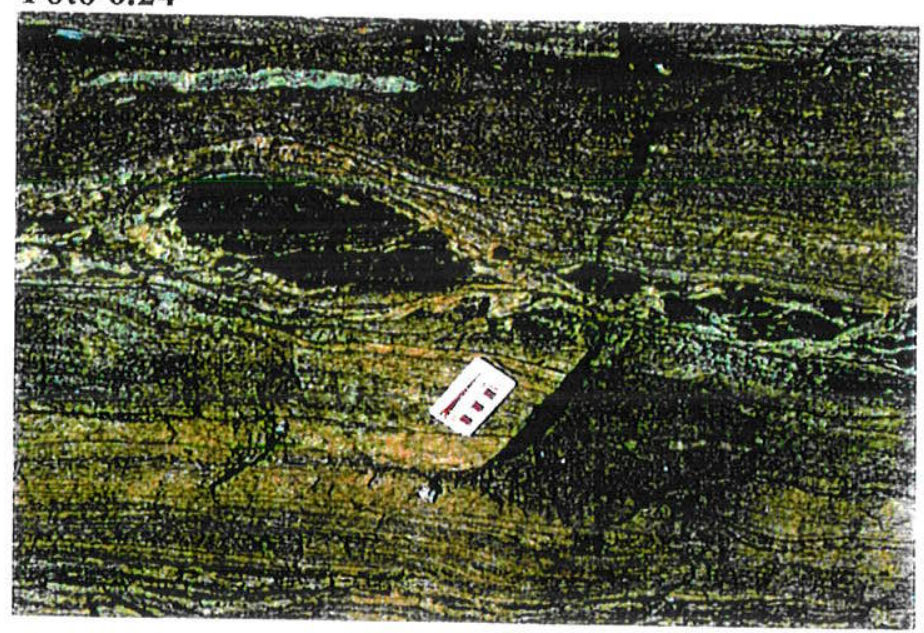

Foto 6.21 - Cristal de ortopiroxênio como fase estável com hornblenda marrom-verde e biotita vermelha (enriquecida em Ti), em rochas metabásicas com paragênese plagioclásio + biotita + hormblenda + granada $+K$-feldspato \pm clinopiroxênio intercaladas aos terrenos gnáissicos envolvidos pela ZCRP, sob condições da "Zona Superior da Sillimanita". Fotomicrografia com aumento de 250x e NP.

Foto 6.22 - Aspecto de gnaisse do embasamento milonitizado sob condições do fácies granulito de pressão baixa a intermediária ("Zona Superior da Sillimanita", T $>700^{\circ} \mathrm{C}$ ), mostrando as concentrações de turmalina + clinopiroxênio \pm ortopiroxênio \pm flogopita na foliação principal $\mathrm{S}_{3}$, que redobra as foliações prévias $\mathrm{S}_{0} / / \mathrm{S}_{2}$ (porção superior da foto). Afloramento na ZCRP (3600'21'W/65 '59'S).

Foto 6.23 - Cristal de ortopiroxênio em paragênese típica do fácies granulito com plagioclásio + clinopiroxênio + flogopita + turmalina + hornblenda verde-marrom \pm granada \pm quartzo \pm ilmenita, em metabásicas intercaladas aos metapelitos e gnaisses migmatíticos envolvidos pela ZCRP. Fotomicrografia com aumento de $160 x$ e NP.

Foto 6.24 - Aspecto do gnaisse do embasamento envolvido pela ZCRP com evidências do início da fusão parcial $\sin -\mathrm{D}_{3}$ expressa nos anfibolitos intercalados, boudinados e estirados em $\mathrm{S}_{3} / / \mathrm{C}_{3}$, com paragênese de clinopiroxênio + turmalina \pm ortopiroxênio \pm flogopita. Afloramento na ZCRP (3600'59"W/658'20"S). 


\subsection{3 -Termobarometria das Condições do Fácies Granulito}

No estudo das condições de P-T dos terrenos no fácies granulito da ZCRP e ZCCG-CCG foram aplicados os métodos convencionais envolvendo o geobarômetro do $\mathrm{Al}$ no anfibólio (Hammarstrom \& Zen 1986, Hollister et al. 1987, Johnson \& Rutherford 1989, Schmidt 1992) e os geotermômetros plagioclásio-anfibólio (Blundy \& Holland 1990) e ortopiroxênio-clinopiroxênio (Wood \& Banno 1973). No Anexo 4 foram apresentadas as composições químicas médias dos minerais selecionados para os cálculos termobarométricos na estimativa do ápice do metamorfismo $\mathrm{M}_{3}$ nos metapelitos migmatíticos (VJ-22B), granulitos máficos (VJ-23A) e quartzo dioritos a granodioritos do Complexo Campina Grande (VJ-32, VJ-34, VJ-36). Os minerais foram analisados com a Microssonda Eletrônica Camebax da Université Blaise Pascal (Clermont-Ferrand, França), operando com aceleração potencial de $15 \mathrm{kV}$ e corrente variando de $90-145 \mathrm{nA}$.

Os metapelitos granulíticos migmatizados apresentaram variações de $T \sim 781$ $811^{\circ} \mathrm{C}$ e $\mathrm{P} \sim 3,8-5,9 \mathrm{kbar}$, enquanto os granulitos máficos intercalados mostraram variações de $\mathrm{T} \sim 799-823^{\circ} \mathrm{C}$ e $\mathrm{P} \sim 3,0-4,5$ kbar pelos métodos plagioclásio-anfibólio e $\mathrm{Al}$ no anfibólio, e $\mathrm{T} \sim 818-973^{\circ} \mathrm{C}$ no geotermômetro ortopiroxênio-clinopiroxênio. Os anfibólios possuem cores verde-escuro a acastanhado (Mg-hornblenda a hornblenda-edenítica) com $\mathrm{TiO}_{2} \sim 0,8-1,63$ $\%$, Si $\sim 6,8-7,83$, e enriquecidas em Mg ( $m g \# \sim 0,55-0,69$ ). O conteúdo de anortita nos plagioclásios varia de 30-35\%An. As biotitas são ricas em $\mathrm{TiO}_{2}(\sim 4,5 \%)$, fato comum nas rochas de alto grau (Indares \& Martignole 1985). O ortopiroxênio é enriquecido em enstatita, com baixos teores de $\mathrm{Ca}$ e $\mathrm{Mn}(<0,7 \%)$, enquanto o clinopiroxênio é enriquecido em diopsídio, com altos teores em $\mathrm{Ca}(\sim 22 \%)$ e teores variáveis de Fe e Mg. Nas amostras do CCG as variações são de $\mathrm{T} \sim 713-835^{\circ} \mathrm{C}$ e $\mathrm{P} \sim 2,5-5,5$ kbar pelos métodos plagioclásioanfibólio e $\mathrm{Al}$ no anfibólio, alcançando valores de $\mathrm{T} \sim 1160^{\circ} \mathrm{C}($ ?) pelo método ortopiroxênioclinopiroxênio. Os anfibólios (Mg-hornblenda a hornblenda-edenítica) são verde escuro enriquecidos em $\mathrm{TiO}_{2} \sim 0,11-1,9 \%, \mathrm{Mg}(m g \# \sim 0,53-0,67)$ e $\mathrm{Si} \sim 6,14-7,31$. O plagioclásio tem os teores em anortita entre 25-49\%An. O ortopiroxênio é enriquecido na molécula enstatita, enquanto o clinopiroxênio é rico na molécula do diopsídio.

Souza et al. (Submet.) obtiveram para rochas noriticas do plúton de Serrinha, sintectônico à ZCSE e intrusivo no DLD, condições metamórficas variando entre $\mathrm{T} \sim 680$ $730^{\circ} \mathrm{C}$ e $\mathrm{P} \sim 4,5-5,1$ kbar pelo método plagioclásio-anfibólio, e $\mathrm{T} \sim 744-856^{\circ} \mathrm{C}$ pelo método 
ortopiroxênio-clinopiroxênio, concordantes com os valores para a ZCRP e ZCCG. A coerência entre as relaçð̃es texturais e as condiçð̃es P-T, também demonstrada nos métodos empregados, sugerem que o ápice do metamorfismo granulítico que afeta o MSJC ocorreu em temperaturas da ordem de $820^{\circ} \mathrm{C}$ (ou superiores) e pressão baixa (3,0-5,5 kbar).

\subsection{4 - Aspectos Gerais da Migmatização Associada ao Metamorfismo Brasiliano}

A extensiva migmatização afeta os terrenos gnáissicos e metapelíticos, normalmente vinculada às zonas de cisalhamento de alta-T e áreas de alto strain, com evidências de fusão parcial in situ de ortognaisses tonalíticos a dioríticos do embasamento (DLD), estruturas estromatíticas e nebuliticas (Ashworth 1985) nas faixas metapeliticas, comumente concordantes com o fabric $\mathrm{D}_{3}$ (Foto 6.28, 6.29 e 6.30). O sincronismo da migmatização com a deformação cisalhante é demonstrada na cinemática coerente das fases de alta-T e no acúmulo dos leucossomas graníticos em estruturas como: o plano axial de dobras sin- $\mathrm{F}_{3}$, os planos de cisalhamento conjugados, boudins assimétricos que indicam o critério cinemático da deformação (Foto 6.28 e 6.29) e necks de boudins de rochas anfiboliticas.

Os metapelitos migmatíticos estromatíticos compreendem leucossomas graníticos a trondhjemíticos intercalados com melanossomas pelíticos aluminosos (restito refratário?). Comumente, os leucossomas formam proporções de volume $>25 \%$ das rochas migmatíticas (Foto 6.28 e 6.29 ), por vezes alcançando $\sim 40 \%$ (Foto 6.30 ). O grande volume de leucossoma e a intensidade da deformação $\mathrm{D}_{3}$ dificultam a determinação da amplitude de extração e segregação dos fundidos com base nas evidências texturais (Fitzsimons 1996). Os leucossomas formam níveis lenticulares com assembléia dominada por grãos poligonais de K-feldspato pertítico (tipo bulboso), quartzo e plagioclásio mirmequítico, por vezes com granada intercrescida com quartzo e cordierita. Os melanossomas constituem níveis de fabric anastomosado, com a foliação definido por biotita, freqüentemente intercrescida com sillimanita, envolvendo cristais de granada, plagioclásio mirmequítico, quartzo e hornblenda. Por vezes a migmatização afeta diques anfibolíticos possivelmente pré- $\mathrm{D}_{2}$ (Foto $4.13 \mathrm{e}$ ), como sugerem as apófises anteriores aos dobramentos $D_{2}$. Os leitos e veios centimétricos de leucossomas e melanossomas intercalados, e a semelhança entre as fases minerais paragenéticas, sugerem derivação a partir dos metapelitos contíguos. Contudo, o controle 
Foto 6.25 - Aspecto geral dos anfibolitos com fusão parcial $\left(T>700^{\circ} \mathrm{C}\right) \sin -\mathrm{D}_{3}$ e geração de grande volume de remobilizados anatéticos de composição granitica e pegmatóides com turmalina + relictos de piroxênios, intercalados aos terrenos gnáissicos e metapelíticos envolvidos na ZCRP (36 $00^{\circ} 22^{\prime \prime} \mathrm{W} / 6^{\circ} 57^{\prime}$ '59"S)

Foto 6.26 - Veios pegmatíticos sin- $\mathrm{D}_{3}$ com $\mathrm{K}$-feldspato translúcido e turmalina acompanhando a foliação $S_{3}$, caracterizando o aporte de flúor e boro durante $D_{3}$, associados a remobilizados anatéticos, em micaxistos migmatíticos migmatizados e milonitizados na ZCRP, sob condições da "Zona Superior da Sillimanita". Afloramento na ZCRP (36 14'18"W/6 $59^{\circ} 53^{\prime}$ "S).

Foto 6.27 - Veio pegmatítico $\sin -\mathrm{D}_{3}$ que intercepta micaxistos migmatíticos milonitizados na ZCRP sob condições da "Zona Superior da Sillimanita" e apresenta cristais de turmalina acompanhando a foliação $S_{3}$. Afloramento na Faixa de Metassedimentos de Barra de Santa Rosa (36 $\left.144^{\prime} 18^{\prime \prime} \mathrm{W} / 6^{\circ} 59^{\prime} 53^{\prime \prime} \mathrm{S}\right)$.

Foto 6.28 - Aspecto geral dos micaxistos migmatíticos milonitizados na ZCRP, sob condições da "Quebra da Muscovita" e início da "Zona Superior da Sillimanita" (T $>700^{\circ} \mathrm{C}$ ), mostrando remobilizados graníticos e veios pegmatíticos com granada, em proporções de volume $>25 \%$, formado boudins sigmoidais dextrais no fabric $\mathrm{D}_{3}$. Afloramento na Faixa de Micaxistos de Barra de Santa Rosa (35⒌'1 $8^{\prime \prime W} / 6^{\circ} 55^{\prime} 36^{\prime \prime}$ ).

Foto 6.29 - Micaxistos migmatíticos com paragênese biotita + granada + cordierita + sillimanita da "Zona Superior da Sillimanita" $\left(\mathrm{T}>720^{\circ} \mathrm{C}\right)$ e grande volume de remobilizados com agregados de granada \pm cordierita \pm quartzo azulado $\pm \mathrm{K}$-feldspato segundo o fabric $\mathrm{D}_{3}$, em proporções de volume $>25 \%$. Afloramento na ZCBNC, uma das ramificações da ZCRP, a norte de Belém

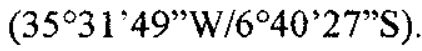

Foto 6.30 - Aspecto geral dos micaxistos migmatíticos milonitizados na ZCRP, sob condições da "Zona Superior da Sillimanita" $\left(\mathrm{T}>720^{\circ} \mathrm{C}\right)$, mostrando remobilizados graníticos e veios pegmatíticos com granada, em proporções de volume $>40 \%$, formado boudins sigmoidais dextrais no fabric $\mathrm{D}_{3}$. Afloramento na Faixa de Micaxistos de Barra de Santa Rosa a algumas dezenas de metros do afloramento apresentado na Foto 6.28 (35 $\left.58^{\circ} 18^{\prime \prime} \mathrm{W} / 6^{\circ} 55^{\prime} 36^{\prime \prime} \mathrm{S}\right)$. 


\section{Foto 6.25}

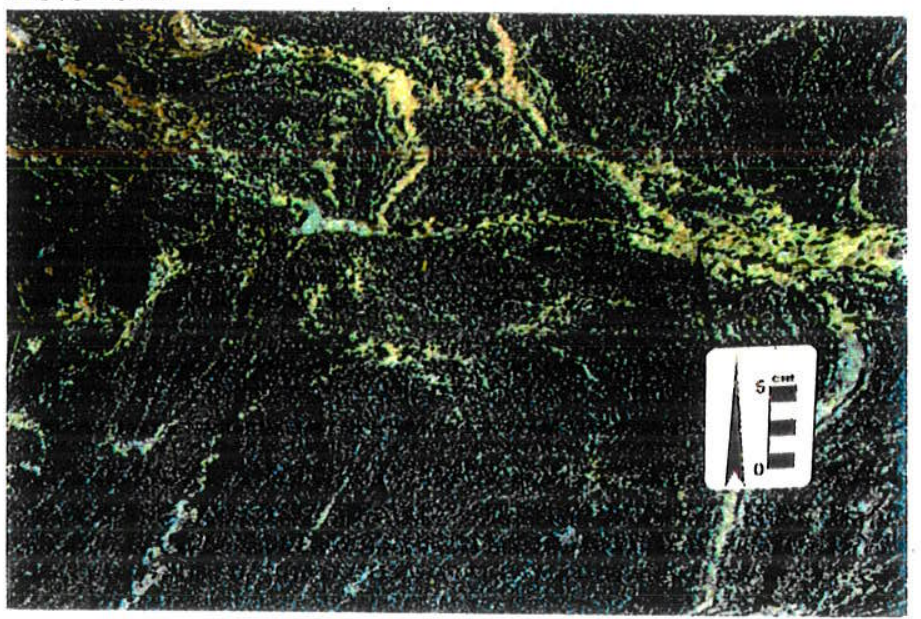

\section{Foto 6.27}

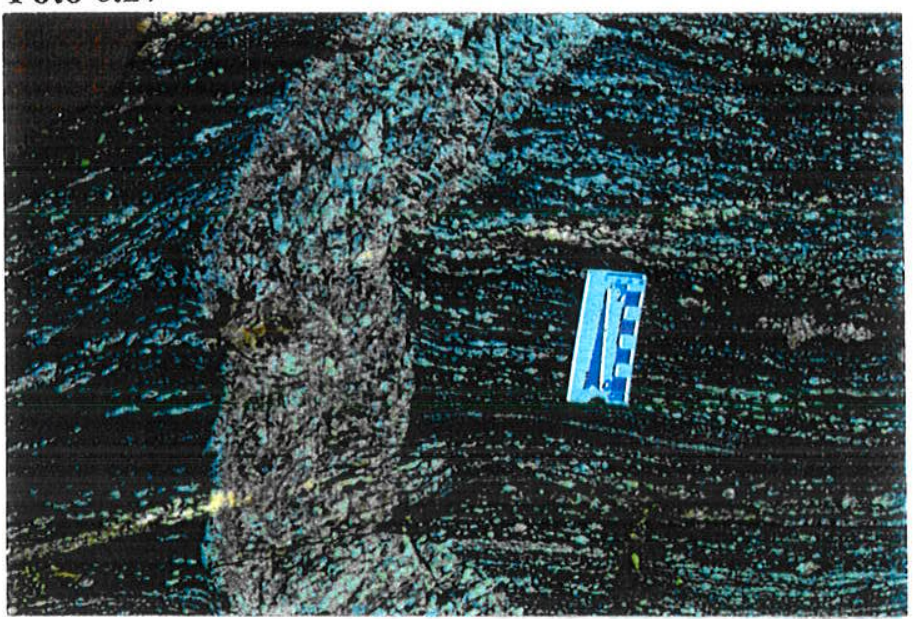

Foto 6.29

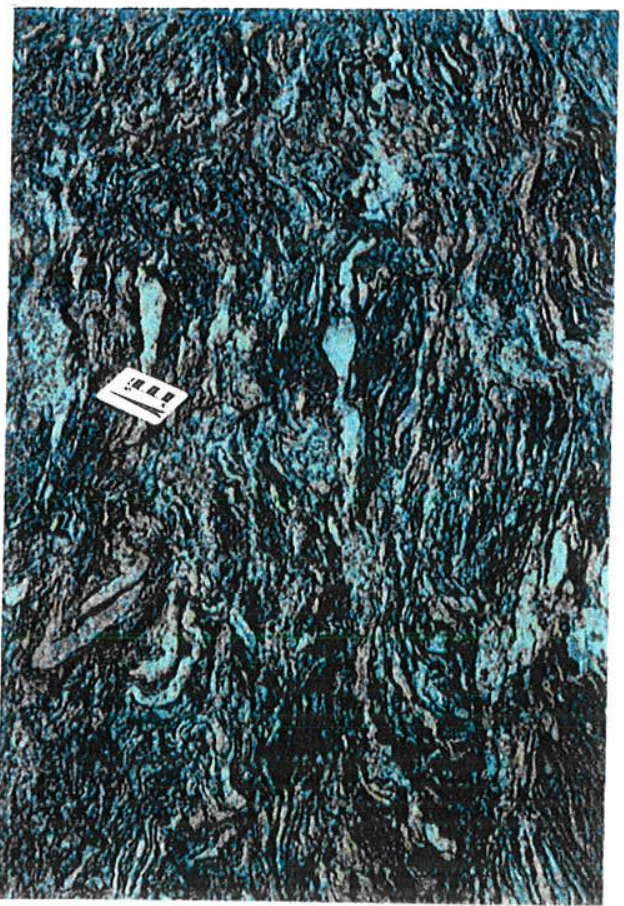

\section{Foto 6.26}

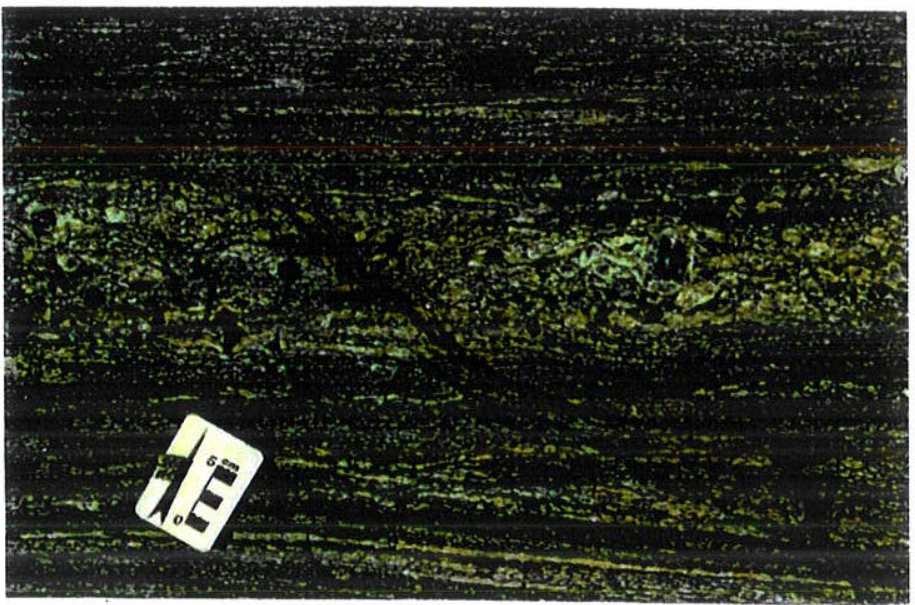

Foto 6.28

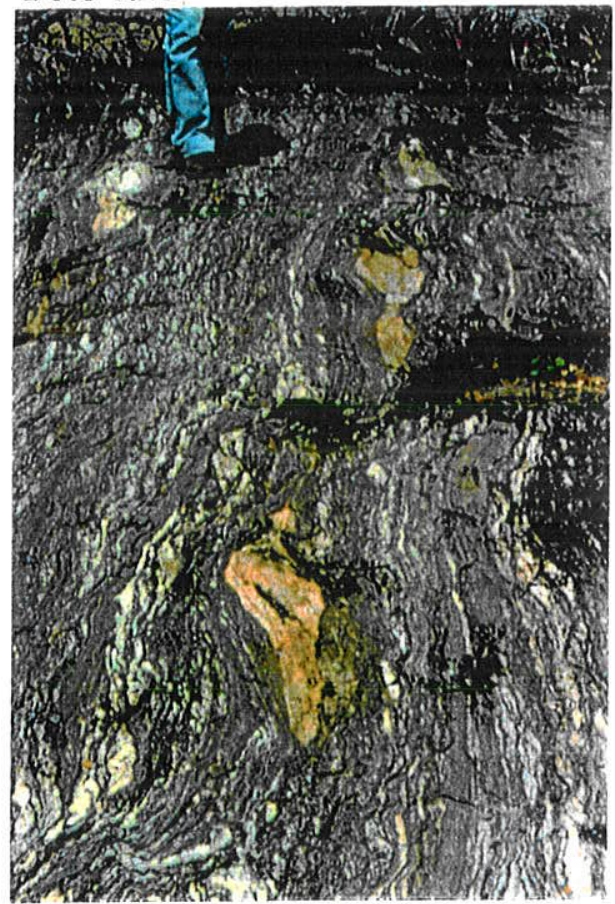

Foto 6.30

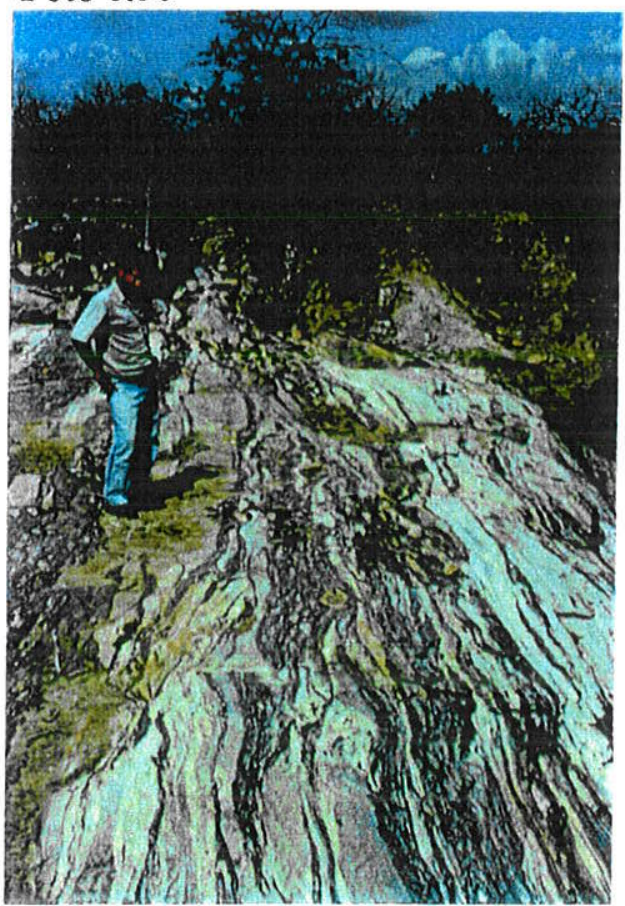


das zonas de cisalhamento sobre os leucossomas implica na migração de pelo menos parte do fundido por meio do fabric $\mathrm{D}_{3}$.

Nos terrenos gnáissicos, a migmatização gera estruturas schlieren a estromatíticas pelas intercalações lentiformes múltiplas de leucossoma quartzo-feldspático e melanossoma, por vezes separados por mesossoma (rocha parental ?). A migmatização relativa a $\mathrm{M}_{3}$ afeta os gnaisses bandados e ortognaisses do embasamento interceptados por zonas de cisalhamento de alta-T e na região do DLD. Os gnaisses bandados possuem textura granolepidoblástica e bandamento milimétrico bem definido, com quartzo e feldspatos equidimensionais, e composição variando de granodioríticos a tonalíticos. Os ortognaisses apresentam textura granoblástica a granolepidoblástica, equigranular grossa a média, bandamento pouco proeminente e tipos variando de sienograníticos a tonalíticos. Diversas estruturas ilustram o controle exercido pela deformação heterogênea $D_{3}$ e pelo stress diferencial na segregação, migração e acúmulo dos fundidos leucocráticos para estruturas como: foliação e zonas de cisalhamento (Foto $4.13 \mathrm{c}$ e $4.13 \mathrm{~d}$ ), shear bands conjugadas (Foto $4.7,4.10,4.12 \mathrm{~d}, 4.12 \mathrm{e}$ e $4.13 \mathrm{a}$ ), zonas de cisalhamento extensionais (Foto 4.8), necks de boudins (Foto 4.12c) e plano axial de dobras de alto strain (Foto 4.13b). A fusão parcial promove a perda do fabric prévio $\left(\mathrm{D}_{2}\right.$ e/ou $\left.\mathrm{D}_{3}\right)$ do protólito, como evidencia a gradação progressiva para rochas remobilizadas não-foliadas de textura ígnea fina a média, equigranular a porfirítica, com relíctos aleatórios dos máficos foliados residuais e enclaves do protólito (Foto 6.3b). Nos mobilizados leucocráticos, as fases paragenéticas correspondem a K-feldspato pertítico (tipo string) com textura poligonal, plagioclásio mirmequítico e quartzo, por vezes granada, sillimanita, hornblenda e turmalina, comumente envoltos por níveis ricos em biotita (melanossoma). A presença de diques metadioríticos porfiríticos intrusivos nos ortognaisses migmatíticos e condicionados às zonas de cisalhamento (ZCJ, ZCSJC e ZCRJS) atestam a colocação sintectônica de magmas básicos acompanhando ambientes extensionais de alto grau (Foto 4.2 e 4.11 a). A intrusão dos diques, seguida da deformação e fusão parcial, ocorreu durante o cisalhamento sob alta- $\mathrm{T}$. Tais diques são contemporâneos ao alojamento dos plútons dioríticos e dos granitóide porfirítico de Serrinha, Monte das Gameleiras e Japi, controlado pela deformação $D_{3}$ de caráter extensional nas ZCRJS, ZCSE e ZCJ. A intrusão do CCG sintectônica ao sistema extensional da ZCCG é comprovada pelos elementos cinemáticos que denotam aspectos das 
deformaç̃es SPD e PFC: enclaves máficos assimétricos (Foto 4.22g), shear bands (Foto $4.22 \mathrm{~h}$ ), porfiroclastos rotacionados do tipo delta, relações S-C (Foto 4.22f), veios e sheets pegmatíticos assimétricos, entelhamento de fenocristais de $\mathrm{K}$-feldspato nos tipos porfiríticos. No CCG são comuns as estruturas de magma mixing e mingling entre os termos granodioríticos a monzoníticos porfiríticos e os dioríticos, indicando o baixo contraste de viscosidade, e a ocorrência de xenólitos de granulitos. Os filozes pegmatíticos com quartzo + anfibólio + biotita $+\mathrm{K}$-feldspato \pm piroxênio recortam os tipos gabro-dioríticos e denotam a percolação de fluidos controlando a fraturação hidráulica, e provavelmente a segregação dos termos mais graníticos pela diferenciacão dos termos mais máficos. Estas evidências sugerem que os termos máficos do CCG representariam, provavelmente, magmas de derivação mantélica em underplating e/ou intrusivos na crosta inferior, canalizados pelo sistema de zonas de cisalhamento. Estes magmas seriam responsáveis pelo aporte de fluidos e calor na formação dos granulitos e anatexia da crosta inferior, pela diferenciação e mistura com fundidos crustais para geração dos variados tipos de magmas de composição granítica a intermediária.

A fusão parcial das rochas compostas por assembléias de minerais hidratados, na ausência de fase fluida ( $\mathrm{H}_{2} \mathrm{O}$-livre), foi descrita como "fusão por desidratação" (Thompson 1982, Clemens 1984, Wolf \& Wyllie 1991). A geração de fundidos graníticos não-saturados em água $\left(\mathrm{a}_{\mathrm{H} 2 \mathrm{O}}<1\right)$ está relacionada à dissolução dos minerais hidratados presentes nos protólitos (muscovita, biotita e anfibólios). Nas faixas metapelíticas estudadas, os migmatíticos estão comumente associados a metapelitos sob condições superiores à segunda isógrada da sillimanita, onde ocorreu a desestabilização da muscovita $\left(\mathrm{a}_{22 \mathrm{O}}<1\right)$. A Fig. 6.2 mostra que a curva solidus para os granitos (sistema CKNASH) ocorre no fácies anfibolito alto $\left(\mathrm{T} \sim 625^{\circ} \mathrm{C}\right.$ para $\mathrm{P}=5 \mathrm{kbar}$ ). Nos metapelitos, a muscovita e a biotita são as principais fases minerais hidratadas que alcançam fusão com a fase fluida ausente. A água liberada pela desidratação destes minerais reage com quartzo e feldspatos na produção de fundidos leucograníticos, conforme as reações (Clemmens \& Wall 1981, Le Breton \& Thompson 1988):

\footnotetext{
- mus + qtz $\rightarrow$ sill $+\mathrm{Kf}+$ fundido

- mus $+\mathrm{pl}+\mathrm{qtz} \rightarrow \mathrm{Kf}+\mathrm{Al}_{2} \mathrm{O}_{5}+$ fundido
} 
- $b t+\mathrm{Al}_{2} \mathrm{O}_{\mathbf{5}}+\mathrm{pl}+\mathrm{qtz} \rightarrow \mathrm{gt}+\mathrm{Kf}+$ fundido

- $b t+$ sill $+q t z \rightarrow g t+c d+K f+$ fundido

- $\mathrm{bt}+\mathrm{pl}+\mathrm{qtz} \rightarrow$ opx $+\mathrm{Kf}+$ fundido

Para pressões entre 3 e 14 kbar, a muscovita desidrata primeiro, produzindo uma quantidade inicial de fundido, seguida pela biotita que desidrata sob alta-T $\left(>720^{\circ} \mathrm{C}\right.$, Le Breton \& Thompson 1988, Patiño-Douce \& Johnston 1991, Gardien et al. 1995). A quantidade de fundido produzida depende da quantidade inicial das fases hidratadas, da proporção relativa de feldspatos em relação ao quartzo, e da pressão em que ocorrem as reações de fusão (Spear 1993, Gardien et al. 1995). O aumento do volume, decorrente da fusão crustal por desidratação, conduz o incremento no fluxo cataclástico e ao fraturamento provocado pelo fundido (Rutter \& Neumann 1995). Diversos modelos avaliaram os mecanismos de geração de magmas graníticos baseados na fusão por desidratação de assembléias ricas em micas, durante o metamorfismo de alto grau:

- Clemens e Wall (1987) deduziram o início da fusão (P 1-10 kbar) de assembléias com biotita + plagioclásio + quartzo em $\mathrm{T} \sim 740-780^{\circ} \mathrm{C}$, e assembléias com biotita $+\mathrm{Al}_{2} \mathrm{O}_{5}+$ plagioclásio + quartzo em $\mathrm{T} \sim 690-710^{\circ} \mathrm{C}$;

- Rutter e Wyllie (1988) definiram o início da decomposição de biotita em $825 \pm 25^{\circ} \mathrm{C}$, da formação do ortopiroxênio entre $850-875^{\circ} \mathrm{C}$, da dissolução da hornblenda e aparecimento do clinopiroxênio entre $950-1000^{\circ} \mathrm{C}$, para $\mathrm{P}=10 \mathrm{kbar}$;

- Vielzeuf e Montel (1994) investigaram o início da fusão por desidratação de metagrauvacas com composição de tonalitos em $800^{\circ} \mathrm{C}(\mathrm{P} \sim 1-20 \mathrm{kbar}$ ), com aparecimento do ortopiroxênio entre $810-970^{\circ} \mathrm{C}(\mathrm{P} \sim 1-12 \mathrm{kbar})$;

- Patiño-Douce e Beard (1995), para biotita gnaisse e quartzo anfibolito sintéticos, obtiveram o início da fusão variando entre $\mathrm{T} \sim 800^{\circ} \mathrm{C}(\mathrm{P}=3 \mathrm{kbar})$ e $\mathrm{T} \sim 930^{\circ} \mathrm{C}(\mathrm{P}=15 \mathrm{kbar})$; - Os experimentos realizados por Gardien et al. (1995), envolvendo assembléias com biotita e/ou muscovita $(\mathrm{P}=1 \mathrm{Gpa})$, demonstraram que: (i) os protólitos apenas com biotita produziram volumes de fundido granítico metaluminoso inferiores a $15 \%$ abaixo de $900^{\circ} \mathrm{C}$ (solidus em $800^{\circ} \mathrm{C}$ ), alcançando $25 \%$ em $950^{\circ} \mathrm{C}$, e restitos granulíticos com ortopiroxênio; (ii) os metapelitos a duas micas geraram fundido granítico peraluminoso com $40-60 \%$ 
volume entre $800-900^{\circ} \mathrm{C}$ e restito aluminoso de granada + sillimanita + biotita + quartzo + plagioclásio;

- Williams et al. (1995) descreveram a geração de fundidos tonalíticos a trondhjemíticos pela fusão por desidratação de diques anfiboliticos de derivação mantélica intrusivos na crosta inferior, sob condições de $\mathrm{T} \sim 750-850^{\circ} \mathrm{C}$ e $\mathrm{P}=1,0 \mathrm{Gpa}$. A intrusão dos diques teria ocorrido sob regime de deformação dúctil no fácies granulito. $\mathrm{O}$ mecanismo de geração dos diques decorreria do underplating de magmas máficos, que propiciariam o calor e o material para a geração de magmas félsicos. As zonas de cisalhamento controlariam a redistribuição do fluxo de calor, a canalização dos magmas para a crosta inferior e a segregação do material félsico juvenil. Os trabalhos experimentais de Wolf e Wyllie (1995) confirmaram a segregação de fundidos silicáticos pela desidratação de anfibolitos entre $750-1000^{\circ} \mathrm{C}$ e 1 $\mathrm{GPa}$, pela reação geral: hornblenda + plagioclásio $\rightarrow$ clinopiroxênio + granada $+\mathrm{Al}-$ hornblenda + ortopiroxênio + fundido;

- Recentemente, Singh e Johannes (1996a, 1996b) descreveram o início da fusão parcial do sistema tonalítico (biotita + plagioclásio + quartzo) entre $750-770^{\circ} \mathrm{C}$ para $\mathrm{P} \sim 2-5 \mathrm{kbar}$, em $740^{\circ} \mathrm{C}$ para $\mathrm{P}=8 \mathrm{kbar}$ e $700-730^{\circ} \mathrm{C}$ para $\mathrm{P}=10 \mathrm{kbar}$. Os fundidos resultantes apresentaram composição granitica a granodiorítica com restito granulitico (fundido + ortopiroxênio + clinopiroxênio + K-feldspato + anfibólio), em baixa-P $(<10 \mathrm{kbar})$, com zoisita e granada em alta-P ( $\sim 12$ kbar). A ocorrência do K-feldspato, não descrito em nenhum dos trabalhos anteriores, corresponde ao início da fusão por desidratação e confirma o envolvimeno de processos anatéticos nesse sistema tonalitico (Ashworth 1985). Com o aumento da temperatura, o fundido é enriquecido em $\mathrm{Al}_{2} \mathrm{O}_{3}, \mathrm{FeO}+\mathrm{MgO}$ e $\mathrm{Na}_{2} \mathrm{O}$. O fracionamento de fundido aumenta de 11 para $25,8 \%$ com o incremento da temperatura de 800 para $950^{\circ} \mathrm{C}$, para $\mathrm{P}=5$ kbar. Rutter e Wyllie (1988) e Patiño-Douce e Beard (1995) descreveram a formação de clinopiroxênio apenas após a dissolução da hornblenda ou sob condições altas de P-T.

\subsection{5 - Modelos para Geração das Condições de Fácies Granulito}

O fácies granulito é caracterizados pela paragênese de minerais desidratados (ortopiroxênio, clinopiroxênio, granada, etc.) sob condições de temperatura variando desde $700^{\circ} \mathrm{C}$ até acima de $900^{\circ} \mathrm{C}$ e pressão entre 4-12 kbar, com valores médios entre $\mathrm{T} \sim 800 \pm 50^{\circ} \mathrm{C}$ e $\mathrm{P} \sim 7,5 \pm 1 \mathrm{kbar}$ (Harley 1988 , Newton 1985). Os terrenos no fácies granulito 
caracterizam os processos operantes na crosta média e inferior concernentes a três tipos de ambientes: 1) compondo faixas no escudo continental representando os níveis profundos da crosta soerguida e exposta; 2) fatias ou fragmentos tectonicamente transportados; 3) xenólitos inclusos em magmas basálticos e kimberlíticos (Harley 1988). Os metapelitos no fácies granulito de baixa- $P$, freqüentemente associados a metamorfismo progradante do fácies andaluzita a sillimanita e extensiva fusão por desidratação, descrevem ambientes de extensão regional com ampla anomalia térmica associada (Huppert \& Sparks 1988, De Yoreo et al. 1991).

A origem das rochas no fácies granulito permanece sujeita a considerável debate (Vielzeuf et al. 1990, Vielzeuf \& Vidal 1990). As diversas proposições e modelagens podem ser reduzidas a dois modelos principais contrastantes:

1. Metamorfismo na ausência de fluido, com a queda da atividade d'água atribuída aos processos magmáticos (Lamb \& Valley 1984, Valley et al. 1990, Valley 1992). Durante o processo metamórfico não ocorre fluido $\left(\mathrm{H}_{2} \mathrm{O}\right)$ como fase livre, presente apenas nas estruturas dos minerais e/ou dissolvida nos fundidos - "conceito da degranitização" de Fyfe (1973). Os granulitos são vistos como restitos deixados após a segregação e migração dos fundidos graníticos em direção aos ambientes dilatantes da crosta inferior e média, conduzidos pelo stress diferencial (Thompson 1990), sob condições de ausência de fluidos e $\mathrm{T}>850^{\circ} \mathrm{C}$ (Clemens 1990). Desta forma, os granulitos constituem os restitos na presença de fusões graníticas in situ nas rochas migmatíticas.

2. Metamorfismo carbônico, onde a diminuição da atividade d'água é atingida pela presença de fase fluida não-aquosa externa $\left(\mathrm{CO}_{2}\right.$, Touret 1974, Newton et al. 1980), como indicam os dados de inclusões fluidas e a restrição dos granulitos essencialmente como restitos. A atividade dos fluidos nos granulitos conduziram a modelos diversos quanto à sua natureza $\left(\mathrm{H}_{2} \mathrm{O}\right.$ e/ou $\left.\mathrm{CO}_{2}\right)$ e à forma de condução (canalizada ou pervasiva). $\mathrm{O}$ amplo estudo de inclusões fluidas demonstrou que o $\mathrm{CO}_{2}$ é o fluido dominante $\left(\mathrm{CO}_{2}>>\mathrm{H}_{2} \mathrm{O}>\mathrm{CH}_{4}\right.$ $\mathrm{N}_{2}$-saumouras, Touret 1996). A baixa atividade d'água foi atribuída à ausência de fluido (Thompson 1983), à fusão parcial (Clemens 1990), à percolação por fluxos volumosos de $\mathrm{CO}_{2}$ (Newton 1987) e à presença de salmouras (Shmulovich \& Graham 1996).

Touret (1992) sugeriu o modelo de underplating, onde o metamorfismo granulítico é causado pelo acúmulo de magmas de derivação mantélica na base da crosta, 
que fornecem $\mathrm{o} \mathrm{CO}_{2}$ para as reações metamórficas na crosta inferior. A canalização do fluxo de $\mathrm{CO}_{2}$ de origem mantélica pelas zonas de cisalhamento foi o mecanismo proposto para o metamorfismo granulítico na Índia e Madagascar (Dunai \& Touret 1993). Pili (1997) descreveu a drenagem direta do $\mathrm{CO}_{2}$ dos fluidos mantélicos pelas zonas de cisalhamento no fácies granulito de Madagascar, através de uma interface crosta-manto permeável em domínio transpressional. Frost et al. (1989) sugeriram que a fusão parcial e o fluxo de $\mathrm{CO}_{2}$ nos granulitos são processos resultantes de intrusðes magmáticas na crosta inferior que conduzem o calor e o $\mathrm{CO}_{2}$ derivado do manto, como confirmado por Van der Kerkhoff et al. (1994) na análise geoquímica de isótopos estáveis. As inúmeras intrusões magmáticas são canalizadas pelas zonas de cisalhamento, liberando os voláteis de maneira pervasiva (Wickham et al. 1994, lyer et al. 1995).

As condições P-T dos granulitos e da curva solidus das rochas crustais (granitóides alcalinos) se superpõem na presença de fluidos $\left(\mathrm{H}_{2} \mathrm{O}-\mathrm{CO}_{2}\right.$, Bohlen et al. 1995, Pili 1997), indicando a importância dos granitóides e da fusão parcial na gênese e na transferência de fluidos na base da crosta continental. As zonas de cisalhamento dúcteis são os caminhos preferenciais de migração de fluidos mantélicos e crustais, pela infiltração pervasiva na rede interconectada de porosidade (Tullis et al. 1991, Thompson \& Connoly 1992, Hickman et al. 1995), inclusive na redistribuição térmica na crosta (Beach 1976, Peacock 1989).

\section{5 - Mecanismos Responsáveis pelo Metamorfismo Granulítico e Migmatização no MSJC-MCB}

A fusão da crosta continental decorre dos seguintes mecanismos não-excludentes (Thompson \& Connolly 1995): (1) no suprimento de $\mathrm{H}_{2} \mathrm{O}$ às rochas em temperaturas acima das curvas solidi de saturação da $\mathrm{H}_{2} \mathrm{O} ;(2)$ por reações de fusão por desidratação, por meio de mecanismos de descompressão; e (3) pelo incremento no fornecimento de calor pela Moho e/ou magmas intrusivos na base da crosta.

Nos ambientes extensionais é corrente a vasta associação de granitóides intrusivos com rochas nos fácies metamórficos andaluzita-sillimanita de baixa pressão (Wickham \& Oxburg 1987, De Yoreo et al. 1991). A fusão crustal disseminada requer o intenso aporte de calor nesses ambientes, decorrente do resfriamento de magmas de 
derivação mantélica intrusivos na base da crosta e/ou em underplating, ou do soerguimento da astenosfera provocado pelo afinamento da litosfera (Powers \& Bohlen 1985, Huppert \& Sparks 1988, Patiño-Douce et al. 1990, Thompson 1990). Miller et al. (1988) sugeriu que os batólitos do tipo-I, isotopicamente homogêneos, ocorrem em regið̃es de elevado gradiente termal, refletindo ampla fusão crustal relacionada à intrusão de magmas mantélicos. Os granitos do tipo-S onde a geoquímica apresenta algumas características mantélicas podem ser gerados pela hibridização entre olivina-toleitos de alto-Al e metapelitos aluminosos (Patiño-Douce 1995). Diversos modelos demonstraram que a acresção de magmas básicos na base da crosta, provenientes do manto litosférico inferior e/ou astenosfera, constitui a fonte de calor necessária ao desencadeamento dos processos de fusão por desidratação e conseqüente geração de granulitos e granitóides na crosta inferior (p.ex. Ellis 1987, Huppert \& Sparks 1988, Spear 1993, Warren \& Ellis 1996).

Harry e Leeman (1995), na modelagem das condições de P-T responsáveis pela fusão por descompressão durante extensão litosférica, demonstraram a geração de magmas a partir da fusão parcial dos componentes máficos da litosfera inferior metassomatizada e com espessura inicial de $\sim 125 \mathrm{~km}\left(\mathrm{~T} \sim 1300^{\circ} \mathrm{C}\right.$ e profundidades $>75 \mathrm{~km}$ ). A geração de fundidos de derivação astenosférica, a partir da fusão por descompressão do manto peridotítico, somente ocorreria com a litosfera submetida a extensão superior a $50 \%$. Nesse modelo de extensão difusa da litosfera, a localização dos fundidos, resultantes da fusão por descompressão e do soerguimento do manto, seria controlada pelas estruturas de cisalhamento simples (p.ex. zonas de cisalhamento, suturas). A interação dos fundidos com as rochas crustais, ou seja, os processos de fracionamento e anatexia crustal provocada pelo aporte de calor pelos magmas mantélicos ascendentes, produziriam magmas com ampla variedade composicional desde intermediários a ácidos.

Os mecanismos envolvendo apenas o espessamento crustal seriam insuficientes na geração das temperaturas elevadas necessárias ao metamorfismo de alto grau e à migmatização dos niveis de crosta inferior a média (Looseveld \& Etheridge 1990, Sandiford $\&$ Powell 1991). Esses processos demandam a ingerência de calor advectivo, por meio dos mecanismos não-excludentes: (1) a partir de intrusões na crosta inferior derivadas da astenosfera, litosfera inferior metassomatizada e/ou base da crosta (fracionamento e/ou 
anatexia); (2) underplating de magmas de derivação mantélica; (3) afinamento do manto litosférico e soerguimento da astenosfera.

No MSJC-MCB, o controle exercido pelas zonas de cisalhamento dúcteis no metamorfismo de alta- $T$, na fusão parcial por descompressão e na intrusão de plútons granitóides (ácidos a básicos) está relacionado ao afinamento litosférico decorrente do regime extensional no Brasiliano. As principais evidências que suportam este mecanismo são:

1. O metamorfismo de alta- $\mathrm{T}$ e baixa-P $\left(\mathrm{T}>820^{\circ} \mathrm{C}\right.$ e $\mathrm{P} \sim 3,0-5,5 \mathrm{kbar}$ ) com extensiva migmatização nas zonas de cisalhamento dúcteis contemporâneos ao regime cinemático transtracional e extensional;

2. O elevado gradiente geotermal $\left(\sim 60^{\circ} \mathrm{C} / \mathrm{km}\right)$;

3. Os granitóides intrusivos (elevada $\mathrm{R}_{0} \mathrm{Sr}$ ) sintectônicos ao ambiente extensional (Monte das Gameleiras, Dona Inês, Japi, Serrinha, CCG) e plútons básicos associados; os enclaves máficos e as feições texturais de magma mixing e mingling, que sugerem componentes derivados do manto (Vernon 1983); os xenólitos de granulitos presentes em alguns plútons gabro-dioríticos (Totoró, CCG, S.J.Sabugi) indicando gênese em níveis profundos (crosta inferior a manto litosférico);

4. As assinaturas gravimétricas e aeromagnéticas regionais e residuais positivas associadas às zonas de cisalhamento de alta-T, ao DLD e aos granitóides de composição intermediária a básica e alcalina, sugerindo a correlação com magmas máficos desde profundidades do manto litosférico $(\sim 80 \mathrm{~km})$.

Estas feições correlacionam o extenso aquecimento da região às zonas de cisalhamento e intrusões granitóides, sugerindo ampla fusão parcial da crosta inferior e manto litosférico, provavelmente relacionado ao soerguimento do manto astenosférico, com as zonas de cisalhamento profundas (pelo menos profundidades de manto litosférico) canalizando fluidos de alta-T e magmas crustais e mantélicos (Pili et al. 1997).

No contexto do modelo geodinâmico para a Província Borborema/Faixa TransSahara, considerando o amálgama de blocos e microplacas continentais alóctones durante a orogênese Brasiliana (Jardim de Sá 1994), a questão da contemporaneidade entre o espessamento crustal produzido no ambiente transpressional na Faixa Seridó e os sítios transtracionais do MSJC-MCB poderiam ser compensatórios, produzindo mecanismos 
coerentes de exumação dos terrenos granulíticos e descompressão concomitante à fusão parcial e espessamento.

Em ambientes análogos, Fitzsimons (1996) e Carson et al. (1997) descreveram mecanismos de descompressão, com intensa fusão parcial e geração de granitos sintectônicos, durante transpressão crustal sincrônica a estágio extensional em níveis superiores da crosta. Os mecanismos de descompressão seriam contemporâneos ao desenvolvimento das zonas de cisalhamento, responsáveis pelo transporte dos fundidos e fluidos (magmas e voláteis), pela disseminação do calor e exumação dos terrenos granulíticos (tectonic unroofing). Com o soerguimento da astenosfera, as zonas de cisalhamento controlariam a localização do calor necessários às reações da fusão parcial dos componentes máficos e dos materiais crustais. 


\section{7 - GEOARQUITETURA CRUSTAL E \\ ASPECTOS DAS ASSINATURAS GEOFÍSICAS DAS ZONAS DE \\ CISALHAMENTO DÚCTEIS BRASILIANAS}

\section{1 - Introdução: Os Dados Geofísicos e a Análise Qualitativa}

$\mathrm{O}$ arranjo litológico e estrutural dos terrenos da porção Extremo Nordeste da Província Borborema foram apresentados nos mapas regionais em escala 1:250000 do Projeto Leste da Paraíba e Rio Grande do Norte (DNPM/CPRM 1974) e do Projeto Extremo Nordeste do Brasil (DNPM/CPRM 1978). Diversos outros trabalhos produziram mapas geológicos em escalas de detalhe e semi-detalhe no MSJC-MCB, sobretudo os Trabalhos de Graduação e Dissertações de Mestrado conduzidos pela UFRN, UFPE e UFPB-Campina Grande, Teses de Doutorado e Livre Docência, geralmente com ênfases nas investigações detalhadas dos aspectos estruturais, metamórficos e geoquímicos dos terrenos.

A análise conjunta dos dados geofisicos (gravimétricos e aeromagnéticos), com base nas anomalias regionais e residuais resultantes das filtragens no dominio do comprimento de onda, combinados aos dados geológicos de campo e aos produtos de sensoriamento remoto, conduziram à modelagem mais ampla e detalhada da estruturação crustal da região, reflexo das deformações proterozóicas. A interpretação combinada desses dados, com vantagens sobre os mesmos métodos de investigação isolados e a exemplo de terrenos proterozóicos e arqueanos em outros continentes, concentrou-se no realce das feições relevantes à interpretação tectônica do arranjo estrutural bidimensional e tridimensional da crosta continental no Brasiliano.

No presente trabalho, foram efetuados os realces de anomalias regionais $\mathrm{e}$ residuais de comprimentos de onda variados indicadoras de fontes em diferentes profundidades da crosta, pela filtragem dos dados de anomalia Bouguer e intensidade magnética total nos domínios da frequeência e espaço-temporal. Os filtros utilizados foram do tipo passa-alta, passa-baixa, passa-banda e filtros medianos quadrados (boxcar), definidos de acordo com os comprimentos de onda que se pretendeu realçar. Esses filtros correspondem aos processos de transformações lineares que modificam as relações de amplitude e/ou fase da assembléia de ondas senoidais que constituem os mapas interpolados e os perfis dos dados geofísicos. As mudanças são efetuadas pela multiplicação da transformada de Fourier 
na obtenção das alterações de amplitude e/ou fase do conjunto de dados, e então transformando o espectro dos dados modificados de volta ao domínio do espaço. As mesmas transformações podem ser obtidas no domínio do espaço pela convolução de filtros com coeficientes semelhantes às mudanças de amplitudes pretendidas (Gonzalez \& Woods 1992, Milligan \& Gunn 1997).

O emprego de vários filtros nos diferentes domínios teve como intuito ampliar os subsídios de imagens das anomalias residuais e reduzir o efeito das distorções criadas em função dos tratamentos. Desta forma, buscou-se beneficiar a análise e a interpretação dos resultados mantendo-se o controle visual, e portanto qualitativo, das filtragens em relação às informações geológicas da área. Numa abordagem qualitativa, as anomalias são detectadas mas a natureza fisica das fontes pode ser inferida, sendo as anomalias positivas relacionadas aos contrastes de densidade e magnetismo/susceptibilidade positivos, e vice-versa, onde o posicionamento geográfico do centro da fonte é obtido com precisão razoável (Beltrão \& Silva 1993). Uma análise quantitativa requer informações sobre a densidade, susceptibilidade, geometria, profundidade e extensão das fontes, além da plausibilidade geológica de um modelo de inversão ou 3-D (Jachens \& Griscom 1985, Up de Graf \& Luyendyk 1989), que foge ao escopo deste trabalho.

\section{2 - Correlações Entre as Anomalias Gravimétricas e as Feições Geológicas}

$\mathrm{Na}$ avaliação dos mapas das anomalias residuais, as Fig. 7.1 e 7.2 puderam ser agrupadas para interpretação, pois apresentaram diferenças sutis quanto aos valores de amplitude e presença de ruido. A Fig. 7.1 mostra o mapa de anomalias gravimétricas residuais obtidas com filtro passa-banda que permitiu a passagem de comprimentos de onda entre 80 e $250 \mathrm{~km}$, rejeitou comprimentos de onda superiores a $600 \mathrm{~km}$ e inferiores a $30 \mathrm{~km}$, e os valores intermediários foram cosine-tapered. A Fig. 7.2 corresponde à filtragem do tipo passa-baixa que permitiu a passagem de comprimentos de onda maiores que $250 \mathrm{~km}$, rejeitando os valores inferiores a $10 \mathrm{~km}$ e cosine-tapered os valores intermediários. Como visto na Fig. 3.2, os comprimentos de onda superiores a $300 \mathrm{~km}$ tiveram participação nula nos valores das amplitudes de fontes de até $40 \mathrm{~km}$ de profundidade.

As Fig. 7.3 e 7.4 referem-se às continuações para cima de $13 \mathrm{~km} \mathrm{e} 1 \mathrm{~km}$, respectivamente, que produziram o alisamento de anomalias superficiais de alta freqüência. 


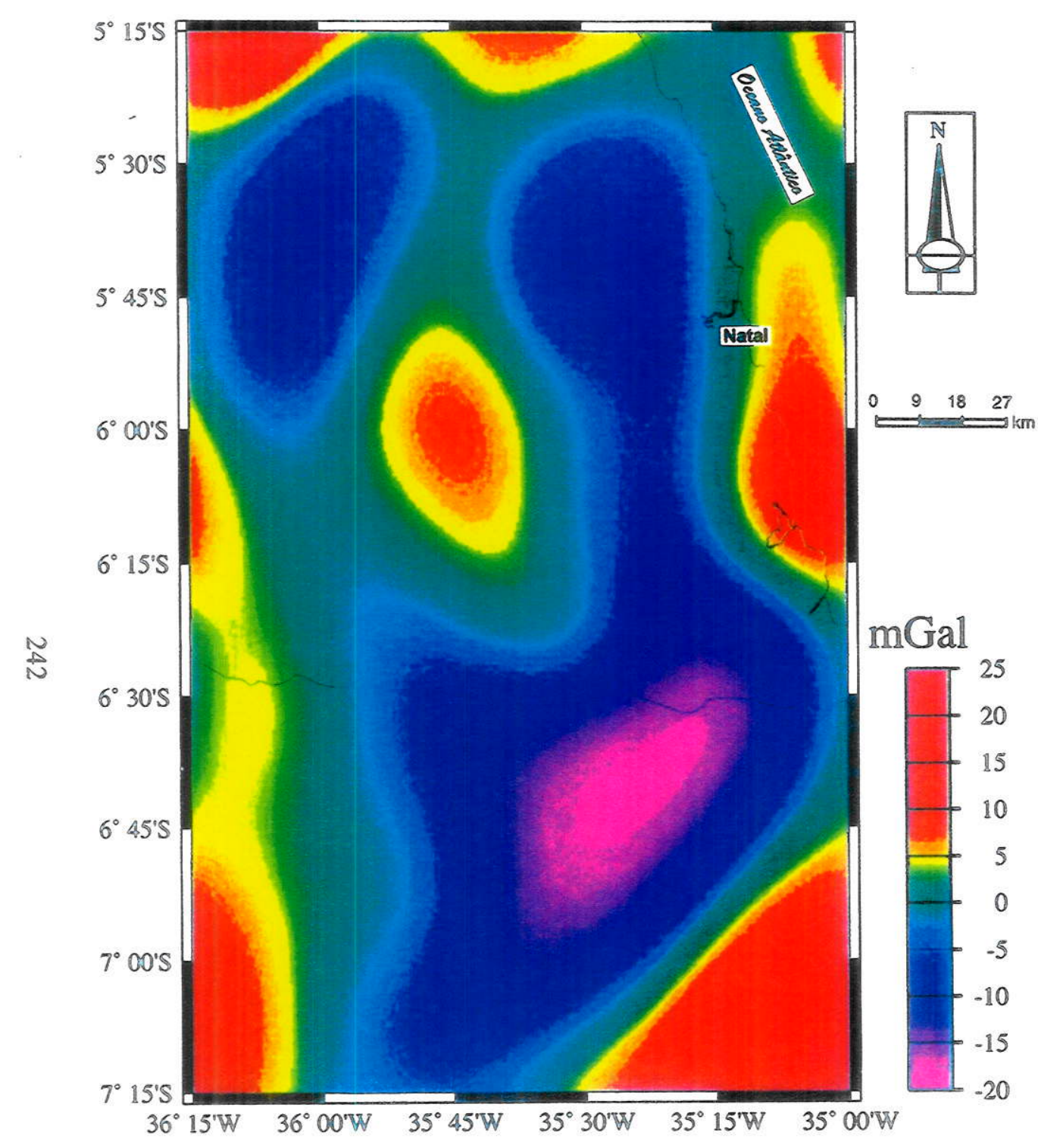

Figura 7.01- Mapa de anomalias gravimétricas obtidas a partir de filtragem no domínio da freqüência com filtro passa-banda que permite a passagem de $80 \mathrm{~km}<\lambda<250 \mathrm{~km}$, rejeita $\lambda>600 \mathrm{~km}$ e $\lambda<30 \mathrm{~km}$ e cosine-lapered os valores intermediários. 0 mapa indica a localização da cidade de Natal/RN. $\lambda=$ Comprimento de onda.

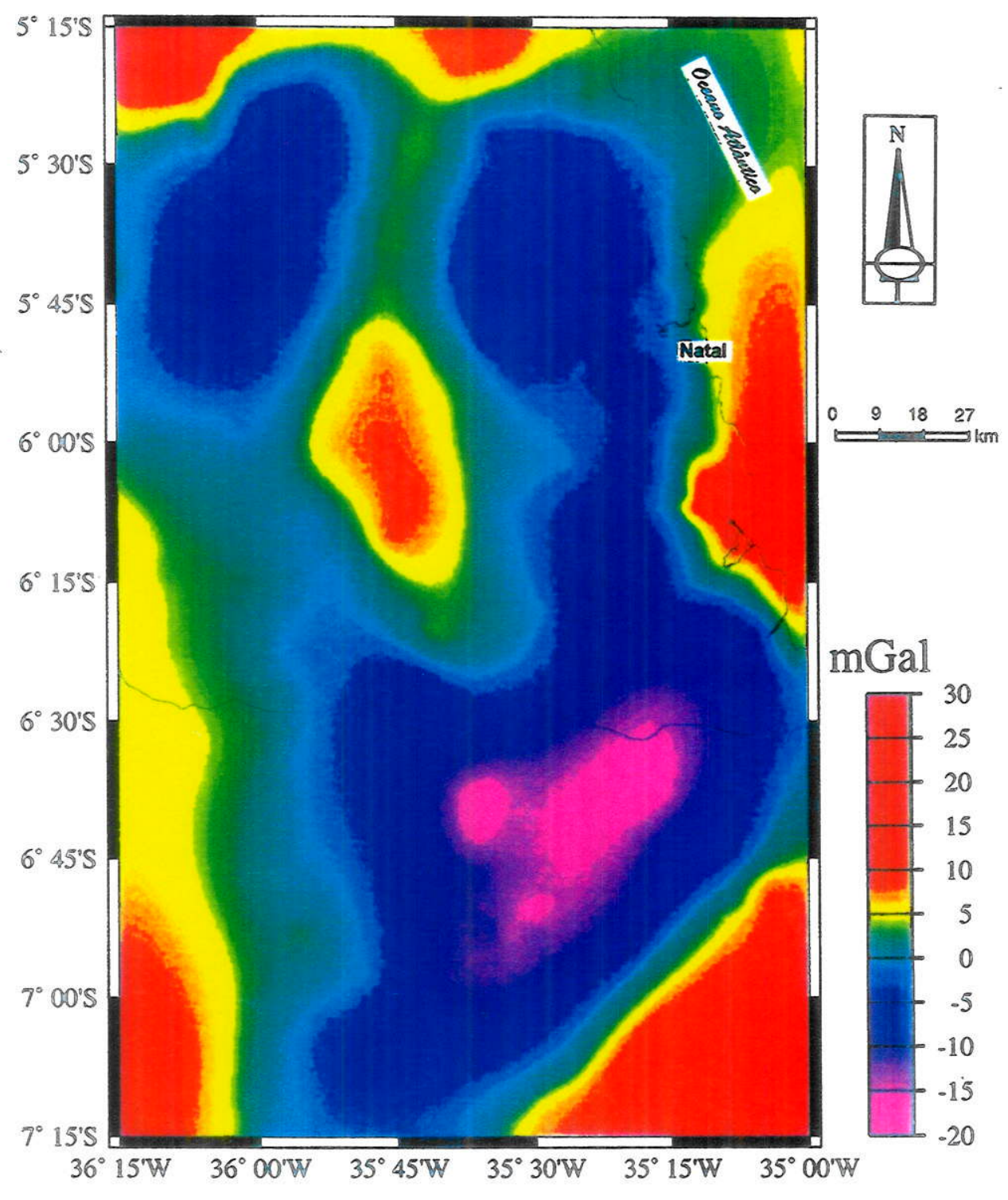

Figura 7.02 - Mapa de anomalias gravimétricas obtidas a partir de filtragem no domínio da freqüuência com filtro passa-baixa que permite a passagem de $\lambda>250 \mathrm{~km}$, rejeita $\lambda<10 \mathrm{~km}$ e cosine-tapered os valores intermediários. 


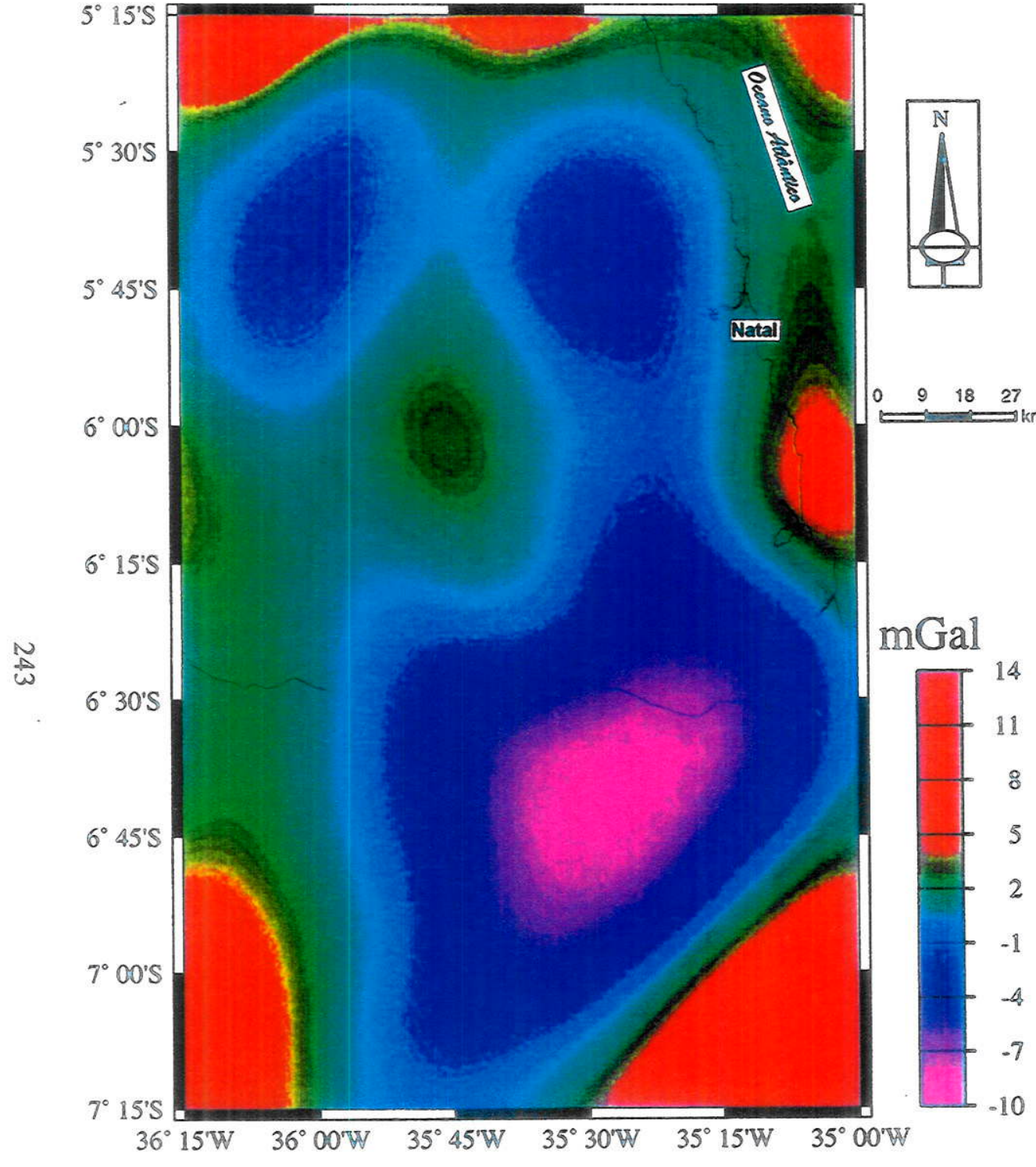

Figura 7.03 - Mapa de anomalias gravimétricas obtidas a partir de filiragem em continuação para cima de $13 \mathrm{~km}$.

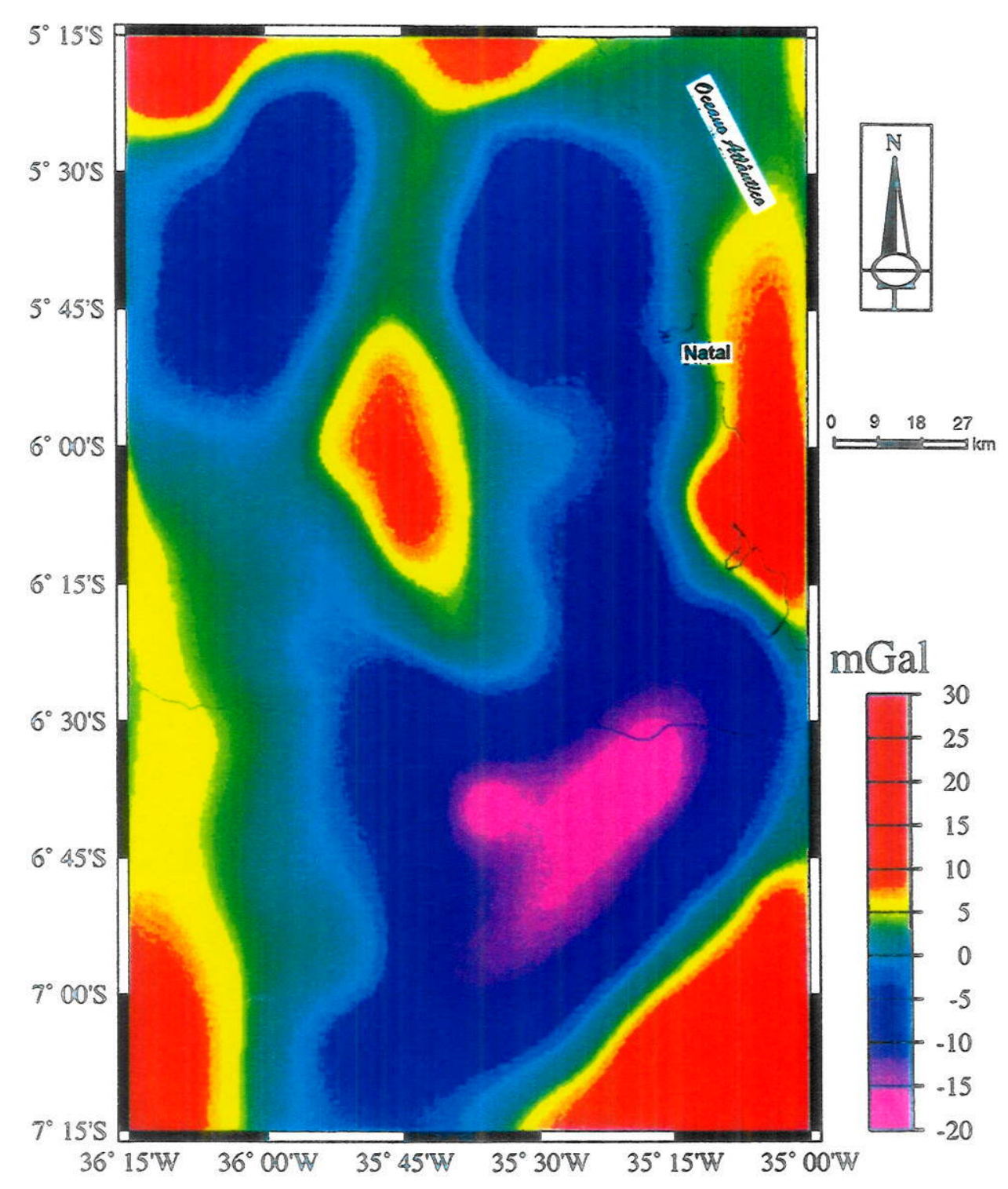

Figura 7.04 - Mapa de anomalias gravimétricas obridas a partir de filltragem em continuação para cima de $1 \mathrm{~km}$. 
As Fig. 7.2 e 7.4, comparadas às Fig. 7.1 e 7.3, mantiveram-se parcialmente contidas nas anomalias de comprimentos de onda longos, o que facilitou algumas das correlações com a geologia de superfície. As anomalias positivas e negativas estão justapostas e possuem formas elipsoidais, com comprimentos dos eixos maiores entre 70-150 km, acompanhando a principal estruturação neoproterozóica da região. A feição marcante dos mapas é o aspecto alongado das anomalias e dos gradientes íngremes ressaltados pela filtragem. A estimativa de profundidade média para as fontes dessas anomalias é de $20-25 \mathrm{~km}$, nos níveis da crosta média-inferior atual.

A anomalia negativa (-13 mGal) sobre a Faixa Seridó tem o eixo maior passando pela porção central da faixa (região de Cachoeira do Rio dos Ventos) e pelo granitóide Totoró, se estendendo alguns quilômetros pelo interior da Bacia Potiguar. A Fig. 7.2 mostra a divisão da anomalia negativa em dois máximos, um centralizado mais a norte, relacionado à continuidade do plúton Totoró sob a cobertura sedimentar, e outro deslocado para o centro da faixa. A causa geológica direta desta anomalia é o espessamento crustal da parte central da faixa de micaxistos em regime transpressional, acompanhado por intensa granitogênese (p.ex. granito Totoró). Os flancos da anomalia estão controlados por gradientes lineares positivos que marcam zonas com mudanças abruptas no contraste de densidade, entre a faixa de metassedimentos e o embasamento gnáissico, correspondente à ZCPJC, na borda leste, $\mathrm{e}$ as ZCLCC e ZCSM na borda oeste, todas definidas por zonas miloníticas em cinemática de transpurrão. Os estudos das perfilagens sísmicas profundas (Matos 1992) e termobarometria (Lima 1987, 1992) permitiram a estimativa de $45 \mathrm{~km}$ de espessamento crustal para o setor central da faixa ao final do Brasiliano.

Outra anomalia negativa (-13 mGal) delineia a faixa de micaxistos da região de Taipu-Ielmo Marinho e os granitóides sin- a tarditectônicos de Taipu, Pitombeira, Nova Descoberta, Gameleira, Primeira Lagoa e Matão. A disposição alóctone dos micaxistos com contato basal de cinemática extensional (topo para $\mathrm{NE}$ ), as estruturas $\mathrm{D}_{3}$ com mergulho suave para $\mathrm{NE}$ e as formas tabulares e ovaladas dos granitóides definem a amplitude e a forma dos comprimentos de onda da anomalia. A centralização da máxima amplitude da anomalia nas proximidades de Ceará-Mirim é decorrente do provável aumento do volume dos micaxistos e granitóides, sobretudo os plútons Gameleira, Primeira Lagoa e Matão, sob a 
cobertura sedimentar, acompanhando o alojamento transtracional da fatia de micaxistos durante o Brasiliano. Na Fig. 7.2 ocorre outro máximo centralizado sobre o granito Taipu, separado daquele de Ceará-Mirim por um estreito alto linear relativo que marca uma zona de cisalhamento transtracional dextral no contato entre o plúton Taipu e a fatia de micaxistos. $\mathrm{O}$ gradiente linear que define o limite ocidental da anomalia é correlato à inflexão de NW para NE da ZCBJ, acompanhando o padrão coalescente formado entre as zonas de cisalhamentos sinistrais de trend geral NW (ZCJ, ZCBJ e ZCLP) e a ZCPJC dextral de trend NNE. O granitóide Pitombeira não está incluso na anomalia negativa como os demais granitóides da área, provavelmente devido às feições de stockwork com rochas dioríticas e os enclaves de rochas gabróicas foliadas (PFC//SPD), mas encontra-se envolvido pela inflexão NE das zonas de cisalhamento, compondo a borda da anomalia. O limite oriental da anomalia acompanha o traçado da região costeira, paralela ao limite da crosta continental atual, da mesma forma que o eixo negativo que segue para sul a partir da região de Natal. Este eixo negativo sofre as incursões sinuosas dos gradientes que definem as ZCLP e ZCBJ em direção ao alto gravimétrico da região das lagoas de Guaraíra e Bonfim. Para este região convergem as zonas de cisalhamento ZCBJ, ZCLP, ZCSE e ZCBNC, o que intensificaria a deformação num regime transcorrente-extensional (cisalhamento geral) favorecendo a instalação de magmas mantélicos numa extensa área da base da crosta continental, responsáveis pela anomalia positiva observada no continente.

A anomalia positiva ( $10 \mathrm{mGal})$, e gradientes lineares de borda, da parte central da área acompanha a estruturação dos blocos limitados pelas zonas de cisalhamento transcorrentes-extensionais ZCBJ, ZCLP e ZCT, desde a justaposição anastomosada com as estruturas em leque da ZCPJC, na parte norte, até a provável convergência com as ZCSE e $\mathrm{ZCBNC}$, a leste. Esta anomalia envolve os terrenos arqueanos formados por ortognaisses TTG e migmatitos bandados granadiferos do Complexo Presidente Juscelino (Dantas 1997). Para sul, a anomalia delineia o corpo diorítico de Serrinha, entre a porção NNE do batólito de Monte das Gameleiras e o granito da Serrinha, além das zonas de cisalhamentos transcorrentes-extensionais que controlam o alojamento desses granitos. Dois máximos de amplitude (Fig. 7.2 e 7.4) estão localizados próximo aàs cidades de Senador Elói de Souza e entre Presidente Juscelino e Tangará, provavelmente assinalando maiores proporções de anfibolitos, metagabros e meta-anortositos, envolvidos pela ZCLP e intercalados nos 
ortognaisses e migmatitos dominantes nos terrenos arqueanos. A relação morfológica e cinemática desses terrenos com as zonas transcorrentes e extensionais permite a sugestão do afinamento crustal para a área, com a instalação de corpos básicos na base da crosta seguindo a orientação das principais estruturas brasilianas.

A proeminente anomalia negativa $(-20 \mathrm{mGal})$ parcialmente controlada pela estruturação NE dos ramos anastomosados das ZCRP e ZCCG, abrangendo setores dos granitóides de Dona Inês, Pocinhos e Areia, e da faixa de micaxistos de Duas Estradas. Na Fig. 7.2 duas amplitudes máximas estão definidas, uma centrada no granito Dona Inês e outra na região entre Duas Estradas e Montanhas (aproximadamente centrada em Jacaraú). A provável causa dessa extensa anomalia negativa são corpos granitóides, com baixo contraste de densidades com o embasamento gnáissico, presentes em grande volume nos niveis inferiores da crosta, condicionados ao regime transcorrente-extensional do sistema anastomosado de zonas de cisalhamento, e provavelmente um bloco crustal mais espesso na região de Jacaraú. Essa anomalia negativa de comprimentos de onda de primeira ordem acompanhando setor de alto strain $\mathrm{D}_{3}$ poderia ainda refletir como fonte o manto litosférico submetido a processos de fracionamento e fusão parcial sob condições de alta- $T$, condicionados a zonas de cisalhamento com raizes mantélicas, a exemplo de orógenos semelhantes na África (Browne \& Fairhead 1983, Halliday et al. 1990, Poudjom Djomani et al. 1993).

Uma anomalia residual positiva de baixa amplitude ocorre na região da estrutura em flor negativa de Barra de Santa Rosa, relacionada ao regime transtracional da ZCRP. A anomalia positiva está expressa linearmente sobre o domínio de mergulhos fortes da ZCRP, marcado por metamorfismo granulitico e intensa migmatização, com uma anomalia de curto comprimento de onda coincidente com o granito alcalino de Algodão. Esta anomalia pode ser atribuída ao afinamento crustal nesse setor, com a ZCRP enraizada no manto litosférico, provocando a deformação da Moho e favorecendo a instalação em niveis crustais de rochas provenientes do manto.

Um eixo negativo de baixa amplitude e direção NW engloba parte do bloco paleoproterozóico, na porção entre os granitóides de Monte das Gameleiras, Caxexa e Japi, relacionado à continuidade das rochas gnáissicas para esses níveis crustais. Os plútons de Caxexa e Japi estão relacionados ao gradiente linear positivo que controla a zona de 
cisalhamento de Japi e parte da região de Barra de Santa Rosa, sugerindo prováveis fontes mantélicas para esses granitóides. O mesmo ocorre com o granitóide Barcelona parcialmente condicionado aos gradientes lineares positivos das ZCPJC e ZCT.

Os mapas de anomalias residuais das Fig. 7.5 e 7.6 foram agrupados para descrição e correlação das anomalias. A Fig. 7.5 é o resultado da filtragem passa-alta que permitiu a passagem de comprimentos de onda inferiores a $50 \mathrm{~km}$, rejeitou os superiores a $250 \mathrm{~km}$ e os valores intermediários foram cosine-tapered. A profundidade estimada para as fontes realçadas por esse filtro foi de cerca de $7-10 \mathrm{~km}$, em niveis médio-superior da crosta atual. O resultado pode ser comparado àquele da Fig. 2.7 obtida por Lins et al. (1993), mas sobrelevando maiores detalhes. A filtragem passa-alta da Fig. 7.6 permitiu a passagem de comprimentos de onda inferiores a $30 \mathrm{~km}$, rejeitou os superiores a $250 \mathrm{~km}$ e cosine-tapered os valores intermediários. Os valores de profundidade máximos inferidos foram da ordem de 6-9 km. As informações contidas nos mapas residuais correspondem diretamente às feições geológicas dos terrenos em superficie. Os comprimentos de onda das anomalias combinam com a forma dos corpos em superficie (seção $\mathrm{XZ}$ do strain $\mathrm{D}_{3}$ ), os efeitos dos lóbulos de sinais opostos foram suprimidos, os gradientes são íngremes e controlam os altos e baixos gravimétricos, conforme a estruturação principal do terreno. Para esses mapas foram apresentadas exclusivamente as feições complementares ou discordantes daquelas previamente descritas para os mapas resultantes das filtragens para os níveis de crosta inferior.

Na Faixa Seridó foram diferenciadas a ampla anomalia negativa do granito Totoró, na maior parte sob a cobertura sedimentar, daquelas da porção central da faixa de micaxistos relacionadas às estruturas dômicas $F_{3}$, reflexos da transpressão e do espessamento crustal, e às intrusões graniticas. Alguns outros baixos gravimétricos foram individualizados e relacionados diretamente aos corpos granitóides alongados que intrudem os micaxistos em faixas miloníticas e o embasamento ao longo da ZCPJC.

$\mathrm{Na}$ região de Taipu-Ielmo Marinho foram distintos os baixos gravimétricos relacionados à faixa de micaxistos, com maior comprimento de onda e menor amplitude, daqueles marcadores dos granitos, que acompanham a forma cartografada dos corpos. Um estreito e íngreme gradiente separa as anomalias entre os granitos Taipu, Gameleira e 


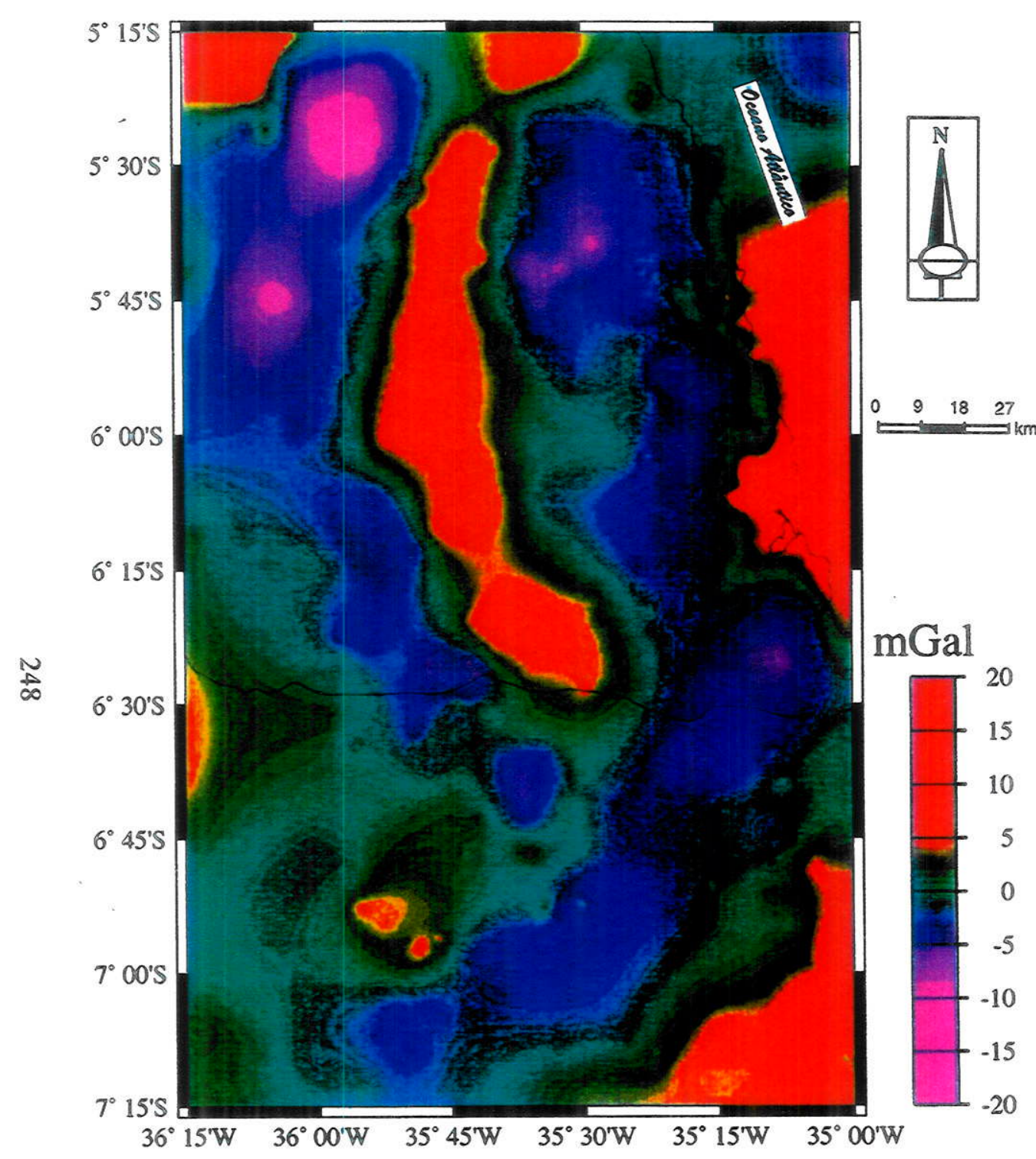

Figura 7.05 - Mapa de anomalias gravimétricas obtidas a partir de filtragem no domínio da freqüência com filtro passa-alta que permite a passagem de $\lambda<50 \mathrm{~km}$, rejeita $\lambda>250 \mathrm{~km}$ e cosine-tapered os valores intermediários.

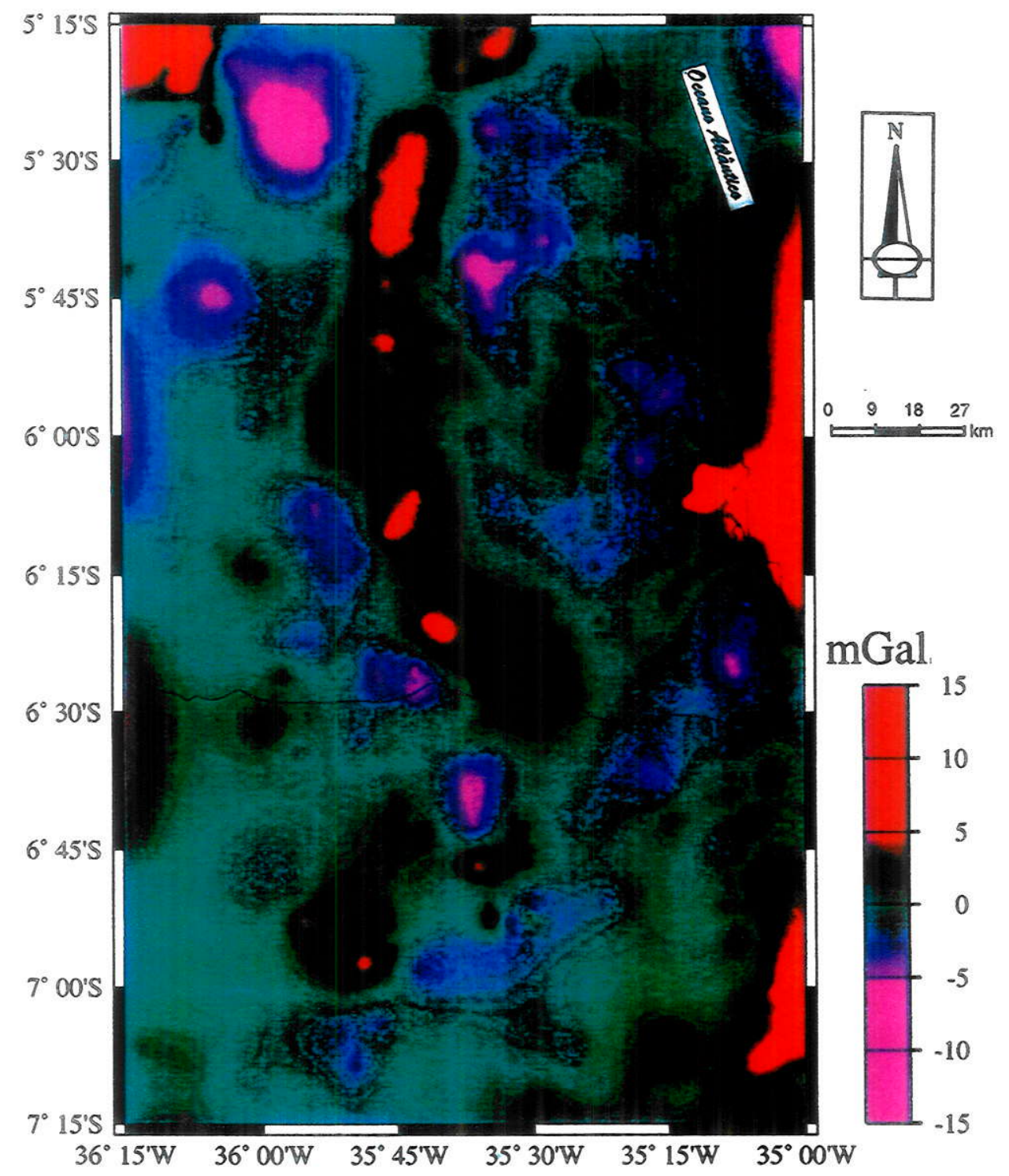

Figura 7.06 - Mapa de anomalias gravimétricas obtidas a partir de filtragem no domínio da freqüência com filtro passa-alta que permite a passagem de $\lambda$ $<30 \mathrm{~km}$, rejeita $\lambda>250 \mathrm{~km}$ e cosine-tapered os valores intermediários. 
Primeira Lagoa, descrevendo uma estreita zona de cisalhamento transtracional dextral no contato entre o plúton Taipu e os micaxistos.

No eixo de anomalias negativas de direção NS paralelo à costa, diversos baixos foram individualizados sob a cobertura sedimentar, provavelmente designando a ocorrência de corpos graníticos ovalados e alongados (Suite Natal?, Dantas 1997) nesse nível crustal, semelhantes ao plúton Macaiba. Na região da ZCLP, algumas anomalias menores compõem um eixo que segue a linearidade da faixa milonítica, sugerindo a intrusão de alguns corpos graníticos relacionados à cinemática transcorrente-extensional desta zona.

A anomalia positiva na porção central dos mapas constitui um eixo NNE virgando para SE, formado por várias anomalias de curtos comprimentos de onda e amplitudes médias, centralizadas entre as cidades de João Câmara e Poço Branco, Presidente Juscelino e Tangará, em São Paulo do Potengi, na região central do bloco arqueano, e sobre o diorito e granitóide de Serrinha e no DLD. Na borda NE do batólito Monte das Gameleiras, um gradiente de trend NW acompanha a ZCSSB e separa a anomalia negativa da porção principal do corpo, da anomalia positiva que marca o diorito Serrinha. Uma anomalia positiva, controlada pelo trend $\mathrm{NNE}$ da ZCBJ, coincide com a forma do granito Pitombeira. As ZCLP e ZCBJ mantiveram-se delineadas pelos gradientes lineares nas bordas da anomalia positiva. O afinamento crustal favoreceria o alojamento de magmas básicosintermediários em níveis crustais mais rasos (crosta média-superior), fontes das anomalias descritas, canalizadas pelas zonas de cisalhamento de cinemática transtracional.

A porção norte do plúton Barcelona é controlada pelos gradientes ingremes entre a anomalia negativa da Faixa Seridó e a anomalia positiva do bloco arqueano, enquanto na borda sudeste ocorre uma anomalia negativa relacionada a ZCT, sugerindo diferentes fontes na geração do batólito.

Um baixo gravimétricos de curto comprimento de onda e alta amplitude coincide com a forma ovalada do plúton Dona Inês. $O$ eixo de anomalias negativas na região entre a ZCRP e ZCCG é definido por anomalias centradas na faixa de micaxistos e granitos de Duas Estradas, na fatia micaxistos de Araras-Solânea e Alagoa Grande, e no setor ocidental do granitóide de Pocinhos. A ampla anomalia negativa da região entre Duas Estradas e Jacaraú têm as bordas limitadas pelas ZCMN e ZCRP. 
A ZCRP tem sua extensão marcada por gradientes positivos com anomalias curtas de alta amplitude definindo o plúton de Algodão, a faixa de granulitos, as ramificações de alta-T (ZCCC, ZCPF, ZCBNC) e a região dos granitóides intermediários de Bananeiras, relacionada às raízes básicas desses corpos.

Apesar de disposto na borda dos mapas, o granitóide de Picuí está assinalado por uma anomalia positiva, provavelmente decorrente de corpos básicos instalados em sua raiz nas profundidades sugeridas.

A porção SE dos mapas é controlada pela $\mathrm{ZCCG}$ e zonas de cisalhamento sinistrais do limite noroeste do $\mathrm{MCB}$, definindo anomalias positivas de curtos comprimentos de onda alinhadas segundo o trend NE da principal estruturação dos terrenos. Essa localização das anomalias acompanha o CCG, nas proximidades da cidade de Campina Grande, e as zonas de cisalhamento no fácies granulito e com intensa migmatização.

As Fig. 7.7 e 7.8 apresentam as filtragens passa-alta aplicadas na distinção das anomalias de alta frequêencia dos níveis superiores da crosta. Na Fig. 7.7, o filtro aplicado permitiu a passagem de comprimentos de onda inferiores a $30 \mathrm{~km}$, rejeitando os superiores a $50 \mathrm{~km}$ e cosine-tapered os valores intermediários. A filtragem da Fig. 7.8, complementar à Fig. 7.7, permitiu a passagem de comprimentos de onda inferiores a $10 \mathrm{~km}$, rejeitando os comprimentos de onda maiores que $30 \mathrm{~km}$, cosine-tapered os valores intermediários. Os níveis de profundidade máximas inferidas para as fontes que produziriam as anomalias observadas são inferiores a $7 \mathrm{~km}$. Os mapas possuem diversos altos e baixos gravimétricos de curtos comprimentos de onda de baixa amplitude, coincidentes com os elementos geológicos de superfície. As principais correlações descritas para os níveis inferior e médio da crosta foram mantidos. Sobre os terrenos cristalinos, além das evidências já descritas nos mapas das filtragens anteriores, algumas diferenças foram observadas. O gradiente que delineia a ZCBJ está marcado por anomalias positivas de curtos comprimentos de onda. Esta feição foi descrita por Moreira et al. (1990) que estimaram para essa região a presença de corpos graníticos básicos em níveis crustais rasos. Nos domínios transtracionais de lelmo Marinho-Taipu e Barra de Santa Rosa, destacam-se os baixos gravimétricos relacionados aos granitóides e macaxistos. Anomalias positivas curtas assinalam o diorito e o granito Serrinha, controlados por zonas de cisalhamentos. Na região de Belém, as anomalias positivas acompanham o trend $\mathrm{NE}$ da ZCBNC, indicadora de corpos básico-intermediários 


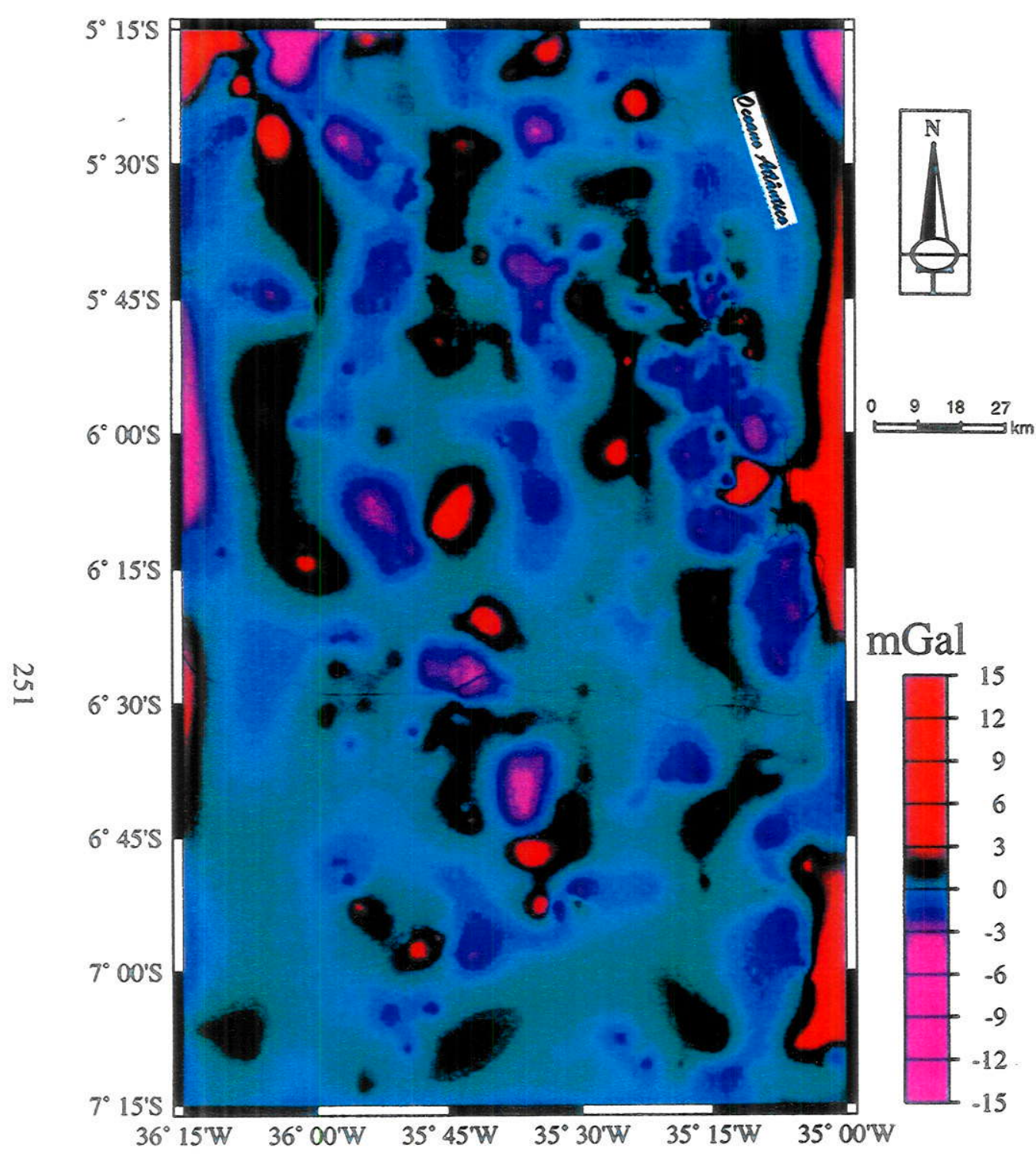

Figura 7.07 - Mapa de anomalias gravimétricas obtidas a partir de filtragem no domínio da freqüência com filtro passa-alta que permite a passagem $\lambda<$ $30 \mathrm{~km}$, rejeita $\lambda>50 \mathrm{~km}$ e cosine-tapered os valores intermediários.

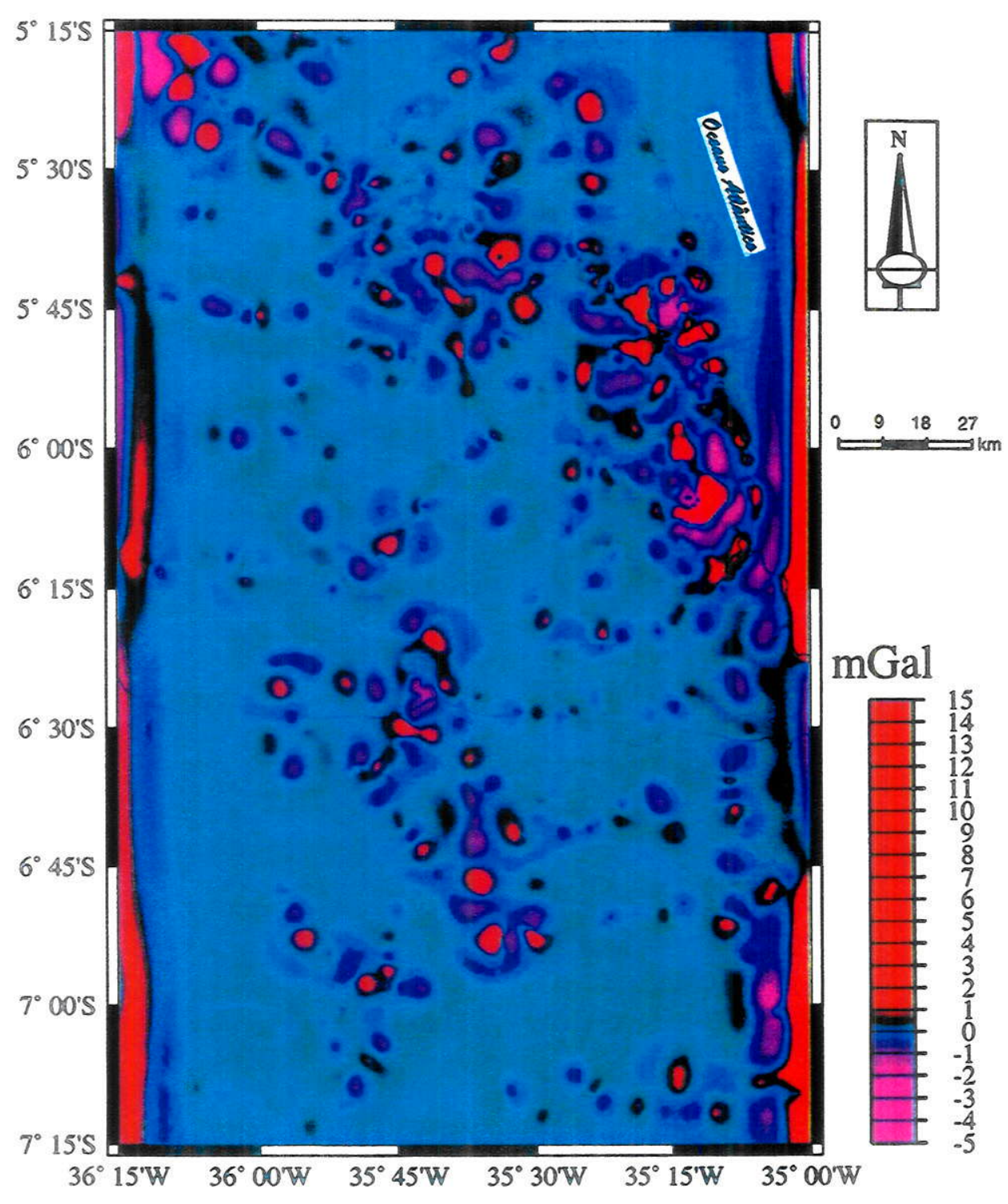

Figura 7.08 - Mapa de anomalias gravimétricas obtidas a partir de filtragem no domínio da freqüuência com filtro passa-alta que permite a passagem de $\lambda$ $<10 \mathrm{~km}$, rejeita $\lambda>30 \mathrm{~km}$ e cosine-tapered os valores intermediários. 
nesse nível crustal, em associação com a ZCRP. Na área do granito Japi, as suítes básicointermediárias estão delineadas por anomalias positivas que seguem o alto positivo da ZCJ no trend NW até a região de Santa Cruz. O granitóide Picuí esta definido parcialmente por anomalias positivas, indicando suas raízes básicas em crosta rasa. $\mathrm{O}$ granitóide Areia, as rochas máficas do CCG e o plúton Algodão, controlados pelo sistema anastomosado das ZCRP e ZCCG, estão destacados por anomalias positivas. Tais anomalias indicam a presença de corpos básicos-intermediários densos como raízes dos granitóides e zonas de cisalhamento brasilianas nos níveis da crosta superior atual $(<7 \mathrm{~km})$. A porção norte da faixa de micaxistos da Barra de Santa Rosa e de Duas Estradas-Pirpirituba estão assinalados por anomalias negativas, sugerindo a continuidade das faixas de micaxistos associadas a granitóides alongados nesses níveis crustais.

$\mathrm{O}$ grande número de anomalias de curtos comprimentos de onda sob as coberturas sedimentares indica a intensa deformação nas bordas do continente, em sistemas de grabens e horsts, com possível aporte de magmas conduzidos pelas estruturas brasilianas reativadas. Nas regiões de Natal, Canguaretama e lagoas do Bonfim e Guaraíra, a correlação é imediata entre a estruturação crustal no regime frágil e as estruturas frágeis-dúcteis e dúcteis profundas relacionadas à deformação no evento Brasiliano, como sugere a linearidade das anomalias e gradientes íngremes de contorno-zero, que delineiam os limites entre áreas com diferentes densidades. Na região próxima a Natal $\left(05^{\circ} 15^{\circ}-06^{\circ} 30^{\prime} \mathrm{S} / 35^{\circ} 00^{\prime}\right.$ $35^{\circ} 45^{\prime} \mathrm{W}$ ) foi realizada a avaliação da correlação entre as feições deformacionais em diferentes níveis crustais, e as possíveis implicações entre a reativação das estruturas brasilianas e na neotectônica, tratada no item 7.6.

Nos mapas das Fig. 7.9, 7.10, 7.11, 7.12, 7.13 e 7.14, obtidos pela filtragem no domínio espaço-temporal (filtros quadrados tipo boxcar), a feição mais proeminente é o paralelismo de isolinhas em relação à margem da crosta continental atual. As amplitudes das isolinhas, coincidentes com a linha da costa, variam de 30-32 mGal a 15-17 mGal. Esta linearidade confirma o afinamento crustal atual, com soerguimento da Moho em direção à interface crosta continental-crosta oceânica, num contexto de margem continental passiva, decorrente da separação dos continentes Sul-Americano e Africano durante o Albiano (100 Ma). Os diversos episódios de esforços influenciaram o estiramento e culminaram com a 


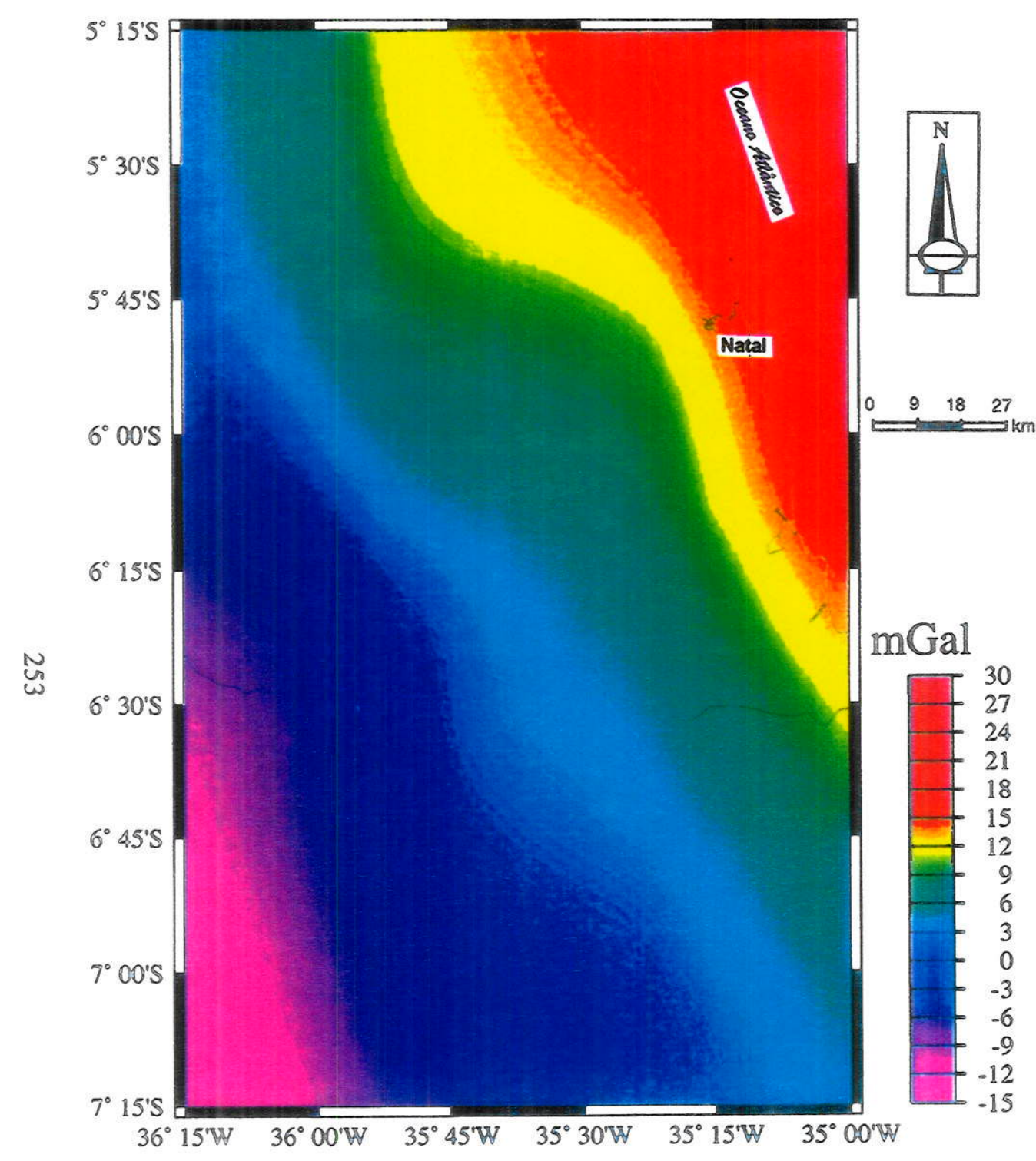

Figura 7.09 - Mapa de anomalias gravimétricas obtidas a partir de filltagem no domínio espaço-temporal com filtro quadrado de $\lambda=200 \mathrm{~km}$.

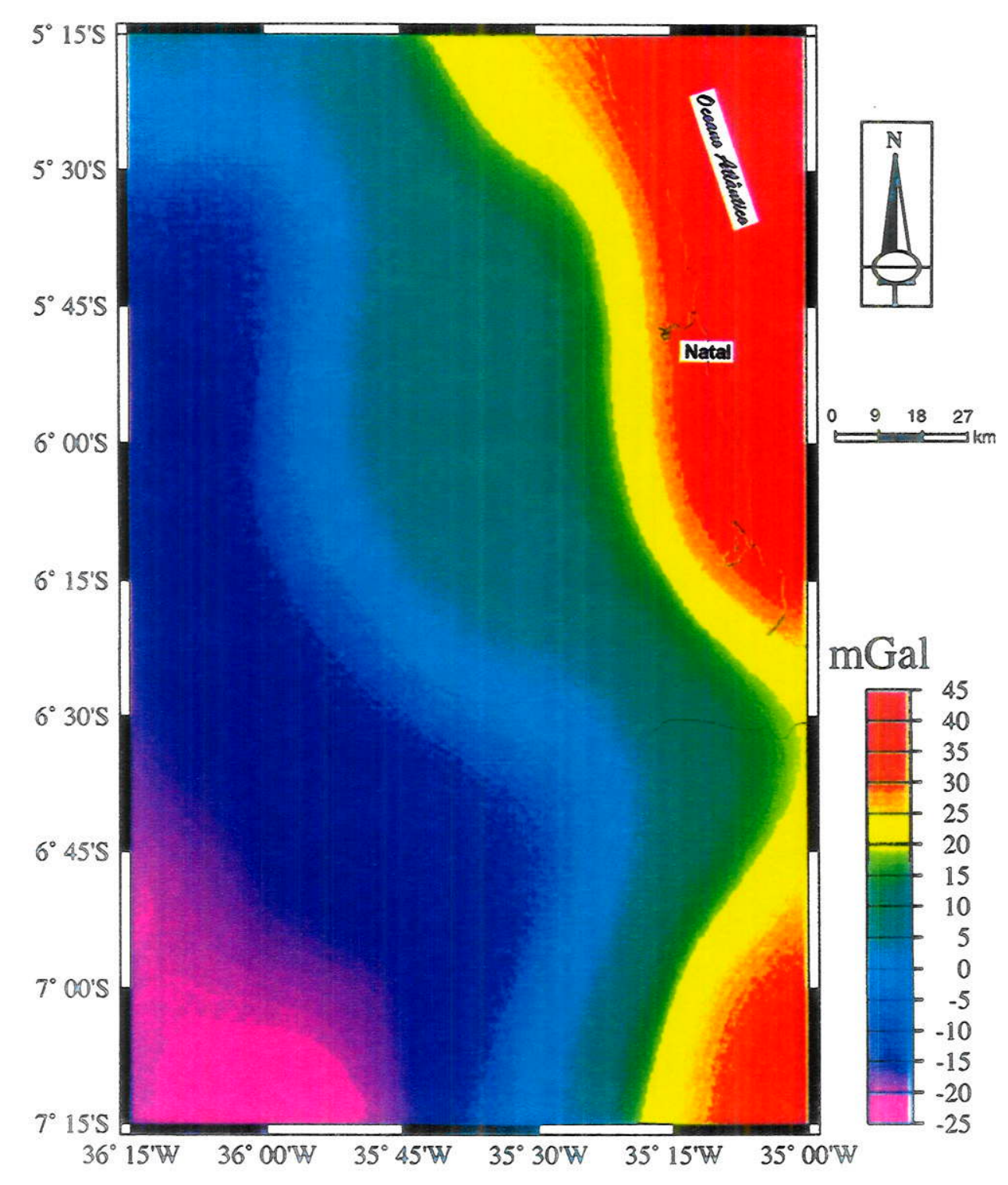

Figura 7.10 - Mapa de anomalias gravimétricas obtidas a partir de filtragem no domínio espaço-temporal com filtro quadrado de $\lambda=50 \mathrm{~km}$. 


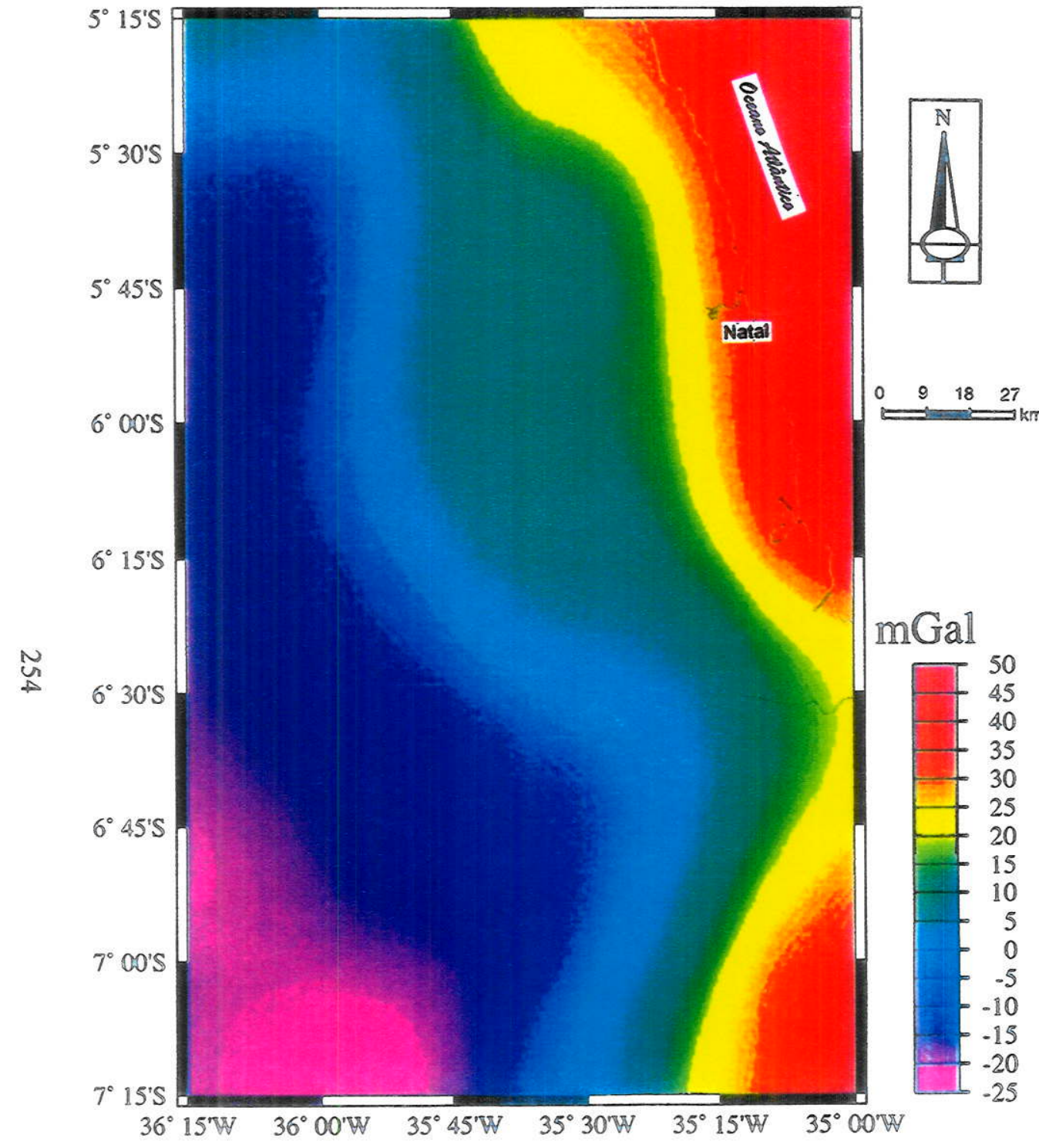

Figura 7.11- Mapa de anomalias gravimétricas obtidas a partir de filtragem no domínio espaço-temporal com filtro quadrado de $\lambda=40 \mathrm{~km}$.

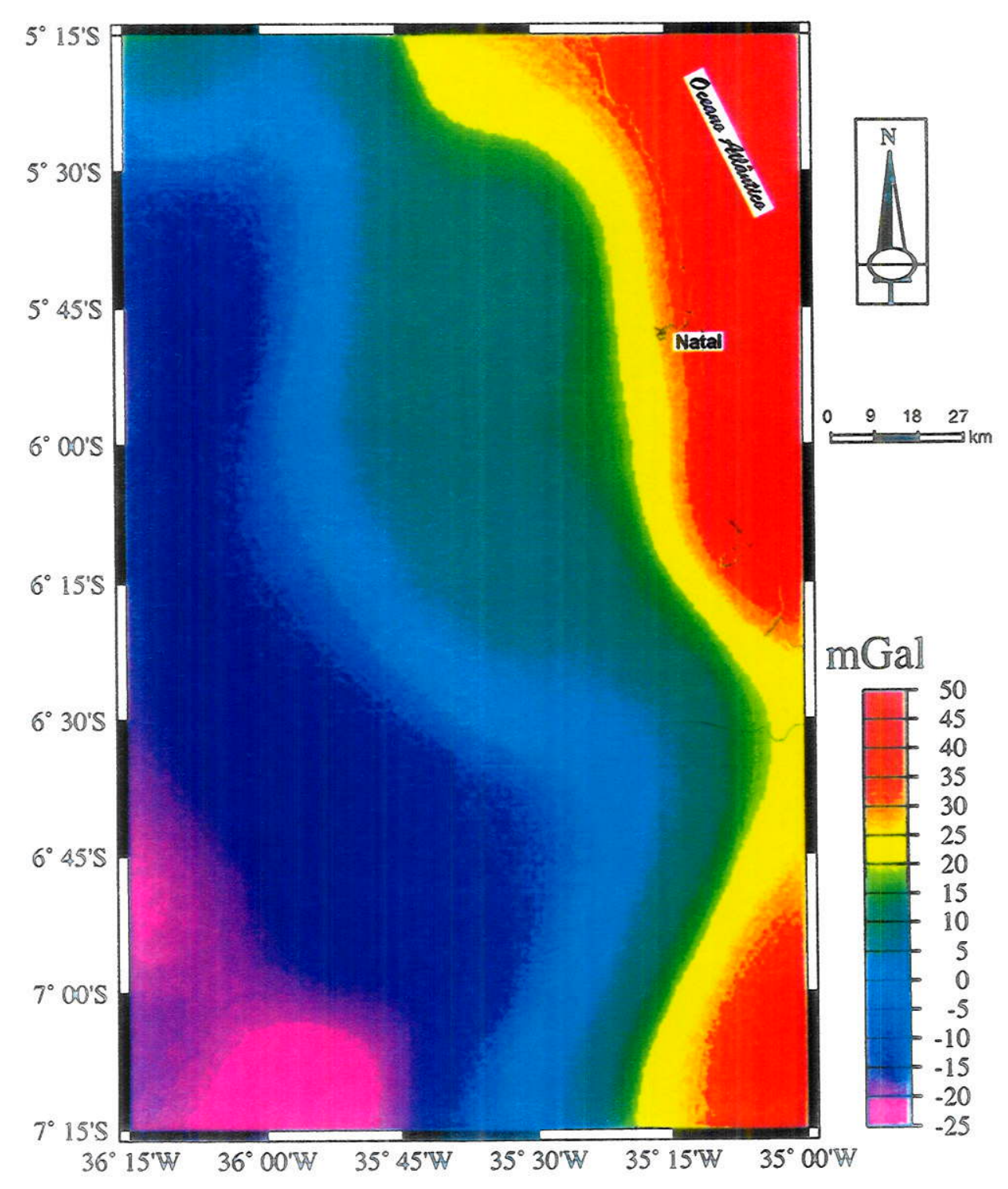

Figura 7.12 - Mapa de anomalias gravimétricas obtidas a partir de filtragem no domínio espaço-iemporal com filtro quadrado de $\lambda=30 \mathrm{~km}$. 


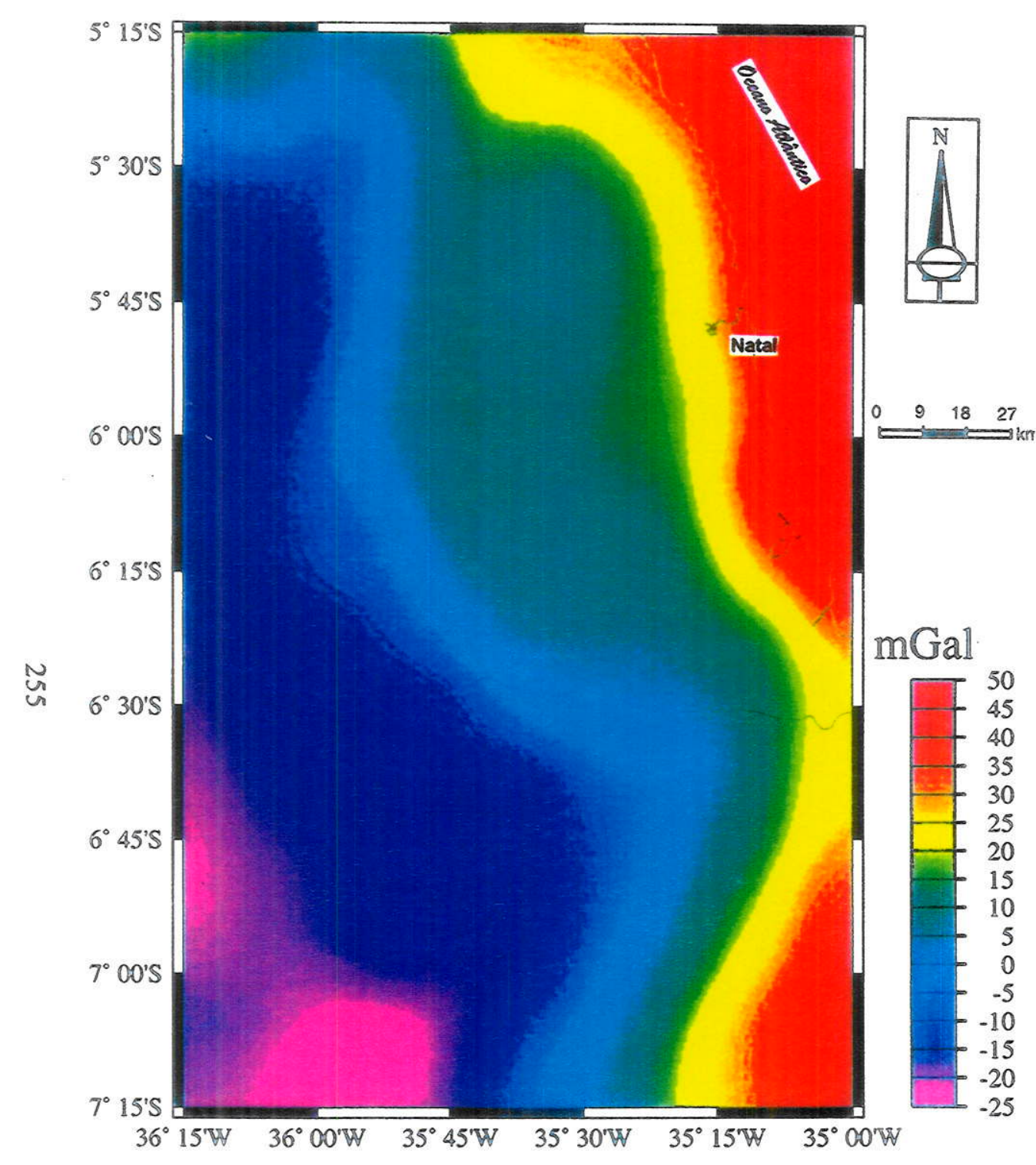

Figura 7.13 - Mapa de anomalias gravimétricas obtidas a parcir de filtragem no domínio espaço-temporal com filtro quadrado de $\lambda=20 \mathrm{~km}$.

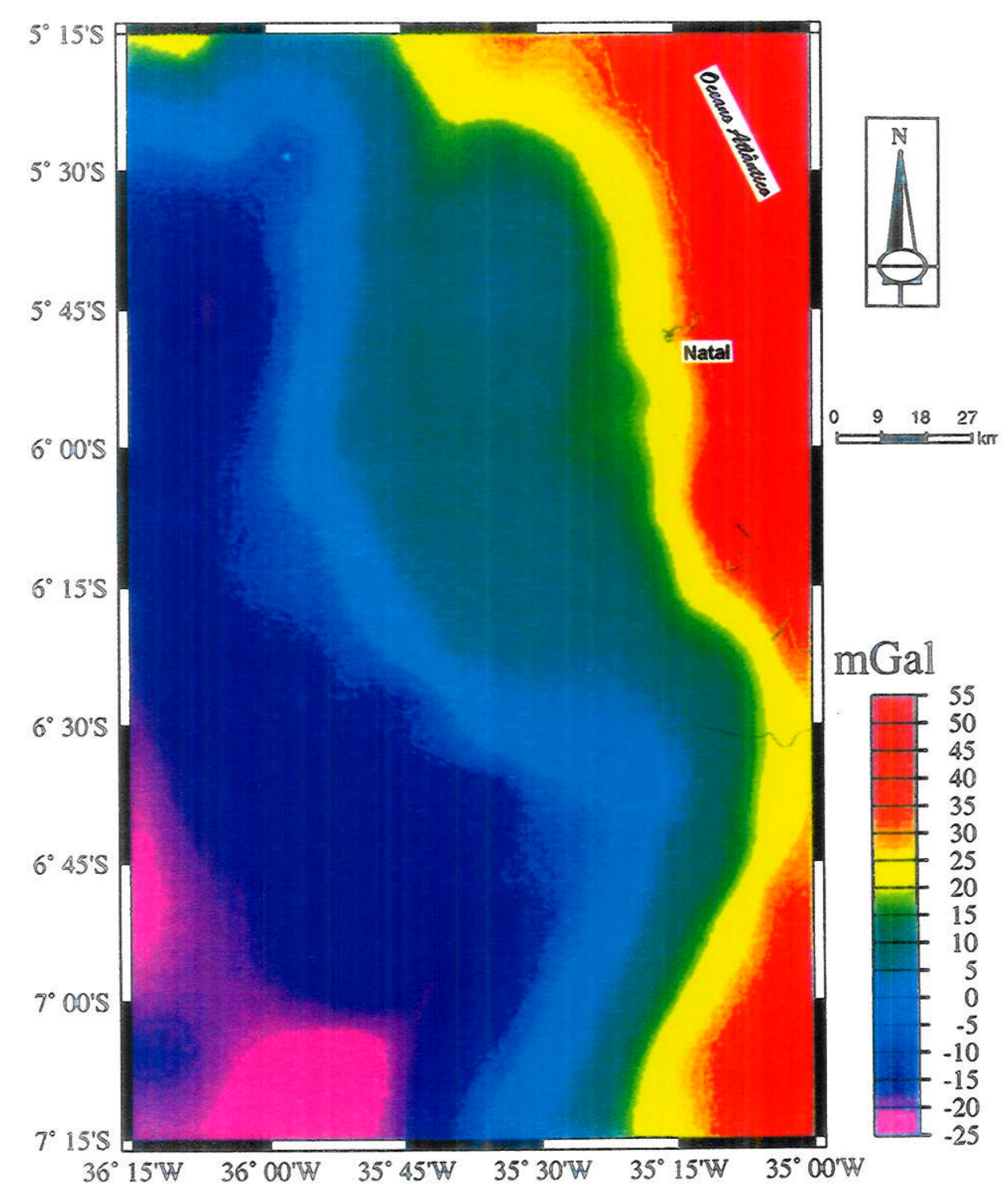

Figura 7.14 - Mapa de anomalias gravimétricas obtidas a partir de filtragem no domínio espaço-temporal com filtro quadrado de $\lambda=10 \mathrm{~km}$. 
ruptura/rifteamento da crosta anisotrópica, controlado pelas extensas zonas de cisalhamento brasilianas que atuaram como zonas de fraqueza. A distribuição e as interrelaçðes das anomalias gravimétricas em diferentes níveis de profundidade sugerem a partição mecânica e a heterogeneidade crustal proterozóica, com prováveis reflexos na estruturação litosférica. Duas faixas de gradientes positivos foram destacadas: (i) a primeira acompanha a linha da costa com valores de $12 \mathrm{mGal} / \mathrm{km}$ em direção ao oceano, iniciando aproximadamente no contato entre o embasamento cristalino e as coberturas sedimentares; (ii) a segunda faixa inicia no contato leste da Faixa Seridó com o embasamento, decorrente do setor com trend NE da ZCPJC, defletindo para SE na borda sudeste do granitóide Barcelona acompanhando a ZCT, passando a nordeste do granitóide Monte das Gameleiras e a sul do DLD; nesta região, na altura do paralelo $06^{\circ} 30^{\prime} \mathrm{S}$, as duas faixas tornam-se paralelas e seguem na direção ZCCG e zonas subsidiárias. Esta faixa contém a isolinha de $0,0 \mathrm{mGal}$ separando dois grandes blocos: um positivo para ENE, provavelmente menos espesso, englobando o bloco arqueano do MSJC e o MCB; e outro negativo para WSW, provavelmente mais espesso, formado pelos blocos paleoproterozóicos do MSJC e parte do sistema ZCRP-ZCCG. Como tais feições estão presentes em todos os mapas residuais confeccionados, desde aquele para comprimentos de onda de $200 \mathrm{~km}$ (Fig. 7.9), sugere-se que o afinamento afete desde níveis litosféricos. $O$ fato da faixa que contém a isolinha zero coincidir com algumas zonas de cisalhamento brasilianas é mais uma indicação de que parte do sistema de zonas de cisalhamento possuem raizes litosféricas e podem representar o retrabalhamento intracontinental de zonas de sutura entre blocos alóctones amalgamados em diversos episódios.

As principais feições observadas nos mapas de 5 e $1 \mathrm{~km}$ (Fig. 7.15 e 7.16, respectivamente) são similares, destacando-se o aumento do ruído à medida que diminuem os comprimentos de onda empregados nas filtragens (diminuição da profundidade na crosta), sobretudo nos mapas com comprimentos de onda inferiores a $30 \mathrm{~km}$, profundidade média teórica da Moho atual para a região (Ussami et al.1993, Castro et al. 1997a). Tais ruídos são decorrentes da intensificação das anomalias intracrustais relativas à estruturação da crosta no Brasiliano. Nos mapas entre 50 e $5 \mathrm{~km}$ (Fig. 7.10 a 7.15), a deflexão das anomalias positivas diminui sua abrangência concentrando-se no eixo positivo relacionado 


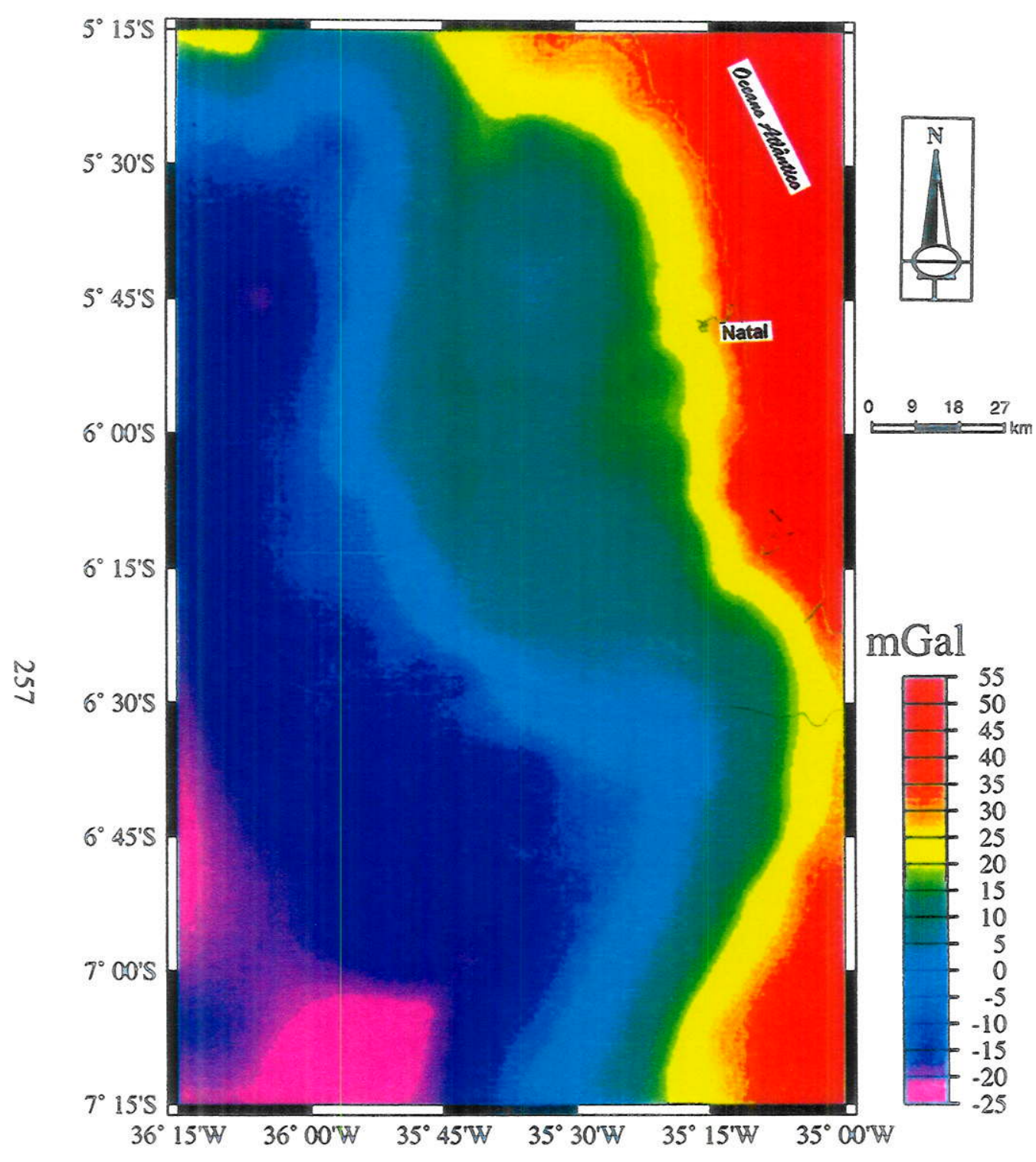

Figura 7.15 - Mapa de anomalias gravimétricas obtidas a partir de filtragem no domínio espaço-temporal com filtro quadrado de $\lambda=5 \mathrm{~km}$.

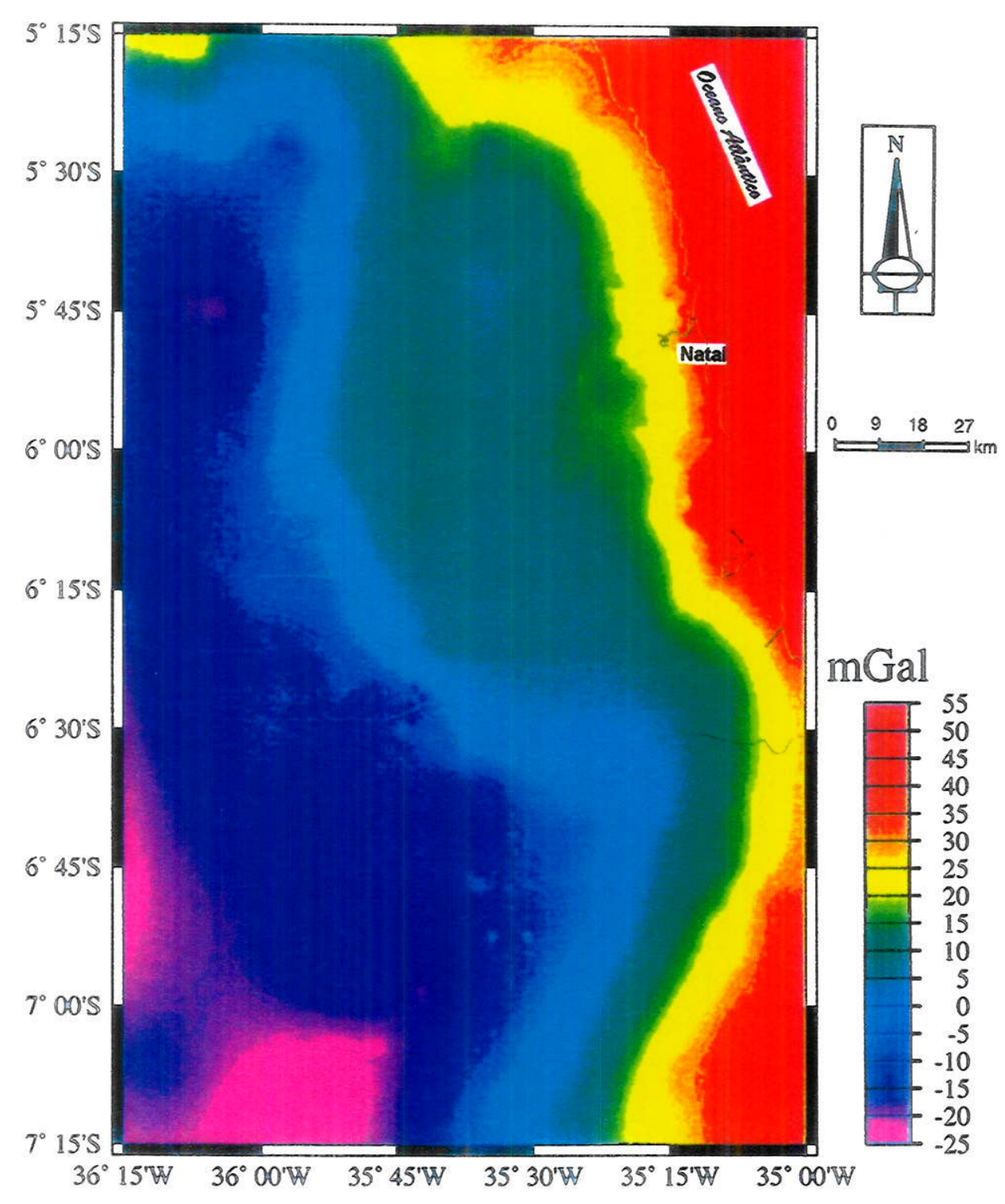

Figura 7.16 - Mapa de anomalias gravimétricas obtidas a partir de filtragem no domínio espaço-temporal com filtro quadrado de $\lambda=1 \mathrm{~km}$. 
às ZCLP e ZCBJ coalescentes à ZCPJC, e à correlação de corpos densos nesses níveis crustais.

Nos mapas inferiores a $30 \mathrm{Km}$ (Fig. 7.12 a 7.16) destaca-se o baixo gravimétrico relativo delineando a região de Taipu-Ielmo Marinho, com a maior amplitude negativa centrada no granito Taipu. Algumas anomalias positivas (15-20 mGal) acompanham as ZCBJ e ZCLP delineando o bloco arqueano.

As anomalias negativas da porção central da Faixa Seridó e do plúton Totoró foram diferenciadas nos mapas com comprimentos de onda inferiores a $30 \mathrm{~km}$, o mesmo ocorrendo para o granito Pocinhos. Entretanto, os granitóides Monte das Gameleiras e Dona Inês foram somente delineados a partir dos mapas de comprimentos de onda inferiores a 20 $\mathrm{km}$. Os demais granitos e faixas de metapelitos não foram destacados nos mapas residuais para esses comprimentos de onda. A isolinha de contorno-zero acompanha a orientação NE da ZCCG na borda oriental do CCG. As isolinhas positivas com trend NE acompanham o limite do bloco no extremo SSE da área, sugerindo que o sistema separa diferentes blocos crustais, onde extensas anomalias positivas marcam a estruturação do MCB (ou terreno Alto Pajeú, Santos 1996).

Os mapas das Fig. 7.17, 7.18, 7.19, 7.20, 7.21 e 7.22 correspondem aos resíduos obtidos pela remoção dos mapas de comprimentos de onda de $200 \mathrm{~km}, 50 \mathrm{~km}, 40 \mathrm{~km}, 30$ $\mathrm{km}, 20 \mathrm{~km}$ e $10 \mathrm{~km}$ (Fig. 7.9, 7.10,7.11, 7.12, 7.13 e 7.14, respectivamente) das anomalias Bouguer. Desta forma, os mapas residuais resultantes contém a somatória das anomalias de componentes de comprimentos de onda variados na dimensão e amplitude, desde as partes mais rasas da crosta até aquelas do comprimento de onda limite, pois os comprimentos de onda maiores que este foram eliminados no mapa residual inicial. Estes mapas residuais apresentaram anomalias em maior número e com maior detalhe do que os mapas resultantes dos filtros passa-banda e passa-alta no domínio da freqüência. As anomalias foram delineadas com as formas precisas e coincidentes com os elementos geológicos de superficie, como os granitóides e zonas de cisalhamento. As anomalias de comprimentos de onda curtos tendem à coalescência com o aumento da profundidade, compondo anomalias e eixos de anomalias condicionados ao sistema de estruturas brasilianas. Este fato é mais um indício de que as fontes e a deformação cisalhante representam a anisotropia em 


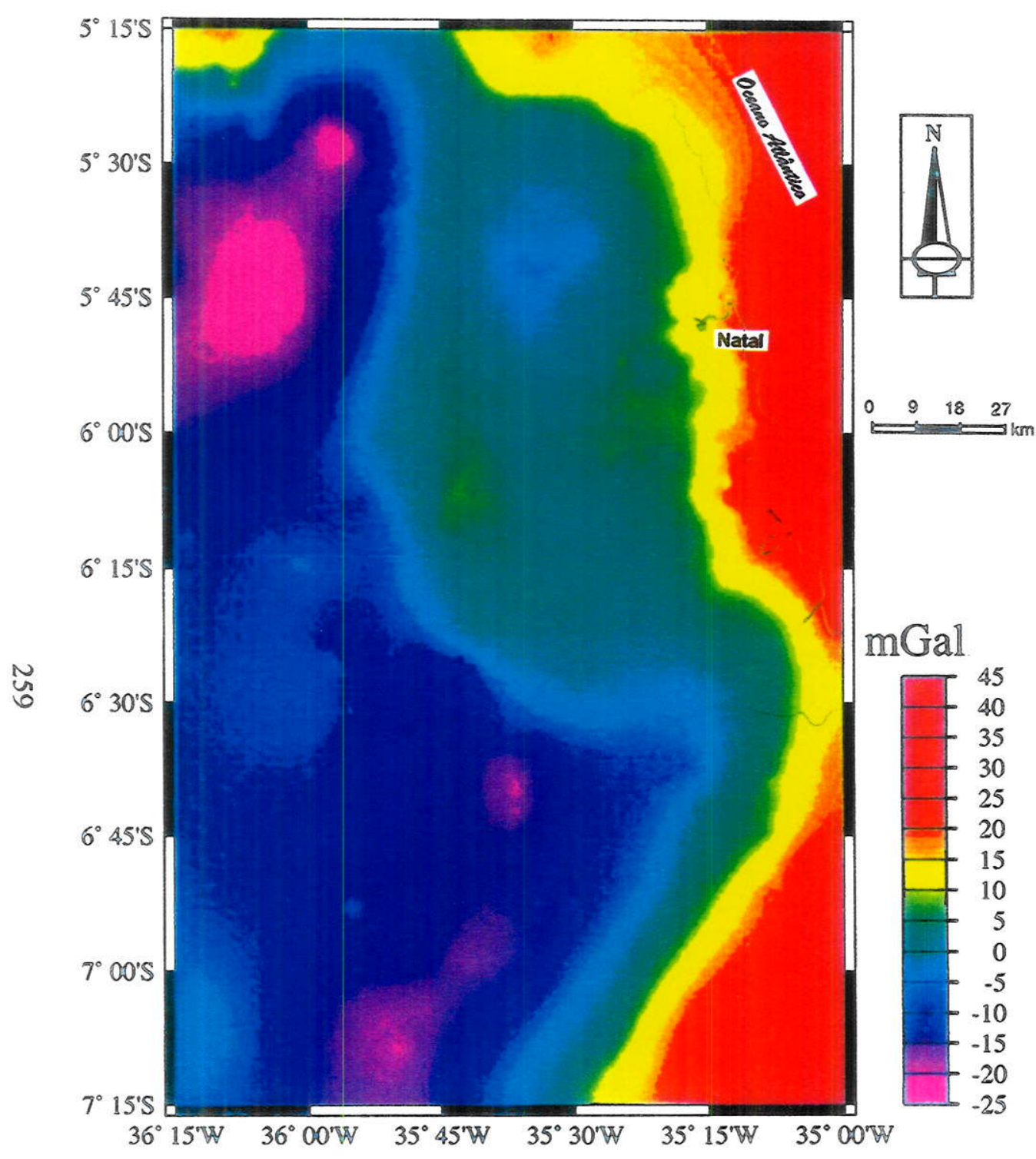

Figura 7.17 - Mapa de anomalias gravimétricas obtidas a partir do resíduo de filtragem no domínio espaço-temporal com filtro quadrado de $\lambda=200 \mathrm{~km}$.

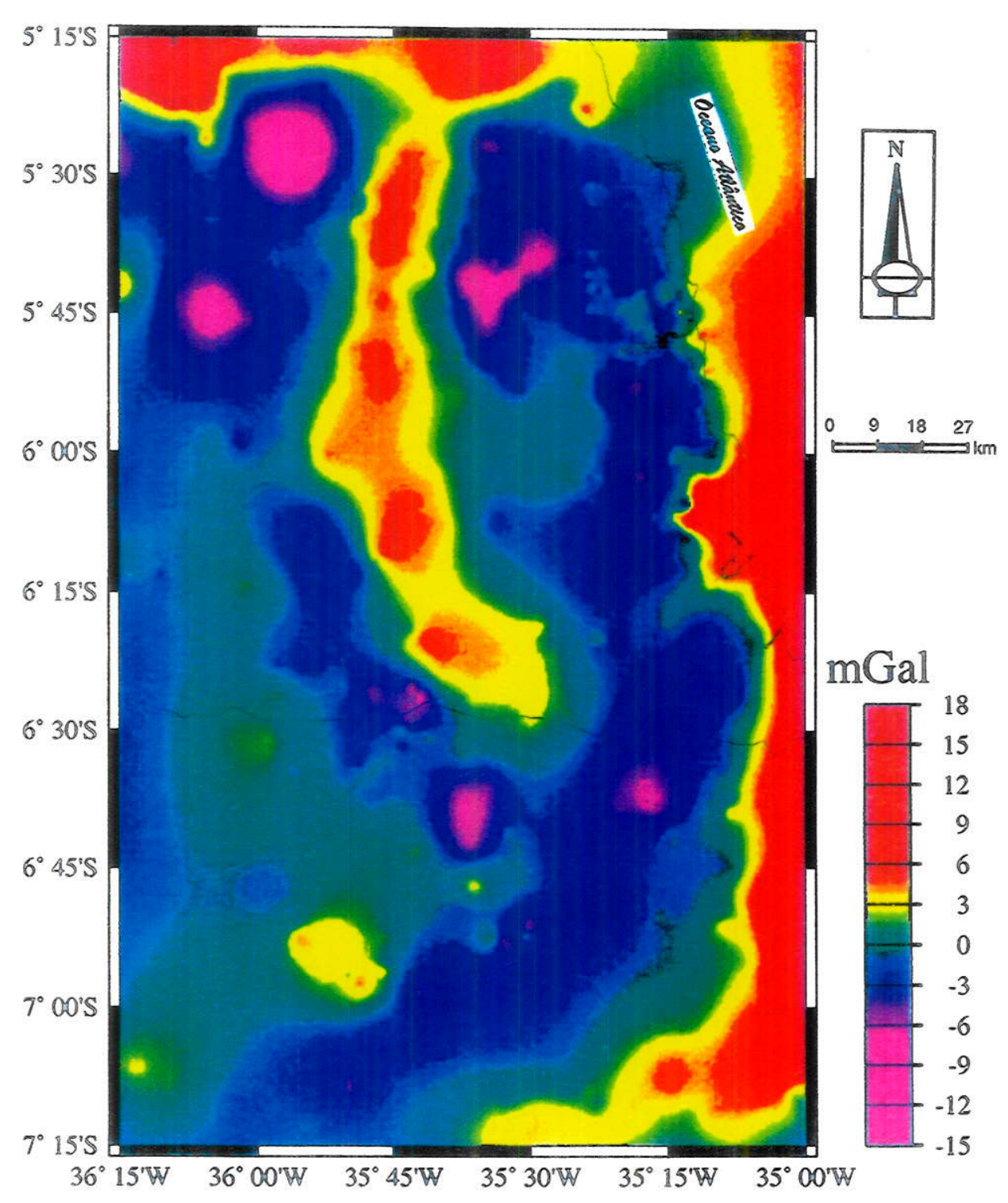

Figura 7.18 - Mapa de anomalias gravimétricas obtidas a partir do resíduo de filtragem no domínio espaço-temporal com filtro quadrado de $\lambda=50 \mathrm{~km}$. 


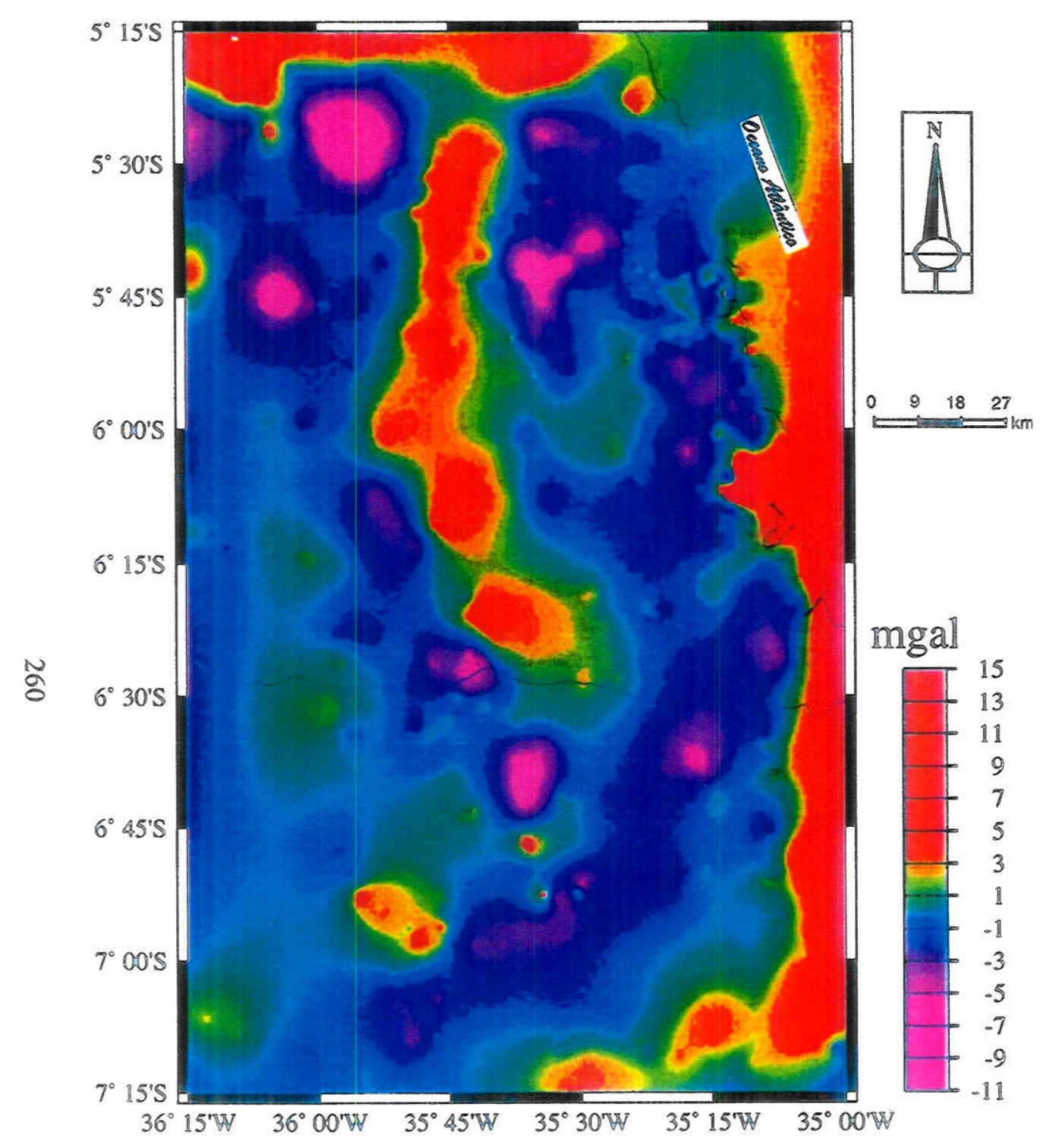

Figura 7.19- Mapa de anomalias gravimétricas obtidas a partir do resíduo de filtragem no domínio espaço-temporal com filtro quadrado de $\lambda=40 \mathrm{~km}$.

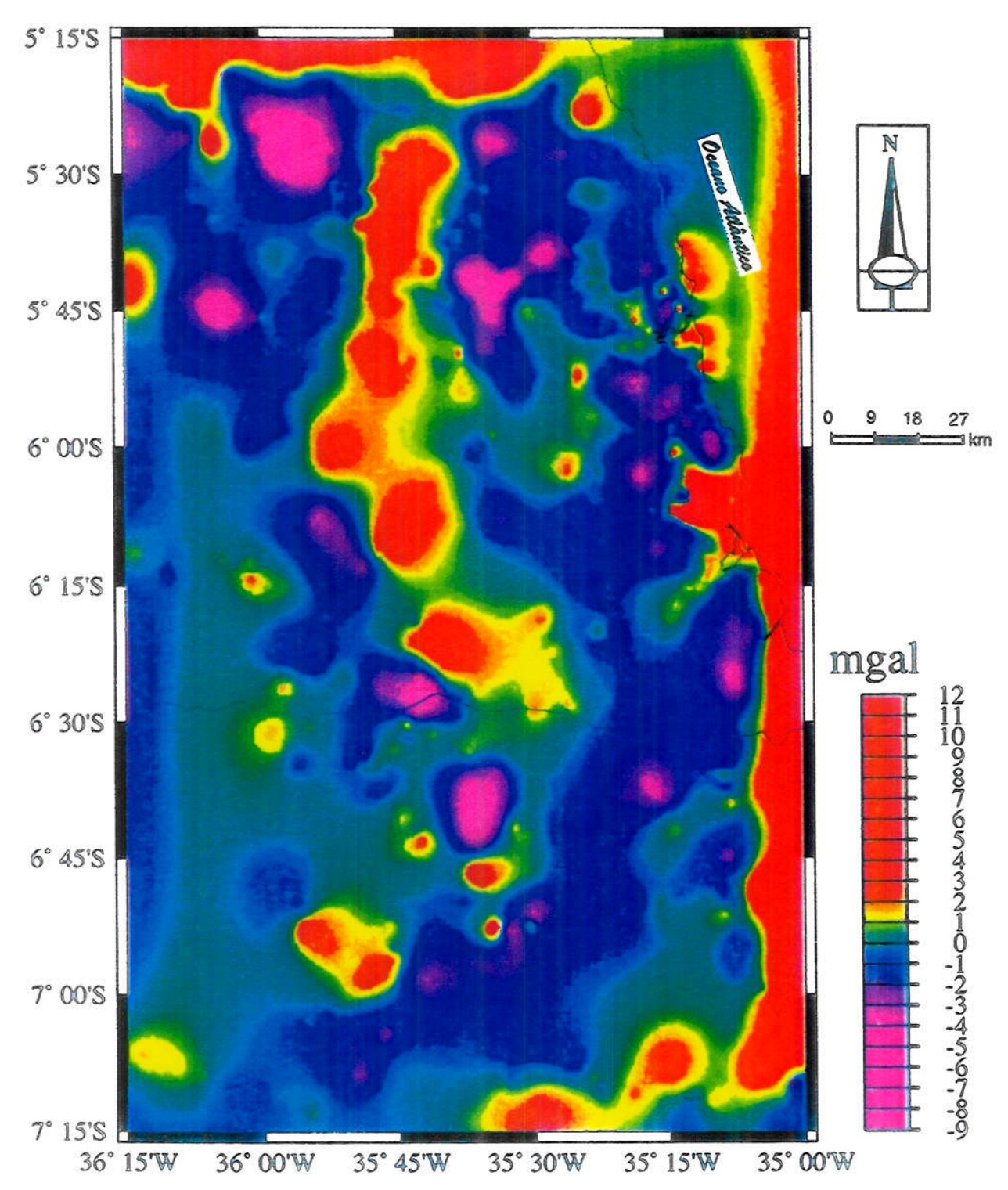

Figura 7.20- Mapa de anomalias gravimétricas obtidas a partir do resíduo de filtragem no domínio espaço temporal com filtro quadrado de $\lambda=30 \mathrm{~km}$. 


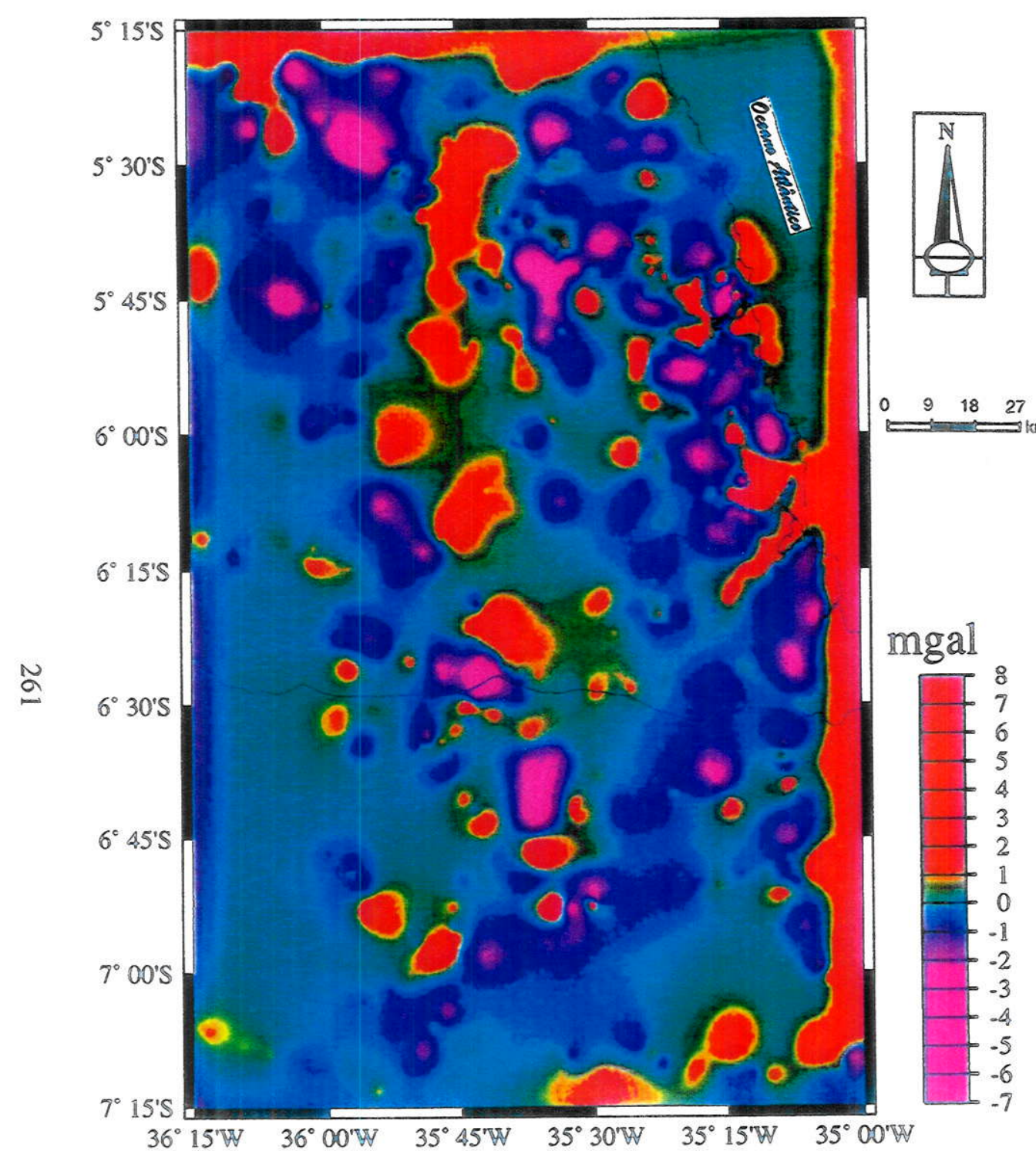

Figura 7.21 - Mapa de anomalias gravimétricas obridas a partir do resíduo de filtragem no domínio espaçoremporal com filtro quadrado de $\lambda=20 \mathrm{~km}$.

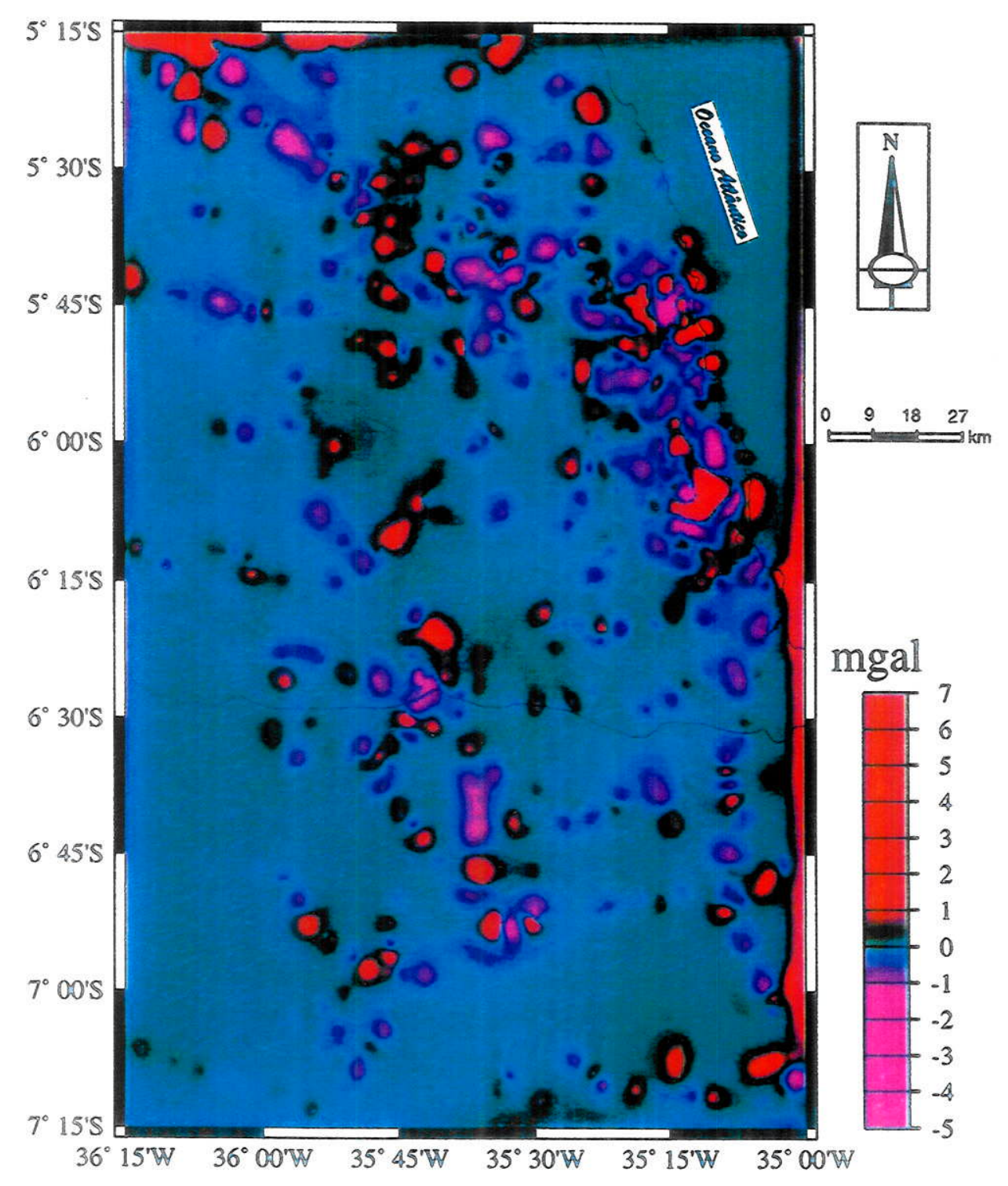

Figura 7.22- Mapa de anomalias graviméricas obtidas a partir do resíduo de filtragem no domínio espaço-temporal com filtro quadrado de $\lambda=10 \mathrm{~km}$. 
profundidades litosféricas, decorrentes da estruturação brasiliana fossilizada na litosfera estável atual.

As principais anomalias, já descritas anteriormente, foram mantidas desde os mapas residuais de 50 e $40 \mathrm{~km}$, sobretudo as anomalias e os extensos eixos de anomalias positivas que acompanham o sistema anastomosado de zonas de cisalhamento e os granitóides de Areia, Algodão, Caxexa e CCG, e os baixos gravimétricos sobre os granitóides de Poço Branco.

Na Faixa Seridó um alto gravimétrico se destaca ZCLCC, desde o mapa residual de $50 \mathrm{~km}$ (Fig. 7.18) até os de comprimentos de onda de $10 \mathrm{~km}$ (Fig. 7.22), sugerindo que os efeitos deformacionais associados aos transpurrões afetaram desde profundidades do manto litosférico. Uma anomalia positiva coincide com a continuidade da orientação NNW e NNE dos transpurrões da faixa sob as coberturas sedimentares. Outras anomalias positivas ocorrem assinalando os domos transpressionais $F_{3}$ no interior da faixa, sugerindo que os efeitos combinados do regime transpressional provocaram a heterogeneidade da crosta brasiliana pela deformação e soerguimento da Moho e/ou instalação de magmas básicos na base dos domos e a canalização pelas zonas de cisalhamento.

Algumas anomalias positivas de curtos comprimentos de onda ocorrem acompanhando a ZCBJ nos mapas residuais inferiores a $40 \mathrm{~km}$ (Fig. 7.19 a 7.22). Nos mapas residuais de 30 e $20 \mathrm{~km}$ (Fig. 7.20 e 7.21), tais anomalias constituem um eixo de trend NW interligando o eixo principal de anomalias positivas, no setor central do bloco arqueano, à região das lagoas do Bonfim e Guaraira. Este fato corrobora à sugestão que a heterogeneidade crustal alcançada pela intensa deformação no Brasiliano permaneceu controlando a evolução crustal da região, no tempo geológico, condicionando os processos de reativação das estruturas principais até o presente.

A porção central do bloco arqueano está delineada por anomalias positivas desde os mapas residuais para comprimentos de onda de $50 \mathrm{~km}$, com orientação NNE sob as coberturas sedimentares na parte norte dos mapas, infletindo para SE nas proximidades da ZCLP, permanecendo até o DLD. O eixo positivo envolve a área do diorito Serrinha separando-o do baixo gravimétrico do batólito Monte das Gameleiras por um gradiente íngreme de orientação NW, marcado pela ZCSSB. 
Na região do plúton Japi, as anomalias são positivas nos mapas de comprimentos de onda de 50 a $30 \mathrm{~km}$ (Fig. 7.18 a 7.20), acompanhando o gradiente positivo da ZCJ. Entretanto, no mapa para $20 \mathrm{~km}$ (Fig. 7.21) ocorre um alto gravimétrico de comprimentos de onda curtos concentrados na áreas onde predominam as suites básico-intermediárias, enquanto uma anomalia negativa maior define o restante do corpo alcalino.

Um eixo de anomalias positivas ocorre no extremo sudeste da área, presente nos mapas desde comprimentos de onda de $50 \mathrm{~km}$, condicionados à orientação NE das zonas de cisalhamento sinistrais do MCB. Nos mapas de comprimentos de onda inferiores a $30 \mathrm{~km}$ (Fig. 7.20 a 7.22), esta ampla anomalia se desagrega em altos gravimétricos de curtos comprimentos de onda que formam um eixo de trend ENE, subparalelo aos plútons do CCG e às faixas granulíticas e migmatizadas da ZCCG. Esta disposição das anomalias acompanha a estruturação do MCB, e o seu limite com o sistema ZCRP-ZCCG.

\section{3 - Mapa de Lineamentos dos Gradientes Aeromagnéticos}

Ao mapa de intensidade magnética total foi adicionado um componente de iluminação direcional de $135^{\circ} \mathrm{Az}$ e $80^{\circ}$ de inclinação, obtido por técnicas de realce dos gradientes por sombreamento. Além de eliminar os artefatos das linhas de vôo NS, a imagem de relevo aeromagnético sombreado delineou a extensiva deformação dúctil da área, propiciando a visualização abrangente dos principais elementos da estruturação crustal brasiliana na região, de forma mais precisa que o mapa de intensidade magnética total e os mapas de anomalias gravimétricas regionais e residuais. O mapa de relevo sombreado foi combinado a todos os mapas regionais e residuais elaborados, de maneira a manter a correlação entre os componentes deformacionais dúcteis maiores da área e as diferentes profundidades crustais estimadas pelo método de Dobrin (1976) e inferidas pelas filtragens. Do mesmo modo que para as anomalias residuais mapeadas, o limite de deteç̧ão da extensão dos gradientes realçados no sombreamento depende da distância entre as linhas de vôo e da malha de interpolação, sendo aproximadamente de $550 \mathrm{~m}$.

O mapa de lineamentos da Fig. 7.23 foi confeccionado a partir do mapa de relevo sombreado, destacando os gradientes íngremes e os limites entre os altos e baixos magnéticos. As direções NE e NW dominantes nos lineamentos coincidem com o fabric $\mathrm{D}_{3}$ (foliações e lineações) e com o sistema de zonas de cisalhamento brasilianas. Todas as 


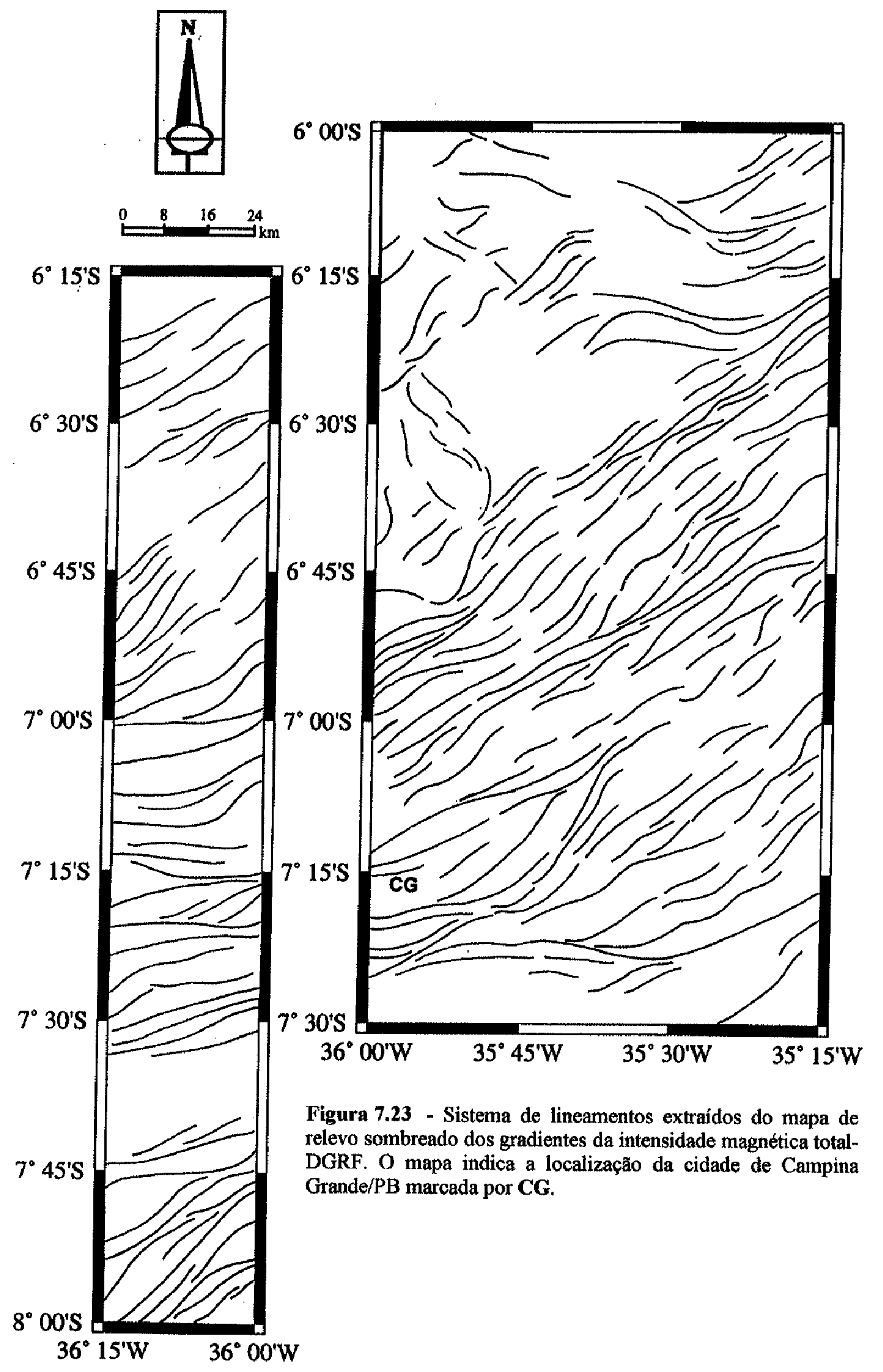


principais zonas de cisalhamento foram identificadas através dos gradientes magnéticos com dezenas a centenas de quilômetros de extensão e larguras quilométricas, por vezes associadas a anomalias não-lineares relacionadas aos granitóides brasilianos. As zonas de cisalhamento foram delimitadas, independente do estilo do elipsóide de strain e do regime de cisalhamento predominante (cisalhamento puro, simples ou geral). $O$ destaque na linearidade dos gradientes magnéticos foi menos evidente no interior dos blocos arqueano $\mathrm{e}$ paleoproterozóicos, concentrando-se em suas margens. Tais evidências podem ser interpretadas como a correspondência direta entre a deformação $D_{3}$ e as anomalias magnéticas nos processos de estruturação crustal dessa região no Brasiliano, concentradas no sistema de zonas de cisalhamento que delimitam os blocos mais antigos.

A utilização da amplitude máxima dos sinais decorrentes dos métodos potenciais, sobretudo da magnetometria, na localização de limites estruturais de blocos, geralmente marcados por sistemas de falhas e zonas de cisalhamento, possui a grande vantagem dos resultados serem independentes dos parâmetros do campo geomagnético e da direção das fontes de magnetização, não sendo necessária a distinção entre magnetização induzida e remanescente (Roest et al. 1992, Roest \& Pilkington 1993, Hsu 1996).

\section{4 - Correlações Entre as Anomalias Aeromagnéticas e as Feições Geológicas}

O mapa residual da Fig. 7.24 é o resultado do filtro passa-banda que permitiu a passagem de comprimentos de onda entre 80 e $250 \mathrm{~km}$, rejeitou comprimentos de onda maiores que $600 \mathrm{~km}$ e menores que $30 \mathrm{~km}$, sendo os valores intermediários cosine-tapered. A feição de maior destaque é a anomalia positiva de amplitude $85 \mathrm{nT}$ e médios a grandes comprimentos de onda, de direção $\mathrm{EW}$ virgando para $\mathrm{NE}$, que corresponde ao sistema ZCRP-ZCCG. Os flancos da anomalia são controlados a norte-noroeste pela ZCRP, e um de seus ramos a ZCCC, e a sul-sudeste pelas ZCCG e ZCGB na região do $\mathrm{CCG}$, composto dominantemente por quartzo-monzonitos a granodioritos porfiríticos associados a dioritos e quartzo-dioritos, delineadas pelos gradientes lineares positivos nas bordas da anomalia. Esta anomalia positiva separa duas anomalias negativas de amplitudes e comprimentos de onda similares, acompanhando o fabric $\mathrm{D}_{3}$ regional de direção NE. Para norte, a anomalia negativa envolve a região dos blocos paleoproterozóicos (MSJC), intrudidos pelos granitóides Caxexa, Japi, Monte das Gameleiras e Serrinha, do DLD e a poção SE dos 


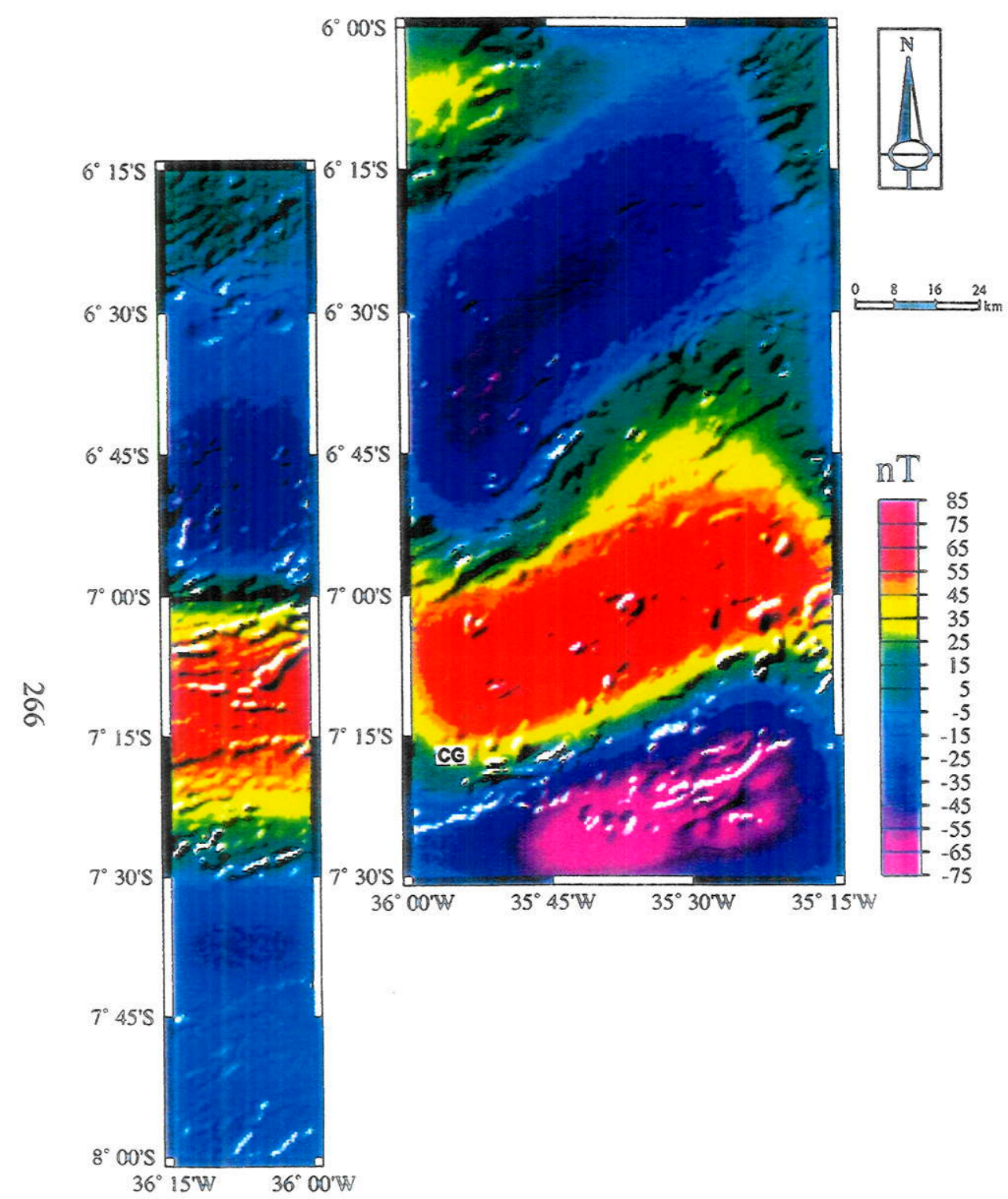

Figura 7.24- Mapa de anomalias aeromagnéticas obtidas a partir da filtragem no domínio da freqüência com filtro passa-banda que permite a passagem de $80 \mathrm{~km}<\lambda<250 \mathrm{~km}$, rejeita $\lambda>600 \mathrm{~km}$ e $\lambda<30 \mathrm{~km}$ e cosine-roppered os valores intermediários. O mapa indica a localizacão da cidade de Campina Grande/PB marcada por CG. $\lambda=$ Comprimento de onda.

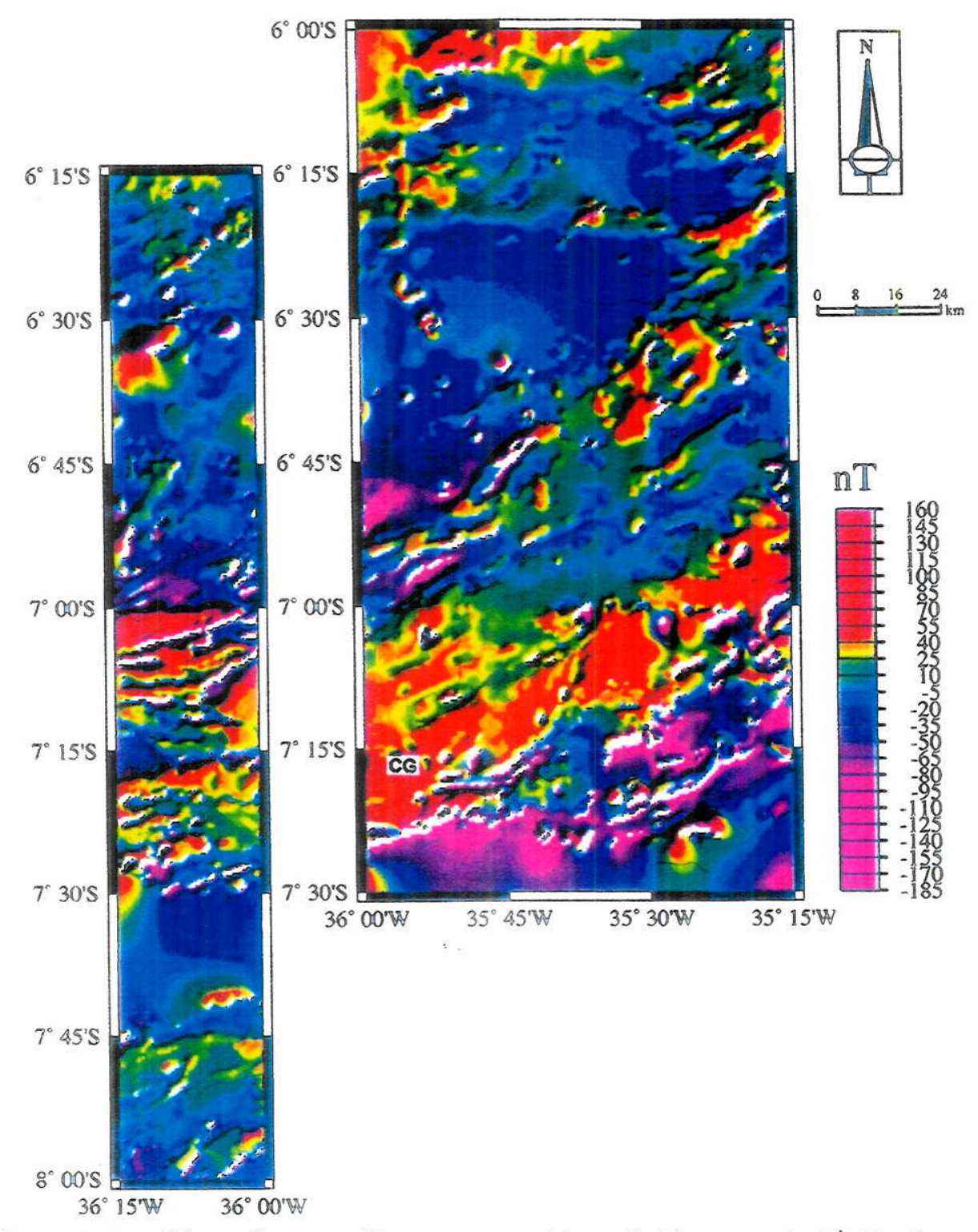

Figura 7.25- Mapa de anomalias aeromagnéticas obtidas a partir dé filtrágem no domínio da freqüência com filltro passa-alta que permite a passagem de $\lambda<50 \mathrm{~km}$, rejeita $\lambda>250 \mathrm{~km}$ e cosine-iopered os valores intermediários. 
blocos arqueanos. No extremo NW da área estão assinaladas anomalias positivas de amplitude média sobre os blocos arqueanos e as ZCT e ZCLP. No extremo SE da área a anomalia negativa abrange os terrenos referentes ao $\mathrm{MCB}$, cujo limite é controlado por zonas de cisalhamento sinistrais de trend $\mathrm{NE}$, que constituem um sistema anastomosado com o sistema ZCRP-ZCCG, definido por gradiente íngreme.

Para esta filtragem, a estimativa da profundidade das fontes, pelo método de aproximação por metade da largura de Dobrin (1976), sugere níveis de crosta inferior limitados pela profundidade média do ponto Curie (25-30 km) acima da Moho atual. Assim, a anomalia positiva do sistema ZCRP-ZCCG seria condizente com rochas granulitizadas associadas a corpos ígneos básico-intermediários controlados pelas zonas de cisalhamento transcorrente-extensionais. O mesmo pode ser inferido para a região dos blocos antigos, com rochas granulíticas básicas como raizes das rochas arqueanas e fontes semelhantes condicionadas às zonas de cisalhamento brasilianas. As anomalias negativas de amplitude média foram correlacionadas às prováveis raizes graníticas resultantes da intensa fusão crustal durante a deformação $\mathrm{D}_{3}$, com menores contrastes de susceptibilidade. $\mathrm{O}$ aporte de material granítico decorrente de intensa fusão crustal poderia ter causado o espessamento crustal relativo e localizado dessas áreas se, comparadas a região dos sistemas ZCRP-ZCCG.

A Fig. 7.25 é o resultado do filtro passa-alta que permitiu a passagem de comprimentos de onda menores que $50 \mathrm{~km}$, rejeitou os maiores que $250 \mathrm{~km}$ e cosine-tapered os valores intermediários. As profundidades estimadas para as fontes corresponderiam as niveis de crosta média atual (13-20 km).

A área que corresponde ao sistema ZCRP-ZCCG continua caracterizada por anomalias sigmoidais positivas de amplitudes altas, marcando a inflexão de EW para NE (terminação em splay do Lineamento Patos) acompanhando a forma dos blocos e corpos granitóides, condicionados pelas zonas de cisalhamento menores definidas pelos gradientes lineares. A ZCRP permanece delineada por anomalias positivas acompanhando as faixas de granulitos, migmatitos e corpos básico-intermediários, indicando a continuação desses corpos em profundidade. A mesma relação se observa sobre as rochas básico-intermediárias e migmatitos da região de Campina Grande, caracterizando a presença de rochas com elevado contraste em profundidade. 
As faixas de micaxistos (Barra de Santa Rosa, Duas Estradas-Pirpirituba e Araras-Cacerengo) estão assinaladas por anomalias negativas nos setores distanciados das bordas miloniticas, que são definidas pelos gradientes lineares positivos referentes às zonas de cisalhamento que conduziram a a colocação alóctone destas faixas. Os plútons Algodão, Caxexa, Japi e Dona Inês estão definidos por anomalias positivas de comprimentos de onda curtos e amplitude média, controlados pelas zonas de cisalhamento, associados às anomalias negativas de comprimentos de onda médios que envolvem os terrenos laterais. Nenhuma distinção é observada entre o granito Monte das Gameleiras e a parte sul do DLD, indicando a ausência de contraste de susceptibilidade das fontes. O granito e o diorito de Serrinha são definidos pelo alinhamento de anomalias positivas curtas, designando suas prováveis raizes básicas.

A região dos blocos arqueanos é caracterizada por anomalias negativas e longas, associadas às anomalias positivas e curtas, todas de baixa amplitude, diretamente relacionadas aos tipos litológicos de menor ou maior susceptibilidade em profundidade. As anomalias positivas e curtas ocorrem condicionadas aos lineamentos que correspondem às zonas de cisalhamento $\mathrm{D}_{3}$. Na porção NW dos blocos, região do granito Barcelona e das coalescências ZCT, ZCLP e ZCPJC, a anomalia positiva é maior e provavelmente indicativa de raizes básicas e/ou granutilizadas controladas por essas zonas de cisalhamento.

$\mathrm{Na}$ porção SE do mapa predominam as anomalias negativas de comprimentos de onda longos, controlados pelos gradientes lineares que marcam as zonas de cisalhamentos e acompanham a forma sigmoidal dos blocos menos afetados pela deformação $\mathrm{D}_{3}$. Algumas anomalias positivas e curtas ocorrem condicionadas aos gradientes marcadores das zonas de cisalhamento.

O mapa de anomalias residuais da Fig. 7.26 foi obtido a partir de filtro passa-alta que permitiu a passagem de comprimentos de onda inferiores a $30 \mathrm{~km}$, rejeitou os superiores a $50 \mathrm{~km}$ e cosine-tapered os valores intermediários. A Fig. 7.27 destaca as anomalias obtidas pela filtragem passa-alta que permitiu a passagem de comprimentos de onda inferiores a 10 $\mathrm{km}$, rejeitou as superiores a $30 \mathrm{~km}$ e cosine-tapered os valores intermediários. As profundidades estimadas para as fontes das anomalias foram de $8-12 \mathrm{~km}$ para a Fig. $7.26 \mathrm{e}$ inferiores a $8 \mathrm{~km}$ para a Fig. 7.27. Desta forma, ambos os mapas são complementares e 


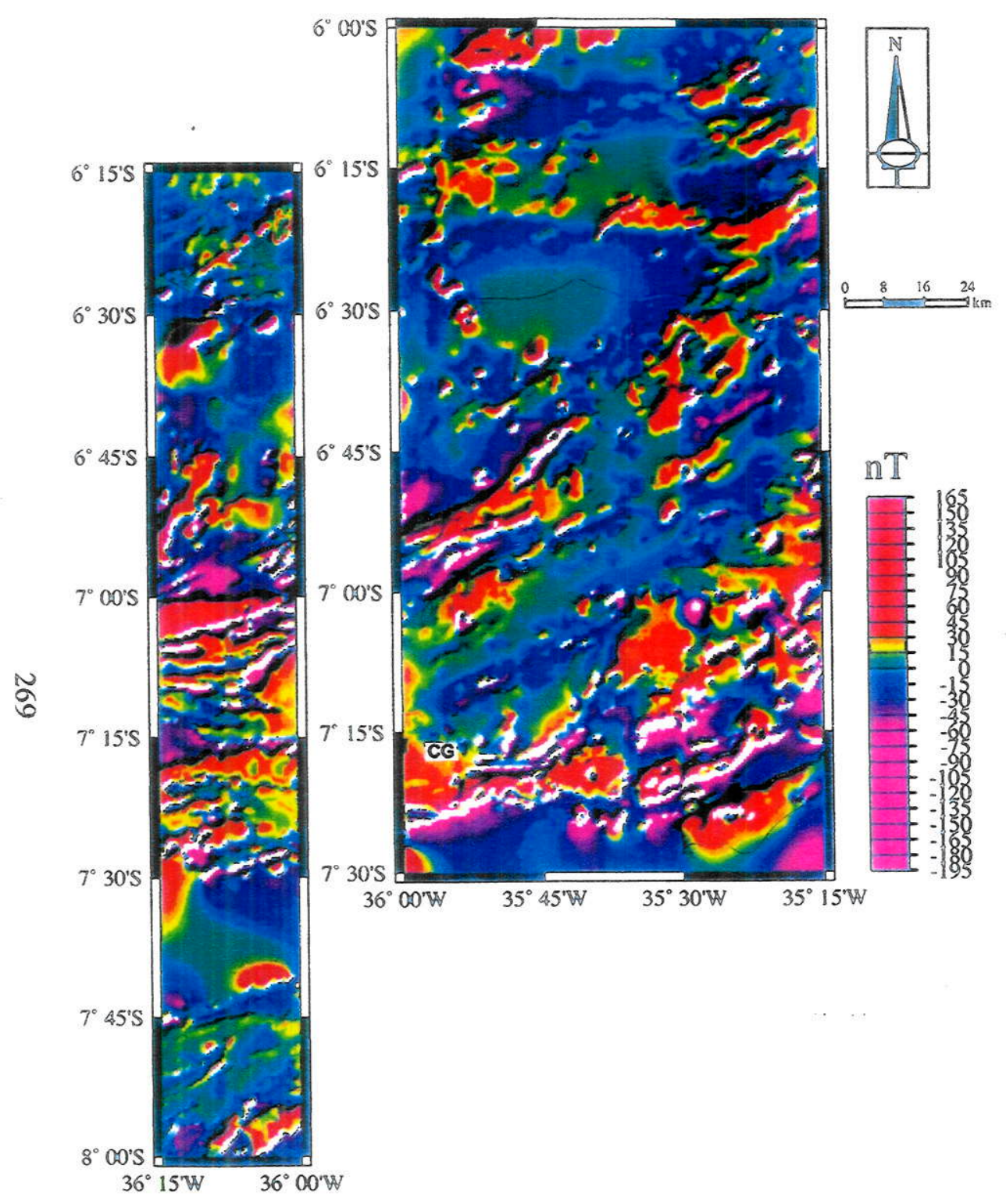

Figura 7.26 - Mapa de anomalias aeromagnéticas obtidas a partir de filtragem no domínio da freqüência com filtro passa-alta que permite a passagem de $\lambda<30 \mathrm{~km}$, rejeita $\lambda>50 \mathrm{~km}$ e cosine-iapered os valores intermediários.

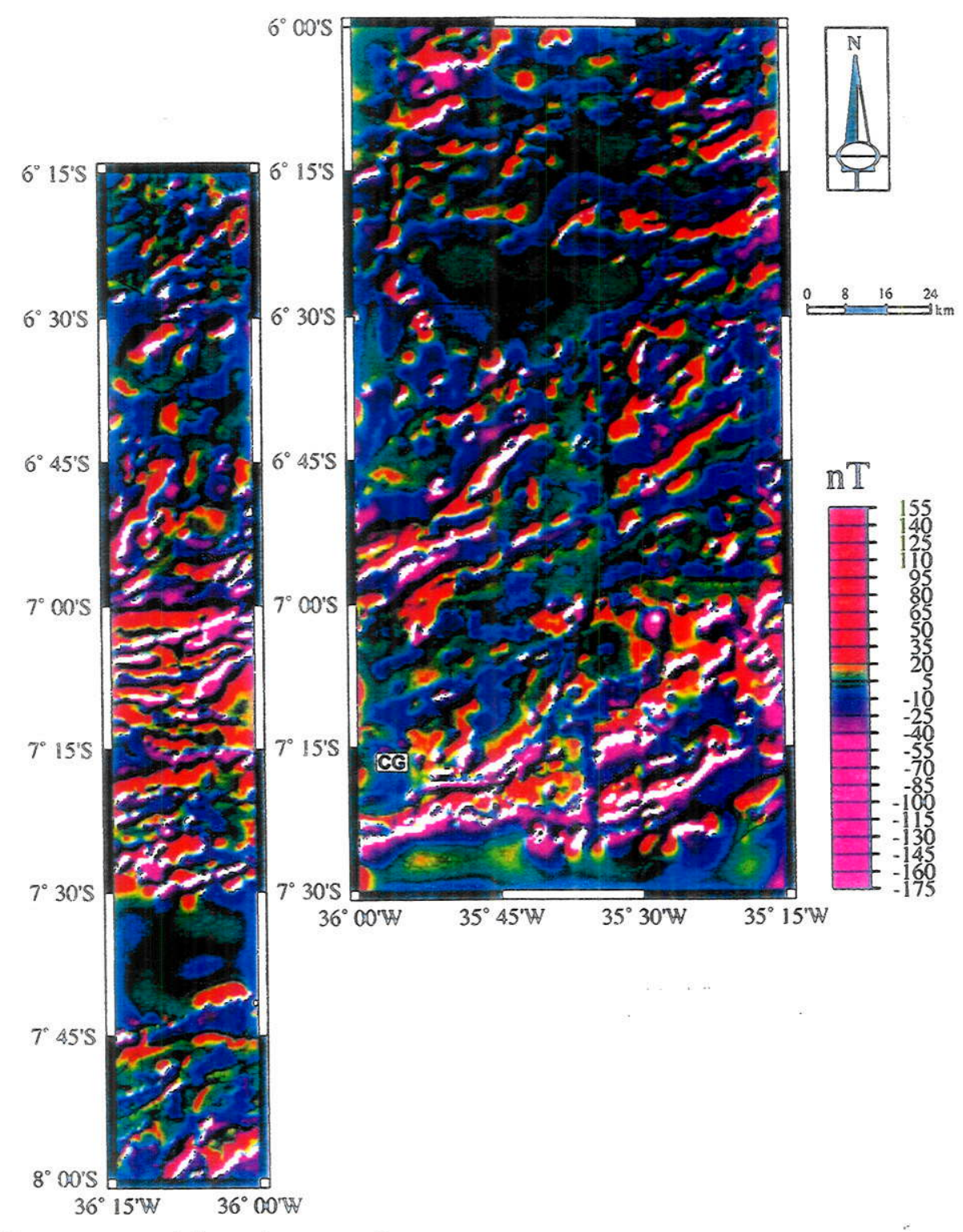

Figura 7.27- Mapa de anomalias aeromagnéticas obtidas a partir de filtragem no domínio da frequiência com filtro passa-alta que permite a passagem de $\lambda<10 \mathrm{~km}$, rejeita $\lambda>30 \mathrm{~km}$ e cosine-tapered os valores intermediários. 
destacaram anomalias com fontes localizadas, ao menos, nos niveis superiores da crosta atual.

A região do sistema ZCRP- ZCCG está definida pela associação de anomalias positivas de comprimentos de onda médios a curtos e anomalias negativas de comprimentos de onda curtos. As anomalias positivas delineiam, isoladamente, as ZCRP e a ZCCG, sobretudo a área das rochas básico-intermediárias do CCG, e parcialmente as áreas do granitóide Pocinhos. As anomalias negativas acompanham algumas zonas de cisalhamento estreitas, marcadas por diversas fatias sigmoidais de granitóides, e as faixas de metassedimentos integradas ao sistema. Desta forma, ficou caracterizada a correspondência direta entre a geologia de superficie e as anomalias decorrentes da crosta superior. As anomalias positivas marcariam a continuação dos corpos básicos-intermediários e faixas granulíticas controlados pelo sistema de zonas de cisalhamento desde a superficie até a base da crosta, enquanto as anomalias negativas estariam relacionadas ao alojamento de fundidos graníticas associadas às zonas de cisalhamento resultantes dos processos de fusão parcial.

As faixas de metapelitos (Barra de Santa Rosa, Araras-Cacerengo, Duas EstradasPirpirituba), em áreas afastadas dos limites marcados por faixas miloniticas, estão assinaladas por anomalias negativas de comprimentos de onda médios.

Os plútons Algodão, Caxexa, Japi, Areia e Barcelona estão definidos por anomalias positivas curtas e de amplitude baixa, confirmando as raizes básico-intermediárias desses corpos. Os granitóides Dona Inês, Monte das Gameleiras, Serrinha e Picuí estão marcados pela combinação de anomalias positivas, sobre os fácies básico-intermediários, e negativas curtas e de amplitude baixa sobre as porções graniticas dos corpos.

O setor do núcleo arqueano e o DLD estão caracterizados por diversas anomalias positivas e negativas de comprimentos de onda curtos e médios e amplitudes variadas. As anomalias positivas de comprimentos de onda curtos estão centradas nas áreas onde ocorrem corpos básicos-intermediários e granulíticos. Outra característica é o condicionamento das anomalias positivas às zonas de cisalhamento que delimitam o bloco arqueano e o contato com os terrenos paleoproterozóicos, indicando a presença de corpos básicos associados aos granitóides controlados pela deformação brasiliana.

A feição mais marcante nos mapas aeromagnéticos residuais (Fig. 7.28, 7.29, $7.30,7.31,7.32,7.33,7.34$ a 7.35 ), obtidos por filtragem (tipo boxcar) no domínio espaço- 


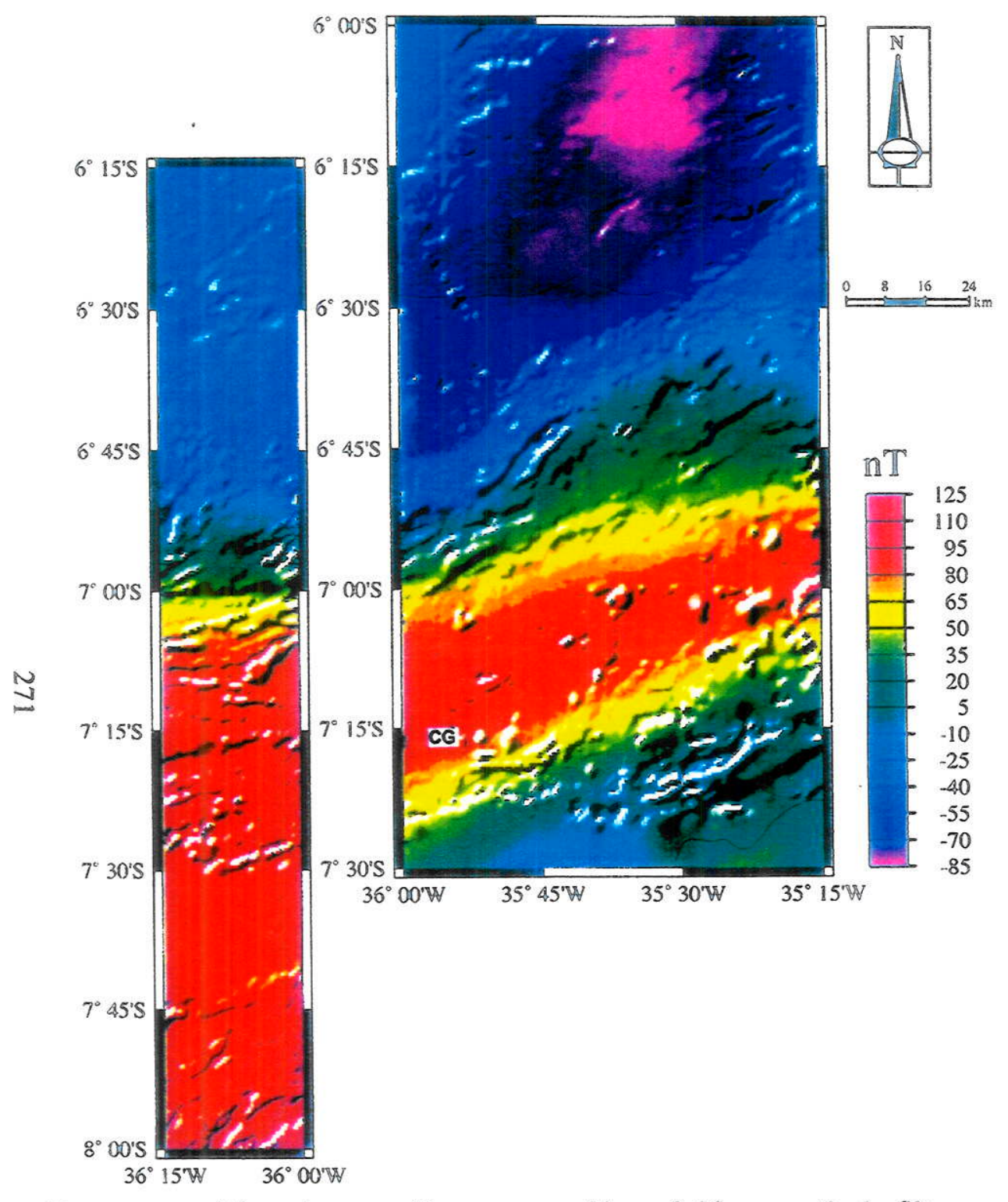

Figura 7.28 - Mapa de anomalias aeromagnéticas obtidas a partir de filtragem no domínio espaço-temporal com filtro quadrado de $\lambda=50 \mathrm{~km}$.

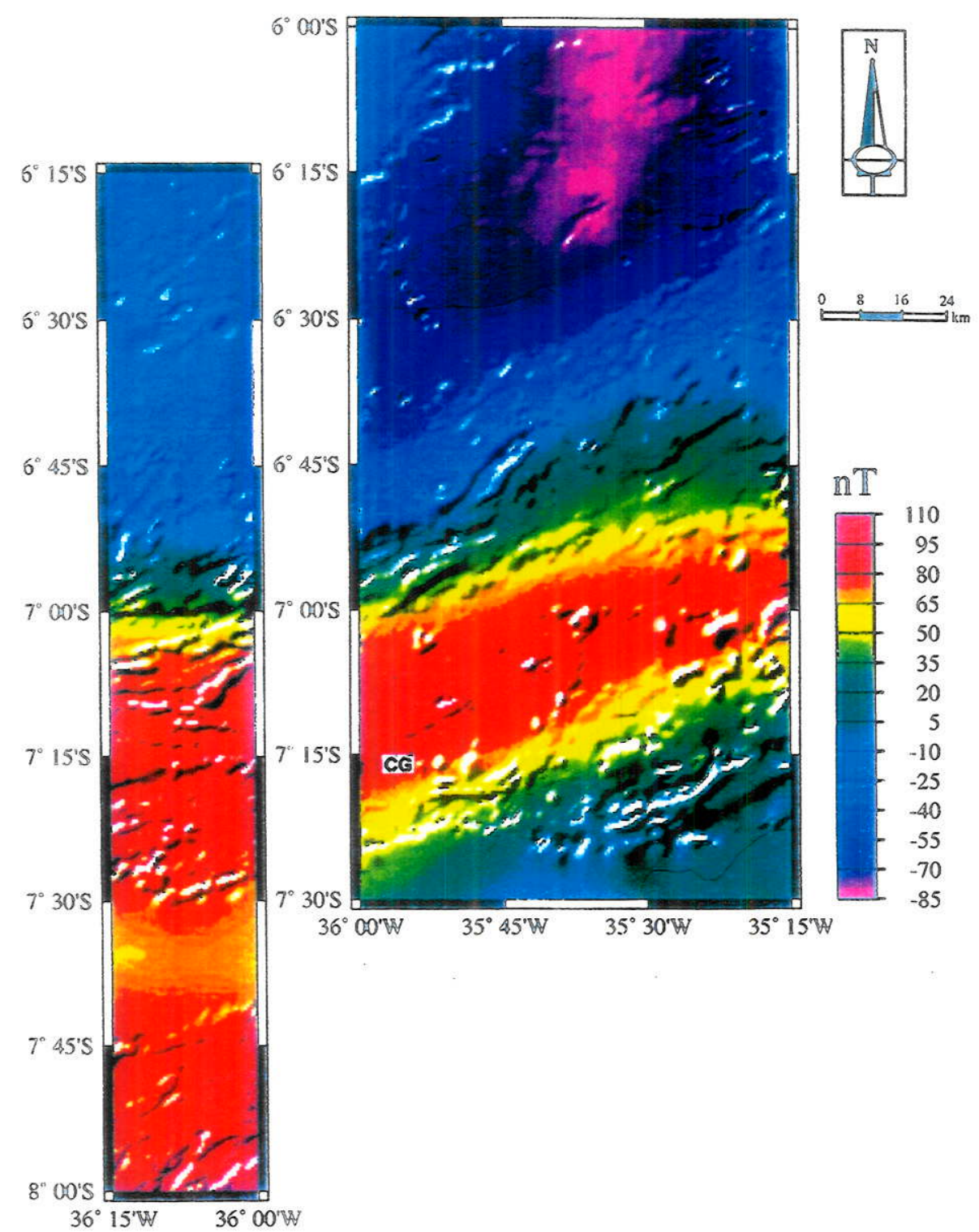

Figura 7.29 - Mapa de anomalias aeromagnéticas obtidas a partir de filtrágem no domínio espaço-temporal com filtro quadrado de $\lambda=40 \mathrm{~km}$. 


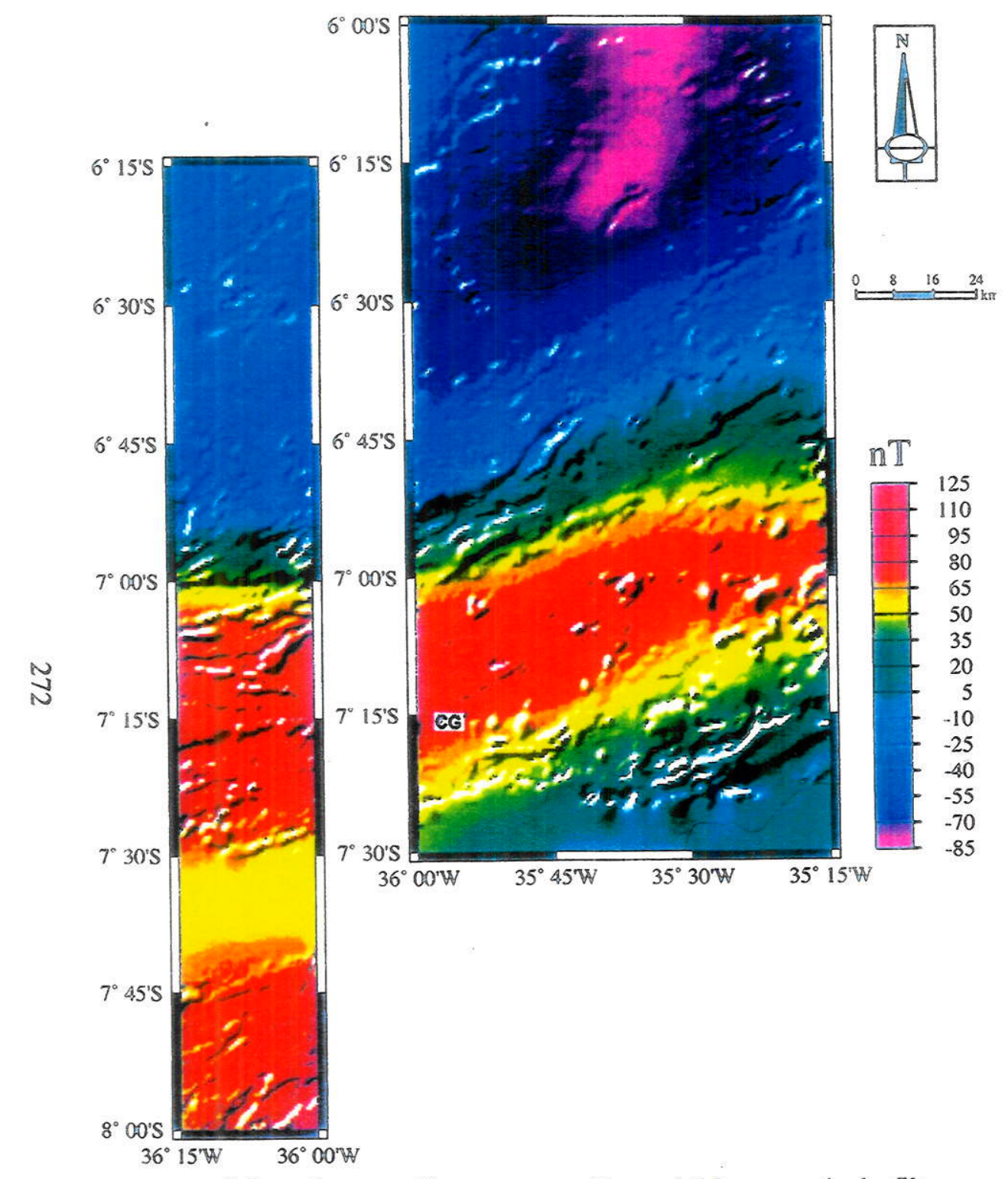

Figura 7.30 - Mapa de anomalias aeromagnéticas obtidas a partir de filtragem no domínio espaço-temporal com filtro quadrado de $\lambda=30 \mathrm{~km}$.

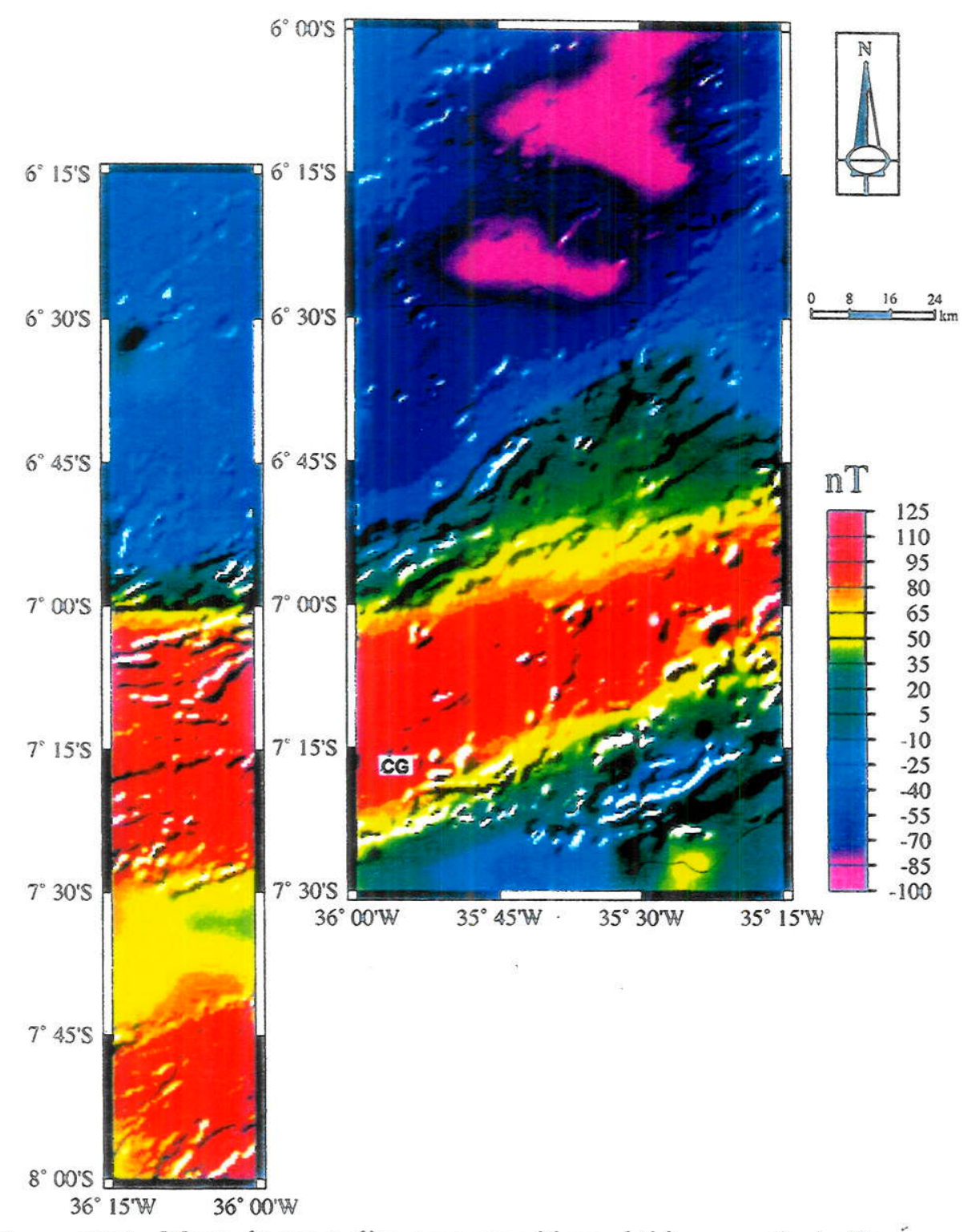

Figura 7.31 - Mapa de anomalias aeromagnéticas obtidas a partir de filtrágem no domínio espaço-remporal com filltro quadrado de $\lambda=20 \mathrm{~km}$. 
temporal, é a anomalia positiva de comprimentos de onda longos e amplitude alta, cuja direção virga de EW para NE acompanhando o sistema anostomosado das ZCRP-ZCCG, ramificações do Lineamento Patos (ZCPA). Esta feição separa dois blocos com anomalias de características diferentes: o bloco a NNW, com anomalias negativas de comprimentos de onda longos e amplitudes altas, que corresponde aos terrenos arqueanos $\mathrm{e}$ paleoproterozóicos do MSJC, onde o efeito da deformação $D_{3}$ concentra-se nas zonas de cisalhamento de direções NW e NE, e na proximidade dos granitóides brasilianos; e o bloco a SSE com anomalias positivas de comprimentos de onda longos e amplitudes baixas, sobre os terrenos que correspondem ao MCB (ou terreno Alto Pajeú, Santos 1996).

A anomalia positiva do sistema ZCRP-ZCCG mantém-se com amplitude alta e comprimentos de onda médios a longos em todos os mapas residuais (Fig. 7.28 a 7.35), sugerindo que as feições geológicas descritas em superficie, como a intensa granutilização e migmatização das faixas miloníticas, os plútons básico-intermediárias e alcalinas sin- a tarditectônicos à deformação $\mathrm{D}_{3}$, correspondem à repercussão da intensa estruturação crustal no Brasiliano, marcada pela deformação da Moho em regime transcorrente-extensional, com canalização de fluidos magmáticos e calor de fontes profundas, descrevendo a intensa influência do manto litosférico nas transformações dos diferentes níveis crustais.

Nas faixas de metapelitos associados aos granitóides sin- a tarditectônicos, as anomalias positivas de amplitude média delimitam os setores de grau metamórfico (fácies granulito) e strain mais elevados, associados às zonas de cisalhamento subverticalizadas e aos plútons alcalinos e básico-intermediários, enquanto as anomalias negativas demarcam os setores de médio grau metamórfico (fácies anfibolito) e fabric $\mathrm{D}_{3}$ subhorizontal. Nos mapas residuais para níveis crustais mais rasos (Fig. 7.33, 7.34 e 7.35), as anomalias positivas mantém a demarcação do traçado das zonas de cisalhamento de alta-T e dos plútons básicointermediários e alcalinos, sugerindo a continuidade em níveis de crosta rasa das rochas granulíticas e/ou básicas que formam as raízes desses corpos em profundidade.

As anomalias negativas sobre os blocos arqueanos permanecem com comprimentos de onda longos e amplitude elevada nos mapas de 50 a 30 km (Fig. 7.28 a 7.30), envolvendo os granitóides Japi, Caxexa, Monte das Gameleiras, Serrinha e o DLD, Essa feição carateriza a ausência de contraste de susceptibilidade entre as rochas que constituem as raizes dos granitóides e do domo, com relação a bases dos blocos arqueanos. 


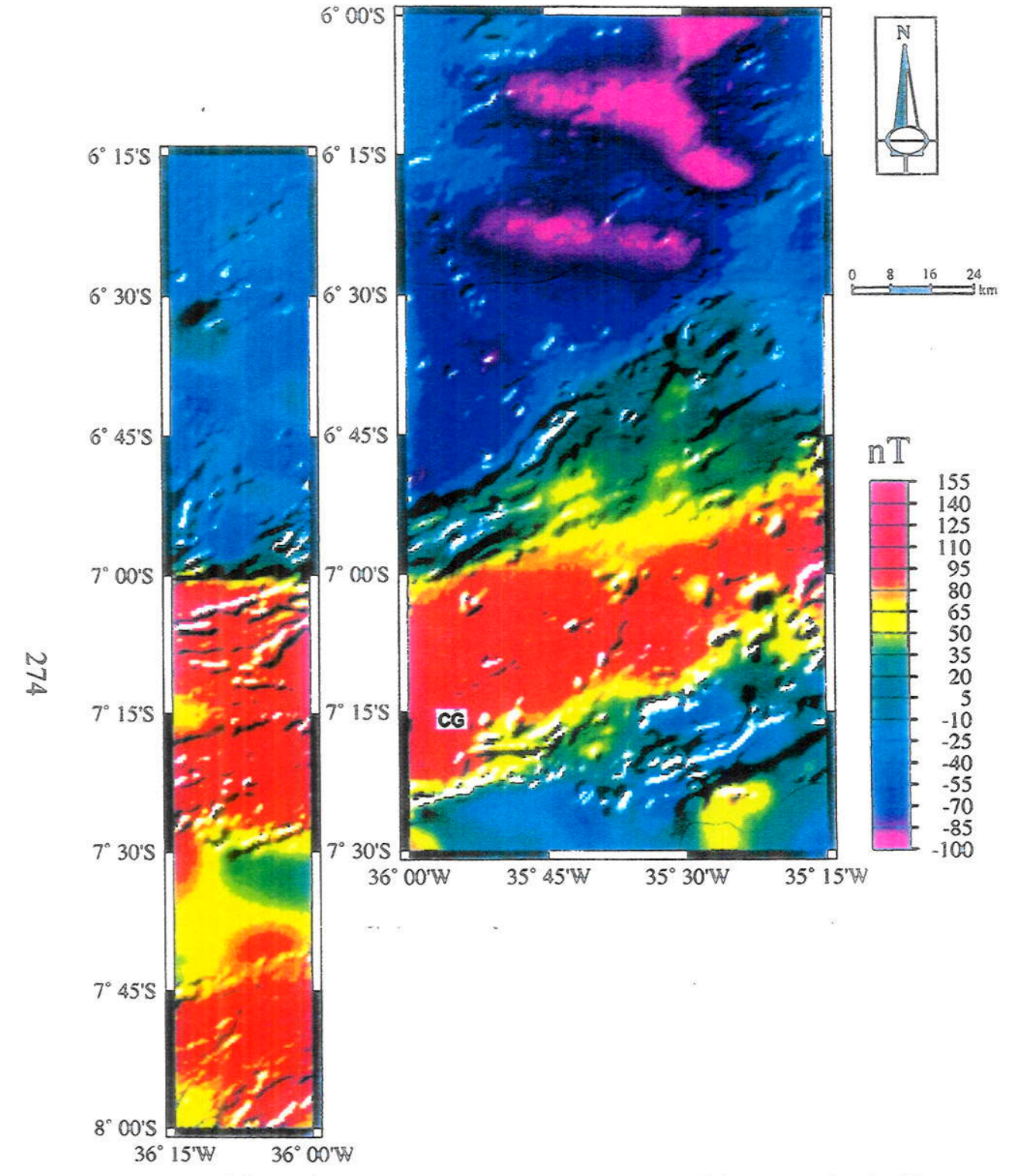

Figura 7.32 - Mapa de anomalias aeromagnéticas obridas a partir de filtragem no domínio espaço-temporal com filtro quadrado de $\lambda=10 \mathrm{~km}$.

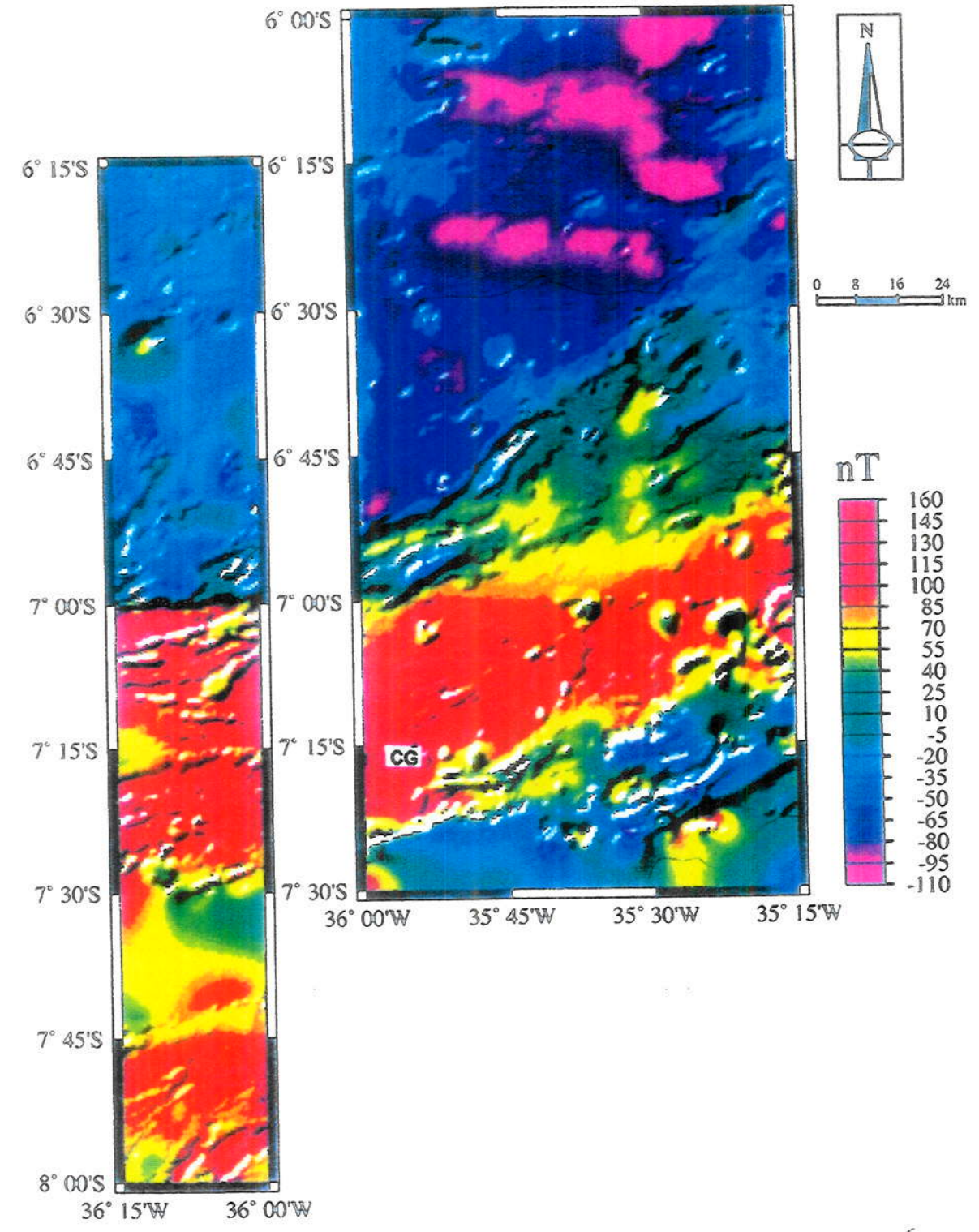

Figura 7.33- Mapa de anomalias aeromagnéticas obridas a partir de filiragem no domínio espaco-temporal com filtro quadrado de $\lambda=5 \mathrm{~km}$. 


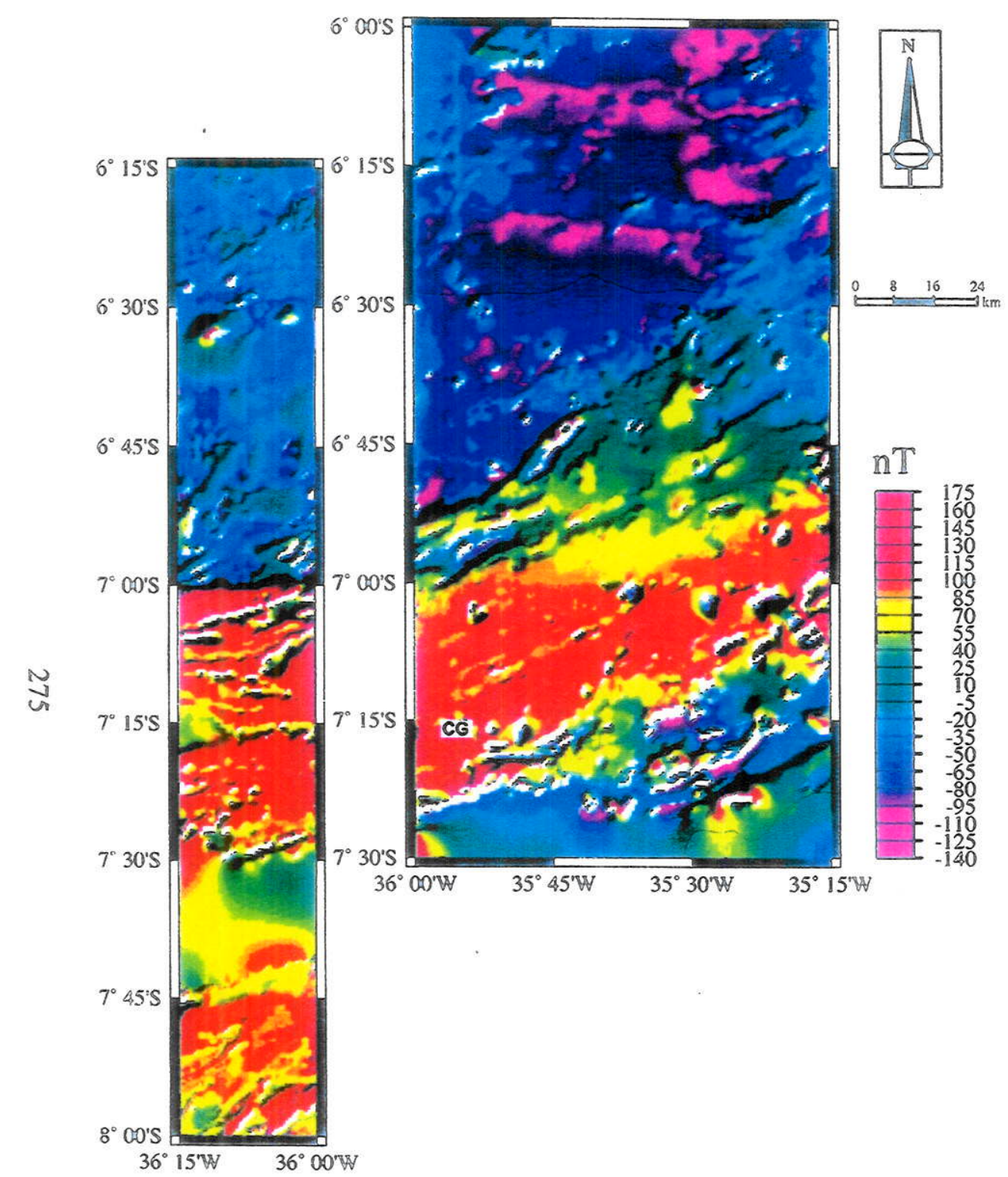

Figura 7.34 - Mapa de anomalias aeromagnéticas obridas a partir de filtragem no domínio espaço-temporal com filtro quadrado de $\lambda=1 \mathrm{~km}$.

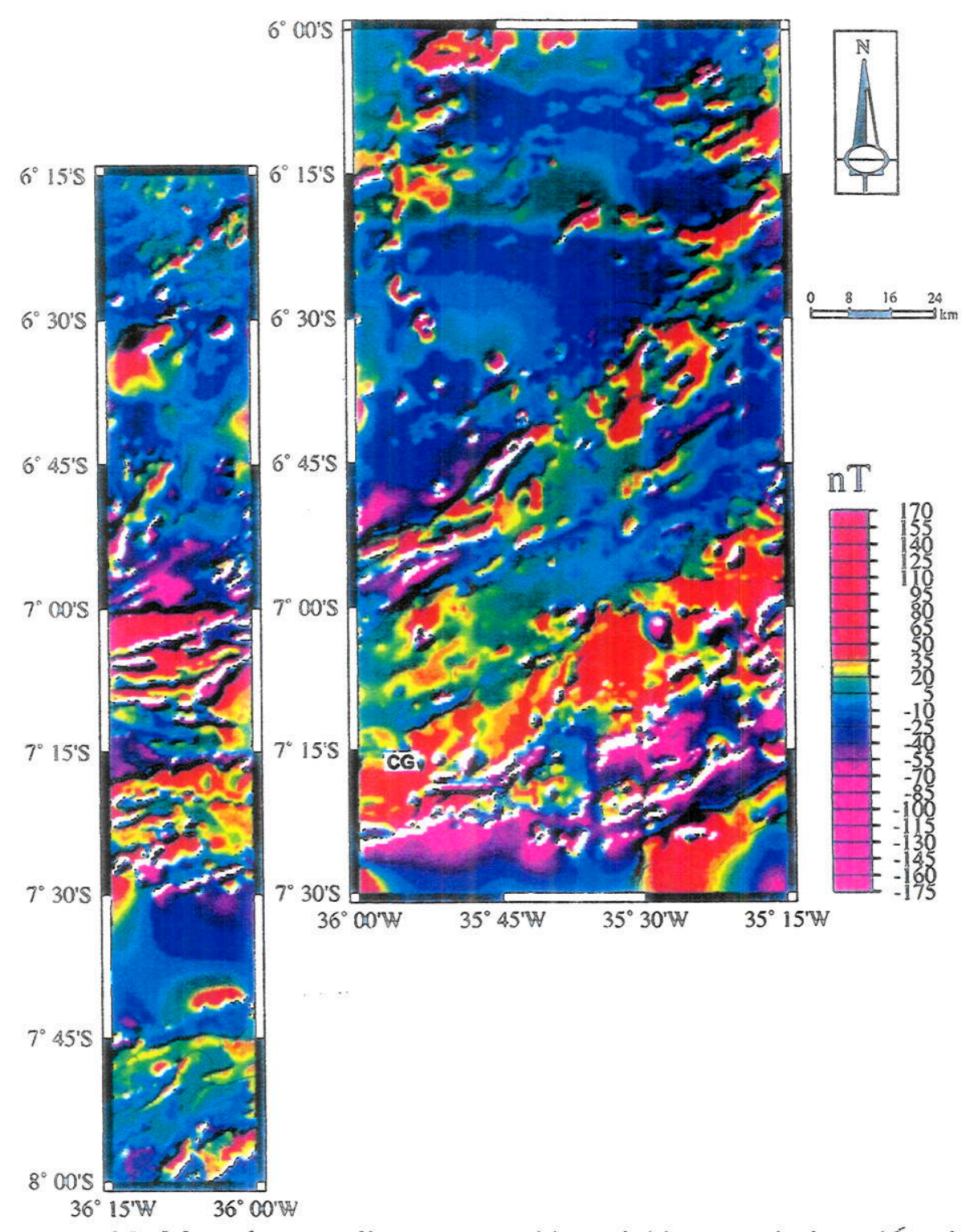

Figura 7.35 - Mapa de anomalias aeromagnéticas obridas a partir do resíduo da filtragem no domínio espaço-temporal com filtro quadrado de $\lambda=50 \mathrm{~km}$. 
A partir do filtro de comprimento de onda de $20 \mathrm{~km}$ (Fig. 7.31), anomalias negativas elipsoidais delimitam os blocos arqueanos, circunscritos pelas zonas de cisalhamento, e parcialmente o bloco paleoproterozóico, o DLD e os granitóides Monte das Gameleiras e Serrinha. Nos terrenos arqueanos, a disposição dessas anomalias negativas sugere a diferenciação de pelo menos dois blocos arqueanos, onde a ZCLP constitui o limite entre eles. Esta mesma feição distingue o bloco arqueano do bloco paleoproterozóico e DLD, com limites definidos pelas ZCT, ZCSE e ZCSJC. Nos blocos arqueano, paleoproterozóico e DLD, as anomalias positivas de comprimentos de onda curtos ocorrem condicionadas às zonas de cisalhamento nas bordas dos blocos, e em setores dos granitóides brasilianos.

No bloco do extremo SSE dos mapas, as anomalias positivas possuem amplitude média a baixa nos niveis crustais mais profundos (Fig. 7.28 a 7.31). Na região entre os paralelos $7^{\circ} 45^{\prime}-8^{\circ} 00^{\prime} \mathrm{S}$ as anomalias são de amplitude alta, demarcando terrenos em contraste com o restante da área, provavelmente com rochas granulíticas e básicas em crosta média-inferior. Um aspecto marcante é a disposição lentiforme das anomalias acompanhando a forma anastomosada dos blocos controlada por lineamentos que definem a concentração da deformação $\mathrm{D}_{3}$ em suas margens. Progressivamente para os níveis crustais mais rasos surgem anomalias negativas e positivas de comprimentos de onda curtos e de amplitudes baixas (Fig. 7.32 a 7.35), que geralmente delineiam a forma dos granitóides relacionados às zonas de cisalhamento brasilianas.

\section{5 -Perfis Geofísicos}

\subsection{1 - Localização dos Perfis Selecionados}

A partir dos mapas geofisicos regionais e residuais foram realizados perfis que, combinados aos mapas e perfis geológicos esquemáticos, apresentam uma compilação das estruturas crustais abrangendo toda a região. As representações bidimensionais dos perfis em escala regional facilitam a observação das variações dos valores e da freqüência dos dados gravimétricos e aeromagnéticos de um bloco a outro, permitindo a comparação destas variações com a geologia de superficie. Desta forma, obtêm-se subsídios na estimativa dos mecanismos geodinâmicos controladores da forma e profundidade do embasamento e do manto litosférico numa região (Woodside \& Verhoef 1989). As variaçð̃es das anomalias gravimétricas e aeromagnéticas relacionadas aos perfis geológicos esquemáticos 
selecionados, permitiram a correspondência com a profundidade estimada das fontes, inclusive da Moho, sugerindo para os diferentes segmentos da região estudada uma estruturação condicionada às estruturas brasilianas.

Os perfis foram selecionados de forma a ilustrar as principais feições geológicas da área e suas relações estruturais no arcabouço tectônico regional, tendo sido tomados perpendicularmente aos principais trends da deformação $\mathrm{D}_{3}$. As disposições dos perfis no terreno estão definidas nas Fig. 7.36 e 7.37, respectivamente para os dados gravimétricos e aeromagnéticos. Os perfis são os mesmos para ambos os dados geofísicos, exceção feita ao perfil AA' que está fora dos limites de abrangência dos dados aeromagnéticos.

O perfil AA' tem direção EW ao londo da latitude $5^{\circ} 45^{\prime} 00^{\prime \prime}$, aproximadamente entre as cidades de Lages e Natal, passando por Caiçara do Rio dos Ventos. Os terrenos envolvidos correspondem à porção central da Faixa Seridó até a fatia de micaxistos de Ielmo Marinho-Taipu, passando pelo bloco arqueano a norte de Riachuelo e Santa Maria. O perfil $\mathrm{BB}^{\prime}$ apresenta direção $\mathrm{N} 50^{\circ} \mathrm{E}$ desde a região de Picuí até Ceará Mirim, atravessando os blocos arqueanos e paleoproterozóico até a faixa de micaxistos de Ielmo Marinho-Taipu. O perfil $\mathrm{CC}^{\prime}$ tem direção $\mathrm{N} 45^{\circ} \mathrm{W}$ entre as cidades de Picuí e Itabaiana, atravessando o bloco paleoproterozóico, a faixa de metapelitos de Barra de Santa Rosa e o sistema ZCRP-ZCCG, próximo à cidade de Campina Grande. O perfil DD' tem direção EW ao longo da latitude $6^{\circ} 00^{\prime} 00^{\prime} \mathrm{S}$ desde a porção central da Faixa Seridó até o litoral do Rio Grande do Norte, interceptando os blocos arqueanos. O perfil EE' tem direção $\mathrm{N} 60^{\circ} \mathrm{W}$ e engloba desde terrenos da porção central da Faixa Seridó até o litoral da Paraíba, atravessando os blocos paleoproterozóico e arqueano, o granito Serrinha, o DLD e a faixa de micaxistos de Duas Estradas encoberta pelos sedimentos costeiros.

\subsection{2 - Perfis Integrados das Anomalias Bouguer e Intensidade Magnética Total}

Numa primeira abordagem foram realizados quatro perfis comparativos envolvendo as anomalias Bouguer e de intensidade magnética total (Fig. 7.38).

A Fig. 7.38a apresenta a assinatura das anomalias para o perfil BB'. Os blocos paleoproterozóico e arqueano estão caracterizados por valores Bouguer negativos (-15 a -5 mGal), que tendem a valores inferiores a $-15 \mathrm{mGal}$ no granito Picuí e em direção a Faixa Seridó. A inversão da polaridade dos valores Bouguer ocorre relacionada à ZCLP (valor 0 mGal), seguindo progressivamente positiva para as bordas da crosta continental atual. A 


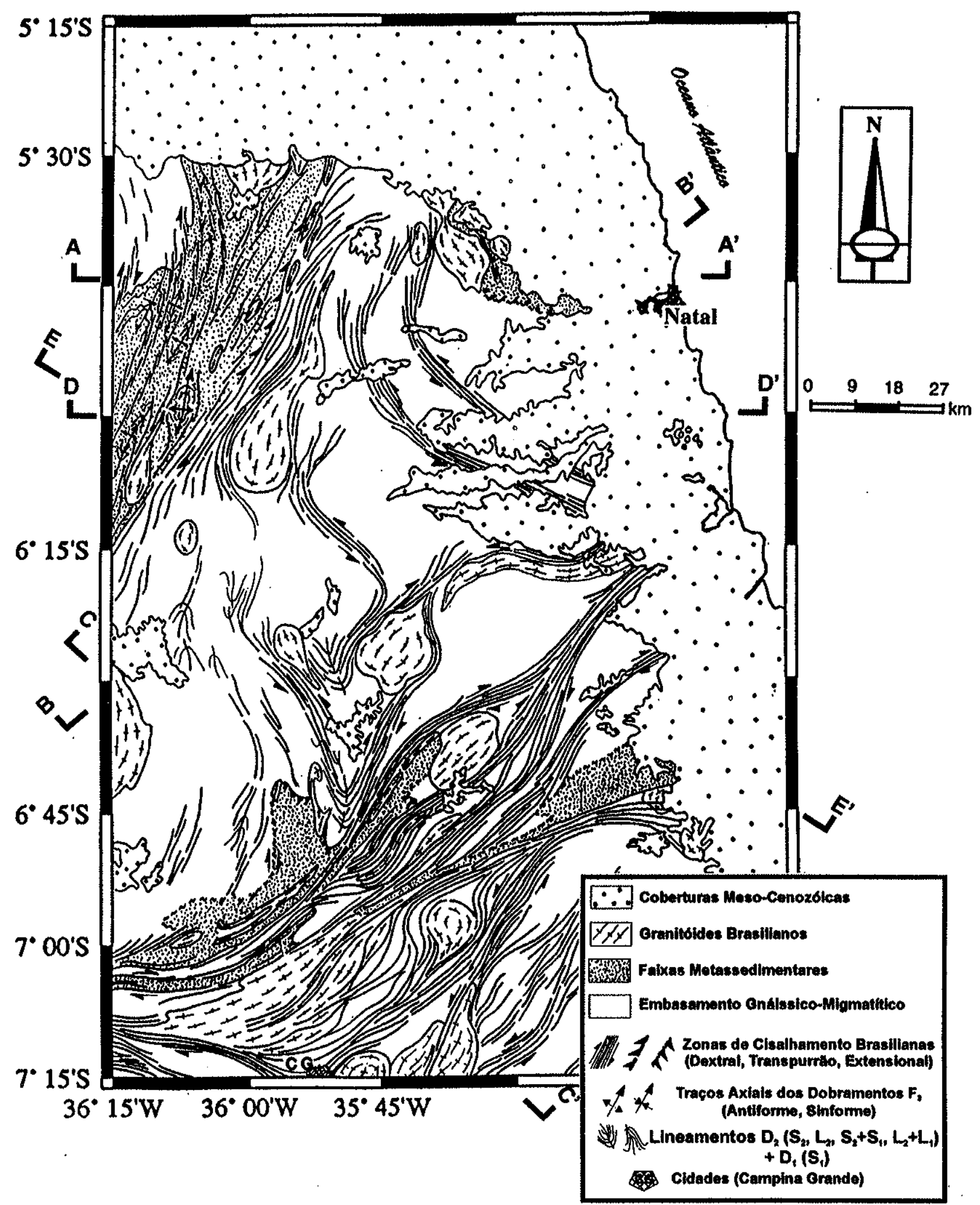

Figura 7.36 - Mapa do arcabouço geológico com a localização das seçðes geológicas e anomalias gravimétricas para a Porção Extremo Nordeste da Província Borborema, região de abrangência dos tratamentos por filtragens regionais e residuais dos dados gravimétricos. 


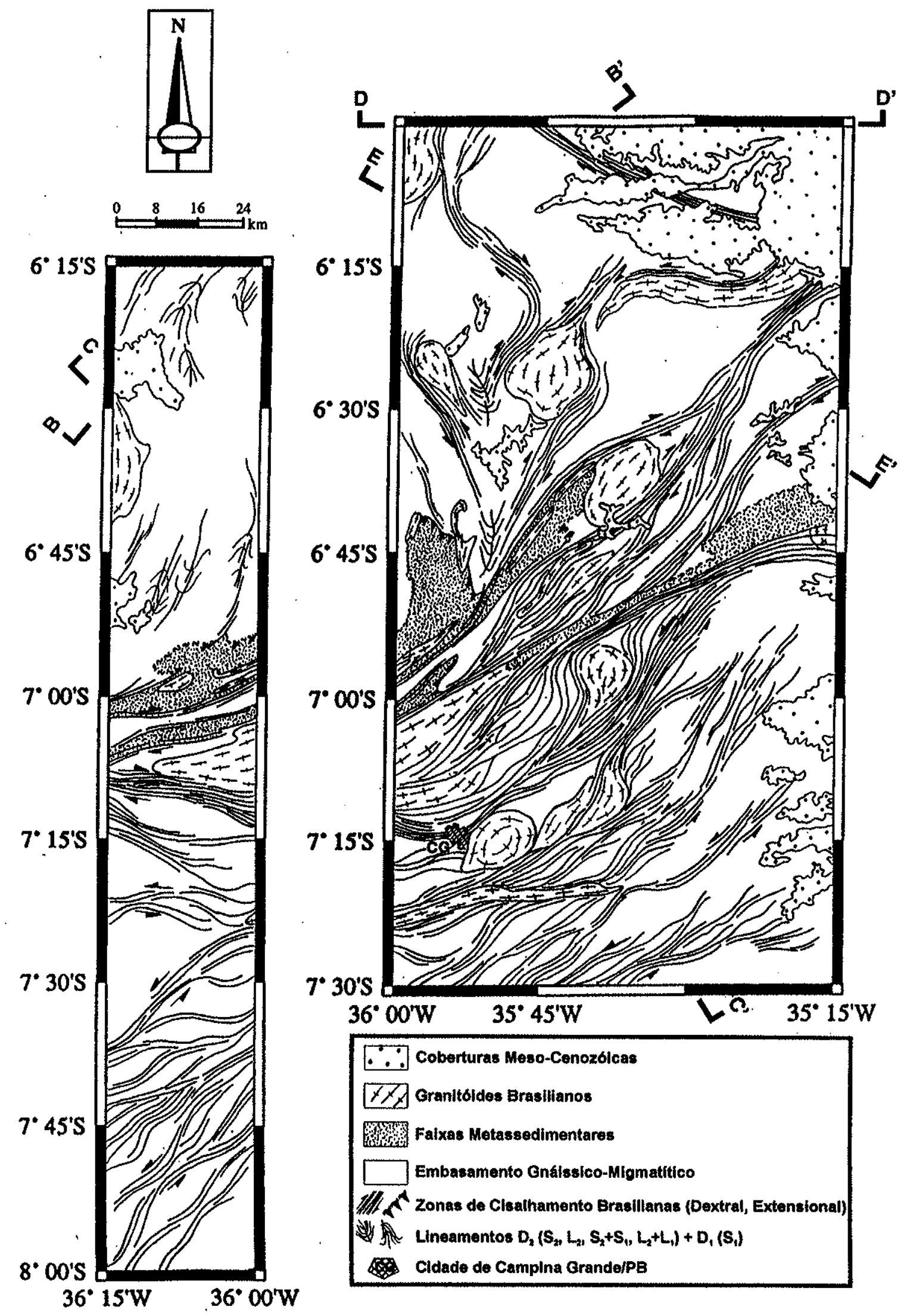

Figura 7.37 - Mapa do arcabouço geológico com a localização das seções geológicas e anomalias aeromagnéticas para a Porção Extremo Nordeste da Província Borborema, região de abrangência dos tratamentos por filtragens regionais e residuais dos dados aeromagnéticos. 
assinatura Bouguer está definida por patamares e inflexões que marcam, respectivamente, os blocos do embasamento e as zonas de cisalhamento em seus limites, sugerindo que os blocos sejam progressivamente menos espessos em direção à costa. $\mathrm{O}$ bloco arqueano controlado pelas ZCLP e ZCBJ, com anomalias de até $15 \mathrm{mGal}$ seria o menos espesso do perfil. A assinatura magnética possui amplitudes entre -100 e $-5 \mathrm{nT}$, distribuídos em comprimentos de onda longos, que marcam os blocos do embasamento, e picos côncavos de comprimentos de onda curtos que localizam as zonas de cisalhamento nas margens dos blocos. As amplitudes magnéticas relativamente maiores e menores sugerem, respectivamente, maiores e menores volumes de rochas de alta densidade instaladas no interior e nas raízes dos blocos, por vezes controladas pelas zonas de cisalhamento.

No perfil CC' (Fig. 7.38b) a assinatura Bouguer está caracterizada por diferentes patamares de amplitudes relativas, relacionados aos blocos crustais segmentados pela zonas de cisalhamento brasilianas. O bloco paleoproterozóico possui valores que variam de $-10 \mathrm{a}$ $20 \mathrm{mGal}$ e -5 a - $100 \mathrm{nT}$ de NW para SE em direção à faixa de micaxistos de Barra de Santa Rosa e às áreas onde a deformação neoproterozóica é mais intensa. Na região de Barra de Santa Rosa e ZCRP, a assinatura Bouguer tende a valores entre -10 e -17 mGal marcando o grande volume de granitóides presentes na área (p.ex. Pocinhos, CCG). As anomalias magnéticas invertem a polaridade para essa região, com valores variando entre -10 e $150 \mathrm{nT}$, estando as máximas amplitudes localizadas sobre as faixas de intensa deformação brasiliana, com granulitização e migmatização generalizadas e corpos básico-intermediários. As minimas amplitudes ocorrem marcando os granitóides em ambas as assinaturas. Esses fatos demonstram a intensa participação de fluidos mantélicos e diferenciados durante os estágios da deformação brasiliana.

No perfil DD' (Fig. 7.38c) as variações da assinatura Bouguer demonstram novamente o afinamento crustal de $\mathrm{W}$ para $\mathrm{E}$, desde a porção central da Faixa Seridó até as bordas da crosta continental, definindo os blocos do embasamento com diferentes espessuras e controlados pelas zonas de cisalhamento brasilianas. A anomalia Bouguer inverte a polaridade na região do bloco arqueano, elevando paulatinamente os valores da amplitude até $38 \mathrm{mGal}$ na linha de costa, com inflexões côncavas marcando as ZCLP e ZCBJ, que também têm suas localizações definidas pelos picos côncavos da assinatura magnética. Estes 
(A)

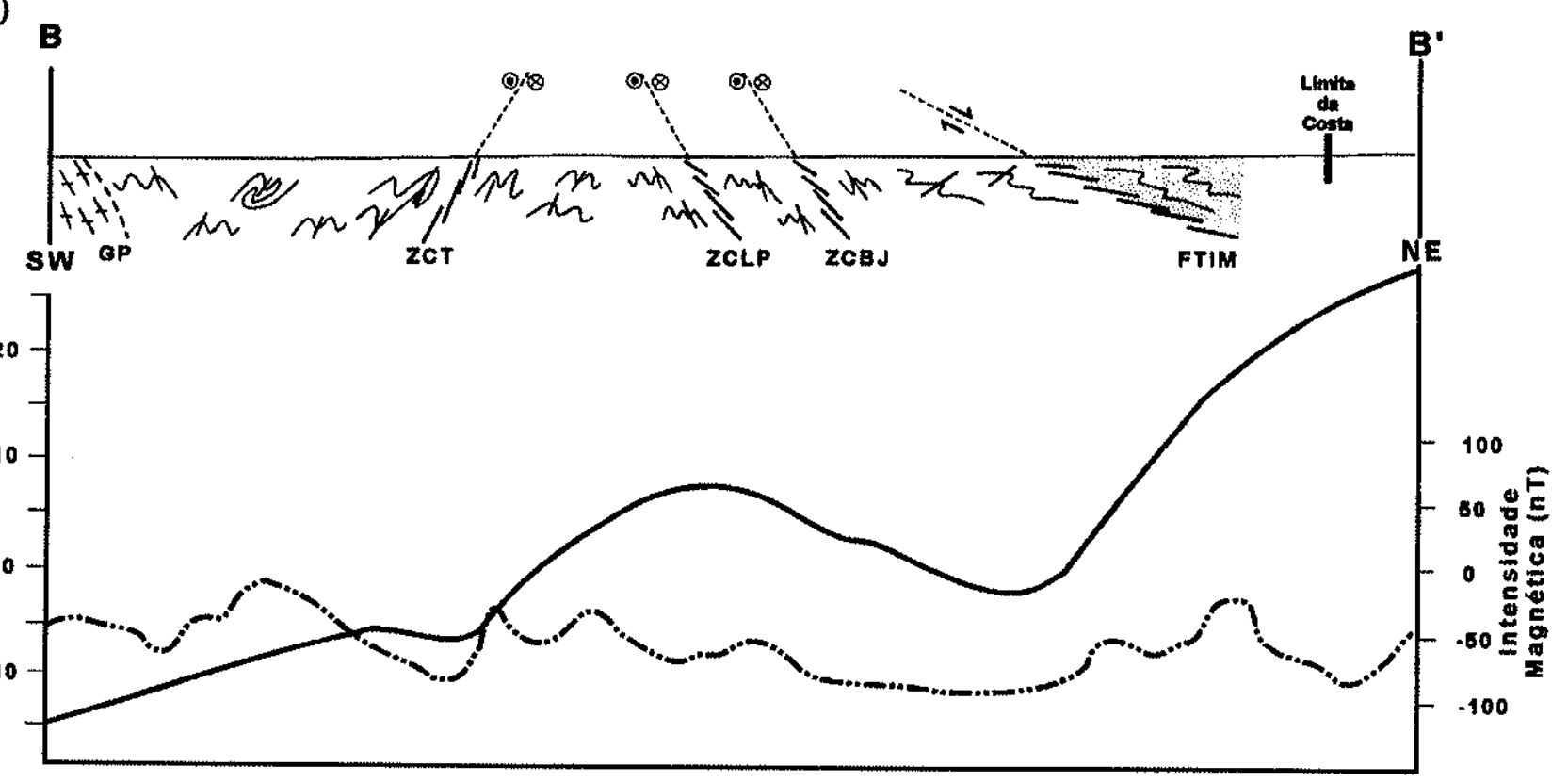

(B)

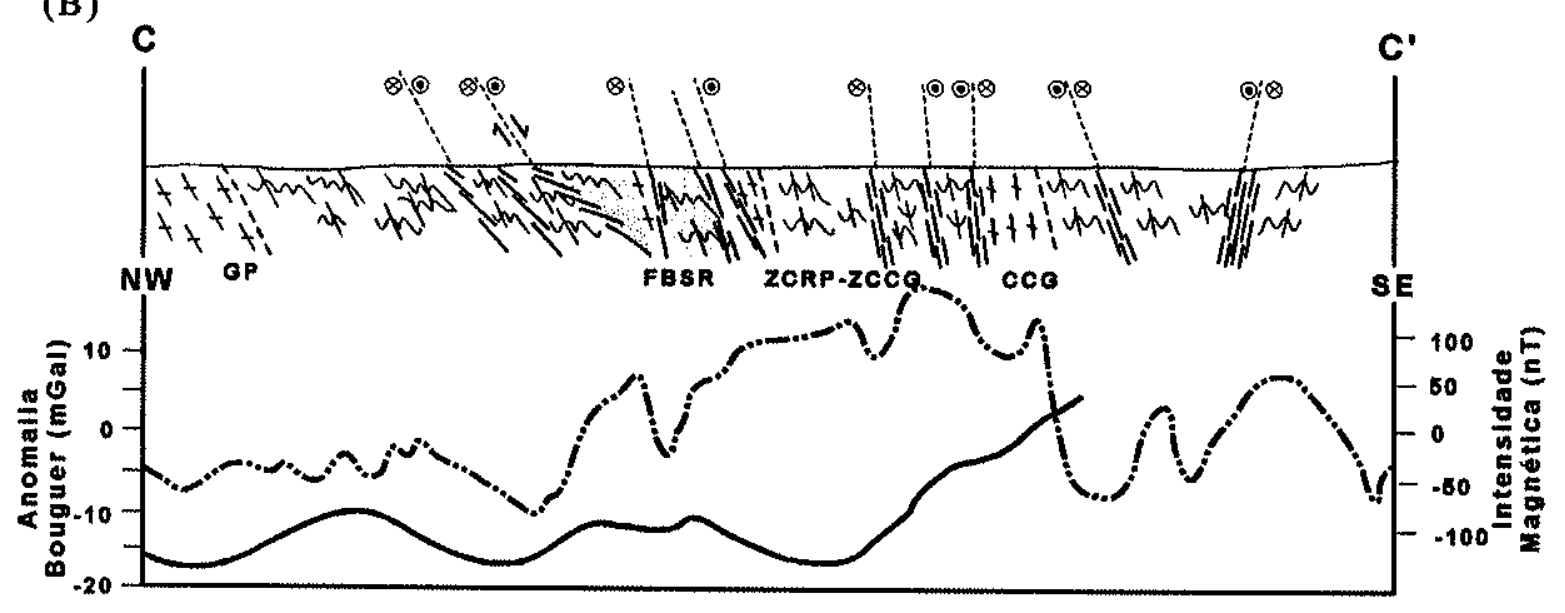

Figura 7.38 - Legenda na próxima página. 

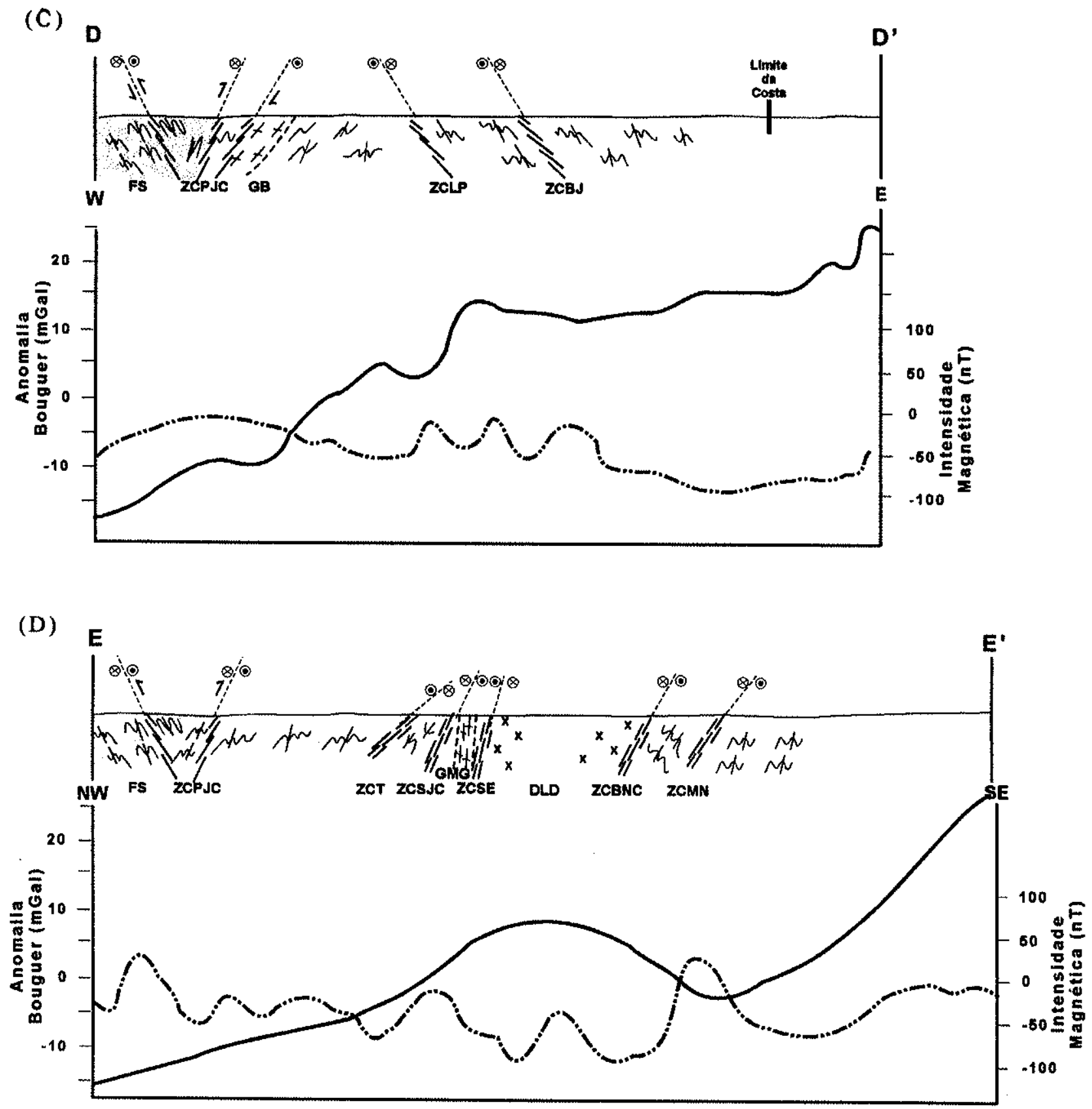

Figura 7.38 - Perfis integrados da anomalia Bouguer ( $\sim$ ), da intensidade magnética total DGRF $(/(i))$ e do esboço geológico simplificado para (A) seção BB', (B) seção CC', (C) seção DD' e (D) seção EE'. As seçðes estão localizadas na Figura 7.36 e 7.37. 
fatos comprovam a importância dessas zonas de cisalhamento na estruturação crustal e na canalização de fluidos mantélicos, durante os processos deformacionais no Brasiliano.

A Fig. 7.38d mostra a assinatura Bouguer para o perfil EE' caracterizada pelo baixo gravimétrico de amplitude inferior a $-10 \mathrm{mGal}$ da Faixa Seridó, pela inversão de polaridade relacionada à ZCT na borda do bloco arqueano e pela assinatura positiva de até $10 \mathrm{mGal}$ no DLD limitado pela ZCBNC. No setor entre a ZCBNC e a ZCMN a assinatura gravimétrica é negativa (-3 Mgal). A assinatura Bouguer sugere o afinamento crustal de W para $\mathrm{E}$ com inflexões diretamente relacionadas às zonas de cisalhamento brasilianas. As localizações dessas zonas de concentração da deformação estão bem definidas pelos picos côncavos e positivos da assinatura magnética.

\subsection{3 - Perfis Integrados das Anomalias Gravimétricas e Aeromagnéticas Resultantes das}

\section{Filtragens nos Dominios da Freqüência e Espaço-Temporal}

As anomalias gravimétricas e aeromagnéticas regionais e residuais obtidas nas filtragens nos domínios da freqüência e espaço-temporal foram referenciadas aos perfis geológicos esquemáticos, de forma a demonstrar a eficiência dos procedimentos de filtragens, independente do domínios empregados, na avaliação do comportamento da crosta a diferentes profundidades e a estreita relação espacial das anomalias com a geologia de superficie, sobretudo dos elementos da deformação neoproterozóica. As assinaturas gravimétricas e aeromagnéticas de cada perfil foram obtidas a partir dos mapas de anomalias regionais e residuais discutidos nos itens anteriores. Desta maneira, buscou-se a coerência das interrelações de critérios bidimensionais e das correlações de dados espaciais que permitissem a modelagem eficiente da crosta brasiliana na região.

\section{- Perfis Integrados das Assinaturas Gravimétricas no Dominio da Freqüencia:}

A Fig. 7.39 apresenta os cinco perfis geológicos esquemáticos combinados às assinaturas gravimétricas regionais e residuais obtidas em filtragens passa-banda e passaalta, representados na Fig. 7.36.

No perfil AA' (Fig. 7.39a), a assinatura senoidal da filtragem passa-banda define a Faixa Seridó, a faixa de metapelitos de Ielmo Marinho-Taipu e os granitóides associados, descritos pela parte convexa e negativa da curva. O bloco arqueano está marcado pela parte côncava e positiva. Como a filtragem passa-banda empregada ressaltou os niveis profundos 


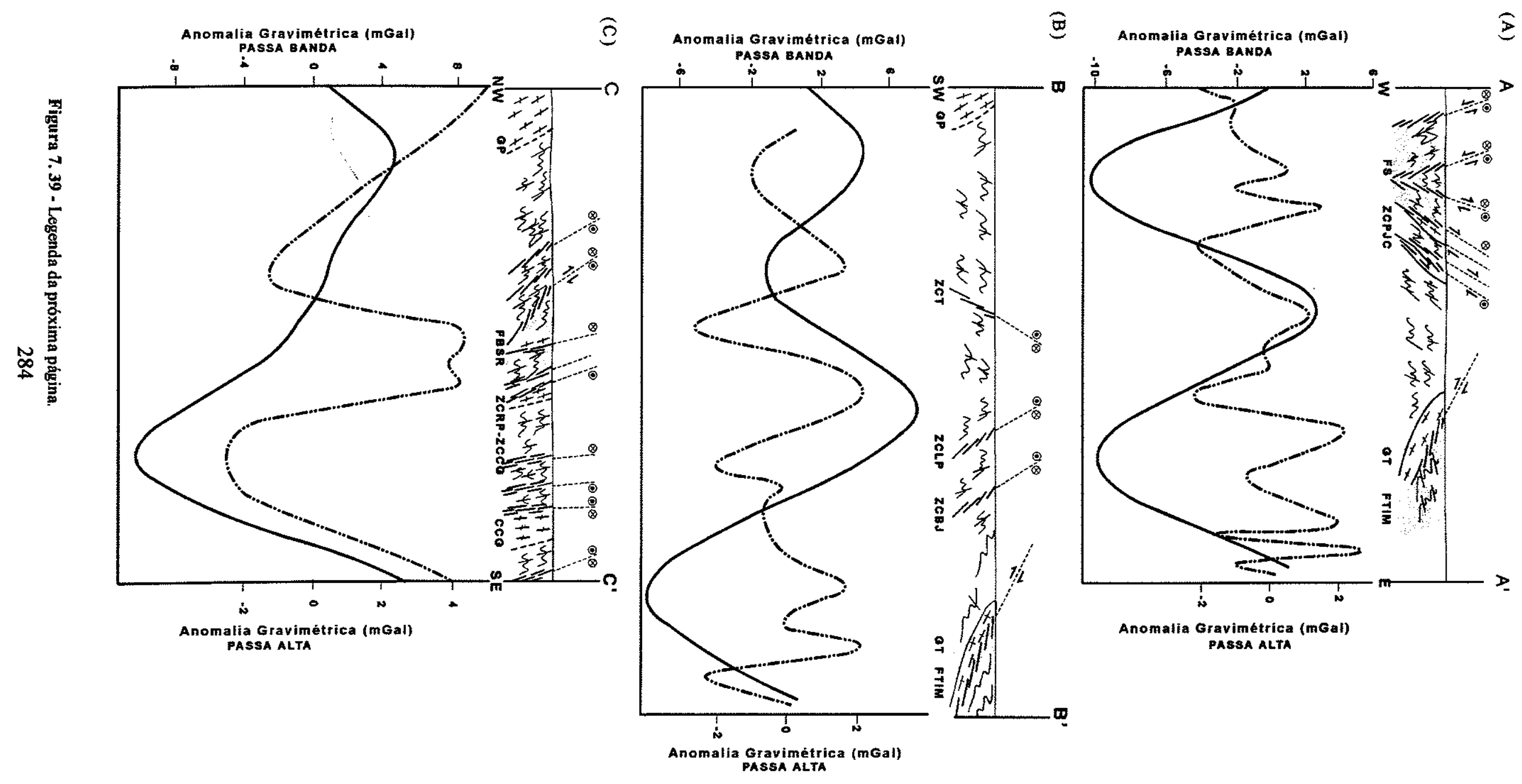




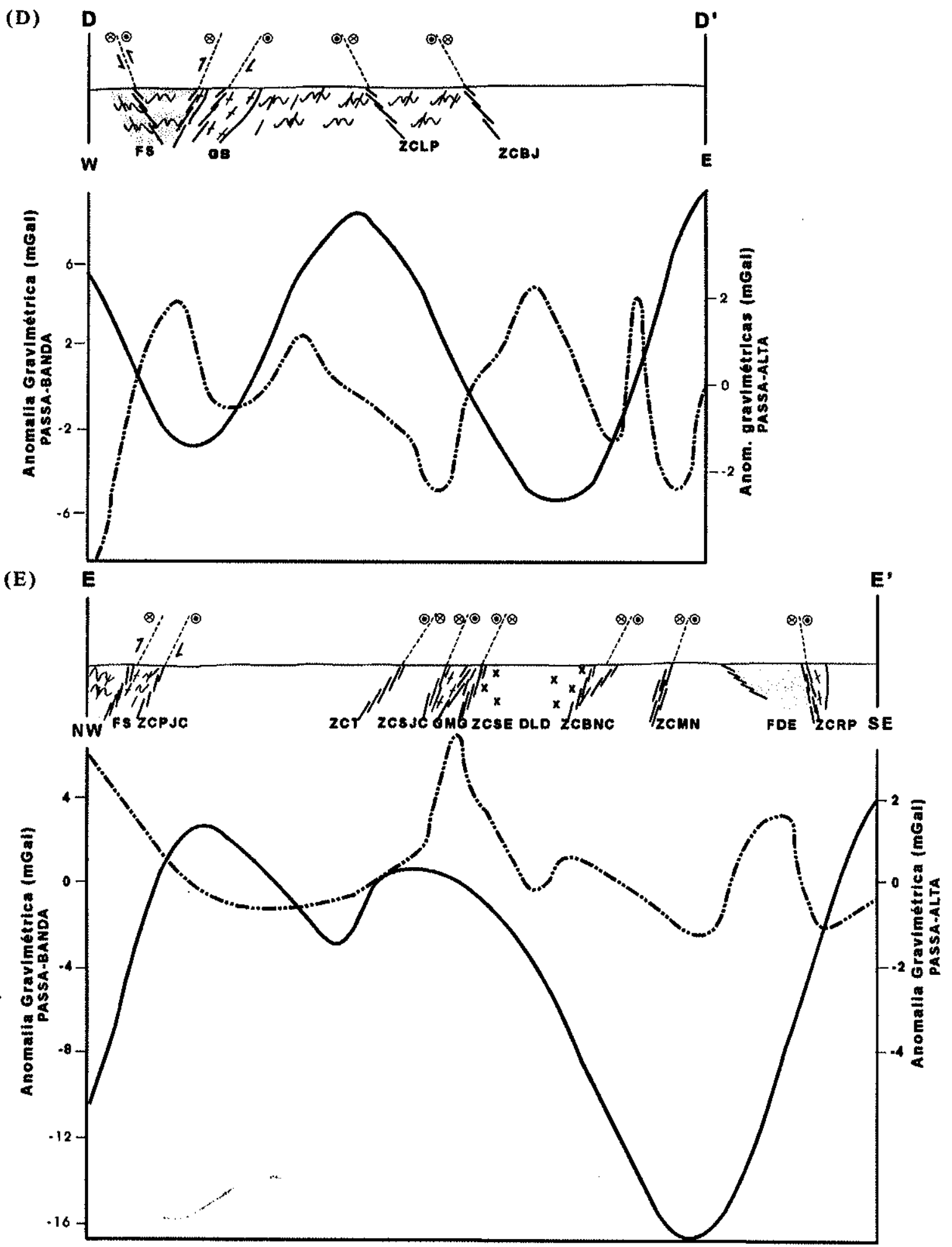

Figura 7.39- Perfis integrados das anomalias gravimétricas resultantes de filtragem no dominio da frequência por filtros passa-banda $(\sim)$ e passa-alta $(\cap) /)$ e do esboço geológico simplificado para (A) seção AA', (B) seção BB', (C) seção CC', (D) seção DD' e (E) seção EE'. O filtro passa-banda permite passagem de $250 \mathrm{~km}<\lambda<80 \mathrm{~km}$, rejeita $\lambda$ $>600 \mathrm{~km}$ e $\lambda<30 \mathrm{~km}$ e cosine-tapered os $\lambda$ intermediários. O filtro passa-alta permite a passagem de $\lambda<30 \mathrm{~km}$, rejeita $\lambda>50 \mathrm{~km}$ e cosine-tapered os valores intermediários. As seçōes estão localizadas na Figura 7.36. 
da crosta, tal assinatura seria condizente com uma maior proporção relativa de rochas mantélicas de alta densidade sob o bloco arqueano menos espesso. A filtragem passa-alta para a crosta média-superior produziu assinatura com maior freqüência (ruído) e menor amplitude, onde as zonas de cisalhamento estão definidas por picos côncavos positivos e os granitóides e faixas de micaxistos por picos convexos negativos, clara indicação da continuidade das zonas de cisalhamento possivelmente condicionando rochas mais densas para esses níveis crustais.

Os perfis BB' e DD' (Fig. 7.39b e 7.39d) praticamente interceptam as mesmas unidades que o perfil $\mathrm{AA}^{\prime}$, com as assinaturas das anomalias gravimétricas guardando as mesmas características. No conjunto dos blocos arqueanos e paleoproterozóicos, a sinuosidade com variação de polaridade da curva da filtragem passa-banda é um indício das espessuras diferenciadas entre os blocos, condicionando a profundidade da Moho. $\mathrm{Na}$ assinatura da filtragem passa-alta, picos côncavos mais largos definiram a posição de algumas zonas de cisalhamento, enquanto outras zonas vizinhas não foram marcadas, provável indicação da coalescência dessas zonas em profundidade. Um importante fator na filtragem passa-alta é o incremento na freqüência da curva em direção à costa, demonstrando a intenso fraturamento na margem do continente.

Para o perfil CC' (Fig. 7.39c) a curva senoidal da filtragem passa-banda associa um baixo de anomalias para o granito Pocinhos, bloco paleoproterozóico e parte do sistema ZCRP-ZCCG, provavelmente devido ao volume de fluidos graníticos gerados da extensiva fusão crustal, comparados aos altos gravimétricos nas laterais do bloco paleoproterozóico e à ZCCG, com as rochas básico-intermediárias e alcalinas do CCG. Na filtragem passa-alta, a assinatura gravimétrica define picos de anomalias positivas relacionadas à faixa de micaxistos de Barra de Santa Rosa, com rochas alcalinas intrusivas, e à ZCRP, no fácies granulito e com a participação de fluidos mantélicos ou derivados, mantendo o baixo relativo para o granito Pocinhos e bloco paleoproterozóico.

No perfil EE' (Fig. 7.39e) a assinatura da filtragem passa-banda caracteriza o bloco paleoproterozóico por um baixo de pequena amplitude $(-1 \mathrm{mGal})$, uma inflexão positiva de pequena amplitude marca a ZCSE e o granitóide Serrinha, enquanto um amplo baixo define a área entre o DLD e a faixa de micaxistos Duas Estradas. A assinatura da filtragem passa-alta define as principais zonas de cisalhamento com picos côncavos e 
positivos, como nos demais perfis. Tais efeitos são decorrentes da ampla fusão crustal na região do DLD, com produção de fluidos de composição granítica, associados às zonas de cisalhamento que deformam a Moho e canalizam fluidos mantélicos para diferentes níveis da crosta.

\section{- Perfis Integrados das Assinaturas Gravimétricas no Domínio Espaço-Temporal:}

As anomalias gravimétricas no domínio espaço-temporal foram combinadas aos perfis $\mathrm{AA}^{\prime}, \mathrm{BB}^{\prime}$ e $\mathrm{CC}^{\prime}$. Ao perfil $\mathrm{AA}^{\prime}$ foram empregados todos os mapas de anomalias regionais e residuais avaliados nos itens anteriores, enquanto que para os perfis BB' e CC' utilizou-se apenas os mapas de comprimentos de onda de $200 \mathrm{~km}, 50 \mathrm{~km}, 30 \mathrm{~km}$ e $10 \mathrm{~km}$ acompanhados de seus residuais.

Para os perfis $\mathrm{AA}^{\prime}$ e $\mathrm{BB}^{\prime}$ (Fig. 7.40 e 7.41) todas as assinaturas regionais dos diferentes comprimentos de onda caracterizam o afinamento crustal desde a Faixa Seridó até os limites da costa, com os traçados das curvas mostrando blocos com diferentes espessuras, evidência que se intensifica nos perfis para menores comprimentos de onda e nos residuais (para os níveis de crosta mais rasos, Fig. 7.40c. 7.40d, 7.40e, 7.41c e 7.41d). As assinaturas residuais de $200 \mathrm{~km}$ e $50 \mathrm{~km}$ para os perfis AA' e BB'(Fig.7.40a, 7.40b, 7.41a e 7.41 b, respectivamente) demonstram a Faixa Seridó mais espessa e o bloco arqueano menos espesso com raizes de alta densidade. Em direção à costa ocorre o aumento da freqüência da assinatura (ruído), provável indicação da intensa deformação e magmagênese afetando as bordas da crosta continental desde niveis crustais profundos.

No perfil BB' (Fig.7.41) foram destacadas as diferentes espessuras dos blocos paleoproterozóicos e arqueanos, com indicação da coalescência em profundidade das zonas de cisalhamento definidas por picos côncavos largos. A partir das assinaturas residuais de 50 $\mathrm{km}$ (Fig. 7.41b) até as de menor comprimentos de onda (Fig. 7.41c e 7.41d), ou seja desde níveis de crosta inferior até crosta superior, torna-se evidente a associação dos picos positivos às localizações das zonas de cisalhamento e dos picos negativos aos granitóides e faixas de metapelitos, em superfície. Todas essas evidências sugerem que as zonas de cisalhamento brasilianas nesse setor (ZCPJC, ZCT, ZCLP e ZCBJ), correspondem a estruturas que interceptam todas os niveis crustais, às vezes com coalescência, provavelmente alcançando e deformando a Moho. 

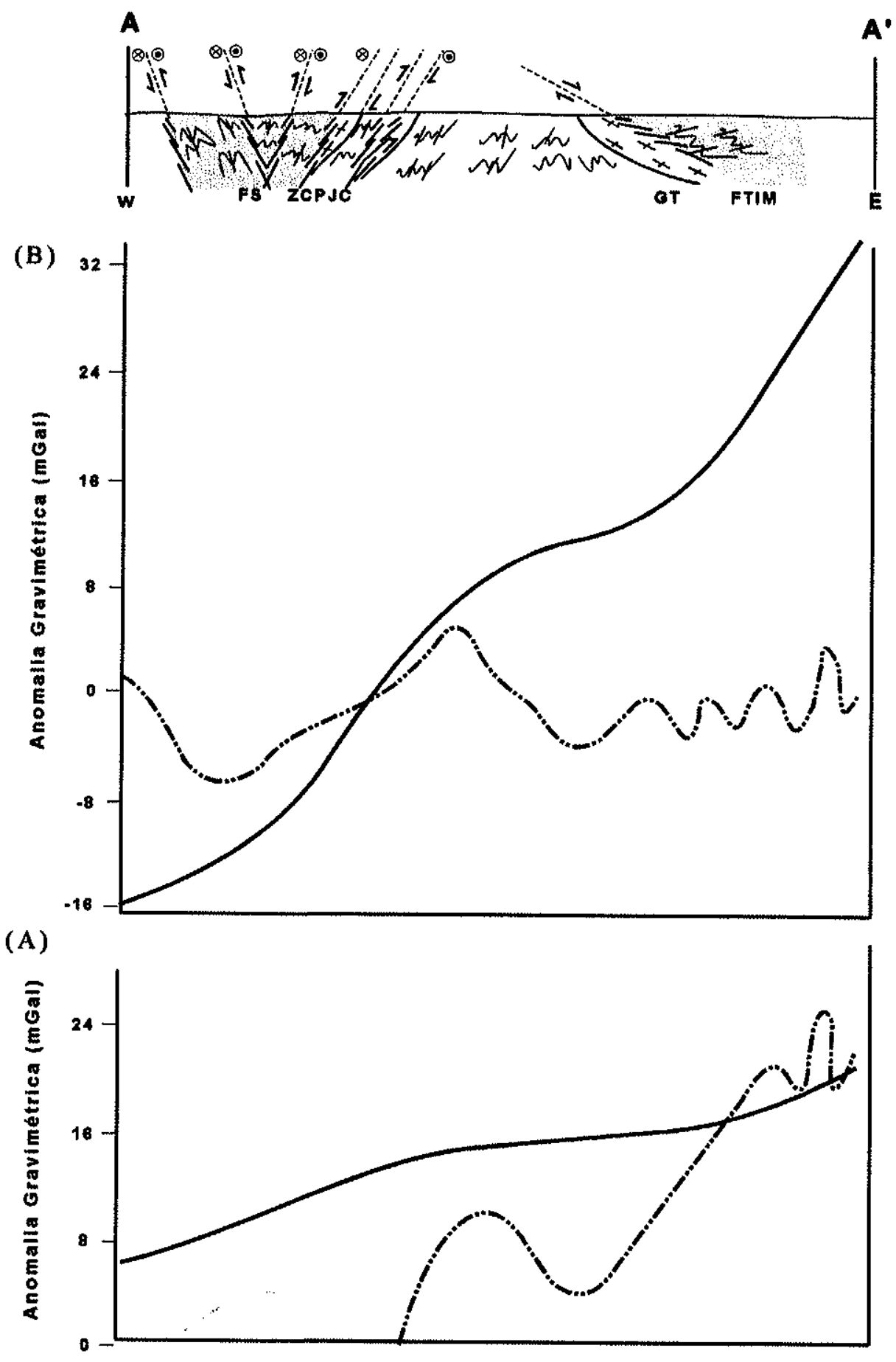

Figura 7. 40 - Legenda da próxima página. 

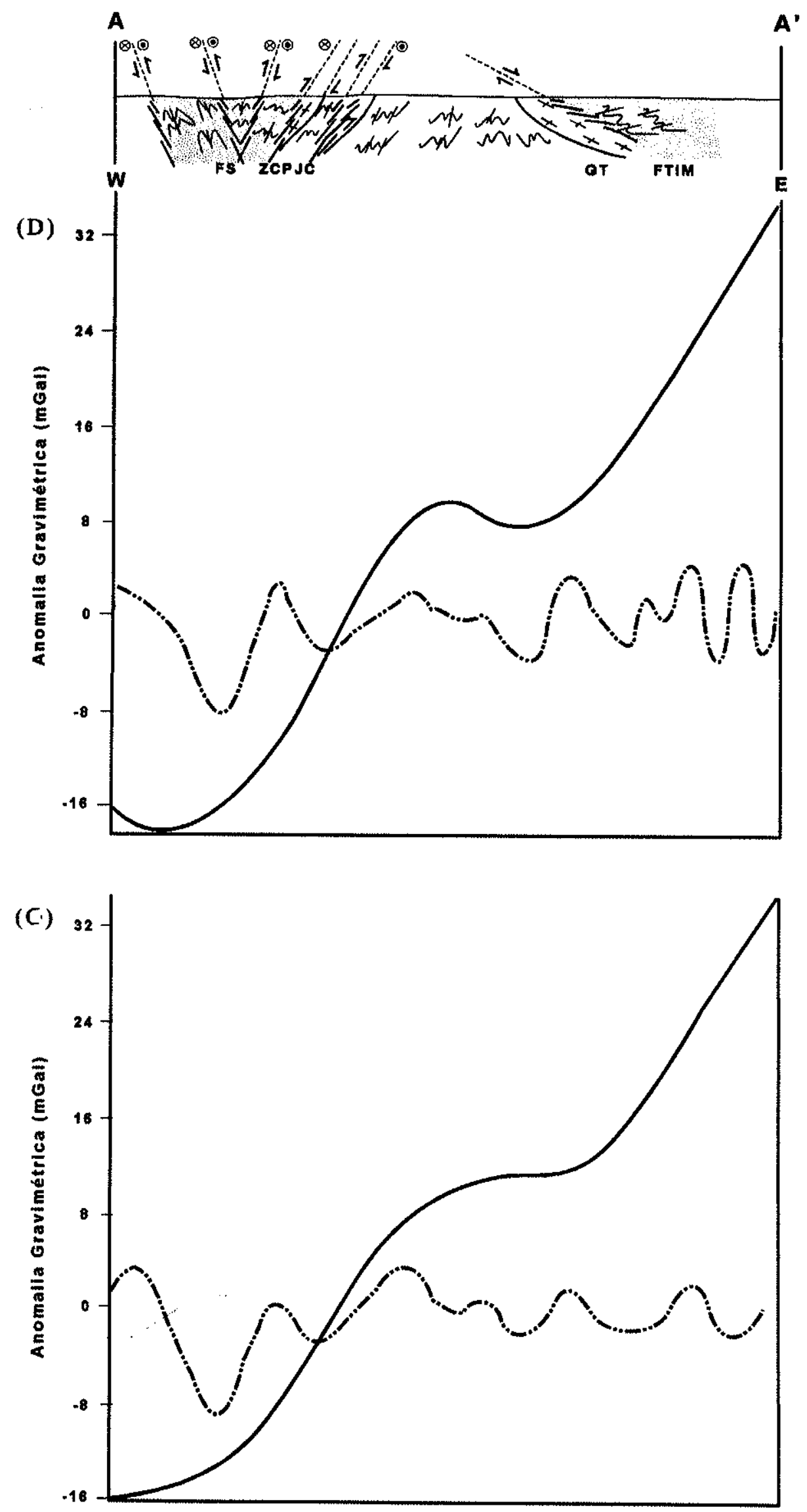

Figura 7. 40 - Legenda da próxima página. 
A
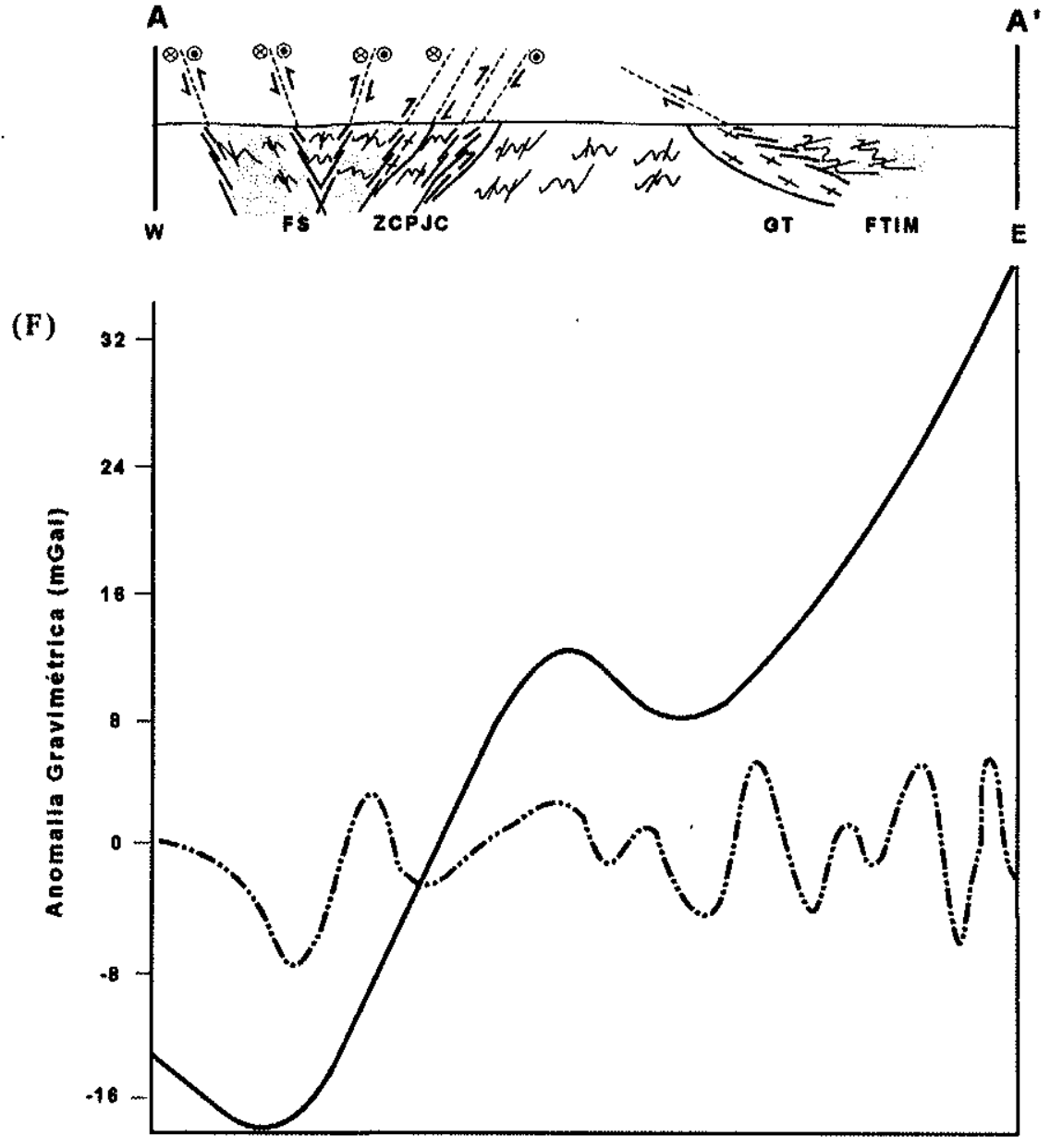

(E)

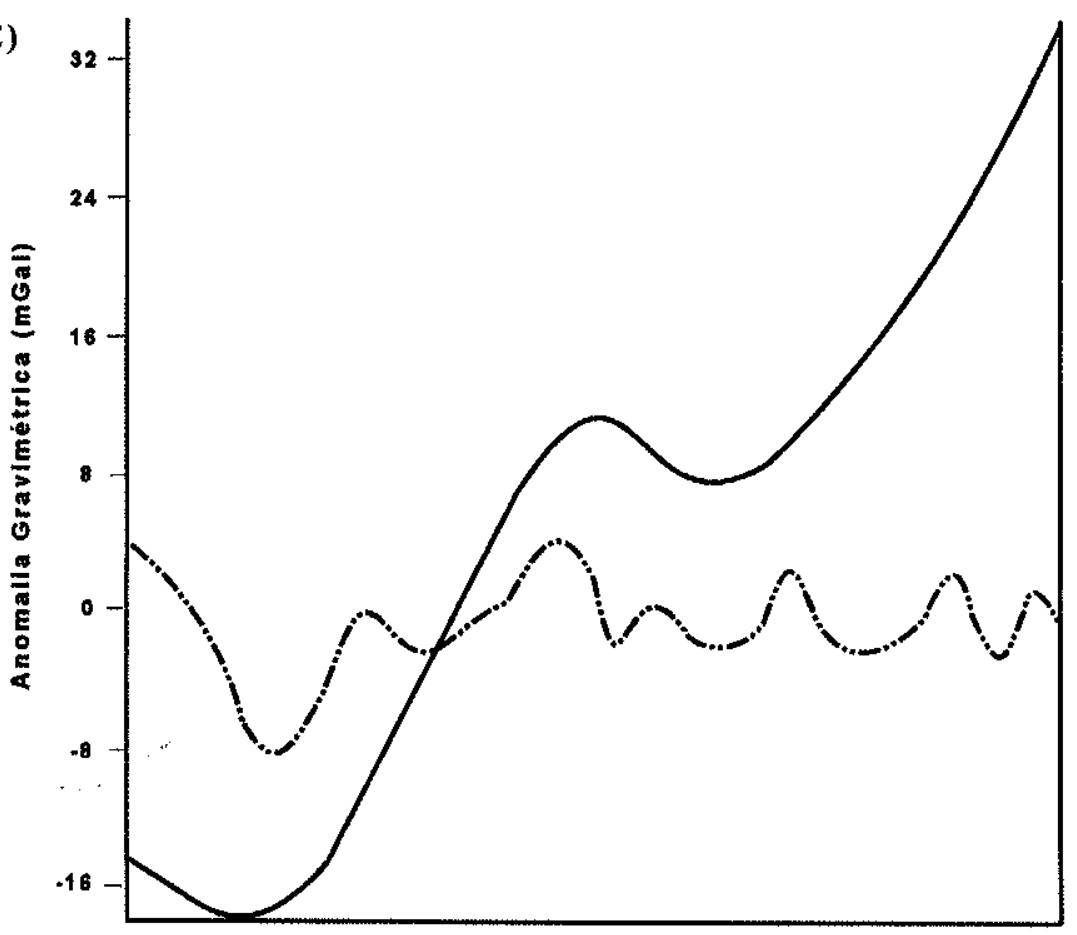

Figura 7.40 - Perfis integrados das anomalias gravimétricas resultantes da filtragem no domínio espaço-temporal por filtros quadrados (A) de $\lambda=200 \mathrm{~km}$ e seu residual, (B) de $\lambda=50 \mathrm{~km}$ e seu residual, (C) de $\lambda=40 \mathrm{~km}$ e seu residual, (D) de $\lambda=30 \mathrm{~km}$ e seu residual, (E) de $\lambda=20 \mathrm{~km}$ e seu residual $\mathrm{e}(\mathrm{F})$ de $\lambda=10 \mathrm{~km}$ e seu residual, e do esboço geológico simplificado para a seção $\mathrm{AA}^{\prime}$. Anomalia regional $(N)$ e residual $(/ ? /)$ ). A seção AA' esta localizada na Figura 7.36. 

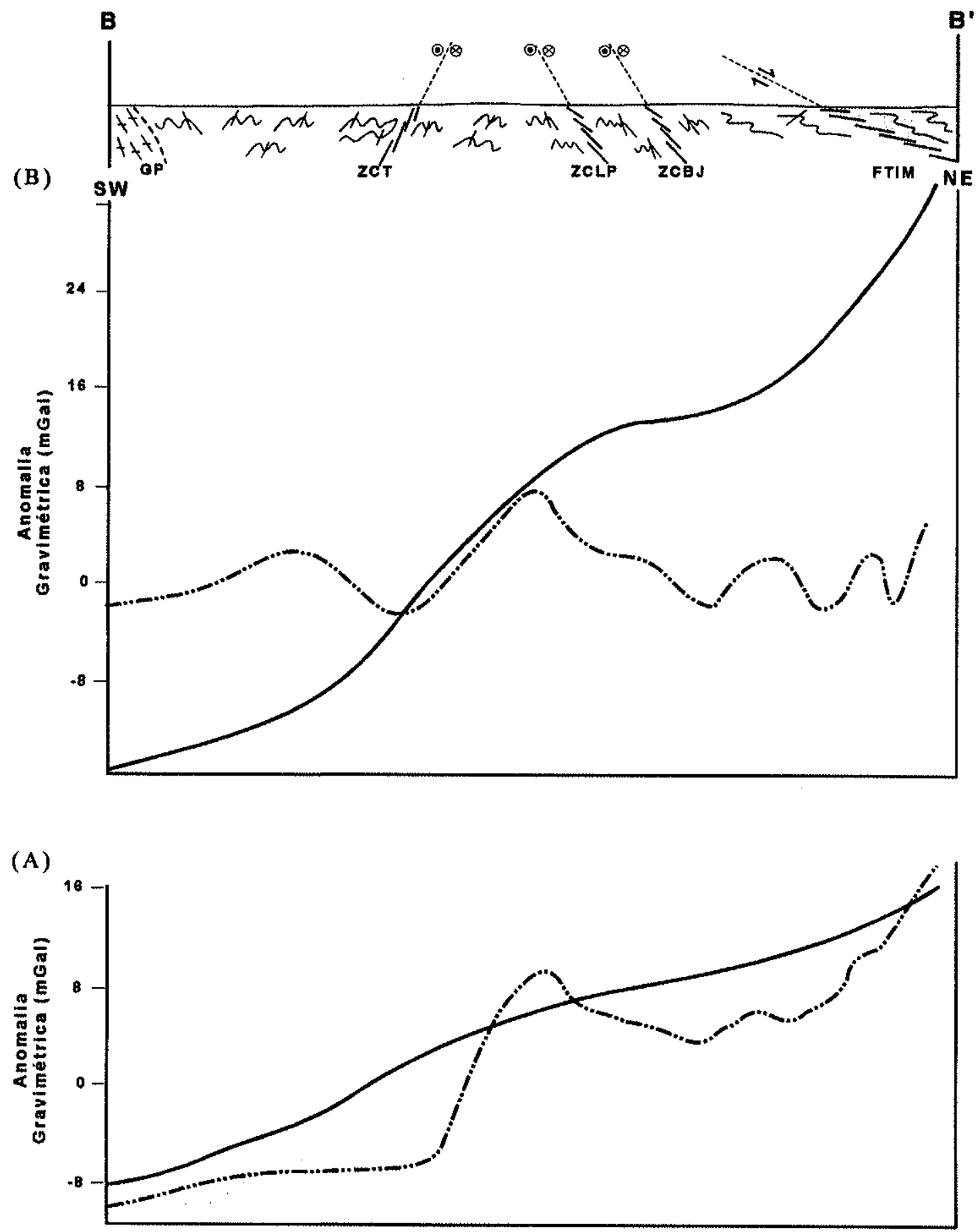

Figura 7. 41 - Legenda da próxima página. 
(D)
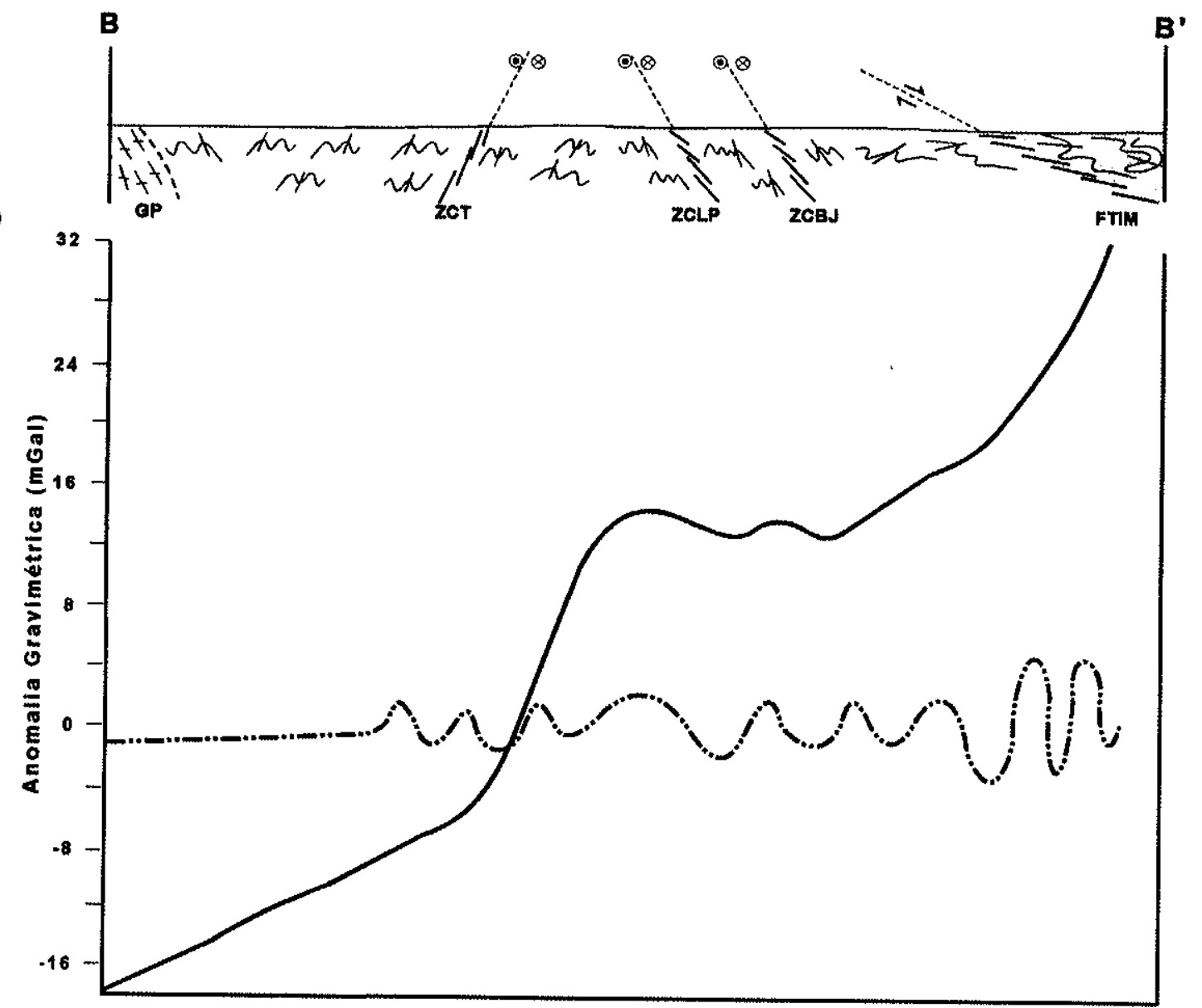

(C)

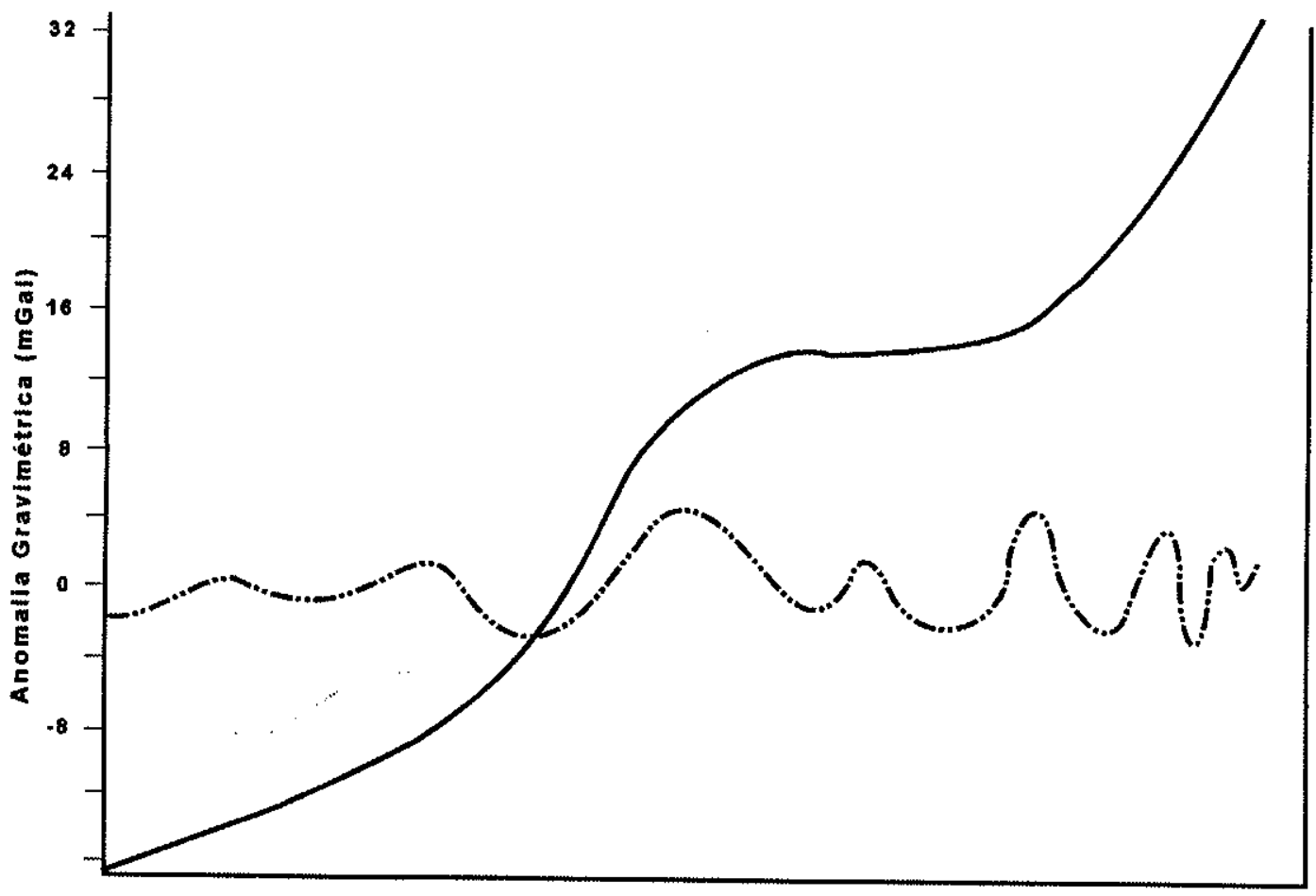

Figura 7.41 - Perfis integrados das anomalias gravimétricas resultantes da filtragem no domínio espaço-temporal por filtros quadrados (A) de $\lambda=200 \mathrm{~km}$ e seu residual, (B) de $\lambda=50 \mathrm{~km}$ e seu residual, (C) de $\lambda=30 \mathrm{~km}$ e seu residual, (D) de $\lambda=10 \mathrm{~km}$ e seu residual, e do esboço geológico simplificado para a seção BB'. Anomalia regional $(\Omega)$ e residual $(\not /)$. A seçåo $A^{\prime}$ esta localizada na Figura 7.36. 
Para o perfil CC' os traçados das curvas das filtragens regionais de $200 \mathrm{~km}, 50$ $\mathrm{km}, 30 \mathrm{~km}$ e $10 \mathrm{~km}$ (Fig. 7.42a, 7.42b, 7.42c e 7.42d) confirmam as características descritas nas filtragens no domínio da freqüência, de baixos relacionados ao espessamento crustal para a Faixa Seridó e ao granito Pocinhos. Nas curvas de $30 \mathrm{~km}$ e $10 \mathrm{~km}$ (Fig. 7.42c e 7.42d) nota-se o alto relacionado à faixa de micaxistos de Barra de Santa Rosa e à ZCRP, com os baixos gravimétricos localizados nos corpos graníticos, e a inversão da polaridade relacionada à $\mathrm{ZCCG}$ e às rochas do CCG. Todas as assinaturas residuais marcam com picos côncavos e positivos o setor da faixa de Barra de Santa Rosa e a ZCRP, com a acentuação da correspondência entre as zonas de cisalhamento e os picos positivos individualizados e aumento da freqüência nas curvas em direção à crosta superior. Esses fatos demonstram que a deformação brasiliana na região da faixa de Barra de Santa Rosa e no sistema ZCRP. ZCCG atingiu níveis do manto litosférico, constituindo uma zona de extrema importância na transferência e distribuição de calor e de fluidos mantélicos pela crosta continental brasiliana.

\section{- Perfis Integrados das Assinaturas Aeromagnéticas no Dominio da Freqüência:}

Os perfis integrados $\mathrm{BB}^{\prime}, \mathrm{CC}^{\prime}$ e EE' foram realizados a partir dos mapas de anomalias aeromagnéticas obtidas pela filtragem no domínio da freqüência (Fig. 7.43, $7.44 \mathrm{e}$ 7.45). Estes perfis mostram a distribuição e a interrelação das anomalias em diferentes niveis crustais, correlacionando-as diretamente com a geologia do terreno e favorecendo a comparação com os dados gravimétricos.

Para os perfis BB' e EE' as curvas para profundidades de crosta inferior (Fig. 7.43a e 7.45a) apresentam amplitudes positivas para a região dos blocos arqueanos e paleoproterozóicos, sugerindo a presença de rochas básicas como raízes dos blocos. As ZCT, ZCLP, ZCSJC, ZCSE, ZCBNC e ZCMN foram definidas por picos positivos, desde níveis de crosta inferior até crosta superior (Fig. 7.43b, 7.43c, 7.43d, 7.45b, 7.45c, 7.45d) sugerindo que estas zonas de cisalhamento interceptam toda a crosta, condicionando rochas básico-intermediárias de origem mantélica.

O fato de maior destaque no perfil CC' (Fig. 7.44) é o alto magnético que caracteriza a faixa de Barra de Santa Rosa e o sistema ZCRP-ZCCG com elevada amplitude $(100 \mathrm{nT})$ desde as filtragens para a base da crosta inferior (Fig.7.44a). Em direção à crosta superior (Fig. 7.44b, 7.44c, 7.44d), o aumento da freqüência (ruído) permitiu a 

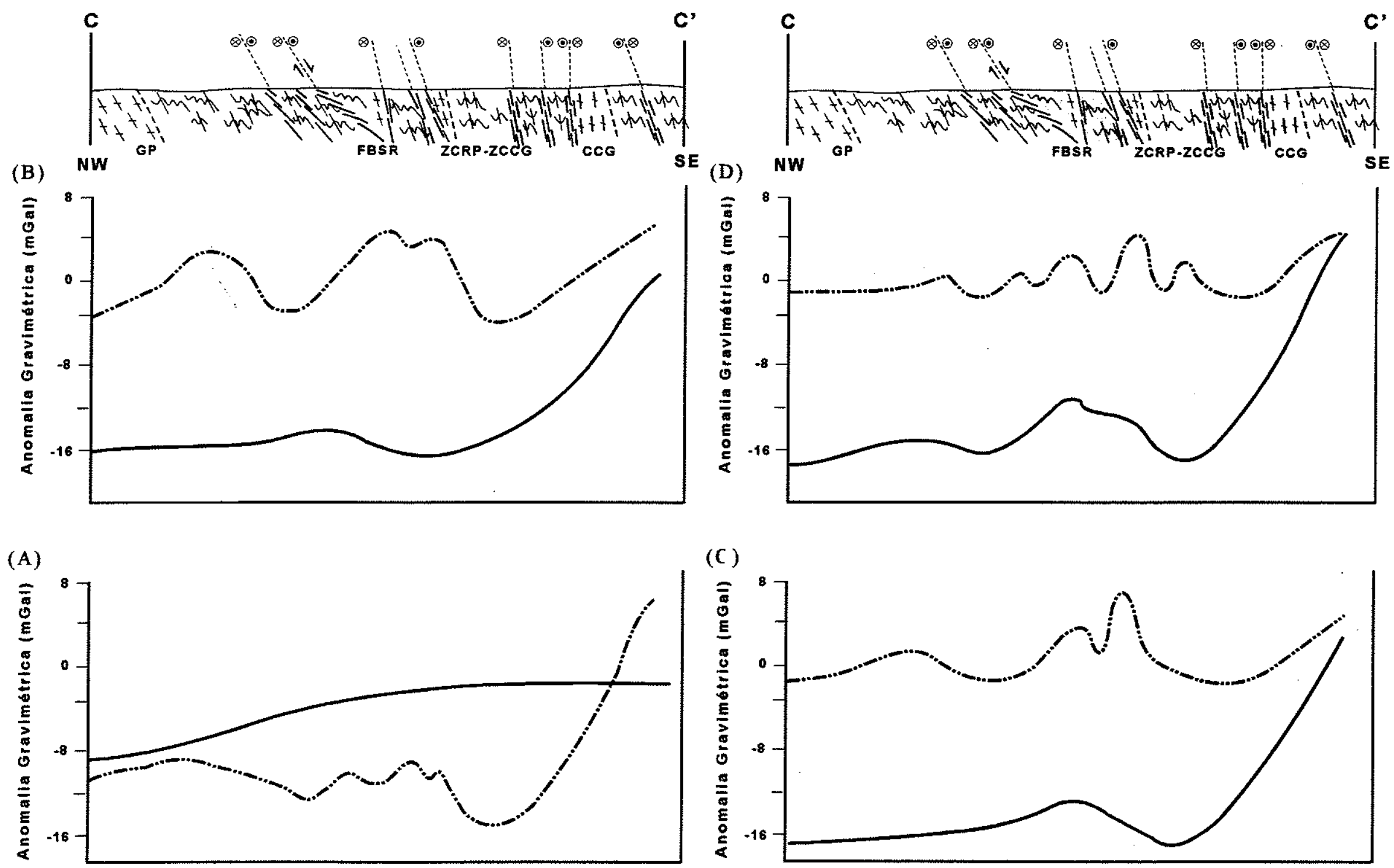

Figura 7.42 - Perfis integrados das anomalias gravimétricas resultantes da filtragem no domínio espaço-temporal por filtros quadrados (A) de $\lambda=200 \mathrm{~km}$ e seu residual, (B) de $\lambda=50 \mathrm{~km}$ e seu residual, (C) de $\lambda=30 \mathrm{~km}$ e seu residual, (D) de $\lambda=10 \mathrm{~km}$ e seu

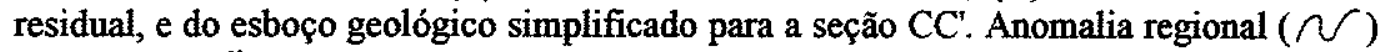
e residual $(\because \ddot{)})$. A seção $C^{\prime \prime}$ esta localizada na Figura 7.36. 

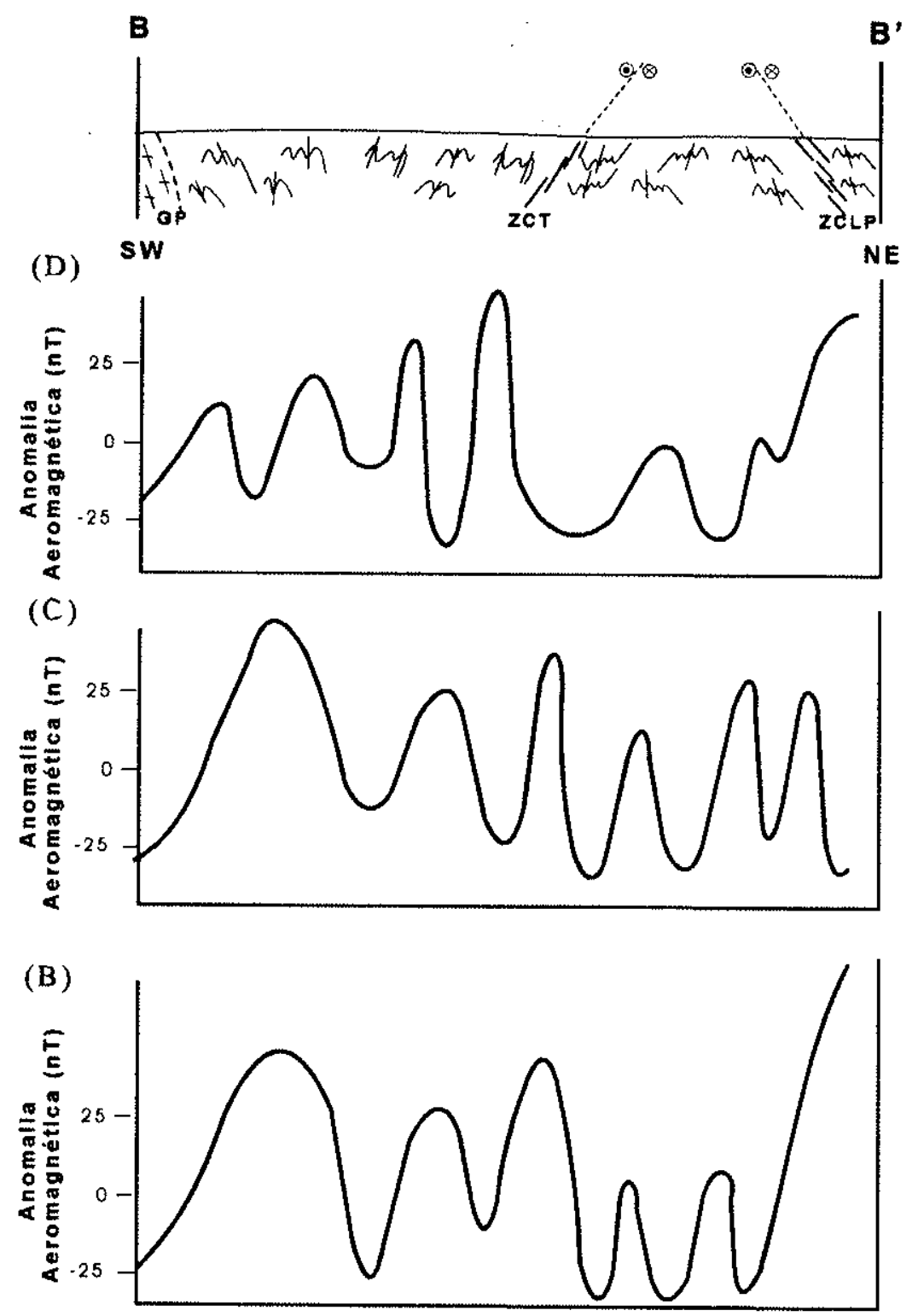

(A)

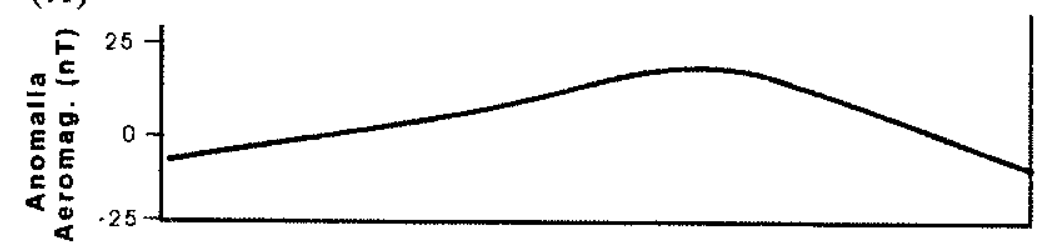

Figura 7.43 - Perfis integrados das anomalias aeromagnéticas resultantes da filtragem no domínio da freqüência por filtros passa-banda (A) e passa-alta $(B, C, D)$ e do esboço geológico simplificado para a seção $\mathrm{BB}$ '. $\mathrm{O}$ filtro passa-banda permite passagem de 250 $\mathrm{km}<\lambda<80 \mathrm{~km}$, rejeita $\lambda>600 \mathrm{~km}$ e $\lambda<30 \mathrm{~km}$ e os $\lambda$ entre esses valores foram cosinetapered. Os filtros passa-alta para (B) permite a passagem de $\lambda<50 \mathrm{~km}$, rejeita $\lambda>250$ $\mathrm{km}$ e os valores intermediários foram cosine-tapered; (C) permite a passagem de $\lambda<30$ $\mathrm{km}$, rejeita $\lambda>50 \mathrm{~km}$ e os valores intermediários foram cosine-tapered; (D) permite a passagem de $\lambda<10 \mathrm{~km}$, rejeita $\lambda>30 \mathrm{~km}$ e os valores intermediários foram cosine. tapered. As seções estão localizadas na Figura 7.37. 

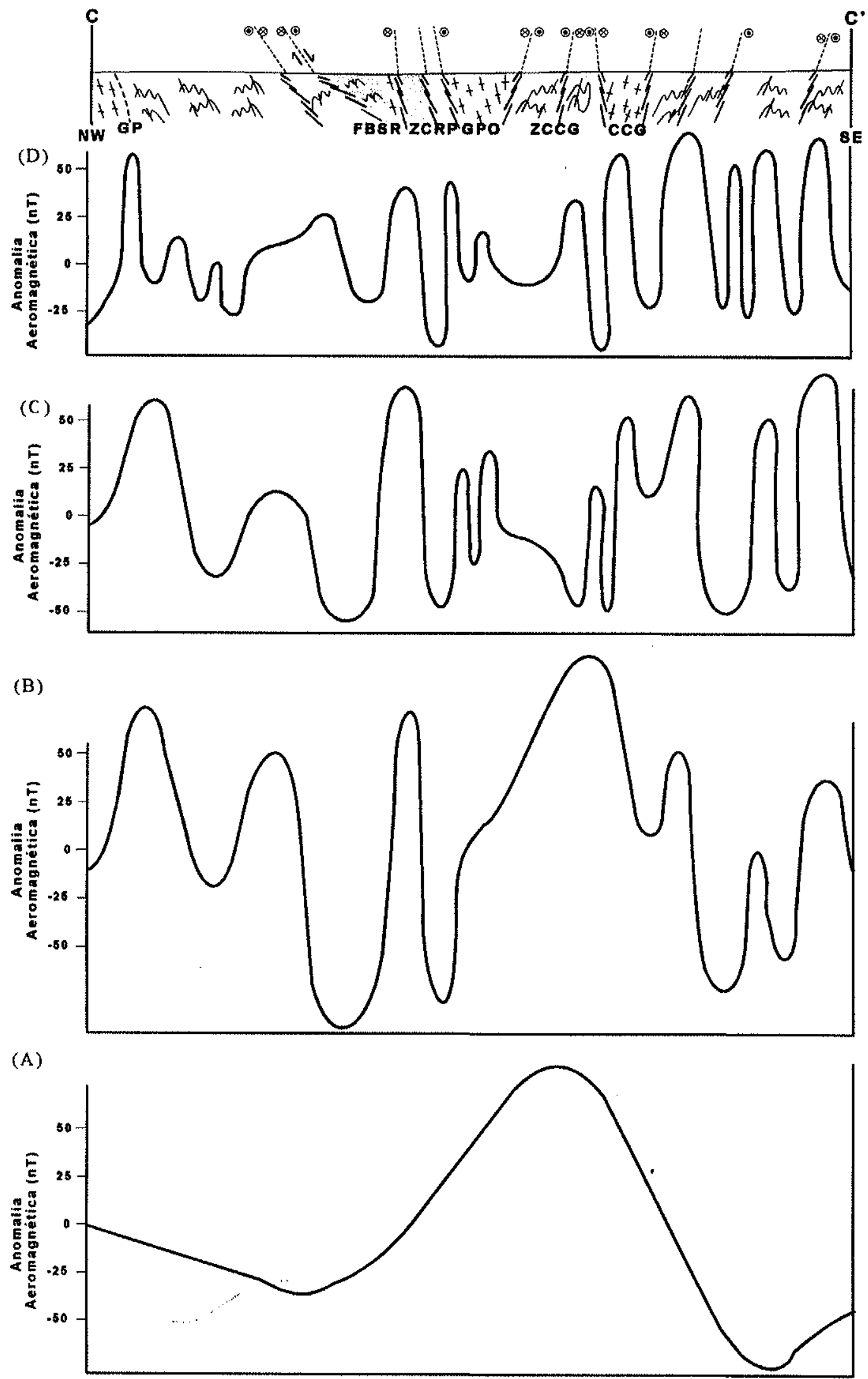

Figura 7.44 - Perfis integrados das anomalias aeromagnéticas resultantes da filtragem no domínio da frequência por filtros passa-banda (A) e passa-alta $(B, C, D)$ e do esboço geológico simplificado para a seção $\mathrm{CC}^{\prime}$. $\mathrm{O}$ filtro passaubanda permite passagem de 250 $\mathrm{km}<\lambda<80 \mathrm{~km}$, rejeita $\lambda>600 \mathrm{~km}$ e $\lambda<30 \mathrm{~km}$ e os $\lambda$ entre esses valores foram cosinetapered. Os filtros passa-alta para (B) permite a passagem de $\lambda<50 \mathrm{~km}$, rejeita $\lambda>250$ $\mathrm{km}$ e os valores intermediários foram cosine-tapered; (C) permite a passagem de $\lambda<30$ $\mathrm{km}$, rejeita $\lambda>50 \mathrm{~km}$ e os valores intermediários foram cosine-tapered; (D) permite a passagem de $\lambda<10 \mathrm{~km}$, rejeita $\lambda>30 \mathrm{~km}$ e os valores intermediários foram cosine tapered. As seções estão localizadas na Figura 7.37. 
individualização por picos positivos das zonas de cisalhamento, dos plútons alcalinos (p.ex. Algodão, Caxexa) e das associaçð̃es máficas do $\mathrm{CCG}$, enquanto a fatia de micaxistos de Barra de Santa Rosa e o granito Pocinhos foram destacados por baixos aeromagnéticos. Este fato demonstra o controle das condiçðes deformacionais do sistema ZCRP-ZCCG no soerguimento da Moho, condicionando os processos como a fusão crustal, a diferenciação magmática, o metamorfismo de alto grau e a canalização de fluidos mantélicos em diferentes niveis da crosta nesse setor.

No perfil EE', a assinatura das anomalias aeromagnéticas para a crosta inferior (Fig. 7.45a) caracteriza com baixo magnético a região do DLD e do granito Serrinha, e com alto a região das ZCBNC e ZCMN, indicação da estreita relação das zonas de cisalhamento com a deformação da Moho. Nos demais perfis (Fig. 7.45b, 7.45c, 7.45d), progressivamente em direção à crosta superior, essa correlação com picos positivos permanece inalterada para as zonas de cisalhamento. No entanto, para a região do DLD e plútons brasilianos surgem picos positivos relacionados, provavelmente relacionados à corpos básicos e intermediários presentes desde níveis de crosta inferior-média.

\section{- Perfis Integrados das Assinaturas Aeromagnéticas no Dominio Espaço-Temporal:}

Os perfis integrados resultantes das filtragens no domínio espaço-temporal para os perfis BB', CC' e EE' (Fig. 7.46, 7.47, 7.48), nos comprimentos de onda de $50 \mathrm{~km}, 30$ $\mathrm{km}, 10 \mathrm{~km} \mathrm{e} 5 \mathrm{~km}$, apresentam as mesmas características e interpretações feitas para os perfis no domínio da freqüência. Todavia, as assinaturas das anomalias mostram-se mais alisadas e concentrando os ruídos nas áreas dos granitóides e zonas de cisalhamento.

No perfil BB' (Fig. 7.46), as localizações das ZCT e ZCLP foram melhor definidas pelas assinaturas de $10 \mathrm{~km} \mathrm{e} 5 \mathrm{~km}$ (Fig. 7.46c, 7.46d), e nas anomalias residuais de $50 \mathrm{~km}$ (Fig. 7.46a), com ruídos de menor amplitude nas filtragens para a crosta médiasuperior e superior (Fig. 7.46b). As curvas para comprimentos de onda de $50 \mathrm{~km}$ e $30 \mathrm{~km}$ (Fig. 7.46a, b) indicam a forma geral da superfície magnética da crosta para essas profundidades, com definição das zonas de cisalhamento relacionado apenas às anomalias residuais. A mesma observação pode ser mantida para os perfis $\mathrm{CC}^{\prime}$ e EE'. Entretanto, a associação dos picos positivos com as zonas de cisalhamento na assinatura residual de 50 $\mathrm{km}$ é uma indicação definitiva da continuidade das zonas de cisalhamento até pelo menos profundidades da Moho. 


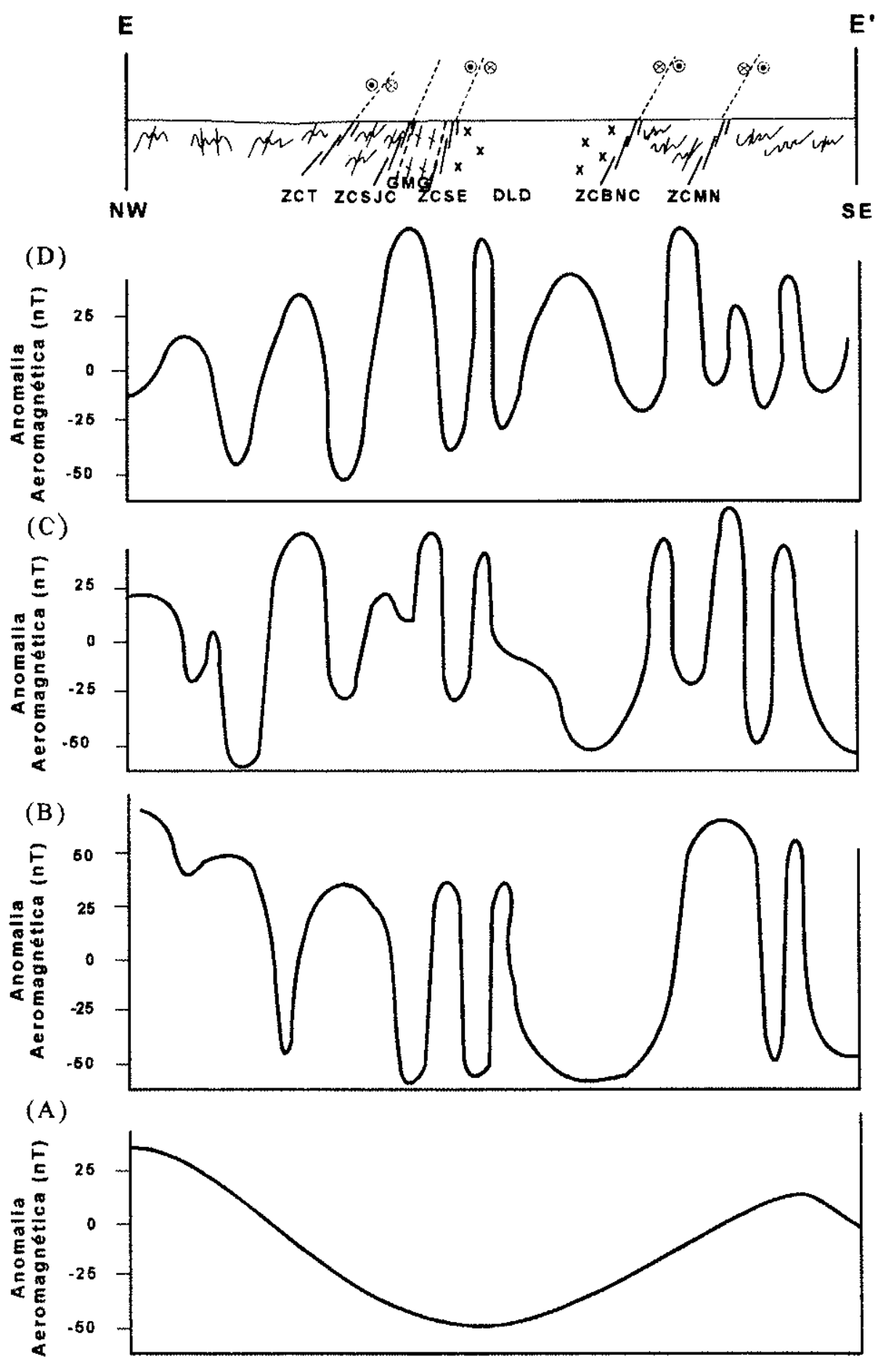

Figura 7.45 - Perfis integrados das anomalias aeromagnéticas resultantes da filtragem no domínio da freqüência por filtros passa-banda $(A)$ e passa-alta $(B, C, D)$ e do esboço geológico simplificado para a seção EE'. O filtro passa-banda permite passagem de 250 $\mathrm{km}<\lambda<80 \mathrm{~km}$, rejeita $\lambda>600 \mathrm{~km}$ e $\lambda<30 \mathrm{~km}$ e os $\lambda$ entre esses valores foram cosinetapered. Os filtros passa-alta para (B) permite a passagem de $\lambda<50 \mathrm{~km}$, rejeita $\lambda>250$ $\mathrm{km}$ e os valores intermediários foram cosine-tapered; (C) permite a passagem de $\lambda<30$ $\mathrm{km}$, rejeita $\lambda>50 \mathrm{~km}$ e os valores intermediários foram cosine-tapered; (D) permite a passagem de $\lambda<10 \mathrm{~km}$, rejeita $\lambda>30 \mathrm{~km}$ e os valores intermediários foram cosinetapered. As seções estão localizadas na Figura 7.37. 

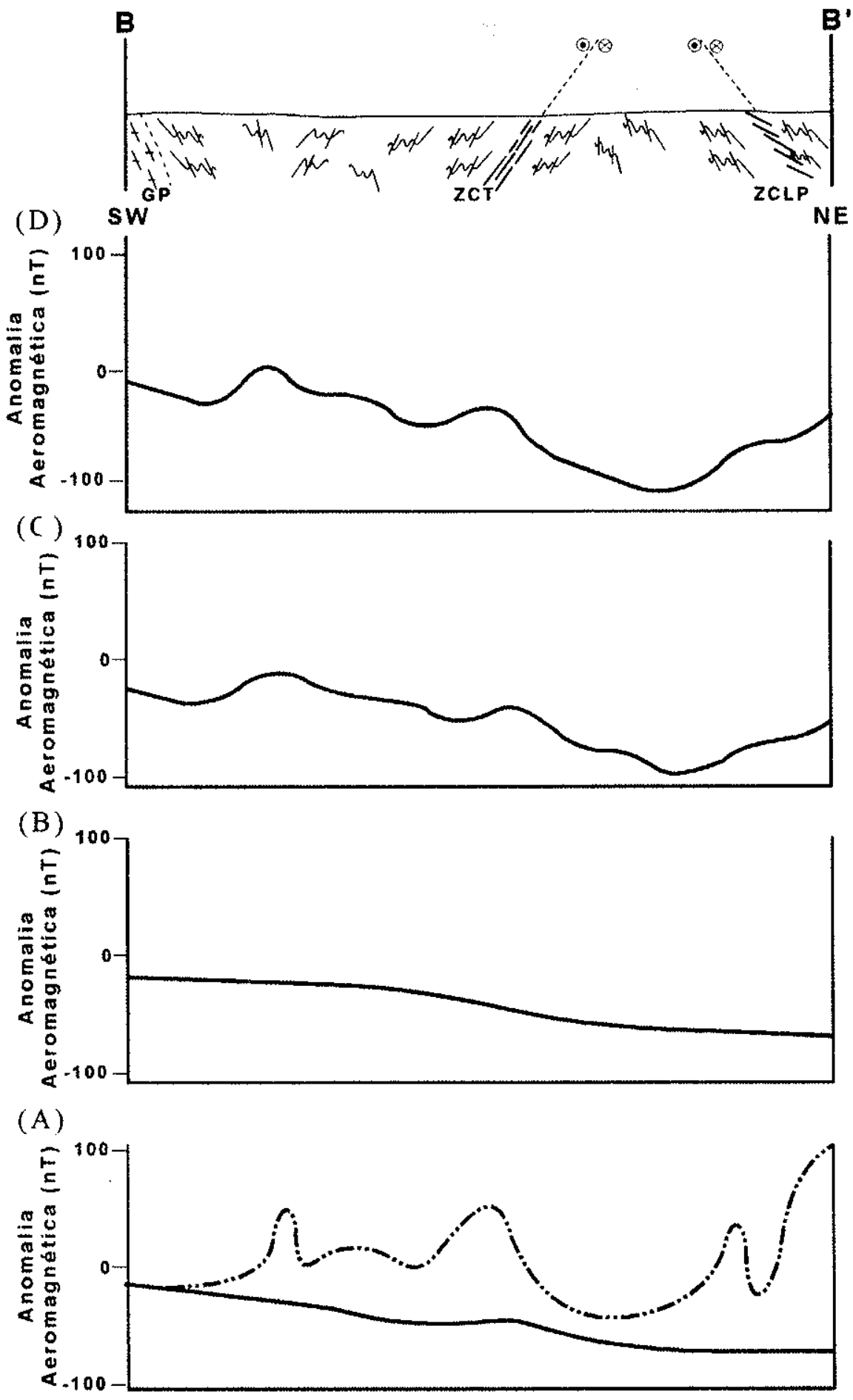

Figura 7.46 - Perfis integrados das anomalias aeromagnéticas resultantes da filtragem no domínio espaço-temporal por filtros quadrados de comprimentos de onda ( $\lambda$ ) de (A) 50 $\mathrm{km}(\sim)$ e seu residual $(/ \mathrm{l})$ ), (B) $30 \mathrm{~km}$, (C) $10 \mathrm{~km}$, (D) $5 \mathrm{~km}$, e do esboço geológico para a seção BB'. A seção está localizada na Figura 7.37. 
No perfil CC' (Fig. 7.47), a faixa de Barra de Santa Rosa e o sistema ZCRPZCCG foram definidas por anomalias magnéticas positivas em todos perfis, desde os comprimentos de onda de $50 \mathrm{~km}$ e $30 \mathrm{~km}$ (Fig. 7.47a e 7.47b). Os picos positivos para a ZCRP e CCG são individualizados nas assinaturas inferiores a $10 \mathrm{~km}$ (Fig. 7.47c, 7.47d). As anomalias residuais de $50 \mathrm{~km}$ (Fig. 7.47a) marca com picos positivos as principais zonas de cisalhamento, mesmo aquelas subhorizontais na borda da fatia de micaxistos de Barra de Santa Rosa, o sistema ZCRP-ZCCG, o CCG e as zonas de cisalhamento sinistrais do MCB. O bloco paleoproterozóico, o granito Pocinhos e o MCB estão definidos por assinaturas negativas em todos os perfis, condicionados por anomalias positivas que indicam as zonas de cisalhamento nas bordas.

Para o perfil EE'(Fig. 7.48), o residual de $50 \mathrm{~km}$ marca com picos positivos a região do diorito Serrinha e das ZCT, ZCSJC e ZCSE, e com largo pico positivo as ZCBNC e ZCMN, indicando a possível coalescência destas zonas em profundidade. Os setores do bloco paleoproterozóico e do DLD foram definidos por assinaturas negativas de baixa amplitude em todos os perfis (Fig. 7.48a até 7.48d), limitado nas bordas pelas zonas de cisalhamento com assinaturas positivas bem definidas nos perfis das Fig. $7.48 \mathrm{c}$ e $7.48 \mathrm{~d}$.

\section{6 - Reativação Tectônica Meso-Cenozóica na Região Litorânea de Natal/RN Com Base nos Dados Gravimétricos, Imagens Landsat 5-TM e GEMS/Banda X}

Na região contida entre os paralelos $05^{\circ} 15^{\prime}-06^{\circ} 30^{\prime} \mathrm{S}$ e os meridianos $35^{\circ} 00^{\prime}$ $35^{\circ} 45^{\prime} \mathrm{W}$, que engloba a áreas urbana e periurbana de Natal e seus entornos, foram avaliadas as implicações da reativação meso-cenozóica das estruturas brasilianas, com base na correlação das filtragens dos dados gravimétricos para níveis crustais intermediários e superiores, com os mapas integrados de lineamentos topográficos, das estruturas frágeis interpretadas e dados de campo em áreas específicas.

O soerguimento orogênico da região, e conseqüente arrefecimento progressivo do principal episódio deformacional, é bem definido pelo retrometamorfismo das zonas de cisalhamento de alta-T em faixas miloníticas de baixa- $\mathrm{T}$ e ultramiloniticas, seguidas por estruturas cataclásticas tardias. A distribuição descontínua da deformação $\mathrm{D}_{3}$, numa etapa tardia, controla a concentração dos deslocamentos em faixas estreitas superimpostas às zonas de cisalhamento principais. Estas faixas estão comumente expressas por lineamentos 

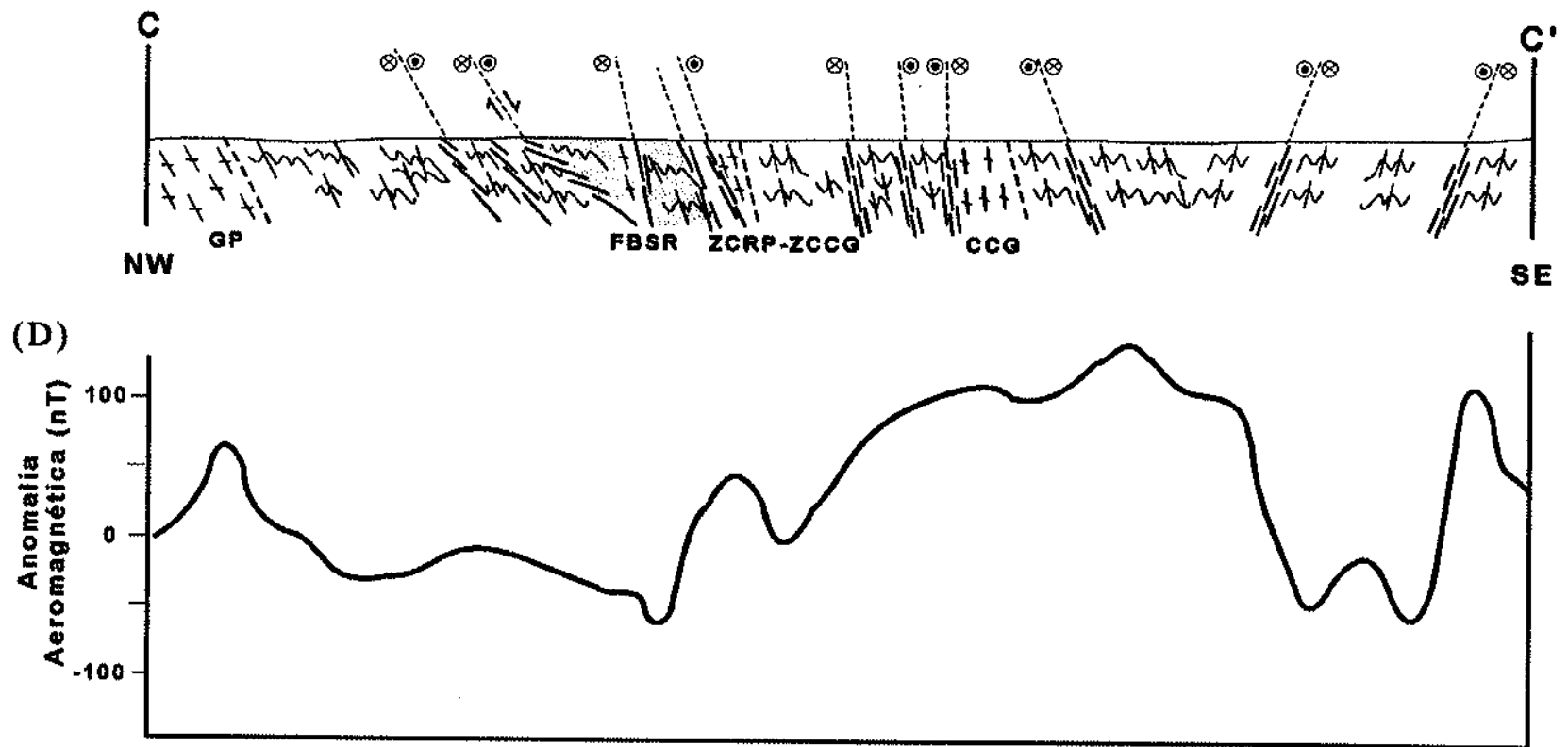

(C)
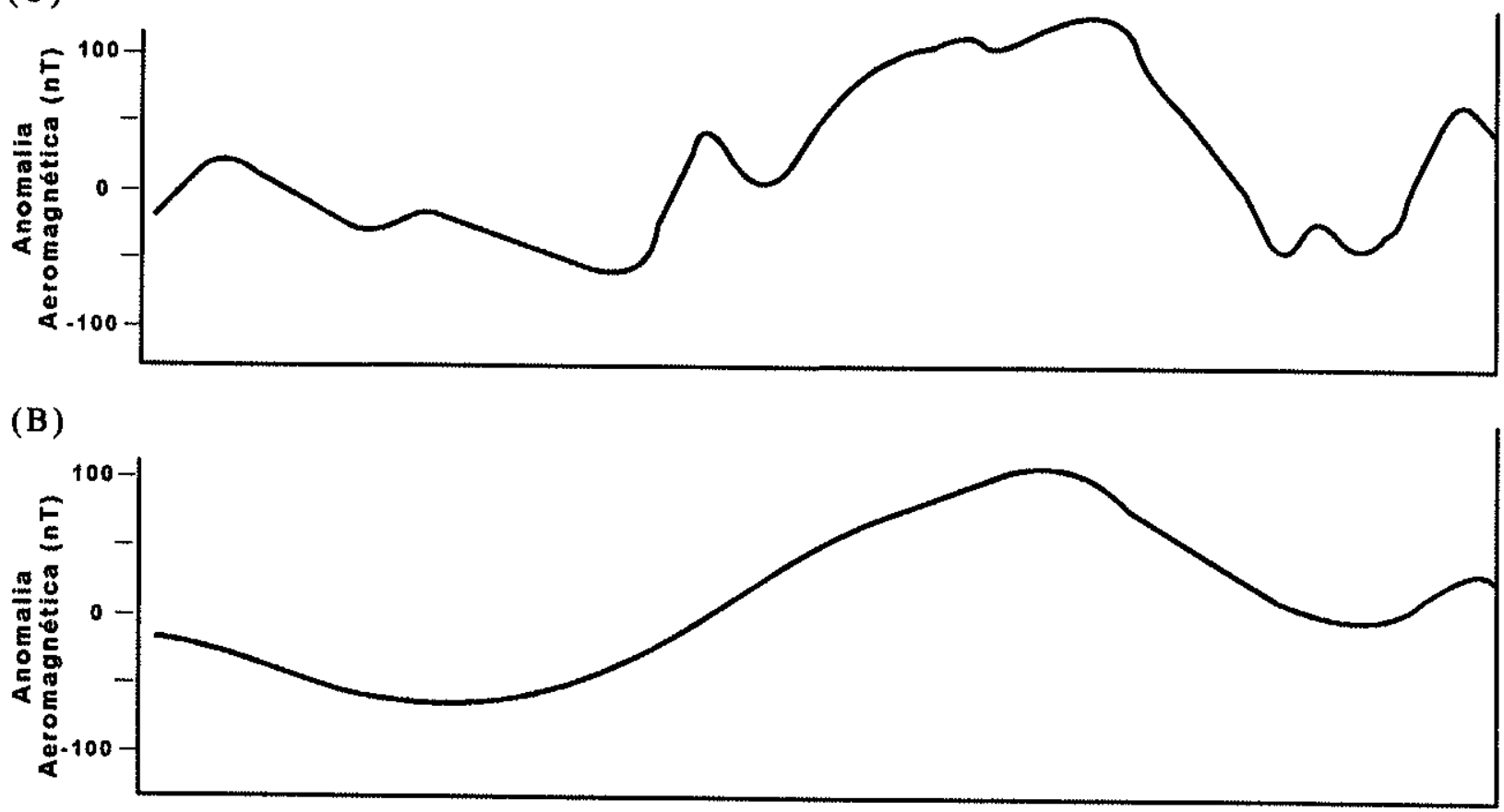

(A)

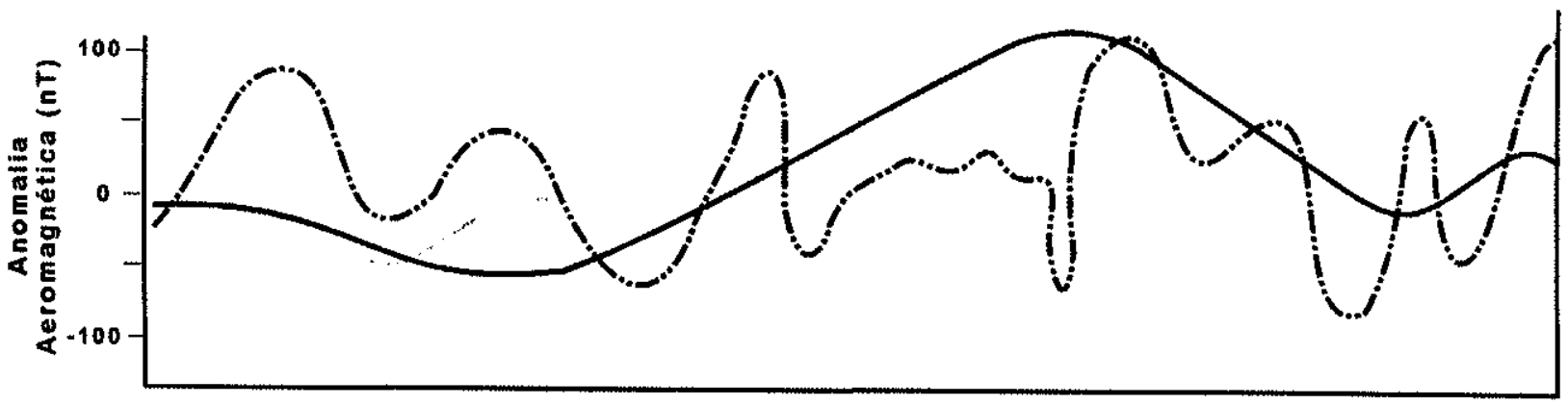

Figura 7.47 - Perfis integrados das anomalias aeromagnéticas resultantes da filtragem no domínio espaço-temporal por filtros quadrados de comprimentos de onda $(\lambda)$ de $(A)$ $50 \mathrm{~km}(\sim)$ ) e seu residual $(r j \backslash)$, (B) $30 \mathrm{~km},(\mathrm{C}) 10 \mathrm{~km},(\mathrm{D}) 5 \mathrm{~km}, \mathrm{e}$ do esboço geológico para a seção CC'. A seção está localizada na Figura 7.37. 

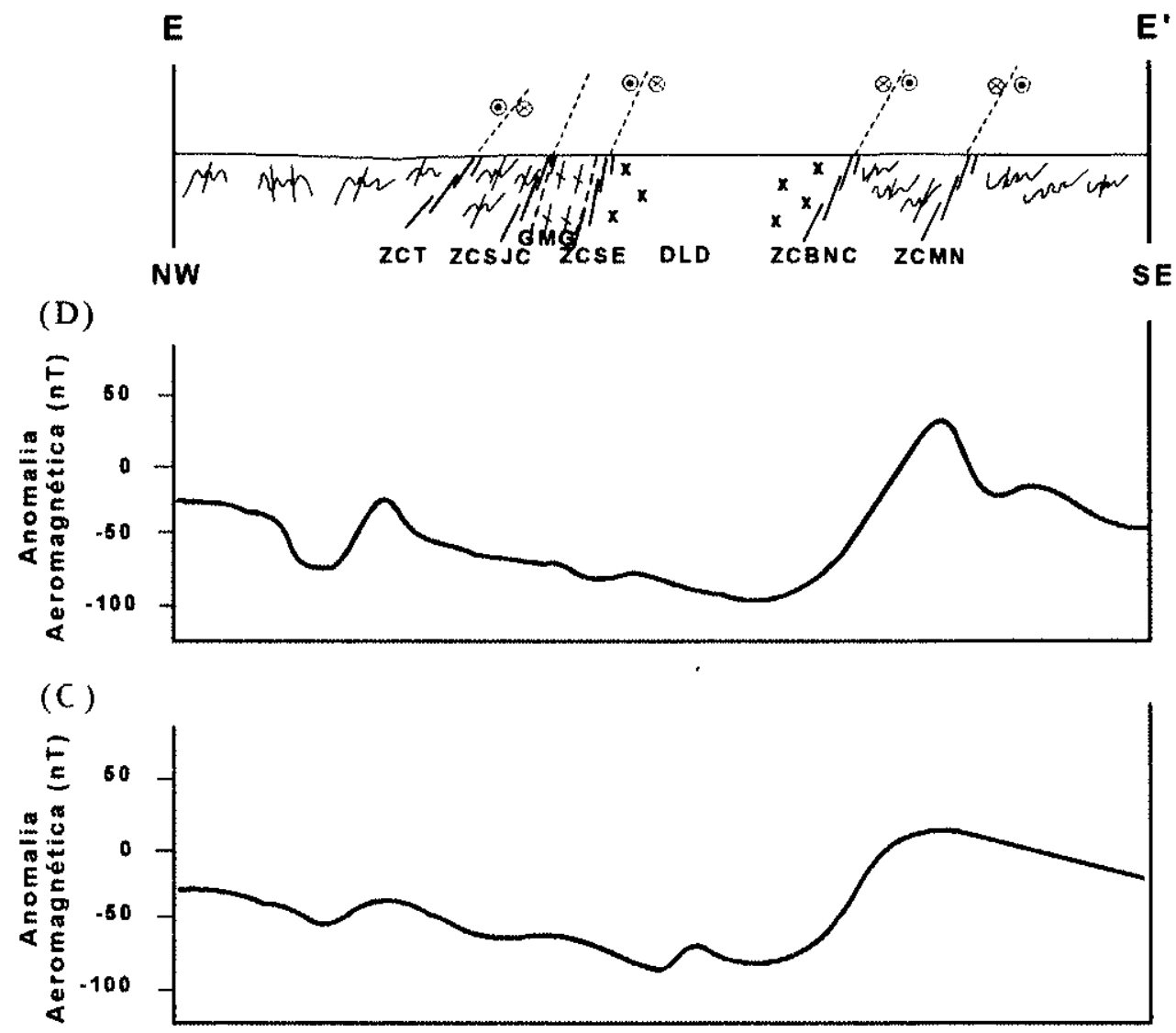

(B)
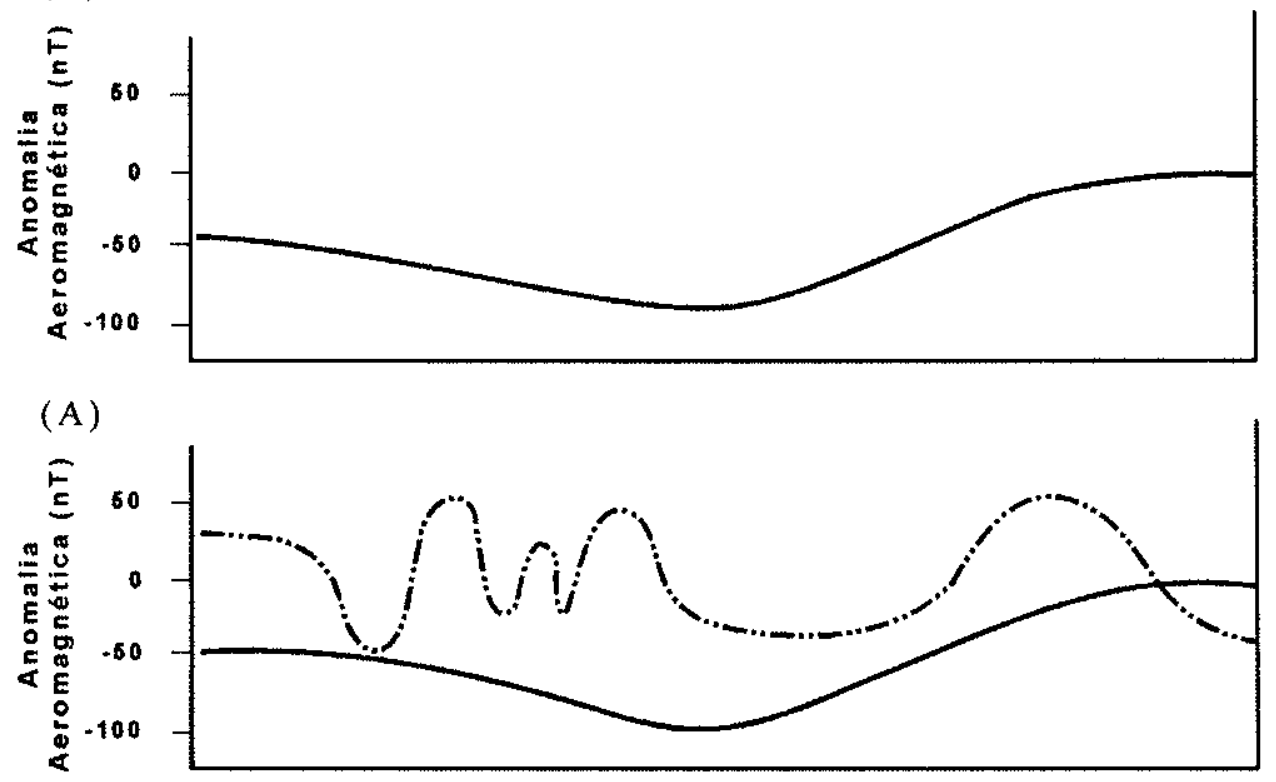

Figura 7.48 - Perfis integrados das anomalias aeromagnéticas resultantes da filtragem no domínio espaço-temporal por filtros quadrados de comprimentos de onda $(\lambda)$ de $(A)$ $50 \mathrm{~km}(\sim$ ) e seu residual (,$\circlearrowleft$ ), (B) $30 \mathrm{~km},(C) 10 \mathrm{~km}$, (D) $5 \mathrm{~km}$, e do esboço geológico para a seção EE'. A seção está localizada na Figura 7.37. 
longos, por vezes escalonados, espacialmente bem definidos e com o mesmo trend das zonas de cisalhamento de alta-T, e correspondem às falhas assinaladas nos mapas regionais préexistentes (DNPM/CPRM 1974, 1978). Outras estruturas tardi-brasilianas, como as fraturas de extensão subverticais, são geralmente transversais aos trends da deformação dúctil, freqüentemente condicionando veios de quartzo e pegmatíticos.

Recentemente, alguns estudos reportaram à evolução neotectônica da região de Natal baseados na interpretação morfotectônica das estruturas frágeis correlacionadas aos dados gravimétricos (Bezerra et al. 1994, Fonseca 1996, Fonseca et al. 1997). Estes estudos demonstraram, baseados no arranjo das anomalias Bouguer, o alinhamento direcional entre as zonas de cisalhamento brasilianas e as falhas de trend geral NE e NW que condicionam os grabens e horsts da faixa litorânea. Bezerra et al. (1996) sugeriram processos de reativação no intervalo Pleistoceno Médio-Holoceno, em função dos sedimentos de terraços fluviais de drenagens atuais terem sido afetados por falhas que interceptam os granitóides brasilianos na região de Natal-Macaíba. Torres (1994), a partir da análise dos padrões de deslocamentos de falhas nos afloramentos da Formação Barreiras, nas proximidades da região epicentral de João Câmara, apresentaram um modelo onde o eixo $\sigma_{1}$ do stress (eixo de compressão máxima) está orientado NW-SE e o eixo $\sigma_{3}$ do stress (eixo de compressão mínima horizontal) está orientado NE-SW, compondo um sistema de Riedel entre duas zonas de cisalhamento com trend EW, a ZCPA e a zona de cisalhamento de Fernando de Noronha em offshore. Estes autores sugeriram que as principais orientações das falhas sismogênicas são $\mathrm{EW}$, NS e $\mathrm{N} 60-70^{\circ} \mathrm{E}$. Ainda sobre a reativação dos elementos da deformação brasiliana, Oliveira (1994) demonstrou para a região metropolitana do Recife/PE a correlação direta entre as zonas de cisalhamento da terminação do lineamento Pernambuco e as principais falhas que controlam os grabens e horsts costeiros, conforme o arcabouço estrutural interpretado dos mapas de anomalias Bouguer.

As anomalias gravimétricas regionais nas principais bacias intracratônicas sugerem uma compartimentação estrutural, com uma área de expressivo afinamento crustal limitada nas zonas de cisalhamento neoproterozóicas (Castro \& Medeiros 1997). A influência das zonas de cisalhamento brasilianas na estruturação e condicionamento da reativação crustal na região define-se ainda nas áreas de espessamento laterais - blocos 
laterais à área de estiramento e ruptura - centradas sobre as Faixas Seridó e Noroeste do Ceará, ambas com espessamento crustal no Brasiliano (Jardim de Sá 1994).

\subsection{1 - Mapa dos Lineamentos Frágeis e/ou Dúcteis-Frágeis e das Anomalias}

\section{Gravimétricas Para a Crosta Média e Superior}

$\mathrm{Na}$ avaliação dos mapas de anomalias gravimétricas em diferentes comprimentos de onda na região litorânea de Natal destacou-se o grande número de anomalias de curtos comprimentos de onda sob a cobertura sedimentar. Estas anomalias demonstram a intensa deformação nas bordas do continente, em sistemas de grabens e horsts, com provável aporte de fluidos magmáticos conduzidos pelas falhas extensas e profundas (Fig. 7.49). Da mesma maneira que na correlação entre as estruturas dúcteis $e$ as anomalias gravimétricas regionais e residuais, foram selecionadas filtragens nos domínios da freqüência e espaço-temporal para profundidades desde a crosta média até superior, ou seja ambientes deformacionais de caráter frágil-dúctil e frágil. O mapa da Fig. 7.50 foi obtido a partir de filtragem no domínio da frequêencia com filtro passa-alta que permitiu a passagem de comprimentos de onda inferiores a $30 \mathrm{~km}$, rejeitando os superiores a $250 \mathrm{~km}$ e cosine-tapered os valores intermediários. Este mapa apresenta as anomalias residuais para o conjunto da crosta continental, de tal forma que favoreça a comparação entre às anomalias residuais das filtragens para os niveis crustais diferenciados

No domínio da freqüência, os filtros selecionados foram (a) o filtro passa-alta que permitiu a passagem de comprimentos de onda inferiores a $30 \mathrm{~km}$, rejeitou aqueles superiores a $50 \mathrm{~km}$ e cosine-tapered os valores intermediários (Fig. 7.51); (b) o filtro passaalta complementar que permitiu a passagem de comprimentos de onda inferiores a $10 \mathrm{~km}$, rejeitando os superiores a $30 \mathrm{~km}$ e cosine-tapered os demais valores (Fig. 7.53). Os filtros quadrados do domínio espaço-temporal escolhidos foram aqueles com comprimentos de onda de $20 \mathrm{~km}$ e $10 \mathrm{~km}$ (Fig. 7.52 e 7.54, respectivamente).

Os mapas de lineamentos de contorno-zero foram obtidos a partir dos mapas de anomalias gravimétricas residuais para comprimentos de onda inferiores a $30 \mathrm{~km}$ (Fig. 7.55), entre $20 \mathrm{~km}$ e $10 \mathrm{~km}$ (Fig. 7.56), e inferiores a $10 \mathrm{~km}$ (Fig. 7.57). Este procedimento permite a definição das bordas dos corpos ou estruturas causativas das anomalias residuais em profundidade. Os mapas exibem os principais trends dos elementos lineares condicionantes das variações gravimétricas que constituem o arcabouço estrutural da região, quanto à 


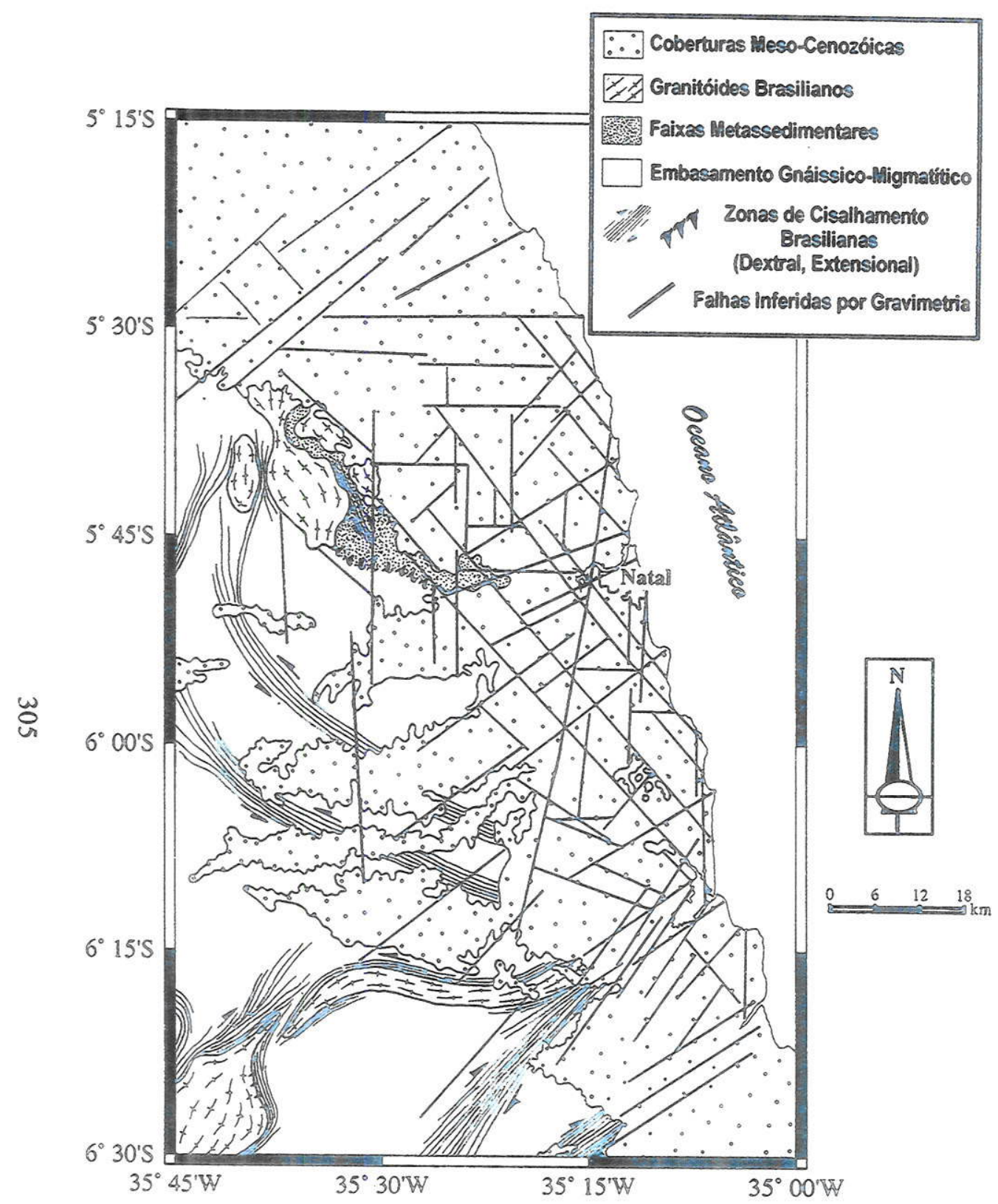

Figura 7.49 - Arcabouço geológico da região costeira de Naral/RN com indicações das principais falhas inferidas da análise dos mapas gravimétricos residuais.

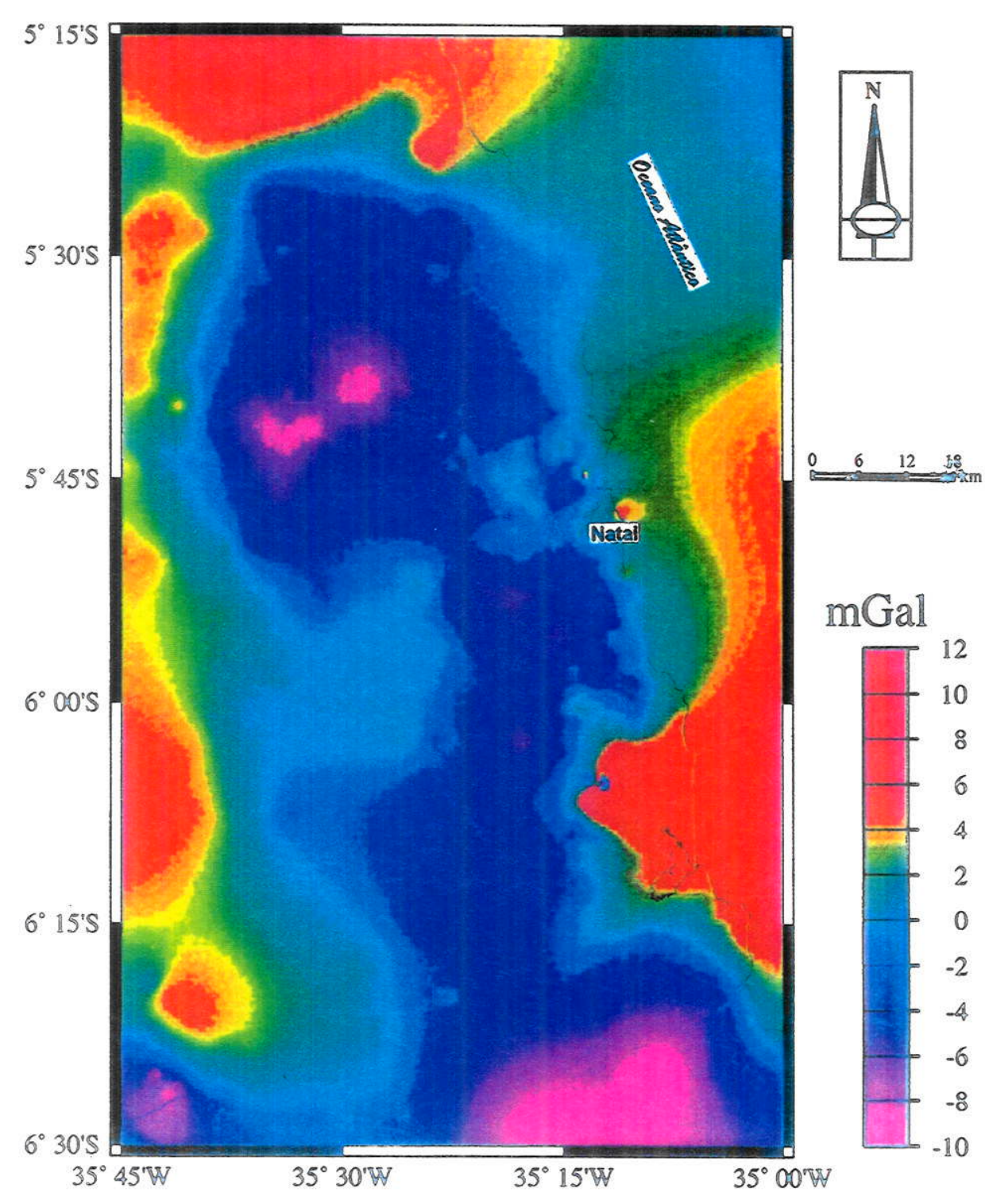

Figura 7.50- Mapa de anomalias gravimétricas da região costeira de Natal/RN obtidas a partir de filtragem no domínio da frequiência com filtro passa-alta que permite a passagem de $\lambda<30 \mathrm{~km}$, rejeita $\lambda>250 \mathrm{~km}$ e cosine-rapered os valores intermediários. 


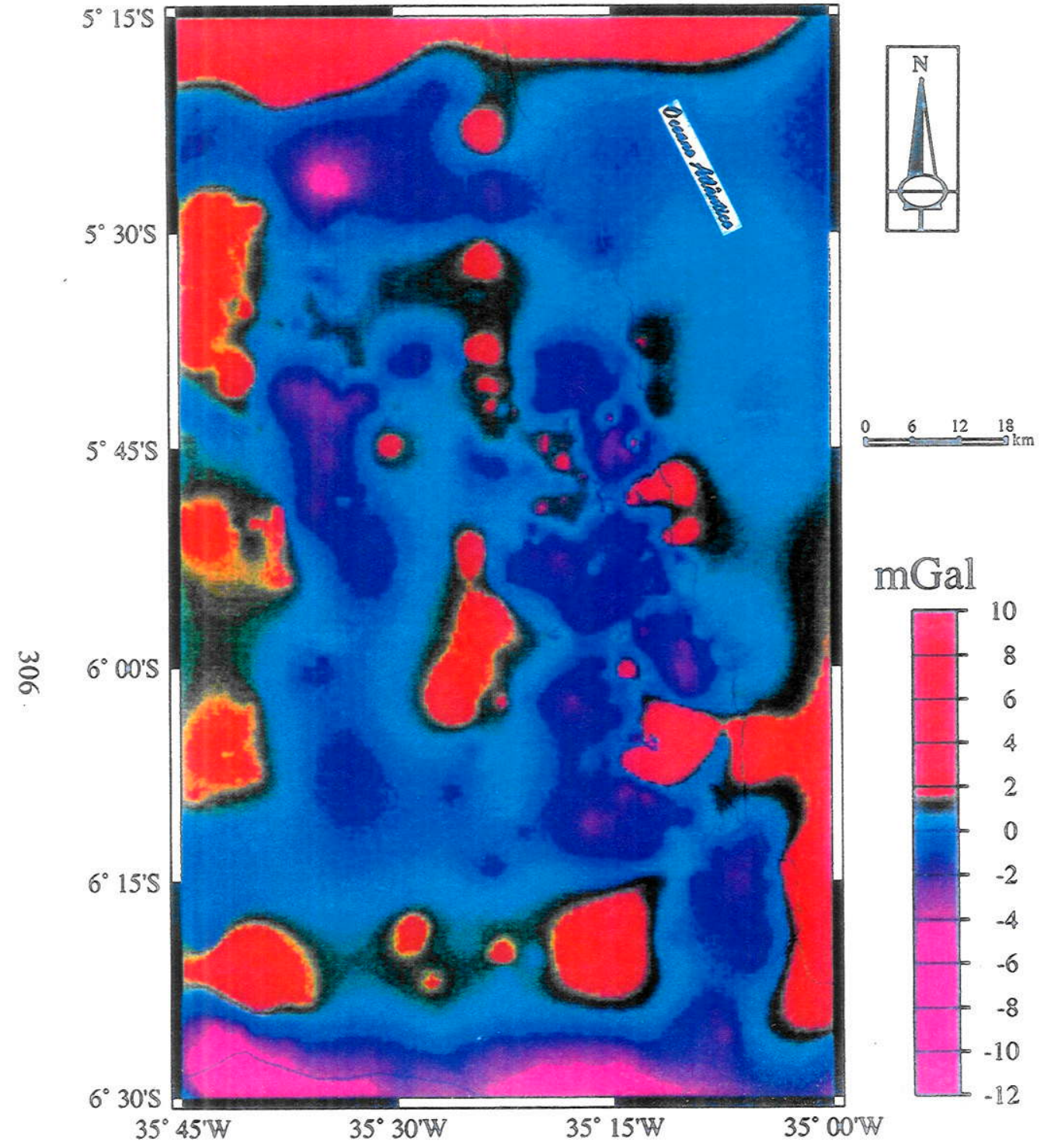

Figura 7.51 - Mapa de anomalias gravimétricas da região costeira de Natal/RN obtidas a partir de filtragem no domínio da frequeência com filtro passa-alta que permite a passagem de $\lambda<30 \mathrm{~km}$, rejeita $\lambda>50 \mathrm{~km}$ e cosine-iopered os valores intermediários.

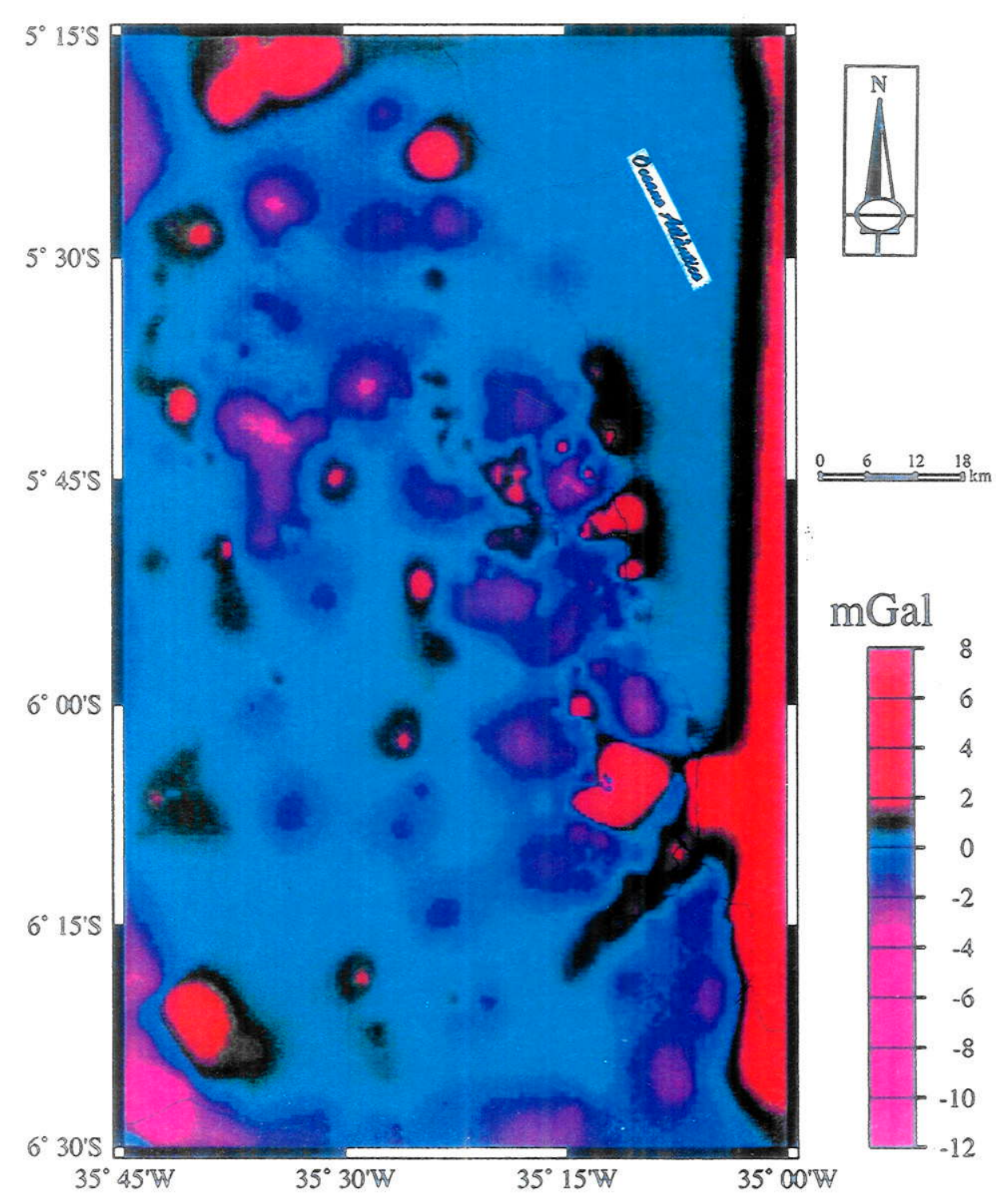

Figura 7.52- Mapa de anomalias gravimétricas da região costeira de Natal/RN obtidas a partir do resíduo de filtragem no domínio espaço-temporal com filtro quadrado de $\lambda=20 \mathrm{~km}$. 


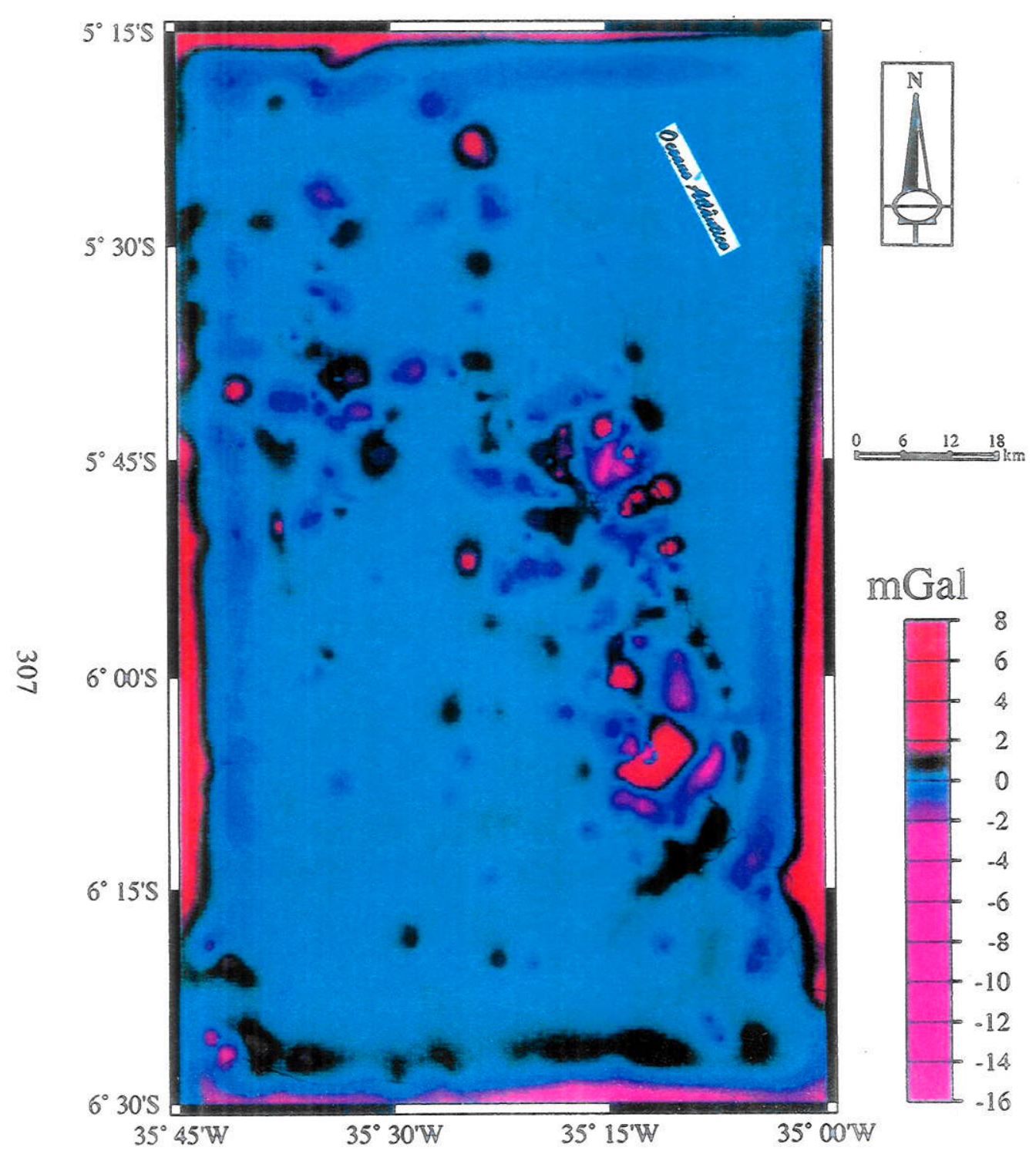

Figura 7.53- Mapa de anomalias gravimétricas da região costeira de Naral/RN obtidas a partir de filtragem no domínio da frequeeência com filtro passa-alta que permite a passagem de $\lambda<10 \mathrm{~km}$, rejeita $\lambda>30 \mathrm{~km}$ e cosine-iapered os valores intermediários.

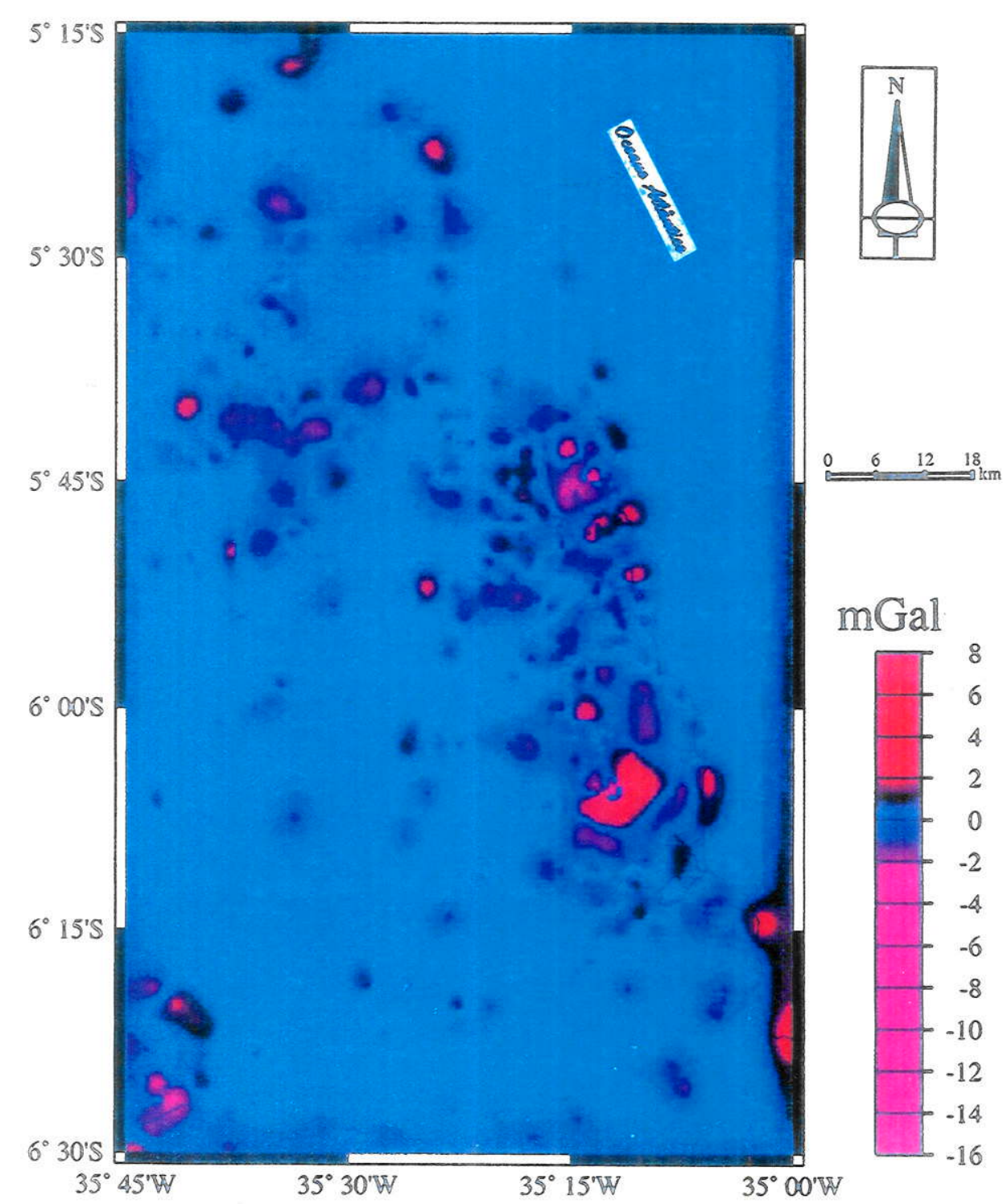

Figura 7.54 - Mapa de anomalias gravimécricas da região costeira de Natal/RN obtidas a partir do resíduo de filtragem no domínio espaco-remporal com filtoro quadrado de $\lambda=10 \mathrm{~km}$. 


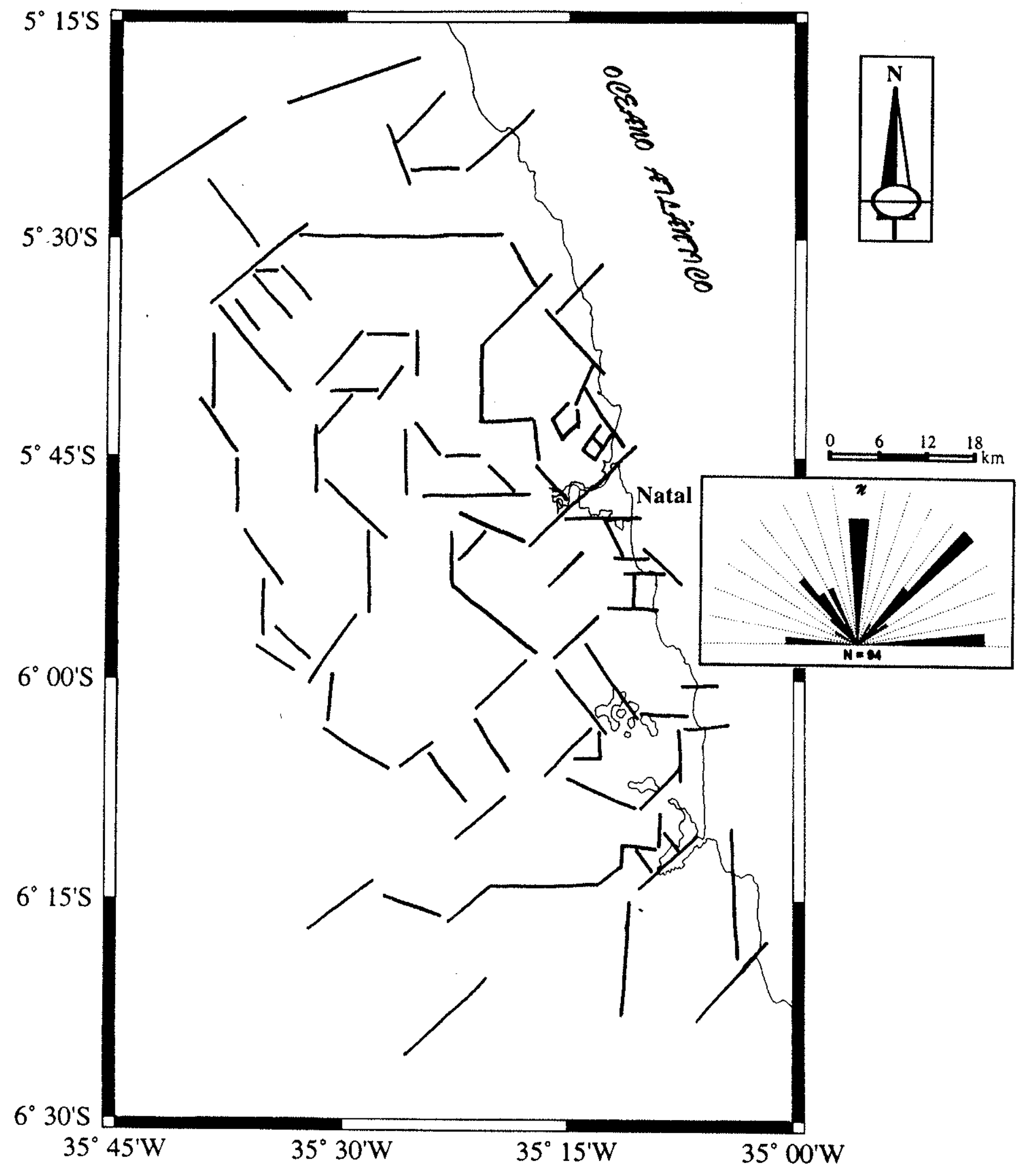

Figura 7.55 - Mapa de lineamentos gravimétricos de contorno zero realizado com base na imagem da Figura 7.51, obtida pela filtragem para comprimentos de onda inferiores a $30 \mathrm{~km}$. 


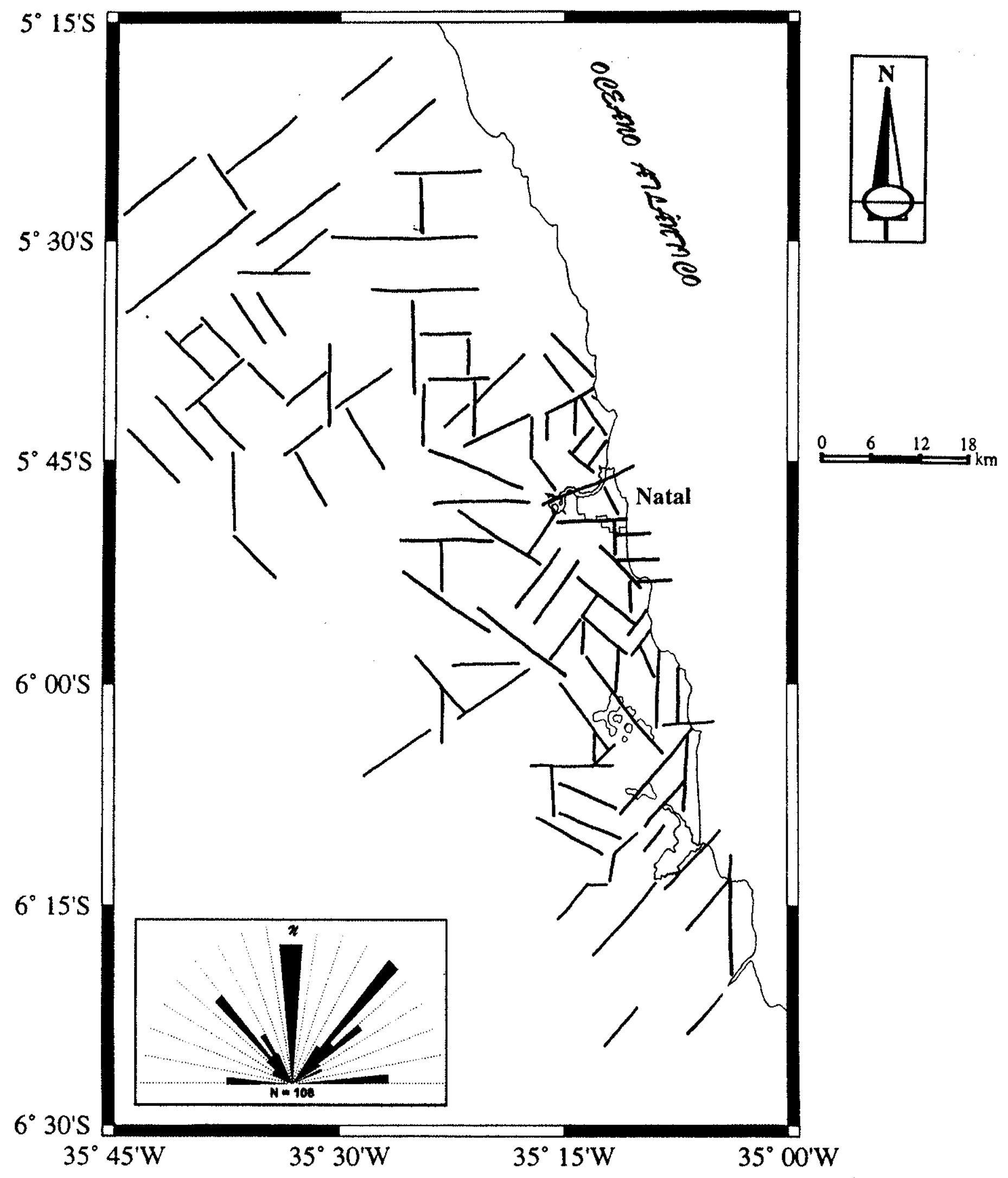

Figura 7.56 - Mapa de lineamentos gravimétricos de contorno zero realizado com base nas imagens das Figura 7.52 e 7.53 obtidas pelas filtragens para comprimentos de onda inferiores entre 10 e $20 \mathrm{~km}$. 


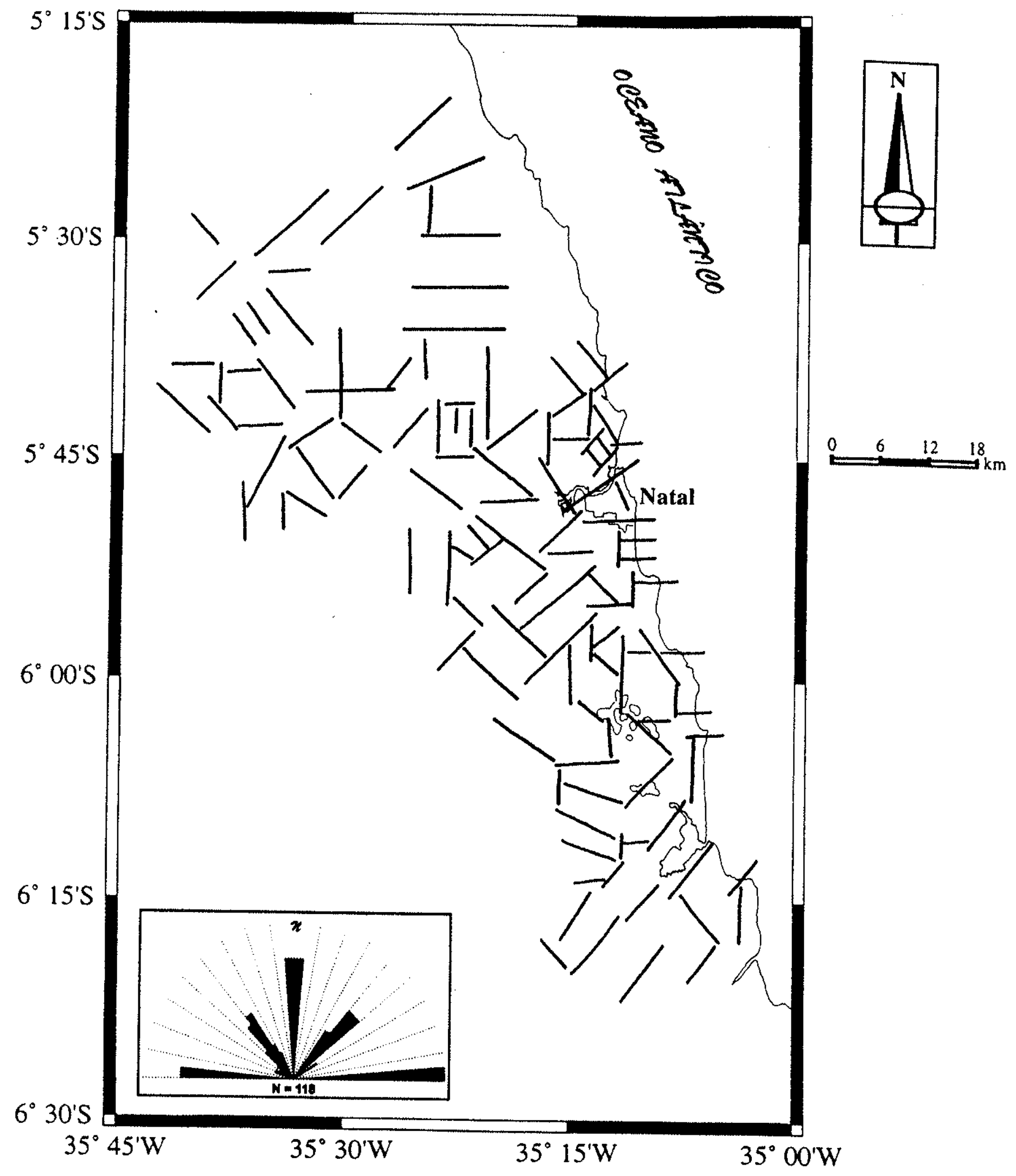

Figura 7.57 - Mapa de lineamentos gravimétricos de contorno zero realizado com base na imagem da Figura 7.54, obtida pela filtragem para comprimentos de onda inferiores a $10 \mathrm{~km}$. 
localização e distribuição espacial nos diferentes niveis da crosta continental. Os trends foram acrescentados ao mapa geológico simplificado da Fig. 7.49 como falhas inferidas por gravimetria. A análise da orientação azimutal (rosáceas) desses lineamentos sugere uma compatibilidade com os trends das feições topográficas lineares das principais falhas condicionantes dos grabens e horsts na região costeira.

Nos mapas da deformação frágil para os terrenos costeiros, baseados nos métodos de interpretação visual e na correlação morfotectônica, as principais orientações detectadas estão presentes em número restrito, enquanto as direções próximas a NS e EW são restritos a ausentes. Entretanto, estas orientações condicionam aspectos geomorfológicos importantes na área, como a estruturação de vales, os contatos do embasamento com a cobertura sedimentar e o traçado da linha costeira, geralmente condicionando os alinhamentos de beachrocks e as falésias da Formação Barreiras.

Nos procedimentos de realce e deteç̧ão por filtragem direcional dos elementos lineares de alta freqüência nas imagens, foi dada ênfase aos lineamentos relativos aos elementos da deformação frágil e frágil-dúctil (falhas e fraturas) tardi- ou pós-deformação brasiliana, conforme os princípios descritos nos itens 2.1 e 3.1. A principal diferença consistiu na classificação dos lineamentos extraídos como referentes às estruturas frágeis, com base nas características intrínsecas a essa classe de lineamentos, quais sejam (a) a extensão continental, (b) a orientação azimutal retilínea, (c) a densidade descontínua, (d) os padrões paralelos (diferenças de azimute inferiores a $30^{\circ}$ ) a ortogonais (diferença de azimute superiores a $60^{\circ}$ ), (e) a ausência de inflexões num único feixe, (f) o comportamento interseccional, e $(\mathrm{g})$ o caráter interceptor independente dos aspectos geológicos.

Os filtros direcionais de melhor realce dos lineamentos foram os filtros Prewitt [(a) a (d)] e Sobel [(e) e (f)] de dimensão $5 \times 5$, com ampliação linear do contraste por transformante logaritmica:
(a) $0 \begin{array}{llllll}-1 & -1 & 0 & 0\end{array}$
$10-1-10$
(b) $0 \begin{array}{lllllll}0 & 0 & -1 & -1 & 0\end{array}$
(c) $0 \begin{array}{rllllll} & -1 & 0 & 1 & 0\end{array}$
(d) 0 - -1 - -1 - -1 r 0
$\begin{array}{lllll}1 & 1 & 0 & -1 & -1\end{array}$

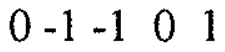
$\begin{array}{lllll}-1 & -1 & 0 & 1 & 1\end{array}$
$\begin{array}{lllll}-1 & -1 & -1 & -1 & -1\end{array}$
$\begin{array}{lllll}0 & 1 & 1 & 0 & -1\end{array}$
$\begin{array}{lllll}-1 & -1 & 0 & 1 & 1\end{array}$
$\begin{array}{lllll}-1 & -1 & 0 & 1 & 1\end{array}$
$\begin{array}{lllll}0 & 0 & 0 & 0 & 0\end{array}$
$\begin{array}{llllllllllll}0 & 0 & 1 & 1 & 0\end{array}$
$\begin{array}{llllll}-1 & 0 & 1 & 1 & 0\end{array}$
$\begin{array}{lllll}-1 & -1 & 0 & 1 & 1\end{array}$
$\begin{array}{lllll}1 & 1 & 1 & 1 & 1\end{array}$
$\begin{array}{lllll}0 & 1 & 1 & 0 & 0\end{array}$
$0 \begin{array}{lllllllll}-1 & 0 & 1 & 0\end{array}$
$\begin{array}{lllll}0 & 1 & 1 & 1 & 0\end{array}$ 


\begin{tabular}{|c|c|}
\hline 10 & \\
\hline $10-3-4-2$ & $-2-4-3$ \\
\hline 23 & $-2-30$ \\
\hline $\begin{array}{lllll}2 & 4 & 3 & 0 & -1\end{array}$ & $-10 ?$ \\
\hline A 0 & \\
\hline
\end{tabular}

O tratamento digital das imagens por técnicas de filtragem direcional, aliado à interpretação visual monoscópica das imagens filtradas, permitiu a confecção dos mapas das Fig. $7.58,7.59$ e 7.60 que mostram a distribuição espacial e a orientação azimutal dos padrões de lineamentos para o setor entre $05^{\circ} 00^{\prime}-08^{\circ} 00^{\prime} \mathrm{S}$ e $34^{\circ} 30^{\prime}-36^{\circ} 00^{\prime} \mathrm{W}$, envolvendo áreas costeiras e parte do embasamento cristalino. $\mathrm{O}$ conjunto de lineamentos interpretados visualmente, referentes à deformação frágil, foram agrupados segundo as orientações azimutais dominantes, de maneira a facilitar as comparações com os elementos morfológicos do terreno (traçado da linha costeira, contatos entre o embasamento cristalino e a cobertura sedimentar, orientações dos vales, etc.) e as combinações aos demais mapas de lineamentos e rosáceas. A Fig. 7.58 apresenta o sistema de lineamentos com orientações entre $\mathrm{N} 15^{\circ} \mathrm{E}$ e $\mathrm{N} 80^{\circ} \mathrm{E}$, predominates na área, que no embasamento cristalino são parcialmente coincidentes com os principais trends da deformação brasiliana e controlam os vales das drenagens principais. A Fig. 7.59 descreve os lineamentos com orientações entre $\mathrm{N} 15^{\circ} \mathrm{W}$ e N70 ${ }^{\circ} \mathrm{W}$, que conjugados aos lineamentos do mapa anterior são os principais controladores da rede de drenagens desse setor da Província Borborema. Esses lineamentos definem a marcante orientação $\left(\mathrm{N} 15^{\circ} \mathrm{W}\right)$ da linha costeira entre Natal/RN e João Pessoa/PB, e os principais contatos entre o embasamento cristalino e as coberturas sedimentares deste setor. Na região do embasamento cristalino próxima a Natal (acima do paralelo $6^{\circ} 30^{\prime} \mathrm{S}$, aproximadamente), as orientações dos lineamentos são coincidentes com a principais estruturas da deformação dúctil. Na Fig. 7.60 estão definidos os lineamentos com orientações próximas a NS e aqueles entre $\mathrm{N} 85^{\circ} \mathrm{E}$ e EW responsáveis, juntamente com os lineamentos $\mathrm{N} 15^{\circ} \mathrm{W}$ a $\mathrm{N} 70^{\circ} \mathrm{W}$, pela geometria chanfrada da linha costeira. Os lineamentos próximos a EW são coincidentes com as orientações do sistema de diques mesozóicos, freqüentes por toda a região, de extensas falhas que interceptam o embasamento cristalino e marcam os contatos com a cobertura meso-cenozóica na porção norte da área.

À análise visual dos lineamentos foram acrescidas as observações metodológicas descritas por Wise et al. (1985) para detecção de feições topográficas lineares e subparalelas 


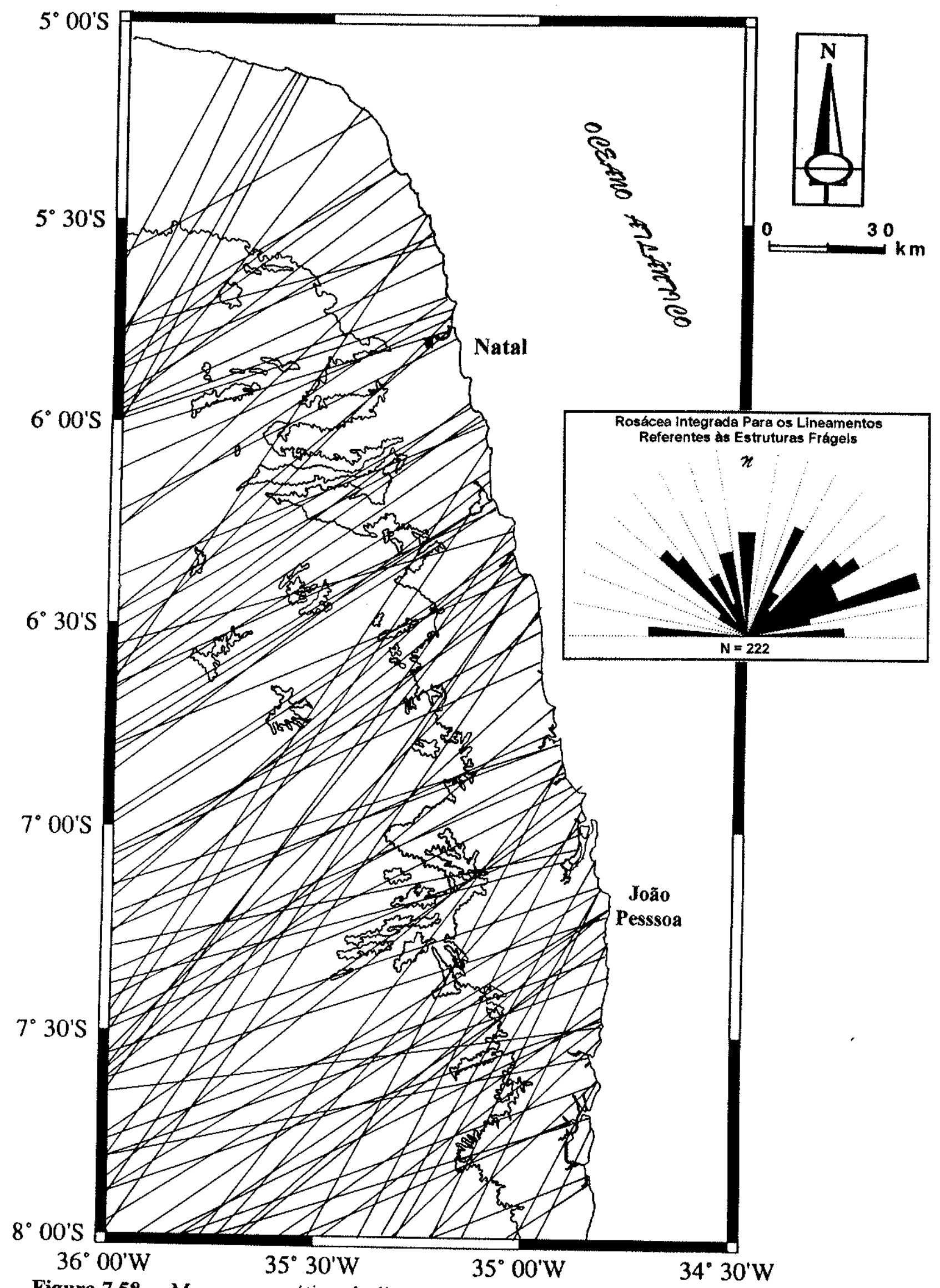

Figura 7.58 - Mapa esquemático de lineamentos da deformação frágil tardi- a pósbrasiliana do Setor Extremo Nordeste da Província Borborema. Na Faixa Litorânea foram localizadas as cidades de Natal/RN e Joåo Pessoa/PB. Os lineamentos apresentados

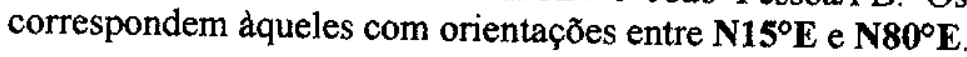




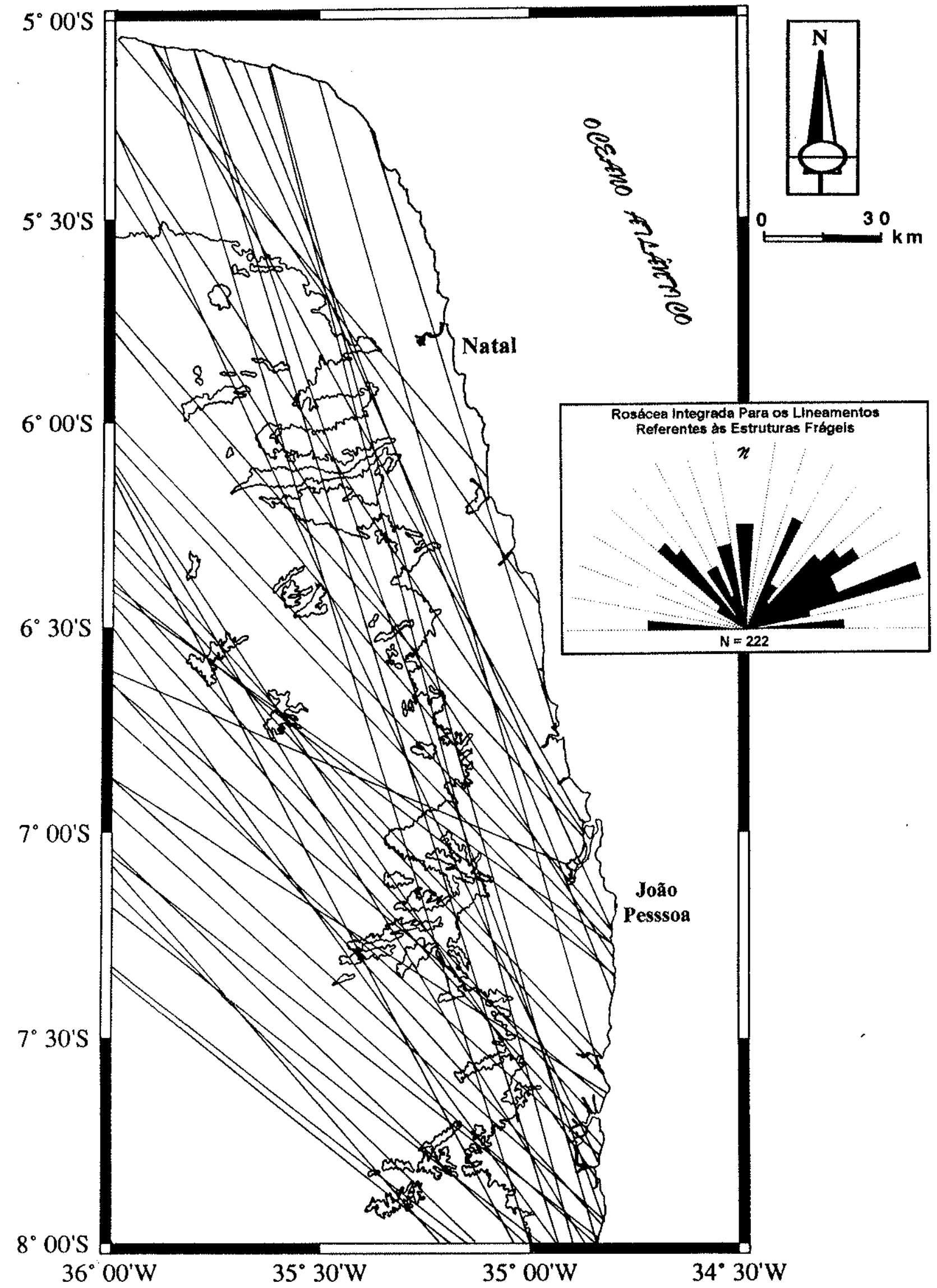

Figura 7.59 - Mapa esquemático de lineamentos da deformação frágil tardi- a pósbrasiliana do Setor Extremo Nordeste da Provincia Borborema. Na Faixa Litorânea foram localizadas as cidades de Natal/RN e João Pessoa/PB. Os lineamentos apresentados correspondem àqueles com orientaçðes entre $N 15^{\circ} \mathrm{W}$ e $N 70^{\circ} \mathrm{W}$. 


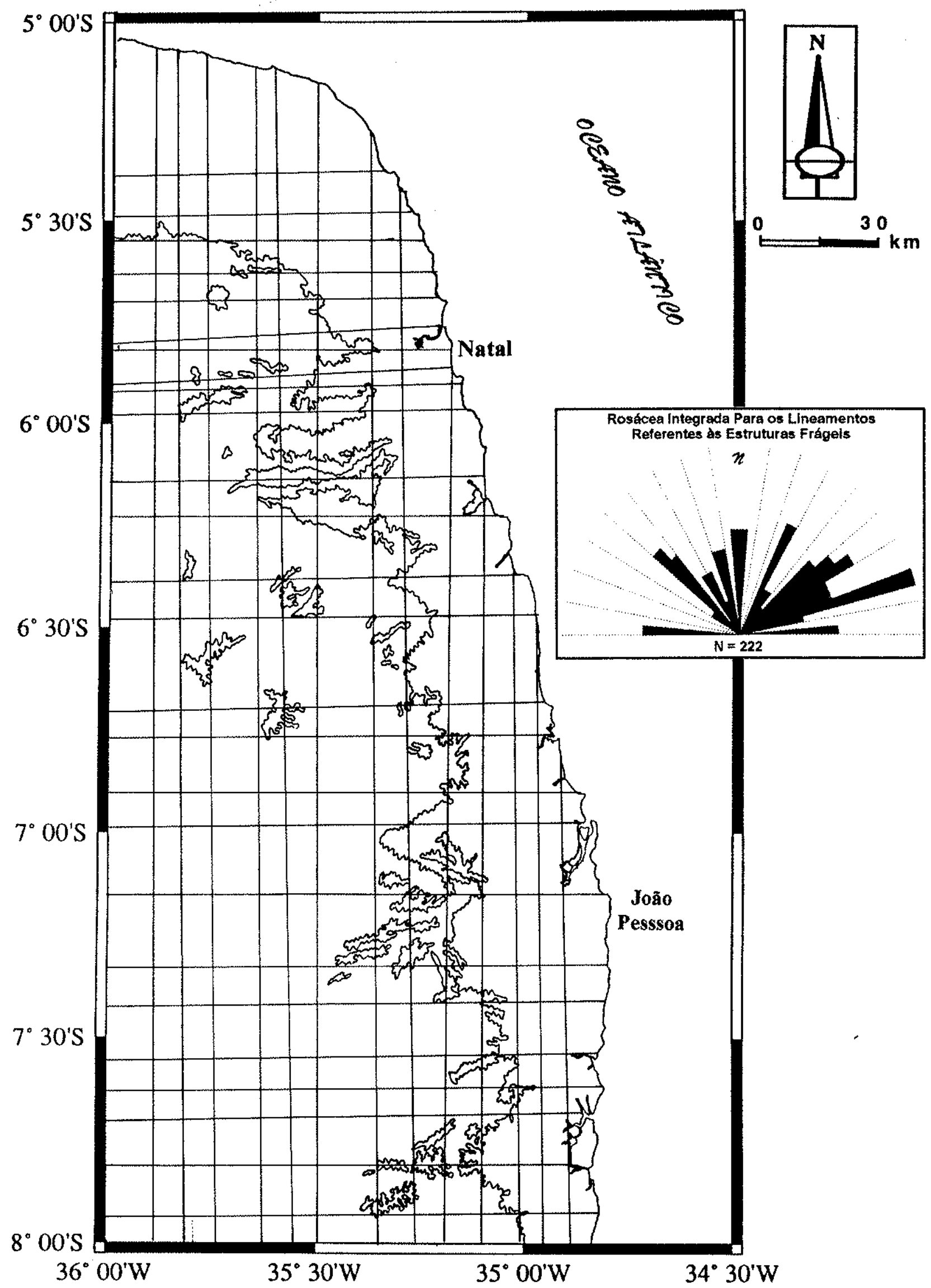

Figura 7.60 - Mapa esquemático de lineamentos da deformação frágil tardi- a pósbrasiliana do Setor Extremo Nordeste da Província Borborema. Na Faixa Litorânea foram localizadas as cidades de Natal/RN e João Pessoa/PB. Os lineamentos apresentados correspondem àqueles com orientaç̃̃es próximas a NS e entre $\mathbf{N 8 5}^{\circ} \mathbf{E}$ e EW. 
de escala regional (Amaro 1995). A integração das metodologias permitiu a confecção dos mapas das Fig. 7.61, 7.62 e 7.63. Estes mapas correspondem aos chamados enxames de lineamentos; termo definido por Wise et al. (1985), que enfatizam a grande população dos maiores e mais proeminentes lineamentos topográficos que afetam a superficie terrestre. $\mathrm{O}$ principal intuito deste procedimento foi o emprego de metodologias que permitissem uma abordagem morfotectônica, no reconhecimento de elementos estruturais que condicionassem feições morfológicas no terreno. Nos procedimentos de análise visual, os enxames de lineamentos topográficos foram representados por rosáceas, calculadas com base na normalização dos dados brutos em curvas gaussianas, como detalhado por Wise et al. (1985) e Oakey (1994). Os valores referentes ao comprimento, azimute e latitude/longitude dos lineamentos foram computados pela digitalização dos pontos extremos e analisados nos histogramas de azimute frequêencia, cujos valores de azimute médio, altura e largura azimutal na meia-altura foram transformados nos diagramas de rosáceas. As rosáceas foram localizadas nos centros de áreas quadradas com $15^{\prime}$ vs. $15^{\prime}$ de latitude e longitude, num total de 49 rosáceas que correspondem a aproximadamente 480 lineamentos detectados (Fig. 7.61). As pétalas das rosáceas foram agrupadas de acordo com a orientação azimutal nos quadrantes NE ou NW, e pelos trends predominantes (Fig. 7.62 e 7.63, respectivamente), facilitando a avaliação do paralelismo, reprodutibilidade e mudanças de direção entre os enxames e a comparação com os aspectos geológicos e geomorfológicos do terreno. A organização do enxame de lineamentos topográficos em padrões ortogonais ou conjugados não caracterizam uma datação relativa dos mesmos, apenas sugere uma origem simultânea (p.ex. sistema de Riedel). A correlação visual entre pétalas adjacentes favorece a compreensão da distribuição e correspondência regional dos enxames de lineamentos topográficos entre as áreas quadradas de $15^{\prime}$ vs. $15^{\prime}$. A análise da dissimetria da rede de drenagem foi realizada concomitante à extração dos enxames de lineamentos, como forma de controle da metodologia, e permitiu a configuração do padrão retangular ou angular nas regiões de cobertura sedimentar e dendrítico a retangular para os terrenos do embasamento.

A combinação dos mapas de rosáceas das feições topográficas lineares, dos mapas de padrões de lineamentos interpretados visualmente e dos mapas de lineamentos de gradiente-zero demonstra uma nítida associação dos enxames de lineamentos topográficos com os principais trends estruturais que caracterizam a deformação dúctil neoproterozóica 


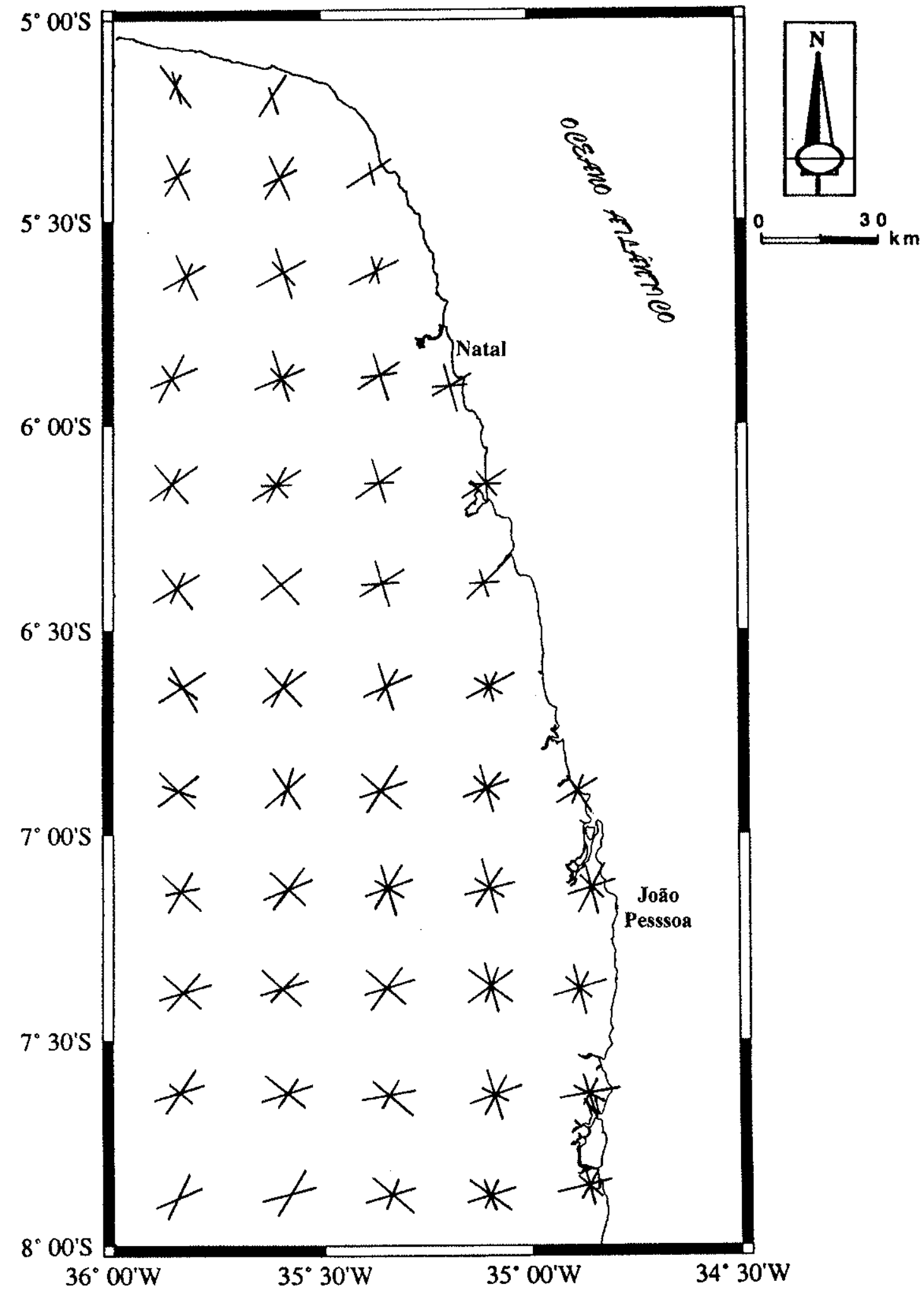

Figura 7.61 - Conjunto de rosáceas para os enxames de lineamentos do Setor Extremo Nordeste da Província Borborema. As 49 rosáceas integram a totalidade de 480 lineamentos extraidos na região. Na Faixa Litorânea foram localizadas as cidades de Natal/RN e João Pessoa/PB. 

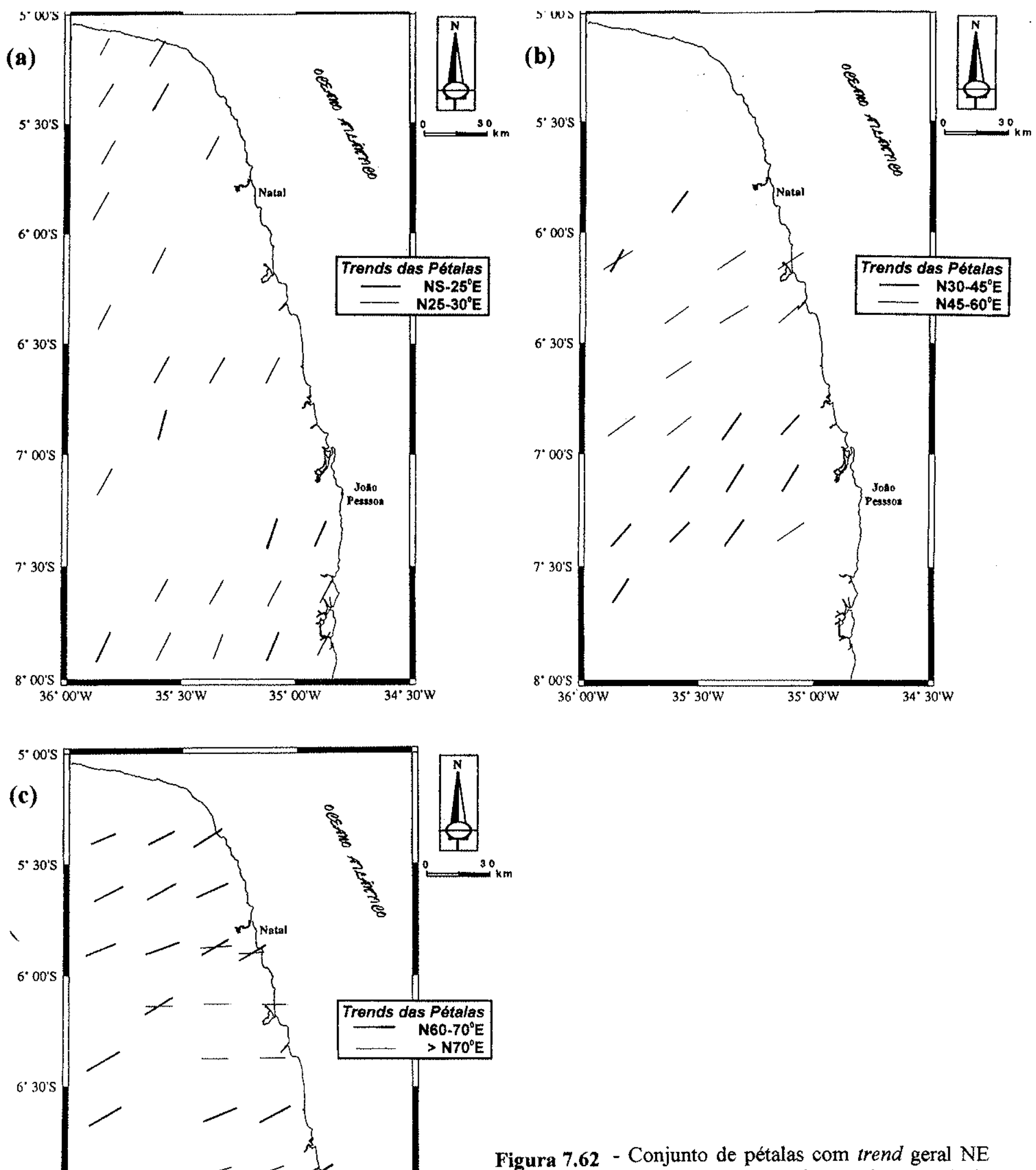

Figura 7.62 - Conjunto de pétalas com trend geral NE para 0 Setor Extremo Nordeste da Província Borborema: (a) Pétalas com trends NS-N25ㄹ (traço grosso) e N25-30 $\mathrm{E}$ (traço fino); (b) Pétalas com trends $\mathrm{N} 30-45^{\circ} \mathrm{E}$ (traço grosso) e $\mathrm{N} 45-60^{\circ} \mathrm{E}$ (traço fino); (d) Pétalas com trends $\mathrm{N} 60-70^{\circ} \mathrm{E}$ (traço grosso) e superiores a $\mathrm{N} 70^{\circ} \mathrm{E}$ (traço fino). 
(a)

$\underset{\omega}{\sigma}$

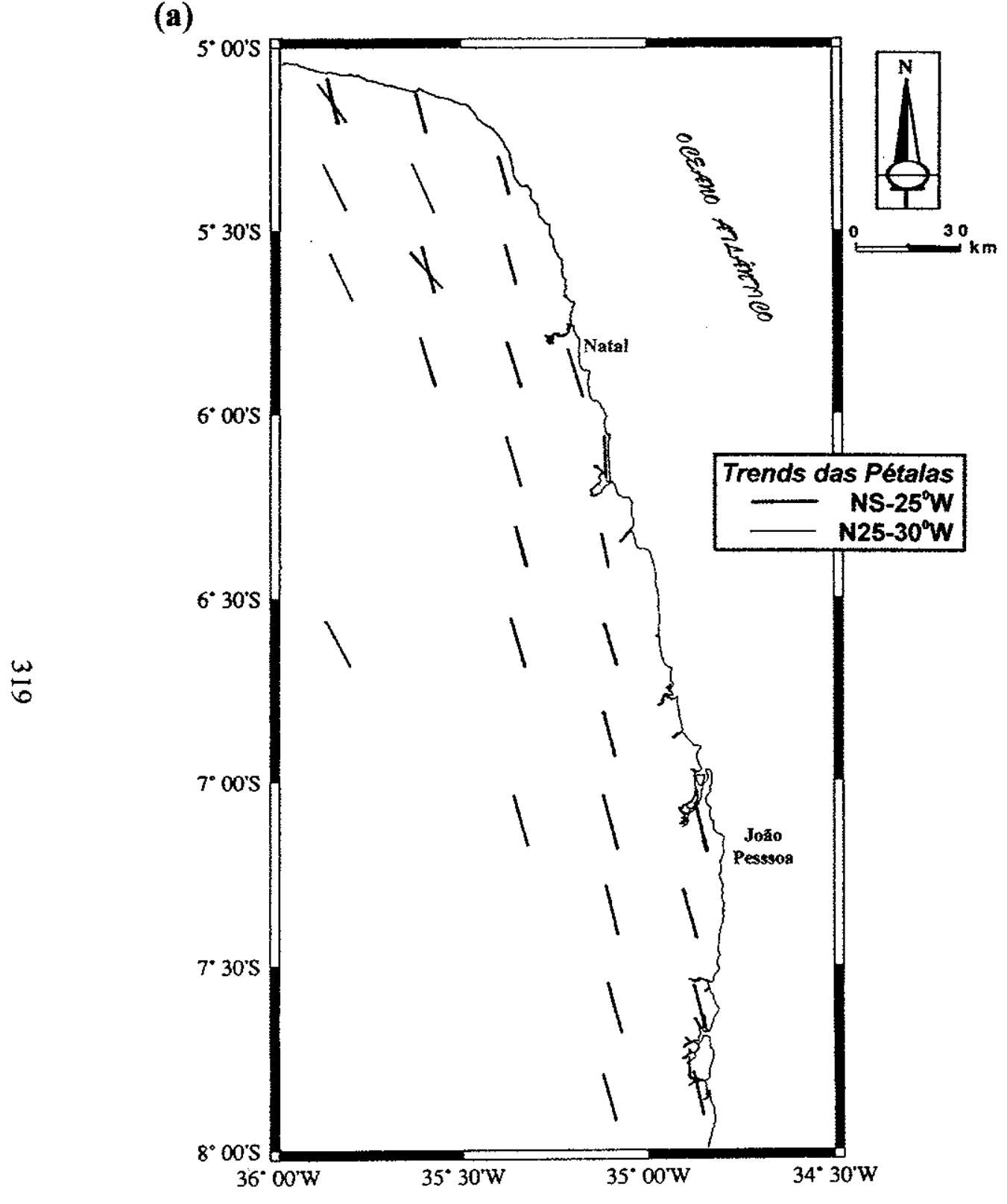

(b)

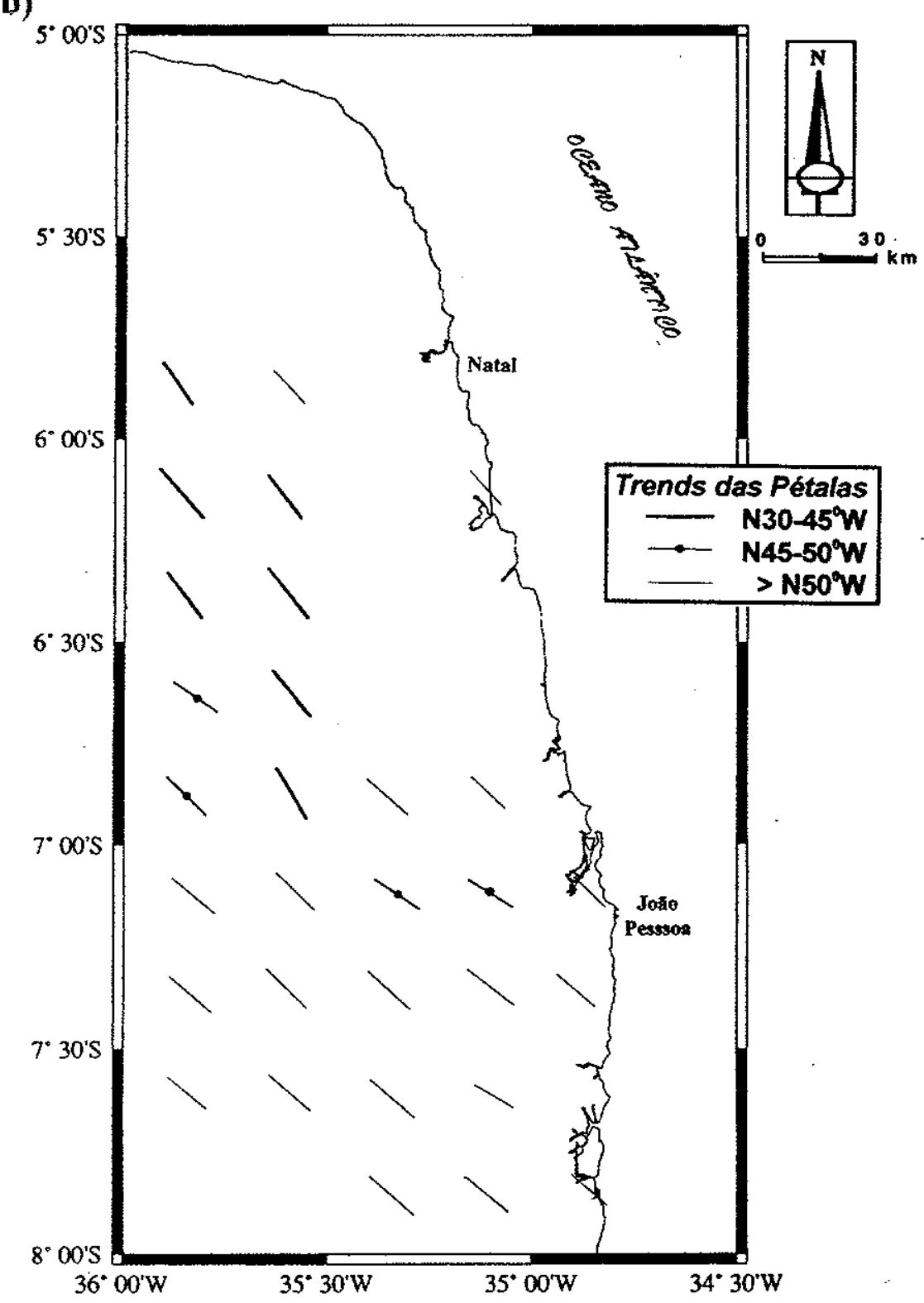

Figura 7.63 - Conjunto de pétalas com trend geral NW para o Setor Extremo Nordeste da Província Borborema: (a) Pétalas com trends NS- $25^{\circ} \mathrm{W}$ (traço grosso) e N25-30 ${ }^{\circ} \mathrm{W}$ (traço fino); (b) Pétalas com trends $\mathrm{N} 30-45^{\circ} \mathrm{W}$ (traço grosso), $\mathrm{N} 45-50^{\circ} \mathrm{W}$ (traço médio com ponto) e superiores a $\mathrm{N} 50^{\circ} \mathrm{W}$ (traço fino). 
no embasamento $\left(\mathrm{N} 70-75^{\circ} \mathrm{E}\right)$, com repercussão nos terrenos sedimentares da Faixa Costeira (Fig. 7.64). Os vales de primeira ordem do principal padrão de drenagem regional ocorrem segundo este trend (rios Paraíba, Miriri, Mamanguape, Potengi, Piúm), e entre N60-50 E (rios Gramame, Curimataú, Jundiai). As drenagens de segunda e terceira ordem acompanham os demais trends, sobretudo entre $\mathrm{N} 40-60^{\circ} \mathrm{W}$ (rios Gurinhém, Trairí, demais riachos e córregos). No entanto, os lineamentos com orientações NS-N20 $\mathrm{W}, \mathrm{N} 25-40^{\circ} \mathrm{E}$ e $\mathrm{N} 85^{\circ} \mathrm{E}-\mathrm{EW}-\mathrm{N} 85^{\circ} \mathrm{W}$, estes últimos entre os paralelos $05^{\circ} 00^{\prime}-06^{\circ} 30^{\prime} \mathrm{S}$, não apresentam correspondência direta com as estruturas dúcteis do embasamento e não condicionam extensos vales. Nos terrenos da Faixa Litorânea tais orientações definem as estruturas frágeis que controlam o traçado da margem costeira, formado por falésias da Formação Barreiras e linhas de beachrocks, relações de contato entre as coberturas sedimentares e o embasamento, e parte da organização dos segmentos das drenagens em todas as ordens.

As modificações na direção, as interrelações e as transições entre os enxames de lineamentos topográficos nos diversos domínios do terreno ocorrem por superposição e jamais por curvatura abrupta, caso dos elementos da deformação dúctil. Isto indica a estreita correlação entre os lineamentos e os elementos da deformação frágil (juntas/fraturas e falhas). As relações de intersecção, que mostram cruzamentos alternados, ora dos lineamentos de trend NW sobre os de trend NE, ora dos lineamentos de trend NS e EW entre si e sobre os demais, evidenciam um fator de contemporaneidade entre estas feições, provavelmente atuantes num sistema conjugado. A análise dos lineamentos quanto ao paralelismo, retidão e extensão mostra que não há apenas relação com os aspectos localizados da topografia, sugerindo que apesar dos processos de fraturamento atuarem na crosta superior, os campos de stress formadores das estruturas afetaram desde niveis profundos da crosta. Desta forma, sugere-se que os padrões de fraturamento definidos pelo enxame de lineamentos topográficos sejam interpretados como feições regionais representantes de estruturas frágeis extensas e largas, que em profundidade assumem comportamento dúctil, provavelmente reativando estruturas as zonas de cisalhamento brasilianas, principais modeladoras da crosta continental na região. 


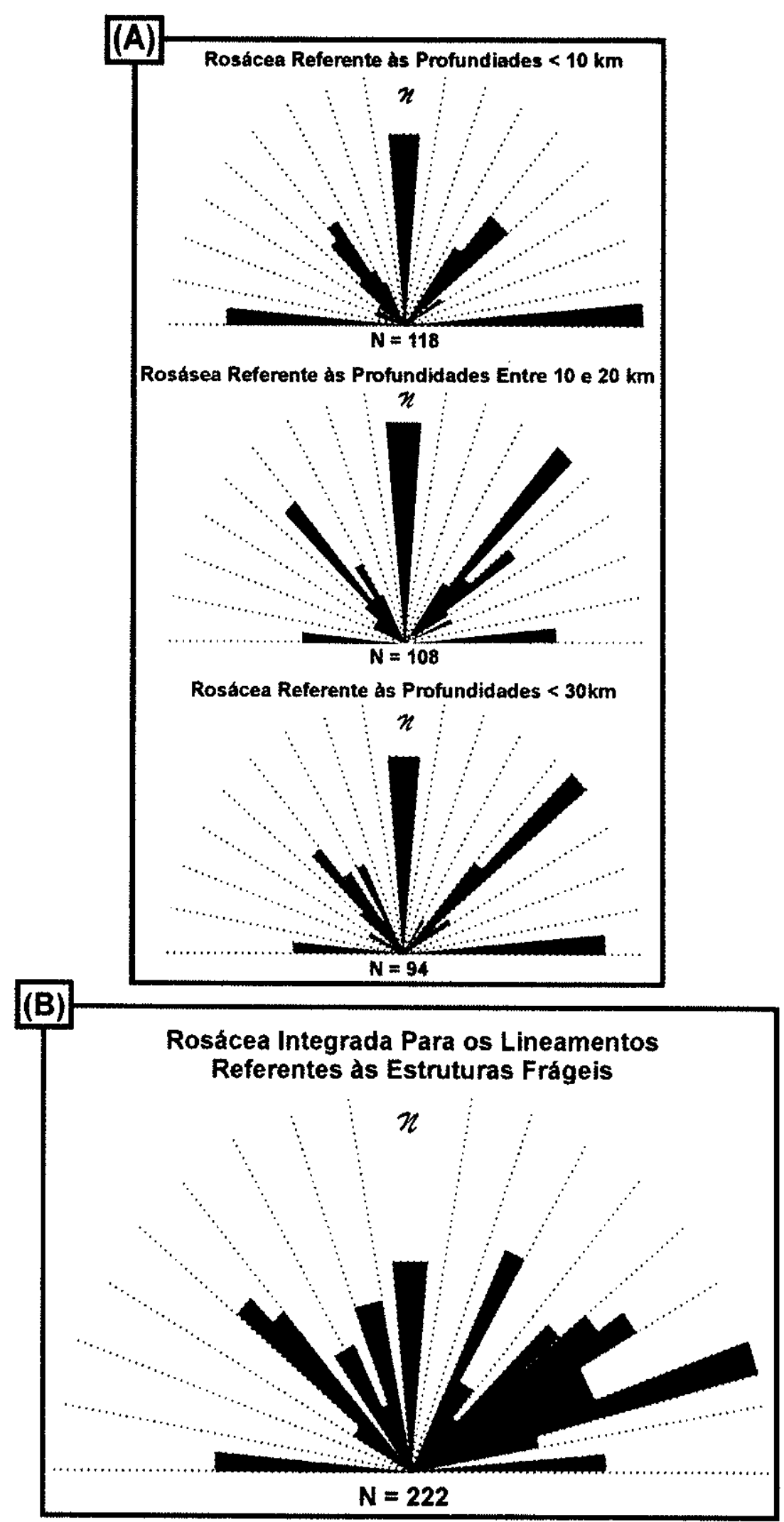

Figura 7.64 - (A) Rosáceas dos lineamentos de contorno zero dos mapas gravimétricos residuais comparados à $\mathbf{( B )}$ rosácea dos lineamentos referentes às estruturas frágeis. 


\subsection{2 - As Feições Gravimétricas, Geométricas e as Estruturas Proterozóicas Reativadas}

O mapa da Fig. 7.50 apresenta as anomalias gravimétricas para o conjunto da crosta continental na área, com os gradientes e anomalias residuais de longos e médios comprimentos de onda acompanhando os blocos arqueanos do MSJC, os granitóides e a faixa de micaxistos de estruturação brasiliana. O bloco arqueano do MSJC está definido pelo eixo de anomalias positivas que envolve ainda o granitóide de Serrinha e parte do DLD, condicionado pelo gradiente íngreme que delinea a ZCBJ e a ZCLP. Uma anomalia positiva ocorre desde áreas oceânicas até os terrenos entre a Lagoa Guaraíra e a região de Nísia Floresta, indicando considerável afinamento crustal para essa área, se comparada às áreas vizinhas. Outra anomalia positiva envolve terrenos da Bacia Potiguar na porção NW do mapa, acompanhando a orientação $\mathrm{N} 20^{\circ} \mathrm{E}$ da região sismogênica de João Câmara. A área da faixa de micaxistos de Ielmo Marinho-Taipu e os granitóides associados estão definidos por anomalias negativas, que sugerem a continuação destes terrenos sob a cobertura sedimentar até aproximadamente os limites do continente. As anomalias negativas de curtos comprimentos de onda que compõem um eixo quase paralelo à linha de costa, a SSW de Natal, indicam provavelmente corpos granitóides como aquele de Macaíba, recobertos pelos sedimentos costeiros.

As Fig. 7.51 e 7.52 mostram anomalias positivas e negativas em maior freqüência e comprimentos de onda curtos para os níveis de crosta média a superior, cuja distribuição espacial e a forma estão condicionados aos corpos granitóides e a algumas partes das zonas de cisalhamentos, sobretudo aquelas de direção geral NE (p.ex. a terminação da ZCRP). Na área sob a cobertura sedimentar surgem várias anomalias de curtos comprimentos de onda que quando interligadas constituem eixos de trends gerais $\mathrm{NS}, \mathrm{EW}, \mathrm{N} 20^{\circ} \mathrm{E}, \mathrm{N} 25^{\circ} \mathrm{W}$ e $\mathrm{N} 50^{\circ} \mathrm{W}$, compatíveis com os trends dos enxames de lineamentos topográficos para a área (Fig.7.61) e evidenciando o controle dos lineamentos sobre as estruturas frágeis-dúcteis e frágeis (Fig. 7.58, 7.59 e 7.60). O mapa de lineamentos de contorno-zero da Fig. 7.55, apresenta lineamentos com extensão média de $15 \mathrm{~km}$ que, localmente nos terrenos do embasamento, possuem direções coincidentes com os elementos da deformação dúctil brasiliana. Este mapa define lineamentos próximos ao trend geral da Falha de Samambaia na porção NW da área. As direções principais dos lineamentos são NS, EW, $\mathrm{N} 40^{\circ}-50^{\circ} \mathrm{E}$ e $\mathrm{N} 40^{\circ}-45^{\circ} \mathrm{W}$ coincidentes com feiç̃es da morfologia costeira (falésias, linhas de beachrocks, 
cúspides praiais, desembocaduras das principais drenagens, margens de lagunas e lagoas) e exercem o controle sobre as anomalias negativas e positivas.

Os mapas das Figs. 7.52 e 7.53 apresentam as anomalias residuais para profundidades de crosta superior, representadas pela alta freqüência dos comprimentos de onda curtos. Os granitóides de Taipu, Gameleira, Macaiba e Serrinha tiveram suas formas definidas por anomalias negativas, mas a maior concentração de altos e baixos alternados ocorre nos terrenos sob a cobertura sedimentar. $O$ nítido aumento na freqüência das anomalias nos mapas sugere uma intensa estruturação da região costeira nessas profundidades crustais, em sistemas de grabens e horsts. Essas estruturas foram individualizadas no traçado dos lineamentos de contorno-zero, marcadores dos padrões de falhas mais relevantes que condicionam o basculamento dos blocos entre si (Fig. 7.56). A disposição espacial, a extensão e as direções preferenciais desses lineamentos (NS, N40 $50^{\circ} \mathrm{E}, \mathrm{N} 40^{\circ}-45^{\circ} \mathrm{W}$ e EW) são condizentes com o controle direcional exercido sobre elementos geomorfológicos e geológicos, tais como: o traçado dos vales da rede de drenagem, o escarpamento de encostas litorâneas e no interior do continente, a estruturação da linha costeira, a orientação e a segmentação da bacias fluviais e trechos praiais, o contato entre o embasamento e as rochas sedimentares meso-cenozóicas, as zonas alagadiças e a estruturação dos corredores dunares.

A Fig. 7.54 apresenta as anomalias residuais de comprimentos de onda curtos, mantendo a tendência de alta freqüência condizente com a estruturação da porção rasa da crosta superior. Os altos e baixos gravimétricos são os mesmos descritos para as Figs. $7.52 \mathrm{e}$ 7.53, com a mesma disposição geográfica mas com abrangência espacial reduzida pelos efeitos da deformação frágil. O mapa de lineamentos de contorno-zero decorrente (Fig. 7.57) mostra a maior densidade espacial dos sistemas de falhas de menores comprimentos individuais $(<8 \mathrm{~km})$ e com a população melhor definida em torno das direções principais $\mathrm{NS}, \mathrm{N} 40^{\circ}-50^{\circ} \mathrm{E}, \mathrm{N} 35^{\circ}-45^{\circ} \mathrm{W}$ e $\mathrm{EW}$, semelhantes àquelas descritas anteriormente.

Os altos gravimétricos de Natal e Tabatinga, com valores de $8 \mathrm{mGal}$, e os baixos de Pirangi-Parnamirim e da margem esquerda do Rio Potengi, onde os valores atingem - 10 mGal, já foram descritos anteriormente (Bezerra et al 1993). No entanto, a combinação das Fig. 7.55, 7.56 e 7.57. favorece a melhor individualização dos altos e baixos gravimétricos e a comparação com os elementos geológicos e geomorfológicos do terreno. Desta maneira, 
outras anomalias são destacadas como os altos gravimétricos das áreas da Ponta de Santa Rita (4 mGal), Muriú ( $3 \mathrm{mGal}$ ), Punaú ( $8 \mathrm{mGal}$ ), Macaíba ( $4 \mathrm{mGal}$ ), o alto alinhado $\mathrm{N} 40^{\circ} \mathrm{W}$ entre São Gonçalo do Amarante e Ceará Mirim (6 mGal), Nísia Floresta ( $8 \mathrm{mGal})$ e os baixos gravimétricos das áreas de Monte Alegre ( $-4 \mathrm{mGal})$, margem direita do Rio Trairi ( -4 $\mathrm{mGal})$, vale do Rio Maxaranguape (-4 mGal) e vale do Rio Jundiai ( $-6 \mathrm{mGal})$. O graben de Canguaretama está definido por um baixo gravimétrico ( $-6 \mathrm{mGal})$, enquanto a área entre a Lagoa Guaraíra e Goianinha por alto gravimétrico ( $4 \mathrm{mGal}$ ) alinhado $\mathrm{N} 45^{\circ} \mathrm{E}$, prolongado para o continente e coincidente com a terminação da ZCSE e ZCBNC, uma das ramificações da ZCRP.

A inspeção visual das imagens resultantes dos procedimentos de filtragem direcional das imagens Landsat 5-TM e das cópias offset do radar GEMS/Banda X, aliados aos trabalhos de campo, permitiu a confecção da Fig. 7.65. O mapa evidencia os padrões de de distribuição espacial, orientação azimutal e cinemática dos sistema de falhas para a região entre Natal e Baía Formosa. Este mapa mostra ainda a disposição de seções transversais aos principais vales neste setor da faixa litorânea que combinam os dados geológicos, geoelétricos e de poços. No região de Canguaretama, as sondagens geoelétricas efetuadas por Queiroz et al. (1985) e os dados de poços obtidos por Bezerra (comum.pes.), indicam um desnivel superior a $70 \mathrm{~m}$ entre o bloco central rebaixado (graben) e intensamente dissecado, com altitudes entre 0-12 $\mathrm{m}$, e os blocos laterais soerguidos, com altitudes superiores a $70 \mathrm{~m}$ (seção AA' Fig. 7.66), controlados por falhas normais e transtracionais dextrais. $\mathrm{Na}$ área da Lagoa Guaraira e Goianinha, as anomalias gravimétricas positivas acompanham o trend $\mathrm{N} 45^{\circ} \mathrm{E}$ do vale controlado por falhas transtracionais dextrais (seção BB', Fig. 7.66). A seção BB'mostra o bloco rebaixado com desnivel vertical superior a $40 \mathrm{~m}$ na base da Formação Barreiras. As falhas de trend $\mathrm{N} 45-50^{\circ} \mathrm{E}$ são conjugadas com as falhas normais de trend $\mathrm{N} 45-50^{\circ} \mathrm{W}$ na região do vale do Trairí, e o par condiciona as bordas da Lagoa Guaraíra. Diversas lagoas ocorrem no bloco soerguido a nordeste do vale do Trairí, orientadas nas direções $\mathrm{N} 60^{\circ} \mathrm{E}$ e $\mathrm{N} 40-45^{\circ} \mathrm{W}$, sugerindo um controle tectônico dessas feições morfológicas. A seção CC'(Fig. 7.66) mostra a Formação Barreiras com espessura superior a $80 \mathrm{~m}$ no bloco rebaixado e com 20-50 m nos blocos soerguidos. A correspondência geométrica com as intensas anomalias gravimétricas positivas sugerem o efeito decorrente 


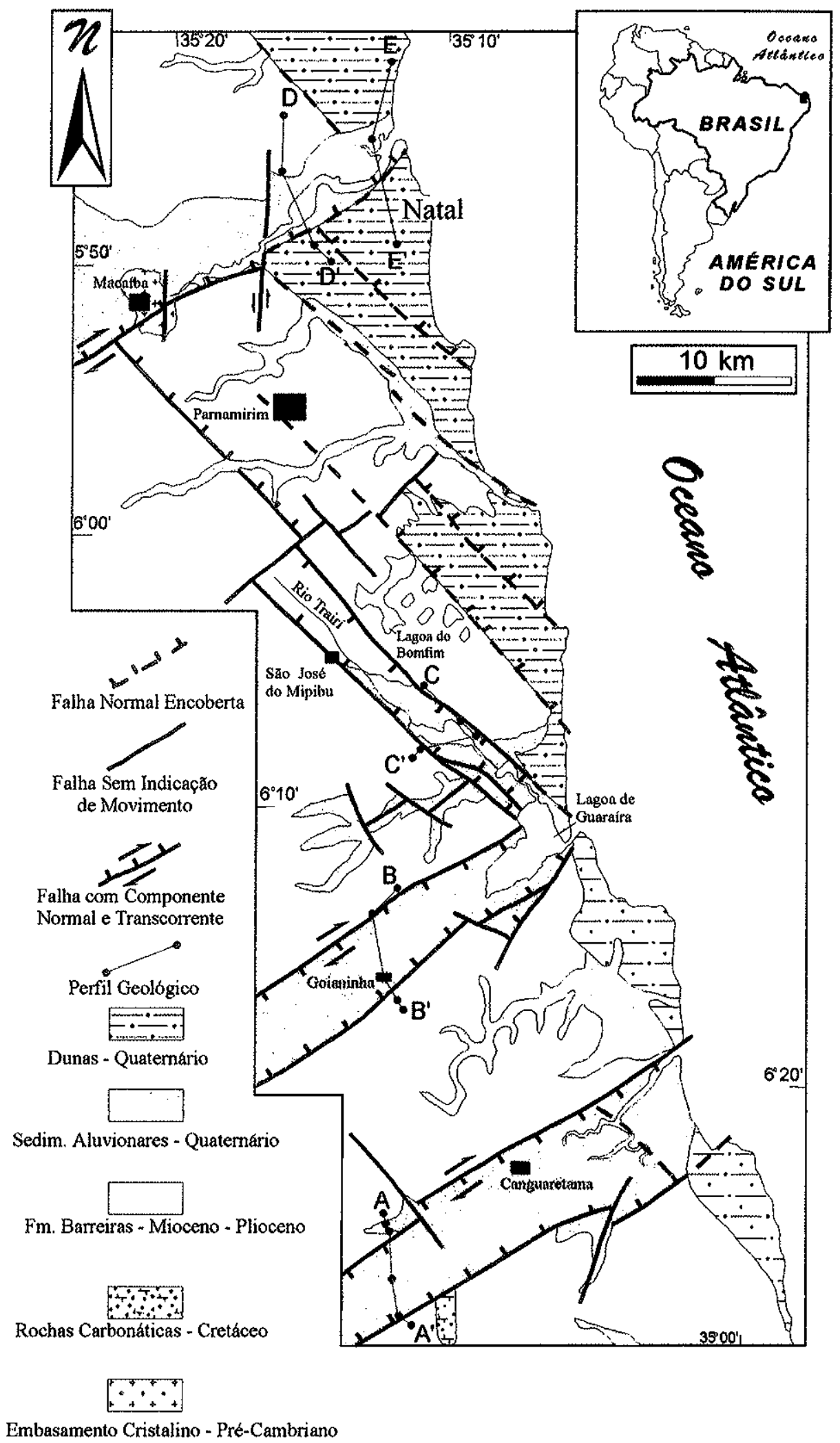

Figura 7.65 - Mapa geológico simplificado da Faixa Litorânea Oriental do Estado do Rio Grande do Norte, entre as cidades de Natal e Baía Formosa. 

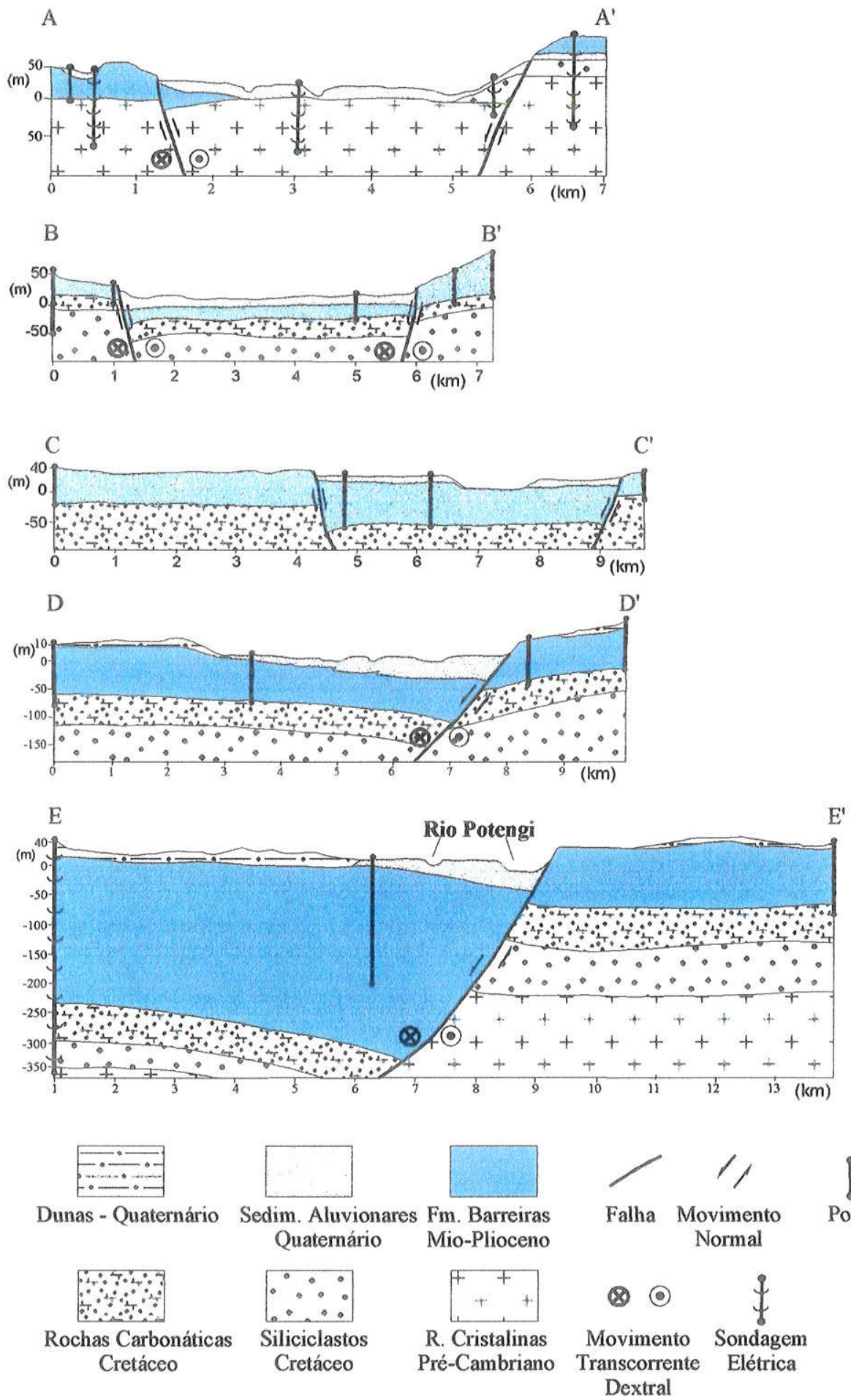

Figura7.66- Seções geológicas transversais aos principais vales da Faixa Litorânea entre Natal e Baía Formosa (RN). Os dados geolétricos foram levantados por Queiroz et al. (1985). As localizações das seções estão na Figura 7.65. 
do alojamento de rochas básicas e o afinamento crustal controlados, provavelmente, pelas zonas de cisalhamento brasilianas e/ou reativações posteriores. Na região da cidade de Natal, o meio-graben do Rio Potengi é preenchido por cerca de $350 \mathrm{~m}$ de rochas sedimentares (seções DD'e EE', Fig.7.66), onde os sedimentos miocenos da Formação Barreiras correspondem a $250 \mathrm{~m}$, enquanto no bloco soerguido a espessura dos sedimentos é de $250 \mathrm{~m}$. Esta assimetria na espessura dos sedimentos justifica as anomalias negativas para o meio-graben e positiva para o horst. Os grabens e áreas de depressões estão delimitados por falhas normais e transtracionais, e mostram correspondência com as anomalias gravimétricas negativas devido às maiores espessuras dos sedimentos nestas áreas.

Além das evidências apresentadas sobre a reativação das estruturas proterozóicas, como as correlações geométricas e gravimétricas, outras feições sugerem a reativação das estruturas no Terciário-Quaternário, tais como: os lineamentos que afetam os depósitos terciário-quaternários, os segmentos de drenagens, a correspondência dos lineamentos com escarpas de falhas quaternárias, as variações nas profundidades e espessuras dos depósitos sedimentares quaternários a pliocênicos e o contato destes depósitos com as rochas da Formação Barreiras e com as coberturas dunares recentes, controlados por lineamentos (Bezerra, comun pes.). Nessas falhas, os dados de campo e as feições morfológicas nas imagens assinalam uma combinação dos componentes transcorrente e normal do strain (Bezerra, comun.pes.)

Os lineamentos correspondem às zonas de intensa formação de fraturas e falhas que mantém o alto mergulho à medida que avançam nos primeiros quilômetros da crosta frágil. Estas zonas de fraqueza facilitariam a percolação de água, o intemperismo e a erosão diferenciada, dando origem às feições topográficas (Isachsen 1976). Esta é uma evidência geométrica da reativação das estruturas neoproterozóicas em episódios subseqüentes, provavelmente até o recente, como confirmam a associação dos epicentos dos terremotos aos trends de algumas das principais zonas de cisalhamento neoproterozóicas $\left(\mathrm{N} 20-40^{\circ} \mathrm{E}\right.$, Assumpção et al. 1985, Takeya et al. 1989). A freqüente sucessão de estruturas e litologias associadas refletiria o resfriamento e o uplift dos terrenos nos estágios finais da orogênese Brasiliana. No entanto, as estruturas que definem os enxames de lineamentos topográficos nem sempre são proeminentes e conspícuas sobre o fabric e/ou unidades lito-estruturais do embasamento (Wise et al. 1985). Estas estruturas representariam ambientes onde padrões 
extensionais diversos poderiam atuar isolados, combinados ou alternados, em função da sucessão dos esforços tectônicos globais e/ou regionais que determinariam a disposição dos campos de stress, do estilo deformacional (uplift, extensão, transcorrência, regimes combinados) impingido à camada dúctil subjacente, e do tempo decorrente na atuação dos esforços.

O modelo da tectônica de placa rígida descreve o calapso da litosfera continental em blocos e flakes controlados por sistemas de zonas de cisalhamento e falhas que são submetidos a episódios complexos de deslocamentos relativos, rotação e deformação interna. Este comportamento da litosfera continental pode ser atribuido às variações laterais dos esforços produzidos pela presença de um fabric orogênico pré-existente, com estruturas prévias como zonas de cisalhamento, falhas e contatos composicionais. Essas zonas de fraqueza tendem a, preferencialmente, acomodarem repetições do strain do que constituirem novas zonas de deslocamento (Holdsworth et al. 1996). Tal processo foi referido com o termo geral herança estrutural, sendo que os elementos resultantes podem ser classificados em dois grupos geneticamente distintos: estruturas reativadas, em que os incrementos regionais do stress (ou strain) sofrem mudanças na orientação entre deslocamentos sucessivos; e estruturas recorrentes, onde os incrementos tectônicos regionais permanecem quase constantes.

Os processos de herança estrutural influenciariam a ruptura entre os continentes, condicionando a instalação preferencial de sistemas de riftes ao longo dos cinturões orogênicos, mesmo quando a direção da extensão não fosse normal ao principal trend estrutural do orógeno (Vauchez et al. 1997b). Este fato é confirmado pela anisotropia mecânica da litosfera, controlada pela anisotropia de fluxo no manto litosférico, caracterizada pela análise da anisotropia sísmica na olivina (Silver \& Chan 1991). A anisotropia mecânica é preservada enquanto as condições de temperatura não provoquem modificaçðes no fabric das rochas mantélicas (Barruol et al. 1997, Vauchez et al. 1997b).

Desde o término da orogênese Brasiliana, o continente Sul-Americano foi afetado por regimes alternados de tectônica extensional e compressional, com a instalação da margem Andina no Paleozóico Superior e da margem Atlântica no Cretáceo Inferior (Cobbold 1996). Os efeitos do estilo tectônico extensional ou compressional no interior do continente Sul-Americano, foram dependentes das relações entre a razão de convergência da 
margem Andina, da razão do escoamento da placa oceânica de Nazca em subducção (margem W do continente) e da posição do polo de rotação que controlou a movimentação do drift entre os continentes Africano e Sul-Americano. Conseqüentemente, a intensidade e orientação dos campos de stress instalados no continente foram função direta da distância em relação ao polo de rotação dos continentes. A deformação intracontinental foi mais intensa nas áreas onde estruturas pré-existentes foram reativadas.

No Paleozóico Superior predominou regime compressional. Do Triássico ao Cretáceo Inferior uma tectônica extensional iniciou a ruptura entre a América do Sul e África paralelamente aos cinturões neoproterozóicos circum-Atlântico Sul, resultando em sistemas de riftes que reativaram as estruturas prévias proterozóicas e paleozóicas. Especificamente a região Nordeste do Brasil foi intensamente afetada pelos dois estágios finais de rifteamento e geração da crosta oceânica no Atlântico Sul (NeocomianoBarremiano Inferior), quando ocorreram os principais períodos de reativação das zonas de cisalhamento neoproterozóicas e extensiva ruptura crustal (Chang et al. 1988, Matos 1992). Nestes estágios (fase sin-rifte II de Matos 1992) foram formadas várias bacias intracratônicas em semi-grabens invariavelmente controladas pela reativação das zonas de cisalhamento neoproterozóicas, segundo esforços extensionais NW-SE. Um padrão de falhas compondo um par conjugado NE vs. NW, trends destacados nos diagramas de rosáceas das Fig. 7.61 e 7.64 e de lineamentos das Fig. 7.58 e 7.59, foram descritos em toda a região costeira e embasamento próximo (p.ex. falhas de Carnaubais, Afonso Bezerra, Samambaia, Natal) como decorrentes da tectônica mesozóica ou mais jovem (?). Este sistema de falhas ocorre associado às falhas direcionais NS que provavelmente correspondem às estruturas geradas na fase rifte (Fonseca 1996).

$O$ deslocamento dos esforços extensionais para direção próxima de EW na abertura do Atlântico Equatorial (fase sin-rifte III, Barremiano Superior) representou o principal episódio de estiramento da crosta e estruturação da geometria de riftes da margem passiva do Nordeste do Brasil. Estes esforços geraram ambientes transtracionais associados a falhas transformantes/transcorrentes que afetaram a litosfera, conduzindo à ligação entre o Atlântico Sul e Equatorial e a completa separação dos continentes Sul-Americano e Africano (Aptiano). O regime tectônico compressional atuante do Cretáceo Superior ao presente produziu a inversão das bacias, falhas reversas e transcorrentes pela reativação das falhas 
normais e transcorrentes dos episódios tectônicos anteriores. A localização da região na margem continental sul-americana implica na influência dos esforços compressivos globais decorrentes dos deslocamentos relativos entre a Cadeia Meso-Atlântica e a Cadeia Andina, associados às tensões distensivas da margem continental (Assumpção 1992). Esta deformação neotectônica descreve padrões de estruturas frágeis com orientações preferenciais NE, NW e NS, refletidas nas feições morfológicas de superficie e integradas à expressiva atividade sísmica da região (Fonseca et al. 1997, Caldas et al. 1997, Dantas et al. 1997, Bezerra et al. 1997). O par conjudados de falhas com trends NE e NW, predominantes na Faixa Litorânea, forma ângulo agudo de $60^{\circ}-70^{\circ}$ cujo bissetor corresponde à orientação do eixo de compressão máxima horizontal (stress horizontal máximo) de direção EW, que aliado ao eixo de distensão NS pode ser o principal mecanismo responsável pela geração de tais falhas no Cenozóico (Assumpção 1992). 


\section{8 - CONSIDERAÇÕES FINAIS}

\section{1 - Introdução}

$\mathrm{Na}$ recente proposta de evolução geodinâmica neoproterozóica para o Setor Setentrional da Província Borborema, que envolve a Faixa Seridó e os terrenos gnáissicomigmatíticos adjacentes, Jardim de Sá (1994) apresentou um modelo de orógeno transcorrente definido pela interação de blocos crustais e litosféricos com movimentos laterais ao longo de zonas de cisalhamento de alta-T enraizadas em detachments na crosta média-inferior e/ou manto litosférico. Para a porção central da Faixa Seridó e terrenos ocidentais (TRP), as estruturas em flor positiva e duplexes transcorrentes-compressionais, referentes à deformação $\mathrm{D}_{3}$, configuram um regime transpressional, marcado pelas relações de baixo ângulo entre as foliações $S_{3} \mathrm{e} \mathrm{C}_{3}$, com mergulhos moderados a fortes conjugados ao baixo rake da $\mathrm{L}_{3}$. Essas feições estruturais estão acompanhadas por metamorfismo de altaT/baixa-P, ampla migmatização e granitogênese sincinemáticas. No setor oriental (MSJC$\mathrm{MCB}$ ), a deformação $\mathrm{D}_{3}$ caracteriza sítios transtracionais-extensionais controlando a geometria de faixas de micaxistos e granitóides, provavelmente sincrônicos às estruturas transpressionais da porção central da Faixa Seridó (Jardim de Sá 1994, Jardim de Sá et al. 1997b, Macedo et al. 1997, Souza et al. Submet.). Os dados gravimétricos indicaram espessamento crustal para o setor central da Faixa Seridó e afinamento crustal acompanhando as estruturas extensionais no MSJC (Moreira et al. 1989a, Lins et al. 1993). As características petro-estruturais, as assinaturas geoquímicas e geocronológicas das suítes de granitóides favoreceram a reconstituição de algumas feições da litosfera neoproterozóica na geração dos magmas identificados nesses setores da Provincia Borborema (Leterrier et al. 1990, Galindo 1993, Jardim de Sá 1994, Dantas 1997, Jardim de Sá et al. 1997b, Galindo et al. 1997): (a) as suites de rochas dioríticas com afinidade cálcio-alcalina potássica a shoshonítica denotam uma fonte mantélica subcontinental antiga enriquecida e com assinatura tipo arco; (b) as suites de granitóides porfiriticos (tipo Itaporanga) com afinidades subalcalina/monzonitica derivadas de fonte crustal do tipo-I com composição intermediária; (c) suite de leucogranitos derivados de fusão crustal de metassedimentos; (d) as suites alcalinas supersaturadas derivadas de fonte mantélica enriquecida (e/ou metassomatizada) pela percolação de fluidos através de zonas de cisalhamento, ou de magmas básicos que 
induzem à fusão crustal em ambiente marcado pelo afinamento litosférico e soerguimento da astenosfera conduzido por zonas de cisalhamento com raizes mantélicas.

No contexto da evolução geodinâmica da cadeia orogênica Brasiliana/PanAfricana no Gondwana, diversos trabalhos reconheceram a continuidade das principais feições estruturais e petrogenéticas entre a Província Borborema e a Faixa Trans-Sahara (p.ex. Caby et al. 1991, Jardim de Sá et al. 1991, Boullier 1991, Brito Neves \& Cordani 1991, Affaton et al.1991, Ngako et al. 1992, Black \& Liégeois 1993, Castaing et al. 1993, Liégeois et al. 1994, e referências ali contidas), destacando-se as revisões e sínteses realizadas por Murphy e Nance (1991) e Jardim de Sá (1994). Nas porções internas da Província Borborema/Faixa Trans-Sahara, o ápice do Ciclo Brasiliano/Pan-Africano estaria caracterizado pelo retrabalhamento transcorrente de microplacas continentais antigas e polideformadas, acopladas ao manto litosférico sub-continental, e segmentos precoces do Neoproterozóico. Nesse ambiente insere-se o MSJC-MCB formado por um mosaico heterogêneo de blocos crustais paleoproterozóicos aglutinados em torno de um núcleo arqueano. A crosta continental do núcleo arqueano foi gerada por acresção durante diferentes episódios magmáticos de retrabalhamento da protocrosta siálica antiga (Paleoarqueano) e geração de segmentos de crosta juvenil (Meso- e Neoarqueano). No Paleoproterozóico destacam-se os processos de acresção lateral e colisão com extensivo retrabalhamento da crosta arqueana, geração de crosta juvenil e aglomeração sucessiva de arcos magmáticos, referido como orogênese Transamazônica/Eburneana. A tectônica contracional resultaria numa deformação tangencial penetrativa $\left(\mathrm{D}_{2}\right)$ sob condições do fácies xisto verde a anfibolito, marcada por dobras recumbentes e zonas de cisalhamento tangenciais, e acompanhada por granitogênese $\left(G_{2}\right)$ de afinidades cálcio-alcalina potássica a subalcalina (monzoniticas e shoshonítica). Dantas (1997) sugere a instauração de um protocontinente paleoproterozóico pela justaposição entre os blocos paleoproterozóicos e arqueanos, com a conseqüente consolidação do MSJC ao final do Ciclo Transamazônico.

Os dados obtidos até o presente conduziram à interpretação da evolução geodinâmica dos terrenos da Província Borborema/Faixa Trans-Sahara num modelo de orógeno transcorrente durante o Ciclo Brasiliano/Pan-Africano (Caby et al. 1981, Boullier 1991, Jardim de Sá et al. 1991, Liégeois et al. 1994), conforme o modelo clássico de Molnar e Tapponier (1975). As principais feições que favorecem ao modelo geodinâmico proposto 
foram apresentados, provavelmente sucessivos no tempo: (i) a interação por colisão obliqua dos crátons do Oeste Africano/São Luís, Congo/São Francisco e Leste do Sahara, com subducção restrita de crosta oceânica (Jardim de Sá 1994, Liégeois et al. 1994); (ii) o evento acrescionário em regime transcorrente/transformante (ca. 850-600 Ma) de terrenos alóctones (microplacas continentais) e crosta continental juvenil (arcos magmáticos associados), gerada nos estágios precoces desse sistema ou durante eventos prévios (p.ex. o evento $c a$. $950 \pm 50 \mathrm{Ma}$ no DZT), intermediários entre as placas continentais principais; (iii) retrabalhamento intracontinental por zonas de transcorrência no estilo extrusão lateral de blocos em regime colisional do tipo Tibetano ( $c a .580 \pm 30 \mathrm{Ma}$ ), após a amalgamação das placas e microplacas continentais antigas e juvenis. $O$ ápice do metamorfismo nas zonas de cisalhamento alcançaria o fácies anfibolito de alta-T a granulito e anatexia, acompanhado por granitogênese com assinatura alcalina a subalcalina (monzonitica e shoshonítica). A cinemática transcorrente dextral predominante nas zonas de cisalhamento principais sugere a colisão oblíqua das placas continentais, com transporte das microplacas para SW, culminando com o retrabalhamento por transcorrência das zonas de sutura, a exemplo da África Ocidental (Boullier 1991, Castaing et al. 1994).

Neste capítulo, além da síntese dos trabalhos efetuados e dos resultados obtidos, pretende-se uma combinação das informações analisadas nas etapas precedentes em seções esquemáticas para a crosta continental-manto litosférico sub-continental do MSJC-MCB, adequadas ao quadro evolutivo proposto para a Província Borborema na orogênese Brasiliana/Pan-Africana. Como referência à evolução tectonometamórfica desses terrenos, foram compendiados alguns aspectos dos modelos numéricos e analógicos que simularam os parâmetros próximos daqueles deduzidos para a litosfera heterogênea e anisotrópica da Província Borborema, tais como os efeitos dos contrastes reológicos verticais e horizontais na propagação do campo de deformação, a localização da deformação em zonas de cisalhamento e a transferência de fluidos por meio das zonas de cisalhamento em escala litosférica. No entanto, a modelagem definitiva desses terrenos, em analogia aos processos modernos de formação/colagem de orógenos, deveria ainda incorporar: (a) um modelo crustal/litosférico quantitativo 21/2-D derivado das anomalias geofísicas; (b) uma avaliação consistente da polaridade dos ambientes deposicionais, graus metamórficos e feições estruturais, com relação às idades relativas dos terrenos suturados; (c) suporte de dados de 
sísmica de reflexão; (d) modelagem tridimensional dessa litosfera neoproterozóica heterogênea submetida a deformação em regime colisional.

Ao final, os principais resultados obtidos nesta Tese, sobretudo os tratamentos digitais de produtos de sensoriamento remoto e dados geofisicos, foram recapitulados e avaliados consoantes à cartografia geológica e geofísica, com destaque para o fabric tectônico em regime transpressional-transtracional sob condições de alta-T/baixa-P, na melhoria da compreensão do arcabouço geológico regional do MSJC-MCB no Neoproterozóico. No que concerne às investigações futuras, foram consideradas algumas perspectivas referentes a tópicos específicos e regionais.

\section{2 - Seções Esquemáticas e Síntese dos Modelos Analógicos}

Os modelos clássicos de colisão continental demonstraram que as amplas variações na intensidade e a partição do strain influenciam os padrões complexos de evolução tectonometamórfica dos orógenos. Essas variações estão relacionadas principalmente às mudanças na velocidade e orientação das margens convergentes ( $p$.ex. convergência normal, oblíqua, indentação, delaminação mantélica, espessamento ou estiramento litosférico) e à geometria irregular das margens continentais (Tapponier et al. 1986, England \& Houseman 1989, Vauchez \& Nicolas 1991). Nos modelos analógicos, a representação desses parâmetros variáveis são combinados ainda aos mecanismos físicomecânicos controlados pelas propriedades inerentes dos materiais que compõem a litosfera continental. $\mathrm{Na}$ análise da estruturação vertical da litosfera foi demonstrado que os principais parâmetros de controle do comportamento reológico são a temperatura e a composição mineralógica (Nicolas \& Poirier 1976). A variação da resistência dos materiais com a profundidade na litosfera foi modelada nos perfis reológicos (Ranalli \& Murphy 1987, Ranalli 1995, 1997) que comparam a resistência à fricção (que aumenta linearmente com a pressão) e a resistência ao creep (fluxo estacionário, velocidade da deformação constante sob stress e temperatura constantes) para uma dada velocidade de deformação (que decresce exponencialmente com o aumento da temperatura). Ranalli (1995) apresentou uma compilação dos resultados experimentais dos parâmentros do creep para rochas e minerais predominantes na litosfera, e demonstrou o aumento na resistência ao creep com o decréscimo no teor de sílica para as rochas silicáticas sob regime dúctil. Este dado implicou 
na interpretação de uma estruturação reológica em camadas para a litosfera continental. Esta representação estratificada da litosfera continental denotou as variaç̃̃es na resistência/viscosidade com a profundidade, relacionando as diferentes camadas composicionais, os nível geotérmicos e as velocidades de deformação sob condições geodinâmicas diversas. Esta configuração para o comportamento reológico da litosfera continental foi confirmada em modelos experimentais e dados geofisicos (p.ex. Fadaie $\&$ Ranalli 1990, Davy \& Cobbold 1988, 1991, Ji \& Zhao 1993), com inúmeras evidências provenientes dos estudos tectônicos e geoquímicos (Nicolas \& Boudier 1975, Mercier \& Nicolas 1975, Nixon 1987, Taylor \& McLennan 1995). A estratificação da litosfera continental comporta uma crosta superior de rochas sedimentares e granitóides (ricas em quartzo), uma crosta inferior composta por granulitos ácidos e básicos (ricos em plagioclásio), e um manto superior lherzolítico (ricos em olivina, Nicolas et al. 1972). Entretanto, na escala da tectônica de placas o principal desvínculo mecânico ocorre entre a litosfera e a astenosfera (Ranalli 1987). A diferenciação na crosta continental decorre das reações metamórficas que acompanham as modificações nas condições P-T com a profundidade e dos processos de fusão parcial que favorecem à tendência a uma crosta superior ácida e uma crosta inferior básica e desidratada. As interfaces entre as diferentes camadas reológicas correspondem, provavelmente, às zonas com comportamentos reológicos transitórios entre aqueles das camadas homogêneas (Handy 1994). Entretanto, o modelo em três camadas para a litosfera continental considera a existência de interface reológica abrupta entre as camadas.

As diferentes composições mineralógicas, as condições de P-T e as variações nas velocidades da deformação controlam as transformações texturais que induzem à localização da deformação e o desenvolvimento das zonas de cisalhamento na litosfera continental. A crosta superior frágil é caracterizada pela deformação heterogênea acomodada pela ruptura e movimentação em planos de falhas, acompanhando mecanismos de cataclase e deformação intracristalina (dissolução por pressão e deslocamentos intracristalinos, Hirth \& Tullis 1994). A crosta superior-média de composição média granítica (quartzo + feldspatos + micas) apresenta deformação dúctil heterogênea sob temperatura superior a $300-350^{\circ} \mathrm{C}$. As heterogeneidades do material e variações nos parâmetros físicos do sistema induzem às instabilidades visco-plásticas que favorecem a localização da deformação em zonas de 
cisalhamento, sobretudo devido à recristalização dinâmica $\mathrm{e}$ às transformações mineralógicas sincinemáticas que diminuem a resistência das rochas (Vauchez 1987). $\mathrm{Na}$ crosta inferior-média, a alta temperatura $\left(600-750^{\circ} \mathrm{C}\right)$ favorece os fenômenos de deslocamento por deslizamento, migração e recristalização dinâmica dos grão minerais, sobretudo quartzo e plagioclásio cálcico (Seront et al. 1993). Neste nível crustal, a ampla fusão parcial sincinemática que freqüentemente acompanha as zonas de cisalhamento denota sobretudo heterogeneidades geométricas e reológicas na localização da deformação (Tommasi 1995). Para o manto superior litosférico $\left(\mathrm{T} \sim 800-1000^{\circ} \mathrm{C}\right)$, as evidências sugerem o predomínio da deformação por recristalização dinâmica da olivina e da enstatita (Boudier et al. 1988, Rutter \& Brodie 1988, Drury et al. 1991).

Os modelos analógicos e numéricos, simuladores da deformação da litosfera continental com heterogeneidades vertical e horizontal, elucidaram algumas das interrelações entre os mecanismos físico-mecânicos e a distribuição espacial das anomalias gravimétricas e das bacias e cadeias de montanhas (Ricard \& Froidevaux 1986, Davy \& Cobbold 1988, 1991, Burg et al. 1994). Ricard e Froidevaux (1986) avaliaram a distribuição preferencial dos comprimentos de onda envolvidos na boudinagem e/ou flambagem da litosfera submetida à tectônica extensional e/ou compressional. No modelo proposto, a heterogeneidade reológica vertical da litosfera foi representada pela crosta superior competente (espessura de $15 \mathrm{~km}$ ), crosta inferior incompetente (espessura de $15 \mathrm{~km}$ ), manto litosférico competente (espessura de $60 \mathrm{~km}$ ) e astenosfera incompetente (espessura $\sim$ ), com interfaces reológicas abruptas (Fig. 8.1). Os resultados sugerem que o padrão de deformação (flambagem e/ou boudinagem) da litosfera, marcado pela alternância entre altos e baixos da topografia e gravimetria, é resultante de instabilidades simultâneas no manto litosférico e na crosta superior, com comprimentos de onda preferenciais da ordem de $\lambda=$ $4 H$ (onde $\lambda=$ comprimento de onda e $H=$ espessura da camada). Para os padrões de deformação com comprimentos de onda entre $\sim 200 \mathrm{~km} \mathrm{e} 30-40 \mathrm{~km}$, a crosta superior sofre boudinagem e o manto litosférico mostra alternância entre boudinagem e flambagem. Burg et al. (1994) apresentou para orógeno colisional do tipo Platô Tibetano o modelo analógico com litosfera subdividida em quatro camadas de regimes frágil e dúctil alternados. Nesse modelo, a espessura total inicial das camadas controla a flambagem regular da litosfera em comprimentos de onda de primeira ordem $(\sim 200 \mathrm{~km})$, e conseqüentemente a deformação do 
ล

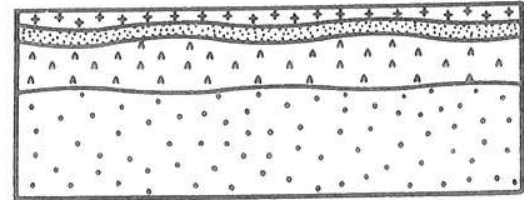

b

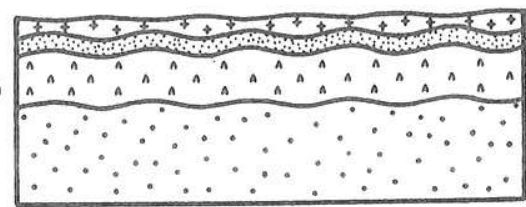

c

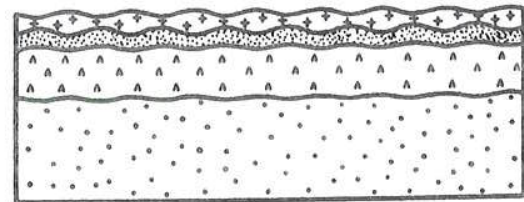

d

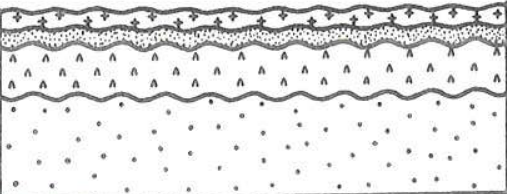

Figura 8.1 - Modelos analógicos para os padrões de deformação da litosfera continental composta por uma crosta superior frágil (densidade $=\rho=2,8$; espessura $=$ $H=15 \mathrm{~km})$, uma crosta inferior dúctil $(\rho=2,8 ; H=15$ $\mathrm{km})$ e um manto litosférico frágil $(\rho=3,2 ; H=60 \mathrm{~km})$, sobrejacentes à astenosfera $(\rho=3,15 ; H=\infty)$. Os perfis representam a deformação para compressão ou extensão com comprimentos de onda de (a) $\sim 150 \mathrm{~km}$, (b) 70-80 $\mathrm{km}$, (c) $50 \mathrm{~km}$ e (d) $30 \mathrm{~km}$. Os resultados mostram a boudinagem da crosta superior em todos os comprimentos de onda e a deformação alternada entre flambagem e boudinagem para o manto litosférico. Modificado de Ricard e Froidevaux (1986).

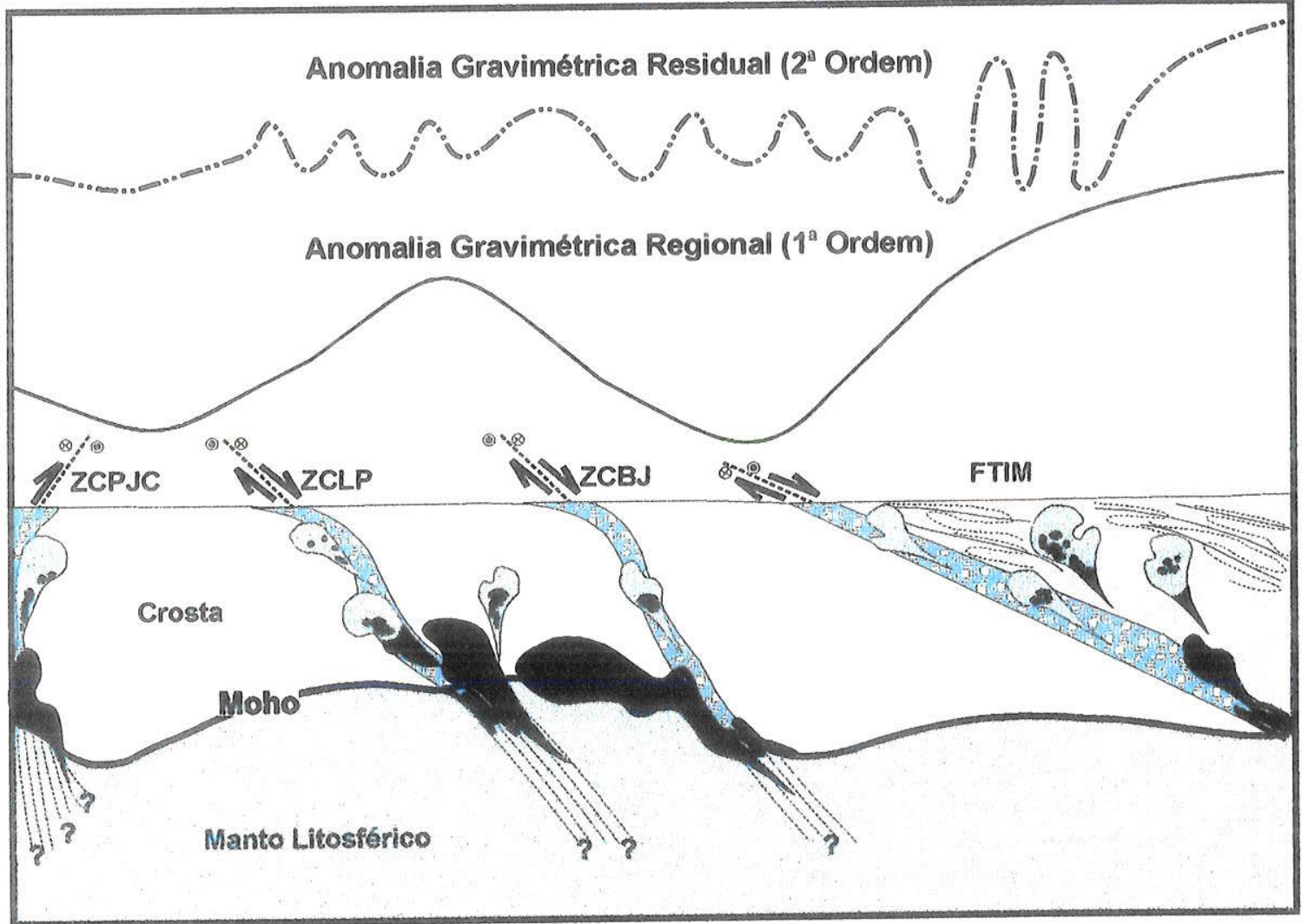

Figura 8.2 - Seção crustal esquemática para a região dos blocos arqueanos do MSJC ao final do Ciclo Brasiliano. As anomalias gravimétricas regionais definem a forma geral da Moho, e conseqüentemente a estruturação (espessura) dos diferentes blocos, sugerindo a boudinagem da crosta. As anomalias gravimétricas residuais descrevem a disposição crustal dos granitóides (básicos e ácidos) e das zonas de cisalhamento brasilianas transpressionais (ZCPJC) e transtracionais (ZCLP e ZCBJ). Abreviaturas: ZCPJC = Zona de Cisalhamento Picuí-João Câmara, ZCLP $=$ Zona de Cisalhamento Lagoa das Pedras, ZCBJ = Zona de Cisalhamento Bom Jesus, FTIM = Faixa TaipuIelmo Marinho. 
manto litosférico, enquanto os comprimentos de onda de segunda ordem (20-30 km) condicionam a deformação da crosta superior frágil (Martinod \& Davy 1992). Para um modelo analógico semelhante submetido a extensão, Allemand e Brun (1991) demonstraram a boudinagem da crosta inferior dúctil e do manto litosférico frágil, com a ascenção da porção inferior do manto litosférico dúctil e da astenosfera. Esse deslocamento é transferido através da crosta inferior até a base da crosta superior frágil, onde promove a formação de rifte simétrico. No modelo esquemático da Fig. 4.11, uma litosfera em três camadas (com baixo contraste de viscosidade) representaria os blocos menos espessos (microplacas, terrenos alóctones, crosta juvenil) em interação por colisão com a placa litosférica mais espessa (cráton). Os comprimentos de onda mais longos refletiriam a deformação da Moho formando lóbulos em direção à crosta inferior (menos competente), ou seja, promovendo o soerguimento da Moho e manto litosférico (mais competente), conforme os modelos de Ricard e Froidevaux (1986) e Burg et al. (1994). Os comprimentos de onda de segunda ordem afetariam a interface entre crosta superior e crosta média-inferior, ou entre os regimes frágil e dúctil, com as cúspides em direção à camada mais competente sugerindo a boudinagem da crosta superior com formação dos riftes (Allemand \& Brun 1991). O soerguimento da Moho modificaria o campo térmico na base da crosta alterando, ao menos localmente, o comportamento reológico desse setor da crosta pelo underplating e alojamento de magmas diferenciados na crosta média a inferior. Pili et al. (1997) calcularam o soerguimento da Moho entre 10-14 km sob as principais zonas de cisalhamento de Madagascar. Essa instabilidade mecânica favoreceria a nucleação das zonas de cisalhamento no manto litosférico ou crosta inferior e a propagação da deformação através da crosta, comumente canalizando o luxo de fluidos. A combinação entre as instabilidades do manto e da crosta, em seus comprimentos de onda respectivos, induzem a nucleação de zonas de cisalhamento inteiramente em niveis crustais. A disposição das zonas de cisalhamento acompanharia a trajetória das elipsóides de strain finito que descrevem a refração do fabric no contato entre as camadas mais e menos competentes, conforme os leques convergentes ou divergentes da clivagem desenvolvidos nas camadas competentes ou incompetentes, respectivamente, submetidas a flambagem (em destaque na Fig. 4.11). Algumas heterogeneidades reológicas localizadas, como a presença de corpos magmáticos parcialmente consolidados, favorece a propagação dessas zonas e afeta a trajetória do fabric, 
conduzindo à coalescência com as demais e/ou o detachment na base da crosta. A Fig. 8.2 apresenta uma seção esquemática para o setor entre a ZCPJC transpressional e os blocos arqueanos do MSJC, dominantemente em regime transtracional e extensional, mostrando a correlação entre as anomalias gravimétricas regional e residual, o controle exercido pelas zonas de cisalhamento sobre o alojamento dos granitóides e a estruturação da crosta. A assinatura gravimétrica de primeira ordem define a forma da Moho e, por conseguinte, o arranjo da crosta em blocos com diferentes espessuras. As anomalias de curtos comprimentos de onda demarcam os corpos granitóides de composiçðes variadas instalados em diferentes níveis crustais, condicionados parcial ou totalmente às zonas de cisalhamento transtracionais e transpressionais, geralmente com raizes mantélicas que sugerem a derivação de magmas básicos de origem mntélica. A combinação desses fatores sugere a estruturação geral em boudinagem para essa porção crustal do MSJC.

Os modelos geodinâmicos de colisão continental sugerem a geração de placas litosféricas continentais através de processos acrescionários sucessivos em torno de núcleos cratônicos, aliados à amalgamação de terrenos alóctones (microplacas continentais). Os extensos deslocamentos envolvidos nos processos colisionais são comumente acomodados por zonas de cisalhamento (Daly 1986, Avouac \& Tapponier 1993) que evoluem ao retrabalhamento transcorrente intracontinental, como no contexto da orogênese Brasiliana/Pan-Africana (Boullier 1991, Liégeois et al. 1994, Jardim de Sá 1994). O arranjo complexo caracteriza as placas continentais como um mosaico heterogêneo de propriedades mecânicas anisotrópicas, em função da aglutinação de blocos com espessuras e fluxos térmicos variados, diferentes idades e fabrics prévios (Barruol et al. 1997, Vauchez et al. 1997b). Essa heterogeneidade reológica lateral e as irregularidades geométricas dos limites das placas conduzem às variações locais no comportamento mecânico da litosfera continental e à localização da deformação (Tommasi 1995). No modelo numérico proposto por Tommasi \& Vauchez (1997) para a evolução mecânica de parte da Província Borborema, representada por dois domínios de baixa viscosidade (bacias sedimentares) e um de alta viscosidade (cráton) submetida a compressão obliqua constante, foi demonstrado que o campo do strain finito é heterogêneo (Fig. 8.3). A localização, a intensidade e a repartição da deformação dependem da geometria e do contraste de viscosidade entre os blocos com diferentes heterogeneidades e a litosfera circundante. A deformação por cisalhamento 

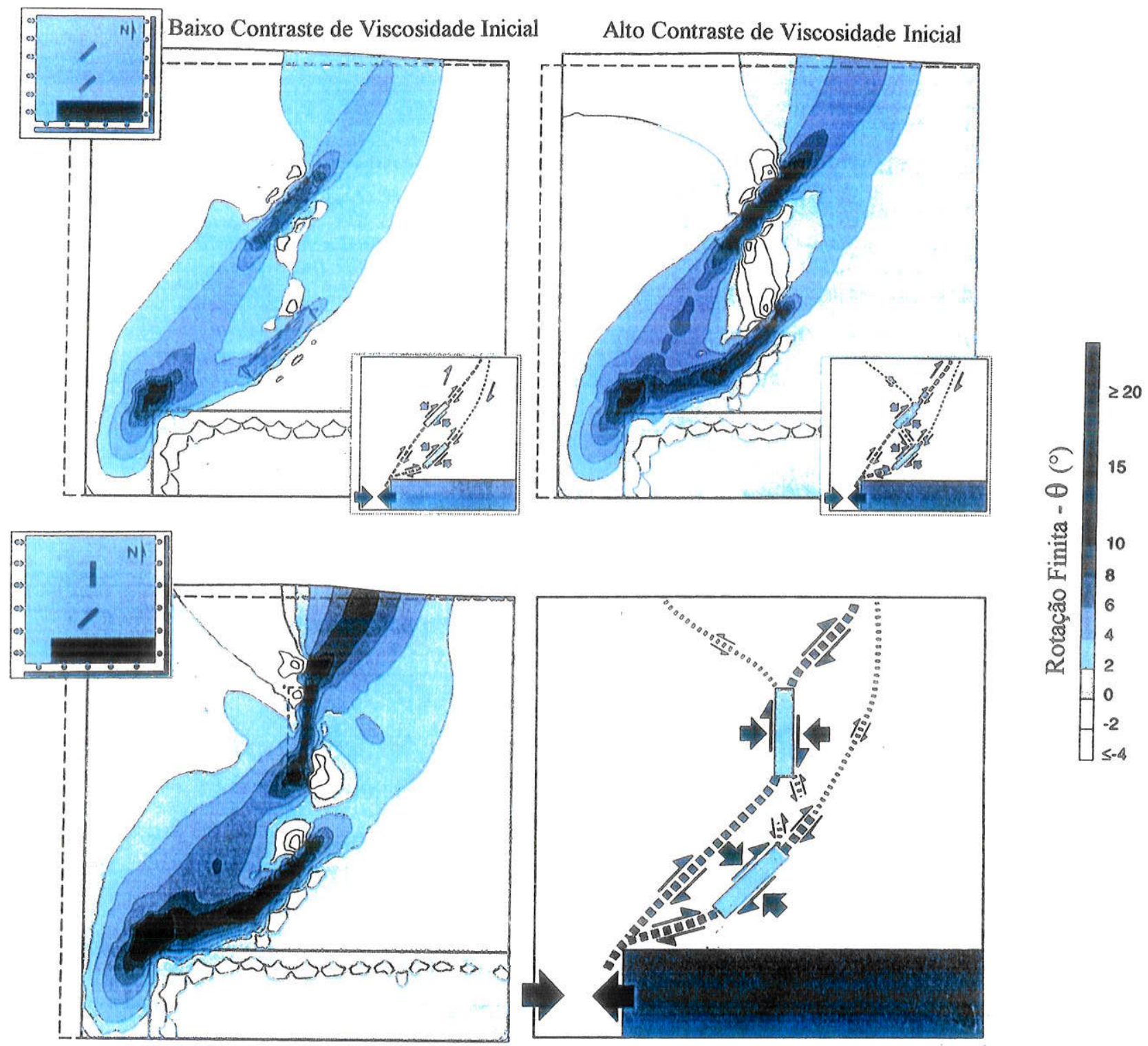

Figura 8.3 - Modelo numérico para o comportamento mecânico da litosfera continental de parte da Província Borborema, representado por dois domínios de baixa competência (faixas metassedimentares), com trends NE e NS, e um bloco rígido (cráton), submetidos a convergência de $120 \mathrm{~km}$. Os destaques acima e a esquerda indicam as geometrias e as condiçôes dos limites para cada modelo. Nos contornos de strain finito, os brancos representam os movimentos sinistrais. Os destaques abaixo e a direita mostram a interpretação ao modelo, com as zonas de cisalhamento (linhas tracejadas) e seus movimentos (setas alternadas), e as áreas compressionais, onde a direção da compressão é indicada pelas setas grossas. As dimensões das setas e as espessuras das linhas representam a magnitude relativa da deformação em cada zona de cisalhamento. Modificado de Tommasi (1995). 
simples inicia-se nas extremidades dos principais contrastes de heterogeneidades, propaga-se a partir dos domínios de baixa viscosidade e coalescem em sistemas de zonas de transferência que circundam blocos pouco deformados. A deformação por cisalhamento puro ocorre preferencialmente localizada nos domínios com baixa viscosidade. A Fig. 8.3 demonstra a ramificação do sistema de zonas de cisalhamento a partir da extremidade do bloco mais viscoso e a propagação coalescente das zonas de cisalhamento dextrais com trends NS e NE, as sinistrais com trends NW e dos regimes transpressionais dextrais nos domínios menos viscosos, acompanhando o fluxo direcional imposto pela distribuição espacial das heterogeneidades. Os modelos mostram estreita correspondência com o campo de strain finito do sistema de zonas de cisalhamento da Província Borborema na margem norte do Cráton do São Francisco: as principais zonas de cisalhamento transcorrentes dextrais (p.ex. os lineamentos Patos e Pernambuco) transferem a deformação para as faixas metassedimentares (p.ex. as faixas Orós e Seridó), e ramificam-se contornando blocos menos deformados (p.ex. os duplexes nas zonas de cisalhamento de Tatajuba e Potengi); nas faixas metassedimentares ocorre a repartição da deformação em zonas transcorrentes dextrais e domínios de strain coaxial (p.ex. as faixas Orós e Seridó); as zonas de cisalhamento sinistrais de trend geral NW geradas nas extremidades dos domínios menos viscosos (p.ex. as zonas de cisalhamento Japi e Trairí), presentes nos modelos mas não reconhecidas em campo por Tommasi e Vauchez (1997). No entanto, os modelos não esclarecem a formação dos domínios transtracionais de cinemática sinistral e trends NE no DZT e com trends NW no MSJC, contemporâneos ao regime transcorrente-transpressional predominates nos demais terrenos.

Diversos trabalhos relataram o amplo controle exercido pelas zonas de cisalhamento sobre a deformação da crosta continental durante uma orogênese (p.ex. White \& Bretan 1985, Handy 1989). Entretanto, permanecem incertezas sobre a transferência do mecanismo que controla o regime deformacional ao manto superior, ou seja, se a característica da deformação localizada nas zonas de cisalhamento permanece no manto superior ou se é uniformente distribuída (p.ex. Drury et al. 1991, Vissers et al. 1995, 1997). A seção esquemática proposta na Fig. 8.4 sintetiza a estruturação Brasiliana/Pan-Africana no setor que engloba os terrenos da Faixa Seridó (porção centro-sul) e o MSJC-MCB, coerente com as principais feiçôes geológicas e geofísicas discutidas anteriormente. As zonas de 

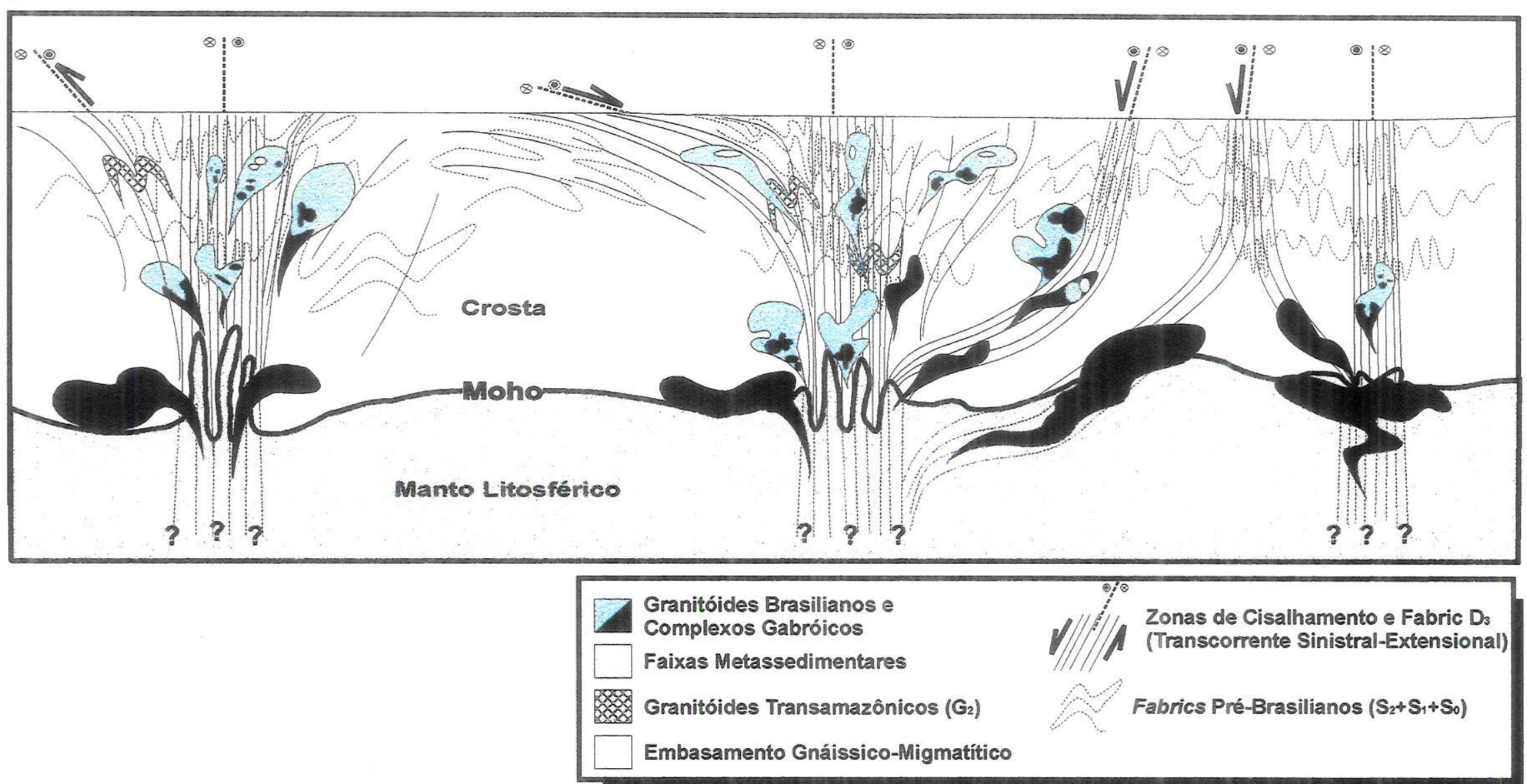

Figura 8.4 - Seção crustal esquemática para o MSJC-MCB ao final do Ciclo Brasiliano. A estruturação dos blocos, a disposição das zonas de cisalhamento (transcorrentes, transpressionais e transtracionais) e do plutonismo brasilianos foram baseados nas faições geofísicas (gravimétricas e aeromagnéticas), dados estruturais e geoquímicos discutidos nesta tese. Neste modelo, as zonas de cisalhamento principais estariam enraizadas no manto e provocariam a transposição da Moho e porção superior do manto litosférico sub-continental. As anisotropias mec6anicas e o fluxo de calor anômalo na base da crosta, decorrente do soerguimento da astenosfera, processos de underplating e canalização de fluidos (magma e voláteis) pelas zonas de cisalhamento, favorecem a progressão e a coalescência das zonas de cisalhamento, bem como a anatexia e a diferenciação magmática na crosta. Os corpos granitóides e mostram evidências de magma mixing e mingling (enclaves máficos), xenólitos das encaixantes e alguns preservam as raízes básicas. 
cisalhamento transpressionais e transtracionais, instaladas respectivamente na Faixa Seridó e na Faixa de Micaxistos de Barra de Santa Rosa, promoveriam a deformação da Moho e porção superior do manto litosférico, e atuariam como condutos preferenciais na transferência de fluidos (magmas e voláteis) e na advecção do calor mantélico para os niveis crustais. Esse processo conduziria à progressão vertical da fusão parcial na crosta e a freqüente associação lateral entre as seqüências metassedimentares de médio grau metamórfico, rochas migmatíticas sinanatéticas e granitóides sintectônicos diferenciados. Os granitóides preservariam resquícios da origem mantélica e/ou crustal nas raizes básicas dos plútons e/ou nos enclaves dos magmas parentais que descrevem os processos de magma mixing e mingling, bem como xenólitos das seqüências encaixantes. As condições metamórficas regionais de alta-T/baixa-P $\sin -\mathrm{D}_{3}$ dos terrenos do $\mathrm{MSJC}-\mathrm{MCB}$ e Faixa Seridó teriam origem nos mecanismos de extensão litosférica, relacionada à fusão parcial por descompressão e, provavelmente, sucedendo ao evento transpressional (Carson et al 1997), pela transfência anômala de calor a partir da astenosfera pelos fluidos canalizados nas zonas de cisalhamento. O armadilhamento de magmas mantélicos quentes na base da crosta (underplating, Huppert \& Sparks 1988) altera localmente o campo térmico e favorece o processo de diferenciação magmática da crosta continental pela fusão parcial da crosta inferior. Estes fatores diminuem significativamente a resistência das rochas e desencadeiam o desenvolvimento de zonas de cisalhamento que controlam o alojamento de magmas na crosta (Fleitout \& Froidevaux 1980, 1982, Dell'Angelo \& Tullis 1988, Vauchez \& Nicolas 1991, Rutter \& Neumann 1995). A intrusão dos magmas contribuiria no abrandamento localizado das propriedades termomecânicas da crosta continental e, portanto, na nucleação e propagação das zonas de cisalhamento (Tommasi et al. 1994, Neves et al. 1996). Os estudos geofisicos e geoquímicos que sugerem a integração mecânica entre a crosta e o manto sub-continental (p.ex. Plamerová et al. 1993, Pavlenkova 1995) facilitam a argumentação a favor do padrão de fluxo heterogêneo (cisalhamento geral não coaxial) instalado no manto litosférico por meio de zonas de cisalhamento, responsáveis pela percolação de fluidos, metassomatismo e enriquecimento geoquímico mantélico (TRL, LIL, razões $I_{S r}$ altas e $I_{N d}$ baixas, Downes 1990). Conforme a intensidade do strain heterogêneo, A deformação da Moho variaria conforme a geometria e intensidade do strain heterogêneo, possivelmente gerando formas de níveis dobrados e transpostos e até geometria em bainha 
(?).Esses fatores sugerem para o soerguimento do manto litosférico um mecanismo intermediário entre aqueles da intrusão do manto em estado sólido ou de múltiplas intrusões de magmas derivados do manto, propostos por Pili et al. (1997). As evidências da sísmica de reflexão confirmam o desenvolvimento de zonas de cisalhamento em níveis profundos da litosfera, tanto em ambientes compressionais quanto extensionais, sugerindo uma homogeneidade mecânica entre o manto subcontinental e a crosta (Warner \& McGeary 1987, Flack et al. 1990, Vauchez \& Egydio-Silva 1992, Plomerová et al. 1993, Pavlenkova 1995). Kelemen e Dick (1995) descreveram a ocorrência de zonas de cisalhamento dúcteis no manto superior condicionando o fluxo de magma dunitico. A percolação de fluidos através dessas zonas facilitariam a fusão mantélica pela diminuição da temperatura solidus do peridotito e o enriquecimento geoquímico do manto litosférico (sobretudo LIL e TRL, Etheridge et al. 1983, Ellis \& Maboko 1992). Este processo estaria na origem dos magmas básicos enriquecidos, e/ou na geração de ambientes contaminantes para os magmas provenientes da astenosfera, canalizados à crosta pelas zonas de cisalhamento litosféricas.

A Fig. 8.5 relaciona a natureza e a distribuição dos fluidos nas zonas de cisalhamento brasilianas do MSJC-MCB, com base na proposta de Pili (1997) para a litosfera continental pan-africana de Madagascar. Com base nas informações apresentadas até o momento, as zonas de cisalhamento seriam as principais responsáveis pela drenagem de fluidos mantélicos e/ou crustais e pelas transferências entre as camadas com reologias contrastantes da litosfera. No esquema proposto por Etheridge et al. (1983), a distribuição e o escoamento dos fluidos estariam restritos às células convectivas condicionadas aos estratos reológicos da crosta continental, e as zonas de cisalhamento seriam as únjcas estruturas que permitiriam a transferência de fluidos pela crosta dúctil, provavelmente desde o manto litosférico. No processo de percolação pervasiva ou canalizada, as interações físico-químicas entre os fluidos quentes $\mathrm{e}$ as rochas alteram as características reológicas dos diferentes niveis crustais induzindo à localização da deformação em zonas de cisalhamento. Esses mecanismos de infiltração e redistribuição dos fluidos na crosta continental incorrem nos processos mineralógicos de recristalização dinâmica e nucleação, que acompanham os retrometamorfismo sincinemático e beneficiam o desenvolvimento de ramificações $\mathrm{e}$ coalescências entre as zonas de cisalhamento crustais. Tais processos seriam resposáveis pela geração das mineralizações de caráter econômico relacionadas às cadeias 

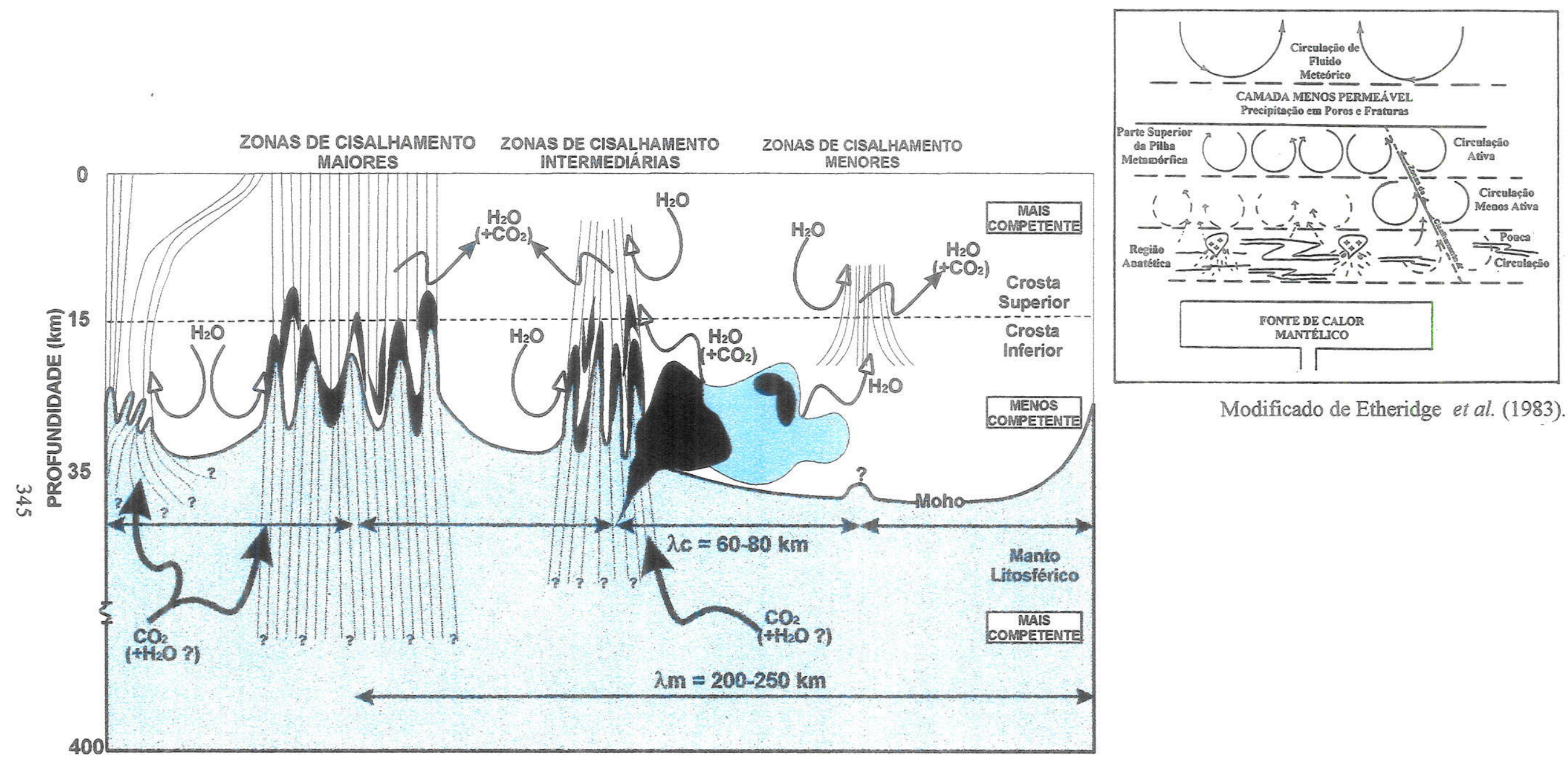

Modificado de Etheridge et al. (1983).

Figura 8.5 - Esquema da distribuição e canalização dos fluidos pelas zonas de cisalhamento brasilianas na crosta continental do MSJC-MCB, com base na proposta de Pili (1997) para Madagascar. As zonas de cisalhamento maiores e intermediárias estão enraizadas no manto litosférico, controladas pelos comprimentos de onda $(\lambda \mathrm{m})$ de 200-250 km, e canalizam $\mathrm{CO}_{2}\left(+\mathrm{H}_{2} \mathrm{O}\right.$ ?) mantélico e $\mathrm{H}_{2} \mathrm{O} \pm \mathrm{CO}_{2}$ dos materiais crustais. As zonas de cisalhamento menores estão enraizadas apenas na crosta inferior, controladas pelos comprimentos de onda $(\lambda c)$ de $60-80 \mathrm{~km}$, e drenam os fluidos $\left(\mathrm{H}_{2} \mathrm{O} \pm \mathrm{CO}_{2}\right)$ produzidos na crosta. Nesta proposta mecânica, os níveis da Moho e porcão superior do manto litosferico sofreriam transposição pela atuacão das zonas de cisalhamento litosféricas. Em destaque, modelo esquemático da distribuição e escoamento dos fluidos na crosta continental proposto por Etheridge et al. (1983), em que apenas as zonas de cisalhamento permitiriam a transferência de fluidos pela crosta inferior dúctil, talvez desde o manto litosférico. 
Brasilianas/Pan-Africanas. O desenvolvimento de zonas de cisalhamento extensionais e transpressionais, como no Setor Extremo Nordeste da Província Borborema, está caracterizado por ampla anomalia geotérmica que permeabiliza a interface crosta-manto, como sugere a infiltração de $\mathrm{CO}_{2}$ de origem mantélica e grande proporção d'água (Pili 1997). Essas zonas de cisalhamento litosféricas promoveriam ainda a drenagem de $\mathrm{CO}_{2}-\mathrm{H}_{2} \mathrm{O}$ derivados do magmatismo básico instalado na base da crosta, relacionado ou não às zonas de cisalhamento, e dos materiais crustais. Para Pili et al. (1997), as zonas crustais canalizariam apenas fluidos ricos em $\mathrm{H}_{2} \mathrm{O}$ de origem crustal e por distâncias de até dezenas de quilômetros. $\mathrm{O}$ volume de fluido drenado e transferido é função da quantidade de magma alojada na crosta, do contexto geotectônico (convergência, rifteamento, etc.) e dos espaços disponiveis abertos pelo regime deformacional instaurado. No metassomatismo das zonas de cisalhamento, decorrente da infiltração dos fluidos com $\mathrm{CO}_{2}$ mantélico, são comuns diopsídio, flogopita, fluorapatita e fluorita, que indicam similaridades com o metasssomatismo no manto, relacionado às interações com magmas carbonatados. Pili (1997) sugere o alojamento de carbonatitos nas raízes das zonas de cisalhamento poderiam propiciar as emanações de $\mathrm{CO}_{2}$ e às condições necessárias à geração dos granulitos (Fourcade et al. 1996). O tempo de duração da anomalia térmica controlaria o funcionamento da drenagem e transferência de fluidos entre o manto e a crosta, mas comumente esta atividade suplanta a duração do episódio tectônico responsável pela geração das zonas de cisalhamento litosféricas (Nicollet et al. 1995). A intensa atividade metassomática nessas estruturas no Brasiliano/Pan-Africano produziram a alteração química do manto litosférico, marcado pelo enriquecimento em TRL e LIL. A disposição espacial dessas "cicatrizes" brasilianas/pan-africanas metassomatizadas influenciaram na reativação do magmatismo alcalino nos eventos térmicos fanerozóicos da África (Black \& Liégeois 1993, Lee et al. 1996), como sugere a correspondência entre a ZCAC e a Linha Vulcânica dos Camarões (Fig. 2.1, Poudjom Djomani et al. 1995, 1997), e entre a Zona de Cisalhamento Sul-Queniana e o vulcanismo alcalino (fonolitos) mio-pliocênicos a quaternários no Rifte do Leste da África (Cardon et al. 1997). 


\section{3 - Principais Conclusões e Perspectivas}

A presente Tese apresenta uma contribuição metodológica à combinação de técnicas de processamento digital de imagens de sensoriamento remoto Landsat 5-TM e geofisicas às informaç̃̃es litológicas e estruturais dos terrenos polideformados da região semi-árida do Nordeste do Brasil. A análise integrada desses tratamentos permitiram a incrementação da cartografia geológica-geofisica e acrescentaram algumas considerações sobre o contexto geodinâmico da crosta continental do Setor Extremo Nordeste da Província Borborema (MSJC-MCB) no Brasiliano/Pan-Africano.

- Na estratégia metodológica empregada nos tratamentos dos produtos do GEMS/Banda X e Landsat 5-TM, o critério condutor foi a interpretação visual monoscópica das imagens monocanais e composições coloridas, combinada ao conceito da unidade de paisagem. No processamento digital das imagens Landsat 5-TM foram aplicadas técnicas de filtragem direcional (filtros Sobel, Prewitt, Kirsch e Laplaciano) e composiçðes coloridas (RGB, IHS, ACP, Razões de Bandas, HRGB) na detecção e realce do sistema de lineamentos e na diferenciação espectral da principais unidades litológicas. Esses tratamentos digitais, combinados às informações de campo e demais abordagens metodológicas, permitiram: (i) a caracterização dos domínios de baixo e alto strain $\mathrm{D}_{3}$ delimitados pelo arranjo geométrico complexo de zonas de cisalhamento brasilianas com trends gerais NW (ZCJ, ZCT, ZCPL, ZCSSB e ZCBJ) e NE (sistema ZCPA-ZCPJC-ZCRP-ZCCG e suas ramificações ZCPF, ZCCC, ZCGB, ZCBNC, ZCMN); (ii) a distinção espectral entre as principais unidades litológicas no setor entre Japi e Campina Grande, conduzindo à reorganização espacial dessas unidades litológicas previamente conhecidas (granitóides e faixas metassedimetares) e a definição de novas unidades e estruturas do fabric $\mathrm{D}_{3}$. O emprego de medidas da espectrometria de reflectância em amostras de mão de rochas e minerais desse setor, demonstraram uma ampla possibilidade de aplicações geológicas, como: (i) o diagnóstico dos principais minerais constituintes das rochas pela posição das feições de absorção, e pela comparação entres as formas das curvas espectrais das rochas e dos minerais; (ii) o agrupamento das rochas em categorias espectrais, baseado no albedo e na forma das curvas espectrais, que podem refletir caracteristicas petrográficas e geoquímicas intrínsecas (p.ex. porcentagem modal relativa entre os minerais félsicos e máficos); (iii) a deteç̧ão de variações sutis nos conteúdos geoquímicos de rochas petrologicamente análogas (p.ex. os 
teores em $\mathrm{Fe}, \mathrm{Ca}, \mathrm{Mg}, \mathrm{Al}$ e $\mathrm{OH}$, entre as suites alcalinas de Japi e Caxexa + Algodão). As comparaçðes entre as disposiçð̃es das assinaturas espectrais nas faixas referentes às bandas do Landsat 5-TM (bandas 1-5 e 7) beneficiaram na conformação de um método estatístico de seleção dos melhores conjuntos de bandas do Landsat 5-TM na distinção das litologias analisadas, de modo mais efetivo que os métodos clássicos FIO (Chavez et al. 1982) e INDEX (Crippen 1989). A interpretação visual das imagens resultantes desses conjuntos de trios e razões de bandas, combinadas nas diferentes técnicas de processamento digital, estendida aos terrenos adjacentes comprovaram a aplicação à cartografia geológica de reconhecimento e semi-detalhe, pela excelente correlação com as unidades geológicas previamente definidas e pela detecção de novas unidades ainda não cartografadas até o presente (Fig. 4.1). Como sugestões à continuidade das investigações em aplicações geológicas tem-se:

$\Rightarrow$ A ampliação das medidas espectrais in situ e em amostras de mão para diversas unidades litológicas, agrupadas de acordo com critérios petrográfícos e/ou geoquímicos, na organização de um "bancos de dados" contendo as assinaturas espectrais de rochas nos diferentes terrenos, como base prévia para os trabalhos de cartografia temática;

$\Rightarrow$ A aplicação dessa metodologia ao mapeamento dos granitóides neoproterozóicos e fanerozóicos da Província Borborema, em acordo ao projeto de pesquisa desenvolvido em cooperação pela UFPE, UFRN e UFBa (Sial et al. 1996), que permitiria a combinação das respostas espectrais e dos melhores conjuntos de imagens digitais do Landsat 5-TM ao acervo de dados geoquímicos e petrológicos disponiveis para os dez grupos geoquímicos de granitóides identificados; a partir dessa prerrogativa, permitindo na diferenciação petrológica e geoquímica entre as suites e mesmo variações em uma mesma suíte em outros setores da Província Borborema;

$\Rightarrow \mathrm{O}$ estudo das interação fluido-rocha, desde os processos envolvendo a drenagem de fluidos mantélicos e crustais pelas zonas de cisalhamento brasilianas até à circulação de fluidos hidrotermais, $\mathrm{e}$ as possibilidades do condicionamento de mineralizações de interesse econômico (p.ex. ouro, urânio, tório, flogopita, micas refratárias) a exemplo de orógenos do Brasiliano/Pan-Africano em outros continentes; 
$\Rightarrow$ A modelagem metalogenética para os terrenos afetados por. zonas de cisalhamento de alto grau metamórfico;

$\Rightarrow \mathrm{Na}$ mesma linha de interesse do ponto anterior, o estudo sobre a influência do metassomatismo Brasiliano/Pan-Africano relacionado ao sistema de zonas de cisalhamento na reativação da crosta continental em eventos térmicos posteriores.

$\Rightarrow$ A combinação dessa abordagem metodológica, envolvendo a espectrometria de reflectância de rochas e minerais aplicadas aos problemas geológicos, aos processamentos digitais com imagens de alta resolução espectral.

- A abordagem sistemática das condições P-T permitiram a confecção do mapa esquemático da distribuição do metamorfismo neoproterozóico $\left(\mathrm{M}_{3}\right)$ relacionado à deformação dúctil e granitóides brasilianos (Fig. 6.1). O ápice do metamorfismo alcançou condições do fácies anfibolito alto a granulito hidratado, associado à extensiva migmatização das rochas do embasamento e das faixas metassedimentares, concomitante ao desenvolvimento das zonas de cisalhamento transpressionais, transtracionais e extensionais. Para essa deformação dúctil de alta-T/baixa-P foi definida a idade de $575 \pm 25 \mathrm{Ma}$ (metapelitos granulíticos, Souza et al. Submet.), correlata ao alojamento sintectônico de granitóides em $555 \pm 10 \mathrm{Ma}$ (norito do granitóide Serrinha) no MSJC-MCB. Na Faixa de Metassedimentos de Barra de Santa Rosa, as medidas termobarométricas pelo geotermômetro plagioclásio-anfibólio (Blundy \& Holland 1990) e pelo geobarômetro do Al no anfibólio (Hammarstrom \& Zen 1986, Hollister et al. 1987, Johnson \& Rutherford 1989, Schmidt 1992) indicaram $\mathrm{T} \sim 781-811^{\circ} \mathrm{C}$ e $\mathrm{P} \sim 3,8-5,9$ kbar para os metapelitos granulíticos migmatizados, enquanto os granulitos máficos intercalados mostraram variações de $\mathrm{T} \sim 799$ $823^{\circ} \mathrm{C}$ e $\mathrm{P} \sim 3,0-4,5$ kbar pelos métodos plagioclásio-anfibólio e $\mathrm{Al}$ no anfibólio, e T 818$973^{\circ} \mathrm{C}$ no geotermômetro ortopiroxênio-clinopiroxênio (Wood \& Banno 1973). Para o CCG os valores obtidos mostraram variações de $\mathrm{T} \sim 713-835^{\circ} \mathrm{C}$ e $\mathrm{P} \sim 2,5-5,5$ kbar pelos métodos plagioclásio-anfibólio e Al no anfibólio. Essas informações termobarométricas, aliadas aos dados de campo, às feições petrográficas e aos modelos experimentais, sugerem para a geração do fácies granulito e da migmatização os mecanismos de fusão por desidratação de magmas básicos, com provável derivação mantélica, instalados na base da crosta e/ou em underplating e/ou condicionados às zonas de cisalhamento com raizes mantélicas que 
transpõem a interface crosta-manto. Essas zonas de cisalhamento litosféricas promoveriam a canalização e redistribuição do fluxo de calor e fluidos (ricos em $\mathrm{CO}_{2}$ mantélico) necessários à fusão dos magmas básicos na ausência de vapor, à segregação de fundidos félsicos, à progressão vertical da fusão parcial, à hibridização dos fundidos e ao metamorfismo granulítico. O regime extensional no MSJC seria quase-sincrônico (concomitante a subseqüente) ao regime transpressional na porção central da Faixa Seridó, onde a ampla fusão parcial e a granitogênese (plútons e pegmatitos sincinemáticos) marcariam os mecanismos de descompressão, conforme contexto similar proposto por Carson et al. (1997) para a Antártida. O espessamento crustal na Faixa Seridó teria como compensação mecânica a extensão no MSJC-MCB, provavelmente promovida por processos de boudinagem da crosta continental e/ou litosfera continental. A datação de $403 \pm 38$ Ma corresponderia ao retrabalhamento do fabric de alta- $\mathrm{T}$ em condições retrometamórficas de baixa- $\mathrm{T}$ ( $\mathrm{T}<$ $530^{\circ} \mathrm{C}$ ), decorrente do soerguimento e exumação dos niveis profundos da crosta. Entretanto, para confirmação e aprofundamento desses resultados sugere-se:

$\Rightarrow$ A ampliação do quadro geocronológico, sobretudo sobre a sincronicidade do funcionamento e o resfriamento das zonas de cisalhamento em regime transpressional e transtracional, baseada nas medidas das diferentes assembléias metamórficas em cristalização sucessiva (p.ex. microssonda em monazitas, $\mathrm{U} / \mathrm{Pb}$ em zircões, ${ }^{40} \mathrm{Ar} r^{39} \mathrm{Ar}$ em micas e anfibólios);

$\Rightarrow \mathrm{O}$ detalhamento termobarométrico das condições P-T-t da deformação dúctil e granitóides sintectônicos neoproterozóicos;

$\Rightarrow O$ estudo do ambiente dinâmico de geração e segreção de fundidos na crosta inferior e migração para a crosta média-superior, controlados pelo stress diferencial e strain heterogêneo nas zonas de cisalhamento;

$\Rightarrow \mathrm{O}$ estudo das inclusões fluidas na determinação da natureza, distribuição e transferência dos fluidos sin- a tardimetamórficos $\left(\mathrm{H}_{2} \mathrm{O} \pm \mathrm{CO}_{2}\right)$ que percolam os diferentes níveis da litosfera continental canalizados pelas zonas de cisalhamento, sobretudo nos domínios de fácies granulito e extensiva migmatização, em relação a repartição heterogênea do strain; 
$\Rightarrow$ A geoquímica comparativa de isótopos estáveis $\mathrm{C}-\mathrm{O}-\mathrm{H}$ de minerais e litologias variadas (rochas carbonáticas, granitóides, metabásicas, migmatitos sintectônicos) entre as áreas de baixo strain e nas zonas de cisalhamento principais, na caracterização do escoamento dos fluidos.

- Os tratamentos por filtragens nos domínios da frequência e espaço-temporal dos dados geofisicos (gravimétricos e aeromagnéticos) mostraram-se coerentes na caracterização dos contrastes de densidades e suceptibilidade em diferentes níveis do manto litosférico-crosta continental, em função dos comprimentos de onda. A correlação das assinaturas geofísicas com as feições geológicas permitiu a proposição do enraizamento mantélico das zonas de cisalhamento, que exerceriam o controle efetivo na deformação da crosta inferior-manto litosférico subcontinental. As anomalias geofisicas regionais e residuais refletem à estruturação impoșta pelo fabric $\mathrm{D}_{3}$ demonstrado no condiçionamento exercido pelas zonas de cisalhamento na geometria de blocos crustais com características geológicas (geoquimicas e geocronológicas) contrastantes, no alojamento de granitóides sintectônicos de origem mantélica, nas condições metamórficas do fácies granulito e na migmatização. A interpretação combinada dessas informações conduziram à modelagem da estruturação crustal no MSJC-MCB, marcada pela transposição da Moho e o soerguimento do manto litosférico, e/ou magmas mantélicos derivadọ, acompanhando o regime tranștracional e extensional nas zonas de cisalhamento. A comparação entre as anomalias gravimétricas residuais para a crosta superior, os enxames de lineamentos topográficos, as feições morfotectônicas e os dados de campo sugere a reativação do sistema de zonas de cisalhamento brasilianas, provavelmente em episódios sucessivos no regime frágil, desde o resfriamento e uplift dos terrenos nos estágios finais da orogênese Brasiliana. No Cenozóico, essas estruturas reativadas formariam um dos principais padrões de falhas que controlam grabens e horsts na Faixa Litorânea do Nordeste. Entretanto, uma descrição precisa da evolução geodinâmica desses terrenos e a modelagem das heterogeneidades mecânicas da litosfera continental exigiria o aporte das informações sugeridas anteriormente em complemento às abordagens como:

$\Rightarrow$ A ampliação da rede regional de perfis geofisicos transversais aos principais terrenos tectonoestratigráficos estruturados no Brasiliano; 
$\Rightarrow$ A modelagem em $21 / 2$-D das feiçðes geofisicas relacionadas aos granitóides e zonas de cisalhamento brasilianas;

$\Rightarrow A$ integração com dados aerogamaespectrométricos (U, Th, K) imprescindiveis: (i) no refinamento do mapeamento geológico; (ii) no detalhamento das propriedades geofisicas e geoquimicas das unidades litológicas; (iii) na modelagem da produção de calor local e por inferência imediata um retrospecto sobre a produção de calor no Neoproterozóico;

$\Rightarrow$ A modelagem 3-D da deformação dúctil brasiliana, considerando-se as amplas variações nos aspectos geológicos laterais/verticais e nos gradientes geotérmicos, reflexo da heterogeneidade reológica e anisotropia mecânica da litosfera continental no Neoproterozóico. 


\section{9 - REFERÊNCIAS BIBLIOGRÁFICAS}

ABDELHAMID, G. \& RABBA, I. -1994 - An investigation of mineralized zones revealed during geological mapping, Jabal Hamra Faddn - Wadi Araba, Jordan, using Landsat-TM data. Int.J.Remote Sensing 15(7):1495-1506.

ABDOU , I. E. \& PRATT, W. R. - 1979 - Quantitative design and evaluation os enhancement/thresholding edges detectors. Proceedings of the IEEE 67(5):753-763.

ABRAMS, M.J. - 1986 - Mapping the Oman ophiolite using TM data. In: Proc. Thematic Conf., $5^{\text {th }}$, Remote Sensing for Exploration Geology, pp.85-95.

ABRAMS, M.J; ROTHERY, D.A. \& PONTUAL, A. - 1988 - Mapping in the Oman ophiolite using enhanced Landsat Thematic Mapper images. Tectonophysics 151:387401.

ADAMS, J.B. \& FILICE, A L. - 1967 - Spectral reflectance 0.4 to 2.0 microns of silicate rock powders. J. Geophys. Res. 72(22):5705-5715.

ADAMS, J.B. - 1974 - Visible and near-infrared diffuse reflectance: spectra of pyroxenes as applied to remote sensing of solid objects in the solar system. J. Geophys. Res. 79:4829-4836.

ADAMS, -1975 - Interpretation of visisble and near-infrared diffuse reflectance spectra of pyroxenes and other rock forming minerals. In: C KARR (ed.). Infrared and Raman Spectroscopy of Lunar and Terrestrial Minerals. Pp. 91-116.

ADAMS, J.R. \& GOULLAUD, L.H. -1978- Plagioclase feldspar: visible and near infrared diffuse reflectance spectra as applied to remote sensing. Proc. 9th Lunar Planet. Sci. Conf. 1937-1945.

AFFATON, P.; RAHAMAN, M.A; TROMPETTE, R. \& SOUGY, R.-1991- The Dahomeyde Orogen: tectonothermal evolution and relationships with the Volta Basin. In: R.D.DALLMEYER \& J.P.LÉCORCHÉ (eds.). The West African Orogens and Circum-Atlantic correlatives. Springer-Verlag pp.107-122.

ALBEE, A L. - 1965 - A petrogenetic grid for the Fe-Mg silicates of pelitic schists. Amer. J. Sci. 263: $512-536$.

ALBEE, A L. - 1968 - Metamorphic zones in Northern Vermont. In: E. ZEN, W.S. WHITE, J.B. HADLEY \& J. B. THOMPSON (eds) Studies in Apallachian Geology, Northern and Maritime. John Wiley \& Sons 329-341.

ALLEMAND, P. \& BRUN, J. P. - 1991 - Width of continental rifts and rheologica layering of the lithosphere. Tectonophysics 188:63-69.

ALLEN, W.H.; MARTIN, J. A. \& RATH, D .L. - 1973 - First look analysis of geologic ground patterns on ERTS I imagery of Missouri. NASA Spec. Paper 327, 1G:317-378.

AL-RAWI, F. \& BROOKS, M. - 1992 - A deep crustal model to explain regional aeromagnetic and gravity anomalies in southwest England. Tectonophysics 212:109115. 
ALMEIDA, F. F. M.; LEONARDOS Jr, O H. \& VALENÇA, J. - 1967 - Granitic rocks of norteast South America. IUGS/UNESCO Symp., Recife 41 pp.

ALMEIDA, F. F. M.; HASUI, Y.; BRITO NEVES, B. B. \& FUCK, R. A - 1981 - Brazilian structural provinces: An introduction. Earth Science Review 17:1 -29.

ALMEIDA, C.N; GUIMARÃES, I.P.; BEURLEN, H. \& SAMPAIO, A S. -1993 Litoquímica de elementos traços e terras raras em anfibolitos relacionados às ocorrências de Ti-Fe em Itatuba, Estado da Paraíba, Brasil. $15^{\circ}$ Simp. Geol. Nordeste pp. 172-174.

ALMEIDA, C.N; GUIMARÃES, I.P.; SILVA FILHO, A F. \& BEURLEN, H. - 1997 - Sm$N d$ isotope geochemistry and U/Pb geochronological data of the Campina Grande Complex, Paraiba state, NE Brazil. $17^{\circ}$ Simp. Geol. Nordeste, 15:3-6.

AMARO, V. E.; JARDIM DE SÁ, E. F. \& VAUCHEZ, A. -1991a - Foto-análise preliminar dos lineamentos brasilianos da porção central da Provínca Borborema. $14^{\circ}$ Simp. Geol. Nordeste, Recife, Atas, p. 306-309.

AMARO, V. E.; CORSINI, M. \& VAUCHEZ, A. - 1991b - Geometria, cinemática e deformação da zona de cisalhamento de Campina Grande. $14^{\circ}$ Simp. Geol. Nordeste, Recife, Atas, 303-305.

AMARO, V. E.; VAUCHEZ, A., JARDIM DE SÁ, E .F. \& DUARTE, M. I .M. - 1993a Integração $e$ análise de imagens multiespectrais na melhoria da interpretação geotectônica da Provincia Borborema (NE do Brasil). $7^{\circ}$ Simp. Bras. Sensoriamento Remoto, Curitiba, Anais, v.3: 148-151

AMARO, V. E.; BEZERRA, F. H. R.; FONSECA, V. P.; JARDIM DE SÁ, E. F. \& MACEDO, J. W. P. - 1993b - Aplicação do sensoriamento remoto ao estudo da deformação dúctil e frágil na Região do Médio Rio Jaguaribe (CE). $4^{\circ}$ Simp. Nac. Estudos Tectônicos, Belo Horizonte, Atas.

AMARO, V. E.; BEZERRA, F. H. R.; FONSECA, V. P.; ACCIOLY, P. C. V. \& DUARTE, M.I.M.- 1993c - Técnicas de realce espectral de imagens LANDSAT 5-TM aplicadas à discriminação litológica na Região do Médio Rio Jaguaribe (CE). $15^{\circ}$ Simp. Geol.Nordeste, Natal, Atas, p.234-236.

AMARO, V: E. - 1994 - Avaliação do uso do espectro visível-infra vermelho próximo do LANDSAT 5-TM no mapeamento geológico regional da porção central da Província Borborema ( $N E$ do Brasil). $38^{\circ}$ Cong. Bras.Geol., Camburiú, Anais, p. 447-449.

AMARO, V. E. \& STRIEDER, A.J. - 1994 - Análise de fotolineamentos e padrões estruturais em imagens de satélite. $38^{\circ}$ Cong. Bras. Geol., Camburiú, Anais, p. 443444.

AMARO, V. E. - 1995 - Caracterização do enxame de lineamentos da Porção Oriental da província Borborema: uma outra abordagem metodológica. $5^{\circ}$ Simp. Nac. Estudos Tectônicos, Atas pp. 7-8.

ANANABA, S. E. \& AJAKAIYE, D. E. - 1987 - Evidence os tectonic control on mineralisation in Nigeria from lineament density analysis. Int. J. Remote Sens. $8(10): 1445-1453$. 
ARAÚJO, J.M.M. - 1995 - Mapeamento geológico de uma área a $N W$ de Pocinhos (PB). Relatório de Graduação, UFRN, 97 pp., inédito.

ARCHANJO, C.J. -1987 - Organização petroestrutural do segmento sul da Faixa Seridó, a leste da cidade de santa Luzia (PB). Dissertação de Mestrado UFPE, 128pp., inédita.

ARCHANJO, C.J. -1993- Fabriques de plutons granitiques et deformation crustale du Nord-Est du Brésil. Thése de Doctorat, Univ. de Toulouse III, 167p, inédita.

ARCHANJO, C.J. \& BOUCHEZ, J. L. -1991- Le Seridó, une chaîne transpressive dextre au Próterozoique supérieur du Nord-Est Brésil. Bull. Soc. géol. France, 162:637-647.

ARCHANJO, C.J. \& BOUCHEZ, J. L. -1992- Fábrica magmática dos granitos brasilianos de Acari e Picuí e a cronologia de deformações das rochas encaixantes (Faixa Seridó, Nordeste do Brasil). $37^{\circ}$ Congr. Bras. Geol. Bol. Res. Exp. $1: 380-382$.

ARKANI-HAMED, J; STRANGWAY, D.W.; TESKEY, D.J. \& HOOD, P.J. - 1985 Comparison of MAGSAT and low-level aeromagnetic data over the Canadian Shield: implications for GRM. Can. J. Earth Sci. 22:1241-1247.

ARKANI-HAMED, J. \& STRANGWAY, D.W. -1986- Effective magnetic susceptibity of the oceanic upper mantle derived from Magsat data. Geophys. Res. Lett. 13:999-1002.

ARTHAUD, M. H. \& HARTMANN, M.B. -1986- A geologia da região de Independência (CE): um exemplo de tectônica de nappe no Ceará. Anais $34^{\circ}$ Congr. Bras. Geol. 3:1160-1169.

ASHWORTH, J. R. - 1985 - Introduction to migmatites. In: J.R. ASHWORTH (ed.). Migmatites. Blackie, 1-35.

ASSUMPÇÃO, M.; SUAREZ, G. \& VELOSO, J.A.V. - 1985 - Fault plane solutions of intraplate earthquakes in Brazil: some contraints on the regional stress field. Tectonophysics 113:283-292.

ASSUMPÇÃO, M. -1992 - The regional intraplate stress field in South America. J. Geophys. Res. 97:11889-11903.

ATCHUNTA RAO, D; RAMBABBU, H.V. \& SIVAKUMAR, G.D.J. - 1992 - Crustal structure associated with Gondwana graben across Narmanda-Son Lineament in India: an inference from aeromagnetics. Tectonophysics 212:163-172.

AVOUAC, J. P. \& TAPPONIER, P. - 1993 - Kinematic model of active deformation in Central Asia. Geophysical Research Letters 20:895-898.

BABCOCK, E. A. -1974 - A statistical analysis of photolineaments and joints, terrain parameters and lineament density near Lethbridge, Alberta. Proc.Int.Conf. New Basement Tectonics, $1^{\text {th }}$, Utah, 5:437-448.

BAKER, R.N. \& HENDERSON, F.B. - 1987 - Results of the Geosat program to evaluate SPOT data for petroleum and mineral exploration. Proc. SPOT 1. Utilisation des images, bilan et résultats. Cepadues, Toulouse, pp. 731-738.

BANCROFT, A. M. - 1960 - Gravity anomalies over a buried step. J. Geophys. Res. 65:1630-1631. 
BARDINET, C.; GABERT, G.; MONGET, J. M. \& YU, Z. - 1988 - Application of multisatellite data to thematic mapping. Geogishes Jahrbuch B., Regionale Geologie Aurland, Heft 67, $74 \mathrm{pp}$.

BARKER, A J. - 1990 - Introduction to metamorphic textures. Blackie 162 pp.

BARLOW, C. \& ODGEN, A E. - 1982 - A statistical comparison of joint straight cave segment and photo-lineament orientations. The NSS Bull. 44(4):107-110.

BARRUOL, G.; HELFFRICH, G. \& VAUCHEZ, A - 1997 - Shear wave splitting around the northern Atlantic: frozen Pangaean lithospheric anisotropy? Tectonophysics 279:135-148.

BATCHELOR, R. A \& BOWDEN, P. - 1985 - Petrogenetic interpretation of granitoid rock series using multicationic parameters. Chem. Geol. 48:43-55.

$\mathrm{BEACH}, \mathrm{A}$-1976- The interrelations of fluid transport, deformation, geochemistry and heart flow in early Proterozoic shear zones in the Lewissian complex. Phil. Trans. R. Soc. London A280:569-604.

BEHRENDT, J. C. \& GRIMM, M. S. - 1985 - Structure of the U.S. Atlantic Continental margin from derivative and filtered maps of the magnetic field. In: W.J. HINZE (ed.) The Utility of Regional Gravity and Magnetic Anomaly Maps. Soc. Expl. Geophysicists, p. $325-338$.

BELL, T. H. - 1981 - Foliation development: the contribution, geometry and significance of progressive, bulk, inhomogeneous shortening. Tectonophysics 75:273-296.

BELL, R. E.; KARNER, G. D. \& STEKLER, M. S. - 1988 - Early mesozoic rift basins of eastern North America and their gravity anomalies: the role of detachment during extension. Tectonics 7:447-462.

BELL, T. H. \& JOHNSON, S. E. - 1989 - Porphyroblast inclusion trails: the key to orogenesis. J. Metam. Geol. 7:279-310.

BELL, T. H. \& JOHNSON, S. E. - 1992 - Shear sense: a new approach that resolves conflicts between criteria in metamorphic rocks. J. Metam. Geol. 10:99-124.

BELTRÃO, J. F.; SILVA, J.B.C. \& COSTA, J. C. - 1991 - Robust plynomial fitting method for regional gravity estimation. Geophysics 56(1):80-89.

BELTRÃO, J. F. \& SILVA, J.B.C. - 1993 - Mapping and depth ordering of residual gravity sources. Geophysics 58(10):1408-1416.

BEURLEN, H. -1988- Fazenda Esperança (Bodocó) e Riacho da Torre (Floresta): duas ocorrências atípicas de Fe-Ti no Estado de Pernambuco. Tese Prof. Titular, UFPE, Recife, 72p.

BEURLEN, H.; PESSOA, R. R.; ALMEIDA, C. N. \& ALENCAR S. G. - 1991 - Itatuba (PB): Novas ocorrências de eclogitos proterozóicos associados a minério de Fe-Ti na Provincia Borborema. XIV Simp. Geol. Nordeste, Recife, Atas, 236-239.

BEURLEN, H.; SILVA FILHO, A. F.; GUIMARÃES, I. P. \& BRITO, S. B. - 1992 Proterozoic C-type eclogites hosting unusual $\mathrm{Ti}-\mathrm{Fe} \pm \mathrm{Cr} \pm \mathrm{Cu}$ mineralization in northeastern Brazil. Precambrian Res. 58:195-214. 
BEZERRA, F. H.R.; SAADI , A.; MOREIRA, J. A. M.; LINS, F. A. P. L.; NOGUEIRA, A. M. B.; MACEDO, J. W. P.; LUCENA, L. F. \& NAZARÉ Jr., D. - 1993 - Estruturação neotectônica do litoral de Natal-RN, com base na correlação entre dados geológicos, geomorfológicos e gravimétricos. IV Simp. Nac. Estudos Tectônicos, Belo Horizonte, Atas.

BEZERRA, F. H. R.; AMARO, V. E.; ACCIOLY, P. C. V., MACHADO, M. F., DUARTE, M. I. M. \& ARAÚJO, M.A.T.-1994- Correlação preliminar entre estruturas do embasameto cristalino e da faixa sedimentar costeira oriental do RN/PB. $38^{\circ}$ Cong. Bras. Geol., Camburiú, Anais.

BEZERRA, F. H. R.; JARDIM DE SÁ, E.F.; SAADI, A \& FONSECA, V.P.- 1996 - Falhas neotectônicas nos granitos da região de Macaiba, $R N$. Simp. Estudos Tectônicos

BEZERRA, F. H. R.; LIMA FILHO, F.L.; AMARAL, R.F.; CALDAS, L.H.O \& COSTA NETO, L.X.- 1997 - Late quaternary coastal tectonics meeting, Geol. Soc. London, Abs.

BICKLE, M. J. \& ARCHIBALD, N. J. - 1984 - Chloritoid and staurolite stability: implications for metamorphism in Archean Yilgarn Blck, western Australia. J. Metam. Geol. 2:179-203.

BLACK, R.; LAMEYRE, J. \& BONIN, B. - 1985 - The structural setting of alkaline complexes. J. Afr. Earth Sci. 3:5-16.

BLACK, R. \& LIÉGEOIS, J. P. - 1993 - Cratons, mobile belts, alkaline rocks and continental lithospheric mantle: the Pan-African testimony. J. Geol. Soc 150:89-98.

BLANCHET, P.H. - 1957 - The development of fracture analysis as na exploration method. Am. Assoc Petrol. Geologists Bull. 41:1748-1759.

BLEVIN, P.L. \& CHAPPELL, B.W. -1992- The role of magma sources, oxidation states and fractionation in determining the granite metallogeny of eastern Australia. Trans.R.Soc.Edinb., Earth Sci. 83:305-316.

BLEVIN, P.L. - 1994- Magnetic susceptibility of the Lachlan Fold Belt and New England Batholith granites. Austral. Min. Ind.Res. Assoc. Project P147B.

BLODGET, H. W.; GUNTHER, F. J. \& PODWYSOCKI, M. H.- 1978 - Discrimination of rock classes and alteration products in southwestern Saudi Arabia with computerenhanced Landsat data. NASA Technical Paper 1327.

BLUNDY, J.D. \& HOLLAND, T.J.B. - 1990 - Calcic amphibole equilibria and a bew amphibole-plagioclase geothermometer. Contr. Mineral. Petrol. 104:208-224.

BODECHTEL ,J. \& LAMMERER, B. - 1973 - New aspects on the tectonic of the Alps and the Apennines revealed by ERTS 1 data. NASA Spec. Paper 327, 1A:493-499.

BODECHTEL ,J. \& MUNZER, U. -1978- Satellite lineaments of the central Mediterranean region (Sicily/Calabria). In: H. CLOOS; D. ROEDER \& K. SCHMIDT (eds.). Alps, Apennines, Hellenides: Interunion Commission on Geodynamics. Sci. Pepport 38:339340 . 
BOHLEN, S. R.; ECKERT, J.O \& HANKINS, W.B. - 1995 - Experimentally determined solidi in the Ca-bearing granite system $\mathrm{NaAlSi}_{3} \mathrm{O}_{8}-\mathrm{CaAl}_{2} \mathrm{Si}_{2} \mathrm{O}_{8}-\mathrm{KAlSi}_{3} \mathrm{O}_{8}-\mathrm{SiO}_{2}-\mathrm{H}{ }_{2} \mathrm{O}-$ $\mathrm{CO}_{2}$. Amer. Mineral. 80:752-756.

BONNEFOY, D.; CHEVREL, S.; DUTARTRE, P.; MINOUX, L. \& ORGEVAL, J. - 1986 Télédétection, discrimination d'objects géologiques et miniers; analyse multitemporale des données spatiales et de leur relations avec les données geochimiques- $2^{\text {eme }}$ partie. Tunisie (Zone des Dômes). Rapport public BRGM 86 TUN 163 GEO, 174 pp.

BONHAM-CARTER, G. F.; RENCZ, A N. \& HARRIS, J. R. - 1985 - Spatial relationship of gold ocurrences with lineaments derived from Landsat and Seasat imagery, Meguma Group, Nova Scotia. Fourth International Symposium on Remote sensing of Environment. Remote Sensing for Exploration Geology 1:755-768.

BOTT, M. H. P. \& SMITH, R. A - 1958 - The estimation of the limiting depth of gravitating bodies. Geophys. Prospect. 6:1-10.

BOULLIER, A. M. - 1991 - The Pan-African Trans-Saharan Belt in the Hoggar Shield (Algerie, Mali, Niger): a review. In: DALLMEYER, R. D. \& LÉCORCHÉ, J. P. (eds.). The West Africain Orogens and Circum-Atlantic Correlatives. Springer-Verlag 85-105.

BRITO NEVES, B. B. -1975 - Regionalização geotectônica do Pré-Cambriano Nordestino. Tese de Doutoramento, IGUSP $198 \mathrm{pp}$, inédita.

BRITO NEVES, B. B. -1983-O mapa geológico do Nordeste do Brasil, escala 1:1000.000. Tese Livre Docência, USP, São Paulo, 177p.

BRITO NEVES, B. B.; KAWASHITA, K. \& MONTOVANNI, M. S. - 1975 - Contribuição à geocronologia do Pré-cambriano cearense. Atas $7^{\circ}$ Sinp. Bras. Geol. Nordeste, 299318.

BRITO NEVES \& CORDANI, U. G. - 1991 - Tectonic evolution of South America during the Late Proterozoic. Precambrian Res., 53:23-40.

BRITO NEVES, B. B.; VAN SCHMUS, W.N.; HACKSPACHER, P. C. \& SANTOS, E. J. 1995 - Geocronologia da Borborema, 1995: os fatos e as questões abertas. $16^{\circ}$ Simp. Geol. Nordeste, 410-413.

BRITO NEVES, B. B.; VAN SCHMUS, W. R.; SANTOS, E. J.; CAMPOS NETO, M. C. \& KOZUCH, M. - 1996 - O evento Cariris Velhos na Província Borborema : integração de dados, perspectivas e implicações. $39^{\circ}$ Congr. Bras. Geol. 6:19-21.

BROOME, J.; SIMARD, R. \& TESKEY, D. - 1985 - Presentation of magnetic anomaly map data by stereo projection of magnetic shadowgrams. Can. J.Earth Sci. 22:311-314.

BROOME, H. J. - 1990 - Generation and interpretation of geophysical images with examples from Rea Province, northwestern Canada shield. Geophysics 55(8):977-997.

BROWN, E. H. - 1975 - A petrogenetic grid for reactions producing biotite and other Al$\mathrm{Fe}-\mathrm{Mg}$ silicates in the greenschists facies. J. Petrol. 16:258-271.

BROWN, M.; AVERKIN, Y.A; McLELLAN, E.L. \& SAWYER, E.W.- 1995 - Melt segregation in migmatites. J. Geophys. Res. 100(B8):15655-15679. 
BROWNE, S.E. \& FAIRHEAD, J.D.- 1983 - Gravity study of the Central African Rift System: a model of continental disruption, 1, The Ngaoundere and Abu Gabra Rifts. Tectonophysics 94:187-203.

BUCK, W. R.; MARTINEZ, F.; STECKLER, M. S. \& COCHRAN, J. R. - 1988 - Thermal consequences of lithosphere extension: pure and simple. Tectonics 7:213-234.

BUCKINGHAM, W.F. \& SOMMER, S.E. - 1983 - Mineralogical characterization of rock surfaces formed by hydrothermal alteration and weathering - Application to remote sensing. Econ. Geol. 78:664-674.

BURDICK, R. G. \& SPEIRER, R. A - 1980 - Development of a method to detect geologic faults and other linear features from Landsat images. U. S. Bureau of Mines Rept. of Invest. $8413,73 p$.

BURG, J. P.; DAVY, P. \& MARTINOD, J. - 1994 - Shortening of analogue models of the continental lithosphere: new hypothesis for the formation of the Tibetan plateau. Tectonics 13(2):475-483.

BURNS, R.G. -1970- Mineralogical application of crystal field theory. Cambridge Univ. Press, Cambridge.

BURNS, K.L. \& SHEPARD, J. - 1976 - Satellite lineaments in southeast Australia. Proc. Intern. Conf. New Basement Tectonics 5:354-368.

BURNS, R.G. - 1993 - Mineralogical Applications to Crystal Field Theory. 551 pp.

CABY, R.; BERTRAND, J. \& BLACK, R. - 1981 - Pan-African ocean closure and continental collision in the Hoggar-Iforas segment, central Sahara. In : KRONER, A (ed.) Precambrian Plate tectonics. Elsevier 407-434.

CABY, R. - 1989 - Precambrian terranes of Benin-Nigeria and Northeast Brazil and the late Proterozoic South Atlantic fit. Geol. Soc. of America, Special Paper 230: 145-158.

CABY, R.; SIAL, A. N.; ARTHAUD, M. \& VAUCHEZ, A. - 1991 - Crustal evolution of the Borborema Province, Brasiliano/Panafrican belt (Northeast Brazil). In: R. D. DALLMEYER \& J. P. LÉCORCHÉ (eds). The West African Orogens and CircumAtlantic Correlatives. Springer - Verlag, 373-397.

CALDAS, L.H.O; CORIOLANO, A C.F.; DANTAS, E.P. \& JARDIM DE SÁ, E.F.-1997Os beachrocks no litoral Rio Grande do Norte: potencial como marcadores neotectônicos. $17^{\circ}$ Simp. Geol. Nordeste pp. 369-374.

CAMPELO, R. C. - 1997 - Mapeamento geológico de uma área a oeste de Santo Antônio do Salto da Onça (RN). Relatório de Graduação, UFRN, 66 pp., inédito.

CAMPOS NETO, M. C.; BITTAR, S.M.B. \& BRITO NEVES, B.B. - 1994 - Domínio tectônico Rio Pajeú - Província Borborema: orogêneses superpostas no Ciclo Brasiliano/Pan-Africano. $38^{\circ}$ Congr. Bras. Geol. 1:221-222.

CARDON, H.; PILI, E. VIDAL, G. - 1997 - Pan-African lithospheric structures or how the Gregory rift helps to reconstruct Madagascar paleoposition. $9^{\circ}$ EUG, Terra Abs. 
CARNEIRO, C D.R.; MONMA, R.; FERREIRA, F.J.F.; DEHIRA, L.K. \& MAGALHÃES, F.S. - 1988 - Ensaio de integração geológico-geofisica sobre o Nordeste Oriental com base em mapas aeromagnéticos. $35^{\circ}$ Cong. Bras. Geol. 5:2122-2136.

CARPER, W.J.; LILLESAND, T.M. \& KIEFER, R.W. - 1990 - The use of Intensity-HueSaturation transformations for merging SPOT panchromatic and multispectral image data. Photogramm. Eng. Remote Sensing 56(4):21-30.

CARSON, C. J.; POWELL, R.; WILSON, C.J.L. \& DIRKS, P.H.G. - 1997 - Partial melting during tectonic exhumation of a granulite terrane: a $n$ exemple from the Larsemann Hills, east Antarctica. J. Metamor. Geol. 15:105-126.

CASTAING, C.; TRIBOULET, C.; FEYBESSE, J.L; THIÉBLEMONT, D. \& CHEVREMONT, P. - 1993 - Tectonometamorphic evolution of Ghana, Togo and Benin in the light of the Pan-African/Brasiliano orogeny. Tectonophysics 218:323-342.

CASTAING, C.; FEYBESSE, J.L.; THIÉBLEMONT, D.; TRIBOULET, C. \& CHËVREMONT, P. - 1994 - Paleogeographical reconstructions on the PanAfrican/Brasiliano orogen: closure of an oceanic domain or intracontinental convergence between major blocks? Precambrian Research 69:327-344.

CASTLEMAN, K. R. - 1996 - Digital image processing. Prentice Hall, 677 pp.

CASTRO, D.L.; BARBOSA, V.C.F.; SILVA, J.B.C. \& MEDEIROS, W.E.- 1997a - Relevo da interface crosta-manto no Nordeste Setentrional do Brasil: comparação entre vínculos de isostasia e suavidade. $5^{\circ}$ Cong. Intern. Geof., submetido.

CASTRO, D.L.; MEDEIROS, W.E.; MOREIRA, J.A M. \& JARDIM DE SÁ, E.F. -1997bMapa gravimétrico do Nordeste Setentrional do Brasil e Margem Continental Adjacente. $5^{\circ}$ Cong. Intern. Geof., submetido.

CASTRO, D.L. \& MEDEIROS, W.E. - 1997 - Afinamento crustal associado à implantação das bacias intracratônicas do trend Cariri-Potiguar. $17^{\circ}$ Simp. Geol. Nordeste pp. 334338.

CAVELIER, C.; SCANVIC, J. Y.; WEECKSTEEN, G. \& ZISERMAN,.- 1973 - Capability of ERTS I imagery to investigate geological and structural features in a sedimentary basin (Bassin Parisienne-France). NASA Spec. Paper 327, 1:273-282.

CHANG, H.K.; KOSWMANN, R.O \& FIGUEIREDO, A M.F. -1988- New concepts on the development of east Brazilian marginal basins. Episodes 11(3):194-202.

CHAPPELL, B.W. \& WHITE, A J.R.-1974- Two contrasting granite types. Pacific Geol. 8:173-174.

CHAVEZ, P. S.; BERLIN, G. L. \& SOWERS, L. B. - 1982- Statistical method for selecting Landsat MSS ratios. J.Applied Photog. Eng. 8.

CHAVEZ, P. S.; GUPTIL, S. C. \& BOWELL, J. A. - 1984 - Image processing techniques for Thematic Mapper data. Proc. Am. Soc.Photogramm. Conf.

CHAVEZ, P. S. \& KWARTENG, A Y. - 1989 - Extrating spectral contrast in Landsat Thematic mapper image using selective principal component analysis. Photogramm. Eng. Remote Sensing 55(3):339-348. 
CHAVEZ, P. S.; SIDES, S. C. \& ANDERSON, J. A.- 1991 - Comparison of three different methods to merge multiresolution and multispectral data: Landsat TM and SPOT panchromatic. Photogramm. Eng. Remote Sensing 57:295-303.

CHOROWICZ, J. - 1984 - Importance of pattern recognition for geological remote sensing. Application and new look at geological maps. Documents BRGM 82:29-40.

CHOROWICZ, J;; MEKARNIA, A. \& RUDANT, J .P.- 1988 - Cartographie géologique détaillée du Massif Sainte Victoire (Provence, France) à l'aide de l'imagerie SPOT. Comparaison avec d'autres donées multisources. Nouvelle interprétation tectonique de cette région. Proc. SPOT1- Image utilization, assesment, results. Paris, pp. 905-913.

CHOROWICZ, J.; KIM, J.; MANOUSSIS,S.; RUDANT, J.P.; FOIN, P. \& VEILLET, I. 1989 - A new technique for recognition of geological and geomorphological patterns in digital terrain models. Remote Sens. Environm. 29:229-239.

CHOROWICZ, J; ; LUXEY ,P.; LYBERIS, N.; CARVALHO, J. \& PARROT, J. P.- 1994The Maras Triple Junction (southern Turkey) based on digital elevation model and satellite imagery interpretation. J. Geophysical Res. 99(B10):20225-20242.

CLARK, R.N. - 1983 - Spectral properties of mixtures of montmorillonite and dark carbon grains: implications for remote sensing mineralscontaining chemically and physically adsorbed water. J. Geophys. Res. 88(B12):10635-10644.

CLARK, R.N. \& LUCEY, P.G. - 1984 - Spectral properties of ice-particulate mixtures and implications for remote sensing. I. Intimate mixtures. J. Geophys. Res. 89:6341-6348.

CLARK, R.N. \& ROUSH, T.L. - 1984- Reflectance spectroscopy: quantitative analysis techniques for remote sensing applications. J. Geophys. Res. 89(B7):6329-6340.

CLARK, R.N.; KING, T.V.V.; KLEJWA,M.; SWAYZE,G. \& VERGO, N. - 1990 - High spectral resolution reflectance spectroscopy of minerals. J. Geophys. Res. 95(B8): 12653-12680.

CLARK, D. A; FRENCH, D.H; LACKIE, M.A \& SCHMIDT, P.W. - 1992 - Magnetic petrology: application of integrated rock magnetic and petrological techniques to geological interpretation of magnetic surveys. Expl. Geophys. 23:65-68.

CLARK, D.A - 1997 - Magnetic petrophysics and magnetic petrology: aids to geological interpretation of magnetic surveys. AGSO J. Austral. Geol. \& Geophys. 17(2):83-103.

CLEMENS, J.D. - 1984 - Water contents of silicic to intermediate magmas. Lithos $17: 273$ 287.

CLEMENS, J.D. \& WALL, V. D. - 1987 - Origin and crystalization of some peraluminous (S-type) granitic magmas. Can. Mineral. 19:111-131.

CLEMENS, J.D. - 1990 - The granulite-granite connexion. In: D. VIELZEUF \& Ph. VIDAL (eds.). Granulites and Crustal Evolution. Kluwer Academic, 311:25-36.

COBBOLD, P.R. - 1996 - South America: a heterogeneous continent with as episodic history of finite deformation, fault reactivation and basin inversion. Intern. Conf. The Role of Basement Reactivation in Continental Deformation, Tectonic Studies Group Geol. Soc. of London, London, march 1996. 
COLES, R.L.; HAINES, G.V. \& HANNAFORD, W. - 1976 - Large scale magnetic over western Canada and the Arctic: a discussion. Can. J. Earth Sci. 13:790-802.

COLLINS, W. J. \& TEYSSIER, C - 1989 - Crustal-scale ductile fault systems in the Arunta Inlier, central Australia. Tectonophysics 158:49-66.

CONESE, C \& MASELLI, F. - 1993 - Selection of optimun bands from TM scenes through mutual information analysis. ISPRS J. Photogramm. Remote Sensing 48(3):2-11.

COOK , F.A; VARSEK, J.L. \& THURSTON, J.B. - 1995 - Tectonic significance of gravity and magnetic variations along the Lithoprobe southern Canadian Cordillera Transect. Can. J. Earth Sci. 32:1584-1610.

CONRADSEN, K.; NILSSON, G. \& THYRSTED, T. - 1986 - Statistical analysis in south Greenland based on Landsat imagery. IEEE Trans. Geosc. Remote sensing GE-2, 3:313-321.

CORSINI, M.; VAUCHEZ, A.; ARCHANJO, C. J. \& JARDIM DE SÁ, E. F. - 1991 - Strain transfer at continental scale from a transcurrent shear zone to a transpressional belt: the Patos - Seridó system, northeastern Brazil. Geology 19: 586-589.

CORSINI, M.; VAUCHEZ A. \& AMARO, V. E. - 1992 - Relais de cisaillements ductiles transcurrents à l'échelle continentale: Exemple de la Province de Borborema (NE Brésil). C.R. Acad Sci. Paris, Tome 314, Série II, 845-850.

COUPEZ, Y.; TOMKINSON, M. \& PHILLIPS, A - 1988 - Use of correlations between structural analysis of outcrops, remote sensing and gravity data to aid exploration for base metal mineralization in the Almaden region of Spain. $2^{\text {nd }}$ European Workshops on Remote Sensing in Mineral Expl. (CEC) pp. 177-242.

CRIPPEN, R.E. - 1989 - Selection of Landsat TM band and band ratio combinations to maximize lithologic information in colour composite displays. Proc. $7^{\text {th }}$ Thematic Conf. Remote Sens. Explor. Geol., Calgary, Canada.

CURRIE, K. L. -1971 - The reaction 3 cordierite $=2$ garnet +4 sillimanite +5 quartz as a geological thermometer in the Poinicon Lake Region, Ontario. Contrib. Mineral. Petrol. 33:215-226.

DAILY, M. - 1983 - Hue-Saturation-Intensity split-spectrum processing of SEASAT radar imagery. Photogramm. Eng. Remote Sensing 49(3):349-355.

DALY, M. C. - 1986 - Crustal shear zones and thrust belts: their geometry and continuity in Central Africa. Philos. Trans. Royal Soc. of London A317:111-128.

DANTAS, E. L.; CORDANI, U.; VAN SCHMUS, W. R.; HACKSPACHER, P. C.; BRITO NEVES, B. B. \& NUTMAN, A. P. - 1995 - Terrenos arqueanos e paleoproterozóicos do Maciço Caldas Brandão na Província Borborema. $16^{\circ}$ Simp. Geol. Nordeste 14: 319-342.

DANTAS, E. L.; VAN SCHMUS, W. R.; HACKSPACHER, P. C. \& BRITO NEVES, B. B. - 1996 - Crustal Nd isotopic evolution and differentiation during Archean and Paleoproterozoic of Caldas Brandão Massif, NE Brazil. $39^{\circ}$ Congr. Bras. Geol. 495498. 
DANTAS, E. L. - 1997 - Geocronologia U-Pb e Sm-Nd de terrenos arqueanos e paleoproterozóicos do Maciço Caldas Brandão, NE do Brasil. Tese de Doutorado, UNESP, $208 \mathrm{pp}$.

DANTAS, E. L.; HACKSPACHER, P.C.; VAN SCHMUS W. R. \& BRITO NEVES, B. B. 1997 - Diferentes episódios de magmatismo e acresção arqueana no Maçico Caldas Brandão, Província Borborema (RN). 17 Simp. Geol. Nordeste, 24-27.

DANTAS, E.P.; CALDAS, L.H.O; CASTRO, D.L. \& JARDIM DE SÁ, E.F. -1997Gravimetria e sensoriamento remoto aplicados na caracterização do Lineamento de Afonso Bezerra e do sistema de falhas de Carnaubais (RN). $17^{\circ}$ Simp. Geol Nordeste pp.343-345.

DAVIS, L. S. - 1975 - A survey of edge detection techniques. Computers Graphics and Image.

DAVIS, P.A. \& BERLIN ,G. L.- 1989 - Rock discrimination in the complex geologic environment of Jabal Salma, Saudi Arabia, using Landsat Thematic mapper data. Photogramm. Eng. Remote Sensing 55(8):1147-1160.

DAVISON, I.; McCARTHY, M.; POWELL, D.; TORRES, H. H. F. \& SANTOS, C. A. 1995 - Laminar flow in shear zones: the Pernambuco shear zone, NE-Brazil. J. Struc. Geol. 17(2):149-161.

DAVY, Ph. \& COBBOLD, P.R. -1988- Indentation tectonics in nature experiments. 2, Central Asia. Bull. Geol. Inst. Uppsala 14:129-141.

DAVY, Ph. \& COBBOLD, P.R. -1991 - Experiments on shortening of a 4-layer model of the continental lithosphere. In: P.R. COBBOLD (ed.). Experimental and Numerical Modelling of Continental deformation. Tectonophysics 188:1-25.

DEBAINE, F.; MERING, C. \& PONCET, Y. - 1988 - La morphologie mathématique en teintes de gris appliquée à la mise en evidence de réseaux. Revue Photo-interprétation $5(2): 17-26$.

DEBEGLIA, N. \& WEBER, C. - 1985 - Geologic mapping of the basement of Paris basin (France) by gravity and magnetic-data interpretation. In: W. J. HINZE (ed.). The Utility of Regional Gravity and Magnetic Anomaly Maps. Soc. Expl. Geophysicists.

DEBON, F. \& LEFORT, P - 1983 - A chemical-mineralogical classification of common plutonic rocks and associations. Trans. R. Soc. Edin. Earth Sci. 73:135-149.

DEBON, F. \& LEFORT, P - 1988 - A cationic classification of common plutonic rocks and their magmatica associations: principles, methods, applications. Bull. Miner. 111:493510 .

DE LA ROCHE, H.; LETERRIER, J. \& GRANDCLAUDE, P. - 1980 - A classification of volcanic and plutonic rocks and associations. Chem. Geol. 29:183-210.

DELL'ANGELO, L. \& TULLIS, J. - 1988- Experimental deformation of partially melted granitic aggregates. J. Metamorphic Geol. 6:495-515.

DENNIS, J.G.- 1967 - International tectonic dictionary. Amer. Assoc. Petrol. Geol. Mem., $7,195 \mathrm{p}$. 
DE WAARD, D.- 1965- The occurence of garnet in granulite-facies terrane of Adirondack Highlands. J.Petrol. 6(1):165-191.

DEROIN, J. G. - 1992 - Méthodologie d'utilisation de l'imagerie satellitaire a haute résolution spatiale en zone temperée. BRGM n ${ }^{\circ} 208,309 \mathrm{pp}$.

DESLANDES, S. \& GWYN, Q. H. J. - 1991 - Évaluation de Spot et Seasat pour la cartographie des linéaments: comparaison basée sur l'analyse des spectres de Fourier. Can. J. Remote Sensing 17(2):98-110.

DE YOREO, J. J.; LUX, D.R. \& GUIDOTTI, C.V.- 1991 - Thermal modelling in lowpressure/high temperature metamorphic belts (Review). Tectonophysics 188:209-238.

DIX, O. R. \& JACKSON, M. P. - 1981 - Statistical analysis of lineaments and their relation to fracturing, faulting and halokinesis in the East Texas Basin. Bureau of Economic Geology, University of Texas. Report of Investigation n¹10, $29 \mathrm{pp}$.

DNPM/Nuclebrás - 1976/1978 - Projeto Aerogeofísico Esperança. Mapas Aerogeofísicos $1: 100000$ e $1: 250000$.

DNPM/CPRM - 1974 - Projeto Leste da Paraiba e Rio Grande do Norte. Mapas Geológicos/Folhas SB.25-V-C e SB.25-Y-A, escala 1:250000, CPRM/Recife.

DNPM/CPRM - 1978 - Projeto Extremo Nordeste do Brasil. Mapa Geológico/Folha João Pessoa SB.25-Y-C, escala 1:250000, CPRM/Recife.

DOBRIN, M.B. - 1976 - Introduction to geophysical prospecting. McGraw-Hill.

DOLIVO-DOBROVOL'SKY, A. V. \& STRELNIKOV, S. I.- 1974 - The remote sensing study of the largest lineaments and their systems with reference to some regions of Eurasia. Proc. Int. Conf. New Basement Tectonics, $1^{\text {th }}$, Utah, 5:309-326.

DORBATH, C.; DORBATH, L.; FAIRHEAD, J. D. \& STUART, G. W. - 1986 - A telesismic delay time study across the Central African Shear Zone in the Adamawa region of Cameroon, West Africa. Geophys. J. R. astr. Soc. 86:751-766.

DOWNES, H. - 1990 - Shear zones in the upper mantle - Relation between geochemical enrichment and deformation in mantle peridotites. Geology 18:374-377.

DRAHOVZAL, J. A.- 1974 - Lineaments of north Alabama and possible regional implications. Proc. Int.Conf.New Basement Tectonics, $1^{\text {th }}$, Utah, 5:250-262.

DRUDY, S.A - 1986 - Remote sensing of geological structure in temperate agricultural terranes. Geol. Mag. 123:113-121.

DRURY, S. A -1984 - Applications of digital image enhancement in regional tectonic mapping of South India. Symp. Rem. Sen. Environ., 18 ${ }^{\text {th }}$, pp. 1895-1904.

DRURY, S. A. - 1990 - SPOT image data as an aid to structural mapping in the southern Aravalli Hills of Rajasthan, India. Geol. Mag. 127(3):195-207.

DRURY, S. A. \& HUNT, G. A. - 1989 - Geological uses of remotely sensed reflected and emitted data of lateritized Archean terrain in Western Australia. Int.J.Remote Sensing 10(3):475-497. 
DRURY, M.R.; VISSERS, R.L.M. \& VAN DER WAL, D.- 1991 - Shear localisation in upper mantle peridotites. Pure and Applied Geophysics 137: 439-460.

DUNAI, T. \& TOURET, J.L.R. - 1993 - A noble gas study of a granulite sample from the Nilgiri Hills, southern India: implications for granulite formation. Earth Plan. Sci. Letters 119:271-281.

DUTRARTE, Ph. \& KING, Ch. - 1986 - Structural and geobotanical contribution of remote sensing to exploration of ore deposits in Rhodope (Greece). Rapport CEE MSM 037F/BRGM, 86GRC $099 \mathrm{Geo}, 85 \mathrm{pp}$.

EDWARDS, K. \& DAVIS, Ph. A - 1994 - The use of Intensity-Hue-Saturation transfromation for producing color shaded relief images. Photogramm. Eng. Remote Sens. 60(11):1369-1374.

EL-ETR, H. A. \& RAHMAN, M. A. A. - 1974 - Airphoto lineations of the southern part of the Gulf of Suez region, Egypt. Proc. Int. New Basement Tectonics, $1^{\text {th }}$, Utah, 5:309326.

EL-HADJ, T; AFFATON, P.; LOUIS, P.; LESQUER, A; SOCOHOU,A \& CABY, R. 1993- Gravity characteristics of the northern part of the Dahomeyides: continental

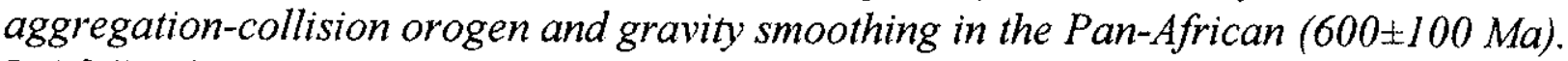
J. Afr.Earth Sci. 17(2):203-211.

ELLIS, D.J. -1987- Origin and evolution of granulites in normal and thickened crusts. Geology 15:167-170.

ELLIS, D.J. \& MABOKO, M.AH.-1992- Precambrian tectonics and the physicochemical evolution of the continental crust. 1. The gabbro-eclogite transition revisited. In: D.D. VAN REENEN; C. ROERING; L.D. ASHWAL \& M.J. DE WIT (eds.). The Arcaean Limpopo Granulite Belt: Tectonics and Deep Crustal Processes. Precambrian Res. 55:491-506.

ELRICH, R. W.- 1977 - Detection of global edges in textured images. IEEE Trans. Comp. C-26(6):589-603.

ELRICH, R. W.- 1979 - Detection of global lines and edges in heavily textured images. Proc. 2nd Intern. Conf. Basement Tectonics 508-513.

ENGLAND,P. \& HOUSEMAN, G. -1989- Extension during continental convergence, with application to the Tibetan Plateau. J.Geophys.Res. 94:17561-17579.

EOSAT - 1988 - Mineral exploration in Central Spain. Landsat Application Notes 3(1), 4 $\mathrm{pp}$.

ETHERIDGE, M.A; WALL, V.J. \& VERNON, R.H. -1983- The role of fluid phase during regional metamorphism and deformation. J. Metam. Geol. 1:205-226.

EWART, A -1982- The mineralogy and petrology of Tertiary-Recent orogenic volcanic rocks: with special reference to the andesitic-basaltic compositional range. In: R.S. THORPE (ed.). Andesites. John Wiley \& Sons 25-95.

FADAIE, K. \& RANALLI, G. - 1990 - Rheology of the lithosphere in the East African Rift System. Geophys. J. Inter. 102:445-453. 
FAIRHEAD, J.D.-1988- Mesozoic plate tectonic reconstructions of the central South Atlantic Ocean: the role of the West and Central African rift system. Tectnophysics 155:181-191.

FEININGER, T. \& ERMANOVICS, I. - 1994 - Geophysical interpretation of the Torngat orogen along the North River - Nutak transect, Labrador. Can. J. Earth Sci. 31:722727.

FERNADEZ-ALONSO, M. \& TAHON, A - 1991 - Lithological discrimination and structural trends in W-Rwanda (Africa) on images of airborne radiometric and aeromagnetic surveys, coregistered to a Landsat-TM scene. Photogramm. Eng \& Remote Sens. 57(9):1155-1162.

FÉRAUD, G.; FIGUEIREDO, L.L.; CORSINI, M.; CABY, R.; VAUCHEZ, A \& RUFFET, G. -1993 - Thermo-tectonic evolution of a syn-orogenic lithospheric shear zone through a detailed single grain 40Ar/39Ar study: Patos area, Late Proterozoic Brasiliano belt of northeast Brazil. Terra Nova Abs. 5:386.

FERREIRA, V. P. \& SIAL, A. N. - 1986 - The peralkaline magmatism in the Precambrian Cachoeirinha-Salgueiro foldbelt, Northeast Brazil: geochemical aspects. Rev. Bras. Geoc. 16:73-85.

FERREIRA, V. P. \& SIAL, A. N. - 1993 - Mica piroxenite as probable source for ultrapotassic and magmas in northeastern Brazil. Acad. Bras. de Ciências 65:51-62.

FIGUEIREDO, L.L.; FERRAUD, G.; CABY, R.; CORSINI, M.; ARTHAUD, M.; ARCHANJO, C.J.; JARDIM DE SÁ, E.F. \& EGYDIO-SILVA, M.E. - 1992 - O sincronismo termo-tectônico polifásico brasiliano dos sistemas cisalhanetes PatosSeridó e Campina Grande (Província Borborema) à luz de datações ${ }^{40} \mathrm{Ar}{ }^{\beta 9} \mathrm{Ar}$ de mono cristais com sonda-laser. $37^{\circ}$ Congr. Bras. Geol. Res. Exp. 2:378-379.

FITZSIMONS, I.C.W.; - 1996 - Metapelitic migmatites from Brattstrand Bluffs, East Antarctica - Metamorphism, melting and exhumation of the mid crust. J.Petrol. 37(2):395-414.

FLACK, C.A; KLEMPERER, S.L; McGEARY, S.E.; SNYDER, D.B. \& WARNER, M.R.1990- Reflections from mantle fault zones around the British Isles. Geology 18:528532.

FLEITOUT, L. \& FROIDEVAUX, C. - 1980 - Thermal and mechanical evolution of shear zones. J. Struc. Geol. 2:159-164.

FLEITOUT, L. \& FROIDEVAUX, C. - 1982 - Tectonics and topography for a lithosphere containing density heterogeneities. Tectonics 1:21-56.

FONSECA, V. P.; BARBALHO, A H.P. \& JARDIM DE SÁ, E. F. - 1991 - Metamorfismo barroviano na Faixa Seridó e seu contexto tectônico: o caso da região de Lajes $(R N)$. $14^{\circ}$ Simp. Geol. Nordeste 240-243.

FONSECA, V.P.- 1996- Estudos morfo-tectônicos na área do baixo curso do Rio Açu (AçuMacau), Rio Grande do Norte. Dissertação de Mestrado, UFMG, 103 pp., inédita. 
FONSECA, V.P.; MELO, F.T.L.; BEZERRA, F.H.R.; AMARAL, R.F. \& AMARO, V.E.1997- Mapeamento geológico-geomorfológico (1:250000) do litoral oriental do estado do Rio Grande do Norte: primeiros resultados. $17^{\circ} \mathrm{Simp}$. Geol. Nordeste 378-382.

FORTES, F.P. - 1986 - A tectônica de teclas da Bacia Potiguar. 34 Cong. Bras. Geol, Anais.

FORTES, F.P. -1988 - A origem da Bacia Potiguar como decorrência do Ciclo TectonoOrogênico Brasiliano. $35^{\circ}$ Cong. Bras. Geol. 5:2091-2106.

FOURCADE, B. - 1979 - Deux méthodes d'utilisation de la télédétection en geologie. Cartographie automatique des elements linéaires, stéréoscopie et gravimetrique. Thèse de Doctorat, Université de Bourdeaux III, $231 \mathrm{pp}$.

FOURCADE, S.; KIENAST, J.R. \& OUZEGANE, K. 1996 - Metasomatic effects related to channeled fluid streaming through deep crusta: fenites and associated carbonatites (In Ouzzal Proterozoic granulites, Hoggar, Algeria). J. Metam. Geol. 14:763-781.

FROST, B.R.; FROST, C. D. \& TOURET, J.R.L. - 1989 - Magmas as a source of heat and fluids in granulite metamorphism. In: D. BRIDGEWATER (ed.). Fluid Movements Element transport and the Composition of the Deep Crust. Kluwer Academic, 281:118.

FUNG, T. -1987- Application of Principal Component Analysis to change detection. Photogramm. Eng. Remote Sensing 53:1649-1658.

FYFE, W.S. -1973 - The granulite facies, partial melting and the Archean crust. Phil. Trans. R. Soc. London A273:457-461.

GAFFEY, S.; McFADDEN, L.A; NASH, D. \& PIETERS, C M. - 1993- Ultraviolet, visible and near-infrared reflectance spectroscopy: laboratory spectra of geologic materials. In: C.M. PIETERS \& P.AJ. EGLERT (eds.). Remote Geochemical Analysis: Elemental and Mineralogical Composition. Cambridge Univ. Press, pp. 43-78.

GAGNON, H.1974- La photoaérienne. Son interprétation dans les études de l'environnement et de l'aménagement du territoire. Ed. HRW Itée, Montreal, $278 \mathrm{pp}$.

GALINDO, A C. - 1981 - Geocronologia do Pré-cambriano do Rio Grande do Norte. Bol. Depto. Geologia -CCE/UFRN 1:20-35.

GALINDO, A C. - 1982 - Estudo petrológico do corpo granítico de Monte das Gameleiras $(R N-P B)$. Dissertação de Mestrado, UFPE, 99 pp., inédita.

GALINDO, A C. - 1984 - O granito Monte das Gameleiras (RN-PB). $11^{\circ} \mathrm{Simp}$. Geol. Nordeste 79-92.

GALINDO, A C.; DALL'AGNOL, R.; McREATH, I \& SCHELLER, T. - 1991 - Granitóide Tourão: um batólito subalcalino brasiliano no oeste do rio Grande do Norte. $14^{\circ}$ Simp. Geol. Nordeste. 160-163.

GALINDO, A C. - 1993 - Petrologia dos granitóides brasilianos da região de Caraúbas e Umarizal (oeste do Rio Grande do Norte). Tese de Doutorado, UFPA 386 pp.

GALINDO, A C.; DALL'AGNOL, R.; McREATH, I.; LAFON, J.M. \& TEIXEIRA, N. 1995 - Evolution of Brasiliano-age granitoid types in a shear-zone environment, 
Umarizal-Caraúbas region, Rio Grande do Norte, northeast Brazil. J.South Amer.Earth Sci. 8(1):79-95.

GALINDO, A C.; JARDIM DE SÁ, E. F.; NASCIMENTO, R. S.C.; HOLLANDA, M. H. B. M.; NASCIMENTO, M. A \& LARDEAUX, J. M. - 1997 - Caracterização geoquímica e contexto geodinâmico dos granitóides alcalinos na porção oriental da Faixa Seridó (RN-PB). $17^{\circ}$ Simp. Geol. Nordeste, 263-267.

GAMA Jr, T. \& ALBUQUERQUE, C.A R. - 1979 - Metamorfismo e deformação do Grupo seridó/Complexo Seridó (RN). $9^{\circ}$ Simp. Geol. Nordeste 332-342.

GAMA Jr, T. - 1981 - Petrologia da seqüência xistosa Seridó, Currais Novos-Parelhas (RN). Tese, UFPA, 65 pp., inédita.

GAPAIS, D. - 1989 - Shear structures within deformed granites: mechanical and thermal indications. Geology 17:1144-1147.

GARDIEN, V.; THOMPSON, D.; GRUJIC, D. \& ULMER, P. - 1995 - Experimental melting of biotite + plagioclase + quartz \pm muscovite assemblages and implications for crustal melting. J. Geophys. Res. 100(B8):15581-15591.

GELNETT, R. - 1974 - Lineament patterns from radar imagery in Alaska, Arizona. California and Montana. Proc.Int.Conf. New Basement Tectonics, 1th, Utah, 5:490499.

GIBB, R. A. \& THOMAS, M. D. - 1976 - Gravity signature of fossil plate boundaries in the Canadian Shield. Nature 262:199-200.

GIBB ,R. A.; THOMAS, P. L.; LAPOINTE, P. L. \& MUKHOPADHYAY, M. - 1983 Geophysics of proposed proterozoic sutures in Canada. Precambrian Research 19:349384.

GILLESPIE, A. R.; KAHLE, A. B. \& WALKER, R. E - 1986 - Color enhancement of highly correlated images. I. Decorrelation and HSI contrast stretches. Remote Sensing Environ. 20:209-235.

GLIKSON, A. Y. - 1994 - Landsat-5 TM correlation: application to NGMA mapping of the Western Musgrave Block, central Australia. Australian Geol. Survey Org., Rec. 1994/7.

GLICKSON ,A. Y. \& CREASEY, J. W. - 1995 - Application of Landsat-5 TM imagery to mapping of the Giles Complex and associated granulites, Tomkinson Ranges, western Musgrave Block, Central Australia. AGSO J. Australian Geol \& Geoph. 16(1-2):173193.

GREEN, A. A.; HUNTINGTON, J. F. \& ROBERTS, G. P. - 1978 - Landsat digital enhancement techniques for mineral exploration in Australia. Proc. 21th Intern. Symp.Rem.Sen. Envir. III:1757-1761.

GREEN, A. A. \& CRAIG, M. D.- 1985 - Analysis of aircraft spectometer data with logarithmic residuals. Jet Propulsion Laboratory Publ. 85-41:111-119.

GOETZ, A. F. H.; HAUFF, Ph.; SHIPPERT, M. \& MAECHER, A G. - 1991- Rapid detection and identification of oil-bearing minerals in the 0.9-1.0 $\mu \mathrm{m}$ region using a 
field portable spectrometer. $8^{\text {th }}$ Thematic Conf. Geologic Remote Sensing, Denver, pp.1-25.

GOLD, D. P.; PARIZEK, R. P. \& ALEXANDER, S. A - 1973 - Analysis and application of ERTS 1 data for regional geological mapping. Symp. Significant Results Obtained from the Earth Res. Technolgy Satellite, 1A:231-242.

GONZALEZ R.C. \& WOODS, R. E. - 1992 - Digital image processing. Addison Wesley, $716 \mathrm{pp}$.

GRANT, F.S.-1985- Aeromagnetics, geology and ore environments. I. Magnetite in igneous, sedimentary and metamorphic rocks: An overview. Geoexploration 23:303333.

GUNN, P.J. - 1975 - Linear transformations of gravity and magnetic fields. Geophysical prospecting 23:300-312.

GUNN, P.J. - 1997 - Quantitative methods for interpreting aeromagnetic data: a subjective review. AGSO J. Austral. Geol. Geophys. 17(2):105-113.

GUNN, P.J.; MAIDMENT, D. \& MILLIGAN, P. R. - 1997 - Interpreting aeromagnetic data in areas of limited outcrop. AGSO J. Austral. Geol. \& Geophys. 17(2):175-185.

GUPTA, V. K. \& RAMANI, N. - 1980 - Some aspects of regional-residual separation of gravity anomalies in a Precambrian terrain. Geophysics 45(9): 1412-1426.

GUPTA, R. P. - 1991 - Remote sensing geology. Springer-Verlag, 356 pp.

HACKSPACHER, P. C. \& SÁ, J. M. - 1984 - Critério lito-estrutural para diferenciácão do embasamento Caicó do Grupo Seridó, RN-Brasil. 33 Congr. Bras. Geol. 4:1679-1692.

HACKSPACHER, P. C.; MACAMBIRA, M.; McREATH, I. \& SCHELLER, T. - 1987 Tectono-magmatic evolution of the Taipu-Cardoso polydiapiric granitoid bodies, Rio Grande do Norte, Brazil. Inter. Symp. Granites Assoc. Mineraliz, Ext. Abs. 91-95.

HALLIDAY, A N.; DAVIDSON, P.; HOLDEN, P.; DEWOLF, C.; LEE, D.C. \& FITTON, J.G. - 1990 - Trace element fractionation in plumes and the origin of HIMU mantle beneath the Cameroon Volcanic Line. Nature 347:523-528.

HAMMARSTROM, J. M. \& ZEN, E. - 1986 - Aluminum in hornblende: an impirical geobarometer. Amer. Mineral 71:1297-1313.

HANCOCK, P.L.; AL-HADHI, A; BARKA, A A \& BEVAN, T.G.-1987- Aspects of analysing brittle structures. Annales Tectonicae I(1):5-19.

HANDY, M.R.- Deformation regimes and the rheological evolution of fault zones in the lithodphere: the effects of pressure, temperature grain size and time. Tectonophysics 163:119-152.

HANDY, M.-1994- Flow lows for rocks containing two non-linear viscous phases: a phenomenological approach. J.Struct. Geol. 16:287-301.

HARRY, D.L. \& LEEMAN, W.P. -1995- Partial melting of melt metasomatized subcontinental mantle and the magma source potencial of the lower lithosphere. J. Geophys. Res. 100 (B7):10255-10269. 
HARTE, B. \& HUDSON, N. F. C. - 1979 - Pelite facies series and temperatures and pressures of Dalradian metamorphism in E Scotland. In: A L. HARRIS, C. H. HOLLAND \& B. E. LEAKE (eds.) Geol. Soc. Spec. Publi. 8:323-337.

HARTLEY, R.; WATTS, A B. \& FAIRHEAD, J. D. - 1996 - Isostasy of Africa. Earth Plan. Sci. Lett. 137:1-19.

HENGESON, H.C.; DELANY, J. M.; NESBITT, H. W. \& BIRD, D. K. - 1978- Summary and critique of the thermodinamic properties of rock-forming minerals. Amer. J. Sci. 278A:1-299.

HENKEL, H. -1991 - Petrophysical properties (density and magnetization) of rocks from the northern part of the Baltic Shield. Tectonophysics 192:1-19.

HESS, P. C. - 1969 - The metamorphic paragenesis of cordierite in pelitic rocks. Contrib. Mineral. Petrol. 24:191-207.

HICKMAN, S.; SIBSON, R. \& BRUHN, R. -1995- Introduction to special section: mechanical involvement of fluids in faulting. J. Geophys. Res. 100:12831-12840.

HIRTH, G. \& TULLIS, J. - 1994 - The brittle-plastic transition in deformed quartz aggregates. J. Geophys. Res. 99:11731-11747.

HOBBS, W. H. -1904- Lineament of the Atlantic border region. Geol.Soc.Amer.Bull, 15:483-506.

HOBBS, W. H. - 1912 - Earth features and their meaning. MacMillan, New York, 506 pp..

HODGSON, R. A.- 1974- Review of significant early studies in lineament tectonics. Proc. Int.Conf.New basement Tectonics, 1th, Utah, 5:1-10.

HOFFMAN, P. F. - 1988 - United plates of America the birth of a craton: Early proterozoic assembly and growth of Laurentia. Ann. Rev.Earth Plan.Sci. 16:543-603.

HOLDAWAY, M. J. - 1971 - Stability of andalusite and the aluminumsilicate phase diagram. Amer. J. Sci. 271:97-131.

HOLDSWORTH, R.E; BUTLER, C \& ROBERTS, A - 1996 - Recognition and importance of structural inheritance during deformation of the continental lithosphere. The role of basement reactivation in continental deformation. Intern. Conf. The Role of Basement Reactivation in Continental Deformation, Tectonic Studies Group Geol. Soc. of London, London, march 1996.

HOLLANDA, M. H. B. M. - 1996 - Mapeamento geológico e petrografia do plúton de Japi $(R N)$. Relatório de Graduação, UFRN, 97 pp., inédito.

HOLLISTER, L. S.; GRISSON, G.C.; PETERS, E. K.; STOWELL, H.H. \& SISSON, V.B. 1987 - Confirmation of the empirical correlation of aluminum in hornblende with pressure of solidification of calc-alkaline plutons. Amer. Mineral. 72:231-239.

HORNSBY, J. \& BRUCE, B. - 1985 - A preliminary analysis of Landsat MSS and TM data in the Levack Area, Sudbury, Canada. EGARSS Remote Sensing Instrum. Technol. Sci. Appl. Pp. 131-140. 
HSU, S-K.; SIBUET, J-C; \& SHYU, C-T. - 1996 - High-resolution detection of geologic boundaries from potencial-field anomalies: an enhanced analytic signal technique. Geophysics 61(2):373-386.

HULL, J. - 1988 - Thickness-displacement relationships for deformation zones. J. Struct: Geol. 10: 431-435.

HUNT, G. R. \& SALISBURY, J.W. - 1970 - Visible and near infrared spectra of minerals and rocks, I, Silicate minerals. Mod. Geol. 1:283-300.

HUNT, G. R. \& SALISBURY, J.W.- 1971 - Visible and near infra-red spectra of minerals and rocks, II, Carbonates. Mod. Geol. 2:23-30.

HUNT, G. R.; SALISBURY, J.W. \& LENHOFF, C J. - 1971a - Visible and near infrared spectra of minerals and rocks, III, Oxides and hydroides. Mod. Geol. 2:195-205.

HUNT, G. R.; SALISBURY, J.W. \& LENHOFF, C J. - 1971b - Visible and near infrared spectra of minerals and rocks, $I V$,Sulphides and sulphates. Mod. Geol. 3:1-14.

HUNT, G. R.; SALISBURY, J.W. \& LENHOFF, C J. - 1972 - Visible and near infrared spectra of minerals and rocks, $V$, Halides, arsenates, vanadates and borates. Mod, Geol. 3:121-132.

HUNT, G. R.; SALISBURY, J.W. \& LENHOFF, C J. - 1973a - Visible and near infrared spectra of minerals and rocks,VI, Additional silicates. Mod. Geol. 4: 85-106.

HUNT, G. R.; SALISBURY, J.W. \& LENHOFF, C J. - 1973a - Visible and near infrared spectra of minerals and rocks, VII, Acidic igneous rocks. Mod. Geol. 4:217-224.

HUNT, G. R.; SALISBURY, J.W. \& LENHOFF, C J. - 1974a - Visible and near infrared spectra of minerals and rocks, VIII, Intermediate igneous rocks. Mod. Geol. 4:237-244.

HUNT, G. R.; SALISBURY, J.W. \& LENHOFF,C J.-1974-Visible and near infrared spectra of minerals and rocks, IX, Basic and ultrabasic igneous rocks. Mod. Geol. 5:1522.

HUNT, G. R. \& SALISBURY, J.W. - 1976 - Visible and near infrared spectra of minerals and rocks, XII, Metamorphic Rocks. Mod. Geol. 5:219-228.

HUNT, G. R.- 1977- Spectral signatures of particulate minerals in the visible and near infrared. Geophysics 42:501-513.

HUNT, G. R. - 1979 - Near-infrared (1.3-2.4 mm) spectra of alteration minerals - Potencial for use in remote sensing. Geophysics 44:1974-1986.

HUNT, G. R. - 1980 - Modifications of integrating sphere accessory to allow spectroscopic measurements of horizontal surfaces from above. Appl. Opt. 19:1746-1747.

HUNT, G. A.; DRURY, S. A. \& ROTHERY, R. A.- 1986- Techniques for choosing the optimum TM channel combinations for lithological mapping in semi-arid terrains. Proc. International Symposium on Mapping from Modern Imagery pp 637-646.

HUPPERT, H. E. \& SPARKS, R. S. - 1988 - The generation of granitic magmas by intrusion of basalts into continental crust. J. Petrol. 29:599-624. 
HUTTON, D. H. W. - 1988 - Granite emplacement mechanisms and tectonic controls: inferences from deformation studies. Trans. R. Soc. Edinb., Earth Sci., 79:245-255.

IBRAHIM, A E.; EBINGER, C.J. \& FAIRHEAD, J.D. -1996- Lithospheric extension northwest of the Central African Shear Zone in Sudan from potencial studies. Tectonophysics 255:79-97.

IRVINE, T. N. \& BARAGAR, W. R. A. - 1971 - A guide to chemical classification of the common volcanic rocks. Can. J. Earth Sci. 8:523-548.

ISACHSEN, Y. W.; FAKUNDINY, R. H. \& FORSTER ,S. W. - 1973 - Evaluation of ERTS I imagery for geological sensing over the diverse geological terranes of New York State. NASA Spec. Paper 327, 1:223-230.

ISACHSEN, Y. W.; FAKUNDINY, R. H. \& FORSTER, S. W.- 1974 - Evaluation of ERTS imagery for spectral geological mapping in diverse terranes of New York State. NASA Spec. Paper 351, 1:691-718.

ISACHSEN, Y. W. - 1976 - Fracture analysis of New York State usisng multi-stage remote sensor data and ground study: possible application to plate tectonic modelling. In: R.A HODGSON; S.P. GAY \& J.Y. BENJAMINS (eds.) Inter. Conf. New Basement Tectonics. ${ }^{\text {st }}$, Proc. Utah Geological Assoc., 5:200-217.

ISHIHARA, S. - 1977 - The magnetite-series and ilmenite-series granitic rocks. Mining Geology 27:293-305.

ISLES, D.J.; HARMAN, P.G. \& CUNNEN, J.P. -1989- The contribution of high resolution aeromagnetics to Archean gold exploration in the Kalgoorlie region, Western Australia. Econ. Geol. Monograph 6:389-397.

ISLES, D.J.; COOK, A \& HALBERG, J.A -1990 - Aeromagnetic evaluation. In: S.E. HO, D. I. GROVES \& J. M. BENNET (eds.). Gold Deposits of the Archaean Yilgarn Block, Western Australia: Nature, Genesis and Exploration Guides. Geology Key Centre \& University Extension, University of Western Australia, Department of Geology Publ. 20:342-347.

IYER, S.S.; BARBOSA, J.S.A \& KROUSE, H. R. - 1995 - Possible sources of CO2 in granulites: carbon isotope evidence from the Jequié Complex, Brazil. Petrology 3:226237.

JACHENS, R.C. \& GRISCOM, A - 1985 - An isostatic residual gravity map of California a residual map for interpretation anomalies from intracrustal sources. In: W.J.HINZE (ed.). The Utility of Regional Gravity and Magnetic Anomaly Maps. Soc Expl. Geophys. Pp. 347-360.

JAQUES, A L.; WELLMAN, P.; WHITAKER, A \& WYBORN, D. - 1997 - Highresolution geophysics in modern geological mapping. AGSO J. Austral. Geol. \& Geophys. 17(2):159-173.

JARDIM DE SÁ, E. F. - 1978 - Revisão preliminar sobre a Faixa Dobrada do Seridó e eventuais correlatos no Nordeste. Rev. Ciência, UFRN, 1:77-83.

JARDIM DE SÁ, E. F. - 1984 - A evolução proterozóica da Província Borborema. $11^{\circ}$ Simp. Geol. Nordeste, 237-316. 
JARDIM DE SÁ, E. F.; LEGRAND, J. M.; GALINDO, A C.; SÁ, J.M.; HACKSPACHER, P.C. - 1986 - Granitogênese brasiliana no Seridó: o maciço de Acari (RN). Rev. Bras. Geoc. 16:95-105.

JARDIM DE SÁ, E. F.; MACEDO, M. H. F.; LEGRAND, J. M.; MCREATH, I.; GALINDO, A. C.; \& MARTINS SÁ, J. - 1987 - Proterozoic granitoids in a polycyclic setting: the Seridó region, NE Brazil. Int. Symp. Granites and Assoc. Miner., Salvador, Ext. Abst., 103-110.

JARDIM DE SÁ, E. F.; MACEDO, M. H. F.; TORRES, M. H. F. \& KAWASHITA, K. 1988 - Geochronology of metaplutonics and the evolution of supracrustal belts in the Borborema Province, NE Brazil. VII Cong. Latinoamer. Geol.

JARDIM DE SÁ, E. F.; SÁ, J. M. \& MACEDO, M. H. F. - 1990 - Les ceintures mono-et polycycliques $d u N E d u$ Brésil: Correlations avec les ceintures pan-africaines de l'Ouest Africain. XV Coll. de Geol. Africaine, Nancy 6p.

JARDIM DE SÁ, E. F.; SOUZA, Z. S.; AMARO, V. E. \& HOLLANDA, M.H.B.M. - 1993a - Estruturas tangenciais relacionadas à deformação transcorrente: Exemplos na porção oriental da Faixa Seridó. XV Simp. Geol. Nordeste, Natal, Atas, p.269-271.

JARDIM DE SÁ, E. F.; AMARO, V. E.; HOLLANDA, M. H. B. M. \& DUARTE, M. I. M. - 1993b - Utilização de produtos de sensoriamento remoto para determinação do controle estrutural de plutons: Exemplos dos granitóides brasilianos da Faixa Seridó, $N E$ do Brasil. $7^{\circ}$ Simp. Bras. Sensoriamento Remoto, Curitiba, Anais, 3:226-229.

JARDIM DE SÁ, E. F.-1994- A Faixa Seridó (Província Borborema, NE do Brasil) e o seu significado geodinâmico na cadeia Brasiliana/Pan-Africana. Tese de Doutorado, UnB, 803 pp., inédita.

JARDIM DE SÁ, E. F.; MEDEIROS, V.C. \& AMARO, V.E. - 1995 - Os cisalhamentos brasilianos na zona transversal, $N E$ do Brasil: uma mega-estrutura em dominó. $16^{\circ}$ Simp. Geol. Nordeste, Atas, pp.134-137.

JARDIM DE SÁ, E. F.; MEDEIROS, W. E. \& CASTRO, D.L. - 1997a - Contribuição da gravimetria aos modelos de estruturação crustal da Provincia Borborema, Nordeste do Brasil. $17^{\circ}$ Simp. Geol. Nordeste, 352-357.

JARDIM DE SÁ, E. F;; TRINDADE, R.I; HOLLANDA, M.H.B.M.; GALINDO, A C.; AMARO, V. E.;; SOUZA, Z. S.; VIGNERESSE, J.L. \& LARDEAUX, J. M. - 1997bSyntectonic alkaline granites emplaced in a Brasiliano-age strike slip/extensional setting (eastern Seridó Belt, NE Brazil). II Intern. Symp. Granites Assoc. Mineraliz. (ISGAM) 310-312.

JI, S. \& ZHAO, P. -1993 - Flow laws of ultiphase rocks calculated from experimental data on the constituent phases. Earth Plan.Sci. Lett. 117:181-187.

JOHNSON, P. R.; ZIETZ, I. \& BOND, K. R. - 1990 - U.S. west coast revisited: an aeromagnetic perspective. Geology 18:332-335.

JOHNSON, M.C. \& RUTHERFORD, M.J. - 1989 - Experimental calibration of the aluminum-in-hornblende geobarometer with application to Long Valley Caldera (California) volcanic rocks. Geology 17:837-841. 
KANE, M. F. \& BROMERY, R. W. - 1968 - Gravity anomalies in Maine. In: E. ZEN, W.S. WHITE \& J. B. HADLEY (eds.). Studies of Appalachian Geology: Northern and Maritime. John Wiley \& Sons 415-423.

KANE, M. F. \& GODSON, R. H. - 1985 - Features of a pair of long wavelenght $(>250 \mathrm{~km})$ and short wavelenght $(<250 \mathrm{~km})$ Bouguer gravity maps of the United States. In: W.J. HINZE (ed.). The Utility of Regional Gravity and Magnetic Anomaly Maps. Soc. Expl. Geophysicists, 46-61.

KARNER, G. D. \& WATTS, A B. - 1983 - Gravity anomalies and flexure of the lithosphere at mountain ranges. J. Geophys. Res. 88:10449-10477.

KAUFMANN, H. -1988 - Mineral exploration along the Aqaba-Levant structure by use of TM-data: Concepts, processing and results. Int.J.Remote Sensing 9:1639-1658.

KELLER, G. R.; SMITH, R. A; HINZE, W.J. \& AIKEN, C. L. V. - 1985 - REGIONAL GRAVITY AND MAGNETIC STUDY OF WEST Texas. In: W.J. HINZE (ed.) - The Utility of Regional Gravity and Magnetic Anomaly Maps. Soc. Expl. Geophysicists, 198-212.

KELEMEN, P.B. \& DICK, H.J.B. - 1995 - Focused melt flow and localized deformation in the upper mantle: juxtaposition of replacive dunite and ductile shear zones in the Josephine peridotite, SW Oregon. J. Geophys. Res. 100:423-438.

KING, E. R. - 1990 - Precambrian terrane of north-central Wisconsin: An aeromagnetic perspective. Can J.Earth Sci. 27:1472-1477.

KIRSCH, R. A - 1971 - Computer determination of the constituent structure of biological images. Comput. Biom. Res. 4:315-328.

KOOPSMAN, B. N. - 1986 - A compartive study of lineament analysis from different remote sensing imagery over areas in the Benue Valley and Jos Plateau Nigeria. Intern. J. Remote Sens. 7(12):1763-1771.

KOWALIK, W. S. \& GOLD, D. P.- 1974 - The use of Landsatl imagery in mapping lineament in Pennsylvania. Proc. Int.Conf. New Basement Tectonics, 1th, Utah Geol. Assoc. Publ. 5:369-378.

KRÖNER, A. - 1981 - Precambrian plate tectonics. In: A . KRÖNER (ed.). Precambrian plate tectonics. Elsevier 57-90.

LABOTKA, T. C. - 1981 - Petrology of na andalusite-type regional metamorphic terrane, Panamint Mountains, California. J. Petrol. 22:261-296.

LAMB, W. N. \& VALLEY, J. W. - 1984 - Metamorphism and reduced granulites in low $\mathrm{CO}_{2}$ vapour-free environment. Nature 312:56-58.

LAMBECK, K. - 1983 - Structure and evolution of the intracratonic basins of Central Australia. Geophys. J. R. Astr. Soc. 74:843-886.

LAMBECK, K.; BURGESS, G. \& SHAW, R.D.- 1988 - Teleseismic travel time anomalies and deep crustal structure in central Australia. Geophys. J. 94:105-124.

LAMEYRE, J. -1987-Granites and evolution of the crust. Rev. Bras. Geoc. 17:349-359. 
LAMMAR, D. L. \& MERIFIELD, P. M. - 1974 - Investigation of lineaments on Skylab and ERTS images images of Peninsular Ranges, southwestern California. U.S.Geol. Survey. Technical Report 74-75.

LARSEN, H.C. - 1981- A high-pressure granulite facies complex in north-west Payers Land, East Greenland fold belt. Bull. Geol. Soc. Den. 29:353-369.

LATHRAM, E. H. \& ALBERT, N. R. - 1974 - Significance of space image linears in Alaska. Proc. Int. Conf. New Basement Tectonics, 1th, Utah Geol. Assoc.Publ. 5:11-26.

LÉCORCHÉ, J. P.; ROUSSEL, J. \& SOUGY, J. - 1983 - An interpretation of the geology of the Mauritanides orogenic belt (West Africa) in the light of geophysical data. Geol.Soc.Amer. Memoir 158:131-147.

LE BRETON, N. \& THOMPSON, A B. - 1988 - Fluid-absent (dehydration) melting of biotite in metapelites in the early stages of crustal anatexis. Contrb. Mineral. Petrol. 99:226-237.

LEE, D.C.; HALLIDAY, A N.; DAVIES, G.R.; ESSENE, E.J.; FITTON, J.G. \& TEMDJIM, R. -1996- Melt enrichment of shallow depleted mantle: a detailed petrological, trace element and isotopic study of mantle-derived xenoliths and megacrysts from the Cameroon Line. J. Petrol. 37:415-441.

LEGRAND, J. M. \& SALIM, J. - 1980 - Evolução metamórfica de rochas hospedeiras da mineralização scheelitifera da região do Seridó, RN-PB. $31^{\circ}$ Congr. Bras. Geol. 3:1601-1615.

LEGRAND, J. M. \& SÁ, J. M. - 1986 - Geotermometria, geobarometria e a zonação metamórfica do sinforme de Cruzeta, RN/Brasil. $34^{\circ}$ Congr. Bras. Geol. 4:1407-1423.

LESQUER, A.; ALMEIDA, F. F. M.; DAVINO, A.; LACHAUD, J. C. \& MAILLARD, P. 1981 - Signification structurale des anomalies gravimetriques de la partie sud $d u$ craton de Sao Francisco (Bresil). Tectonophysics 76:273-293.

LESQUER, A.; BELTRÃO, J. F. \& ABREU, F. A. M. - 1984 - Proterozoic links between northeastern Brazil and West Africa: A plate tectonic model based on gravity data. Tectonophysics 110:9-26.

LETERRIER, J.; JARDIM DE SÁ, E. F.; MACEDO, M. H. F. \& AMARO, V .E. - 1990 The magmatic and geodynamic signature of the Brasiliano cycle plutonism in the Seridó Belt, NE Brazil. $36^{\circ}$ Cong. Bras. Geol., Natal, Anais, v.4:1640-1655.

LETERRIER, J.; JARDIM DE SÁ, E. F.; BERTRAND, J.M. \& PIN, C. - 1994 - Ages U-Pb sur zircon de granitoides "brasiliano"de la ceinture do Seridó (Province Borborema, NE Brésil). C. R. Acad. Sci. Paris II, 318:1505-1511.

LIÉGEOIS, J.P.; BLACK, R.; NAVEZ, J. \& LATOUCHE, L.-1994- Early and late PanAfrican orogenies in the Air assembly of terranes (Tuareg Shield, Niger). Precambrian Res. 67:59-88.

LIMA, E. A M. et al. - 1980 - Projeto Scheelita do Seridó. DNPM/CPRM, Rel. Final, texto e mapas, inédito. 
LIMA, E.S.-1986- Metamorphism and tectonic evolution in the Serido region, Northeastern Brazil. PhD Thesis, University of California, $214 \mathrm{pp}$, inédita.

LIMA, E.S. - 1987 - Evolução termo-barométrica das rochas metapelíticas da região do Seridó, Ne Brasileiro. RBG. 17:315-323.

LIMA, E.S. - 1992 - Metamorphic condictions in the Serido region of northeastern Brazil during the Brasiliano Cycle (Late Proterozoic). J. South Amer.Earth Sci. 5 (3/4):265273.

LIMA, R. G. - 1997 - Geologia da região de São José do Campestre e Passa-e-Fica (RN). Relatório de Graduação, UFRN, 66 pp., inédito.

LINS, F. P. L.; JARDIM DE SÁ, E. F.; MACEDO, J. W. P. \& MOREIRA, J. A. M. - 1993 Assinatura gravimétrica da estruturação crustal brasiliana na porção oriental da Faixa Seridó. $15^{\circ}$ Simp. Geol. Nordeste p.272-275.

LIU, J.G. \& MOORE, J.M. - 1990 - Hue image RGB colour composition. A simple technique to supress shadow and enhance spectral signature. Int. J. Remote Sensing 11(8):1521-1530.

LOOSEVELD, R.J.H. \& ETHERIDGE, M.A-1990- A model for low-pressure facies metamorphism during crustal thickening. J. Metam. Geol. 8:257-267.

LOUGHLIN, W. P. \& TAWFIQ, M. A. - 1985 - Discrimination of rocks types and alteration zones from airborne MSS data: The Samran-Shayban and Mahd Adh Dhahab areas of Saudi Arabia. In: Proc. Int.Symp.Remote Sensing Environ., $4^{\text {th }}$, San Francisco.

LOWMAN, P. D.; HARRIS, J.; MASUOKA, P. M.; SINGROY, V. H. \& SLANEY, V. R. 1987 - Shuttle imaging radar (SIR-B) investigations of the canadian shield. Initial Report. IEEE Trans. Geoc. Remote Sens. GE-25 1:55-66.

LYON-CAEN, H.; MOLNAR, P. \& SUÁREZ, G. - 1985 - Gravity anomalies and flexure of Brazilian Shield beneath the Bolivian Andes. Earth Planet. Sci. Lett. 75:81-92.

MACEDO, M. H. F.; JARDIM DE SÁ, E. F.; SOUZA, Z.S.; MENDES, F.S. \& RAMALHO, K.A C. - 1997 - Implantação do Laboratório Intermediário de Geocronologia na UFRN: a datação do granitóide de Serrinha (RN) e da deformação extensional brasiliana correlata. $17^{\circ}$ Simp. Geol. Nordeste, 81-85.

MACIAS, L. F.- 1995 - Remote sensing of mafic-ultramafic rocks: Examples from Australian precambriam terranes. AGSO J.Australian Geol. \& Geoph. 16(1/2):163171.

MARANGONI, Y. R. - 1994 - Modelo crustal para o norte de Goiás a partir de dados gravimétricos. Tese de Doutorado, LAG-USP, $105 \mathrm{pp}$.

MAREMBECK, B.F.; BORDEN, M.H.; PODWYSOCKI, M.H. \& APPLEGATE, D.N.1977- Application of canonical analysis to multispectral scanner data. Proc. 14th Symp. Appl. Comp. Methods Mineral Industry, AIMMPE.

MARIANO, J. \& HINZE, W. J. - 1994 - Gravity and magnetic models of the Midcontinent Rift in eastern Lake Superior. Can. J. Earth Sci. 31:661-674. 
MARIANO, G. \& SIAL, A. N. - 1988 - Evidence of magma mixing in the Itaporanga batholith, northeastern Brazil. Rediconti della Soc. Italiana Miner. Petrol. 43:555-568.

MARTINOD, J.-1991- Instabilités périodiques de la lithosphere (flambage, boudinage) en compression et en extension. Thèse de Doctorat, Université de Rennes, $182 \mathrm{pp}$.

MARTINOD, J. \& DAVY, P. - 1992 - Periodic instabilities during compression and extension of the lithosphere, 1, Deformation models from an analytical perturbation method. J. Geophys. Res. 97:1999-2014.

MATOS, R.M.D. - 1992 - Deep seismic profiling, basin geometry and tectonic evolution of intracontinental rift basins in Brazil. PhD Thesis, Cornell University, 276 pp., inédita.

MAUSEL, P.W.; KRAMBER, W.J. \& LEE, J.K. - 1990 - Optimum band selection for supervised classification of multispectral data. Photogramm. Eng. Remote Sensing 56:55-60.

MAYHEW, M. A \& JOHNSON, B. D. - 1987 - An equivalent layer magnetization model for Australia based and Magsat data. Earth Plan. Sci. Letters 83:167-174.

McMURRY, J.; LONG, L. E.\& SIAL, A N. - 1987a - Petrology and isotope systematicsof magma mushes: some porphyritic granitoids of Northeastern Brazil. Rev. Bras. Geoc. 177:473-480.

MCMURRY, J.; LONG, L. E.\& SIAL, A N. - 1987b - Evolution of a heterogeneous, continentally derived granite: Dona Inês luton, Northeastern Brazil. J. Geol. 95:107117.

McREATH, I. \& JARDIM DE SÁ, E. F. - 1979 - Datações geocronológicas em rochas policíclicas: interpretação alternativa para os dados no Seridó (RN-PB). $9^{\circ}$ Simp. Geol. Nordeste

MEANS, W.D. - 1984 - Shear zones of types I and II and their significance for reconstruction of rock history. Geol. Soc. Amer. Abs. W. Progr. 16:50

MEANS, W.D. - 1993 - Elementary geometry of defromation processes. J. Struct. Geol. 15(3-5):343-349.

MEDEIROS, V.C. - 1995 - Sensoriamento remoto e petrologia de granitóides brasilianos no Dominio Zona Transversal, Nordeste do Brasil. Dissertação de Mestrado, UFPE, $149 \mathrm{pp}$., inédita.

MEDEIROS, V.C.; JARDIM DE SÁ, E.F.; SIAL, A N. \& AMARO, V. E. - 1996 Fotolineamentos e granitóides brasilianos do Domínio Zona Transversal, NE do Brasil. $39^{\circ}$ Congr. Bras. Geol. 1:86-89.

MELLO, A.A \& MELLO, Z. F. - 1974 - Metamorphic zoning in the Serido region, northeastern Brazil. Rev. Bras. Geoc. 4:1-14.

MERCIER, J. C. \& NICOLAS, A. - 1975 - Textures and fabrics of upper mantle peridotites as illustrated by xenoliths from basalts. Journal of Petrology 16:454-487

MEREMBECK, B. F.; BORDEN, F. Y.; PODWYSOCKI, M .H. \& APPLEGATE, D. N. 1977 - Application of canonical analysis to multispectral scanner data. Proc. Symp. 
Comp.Appl. Mineral Industries, $14^{\text {th }}$, American Institute in Mining, Metallurgical and Petroleum Engineers.

MILLER, C. F.; WATSON, E.B. \& HARRISON, T.M. - 1988 - Perspectives on the source, segregation and transport of granitoid magmas. Trans. R. Soc. Edinburgh Earth Sci. 79:135-156.

MILLIGAN, P. R. \& GUNN, P. J. - 1997 - Enhancement and presentation of airborne geophysical data. AGSO J. Austral. Geol. \& Geophys. 17(2):63-75.

MIRANDA, J. M.; GALDEANO, A; ROSSIGNOL, J. C. \& VICTOR, L. A M. - 1989 Aeromagnetic anomalies in mainland Portugal and their tectonic implications. Earth Plan. Sci. Letters 95:161-172.

MISHRA, D.C - 1992 - Mid-continent gravity "high"of central India and the Gondwana tectonics. Tectonophysics 212(1/2):153-162.

MOLINA, H. C. - 1990 - Modelo crustal da Faixa Araguaia a partir dos dados gravimétricos. Dissertação de Mestrado, IAG-USP, 102 pp.

MOLNAR, P. \& TAPPONIER, P. - 1975 - Cenozoic tectonics of Asia: effects of a continental collision. Science 189:419-426.

MONTEL, J.M.; FORET, S.; VESCHAMBRE,M.; NICOLLET, C. \& PROVOST, A - 1996Electron microprobe dating of monazite. Chem. Geol. 131:37-53.

MOORE, G. \& WALTZ, F.A - 1983 - Objective procedures for lineament enhancement and extraction. Photogramm. Engin. Remote Sens. 49(5):641-647.

MOREIRA, J. A. M.; MEDEIROS, V.E.; LINS, F.P.L.; ARCHANJO, C.J. \& USSAMI, N. 1989a - Mapa gravimétrico do nordeste setentrional do Brasil e sua contribuição ao estudo da tectônica da área. $1^{\circ}$ Congr. Bras. Geof. 2:531-537.

MOREIRA, J. A. M.; MEDEIROS, V.E.; LINS, F.P.L. \& ARCHANJO, C.J. - 1989b - Uma anomalias magnética de caráter regional no Seridó (RN-PB) e uma discussão de sua origem. $1^{\circ}$ Congr. Bras. Geof. 2:592-597.

MOREIRA, J. A. M; LINS, F. A. P. L.; BARAUD, R. \& MACEDO, J. W .P. - 1990 Contribuição da gravimetria para o entendimento da sismicidade de João Câmara-RN. $36^{\circ}$ Cong. Bras. Geol., Ntl, Anais, v. 5: 2145-2153.

MURPHY, J. B. \& NANCE, R. D. - 1991 - Supercontinent model for the contrasting character of late Proterozoic orogenic belts. Geology 19:469-472.

MURRAY, C. G.; SCHEIBNER,E. \& WALKER, R. N. - 1989 - Regional geological interpretation of a digital cloured residual Bouguer gravity image of eastern Australia with a wavelength cut-off of $250 \mathrm{~km}$. Australian J. Earth Sci. 36:423-449.

MURRAY, C. G. \& SCHEIBNER, E. -1990-Regional geological interpretation of a digital coloured residual Bouguer gravity image of eastern Australia with a wavelenght cut-off of $250 \mathrm{~km}$.Reply to Discussion. Australian J. Earth Sci. 37:493-497.

NETLETON, L.L.-1976- Gravity and magnetics in oil prospecting. McGraw-Hill, 464 pp.

NEVATIA R. \& BABU, R. -1980 - Linear extraction and description. Comp. Graph. Image Proces. 13:257-269. 
NEVES, S. P.; VAUCHEZ, A \& ARCHANJO. C.J. - 1996 - Shear zone-controlled magma emplacement or magma-assisted nucleation of shear zones? Insights from northeast Brazil. Tectonophysics 262:349-364.

NEWTON, R.C.; SMITH, J.V. \& WINDLEY, B. D. -1980 - Carbonic metamorphism of granulites and crustal growth. Nature 288:45-49.

NEWTON, R.C -1985- P/T conditions in the amphibolite to granulite facies transition zones. In: A. C. TOBI \& J.L.R. TOURET (eds.). The Deep Proterozoic Crust in the North Atlantic Provinces. Reidel Publ. Comp. Series C: Mathematical and Physical Sci. 158 .

NEWTON, R.C -1987- Late Archaean/Early Proterozoic $\mathrm{CO}_{2}$ streaming through the lower crust and geochemical segregation. Geophys. Res. Lett. 14:287-290.

NGAKO, V.; JEGOUZO, P. \& NZENTI, J.P.-1991- Le cisaillement Centre Camerounais. Rôle structural et géodynamique dans l'orogenèse panafricaine. C.R. Acad. Sci. Paris t.313(II):457-463.

NGAKO, V.; JEGOUZO, P. \& NZENTI, J.P.-1992 - Champ de raccourcissement et cratonisation du Nord Cameroun du Proterozoique Supérieur au Paleozoique Moyen. C.R.Acad.Sci Paris t.315(II):371-377.

NICOLAS, A ; BOUCHEZ, J. L. \& BOUDIER, F. - 1972 - Interprétation cinématique des déformations plastiques dans le massif de lherzolites de Lanzo. Tectonophysics 14:143171.

NICOLAS, A . \& BOUDIER, F. - 1975 - Kinematic interpretation of folds in alpine-type peridotites. Tectonophysics 25:233-260.

NICOLAS, A . \& POIRIER, J. P. - 1976 - Crystalline plasticity and solid state flow in metamorphic rocks. John Wiley \& Sons, 444 pp.

NICOLLET, C.; MONTEL, J.M.; FORET, S.; MARTELLAT, J.E. \& LARDEAUX, J.M. 1995-E-probe monazite dating of the uplift of the precambrian in the S of Madagascar. $8^{\circ}$ EUG, Terra Abs. 7:124.

NIXON, P. H. - 1987 - Mantle xenoliths. John Wiley \& Sons, 844 pp.

OAKEY, G. - 1994 - A structural fabric defined by topographic lineaments: correlation with Tertiary deformation of Ellesmere and Axel Heiberg Islands, Canadian Arctic. J. Geophys. Res. 99(B10):20311-20321.

O'LEARY, D. W. \& SIMPSON, S. - 1975 - Lineaments and tectonism in the northern part of the Mississipi embayment. Ann Arbor, Michigan, pp. 965-974.

O'LEARY, D. W.; FRIEDMAN, J. D. \& POHN, H. A - 1976 - Lineament, linear, lineation: some proposed new standards for old terms. Bull. Geol. Soc. Amer. 87:1463-1469.

OLESEN, O; HENKEL, H.; KAADA, K. \& TVETEN, E. - 1991 - Petrophysical properties of a prograde amphibole-granulite facies transition zone at Sigerfjord, Vesterälen, northern Norway. Tectonophysics 192(1/2):33-40. 
OLIVIER, P. \& ARCHANJO, C.J. - 1994 - Magnetic and magmatic structures of the Emas granodioritic pluton (Cachoeirinha belt, NE Brazil). Relationship with Pan-African strike-slip fault systems. Tectonophysics 229:239-250.

OLIVEIRA, R. G. \& SANTOS, E. J. - 1993 - Seção geológica-geofisica e inferências geotectônicas na porção centro-sul da Província Borborema. $3^{\circ}$ Congr. Inter. Soc. Bras. Geof. Res. Exp. 1:643-647.

OLIVEIRA, R. G. - 1994 - Levantamento gravimétrico da área sedimentar da região metropolitana do Recife. CPRM, Projeto SINGRE.

PATERSON, S. R.; VERNON, R. H. \& TOBISH, O.T. - 1989 - A review of the criteria for the identification of magmatic and tectonic foliations in granitoids. J. Struc. Geol. 11:349-363.

PATIÑO-DOUCE, A E.; HUMPHREYS, E.D. \& JOHNSTON, A D. - 1990 - Anatexis and metamorphism in tectonically thickened continental crustexemplified by the Sevier Hinterland, western North America. Earth Planet. Sci. Lett. 97:290-315.

PATINO-DOUCE, A E. \& JOHNSTON, A D. - 1991 - Phase equilibria and melt productivity in the pelitic system: implications for the origin of paraluminous granitoids and aluminous granulites. Contrib. Mineral. Petrol. 107:202-218.

PATINO-DOUCE, A E. - 1995 - Experimental generation of hybrid silicic melts by reaction of high-Al basalt with metamorphic rocks. J.Geophys.Res.100(B8):15623-15639.

PATINO-DOUCE, A E. \& BEARD, J.S.-1995- Dehydratation melting of biotite gneiss and quartz amphibolite from 3 to 15 kbar. J. Petrol. 36:707-738.

PAVLENKOVA, N.I. -1995- Structural regularities in the lithosphere of continents and plate tectonics. Tectonphysics 243:223-239.

PEACOCK, S.M. - 1989 - Numerical constraints on rates of metamorphism, fluid production, and fluid flux during regional metamorphism. Geol. Soc. Amer. Bull. 101:476-485.

PECERILLO, A \& TAYLOR, S.R. -1976-Geochemistry of Eocene calc-alkaline volcanic rocks from the Kastamanu area, northern Turkey. Contr. Mineral. Petrol. 58:63-81.

PELTZER, G. \& TAPPONIER, P. - 1988 - Centrifugued experiments of continental saclae tectonics in Asia. Bull. Geol. Inst. Univ. Uppsala, N.S. 14:115-128.

PESSOA, R.R. \& ARCHANJO, C.J. - 1984 - Tectônica de empurrões na região de TróiaCE. $33^{\circ}$ Cong. Bras. Geol. $4^{\circ}: 1721-1728$.

PETRÓLEO BRASILEIRO S.A - PETROBRÁS/PRAKLA - 1970 - Plataforma continental do Nordeste - Área Camocim-Salinópolis: mapa escala 1:500000.

PETRORIUS J. P. G. \& PARTRIDGE, T. C. - 1974 - Analysis of angular atypicality of lineaments as na aid to mineral exploration. J. South Afr. Inst. Min. Metall. 74(10):367-369.

PEYVE, A V. - 1990 - Deep seated faults and their role in the structure and evolution of the Earth crust. Nauka, Moscow. 
PICKERING, S. M. \& JONES, R. C. - 1974 - Geologic evaluation and applications of ERTS-1 imagery over Georgia. NASA Spec.Paper 351, 1B:857-868.

PILI, E.; RICARD, Y.; LARDEAUX, J.M. \& SHEPPARD, S.M.F.- 1997 - Lithospheric shear zones and mantle crust connections. Submet. Tectonophysics

PILI, E. - 1997 - Distribution et transfer des fluides à l'échelle de la lithosphere continentale: investigation géochimique et geophysique des granulites de Madagascar. Thèse de Doctorat, Université Claude-Bernard-Lyon 1, 252 pp.

PILKINGTON, M. - 1990 - Lithospheric flexure and gravity anomalies at Proterozoic plate boundaries in the Canadian Shield. Tectonophysics 176:277-290.

PILKINGTON, M. \& ROEST, W.R. - 1996 - An assesment of long-wavelength magnetic anomalies over Canada. Can. J. Earth Sci. 33:12-23.

PLAMEROVÁ, J.; BABUSKA, V.; DORBATH, C.; DORBATH, L. \& LILLIE, R. J.- 1993Deep lithospheric structure across the Central African shear zone in Cameroon. Geophys. J. Intern. 115:381-390.

PONSARD, J.F.; ROUSSEL, J.; VILLENEUVE, M. \& LESQUER, A - 1988 - The PanAfricam orogenic belt of southern Mauritanides and northern Rockelides (southern Senegal and Guinea, West Africa): gravity evidence for collisional suture. J. African Earth Sci. 7:463-472.

POUDJOM DJOMANI, Y. H.; EBINGER, C. J.; DIAMENT. M. \& ALBOUY, Y. - 1993 - $A$ gravity study of Cameroon (Central Africa) and discussion of the origin of the Adamawa uplift. Terra Abstr. 5:110.

POUDJOM DJOMANI, Y. H.; NNANGE, J. M.; DIAMENT. M.; EBINGER, C. J. \& FAIRHEAD, J. D. - 1995 - Effective elastic thickness and crustal thickness variations in west central Africa inferred from gravity data. J. Geophys. Res. 100:22047-22070.

POUDJOM DJOMANI, Y. H.; DIAMENT. M. \& WILSON, M. - 1997 - Lithospheric strusture across the Adamawa plateau (Cameroon) from gravity studies. Tectonophysics 273:317-327.

POWELL, D.W. -1970- Magnetized rocks within the Lewisian of Western Scotland and the Southern Uplands. Scott. J. Geol. 6:353-369.

POWERS, R. E. \& BOHLEN, S.R.-1985 - The role of synmetamorphic igneous rocks in the metamorphism and partial melting of metasediments, northwest Adirondacks. Contr. Mineral. Petrol. 90:401-409.

PREWITT, J. - 1970 - Object enhancement and extration. In: B. LIPKIN \& A ROSENFELD (eds.). Picture processing and psychopictorics. Acedemic Press, New York.

QARI, M. Y. H. T.- 1991 - Application of Landsat TM data to geological studies, Al-Khabt area, southern Arabian shield. Photogramm. Eng.Remote Sensing 57(4):421-429.

QUEIROZ, M.A.; MACEDO, J.W.P.; DE ROOY, C. \& ARAÚJO, T.C.M.-1985Contribuição da Geofisica ao Mapeamento Geológico da Ärea de Canguaretama/RN. Boletim DG-UFRN, Vol. 10:58-67. 
QURESHY, M. N. - 1982 - Geophysical and Landsat lineament mapping - an approch illustrated from west-central and south India. Photogrammetria 37:161-184.

QURESHY, M. N. \& IQBALUDDIN - 1992 - A review of the geophysical constraints in modelling the Gondwana crust in India. Tectonophysics 212:141-151.

RAMSAY, J. G. - 1967 - Folding and fracturing of rocks. McGRaw-Hill 568 pp.

RAMSAY, J. G. \& HUBER, M. I. - 1987 - The techniques of modern structural geology. Vol. 2 Folds and fractures. Academic Press, Londres, 700 pp.

RANALLI, G. -1987 - Rheology of the Earth. Winchester, Allen and Unwin, 366pp.

RANALLI, G. \& MURPHY - 1987 - Rheological stratification of the lithosphere. Tectonophysics 132:281-295.

RANALLI, G. - 1995 - Rheology of the Earth. 2nd Edition, Chapman \& Hall.

RANALLI, G. - 1997 - Rheology of the lithosphere in space and time. In: J.P. BURG \& M. FORD (eds.). Orogeny through time. Geol. Soc. Spec. Publ. 121:19-37.

RAND, H. \& MANSO, V. A. - 1990 - Mapas gravimétricos e magnetométrics da Faixa Costeira do Nordeste do Brasil. $36^{\circ}$ Cong. Bras. Geol., Natal, Anais, v.5:2431-2438.

RAVAT, D.N.; HINZE, W.J. \& VON FRESE, R.R.B. - 1991 - Lithospheric magnetic property contrasts within the South American plate derived from damped least-square inversion of satellite magnetic data. Tectonophysics 192:159-168.

RAVAT, D.N.; ; HINZE, W.J. \& VON FRESE, R.R.B.- 1992 - Analysis of MAGSAT magnetic contrasts across Africa and South America. Tectonophysics 212(1/2):59-76.

REBILLARD, P. \& EVANS, D.- 1983 - Analysis of coregistered Landsat, Seasat and SIR-B images of varied terrain types. Gephysics Res. Letters 10:277-280.

REEVES, J. R. - 1974 - Linears in southeasthern Alaska. Proc. Int. Conf.New Basement Tectonics, 1 th, Utah Geol. Assoc.Publ. 5:35-41.

REGAN, R.D.; CAIN, J.C. \& DAVIS, W.M.- 1975 - A global magnetic anomaly map. J. Geophys. Res. 80:794-802.

RICARD, Y. \& FROIDEVAUX, C. - 1986 - Stretching instabilities and lithospheric boudinage. J. Geophys. Res. 91:8314-8324.

RICHARDS, J. A - 1984 - Thematic mapping from multitemporal image data using the principal components transformation. Remote Sensing Environment 16:35-46.

RICHARDS, J. A - 1995 - Remote sensing digital image analysis. Springer-Verlag, 340 pp.

RICHARDSON, S. W.; BELL, P. M. \& GILBERT, M. C. - 1968 - Kyanite-sillimanite equilibrium between 700 and $1500^{\circ} \mathrm{C}$. Amer. J. Sci. 266:513-541.

RICHARDSON, S. W; GILBERT, M. C. \& BELL, P. M. - 1969 - Experimental determination of kyanite-andalusite and andalusite-sillimanite equilibria: the aluminum silicate triple point. Amer. J. Sci. 267:259-272. 
RINDSTAD, B. \& FOLLESTAD, B. A - 1982 - Digital methods for lineament analysis. Proc. Intern. Symp. Remote Sens. First Thematic Conference: Remote Sensing of Arid and Semi-Arid Lands 2:955-961.

ROEST, W.R.; VERHOEF, J. \& PILKINGTON, M. - 1992 - Magnetic interpretation using $3 D$ analytic signal. Geophysics 57:116-125.

ROEST, W.R. \& PILKINGTON, M. - 1993 - Identifying remanent magnetization effects in magnetic data. Geophysics 58(5):653-659.

ROSS, H.P.; ADLER, J.E.M. \& HUNT, G.R. - 1969 - A statistical analysis of the reflectance of igneous rocks from 0.2 to 2.65 microns. Icarus 11:46-54.

ROTHERY, D. A.- 1984a - The role of Landsat Multispectral Scanner imagery in mapping Oman ophiolite. Geol. Soc. London Spec.Publ. 13:405-413.

ROTHERY, D. A - 1984b-Reflectance of ophiolite rocks in the Landsat MSS bands: Relevance to lithological mapping by remote sensing. J. Geol.Soc. London 141:93-939.

ROTHERY, D. A. -1987a - Improved discrimination of rock units using Landsat Thematic Mapper imagery of the Oman ophiolite. J.Geol.Soc.London 144:587-597.

ROTHERY, D.A - 1987b-Decorrelation stretching as an aid to image interpretation. Int.J.Remote Sensing 8:1253-1254

ROWAN, L .C.; ANTON-PACHECO, C.; BRICKEY, D. W.; KINGSTON, M. J.; PAYAS, A.; VERGO, N. \& CROWLY, J. K. - 1987 - Digital classification of contact metamorphic rocks in Extremadura, Spain, using Landsat thematic mapper data. Geophysics 52:885-897.

RUTTER, M. J. \& WYLLIE, P. J. - 1988 - Melting of vapour-absent tonalite at 10 kbar to simulate dehydration-melting in the deep crust. Nature 331:159-160.

RUTTER, M. J. \& BRODIE, - 1988 - The role of grain size reduction in the rheological stratification of lithosphere. Geologisches Rundschau 77:295-308.

RUTTER, M. J. \& NEUMANN, D.H.K.- 1995 - Experimental deformation of partialy molten Westerly Granite under fluid-absent conditions, with implications for the extraction of granitic magmas. J.Geophys.Res. 100(B8):15697-15715.

SÁ, J. M. \& LEGRAND, J. M. - 1983 - Superposição de fases metamórficas na região de Serra do Chico-Lages/RN. Ciências da Terra 7:12-15.

SÁ, J. M. \& BERTRAND, J. M. - 1992 - Transpressão dextral no sudeste do estado do Ceará, Província Borborema. $37^{\circ}$ Congr. Bras. Geol. Res. Exp. 2:368-371.

SÁ, N.C; USSAMI, N. \& MOLINA, E.C - 1993 - Gravity map of Brazil, l, Representation of Free-Air and Bouguer anomalies. J. Geophys. Res. 98(B2):2187-2197.

SÁ, J. M.; BERTRAND, J. M. \& LETERRIER, J. - 1991 - Évolution géodinamique et géochronologie (U-Pb, Rb-Sr, K-Ar) de la ceinture plissé d'Óros, $N E$ du Brésil. C.R. Acad. Sci. Paris II 313:231-237.

SÁ, J. M. - 1991 - Evolution geodynamique de la ceinture proterozoique d'Orós, Nord-Est $d u$ Brésil. Thèse de Doctorat, CRPG, Université de Nancy I, 177p. 
SABINS, F.F. -1978 - Remote Sensing. Principles and Interpretation. Freeman, New York

SANDIFORD, M. \& POWELL, R.-1991- Some remarks on high-temperature-low pressure metamorphism in convergent orogens. J. Metam. Geol. 9:333-340.

SANTOS, E. J. \& BRITO NEVES, B. B. - 1984 - Província Borborema. In: F.F.M ALMEIDA \& Y. HASUI (eds.). O Pré-Cambriano do Brasil. Edgard Blucher 123-186.

SANTOS, E. F.; COUTINHO, M.G.N.; COSTA, M.P. A \& RAMALHO, R.- 1984 - A região de dobramentos Nordeste e a Bacia do parnaíba, incluindo o cráton de São Luís e as bacias marginais. In: C. SCHOBBENHAUS, D.A CAMPOS, G.R. DERZE \& H.E. ASMUS (eds.) Geologia do Brasil. Texto explicativo do Mapa Geológico do Brasil e da área oceânica adjacente, incluindo depósitos minerais. DNPM 131-189.

SANTOS, E. J. - 1993 - O episódio magmático de 1, 1-0,9 Ga do domínio extremo nordeste. $15^{\circ}$ Simp. Geol. Nordeste 323-324.

SANTOS, E. J. - 1995 - O complexo granítico Lagoa das Pedras: acresção e colisão na região de Floresta (PE, Província Borborema. Tese de Doutorado, USP, 219 pp.

SANTOS, E. J. - 1996 - Ensaio preliminar sobre terrenos e tectônica acrescionária na Província Borborema. $39^{\circ}$ Congr. Bras. Geol. 6:47-50.

SALJE, E. - 1986 - Heat capacities and entropies of andalusite and sillimanite: the influence of fibrolitization on the phase diagram of the $\mathrm{Al}_{2} \mathrm{O}_{5}$ plymorphs. Amer. Mineral. 71:1366-1371.

SANKOV, V. A- 1989 - The depth of fault reactivation. Nauka, Novosileirsky.

SAUTER, D.; FRAIPONT, P. \& CHOROWICZ, J. - 1988 - Ridge and valley line extraction from digital terrain models. Int. Jour Rem. Sensing 9:1175-1183.

SCANVIC, J. C.- 1974 - Structural investigations in the Massif central-France. NASA Spec. Paper 351, 1B:757-766.

SCANVIC, J. C.- 1981 - Télédétection spatiale et recherche minière. S.F.P.T. Bull. 83(3)1724.

SCHLINGER, C.M. - 1985 - Magnetisation of lower crust and interpretation of regional magnetic anomalies: examples from Lofoten and Vesteralen. Norway. J. Geophys. Res. 90:11484:11504.

SCHMIDT, M. W. - 1992 - Amphibole composition in tonalite as function of pressure: a $n$ experimental calibration of the Al-hornblende barometer. Contrib. Mineral. Petrol. 110:304-310.

SCHOWENGERDT, R. A - 1983 - Techniques for image processing and classification in remote sensing. Academic Press, 249 pp.

SERONT, B.; MAINPRICE, D. \& CHRISTENSEN, N.I. - 1993 - A determination of the three dimensional seismic properties of anorthosite: comparison between values calculated from the petrofabric and direct laboratory measurements. J. Geophys. Res. 98:2209-2221.

SHAPIRO, V.A; TSIRULSKY, A V.; FEDOROVA, N.V.; NIKONOVA, F.I; DYAKONOVA, A G.; CHURSIN, AV. \& TURMINA, L.O- 1986 - The anomalous 
magnetic field and its dynamics used to study the deep structure and modern geodynamic processes of the Urals. J. Geodynamics 5:221-235.

SHARMA, P.V. - 1986 - Geophysical methods in geology. Elsevier, 442 pp.

SHEFFELS, B. \& MCNUTT, M. - 1986 - Role of subsurface loads and regional compensation in the isostatic balance of the Transverse Ranges, California: evidence for intracontinental subduction. J. Geophys. Res. 91:6419-6431.

SHEFFIELD,C. -1985- Selecting band combinations from multispectral data. Photogramm.Eng.Remote Sensing 51:681-687.

SHIVE, P.N.; FROST, B.R. \& PERETTI, A -1988- The magnetic properties of metaperidotitic rocks as a function of metamorphic grade: implication for crustal magnetic anomalies. J. Geophys. Res. 93:12817-12915.

SHORT, N. M. - 1974 - Mineral resources, geological structures and landform surveys. NASA Spec. Paper 351, 2:147-167.

SHMULOVICH, K. I. \& GRAHAM, C. M. - 1996 - Melting of albite and dehydration of brucite in $\mathrm{H} 2 \mathrm{O}-\mathrm{NaCl}$ fluids to $9 \mathrm{kbars}$ and $700-900^{\circ} \mathrm{C}$ : implications for partial melting and water activities during high pressure metamorphism. Contrib. Mineral. Petrol. 124:370-383.

SIAL, A. N. \& FERREIRA, V. P. - 1988 - Brasiliano age peralkaline plutonic rocks of the central structural domain, northeast Brazil. Rend. Soc. It. Min. Petr. 43:307-342.

SIAL, A N.; FERREIRA, V. P.; JARDIM DE SÁ, E. F.; SANTOS, E. J.; MEDEIROS, V.C. \& AMARO, V. E. - 1996 - The plutonic map sheet of northeast Brazil: neoproterozoic to phanerozoic granitoids of the Borborema Province. $39^{\circ}$ Congr. Bras. Geol. 6:325329.

SIEGAL, B.S. \& GILLESPIE, A R. -1980 - Remote Sensing in Geology. John Wiley \& Sons, New York.

SILVA FILHO, A F.; GUIMARÃES, I. P. \& THOMPSON, R. N. -1993 - Shoshonitic and ultrapotassic Proterozoic intrusive suites in the Cachoeirinha-Salgueiro belt, NE Brazil: a transition from collisional to post-collisional magmatism. Precambriam Res. 62:323-324.

SILVER, P.G. \& CHAN, W. - 1991- Shear wave splitting and subcontinental mantle deformation. J. Geophys. Res. 96:16429-16454.

SINGER, R.B. - 1981 - Near-infrared spectral reflectance of mineral mixtures: systematic combinations of pyroxenes, olivine and iron oxides. J. Geophys. Res. 86:7967-7982.

SINGH, J. \& JOHANNES, W. - 1996a - Dehydration melting of tonalites. Part I. Beginning of melting. Contrib. Mineral. Petrol. 125:16-25.

SINGH, J. \& JOHANNES, W. - 1996b - Dehydration melting of tonalites. Part II. Composition of melts and solids. Contrib. Mineral. Petrol. 125:26-44.

SKIDMORE, A K. \& TURNER, B.J. - 1988 - Forest mapping accuracies are improved using a supervised nonparametric classifier with Spot data. Phtogramm. Eng. Remote Sensing 52:397-399. 
SKILBREI, J.R.; SKYSETH, T. \& OLESEN, O - 1991- Petrophysical data and opaque mineralogy of high-grade and retrogressed lithologies: implications for the interpretation of aeromagnetic anomalies in Northern Vestranden, Central Norway. Tectonophysics 192:21-31.

SMITH, R.A - 1960 - Some formulae for interpreting local gravity anomalies. Geophys. Prospect. 8:607-613.

SMITH, W.H.F. \& WESSEL, P. - 1990 - Gridding with continuous curvature splines in tension. Geophysics 55:293-305.

SOESILO, I. \& HOPPIN, R. A -1986 - Evaluation of digitally processed Landsat imagery and SIR-A imagery for geological analysis of west Java region, Indonesia. Symp. Remote Sens. Resources Develop. Environmental Management. 173-182

SOHA, J. M. \& SCHWARTZ, A. A.- 1978 - Multispectral histogram normalization and contrast enhancement. In: Proc. Can. Symp. Remote Sensing, 5th, pp.86-93.

SOUZA, L. C. - 1987 - Geologia e petroquímica de uma área ao norte de Equador (RN). Dissertação de Mestrado, UFPE, 318pp., inédita.

SOUZA, L. C.; SILVA, W. L. \& LEGRAND, J. M. - 1992 - Zoneamento metamórfico provocado pelo maciço granítico de Acari-RN: Dados preliminares. XIV Simp. Geol. Nordeste, Recife,, Atas, 250-253.

SOUZA, Z. S.; MONTEL, J. M.; JARDIM DE SÁ, E. F.; LARDEAUX, J. M; VESCHAMBRE, M. \& AMARO, V.E. - 1998 - Electron microprobe monazite dating of high-T shear zones in the Caldas Brandão Massif, NE Brazil. Submet.

SOUZA, Z. S. \& JARDIM DE SÁ, E. F. - 1993 - Metamorfismo de alta temperatura associado a uma estrutura transtracional brasiliana a SE de Barra de Santa Rosa $(P B) .15^{\circ}$ Simp. Geol. Nordeste 124-127.

SPEAR, F.S. \& CHENEY, J.T. - 1989 - A petrogenetic grid for pelitic schists in the system $\mathrm{SiO}_{2}-\mathrm{Al}_{2} \mathrm{O}_{3}-\mathrm{FeO}-\mathrm{MgO}-\mathrm{K}_{2} \mathrm{O}-\mathrm{H}_{2} \mathrm{O}$. Contrib. Mineral Petrol. 101:149-164.

SPEAR, F.S. - 1993 - Metamorphic phase equilibria and pressure-temperature-time paths. Mineral. Soc. Amer. Monograph Series, 799 pp.

SPECTOR, A \& LAWLER, T.L. - 1995 - Application of aeromagnetic data to mineral potencial evaluation in Minnesota. Gophysics 60(6):1704-1714.

STEFOULI, M. \& ANGELOPOULOS, A. - 1990 - Integration of Landsat and aeromagnetic data as aid to the structural analysis of Crete and S.E. Peloponesus. Int. J. Remote Sensing 11(9):1625-1644.

SWAIN, P.H \& DAVIS, S.M. -1978- Remote Sensing : The Quantitative Approach. New York, McGraw-Hill.

SYBERG, F.J.R. - 1972 - A Fourier method for the regional-residual problem of potencial fields. Gophysical Prospecting 20:47-75.

SYLVESTER, P.J. - 1988 - Strike-slip faults. Geol. Soc. Am. Bull. 100:1666-1703.

TABOD, C.T.; FAIRHEAD, J. D.; STUART,B.; ATEBA, B. \& NTEPE, N. - 1992 Seismicity of the Cameroon volcanic line, 1982-1990. Tectonophysics 212:303-320. 
TANAKA, H. \& SAKA, Y. - 1993 - Block rotation by basement strike-slip faulting in the Sanchu graben, central Japan. J. Struct. Geol. 15:1021-1032.

TAKEYA, M.K.; FERREIRA, J.M.; PEARCE, R.G.; ASSUMPÇÃO,M.; COSTA, J.M. \& SOPHIA, C.M. - 1989 - The 1986-1988 intraplate earthquake sequence near João Câmara - evolution of seismicity. Tectonophysics 167:117-131.

TAPPONIER, P.; PELTZER, G. \& ARMIJO, R.-1986- On the mechanics of the collision between India and Asia. In: M.P. COWARD \& A C RIES (eds.). Collision Tectonics. Geol. Soc. Spec. Publ. 19:115-157.

TARLOWSKI, C; McEWIN, A J.; REEVES, C V. \& BARTON, C E. - 1996 - Dewarping the composite aeromagnetic anomaly map of Australia using control traverses and base stations. Geophysics 61(3):696-705.

TARLOWSKI, C; GUNN, P.J \& MACKEY, T. - 1997 - Enhancements of the magnetic map of Australia. AGSO J. Austral. Geol. \& Geophys. 17(2):77-82.

TAYLOR, M. M. - 1974 - Principal components color display of ERTS imagery. Earth Res. Technology Satellite Symp., $3^{\text {th }}$, Washington DC.

TAYLOR, S. R. \& McLENNAN -1995- The geochemical evolution of the continental crust. Reviews of Geophysics 33:2.

TESKEY, D. J. \& HOOD, P.J. - 1991 - The Canadian aeromagnetic database: evolution and applications to the definition of major crustal boundaries. Tectonophysics 192(1/2):41-56.

THOMAS, H.H. - 1987 - A model of ocean basin crustal magnetization appropriete for satellite elevation anomalies. J. Geophys. Res. 92:11609-11613.

THOMPSON, J. B. - 1957 - The graphical analysis of mineral assemblages in pelitic schists. Amer. Mineral. 42:842-858.

THOMPSON, A B. - 1974 - Calculation of muscovite-paragonite-alkali feldspar phase relations. Contr. Mineral. Petrol. 44:173-194.

THOMPSON, A B. - 1976 - Mineral reactions in pelitic rocks: parts I and II. Amer. J. Sci. 276:401-454.

THOMPSON, A B. \& ANGOR, J. R. - 1977 - Model systems for anatexis of pelitic rocks 1. Theory of melting reactions in the system $\mathrm{KAlO}_{2}-\mathrm{NaAlO}_{2}-\mathrm{Al}_{2} \mathrm{O}_{3}-\mathrm{SiO}_{2}-\mathrm{H}_{2} \mathrm{O}$. Contr. Mineral. Petrol. 63:247-269.

THOMPSON, A B. \& TRACY, R. J. -1979 - Model systems for anatexis of pelitic rocks II. Facies series melting and reactions in the system $\mathrm{CaO}-\mathrm{KAlO}_{2}-\mathrm{NaAlO}_{2}-\mathrm{Al}_{2} \mathrm{O}_{3}-\mathrm{SiO}_{2}-$ $\mathrm{H}_{2} \mathrm{O}$. Contr. Mineral. Petrol. 70:429-483.

THOMPSON, A B. - 1982 - Dehydration melting of pelitic rocks and the generation of $\mathrm{H}_{2} \mathrm{O}$-undersatureted granitic liquids. Amer. J. Sci. 282:1567-1595.

THOMPSON, A B. - 1983 - Fluid absent metamorphism. J. Geol. Soc London 140:533-547.

THOMPSON, A B. \& ENGLAND, P. C. - 1984 - Pressure-temperature-time paths of regional metamorphism. II. Their inference and interpretation using meineral assemblages in metamorphic rocks. J. Petrol. 25:929-955. 
THOMPSON, A B. - 1990 - Heat, fluids and melting in the granulite facies. In: D.VIELZEUF \& Ph. VIDAL (eds.). Granulites and Crustal Evolution. NATO ASI Ser. 311:37-57.

THOMPSON, A B. \& CONNOLY, J. A D. - 1992 - Migration of metamorphic fluid: some aspects of mass and heat transfer. Earth Sci. Rev. 32:107-121.

THOMPSON, A B. \& CONNOLY, J. A D. - 1995 - Melting of the continental crust: some thermal and petrological constraints on anatexis in continental collision zones and other tectonic settings. J. Geophys. Res. 100(B8):15565-15579.

TOFT, P.B. \& HAGGERTY, S.E. - 1988 - Limiting depth of magnetization in cratonic lithosphere. Geophys. Res. Lett. 15:530-533.

TOMMASI, A; VAUCHEZ, A; FERNANDES, L.A D \& PORCHER, C.C. - 1994 - Magma assisted strain localization in na orogen-parallel transcurrent shear zone of southern Brazil. Tectonics 13:421-437.

TOMMASI, A- 1995 - Développement de systèmes de décrochements d'échelle continentale dans une lithosphère hétérogène: cas naturels et modélisation numérique. Thèse de Doctorat, Université de Montpellier II, 166 pp., inédite.

TOMMASI, A; VAUCHEZ, A \& DAUDRÉ, B. - 1995 - Initiation and propagation of shear zones in a heterogeneous continental lithosphere. J. Geophys. Res. 100(B11):22083-22101.

TOMMASI, A \& VAUCHEZ, A - 1997 - Continental scale rheological heterogeneities and complex intraplate tectono-metamorphic patterns: insights from a case study and numerical models. Tectonophysics 279:327-350.

TORRES, H.H.F. - 1994 - Metodologia para estudos neotectônicos regionais: o caso de João Câmara. CPRM/Recife, Série Publ. Especiais 2:50 pp.

TOURET, J.L.R. - 1974 - Faciès granulite et fluides carboniques. In: E. BELLIĖRE \& J.C. DUCHESNE (eds.). Géologie des domaines cristallins. Soc. Géol. Belgique, Vol. Spec., 267-287.

TOURET, J.L.R. - 1996 - Fluids in granulites: the quest continues. V.M. GOLDSCHMIDT Conference, Heidelberg, Abs. 1: 623.

TOWNSEND, T.E.-1987- Discrimination of iron alteration mineral in visible and nerainfrared reflectance data. J. Geophys. Res. 92:1441-1454.

TRICART, J.L.F. - 1978 - Méthodes de travail: les enregistrement de télédétection source d'information pour l'étude de l'environnement écologique. Rev. Geomorph, Dyn. 27(1):30-41.

TRINDADE, R. I. - 1995 - Geologia de uma área a norte de Pocinhos (PB): caracterização de um segmento da Zona de Cisalhamento Remigio-Pocinhos. Relatório de Graduação, UFRN, 97 pp., inédito.

TULLIS, T.E; HOROWITZ, F.G. \& TULLIS, J. -1991- Flow laws of polyphase aggregates from end-member flow laws. J. Geophys. Res. 96:8081-8096. 
UP DE GRAFF, J. E. \& LUYENDYK, B.P. - 1989 - Gravity study of the boundary between the western Traverse Ranges and Santa Maria Basin, California. J. Geophys. Res. 94:1817-1825.

USSAMI, N; SÁ, N.C. \& MOLINA, E.C. - 1993 - Gravity map of Brazil. 2. Regional and residual isostatic anomalies and their correlation with major tectonic provinces. $\mathrm{J}$. Geophys. Res. 98(B2):2199-2208.

VALENZUELA ,C. R. \& BAUMGARDNER, M. - 1990 - Selection of appropriete cells sizes for thematic maps. ITC Journal 3:219-224.

VALLEY, J. W; BOHLEN, S.R.; ESSENE, E. J. \& LAMB, W. - 1990 - Metamorphism in the Adirondacks: II. The role of fluids. J. Petrol. 31:555-596.

VALLEY, J. W. - 1992 - Granulite formation is driven by magmatic processes in the deep crust. Earth Sci. Reviews 32:215-230.

VAN DER KERKHOF, A M.; TOURET, J.L.R. \& KREULEN, R. - 1994 - Juvenile $\mathrm{CO}_{2}$ in enderbites of Tromoy near Arendal, Southern Norway - A fluid inclusion and stable isotope study. J. Metamor. Geol. 12:301-310.

VAN SCHMUS, W. R.; BRITO NEVES, B.B. \& HACKSPACHER, P.C. - 1994 Identification of lithospheric domains in NE Brazil and their relevance to the ancestry and assembly of western Gondwana. Inter. Symp. Phys. Chem. Upper Mantle, Ext. Abs. 79-81.

VAN SCHMUS, W. R.; BRITO NEVES, B. B.; HACKSPACHER, P. C. \& BABINSKI, M. - 1995 - U-Pb and Sm-Nd geochronologic studies of the eastern Borborema Province, Northeastern Brazil: initial conclusions. J. South Amer. Earth Sci. 8(3/4):267-288.

VAUCHEZ, A.- 1987 - Mecanismes de deformation et cinematique des zones de mouvements ductiles. Thèse de Doctorat Sci, Université Aix-Marseille $315 \mathrm{pp}$,, inedite.

VAUCHEZ, A.; CORSINI, M.; ARCHANJO, C. J.; AMARO, V. E. \& JARDIM DE SÁ, E.F. - 1991 - Strain transfer at continental scale: shear zone - transpression belt and shear zone - shear zone systems; evidence from NE-Brazil. EUG VIth meeting, Abst., Terra Nova 3:393.

VAUCHEZ, A. \& EGYDIO-SILVA, M. - 1992 - Termination of a continental-scale strikeslip fault in partialy melted crust: The west Pernambuco shear zone (NE Brazil). Geology 20:1007-1010.

VAUCHEZ, A.; AMARO, V. E.; ARCHANJO, C.J.; ARTHAUD, M.; BOUCHEZ, J.L.; CABY, R.; CORSINI, M.; EGYDIO-SILVA, M.; JARDIM DE SÁ, E. F.; PACHECONEVES, S. \& SIAL, A N.- 1992 - The Borborema shear zone system: A tectonic model. $37^{\circ}$ Cong. Bras. Geol., Anais, v.2:371-373.

VAUCHEZ ,A; TOMMASI, A \& EGYDIO-SILVA, M. - 1994 - Self-indentation of continental lithosphere. Geology 22:967-970.

VAUCHEZ ,A;; PACHECO-NEVES, S.; CABY, R.; CORSINI, M.; EGYDIO-SILVA, M.; ARTHAUD, M. \& AMARO, V.E. - 1995 - The Borborema shear zone system. J. Soc. Am. Earth Sci. 8:247-266. 
VAUCHEZ ,A:; PACHECO-NEVES, S. \& TOMMASI, A - 1997a - Transcurrent shear zones and magma emplacement in neoproterozoic belts of Brazil. In: J.L. BOUCHEZ, J.L. HUTTON, W.E. STEPHENS (eds.). Granites: From Melt Segregation to Emplacement Fabrics. Kluwer 273-293.

VAUCHEZ, A; BARRUOL, G. \& TOMMASI, A - 1997b - Why do continents break up parallel to ancient orogenic belts? Terra Nova 9:62-66.

VAUZELLE, M. -1982 - La télédétection pour l'approche des unités paysagiques en milieu bocager: application aux Monts d'Ambazac (Limousin, France). Bull. Soc. franc. Photogramm. Télédét. 88:7-18.

VERGELY, P. \& ZADEH-KADIR ,H. - 1988 - Étude par photointerpretation comparée de la région de Largeniére Les Vans (Languedoc septentrional, France): utilisation de photographies aériennes, des images satellitites et des images radar. Bull. Soc. Géol. France 8:300-314.

VERMA, R. K. \& SUBRAHMANYAM, C. - 1984 - Gravity anomalies and the Indian lithosphere: Review and analysis of existing gravity data. Tectonophysics 105:141-161.

VERNON, R. H. - 1983 - Restite, xenoliths and microgranitoid enclaves in granites. J. Prc. R. Soc. N.S.W. 116:77-103.

VERNON, R. H.- 1996 - Problems with inferring P-T-t in low-P granulite facies rocks. J. Metamorphic Geol. 14:143-153.

VIELZEUF, D.; CLEMENS, C; PIN, C. \& MOINET, E. - 1990 - Granites, granulites and crustal differentiation. In: D. VIELZEUF \& Ph. VIDAL (eds.). Granulites and Crustal Evolution. Kluwer Academic, 311:59-85.

VIELZEUF, D. \& VIDAL, Ph.- 1990 - Granulites and Crustal Evolution. Kluwer Academic, $581 \mathrm{pp}$.

VIELZEUF, D. \& MONTEL, J.M. - 1994 - Partial melting of metagrywackes. Part I. Fluidabsent experiments and phase relationships. Contrib. Mineral. Petrol 117:375-393.

VISSERS, R.L.M; DRURY, M.R; STRATING, E.H.H.; SPIERS, C.J. \& VAN DER WAL, D.-1995-Mantle shear zones and their effect on lithosphere strength during continental breakup. Tectonophysics 249:155-171.

VISSERS, R.L.M; DRURY, M.R; NEWMAN, J. \& FLIERVOET, T.F. - 1997- Mylonitic deformation in upper mantle peridotites of the North Pyrenean Zone (France): implications for strenght and strain localization in the lithosphere. Tectonophysics 279:303-325.

WARNER, M. \& McGEARY, S. -1987 - Seismic reflection coefficients from mantle fault zones. R.Astron.Soc. Geophys. J89:223-230.

WARREN, R.G \& ELLIS, D.J. -1996- Mantle underplating, granite tectonics and metamorphic P-T-t paths. Geology 24(7):663-666.

WASILEWSKI, P.J.; THOMAS, H.H. \& MAYHEW, M.A - 1979 - The Moho as a magnetic boundary. Geophys. Res. Lett. 6:541-544. 
WASILEWSKI, P.J. \& WARNER, R.D. -1988 - Magnetic petrology of deep crustal rocks Ivrea Zone, Italy. Earth Plan. Sci. Lett. 87:347-361.

WELLMAN, P. - 1978 - Gravity evidence for abrupt changes in mean crustal density at the junction of Australian crustal blocks. BMR J.Austral.Geol. \& Geophysics 3:153-162.

WELLMAN, P. - 1985 - Block structure of continental crust derived from gravity and magnetic maps, with Australian examples. In: W.J. HINZE (ed.). The Utility of Regional Gravity and Magnetic Anomaly Maps. Pp. 102-108.

WERTZ ,J. B.- 1974 - Detection and significance of lineaments and lineament intersections in part of the Northern Cordillera. Proc. Int. Conf. New Basement Tectonics, 1th, Utah Geol. Assoc. Publ. 5:42-54.

WESSEL, P. \& SMITH, W.H.F. - 1991 - Free software helps map and display data. EOS Trans. Amer. Geophys. U. 72:441, 445-446.

WESSEL, P. \& SMITH, W.H.F. - 1995 - New version of the generic mapping tools released EOS Trans. Amer. Geophys U. 76:329 leletronic supplement, http://www.agu.org/eos_elec 95154e.html.

WHEELER, R. L.- 1983- Linesmanship and the practice of linear geo-art: Discussion. Geol. Soc. Am. Bull. 94:1377-1379.

WHITAKER, A. J.- 1994 - Integrated geological and geophysical mapping of southwestern Western Australia. AGSO J. Australia Geol.\& Geoph. 15(3):313-328.

WHITE, S.H. \& BRETAN, P.G.-1985- Rheological controls on the geometry of deep faults and tectonic delamination of the continental crust. Tectonics 4:303-309.

WHITING, T.H. - 1988- Magnetic mineral petrogenesis, rock magnetism and aeromagnetic response in the Eastern Arunta Inlier-Northern Territory. Exploration Geophysics 19:377-383.

WICKHAM, S.M. \& OXBURGH, E. R. - 1987 - Low-pressure regional metamorphism in the Pyrénées and its implications for the thermal evolution of rifted continental crust. Phil. Trans. R. Soc. London A321:219-241.

WICKHAM, S.M.; JANARDHAN, A S. \& STERN, R. J.-1994- Regional carbone alteration of the crust by mantle-derived magmatic fluids, Tamil Nadu, South India. J. Geol. 102:379-398.

WILLIAMS, M.L; HANMER, S.; KOPF, C. \& DARRACH, M. - 1995 - Syntectonic generation and segregation of tonalitic melts from amphibolite dikes in the lower crust, Striding-Athabasca mylonite zone, northern Saskatchewan. J. Geophys. Res. 100(B8):15717-15734.

WINKLER, H.G.F. - 1976 - Petrogenesis of metamorphic rocks. 4 ed, Springer-Verlag, New York.

WINTSCH, R.P. \& ANDREWS, M.S. -1988- Deformation induced growth of sillimanite: stress mineral revisited. J. Geol. 96:143-161.

WISE, D.U. - 1982 - Linesmanship and the practice of linear geo-art. Geol. Soc. Am. Bull. 93:886-888. 
WISE, D.U. - 1983 - Reply to discussion of "Linesmanship and the practice of linear geoart". Geol. Soc. Am. Bull. 93:889-897.

WISE, D.U.; FUNICELLO, R.; PAROTTO, M. \& SALVINI, F. - 1985 - Topographic lineaments swarms: clues to their origin from domain analysis of ltaly. Geol. Soc. Am. Bull. 96:952-967.

WOLF, M. B. \& WYLLIE, P.J. - 1991 - Dehydration-melting of solid amphibolite at 10 kbar: textural development, liquid interconnectivity and application to segregation of magmas. Contrib. Mineral. Petrol. 44:151-179.

WOLF, M. B. \& WYLLIE, P.J. - 1995 - Liquid segregation parameters from amphibolite dehydratation melting experiments. J. Geophys. Res. 100(B8):15611-15621.

WOOD, B. J. \& BANNO, S. -1973 - Garnet-orthopyroxene and orthopyroxeneclinopyroxene relationships in simple and complex systems. Contrib. Mineral. Petrol. 42:109-124.

WOODSIDE, J.M. \& VERHOEF, J. - 1989 - Geological and tectonic framework of eastern Canada as interpreted from potencial field imagery. Geol. Survey Canada Paper 88-26.

XIA, J.; SPROWL, D.R \& STEEPLES, D.W. - 1996 - A model of Precambrian geology of Kansas derived from gravity and magnetic data. Computers \& Geoscience 22(8):883895.

YARDLEY, B. W. D. - 1989 - An introduction to metamorphic petrology. Longman, 248pp.

YARDLEY, B. W. D.; MACKENZIE, W. S. \& GUILFORD, C. - 1990 - Atlas of Metamorphic Rocks and their textures. Longman, Londres.

YAMAGUCHI, Y. - 1985 - Image scale and look-direction effects on detectability of lineaments in radar images. Remote Sens. Environ. 17:117-127.

YARGER, H. L. - 1985 - Kansas basement study using spectrally filtered aeromagnetic data. In: W.J. HINZE (ed.). The Utility of Regional Gravity and Magnetic Anomaly Maps. Soc Expl. Geophys. pp. 213-232.

YATABE, S. \& HOWARTH, P. H. - 1984 - Lineament enhancement and interpretation in Northern Ontario from multispectral scanner data. Proc. Intern. Symp. Remote Sens. pp. 1-8.

YÉSOU, H.; BESNUS, Y \& ROLET, J. - 1993a- Extracting of spectral information from Landsat TM data and merger with SPOT panchromatic imagery - a contribution to the study of geological structures. ISPRS J.Photogramm.Rem.Sen. 48(5):23-36.

YÉSOU, H.; BESNUS, Y.;ROLET, J.; PION, J. C. \& AING, A. - 1993b - Merging Seasat and SPOT data. Contribution to structural geological study over temperate agricultural region. Remote Sensing Environment 45:264-278.

YÉSOU, H.; BESNUS, Y. \& ROLET, J. - 1994 - Perception of a geological body using multiple source remotely-sensed data- relative influence of the spectral content and spatial resolution. Int.J.Remote Sensing 15(12):2495-2510.

YON, S.A \& PIETERS, C M.- 1988 - Interaction of light with rough dieletric surfaces: spectral reflectance and polarimetric properties. Proc. $18^{\text {th }}$ Lunar Planet. Sci. 581-592. 
ZEYEN, HJ.; BANDA, E. \& KLINGELE, E. - 1988 - Aeromagnetic reconnaissance of Catalonia, Spain. First Break 6(7):217-222. 
Anexo 3 - Dados estatísticos referentes à cena 214/065 do Landsat 5-TM empregados nos tratamentos digitais de parte do Setor Extremo Nordeste da Província Borborema.

Tabela A3.1 - Dados estatisticos da cena 214/065 do Landsat-TM do Setor Extremo Nordeste da Província Borborema, região da cidade de Campina Grande.

\begin{tabular}{|l|c|c|c|c|c|c|}
\hline & TM-1 & TM-2 & TM-3 & TM-4 & TM-5 & TM-7 \\
\hline Val.Minimo & 21 & 13 & 9 & 2 & 0 & 0 \\
\hline Val.Máximo & 255 & 192 & 251 & 187 & 255 & 255 \\
\hline Média & 57,514 & 28,550 & 26,443 & 75,486 & 73,222 & 19,422 \\
\hline Mediana & 56 & 28 & 28 & 76 & 72 & 18 \\
\hline Desv.Padrão & 6,832 & 5,03 & 8,741 & 14,131 & 16,726 & 8,339 \\
\hline Corr.Auto-Valor & 4,262 & 1,105 & 0,421 & 0,108 & 0,061 & 0,043 \\
\hline Cov.Auto-Valor & 434,94 & 209,19 & 40,35 & 6,24 & 4,88 & 1,77 \\
\hline
\end{tabular}

Tabela A3.2 - Coeficientes de correlação das seis bandas não-termais do LandsatTM do Setor Extremo Nordeste da Provincia Borborema usados nos cálculos das Análises por Principais Componentes.

\begin{tabular}{|c|c|c|c|c|c|c|}
\hline & TM1 & TM2 & TM3 & TM4 & TM5 & TM7 \\
\hline TM1 & 1,000 & & & & & \\
\hline TM2 & 0,892 & 1,000 & & & & \\
\hline TM3 & 0,904 & 0,921 & 1,000 & & & \\
\hline TM4 & $-0,057$ & 0,083 & $-0,155$ & 1,000 & & \\
\hline TM5 & 0,658 & 0,739 & 0,721 & 0,221 & 1,000 & \\
\hline TM7 & 0,783 & 0,790 & 0,849 & $-0,064$ & 0,884 & 1,000 \\
\hline
\end{tabular}

Tabela A3.3 - Matriz de covariância para as seis bandas não-termais do Landsat-TM do Setor Extremo Nordeste da Provincia Borborema

\begin{tabular}{|c|c|c|c|c|c|c|}
\hline & TM1 & TM2 & TM3 & TM4 & TM5 & TM7 \\
\hline TM1 & 46,673 & 30,648 & 53,984 & $-5,536$ & 75,209 & 44,618 \\
\hline TM2 & 30,648 & 25,303 & 40,502 & 5,883 & 62,147 & 33,154 \\
\hline TM3 & 53,984 & 40,502 & 76,399 & $-19,202$ & 105,48 & 61,909 \\
\hline TM4 & $-5,536$ & 5,883 & $-19,202$ & 199,68 & 52,343 & $-7,527$ \\
\hline TM5 & 75,209 & 62,147 & 105,48 & 52,343 & 279,77 & 123,303 \\
\hline TM7 & 44,618 & 33,154 & 61,909 & $-7,527$ & 123,30 & 69,539 \\
\hline
\end{tabular}

Tabela A3.4 - Coeficientes de correlação dos auto-vetores referentes às PC's obtidas com as seis bandas não-termais do Landsat-TM do Setor Extremo Nordeste da Província Borborema.

\begin{tabular}{|c|c|c|c|c|c|c|}
\hline & PC1 & PC2 & PC3 & PC4 & PC5 & PC7 \\
\hline TM1 & 0,446 & 0,099 & 0,439 & $-0,722$ & 0,279 & $-0,012$ \\
\hline TM2 & 0,457 & $-0,052$ & 0,383 & 0,539 & 0,055 & $-0,591$ \\
\hline TM3 & 0,463 & 0,173 & 0,196 & 0,328 & $-0,228$ & 0,747 \\
\hline TM4 & 0,001 & $-0,940$ & 0,217 & $-0,081$ & $-0,216$ & 0,130 \\
\hline TM5 & 0,418 & $-0,271$ & $-0,595$ & 0,095 & 0,614 & 0,106 \\
\hline TM7 & 0,451 & 0,032 & $-0,471$ & $-0,256$ & $-0,666$ & $-0,254$ \\
\hline
\end{tabular}

Tabela A3.5 - Matriz de covariância entre os auto-vetores e as seis bandas nãotermais do Landsat-TM do Setor Extremo Nordeste da Província Borborema usados nos cálculos das Análises por Principais Componentes.

\begin{tabular}{|c|c|c|c|c|c|c|}
\hline & PC1 & PC2 & PC3 & PC4 & PC5 & PC7 \\
\hline TM1 & 0,257 & 0,127 & 0,532 & 0,108 & $-0,781$ & 0,114 \\
\hline TM2 & 0,205 & 0,046 & 0,347 & $-0,238$ & 0,151 & $-0,87$ \\
\hline TM3 & 0,349 & 0,223 & 0,515 & $-0,255$ & 0,534 & 0,462 \\
\hline TM4 & 0,133 & $-0,952$ & 0,239 & 0,098 & 0,074 & 0,062 \\
\hline TM5 & 0,784 & $-0,061$ & $-0,524$ & $-0,292$ & $-0,145$ & 0,027 \\
\hline TM7 & 0,371 & 0,148 & $-0,023$ & 0,878 & 0,236 & $-0,113$ \\
\hline
\end{tabular}


Anexo 4 - Composições químicas médias de alguns minerais das amostras selecionadas para os cáculos termobarométricos na região da ZCRP (amostras VJ-22B e VJ-23A) e CCG (amostras VJ-32, VJ-34 e VJ-36). Os símbolos dos minerais: Bio = Biotita, $\mathbf{H b}=$ Hornblenda, $\mathbf{P 1}=$ Plagioclásio, $\mathbf{O p x}=$ Ortopiroxênio, $\mathbf{C P x}=$ Clinopiroxênio. As análises foram realizadas na Microssonda Camebax do Institut de Géologie, Université Blaise Pascal. Clermont-Ferrand (França).

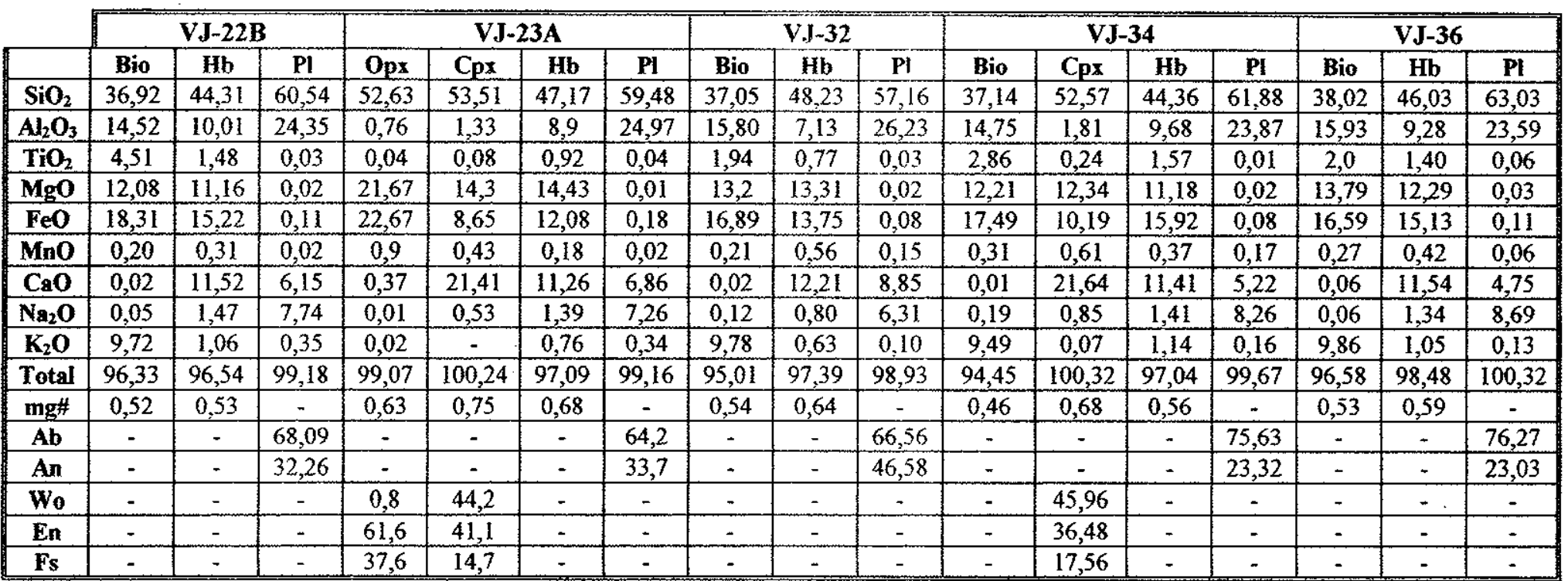


$35^{\circ} 30^{\prime} \mathrm{W}$



EEgENDA ESTRATIGŔ́FICA
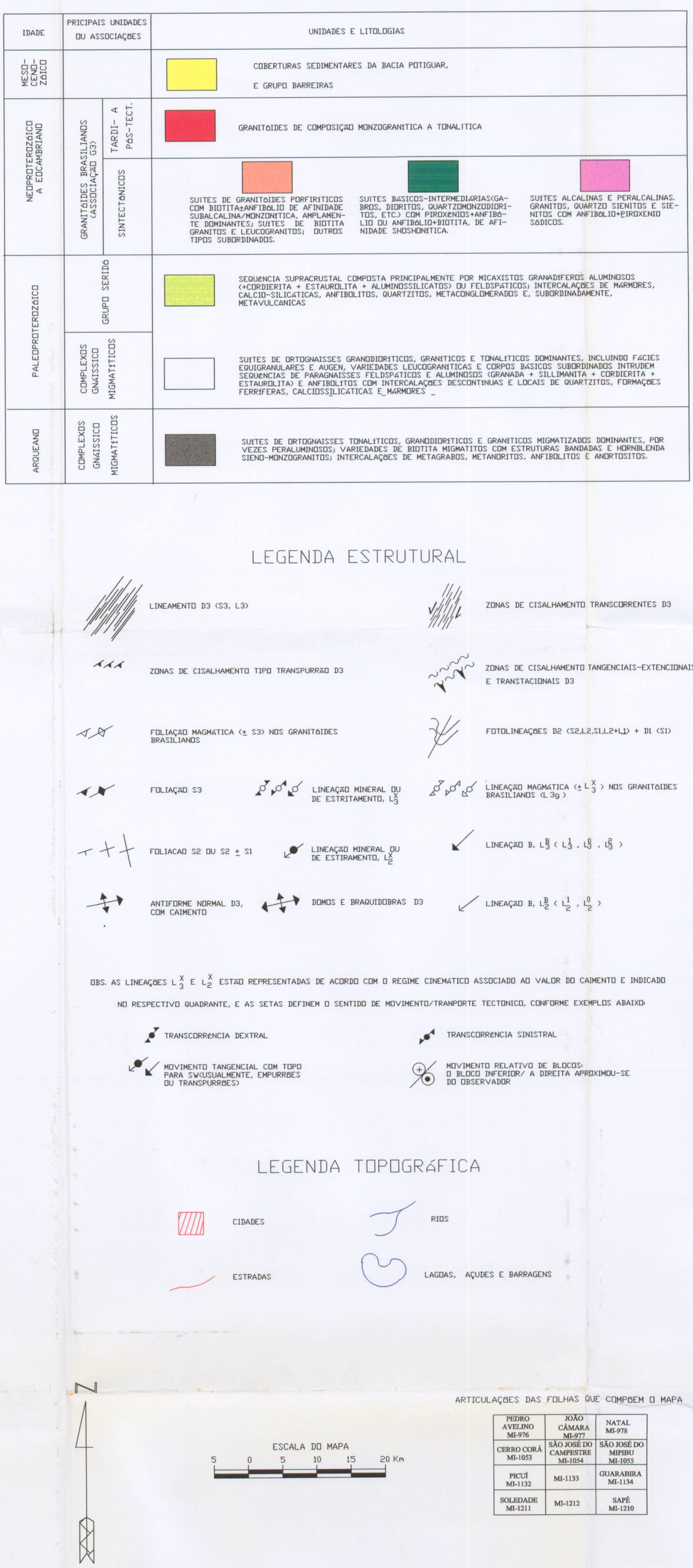

\begin{tabular}{|c|c|}
\hline \multicolumn{2}{|c|}{$\begin{array}{c}\text { UNIVERSIDADE DE SÃO PAULO } \\
\text { DEPARTAMENTO DE GEOLGGIE ECONOOMICA EGOFISICA APLICADA } \\
\text { PROGRAMA DE PÓS-GRADUAÇÃO EM RECURSOS MINERAIS E HIDROGEOLOGIA } \\
\end{array}$} \\
\hline \multicolumn{2}{|c|}{ TESE DE DOUTORADO } \\
\hline \multicolumn{2}{|c|}{ 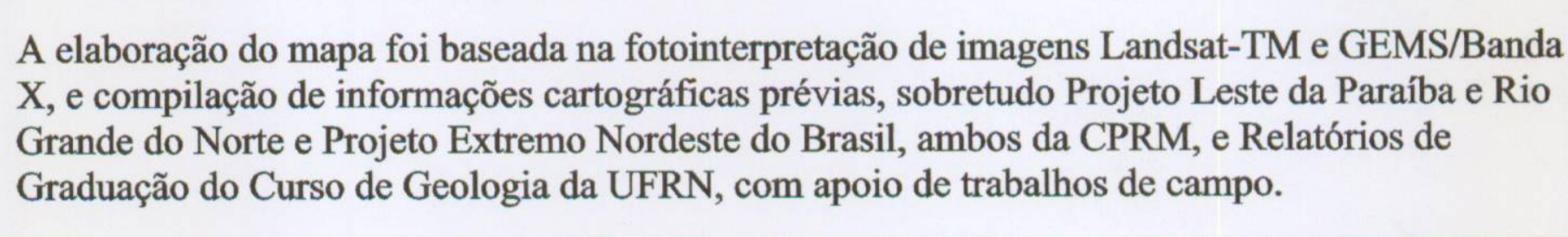 } \\
\hline Autor: Venerando Eustáquio Amaro & hho/19 \\
\hline Orientador: Gilberto Amaral & ANEXO I \\
\hline Editoração Gráfica: Ma. Irian de M. D & \\
\hline
\end{tabular}

